\title{
GEOLOGY AND PETROLOGY \\ OF RUAPEHU VOLCANO AND RELATED VENTS
}

by

William Robert Hackett

A thesis submitted for the degree of DOCTOR OF PHILOSOPHY, Research School of Earth Sciences, Victoria University of Wellington.

April, 1985. 
Ruapehu Volcano is an active, multiple-vent, andesite composite volcano at the southern terminus of the Taupo Volcenic Zone, central North Island, New Zealand. The present-day volume of Ruapenu is estimated at $110 \mathrm{~km}^{3}$, and construction of the massif probably occurred during the past 0.5 m.y. Geologic mapping and stratigraphic studies have led to the recognition of four periods of cone construction, each occurring over $10^{4}-10^{5}$ year time intervals. On the basis of lithologic/petrographic differences, and conspicuous unconformities which separate the deposits of eech cone- building period, four new formations are defined, comprising the Ruapehu Group. Te Herenge formation (new formation name) comprises the oldest deposits of Ruapehu (upper laves ca. $0.23 \mathrm{Ma}$ ) and is exposed as planeze surfaces and arêtes on $\mathrm{N}$ and NW Ruapehu. The formation includes leva flows, tuff breccias, and small intrusive bodies surroundad by zones of hydrothermal alteration. There is little petrographic and compositional diversity; most laves ara porphyritic titanomagnetite- augite- hypersthene- plagioclase basic andesites. Wahianoe Formation (new formation name) is younger than Te Herengo $\mathrm{Fm}$., but of unknown age. It is well exposed on SE Ruapehu, and comprises mostly lave flows and tuff breccias. The lavas comprise acid and besic andesites. Mangawhero Formation (new formation name) is well exposed everywhere except SE Ruapehu, and the upper lavas and pyroclastics (co. $0.02 \mathrm{Ma}$ ) form the present high peaks and main cone of Ruapehu. The lavas are petrographically and geochemically diverse, ranging from besalt to dacite in bulk composition. Some of the lower lovas are olivinebearing andesites of mybrid origin. Whakapapa formation (new formation name; ca. 15,000 years to present) comprises conspicuously young lava flows, tuff breccias, airfall pyroclastics and minor pyroclastic flows of acid- and basic andesite. The deposits of these post-glacial summit and flank eruptions are subdivided into the Iwikau, Rangataus, Tams and Crater Lake Members. 'Relatad vents' produced Houhungatahi Andesite Fm. (2 $0.5 \mathrm{Ma}$ ?), and Holocene deposits of basalt and basic andesite at isolated, monogenetic centres comprising Ohakune Andesite Fm., Pukeonake Andesite Fm., and Waimar ino Basalt Fm. (new formation name).

Most Ruapehu laves are medium-K acid and besic andesites (mean of 144 bulk rock analyses is 57.8 wt $\& \mathrm{SiO}_{2}$ ), but rare basalt and minor dacite are present. Nearly all lavas are porphyritic in plagioclase, augite and hypersthene \pm olivine, with titanomagnetite microphenocrysts, and contain abundant metamorphic and igneous rock inclusions.

Petrography, mineral chemistry and bulk rock chemistry indicate fractional crystallization series from parental basalts ( $52-53 \& \mathrm{SiO}_{2}, \mathrm{Q}$-normative, low-alumina) to medium-K basicand acid andesites ( $58-59 \% \mathrm{SiO}_{2}$ ). Early fractionating minerals are olivine and clinopyraxene with minor chrome spinel and plagioclase, followed by plagioclase, orthopyroxene, clinopyroxene and minor titanomagnetite in later stages of differentiation. Thus, basalt differentiation to produce andesites involves 'POAM-type' (Gill, 1981) fractional crystallization. 
Three second-order differentiation processes operate concurrently with fractional crystallization: (1) Crystal accumulation involves addition of co-genetic plutonic rock fragments and crystais derived from them. These inclusions are common and few rocks represent liquid compositions. (2) Magma mixing involves mingling of magmas in repeatedlyoccupied conduits. End members are as diverse as basalt and dacite, yielding petrographically and chemically distinctive high-Mg andesites of the upper cone complex and parasitic centres. (3) Selective crustal essimilation is suggested by partially fused metamorphic inclusions, positive correlation of ${ }^{87} \mathrm{Sr} /{ }^{86} \mathrm{Sr}$ with $\mathrm{SiO}_{2}$, and failure of simple 'POAM' frectionation to explain dacites $\left(63-65 \% \mathrm{SiO}_{2}\right)$.

Petrogenesis of Ruapehu andesites takes place under open-system conditions, involving production of perental Q-normative basalts in the mantle wedge, concurrent fractional crystallization and crustal contamination, entrainment of co-genetic plutonic rocks, and mixing of magmas in common conduits. 
Many people have contributed directly and indirectly to this work, and I cannot hope to mention them all. First, I thank the people of New Zeeland, who generously supported this research through o New Zealand National Parks Authority Scholarship, administered by the Department of Lands and Survey. I am particularly grateful to Mr. Bruce Jefferies, Chief Ranger of the Tongariro National Park, for placing Park facilities at my disposal, and for his constant good cheer and encouragement. It was my privelege to know Mr. Bill Cooper, Mr. Keith Blumhardt and Mr. Derek White, three Rangers who died in a tragic accident on Mt. Ruapehu. To their loved ones, I can only sey that they gave freely of their knowledge of the Park, and they are remembered. Many individuals at Victoria University of Wellington aided me during 1979-1982: Professor R.H. Clark, Sir Charles Fleming, Mr. Ted Hardy and the technical staff, Ms. Betty Finlayson, Mr. Ken Palmer, Dr. R.H. Grapes, Dr. Barry Roser and Dr. Poul Morris. Special acknowledgement is given to Mr. Greg Cosson, who helped with final corrections and binding while I was overseas. Mr. Ian Grahem courteously allowed me to use his strontium isotopic data from Ruapehu laves and inclusions. Discussions with Drs. R.J. Arculus, R. Yarne, S.D. Weaver, M. MoCullough, J.Y. Wright, C. Wilson and G.P.L. Walker were very helpful to me. John Casey and Mark Phillips of the Photographic Facility, VUW, are credited with the excellent photographic reproductions in this volume, and also gave me valuable advice on camera and darkroom methods. The late Mr. Roy Turner piloted his aircraft while I took oblique aerial photographs of Ruapehu. Ann Gibb typed Part I of this study, and Joan Berg helped with revisions to Part I. Bob Berg has given constant friendship and support, and introduced me to the excellent fly fishing of Nor th Island.

During my life, I have been fortunate to work with a few individuals who, through their example and instruction, have chenged the course of my life. The contributions of three people are so large that this dissertation is perhaps as much theirs as mine. Dr. James W. Cole or iginally suggested the research to me in 1978 when we met in Hawrii, supported me in my efforts to get finencial aid, and maintained this support and encouragement during the six yaers' completion time. Dr. John A. Gamble has given me constant encouragement and extremely valuable advice on petrology and petrogenesis, as well as excellent friendship. Dr. Bruce F. Houghton of the New Zealand Geological Survey, Rotorua, insisted that the physical volcanology and stratigraphy receive detailed attention, and on many occasions accompanied the writer into the field, to help with observations and interpretation. The Coles, Gambles and Houghtons extended their hospitality to me and my family many times, and we are grateful for their friendship.

Finally, I thank my wife Debby who, for six years, has been both mother and father to our children, has kept us whole and healthy, and has weothered the storms of a less-than-genial doctoral candidate. I dedicate this thesis to her. 
Part I: GEOLOOY OF RUAPEHU VOLCANO AND RELATED VENTS

1. GENERAL INTRODUCTION

1.1 Regional Setting

1.2 Previous Work

1.3 Nature and Scope of This Study

1.4 Nomenclature

2. GEOLOOY OF RUAPEHU MASSIF 27

$\begin{array}{ll}2.1 \text { Introduction } & 27\end{array}$

2.2 Use of "Formation" for Volcanic Rock Units 27

2.3 Use of "Facies" for Volcanic Rock Associations 30

2.4 Te Herengs Formation (new formation name) 33

2.5 Wahianoa Formation (new formation name) 54

2.6 Mangawhero Formation (new formation name) 82

2.7 Whak apapa Formation ( new formation name) 98

2.8 The Origin of Lahor Mounds Deposits, NW Ruapehu 116

$\begin{array}{ll}2.9 \text { Elacial Features of Ruepenu Massif } & 120\end{array}$

2.10 Faulting 123

2.11 Implicotions for Volcanic Hozard Assessment at Ruapehu 125

3. GEOLOBY OF RELATED VENTS 129

$\begin{array}{ll}3.1 \text { Introduction } & 129\end{array}$

3.2 Geology of the Pukeonake Vents 129

3.3 Geology of Hauhungatahi 133

3.4 Geology of the Ohakune Vents (a published manuscript) 138

4. SUMMARY OF GEOLOGIC HISTORY 139

5. GEOLOGY OF WAIMARINO BASALT (new formation name) 143

PART II: PETROLOGY AND GEOCHEMISTRY

$\begin{array}{ll}\text { 1. GENERAL INTRODUCTION } & 145\end{array}$

$\begin{array}{ll}1.1 \text { Previous Work } & 145\end{array}$

1.2 Nature and Scope of This Study 146

$\begin{array}{ll}1.3 \text { Results } & 148\end{array}$

2. PETROGRAPHY 149

2.1 Te Herenge Formation $\quad 149$

$\begin{array}{ll}2.2 \text { Wahianoa Formation } & 152\end{array}$

2.3 Mangowhero Formation $\quad 156$

$\begin{array}{ll}2.4 \text { Whakapapa Formation } & 163\end{array}$

2.5 Lavas From Sources Other Than Ruapehu 167

$\begin{array}{ll}2.6 \text { Igneous Nodules } & 173\end{array}$

$\begin{array}{ll}2.7 \text { Metamorphic Xenoliths } & 180\end{array}$

3. SURVEY OF MINERAL CHEMISTRY IN LAVAS 187

$\begin{array}{ll}3.1 \text { Olivine } & 187\end{array}$

$\begin{array}{ll}3.2 \text { Pyroxenes } & 190\end{array}$

$\begin{array}{ll}3.3 \text { Feldspars } & 192\end{array}$

3.4 Oxides 194

3.5 Amphibole 201

3.6 Apatite $\quad 201$

3.7 other Minerals 202

4. SUMMARY OF MINERALOGY AND PETROGRAPHY 202

5. IMPLICATIONS OF MINERAL ASSEMBLAGES AND COMPOSITIONS
FOR PETROOENESIS 
6. BULK ROCK MANOR AND TRACE ELEMENT COMPOSITION 207

6.1 Introduction 207

6.2 Classification $\quad 209$

6.3 Major Elements 211

6.4 Trace Elements $\quad 217$

\section{PART III: PETROGENESIS}

1. INTRODUCTION 222

1.1 General Statement 222

1.2 Nature of the Nor th Island Plate Boundary 223

1.3 Previous Work on Petrogenesis of TVZ Eruptives 225

2. THE ROLE OF THE MANTLE WEDGE 232

2.1 Primitive Nature of Waimarino Basalt 233

2.2 Production of Quar lz Normative Magmas in the Upper Mantle 236

2.3 Composition of Ruapehu Basalt and Relationship to Waimarino Basalt 239

2.4 Compar ison of Woimar ino Basolt with Other Basalt Magma Types 240

2.5 Ultramafic Nodules as Possible Samples of Upper Mantle 245

3. THE ROLE OF BASALT FRACTIONATION 247

3.1 Criteria for Choice of Samples Representing Liquid Compositions 247

3.2 Discussion of Least Squares Modelling 248

4. THE ROLE OF CRYSTAL ACCUMULATION 257

4.1 Introduction 257

4.2 Effects of Accumulation 258

4.3 Summary of Major Points Concerning the Role of Accumulation 263

5. THE ROLE OF MAGMA MIXING 264

$\begin{array}{ll}5.1 \text { Introduction } & 264\end{array}$

5.2 Mineralogical Effects of Magna Mixing 265

5.3 Discussion of Leest Squares Modelling, and Oeochemical Effects of Magma Mixing

6. THE ROLE AND NATURE OF THE CRUST 274

6.1 Introduction 274

6.2 Metamorphic Conditions in the Crust 275

6.3 Xenolith Bulk Compositions 278

6.4 Role of the Crust in Petrogenesis of Ruapehu Lavas 285

7. MAGMA EVOLUTION IN TIME AND SPACE: A RETURN TO THE
STRATIGRAPHIC CONTEXT

8. EPILOGUE 298

$\begin{array}{ll}\text { REFERENCES CITED } & 303\end{array}$

APPENDICES:

I. Stratigraphic Descriptions of Measured Sections I-1

II. Bulk Rock Chemical Analyses II-1

III. Mineral Analyses from Lavas and Pyroclastics III-I

IV. Mineral Analyses from Igneous Nodules IV-I

V. Mineral Analyses from Metamorphic Xenoliths $\quad V_{-}-1$

VI. Least Squares Mixing Calculations VI-I

GEOLOGIC MAP at 1:25,000; plus reduced copy of map (inside back cover) 
Fig 1. Yolcanic centres of the Taupo Volcanic Zone, central North Island 2

Fig 2. Andesite massifs and cones of the Tongariro Volcanic Centre 4

Fig 3. Grain size limits of pyroclastic fragments, after Fisher (1961) is

Fig 4. Lithologic types, after Fisher ( 1966) 15

$\begin{array}{ll}\text { Fig 5. Summary diagram for Genetic Classification } & 17\end{array}$

Fig 6. Stratigraphic summary for Ruapehu massif 28

Fig 7. Generalized geologic map of Ruapehu and related vents 29

Fig 8. Scheme of volcanic facies for a composite volcano 32

Fig 9. Aerial view of the nor thwest slopes, Ruapehu 34

Fig 10. Aerial photograph of the nor thern slopes, showing megascopic features of the Te Herenga Formation exposed at upper Pinnacle Ridge

Fig 11. Outcrop photographs of Te Herenga Formation, central facies, upper Pinnacle Ridge

Fig 12. Proximal facies of Te Herenga Formation at Pinnacle Ridge

Fig 13. Te Herenga and Whakapapa F ms exposed in Whakapapanui Valley, nor thwest Ruapehu

Fig 14. Ruapehu Section $1.145 \mathrm{~m}$ of Te Herenga $\mathrm{Fm}$ exposed in Whakepapanui Gorge, nor thwest Ruepehu

Fig 15. Ruapehu Section 2. $80 \mathrm{~m}$ of Te Herenga Fm exposed at Te Herenga Ridge, nor thwest Ruapehu

Fig 16. Ruapehu section $12.73 \mathrm{~m}$ of Te Herenga and Mangawhero Fms exposed in Whakapapaiti Valley, west Ruapehu

Fig 17. Outcrop photograph of proximal facies lithologies of the Te Herenga Formation, upper Pinnacle Ridge

Fig 18. NRM vectors for two heterolithologic tuff breccias from the proximal facies of Te Herenga Formation

Fig 19. Colluvial deposits of Te Herenga Fm proximal facies, Pinnacle Ridge

$\mathrm{Fig} 20$. North- trending dyke of Te Herenga $\mathrm{Fm}$, P innacle Ridge

Fig 21. Geologic map of Pinnacle Ridge, nor thwest Ruapehu

Fig 22. Aer ial photograph of southeastern slopes of Ruapehu. Wahianos Fm is exposed in headwaters of Wahianoa and Whangaehu Rivers

Fig 23. Geology of the southwest face, Girdlestone Prak. The unconformable contact of Wahianoe and Mangawhero Formations is exposed here.

Fig 24. Central facies of Wahianoa Fm exposed in headwaters of Whangachu River, southeastern summit region of Ruapehu

$\mathrm{Fig} 25$. Wahianoa $\mathrm{Fm}$ exposed in Whangaehu Gorge, southeast Ruapehu

Fig 26. Wahianoa $\mathrm{Fm}$ exposed in Wahianoa Valley, southeast Ruapehu

$\mathrm{Fig} 27$. Ruapehu Section 3. $223.5 \mathrm{~m}$ of Wahianoe $\mathrm{Fm}$ exposed in Whangaehu Gorge, southeast Ruapehu

Fig 28. Ruspehu Section 4 . $13.5 \mathrm{~m}$ of Wahianoa $\mathrm{Fm}$ exposed in the Whangeohu Gorge, southeast Ruapehu

Fig 29. Ruapehu Section 5. $64.4 \mathrm{~m}$ of Wahianos $\mathrm{Fm}$ exposed in Whangachu Gorge, eastern Ruapehu

Fig 30. Ruapehu Section 8 . $37.5 \mathrm{~m}$ of Wahianoa $\mathrm{Fm}$ exposed in an unnamed stream valley of north Ruapehu

Fig 31. Ruapehu Section 7. $26 \mathrm{~m}$ of Wahianoa $\mathrm{Fm}$ exposed at Birdlestone Peak

$\mathrm{F}$ ig 32. Ruapehu Section $6.192 \mathrm{~m}$ of Wahianos $\mathrm{Fm}$ exposed in Wahianos Valley, southeast Ruapehu

Fig 33. Internal blocky jointing developed in Wahianoe Fm lava flow ' 69

Fig 34. Basal platy jointing and underlying autobreccia of Wahianoa $\mathrm{Fm}$ lava flow 69

$\mathrm{Fig} 35$. Flow banding near base of Wahianoe $\mathrm{Fm}$ lava flow 
Fig 36. Transition from lava flow to autobreccia in Wahianos $\mathrm{Fm}$

Fig 37. Lenses of welded, incipient autobreccia in Wahianoa $\mathrm{Fm}$ lava flow

Fig 38. (Omitted)

Fig 39. Unwelded bomb bed, $30 \mathrm{~m}$ interval of RS 3

Fig 40. Mantle- bedded airfall lapilli and ash, $20 \mathrm{~m}$ interval of RS 3

72

Fig 41. Framework- supported, reversely graded heterolithologic tuff breccia; $10.9-11.9 \mathrm{~m}$ interval of RS 4

Fig 42. Matrix-supported, reversely graded heterolithologic tuff breccis; 22.6-26.6 m interval of RS 3

$\begin{array}{ll}\text { Fig 43. Photograph of "Type C" TBh unit, near the } 170-180 \mathrm{~m} \text { interval of RS } 3 & 76 \\ \text { Fig 44. Breadcr usted bombs in "Type C" TBh unit } & 76\end{array}$

Fig 45. Internally shattered, breadcr usted bomb in "Type C" TBh unit 76

Fig 46. NRM vectors for "Type C" heterolithologic tuff breccia 78

Fig 47. Cross-bedded sand filling interstices of coarse breccia; 19.2-19.8 m interval of RS 3

Fig 48. Cross-bedded sand in coarse breccia, Wahianoa Fm

Fig 49. A. Aerial photograph of southwestern slopes of Ruapehu, showing tabular lave flows and autobreccias of Mangawher o $\mathrm{Fm}$

B. Nor theastern slopes, showing main cone of Mangawher 0 and Whakapapa Fms

Fig 50. Ruapehu Section 9. $76 \mathrm{~m}$ of Mangawhero $\mathrm{Fm}$ exposed at Girdlestone

Peak, southeastern summit region of Ruapehu
Fi. Ruapehu Section 10. $42.5 \mathrm{~m}$ of Mangawhero $\mathrm{Fm}$ exposed beneath Tahurangi, southern summit region of Ruapehu

F in 52. Ruapehu Section 11 . $117 \mathrm{~m}$ of Mangawhero Fm exposed in Mangaturuturu River Valley of southwest Ruapehu

$\mathrm{Fig} 53$. Ruapehu Section 13. $117 \mathrm{~m}$ of Mangawhero $\mathrm{Fm}$ exposed in an unnamed stream valley of nor theast Ruapehu

Fig 54. Chrotic association of lava flows and autoclastic breccias, lower $16 \mathrm{~m}$ of RS 11

Fig 55. SG deposits of Mangawhero Fm; 41.5-42.5 m interval of RS 10

Fig 56. SO deposits of Mangawhero Fm; $16-20 \mathrm{~m}$ interval of RS 11

Fig 57. Bedded tuffs and lapilli tuffs of Mangawhero $F m ; 14.8-16.8 \mathrm{~m}$ and $41.5 \mathrm{~m}$ intervals of RS 10

Fig 58. Dykes of Mangawhero $\mathrm{Fm}$ at Birdlestone Peak

Fig 59. Glacial unconformities developed in Mangowhero Fm beneath Tahurangi

Fig 60. Cathedral Rocks, western summit region of Ruapehu

Fig 61. Feeder dyke for nor thern flank er uptions of Mangawhero $\mathrm{Fm}$

Fig 62. Aer ial photograph of the southern slopes of Ruapehu. Vent region for the Rangataua Member is enclosed in box outline

Fig 63. Ruapehu Section 14. $12.5 \mathrm{~m}$ of Rangataua Member (Whakapapa $\mathrm{Fm}$ ) exposed in a stream valley to the east of the vent region, south Ruapehu

Fig 64. Aerial photographs of the northern slopes. Block lava flows of Tama Mbr

Fig 65. Coarse pyroclastics at the vent region for lower lava field of Tama Mbr

Fig 66. Airfall ash and lapilli of the Tama Member, north Ruapehu

Fig 67. Oblique aerial photograph of the northwestern slopes of Ruapehu

Fig 68. Ruapehu Sections 15 A,B , C. Welded airfall tuff of Pinnacle Ridge Mbr, Whak apapa $\mathrm{Fm}$

Fig 69. Welded airfall tuff of Pinnacle Ridge Mbr, at locality for RS I5B

Fig 70. Eutaxitic texture developed in welded airfall tuff, Pinnacle Ridge Mbr

$\mathrm{Fig} 71$. Lithic blocks of under lying Te Herenga $\mathrm{Fm}$ in densely welded airfall tuff, Pinnacle Ridge Member of Whak apapa Fm

Fig 72. Internal stratification in welded airfall tuff, Pinnacle Ridge Member 
Fig 73. Thick, densely welded airfall tuff near the vent region for Pinnacle Ridge Mbr

Fig 74. Block lava flows and autoclastic breccias of I wikau Member

Fig 75. Autobrecciation of block lava flows of I wikau Mbr, exposed at Whakapapa skifield and along Bruce Rood, nor thwest Ruopehu

Fig 76. Crater Lake basin, photographed from Ruapehu summit

Fig 77. Mantle- bedded pyroclestics and subordinate lava flows of Pyram id Peak

Fig 78. Map of 'lahar mounds' deposits, their inferred source regions, and probable paths of the debris flows

Fig 79. Photograph and drawing of lehar mound exposed along SH 48

Fig 80. Glacial moraines of Ruapehu massif

Fig 81. Aerial photographs of Ruapehu glacial features

Fig 82. Ground photographs of Whakapapanui Valley, nor thwest Ruapehu

Fig 83. Ground photographs of glacial features in upper Whakapapaiti Valley

Fig 84. Foult traces on Ruapehu massif

Fig 85. Aerial photograph of Whangeehu lahar fan, eastern ring plain of Ruapehu

Fig 86. Distribution of Pukeonake Andesite Formation

Fig 87. Aer ial photograph of Hauhungatahi, a deeply eroded volcano to the west of Ruspehu

Fig 88. Geologic cross- section of Hauhungatahi

Fig 89. Pyroclastics beneath upper sequence of lava flows, Hauhungatahi

Fig 90. Schematic drawings of Ruapehu history, viewed from the west

Fíg 91. Photomicrographs from Te Herenga Formation

Fig 92. Photomicrographs from Wahianos Formation

Fig 93. Photomicrographs from Mangawhero Formation

Fig 94. Photom icrographs from Whakapapa Formation

Fig 95. Photomicrographs of non-Ruapehu lavas

Fig 96. Photomicrographs of igneous nodules

Fig 97. Photomicrographs of crustal xenoliths

Fig 98. Compositions of coexisting pyroxenes and olivines 188

$\begin{array}{ll}\text { Fig 99. Plagioclase compositions } & 193\end{array}$

Fig 100. Oxide mineral compositions from Waimerino Basalt 196

Fig 101. Oxide mineral compositions from basalt of Mangawher o Fm., Ruapehu 197

Fig 102. Oxide mineral compositions from two basic andesites 198

$\begin{array}{ll}\text { Fig 103. Composite diagram of all oxide mineral compositions } & 199\end{array}$

Fig 104. Composition diagram for Fe-Ti oxides 200

$\mathrm{Fig} 105$. $\mathrm{MgO}$ and $\mathrm{SiO}_{2}$ histograms for 144 bulk rocks from Ruapehu and other vents 208

Fig 106. Silice- potash diagram for 144 bulk rocks $\quad 210$

Fig 107. Silice variation diagrams for 144 bulk rocks $\quad 212$

Fig 108. Trends of iron enrichment for bulk rocks 213

Fig 109. Rubidium variation diagrams for 144 bulk rocks 218

Fig 110 . Tectonic elements of the Taupo-Hikurangi arc-trench system 224

Fig 111 . Geophysical interpretation of the North Island plate boundary 226

Fig 112. Pyrolite melting grid 238

Fig 113. Major and trace element characteristics of 'boninite series' and IAT 242

Fig 114. MORB-normalized plot of Waimarino Basalt and IAT 243

Fig 115. Comparison of calculated and observed mineral proportions during frectional crystallization

Fig 116. Phenocryst mineral proportions for accumulative and non-accumulative lowas 261

Fig 117. Some effects of accumulation on bulk rock compositions 262

Fig 118. Mineral zonation patterns in two hybrid laves , 266

Fig 119. Variation diagrams comparing hybrid lavas with those of frectional crystallization series

Fig 120. Summary of metamorphic conditions inferred from xenolith mineralogy 276 
Fig 121. Major element compositional variation of xenoliths

Fig 122. Physical evidence for assimilation of crustal material

Fig 123. Strontium isotopic data from metamorphic xenoliths and lavas

Fig 124. K/Rb variation in lavas

291

Fig 125. Compositional diversity of lavas and pyroclastics

295 
Iable 1. Modal data from Te Herenga Formation 151a

Table 2. Modal data from Wahianoe Formation 155a

$\begin{array}{lr}\text { Table 3. Modal data from Mangawhero Formation } & 1628\end{array}$

Table 4. Modal date from Whakepapa Formation 1660

Table 5. Modal data from non-Ruapehu lavas 1728

$\begin{array}{ll}\text { Table 6. Modal data from igneous nodules } & 1798\end{array}$

Table 7. Basalt analyses of the present study, with comparative data from other sources 234

Table 8. Summary of least-squares mixing calculations for frectional crystallization of Ruapehu basalt

Table 9. Summery of least-squares mixing calculations for fractional crystallization of Waimarino Basalt

Table 10. Least-squares mixing calculations for hybrid magmas 268

Table 11. Representative bulk rock anolyses of hybrid lavas 272

Table 12. Representative bulk rock analyses of metamorphic xenoliths 280 
PART I : GEOLOGY OF RUAPEHU VOLCANO AND RELATED VENTS

\section{GENERAL INTRODUCTION}

\subsection{REGIONAL SETTING}

The Taupo Volcanic Zone (Healy, 1962) is a region of Pliocene to Recent tectonic activity and volcanism which extends northeastward across the central portion of the North Island (Fig.1). The depression is a structural and topographic low which extends from Ruapehu to White Island, and may merge northwards with the submarine Havre Trough. The volcanic and structural features described by Healy (1962, 1964), Healy et al. (1964), Grindley (1960), Gregg (1960, 1961), and Modriniak and Studt (1959) lead to the conclusion that the Taupo Volcanic Zone (TVZ) is a volcano-tectonic depression, the central portion of which has been infilled to a depth of several kilometres by silicic ignimbrites, lavas and volcanogenic sediments.

Structural elements of the central North Island have been outlined and interpreted in the context of convergent tectonics (Cole and Lewis, 1981). The TVZ is interpreted by these authors as a NNE-trending, Plio-Pleistocene to Recent marginal basin. Recent andesitic to dacitic volcanism along the eastern side of the TVZ is interpreted as a volcanic arc which extends from the Tongariro Volcanic Centre in the south to White Island in the north. Most of these vents erupted olivine-bearing andesite and low-silica andesite, with minor low-alumina basalts; all of the olivine-bearing lavas are considered to be less than about 50,000 years old (Cole, 1979).

Four large rhyolitic volcanic centres -- Taupo, Maroa, Rotorua, and Okataina -- occupy the central part of the TVZ. Healy (1962) estimated $16,400 \mathrm{~km}^{3}$ of silicic lavas and ignimbrites from these centres were spread over an area exceeding 45,000 $\mathrm{km}^{2}$, constructing extensive plateaux which extend beyond the depression itself. Minor amounts $\left(2 \mathrm{~km}^{3}\right.$; Cole, 1979) of high-alumina basalt occur at isolated localities 


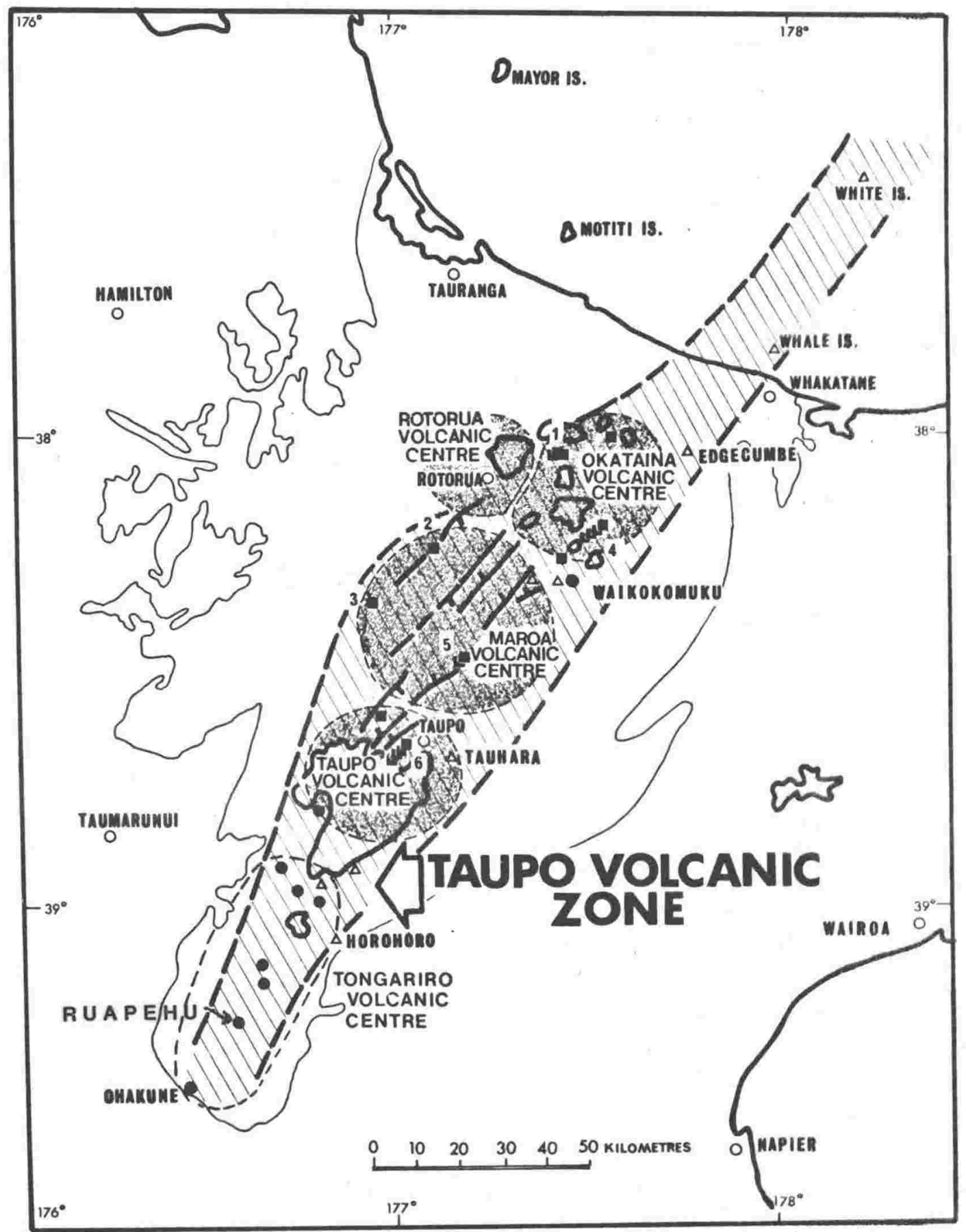

FIG. 1. Volcanic centres of the Taupo Volcanic Zone, central North Island, New Zealand (from: Cole, 1979). 
where NNE-trending regional faults cross caldera structures (Cole, 1972). Intermediate volcanics occur at the northern and southern extremities of the TVZ and have an aggregate volume of $265 \mathrm{~km}^{3}$ (Cole, 1979). At the southern end, five composite volcanoes -- Ruapehu, Ngauruhoe, Tongariro, Pihanga and Kakaramea-Tihia -- comprise the Tongariro Volcanic Centre (Fig. 2). Cole (1978) has identified two structural trends in the Tongariro Volcanic Centre: An older, northwest-trend-ing line of vents defined by Pihanga, Kakaramea-Tihia, and the old Tongariro vents of Mathews (1967), and a NNE-trending lineament which parallels the present-day regional fabric and is defined by the younger multiple vents of Tongariro and Ruapehu. Many recently active NNE-trending normal faults traverse the Tongariro region, and vent locations of at least the last 30,000 years have been controlled by these deepseated basement structures.

Ruapehu is the largest edifice of the Tongariro Volcanic Centre, and represents about 40 percent of the total volume of TVZ intermediate volcanics. The summit reaches 2,797 metres and is the apex of the North Island. The massif has a basal diameter of about $19 \mathrm{~km}$ and covers some $285 \mathrm{~km}^{2}$. Numerous vents were active during its history, and constructed a multiple composite cone with a present-day volume of $110 \mathrm{~km}^{3}$ (J.H. Latter, pers. comm. 1981) which is currently active. Ruapehu is thus of nearly identical size to Vesuvius, and about one fifth to one eighth the volume of such other large and well-known cones as Fujiyama, Etna, Rainier and Shasta. Below the 1,100 metre level, it is surrounded by an extensive ring plain of laharic debris and airfall tephra. To the north, the volcanic deposits of Ruapehu merge with those of Tongariro and Ngauruhoe. To the south and west, they unconformably overlie block-faulted Tertiary marine sediments of the Wanganui Basin. To the east, the ring plain deposits abut Mesozoic metagreywacke of the Kaimanawa Range. It is deduced that Ruapehu was constructed on a dissected and faulted terrain of Tertiary marine sediments and underlying Mesozoic greywacke. Judging from distal exposures of the 


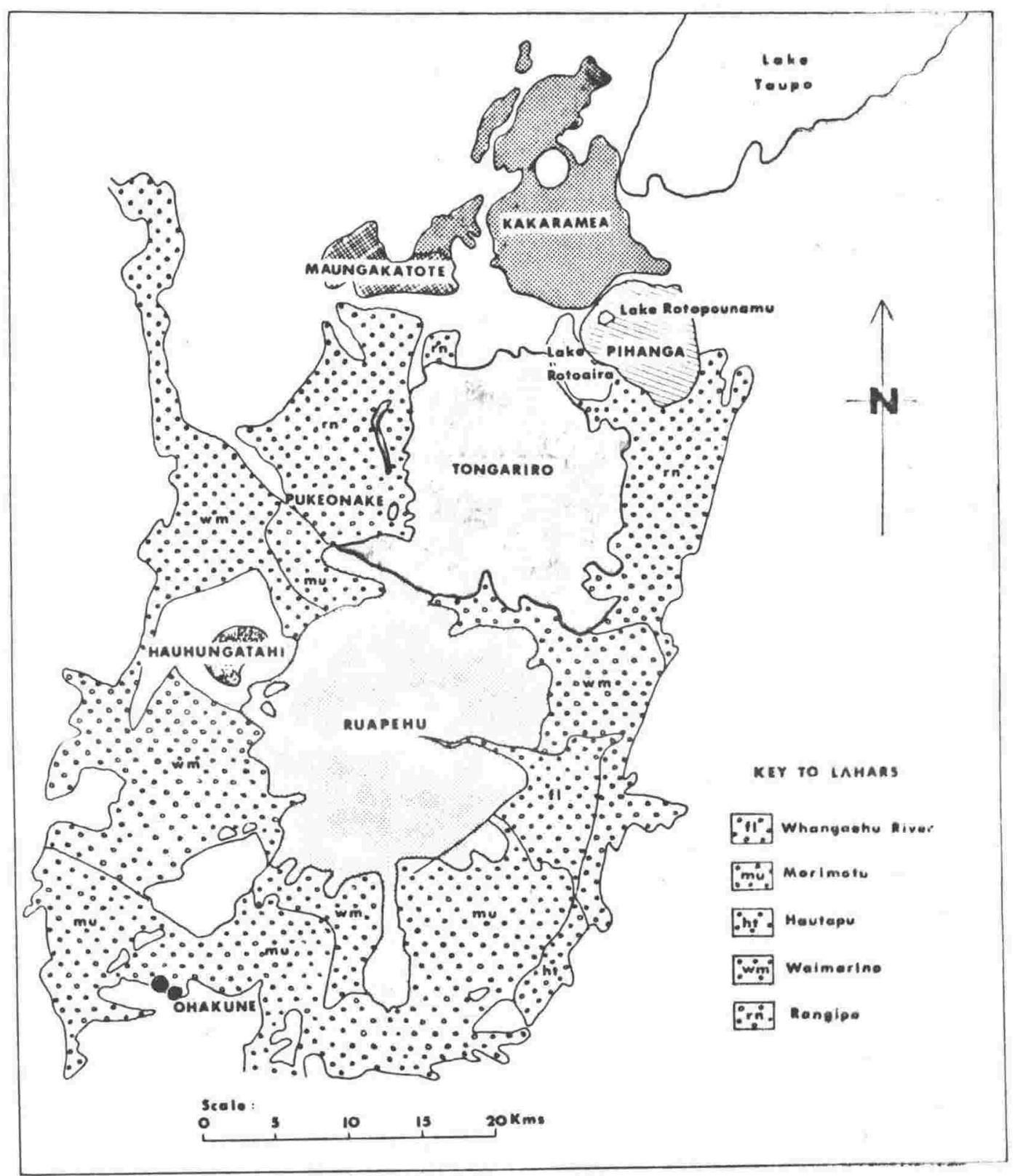

FIG. 2. Andesite massifs and cones of the Tongariro Volcanic Centre (from: Cole, 1978). Lahar formations are those of Grindley (1960). 
southern and western Ruapehu ring plain, the top of the marine sediments there occurs at about 1,000 metres above sea level. Seismic evidence (Latter, 1981) suggests that the top of the marine sequence beneath the centre of Ruapehu occurs approximately at sea level, which is indicative of significant basement downfaulting beneath the massif.

\subsection{PREVIOUS WORK}

Gregg (1960) gives a detailed outline of early observations in the Tongariro area, commencing with Bidwill's ascent of Ngauruhoe in 1839. Geologic observations were rudimentary until the late 1880's, when James Park (1887) climbed Ruapehu and described the summit region. In the next few decades, Ruapehu was climbed by numerous geologists; most described only the activity of the crater Lake. Speight (1908) gave an account of the general geology of the Tongariro National Park, which had been established in 1894 through a gift of Maori land to the New Zealand Government. In a number of papers published between 1910 and 1926, James Park described supposed glacial features around Ruapehu. These were replied to by several authors, notably Grange (1931). After Grange's account, there was little doubt that Park's glacial features were in fact the products of lahars.

Grange and his co-workers are to be credited with the first mapping of the Tongariro region (Grange and Hurst, 1929; Grange and Williamson, 1930, 1933). The four 1:63,360 geological maps resulting from these surveys were later included in New Zealand Geological Survey Bulletin 40, The Geology of Tongariro Subdivision (Gregg, 1960). This was the first major compilation of field data for the area and included the age, lithology, faunas and distribution of the surrounding sedimentary deposits, as well as descriptions of the volcanoes themselves. The early surveys were necessarily of a reconnaissance nature, but the following contributions to the volcanic geology of Ruapehu and related vents were made: 
"The western plateau, which occupies more than threefourths of the district, is here formed of Tertiary beds lying horizontal or dipping gently westward and overlain with volcanic debris. From it rise the volcanic piles of Ruapehu, Ngaumhoe, and Tongariro and dominate the Zandscape."

(Grange and Williamson, 1933, p.18).

"Folzowing a period of faulting and erosion in Pleistocene times, volcanic emptions commenced and still continue. Ruapehu and Tongariro, more particularly the latter, have complex histories. "Ancient Ruapehu" was built up of grey andesites probably to a height a little greater than it is today. Its top down to about the 7,000 foot level was removed by collapse or by explosions, but later lava-flows have almost restored the mountain to its former shape and size. Three grey andesite ridges extend up to about the ?,000 foot lever, the most prominent being that on which are situated the needle-like rocks called the Pinnacles. The latest lava-flows from Ruapehu, extending far down the valleys, are dark coloured and have a rough surface simizar to the "aa" of Hawaii."

(Grange and Hurst, 1929, p.6).

"Some seven miles west-north-west from Fuapehu is Hauhungatahi, a small crescent shaped mesa, two miles and a half long and rather more than a mile wide, surmounted on its eastern edge by a small volcano, 4,983 feet high. ...

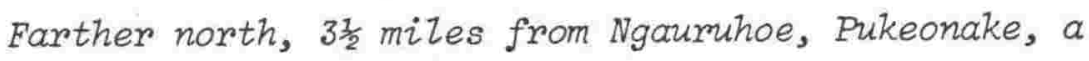
small cone 4,018 feet high stands out from Tongariro.

Raetihi, a small basaltic cone, rises to 2,923 feet a few miles north of Ohakune."

(Grange and Williamson, 1933, p.20).

This early reconnaissance mapping is highly significant in several respects. Grange and his co workers recognized that Ruapehu is a multiple cone with a complex history, as seen from their references to the grey anciesites of "ancient 
Ruapehu" and to the conspicuously young, dark lava flows of northwest Ruapenu. They mapped Hauhungatahi as an eroded volcano, and the parasitic centres at Fukeonake and Ohakune ("Raetihi") were recognized. They also identified "alluvium" and "conglomerate" deposits of several ages, formed during periods of degradation on Ruapehu.

Fleming and Steiner (1950) found no volcanogenic components in the lower Pliocene marine sediments beneath Ruapehu, and inferred that volcanism in the Taupo area must have commenced later than lower Pliocene time. Fleming (1953) identified hypersthene andesite pebbles in Nukumaruan (lower pleistocene) conglomerates of the Wanganui basin, which provides a minimum age of about $1.5 \mathrm{Ma}$ for the beginning of volcanism in the Taupo district.

Grindley (1960) distinguished several lava flow and lahar formations at Ruapehu:

"The history of Ruapehu Andesite voleano is similar to Tongariro but less advanced. The volcano was built to maximum size with a well preserved ring plain (Waimarino Lahars) and is active. Younger flows from Ruapehu ( $\mathrm{m}_{1}$, $\mathrm{mu}_{3}$ ) and from a parasitic cone on the north flank ( $\left.\mathrm{mu}_{2}\right)$ are mapped. Two lahar terraces in the Wangaehu Valley (Houtapu Lahars, Murimotu Lahars) are correlated with waxing of the Ruapehu ice-cap during Stadials of the last Glaciation. Recent lahars ( $f l$ ) are mapped in the Wangaehu Valley and still occur as shown by the Tangiwai disaster of 1953."

With the benefit of vertical aerial photographs, Grindley built upon the earlier observations of Grange, et al. and constructed a geologic map of greater detail. He identified several perioās of eruptive activity at Ruapehu and associated some of the laharic deposits with episodes of glaciation. The influence of NNE-trending normal faults on Tongariro vent locations was also identified. 
In a later map, Grindley and Mathews (1965) listed two andesite formations on Ruapehu, the earlier from the time of "Last Glaciation" and the younger as "post-Glacial". In the accompanying text (Grindley, 1965), the multiple nature of Ruapehu is again referenced:

"Ruapehu is much younger than Tongariro, and in shape and general appearance resembles Mt Egmont in Taranaki, which is probably of comparable age. In distant views, Ruapehu shows faint indications of a two-stage development; the basal section up to 5,000 feet is more deeply dissected, slopes are smoother, and a pronounced break in slope suggests a discontinuity in growth. The youngest extensive flows are those in Whakapapanui Valley, extending from the summit to the Chateau."

To this point, a crude relative chronology had been constructed for Ruapehu massif and its ring plain deposits, largely based on relative degrees of dissection. Stipp (1968) made a significant contribution to Ruapehu geology by providing three whole rock $\mathrm{K}-\mathrm{Ar}$ ages from the mountain. These showed that the oldest subaerially exposed lavas from Ruapehu (as defined in this study) were erupted about a quarter of a million years ago. Younger flows from the southern slopes of Ruapehu returned ages of about 36,000 and 24,000 years.

Hay (1967) mapped lahar deposits from Ruapehu, and Hauhungatahi Andesite to the west of the mountain.

Studies of physical volcanology at Ruapehu include Healy (1965), who made observations on the lahar mounds below the Chateau, and Parsons (1967, 1969). Parsons' (1967) abstract outlines geologic observations on Ruapehu:

"Ruapehu volcano is a compound, andesitic stratovolcano in the Taupo Volcanic Zone of the central North Island, New Zealand. The cone is built largely of thin, massive 
andesite flows and is surrounded by a ring plain of Zaharic breccias and andesitic conglomerates. The last important cone building period occurred during late Pleistocene time, although a few post-glacial flows have been emplaced. Most flows are plagioclase or plagioclase-pyroxene andesites. Recent mapping indicates the presence of an older, partially buried cone on the north side of the volcano. This cone is composed largely of volcanic breccias, in contrast to the flows of the younger main cone. An approximate age of 225,000 years is indicated by potassium-argon (preliminary) dating. A small, complex intmusive plug of fine-grained diorite with an aureole of alteration is present on Pinnacle Ridge. The extmisives are pyroxene andesites similar to the younger flows...."

Parsons also left an undated, unpublished, pencilled map of the Pinnacle Ridge area in the files of the New Zealand Geological Survey, Rotorua (B.F. Houghton, pers. comm., 1981). He mapped a "Pinnacle Series" with dykes, an intrusive plug, altered and unaltered breccias, and moraines. A younger "Whakapapanui Series" was mapped to the west of Pinnacle Riagge, and a "post-Pinnacle, pre-Whakapapanui series" on lower Pinnacle Ridge was mapped as ignimbrite.

Parsons' (1969) review of criteria for the recognition of volcanic breccias includes several illustrated examples from the Tongariro volcanoes. In Plate 1 and the accompanying text (p.271), he describes "eruption debris mixed with brecciated lava flow material" at an undefined locality on Ruapehu. The present writer's observations indicate that this is probably a Pinnacle Ridge deposit. Plate 2 (Parsons, 1969) includes a view of Pukeonake Cinder Cone deposits. Plate 3 and the discussion of page 286 to 287 include descriptions of the lahar mounds deposits on the northern slopes of Ruapehu below the Chateau. 
Topping and his co-workers made several contributions to the Holocene tephra chronology and stratigraphy in the Tongariro region (Topping, 1973, 1974; Topping and Kohn, 1973). Topping (1974) has applied the tephra chronology to Ruapehu and related vents; Pukeonake Scoria Cone, Hauhungatahi, and numerous small craters in the vicinity of ohakune were all shown to have been active prior to 20,000 years ago. The geology of pukeonake tephra and lava flows was discussea in detail by Topping (1974). Most tephra erupted from Ruapehu between about 10,000 to 14,000 years ago were strongly windcontrolled and were deposited to the east or, less frequently, to the north. These Ruapehu tephra comprise most of Topping's (1973) Okupata Tephra Formation, which has a volume exceeding $0.2 \mathrm{~km}^{3}$. He considered the youthful lava fields above the Chateau and on the lower northern flank of Ruapehu to have been erupted between 5,000 and 10,000 years ago, on the basis of their tephra cover. Relatively little tephra were being emitted from Ruapehu between 2,500 and 10,000 years ago. Tephra erupted since 2,500 years ago were probably from the currently-active crater lake vent, with most of the activity from this vent having occurred after the Taupo eruption of 1819 years ago. The post-Taupo Ngauruhoe Tephra Formation (Topping, 1973) has a total volume of $1.3 \mathrm{~km}^{3}$ and its major source was Ruapehu.

Cole and Nairn (1975) outlined the form, structure and geological history of Ruapehu, and addressed the origin of Ruapehu's summit topography:

"The present authors can see no evidence for caldera collapse, and consider that the large number of lahars originating from Ruapehu more than account for material removed from the summit. It is thus considered that the (sumit) craters largely represent explosive emption vents which have been later modified by erosion."

(Cole and Nairn, 1975, p.100). 
In summarizing previous geological work, it is clear that the multiple-vent composite nature of Ruapehu was recognized during the 1920's and 1930's by Grange and his co-workers. Although Grindley (1960) mapped post-Glacial flows on Ruapehu, he did not distinguish the older "grey andesite ridges" which had been noted earlier by Grange, et al. Yet during the mid-1960's, both Parsons (1967, and unpublished map in NzGS Rotorua files) and Stipp (1968) recognized the Pinnacle Ridge and Te Herenga Ridge deposits as segments of an older, deeply eroded Ruapehu cone. Stipp's (1968) contribution of nine $\mathrm{K}-\mathrm{Ar}$ dates from Tongariro Volcanic Centre demonstrated that the oldest subaerially exposed lava flows were erupted about a quarter of a million years ago. Furthermore, the ages from "old Tongariro" and "Old Ruapehu" are nearly comparable within the limits of error. This, along with physiographic evidence, is at odds with Grindley's (1965) statement that Ruapehu is much younger than Tongariro. Both massifs probably commenced activity at about the same time, as judged from both radiometric dating and the comparable degree of dissection of the oldest deposits.

The time of inception of activity at Tongariro Volcanic Centre remains poorly defined. The oldest dated subaerially exposed lavas on the massifs are about a quarter of a million years old, but Fleming (1953) has reported hypersthene andesite pebbles of central North Island provenance in Nukumaruan (about $1.5 \mathrm{Ma}$ ) conglomerates of the Wanganui Basin, and Grindley (1960) reports that the oldest Tongariro flows are exposed in the channel of the Tongariro River. These flows have not yet been dated.

Topping's $(1973,1974)$ Holocene tephra chronology has contributed substantially to knowledge of the volumes and distribution of distal airfall tephra from Ruapehu, as well as enabling datation of some of the younger eruptives on the mountain. 
Cole and Nairn's (1975) work was largely of a review nature, butan additional contribution was made by them in recognizing the origin of Ruapehu summit topography as the result of multiple explosive vents and subsequent erosion, a conclusion with which this writer agrees.

A synthesis of all previous work leads to the conclusion that no detailed geologic studies had been performed on Ruapehu prior to this writing, although general geologic relations had been ascertained.

\subsection{NATURE AND SCOPE OF THIS STUDY}

The primary goal of this section is documentation of the prehistoric geology at Ruapehu volcano and its parasitic vents. Although the cone is surrounded by an extensive ring plain of erosional debris, detailed study has been performed only on the massif - that portion of the cone which is approximately above the 1,000 metre level, which is well exposed, and largely free of bush. Between April 1979 and March 1982, the massif was mapped by ground traverse as to the distribution, relative chronology, structure, and lithology of volcanic deposits. Where significant vertical exposure was present, measured stratigraphic sections were obtained, and these provided a third dimension to complement the ground surveys.

Concurrently with the mapping and stratigraphic studies, specimens of lava flows, pyroclastics, and enclaves were collected for petrographic and chemical studies. These results are reported in later sections.

\subsection{NOMENCLATURE}

1.4.1 Stratigraphic Nomenclature

A detailed stratigraphy for Ruapehu and related vents is given below, with formal stratigraphic designations. Several terms are defined here, following usage in the 1962 edition of the AGI Dictionary of Geological Terms: 
Facies. This term is used in both a petrographic and stratigraphic sense. Petrog.: "Part of a rock body as differentiated from other parts by appearance or composition; a type of rock distinquished from other more or less related types". Stratig.: "A lateral subdivision of a stratigraphic unit, as in lithofacies".

Formation. "The primary unit in lithostratigraphy consisting of a succession of strata useful for mapping or description. Most formations possess certain distinctive lithologic features that may indicate genetic relationships. Ordinarily, the upper and lower boundaries of a formation are determined lithologically, but they may be unconformities... The age or time value of a formation is not necessarily the some wherever it is recognized".

Group. "Lithostratigraphic unit consisting of two or more formations".

\subsubsection{Lithologic Classification}

The nomenclature used here is largely that of Wright, et al., 1980, who have proposed a dual classification:

"No unique classification for pyroclastic rocks can be made and at least two systems are required: (1) a genetic classification, to interpret the genesis of a deposit, and (2) a lithological classification which may be solely descriptive, but which also may be used to discriminate on a lithological basis the mechanisms which produced a particular pyroclastic deposit. ...

... Genetic classification schemes are presented for various types of fall, flow and surge deposits. A lithological classification is given based on grain size limits and distribution, constituent fragments, and degree and type of welding." (from the Abstract).

The grain size limits used here for pyroclastic fragments (Fig. 3) are those of Fisher (1961). Lithologic types (Fig. 4), based on grain size limits and distribution of 


\begin{tabular}{|c|l|l|}
\hline \multirow{2}{*}{$\begin{array}{c}\text { Grain size } \\
\text { (mm) }\end{array}$} & \multicolumn{2}{|c|}{ Pyroclastic fracments } \\
\hline \multirow{2}{*}{256} & coarse & $\begin{array}{l}\text { blocks } \\
\text { and } \\
\text { bombs }\end{array}$ \\
\cline { 2 - 2 } 24 & fine & lapilli \\
\cline { 2 - 2 } 2 & coarse & ash \\
\cline { 2 - 2 } $1 / 16$ & fine \\
\hline
\end{tabular}

FIG. 3. Grain size limits of pyroclastic fragments, after Fisher (1961).

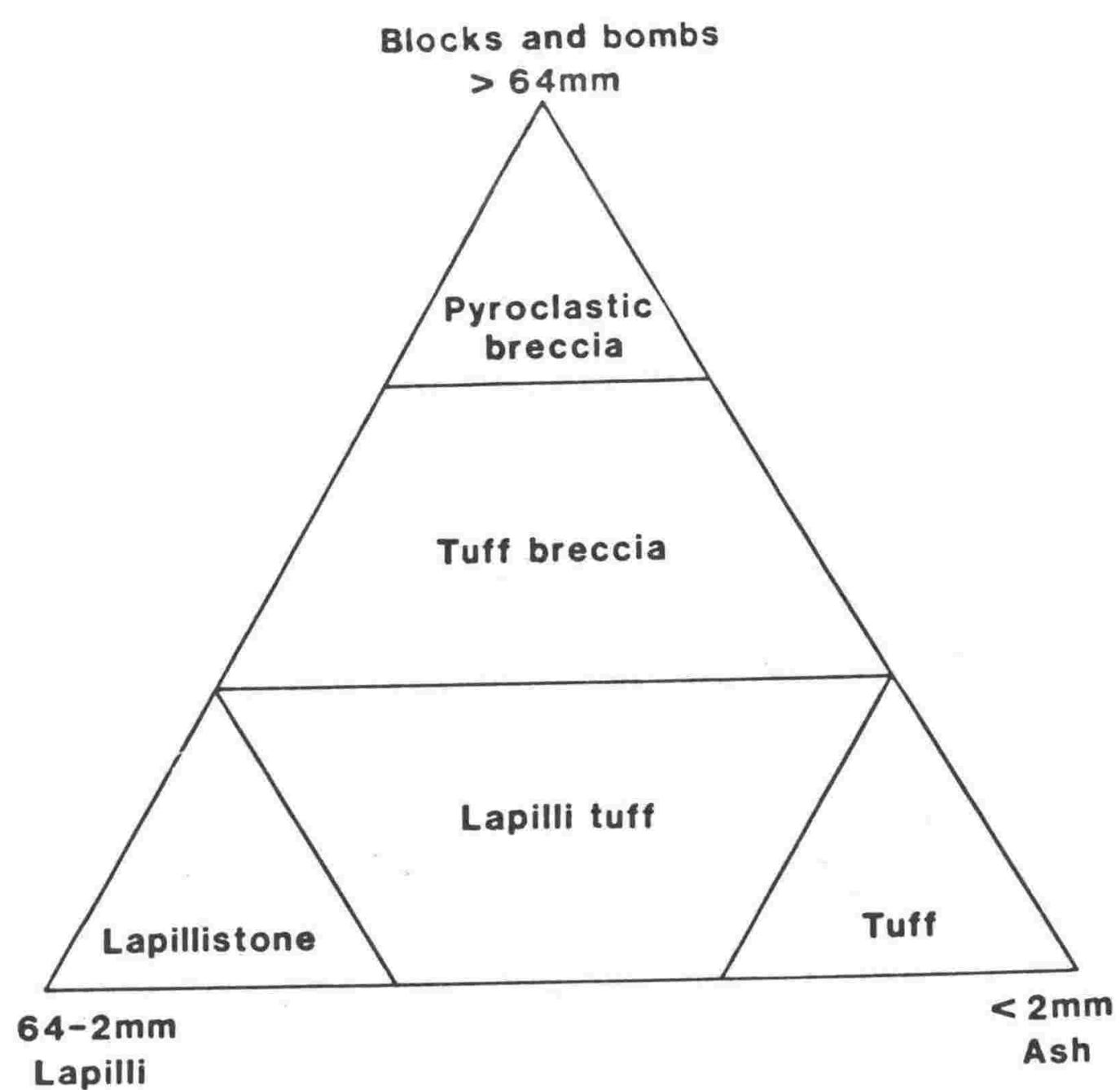

FIG. 4. Lithologic types, after Fisher (1966). Percentage boundaries for the mixtures are purposely omitted, to allow application in the absence of quantitative grain size data. 
pyroclastic fragments, are those of Fisher (1966). The term tuff breccia is used following wentworth and williams (1932, p.46): "volcanic breccias of pyroclastic origin with abundant tuff matrix". In this writer's opinion, the general use of the term tuff for all consolidated deposits of pyroclastic origin (as used by Wright, et al., 1980), while it simplifies terminology, does not adequately convey grain size information. The term tuff breccia is retained here because it adequately describes the wide range of grain sizes which are present in many Ruapehu deposits.

A lithological classification will be used in this study, and when genetic interpretations are possible, these will be discussed separately from the lithological descriptions.

\subsubsection{Genetic Classification}

For the genetic classification of fragmental volcanic deposits, Fisher $(1961,1966)$ emphasizes the process of breaking, and secondly the size of the fragments:

"Genetic categories are autoclastic, pyroclastic, and epiclastic (to which hyaloclastic should be added), thereby placing the emphasis on the manner of fragmentation. It is important to distinguish between fragments that are produced instantly such as the pyroclasts, and those that are produced over a Zonger period of time by the weathering of volcanic rocks ... . Pyroclastic deposits may be dispersed and deposited by streams, but such dispersal does not alter the fact that the fragments are pyroclastic in origin. Thus there may be "primary" (unreworked) as well as "secondary" (reworked) pyroctastic deposits."

(Fisher, 1966, p.296).

It is emphasized that, on the massif, true epiclastic deposits (i.e., fragmented by weathering) are considered to be of very minor abundance, relative to secondary pyroclastic and autoclastic deposits. In practice, Fisher's 
(1966) distinction of these two genetic types has limited application on composite volcanoes. Parsons (1969, p.287) has stated this situation succinctly: "While the resulting breccias are of epigene nature, the actual fragmentation was mainly the result of the volcanic processes".

Parsons (1969) reviewed criteria for the recognition of volcanic breccias, which include (1) structural features (stratification, interbedding with lava flows and sediments, mantle bedding, graded bedding), character of the fragments (size, shape and texture of fragments; degree of sorting; angularity or roundness; vesicularity and percentage of glassy fragments; proportions of essential, accessory, and accidental fragments), and (2) composition and texture of the groundmass (amount of glassy versus crystalline material; porosity; proportion of groundmass to fragments; amount and type of alteration). These criteria will be incorporated here in discussions of genesis.

Genetic classification is based not only on the internal lithologies of units, but also on relationships with other lithologies and on morphology and distribution of the deposits. A summary diagram of genetic types is presented as Figure 5.

\subsubsection{Summary of Lithologic and Genetic Types}

Synthesis of all lithologic information from Ruapehu and related vents, as obtained from ground traverses and measured stratigraphic sections, leads to the recognition of seven lithologic types. To simplify presentation of the stratigraphic data, the measured sections are presented as figures, and lithologic types are noted on the columns with abbreviated labels. Full lithologic descriptions for the measured sections are given in Appendix 1. A general discussion of the lithologic types and their genesis is given below, as a prelude to the more detailed discussions which will occur under the individual Formation headings. 


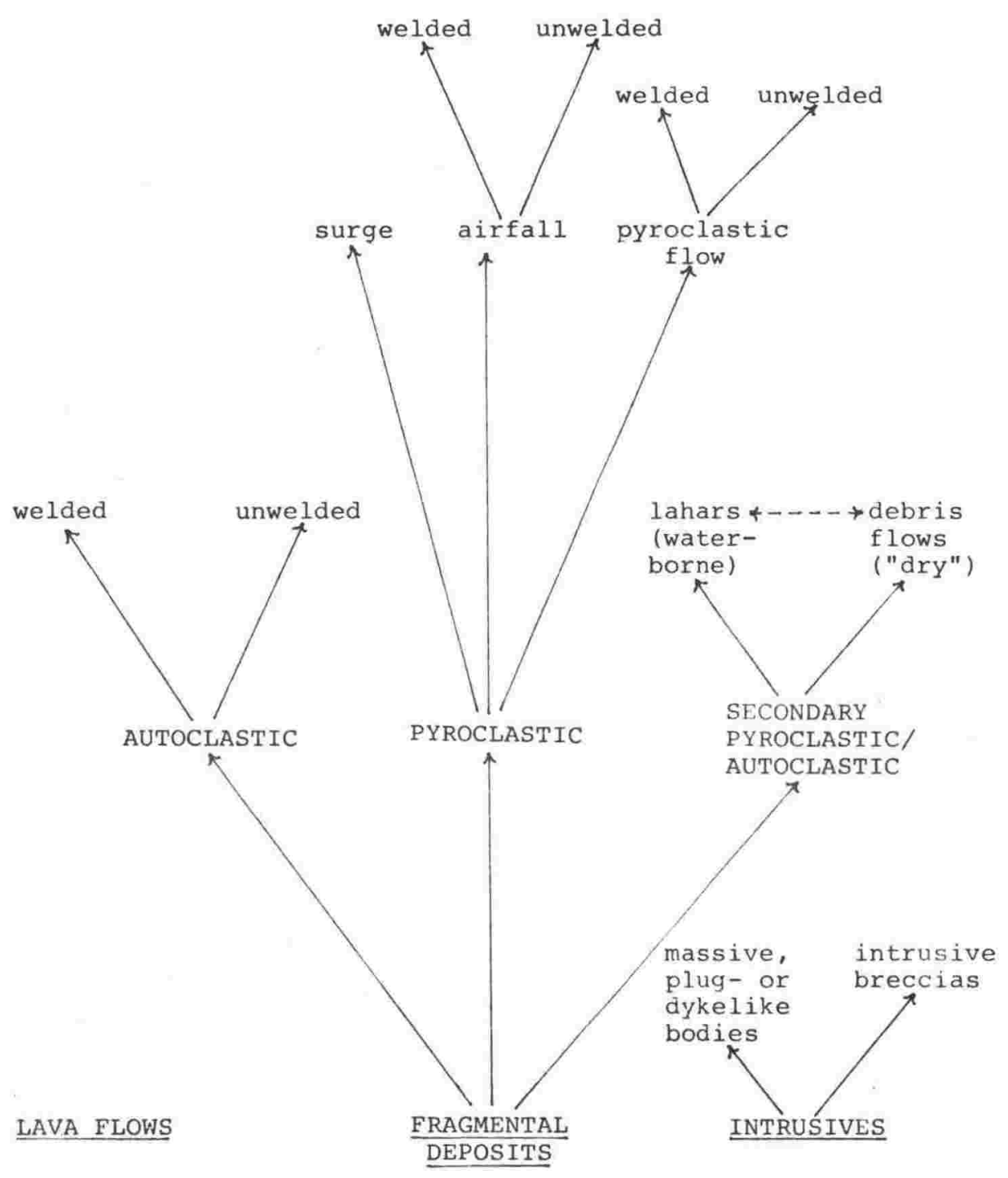

FIG. 5: Summary diagram for Genetic Classification. 
Type of Deposit: Intrusive Igneous Bodies.

\section{Notation: I}

Lithology: Both porphyritic-aphanitic and finely holocrystalline textures are observed. The rocks are usually dense and non-vesicular. Magma bodies occur as vertical, jointed dykes with similar petrography to lava flows, and irregular intrusive plugs which are often highly shattered and jointed. Dyke-like masses of monolithologic tuff breccia are also present.

Relationship to Other Lithologies: Intrusive bodies exhibit cross-cutting relationships with all other deposits. Few concordant intrusives have been identified, but is recognized that these could be confused with lava flows. Near exhumed vent regions, where hypabyssal plugs are closely spaced, hydrothermal alteration pervades both the intrusive bodies and the host cone.

Genesis: These are shallow magma bodies intruded into fragmental deposits and lava flows of the host cone. Local hydrothermal alteration is produced where multiple intrusions have supplied enough heat to drive circulation of phreatic water through the permeable deposits of the host cone. Intrusive breccias originate by the subterranean fragmentation of viscous magma.

\section{Type of Deposit: Lava Flow.}

Notation: L

Lithology: Thicknesses of lava flows vary from one metre to tens of metres, but most are of the order 5 to 10 metres in thickness. They are tabular lithosomes and tend to follow pre-existing drainage channels on the slopes of the edifice. Where exposures are extensive, individual flows can often be traced subaerially or in the subsurface for distances of several kilometres. Flow interiors are transected by a network of irregular fracture surfaces, producing a characteristic blocky jointing. The degree of fracturing is highly variable, but generally equant, angular, metre-sized blocks are produced. A second, non-pervasive type of jointing is nearly always present: subparallel, anastomosing planar 
fractures are developed, commonly parallel to and within a few metres of the bases of flows. This platy jointing is highly characteristic of Ruapehu lava flows. Columnar jointing is sometimes developed in glassy flows, but is not a general phenomenon. Flow banding is commonly developed as contorted laminae in flow interiors, and tabular plagioclase microphenocrysts often exhibit perferred orientation. The banding is usually evident only on weathered surfaces, and is not conspicuous on fresh surfaces or under the microscope. This suggests that the banding is a result of subtle differences in the degrees of groundmass crystallinities.

Lava flows are nearly always phenocryst-rich, containing ten to forty or more volume percent of individual crystals and glomero-phenocrysts. Groundmasses are seldom notably vesicular or glassy, although a dense, microvesicular texture is very common. Centimetre-sized enclaves are ubiquitous in lava flows, and two varieties predominate: White, saccharoidal quartzite, and gray, microcrystalline feldspathic rock. Relationship to Other Lithologies: Lava flows often grade into coarse, monolithologic tuff breccias of welded and unwelded character (see: TBm below). Lava flows are interbedded with all other lithologies at the scale of an outcrop. Genesis: The lava flows were produced during relatively mild effusions of viscous, de-gassed magma, and were emplaced subaerially as tabular bodies with primary dips between about fifteen and thirty-five degrees. A high viscosity for the magmas is inferred from two commonly observed characteristics; the tendency to brecciate under the influence of gravity, and to develop internal shear planes (platy jointing).

Type of Deposit: Monolithologic Tuff Breccia. Notation: TBm, TBmw.

Lithology: These deposits are coarse, unbedded, unsorted tuff breccias with a single clast petrography. The clasts have a porphyritic-aphanitic texture which is identical to that of lava flows. Individual dense, microvesicular clasts are usually angular to subangular and nearly always constitute a 
clast-supported deposit, although matrix-supported varieties are present. The degree of clast rounding is coincident with the degree of matrix-supported character. A complete size gradation exists, from metre-sized angular blocks to fine ash matrix, although the proportion of ash-sized material is always minor. The fine material consists of rock fragments and crystals; no pumice or glass shards are present. The matrix and outer rinds of blocks are characteristically oxidised to a brick-red colour. These deposits are subdivided into unwelded (TBM) and welded (TBmw) varieties. Relationship to Other Lithologies: These fragmental deposits grade laterally and vertically into coherent lava flows, the transition usually occurring over distances of less than 0.5 metres. They are commonly interbedded with, and are sometimes gradational into heterolithologic tuff breccias (TBh). Genesis: TBm and TBmw are not consistent with airfall origin, due to their poor sorting and absence of internal stratification. The lithologic characteristics and common association with lava flows are consistent with an interpretation as autoclastic breccias, produced by the fragmentation of actively growing lava flows through gravitational collapse on steep slopes. Fiske, et al., (1963, p.74) have described similar deposits on the upper slopes of Mt Rainier:

"Interstratified with these lavas high on the mountain are breccias formed by explosive shattering of the lava flows. They contain fragments of porous or compact glassy lava, ranging from small chips to blocks as much as ten feet across, in a matrix of sand-and silt-sized glass particles and crystals. The blocks in these breccias are not a varied assemblage of different kinds of lava, such as might be torm by explosions from the walls of a conduit, but are glassy and scoriaceous equivalents of the adjacent partly crystalline lava into which they grade. The blocks have rough, slaggy surfaces, many of which are reddened by oxidation, or they are covered by agglutinatelike crusts. The breccia commonly grades up through pods and lenses of slaggy, brecciated 
and agglutinated lava into less shattered and reddened lava, and finally into massive lava forming a definite flow. Other breccias are on the tops of flows, and grade downward into them. Still other breccias do not visibly grade into flows, but they enclose small to large roughly concordant streaks, pods and tongues of slaggy Zava."

The coincidence of rounded clasts and matrix-supported character is strong evidence that the matrix is derived by attrition of originally angular clasts. Attrition can occur when blocks are spalled off the noses of actively growing flows, while the active flows override and crush their own debris, or during secondary transport long after effusion has ceased. The ubiquity and great volume of this type of tuff breccia on Ruapehu, and its association with heterolithologic tuff breccias, suggest that the process of autobrecciation produces a major proportion of the fragmental deposits on Ruapehu massif.

Type of Deposit: Heterolithologic Tuff Breccia. Notation: TBh.

Lithology: These poorly sorted tuff breccias contain two or more clast petrographic types and are commonly matrix-supported, in contrast to $\mathrm{TBm}$. Individual clasts can occur up to metre size, and range from angular to subrounded. The degree of rounding and alteration is coincident with increasing vesicularity of clasts, which can range from dense to pumiceous in a single deposit. Clasts can exhibit breadcrusted outer surfaces and intense internal fracturing, while maintaining coherence as individual fragments. Clasts are present exhibiting varying degrees of alteration and oxidation. Very poor sorting is characteristic and complete gradation down to ash grade is common. Matrices are generally reddish brown to pale buff or gray in colour, consist of rock fragments and crystal fragments, and are usually indurated but not welded. Crude internal stratification is sometimes evident in subtle vertical changes of average grain size, or in laterally 
continuous zones of slightly better sorted material. Stratification commonly occurs between depositional units. Relationship to Other Lithologies: TBh are interbedded with all other lithologies. Gradational contacts occur only with TBm and with SG.

Genesis: Genetic interpretations for these deposits must rely not only on lithology, but also on proximity to the inferred vent regions. Explosive eruptions can produce pyroclastic flow deposits with many of the above characteristics; extremely chaotic deposits with no internal stratification and very poor sorting, and containing fragments of previously consolidated and altered rocks, as well as juvenile magmatic fragments. Airfall origin is precluded by the poor sorting, lack of well developed internal stratification, and absence of impact structures beneath large clasts.

Major question arises as to the role of secondary deposition. on the massif, these deposits occur within four kilometres of the inferred vent regions, and can be traced into the vent regions without notable changes in lithology (aside from postdepositional hydrothermal alteration). Thus, the fragments clearly derive directly from active volcanism, and pyroclastic flow mechanisms involving the collapse of eruption columns seem viable. However, the crude internal stratification and the presence of subrounded clasts in many of these deposits suggest some degree of secondary transport. This leads to the question of when to cease labelling deposits as unwelded pyroclastic flows and to begin calling them lahars or debris flows. On Ruapehu massif, lithologic criteria alone are insufficient for deducing the role of secondary transport.

Genetically, all TBh are subaerially emplaced mass flows, probably ranging from cold lahars which were fluidized by water, to relatively dry debris flows, to hot pyroclastic flows which were fluidized by gas. The distinction between "wet" lahars and "dry" debris flows is not easily made. Neither is "hot" emplacement easily demonstrated, and requires 
lithologic evidence (pervasive high temperature oxidation and/or welding; breadcrusted clasts present) as well as paleomagnetic evidence (non-random magnetic vectors for the clast population), in order to postulate high emplacement temperatures.

Type of Deposit: Bedded sand and gravel.

Notation: SG

Lithology: These moderately- to well sorted deposits are heterolithologic and usually matrix-supported. Nearly all clasts are of gravel size or smaller, and show some degree of rounding. Thicknesses of deposits are several metres or less. Internal planar and high angle cross stratification are well developed on a centimetre to decimetre scale.

Relationship to Other Lithologies: SG are nearly always interbedded with TBh and are sometimes gradational into TBh, but comprise a minor component of the overall stratigraphy. Genesis: The sedimentary structures and sorting suggest fluvial origins by redeposition of fine pyroclastic/autoclastic material. Sheet wash, leading to the generation of small, water-laden "lahars" under conditions of heavy rainfall, is a viable mechanism. This process has been observed by the author during field studies.

Type of Deposit: Well sorted, mantle bedded breccia (bombs and blocks) or tuff (lapilli and ash) deposits; BW and Tw are welded equivalents.

Notation: $\mathrm{B}, \mathrm{T}$; $\mathrm{Bw}, \mathrm{Tw}$

Lithology: Well sorted, monolithologic, mantle bedded deposits consisting of angular cognate lithic blocks, rounded vesicular bombs, and subordinate accessory lithic blocks. Well developed internal stratification, shower bedding, good sorting, presence of distinguishable fall units and, where sufficient exposure exists, a systematic decrease in thickness and grain size away from source are characteristic features. Impact structures are present beneath large clasts. Ash grade material is crystal-vitric tuff or vitric-crystal tuff.

Complete gradation exists between the extremes of unwelded and densely welded lithologies. The welded varieties 
(Bw and Tw) also exhibit good sorting when individual clasts can be recognized, and are internally stratified. Lateral and vertical changes in the degree of welding are well developed, and the deposits are most densely welded where the thickness is the greatest. $\quad \mathrm{BW}$ and $\mathrm{Tw}$ are often interstratified with massive, dense, lava-like deposits which seldom exceed a few metres in thickness and may or may not be laterally continuous at the scale of an outcrop. Conspicuous flow banding is developed in some of these dense layers. Relationship to Other Lithologies: Unwelded $\mathrm{B}$ and $\mathrm{T}$ are rare on the massif but are associated with all other lithologies. Contacts with lithologies other than BW and Tw are abrupt.

Genesis: All lithologic characteristics are consistent with airfall origin. Unwelded airfall breccias and tuffs are rare on the massif and are largely restricted to the Holocene. These poorly consolidated deposits apparently have a low preservation potential and were rapidly removed from the steep slopes by fluvial and mass wasting processes. Fine airfall material probably comprises a significant proportion of the matrices in secondary mass flow deposits (lahars and debris flows) of the ring plain.

Bw and Tw are interpreted as welded airfall deposits. Welded airfall tuffs have been described by sparks and Wright (1979) and by Wright (1980). In contrast to ignimbrites, which exhibit regular zones of internal welding produced by compaction of plastic pumice fragments, welded airfall tuffs show significant vertical and lateral fluctuations in flattening of clasts, porosity and density. Sparks and Wright (1979) have attributed these fluctuations to the heterogeneous nature of the stratified airfall ejecta. These authors consider that rapid accumulation is critical toward producing welding in airfall deposits.

Some of the thin, dense, flow banded deposits intercalated with Bw and Tw are probably rheomorphic welded tuffs: 
"Rheomorphism ("flow change") of a welded tuff is the secondary mass flowage of the tuff as a coherent viscous fluid. Rheomorphic welded tuffs are characterized by stretched fiamme which define a lineation parallel to the flowage direction. Flowage is capable of producing folding and other internal flow stmuctures similar to those found in salic lava extmusions." (Wright, et al., 1980, p.332).

\subsubsection{Field Petrographic Nomenclature}

Ruapehu lavas fit a broad petrographic definition of andesite: Mesocratic porphyritic-aphanitic rocks which lack quartz, K-feldspar, and feldspathoids. Hand specimen terminology for Ruapehu lava flows and fragmental deposits is straightforward since nearly all the eruptives contain phenocrysts of plagioclase (plag), augite (cpx) and orthopyroxene (opx). Abundant conspicuous plagioclase phenocrysts are present, generally with lesser amounts of two pyroxenes in approximately equal proportions (i.e., plag $\mathrm{cpx}+\mathrm{opx}$, and $\mathrm{cpx} \simeq \mathrm{opx}$ ). Accessory amounts (less than about one volume percent) of opaque oxide microphenocrysts are present in many lavas, but are inconspicuous in hand specimens. Accessory olivine (ol) is common, but amphibole (am) is rare.

For purposes of geologic discussion, mineral prefixes to the rock names follow the order of modal abundance in hand specimens. Thus, a lava with plagioclase phenocrysts dominant over pyroxenes is termed a plag-cpx-opx andesite. It is usually not possible to accurately judge the relative proportions of $\mathrm{cpx}$ and opx in hand specimens. If a lava contains accessory olivine, it is termed "ol-bearing'. It is emphasized that hand specimen petrography is insufficient for predicting the silica contents of rocks in the field. Andesites and dacites are usually petrographically identical, and conspicuously olivine-bearing lavas range from basalt to anciesite in bulk composition. "Andesite" may be replaced by 
other rock names when the silica content is known from quantitative bulk rock analysis. "Basalt" has less than 53 wt silica, "basic- or low-silica andesite" (used interchangeably by this writer) has between 53 and 57 wt $\%$ silica, "acid andesite" contains 57 to 63 wt $\%$ silica, and "dacite" has greater than 63 wt $\%$ silica. This is a generalization of the chamical terminology of Gill (1981), which will be used in later sections on petrology. The use of these rock names is intended to convey an idea of the compositional variation during geologic discussion. Detailed petrography and major element chemistry is given in Part II. 


\section{GEOLOGY OF RUAPEHU MASSIF}

\subsection{INTRODUCTION}

New formation names proposed for the Ruapehu Group are given in the general stratigraphy, Figure 6, and the subaerial distribution of these formations is given in the generalized geologic map, Figure 7. A detailed geologic map at 1:25,000 scale is present inside the back cover of this volume. It is emphasized that formations are distinguished on the basis of lithologic and petrographic characteristics, in conjuction with conspicuous unconformable relations which define the formation boundaries.

Measured vertical sections are presented, and type areas are designated for each of the formations.

\subsection{USE OF 'FORMATION' FOR VOLCANIC ROCK UNITS}

Although the formations have been established following formal stratigraphic convention, i.e., they are small lithostratigraphic units useful for mapping and description, the nature of volcanic deposits demands a concise definition of this basic stratigraphic unit.

Stratovolcanoes such as Ruapehu are typically among the most complex of volcanic terrains. The distal airfall pro-ducts of stratovolcano eruptions obey the usual stratigraphic axioms of superposition and, to a lesser extent, lateral continuity. In distal regions, it is often possible to recognize single airfall units or groups of temporally related airfall units, and to formally define these as stratigraphic members or formations. Such a stratigraphy was accomplished by Topping (1973), who defined numerous andesitic tephra formations as comprising the Tongariro Subgroup, a sequence of largely airfall deposits which spans the past 14,000 years. Individual airfall units, sometimes 

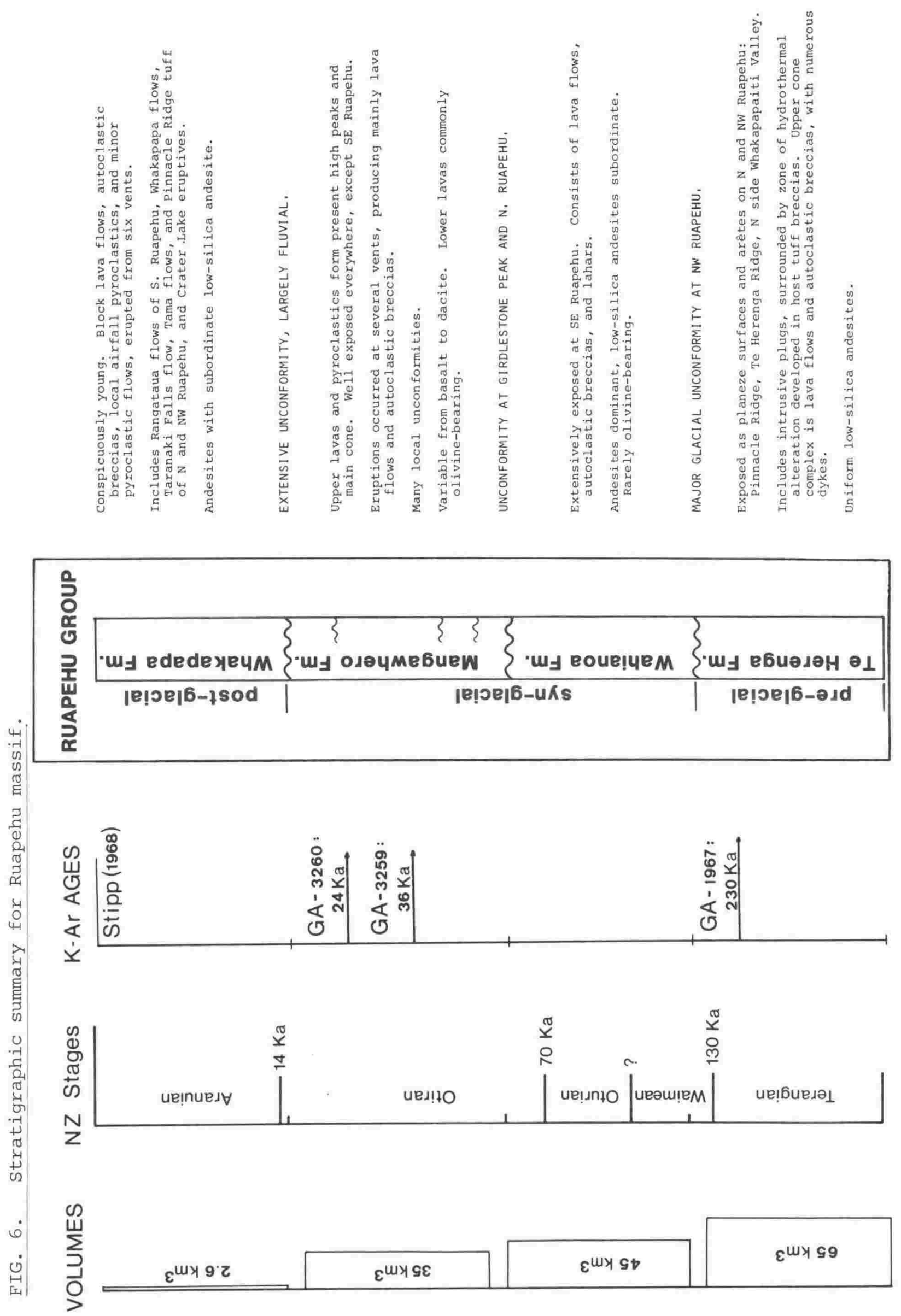


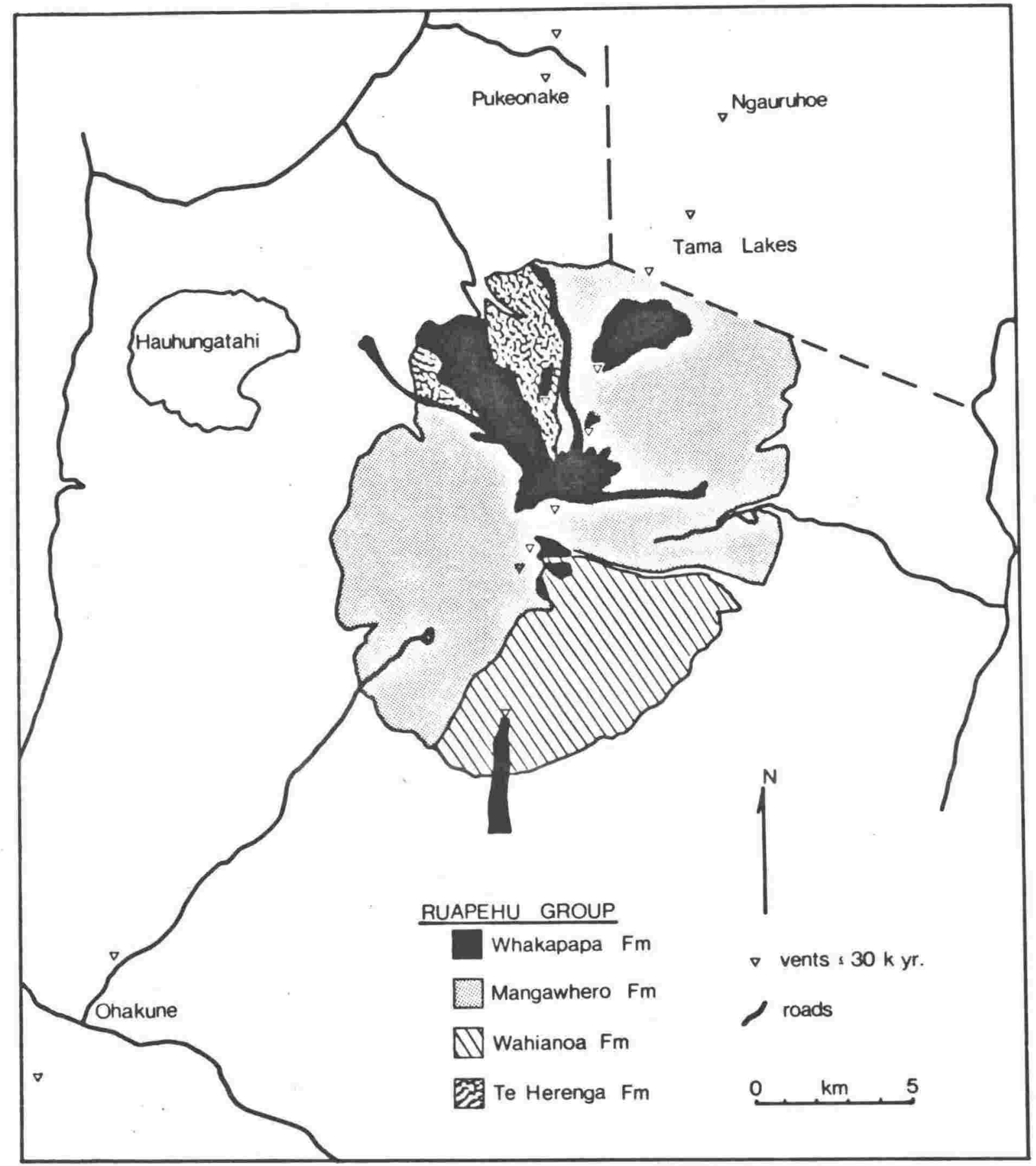

FIG. 7. Generalized geologic map of Ruapehu and related vents. Note the northeasterly alignment of young vents, which parallels the regional trend of normal faults. 
mapped as formations, probably represent several hours or days of activity. Groups of temporally-related airfall units, also mapped as formations, general represent $10^{2}$ to $10^{3}$ years of deposition. Formations can also be defined as the products of each individual monogenetic parasite vent, probably representing months to years of activity.

By contrast, stratocones themselves are regions of persistent volcanism and intense erosion, with concurrent deposition of tabular, valley-confined lava flows, pyroclastic flows, and lahars, as well as more widely dispersed airfall deposits. Local unconformities are common, and the lengths of time they represent are not easily deduced. The observed stratigraphy not only reflects the character of eruptions, but also the potential for preservation. Thus, as will be shown below, poorly consolidated airfall material is rare in the prehistoric record at Ruapehu massif. Rapid lateral changes in lithology occur, and local observations of apparent superposition can lead to erroneous conclusions. In such terrains, a working definition of "Formation" is the smallest lithostratigraphic unit mappable over a large area. At conventional scales of mapping, i.e., 1:25,000 to 1:100,000, the most clearly recognizable subdivision is to group as formations all the products of each discrete cone-building episode. The time scale of such units is probably of the order $10^{4}$ to $10^{5}$ years, as opposed to $10^{0}$ to $10^{3}$ years for the deposition of related airfall formations in distal regions.

\subsection{USE OF 'FACIES' FOR VOLCANIC ROCK ASSOCIATIONS}

The recognition of volcanic facies has proved valuable during the volcano-stratigraphic study of Ruapehu and related vents, and follows the treatment of Williams and McBirney (1979, p.311-312): 
"Certain features are diagnostic of rocks laid down close to emptive vents; others are more typical of the outer slopes, and still others are more likely to be found at greater distances from the locus of volcanism. In such terms, volcanic rocks of any age can be grouped into volcanic facies, not unlike the depositional facies of sediments or the mineralogic facies of metamorphic rocks.

A single outcrop may have no unique significance, but taken together the rocks of various spatial zones have distinctive characteristics. They can be divided into three broad volcanic settings, sometimes referred to as central, proximal and distal zones. Each of these zones can be recognized from one or more lithologic features that is typical of that particular environment of deposition."

Figure 8 is a generalized scheme of these volcanic facies. At Ruapehu, the central facies occurs within about $0.5 \mathrm{~km}$ of the central vent regions. This association is characterized by (1) thin lava flows which are often volumetrically subordinate to fragmental deposits, (2) coarse, poorly sorted breccias and tuff breccias, (3) steep primary dips which are radial to the central vent, (4) dykes which are usually, but not always, radially oriented, (5) small, irregular intrusive bodies which have deformed the deposits of the host cone, and (6) pervasive hydrothermal alteration with steep lateral gradients.

Deposits of the slopes and outer flanks of the cone complex comprise the proximal facies, which includes (1) voluminous and extensive lava flows with associated autoclastic breccias, (2) laharic tuff breccias with angular to subrounded clasts up to several metres in size, (3) volcaniclastic debris which has been reworked by water, and (4) subordinate airfall tephra layers with grain sizes mainly in the lapilli to coarse ash range. 


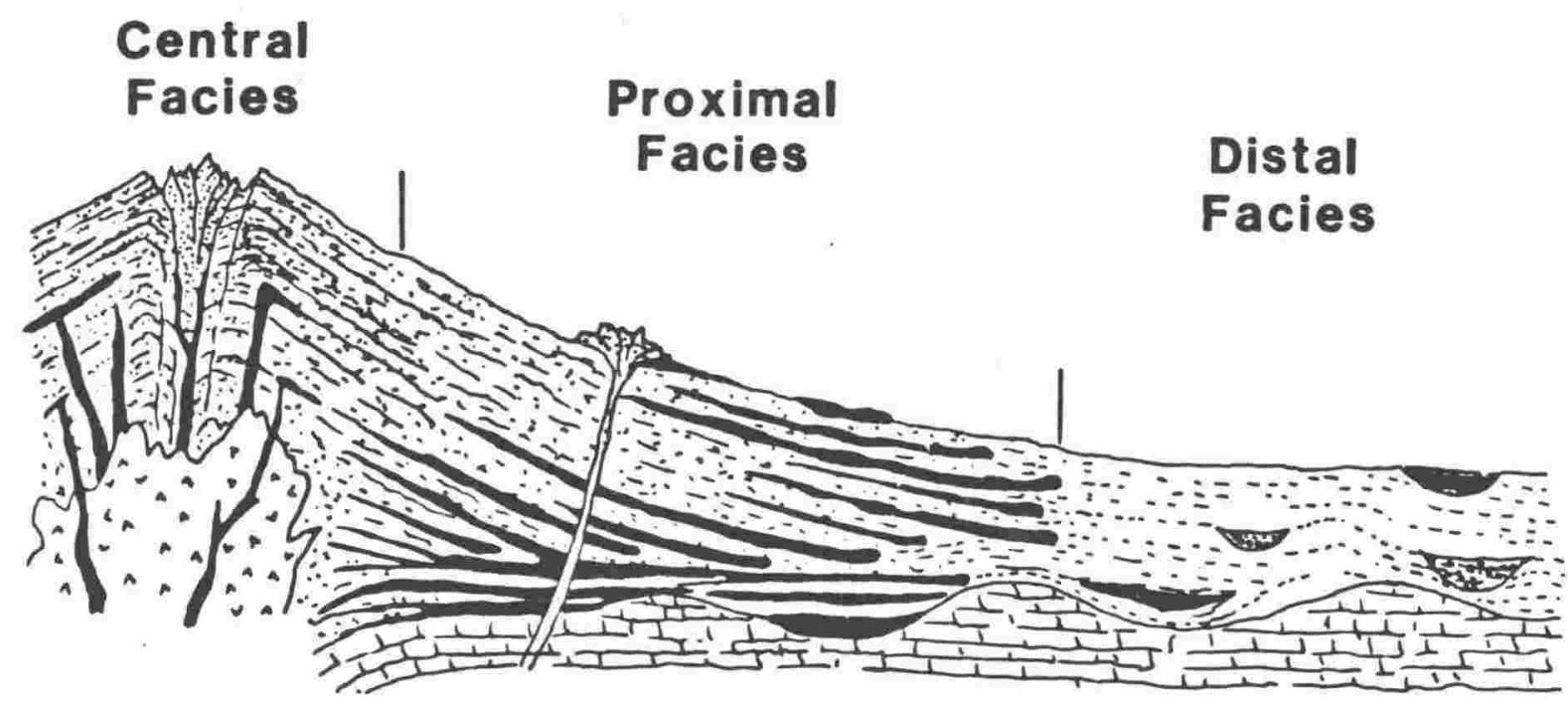

FIG. 8. Scheme of volcanic facies for a composite volcano. Modified after Williams and McBirney (1979, p.313). 
The distal facies of Ruapehu has not been extensively studied here. This facies encompasses deposits which are collectively referred to as the 'ring plain', and includes (1) lahars with subrounded clasts and abundant sand- to mud-sized matrix, (2) finely layered tephra with grain sizes largely in the ash range, (3) interlayered soils and organic matter, and (4) lava flows largely restricted to isolated vents and to local, valley-filling flows.

\subsection{TE HERENGA FORMATION (New Formation Name)}

\section{DISTRIBUTION, THICKNESS AND VOLUME}

The Te Herenga Formation is named from Te Herenga Ridge, a prominent topographic feature of the northern slopes of Ruapehu at about 1,550 metre elevation. The Te Herenga Formation is not exposed over large areas of the mountain, and is restricted to arêtes and planeze surfaces on the northern and northwestern slopes (Fig. 9). The best exposures occur at Pinnacle Ridge, Te Herenga Ridge, and the unnamed ridge and planeze surface to the north of the upper Whakapapaiti Stream. The formation includes lava flows, tuff breccias, and intrusive bodies which occupy these areas and are unconformably overlain by younger deposits. The greatest thickness, about 300 metres is exposed in the Whakapapanui valley, north Ruapehu. The volume of the formation cannot be estimated with precision owing to the extensive cover by younger formations, and subsequent erosion. Assuming a simple cone-like geometry and allowing for material removed by erosion, the original volume was probably of the order $65 \mathrm{~km}^{3}$.

TYPE AREAS: Pinnacle Ridge, Te Herenga Ridge

\section{FORMATION BOUNDARIES}

The base of the Te Herenga Formation is not exposed, and at depth these deposits probably rest unconformably on Tertiary marine sediments of the subvolcanic basement. A conspicuous unconformity, largely of glacial origin, separates the eroded remnants of the Te Herenga cone from younger formations. At 

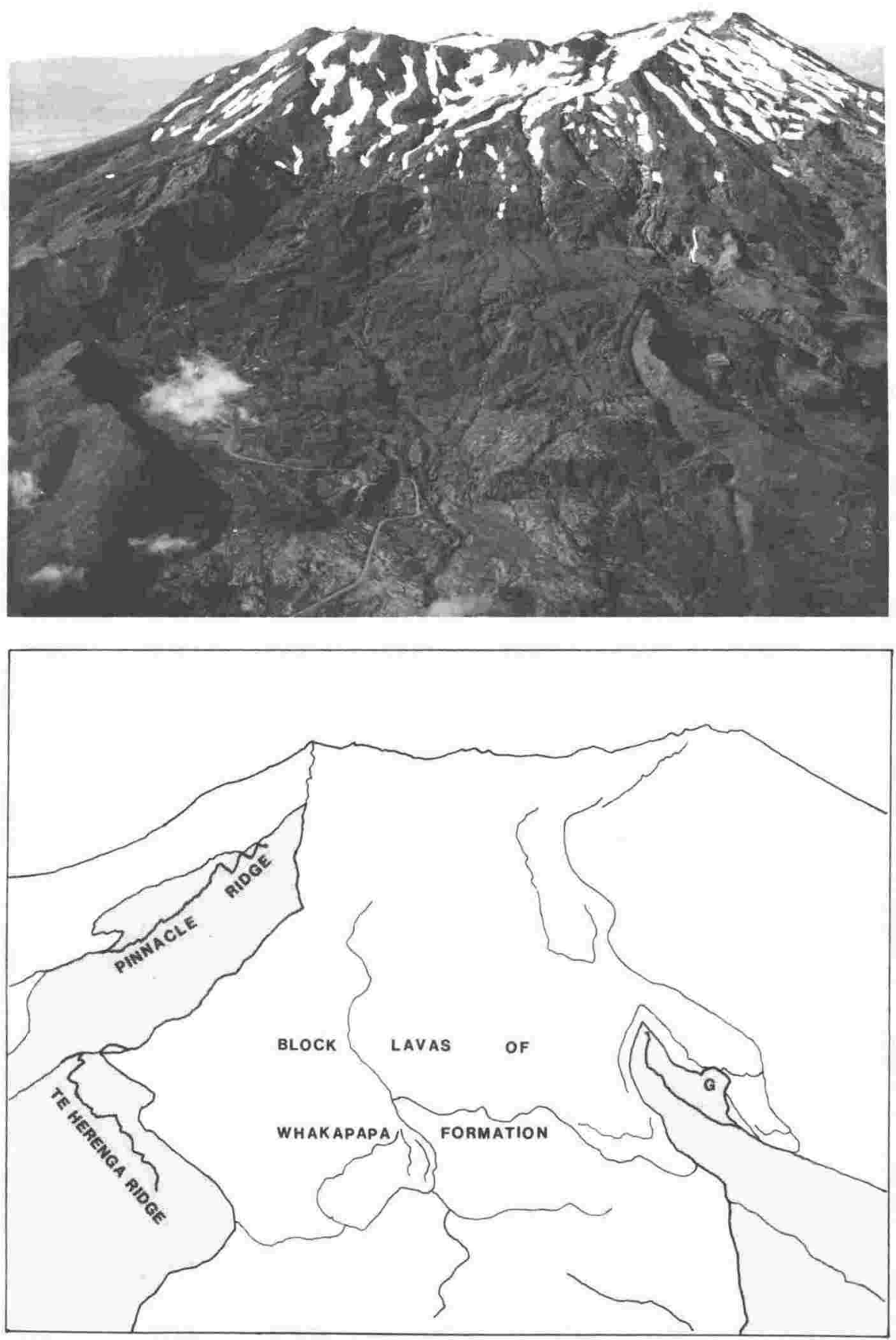

FIG. 9. Aerial view of the northwest slopes, Ruapehu. Te Herenga Formation is indicated by the shaded pattern. Intrusive bodies and a surrounding zone of hydrothermal alteration comprise the central facies of upper Pinnacle Ridge. Lower Pinnacle Ridge, Te Herenga Ridge, and the unnamed ridge at the lower right consist of proximal facies deposits. The unnamed ridge is an arête capped by lateral moraine, and glaciated surfaces are present at "G" (see Fig. 83). Lava flows of the Whakapapa Formation now occupy the broad glacial valley which was developed in the Te Herenga cone. 
most localities, the Te Herenga Formation is unconformably overlain by lava flows of the post-glacial Whakapapa Formation, and the contact relations are particularly well displayed in the upper Whakapapanui Gorge beneath Mead's Wall, and along the northern side of the unnamed ridge which lies to the north of the Whakapapaiti Stream. Te Herenga Formation is unconformably overlain by Mangawhero Formation in the headwaters of the Whakapapaiti Stream (Ruapehu Section 12, Fig. 16).

\section{LITHOLOGY AND PETROGRAPHY}

Deposits of the Te Herenga Formation exhibit great lithologic but little petrographic variation. All lithologic types, except mantle bedded breccias and tuffs ( $B$ and $T$ ) are represented in the measured sections and in other outcrops. Lava flows and associated monolithologic tuff breccias (TBm) comprise about half of the total measured stratigraphy. Lava flows, large angular clasts from the tuff breccias, and dykes exhibit uniform petrographic characteristics. In hand samples the most striking feature of the petrography is the conspicuous glomerophenocrysts of pyroxene which, in contrast to plagioclase, are prominent against the pale matrix. Olivine is absent. Intrusive microdiorite plugs are mineralogically similar to lavas and blocks of the host cone, but exhibit finegrained intrusive textures with great variation in the degree of crystallinity.

\section{$\underline{\text { AGE }}$}

A single whole rock $\mathrm{K}-\mathrm{Ar}$ age of $0.230 \pm 0.006 \mathrm{Ma}$ is given by Stipp (1968), from a lava flow on Te Herenga Ridge. This dates the upper part of the formation, and the age is supported by the paleomagnetic data of Halama (1981), which show that the Te Herenga Fm lava flows of Te Herenga Ridge and Whakapapanui Gorge are all normally magnetized and therefore younger than the Brunhes/Matuyama boundary. The total 
time span of Te Herenga Formation emplacement is unknown, but the absence of both paleosols and major intraformational unconformities suggests rapid cone construction.

\section{VOLCANIC FACIES}

\section{(i) Central Facies \\ Outcroppings of small (tens of metres), irregular} intrusive bodies comprise the uppermost portion of Pinnacle Ridge. These solidified within radially dipping tuff breccias and subordinate thin lava flows of the central cone. Brittle deformation of the tuff breccias and lavas is evident in local dip reversals and oversteepening of beds from 45 degrees to nearly vertical. The intrusives are highly jointed and shattered, are transected by a complex network of highly altered breccia dykes, are themselves pervasively altered to varying degrees, and are surrounded by a brownish aureole of hydrothermal alteration. Megascopic features of the central facies are shown in Figure 10, and outcrop features are given in Figure 11 .

Plagioclase of the intrusives has commonly been totally replaced or veined with pale olive-green clays (montmorillonite, mixed layer illite/montmorillonite, and minor pyrophyllite), and pyroxenes are often replaced by clays and subhedral sulfides. The surrounding zone of hydrothermally altered tuff breccias and thin lava flows is about 80 metres wide, and is crudely zoned both laterally and vertically. An inner zone of orange-brown alteration (gossan) extends from the intrusions for a distance of about 30 metres. Here, the tuff breccias are intensely shattered, are cut by random veins of clay, and are pervaded by finely disseminated sulfides. Many of these breccias have the appearance of advanced spheroidal weathering. Outward from this, pervasive alteration, involving mostly clays and lesser sulfides, gives the breccias a deep green colour. Vertical and lateral zonation is further indicated by veins of colloform silica with associated kaolinite, at the outer periphery of the aureole. 

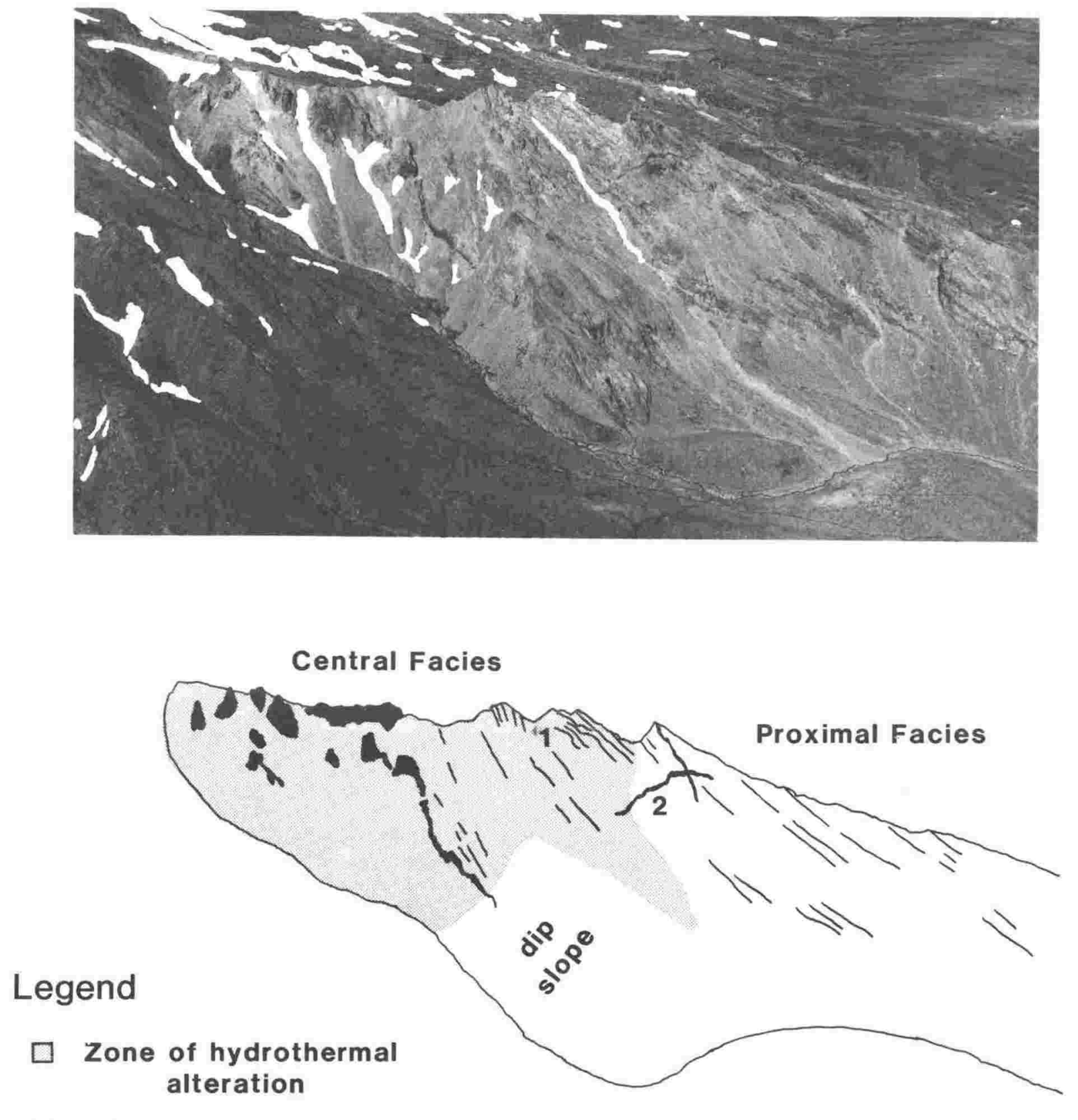

- Intrusive bodies

1 Oversteepened and buckled strata

2 Dyke of Whakapapa Fm.

FIG. 10. Aerial photograph of the northeastern slopes, showing megascopic features of the Te Herenga Formation exposed at upper Pinnacle Ridge. Note progressive oversteepening of strata toward the vent region, as a result of deformation by intrusive bodies. 

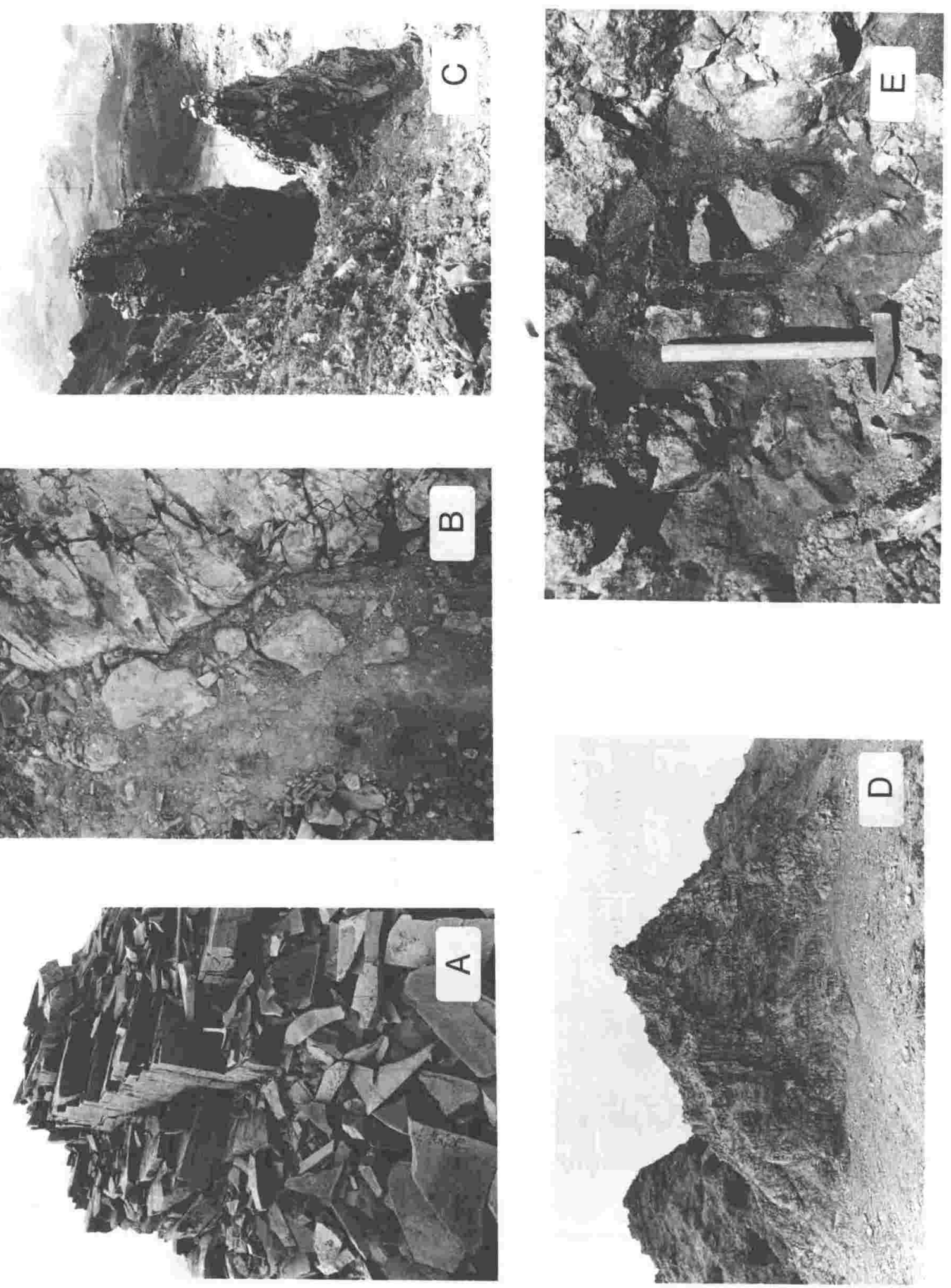
The primary lithologies, deformation, and hydrothermal alteration are expected characteristics of volcanic vent regions. The montmorillonite and mixed layer illite/montmorillonite-dominated alteration assemblage implies relatively low temperatures (less than about $220^{\circ} \mathrm{C}$., which is approximately the point at which illite plus chlorite become dominant), and/or a brief time for the activity of the system (Browne, 1978). Brief duration and low temperatures are consistent with the geology, since the intrusive bodies and the surrounding aureole cover only a small area of about $900 \mathrm{~m}^{2}$. The hydrothermal system is inferred to have existed under nearsurface conditions, as indicated by the hypabyssal textures of the intrusives, brittle behaviour of the deformed tuff breccias, and deposition of silica and kaolinite at the outer periphery of the aureole. The latter aspect is a common occurrence where hydrothermal waters cool and acidify under near-surface oxidizing conditions. The surface of the vent region was probably on the order of 50 to 100 vertical metres above the present-day exposures. Such processes of intrusion, with attendant deformation and hydrothermal alteration, can be imagined beneath the currently-active vent region of Ruapehu.

\section{Proximal Facies}

The proximal facies is well exposed along Pinnacle Ridge, on Te Herenga Ridge, and in the Whakapapanui Gorge which separates these ridges (Figs. 12 and 13). Further exposures occur along the unnamed ridge to the north of Whakapapaiti stream, and in the headwaters of the Whakapapaiti stream. Three measured sections are presented (Figs. 14, 15, 16), one from the Whakapapanui Gorge, one from Te Herenga Ridge, and one from the Whakapapaiti valley. The two valley sections represent the lower portion of the proximal facies, and the Te Herenga Ridge section represents the upper portion.

Three major lithologic types are recorded in the sections. About half of the total measured stratigraphy consists of lava flows and associated monolithologic tuff breccias (TBm), 


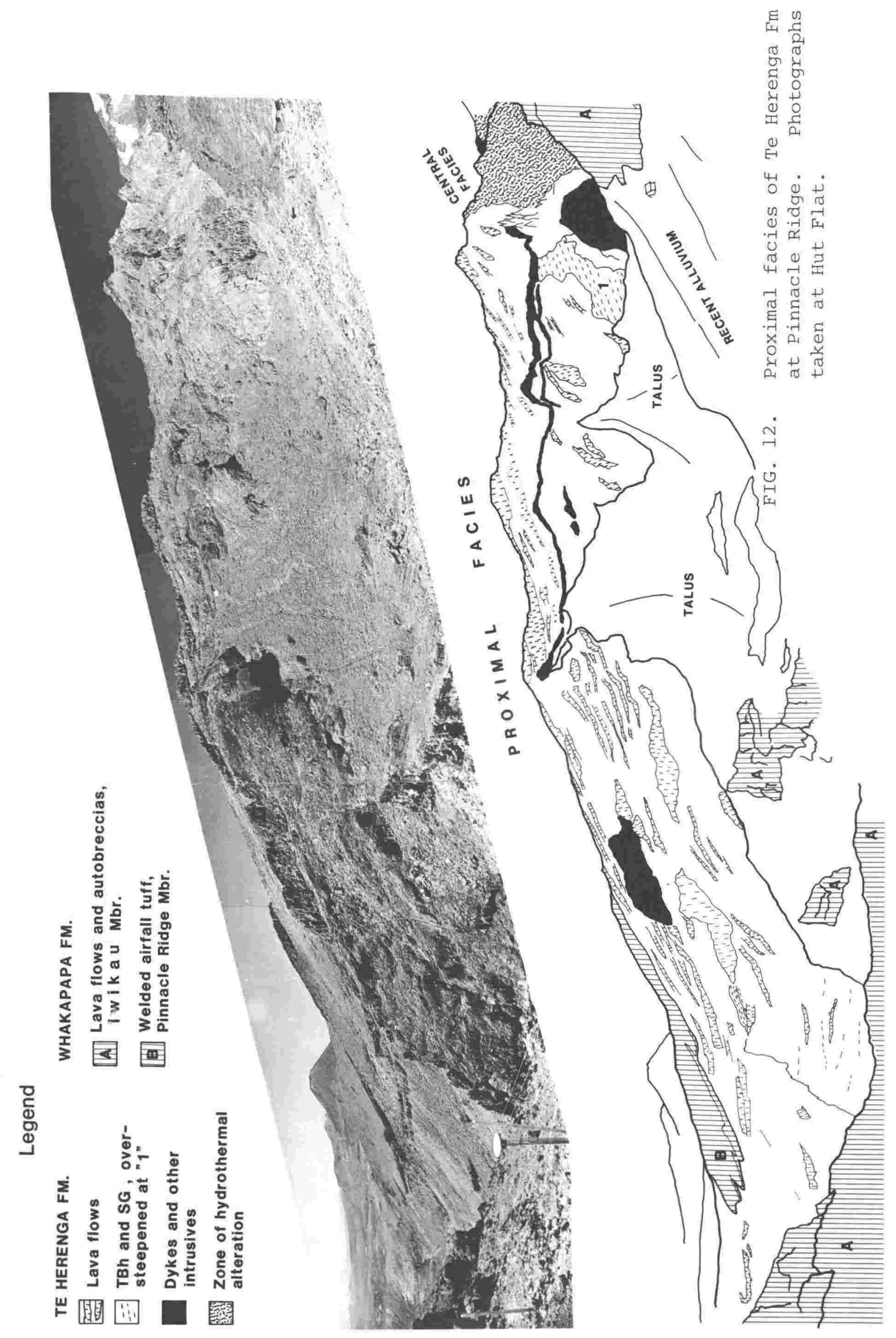



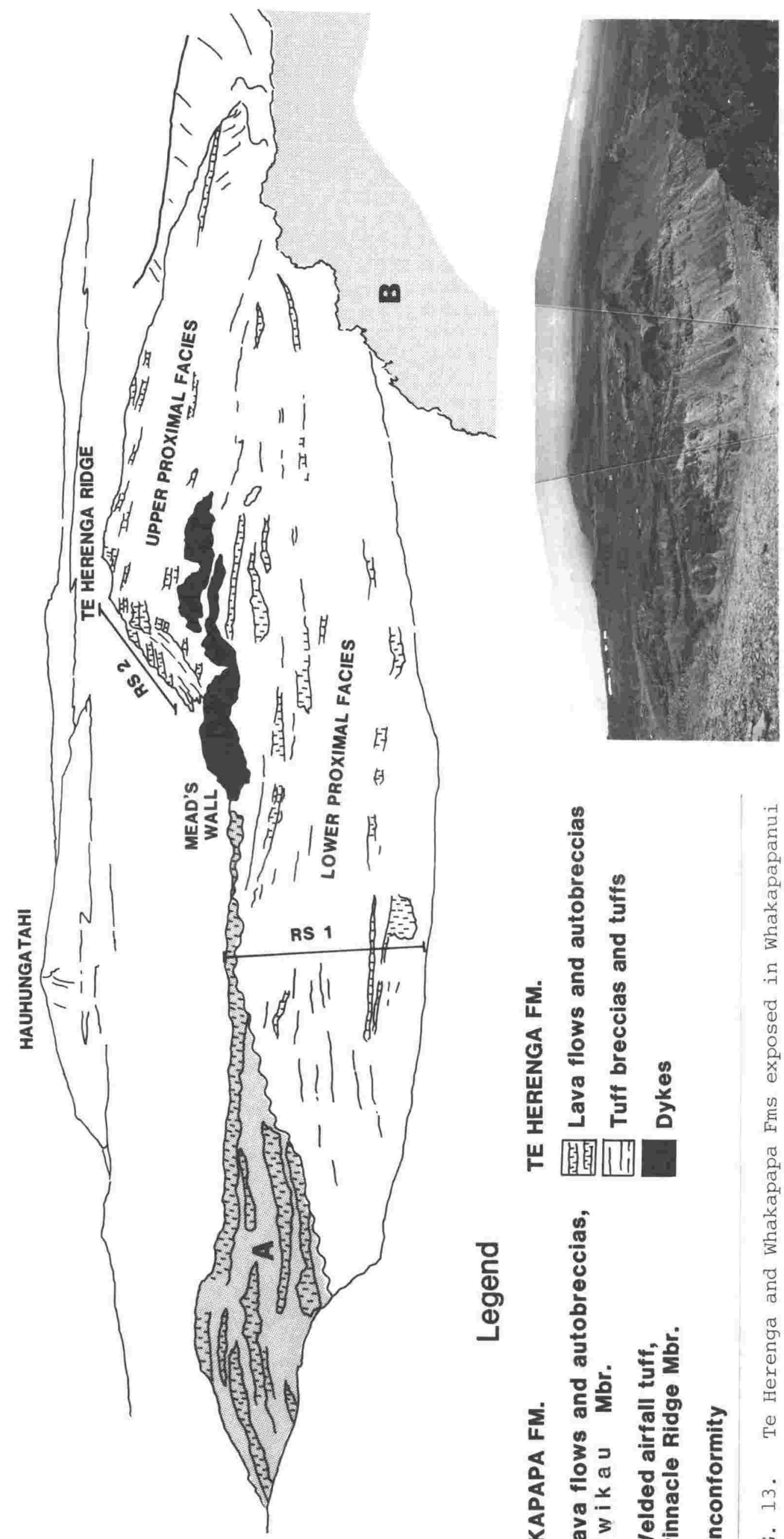

동

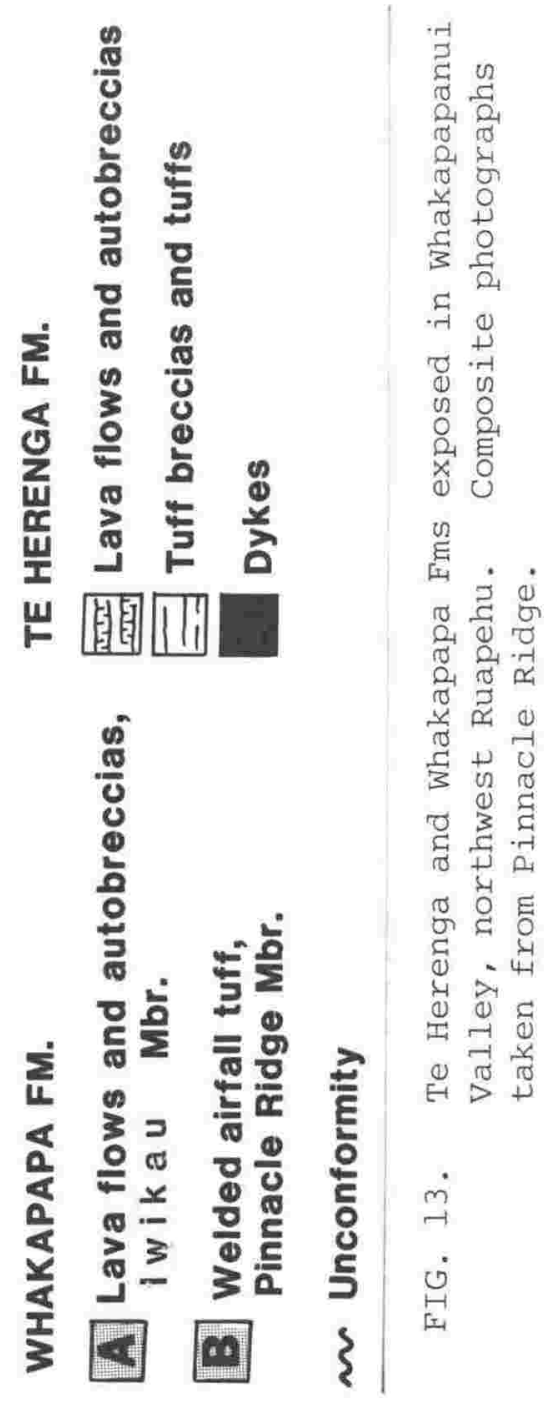


42
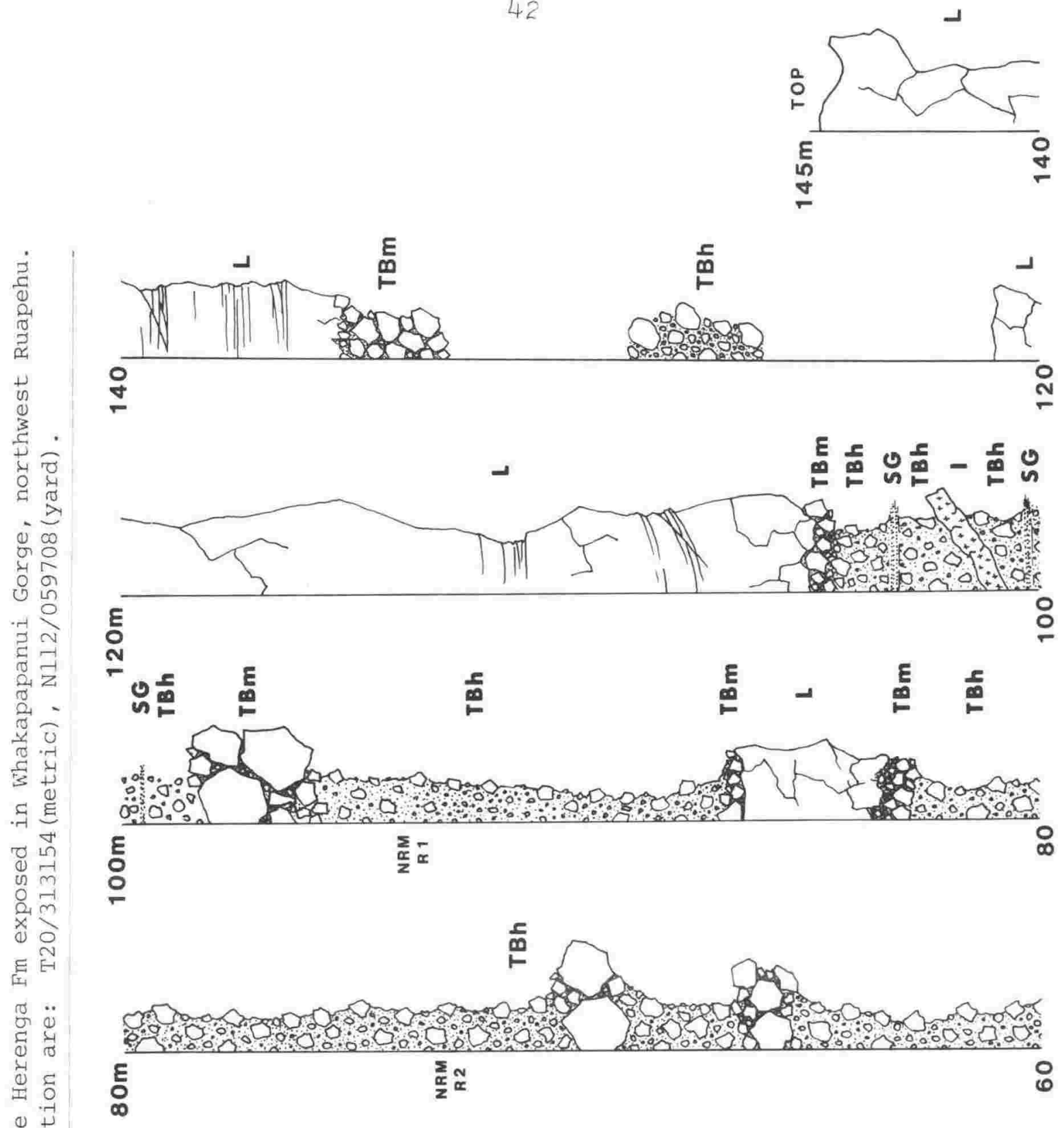

ํㅗㄴ

E 4

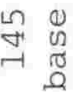

- $\begin{array}{r}40 \\ \text { o }\end{array}$

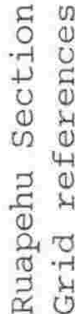

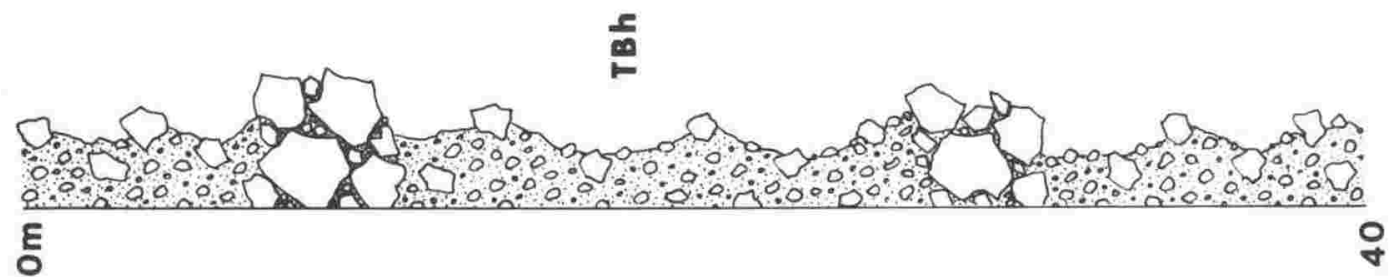
통

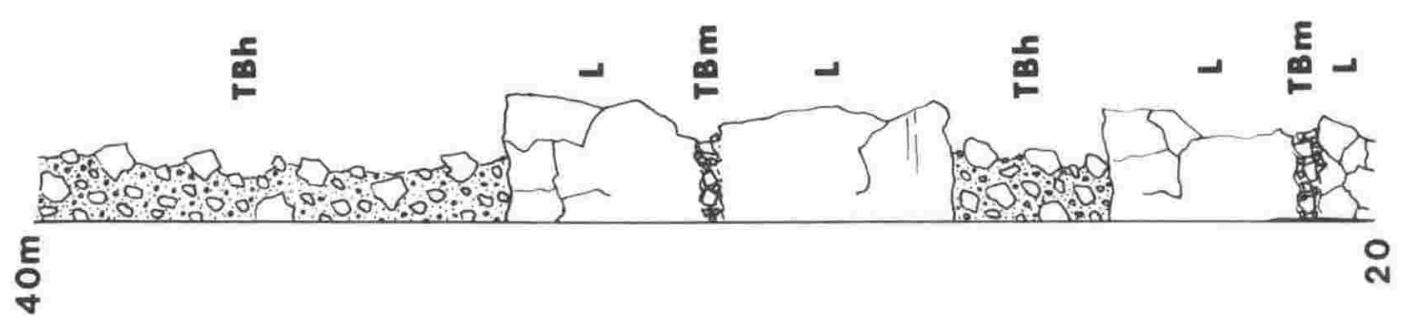

$\stackrel{+}{\leftrightarrows}$
$\dot{0}$
$\stackrel{4}{\mid c}$

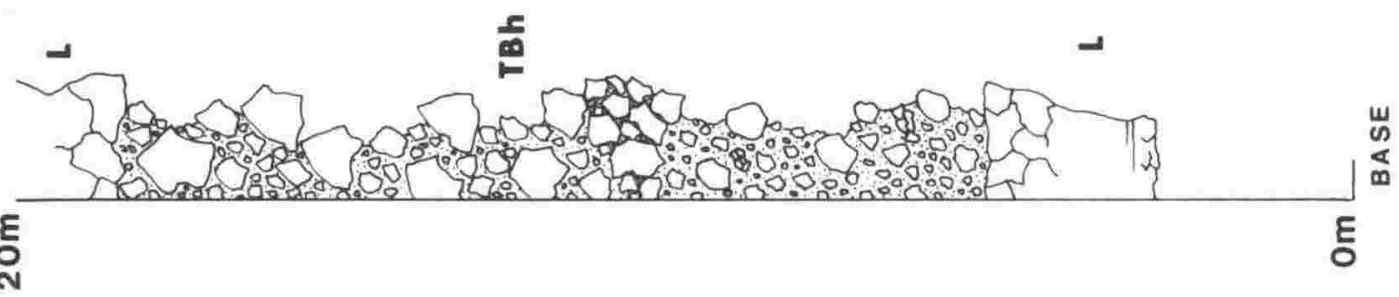




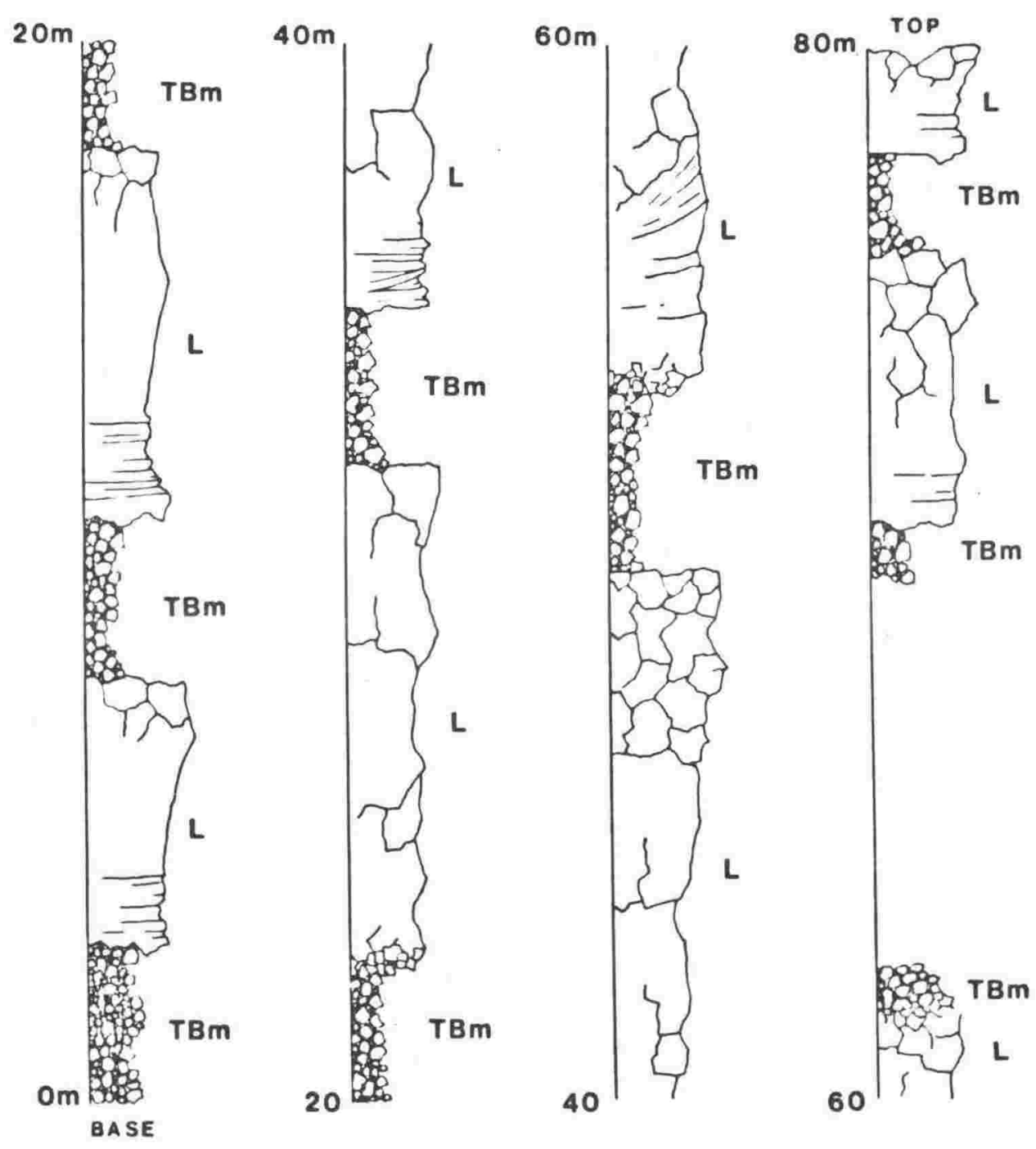

FIG. 15. Ruapehu Section 2. $80 \mathrm{~m}$ of TeHerenga Fm exposed at TeHerenga Ridge, northwest Ruapehu (see: Fig. 13). Grid references for base of section are: T20/307156 (metric), N112/054713 (yard). 

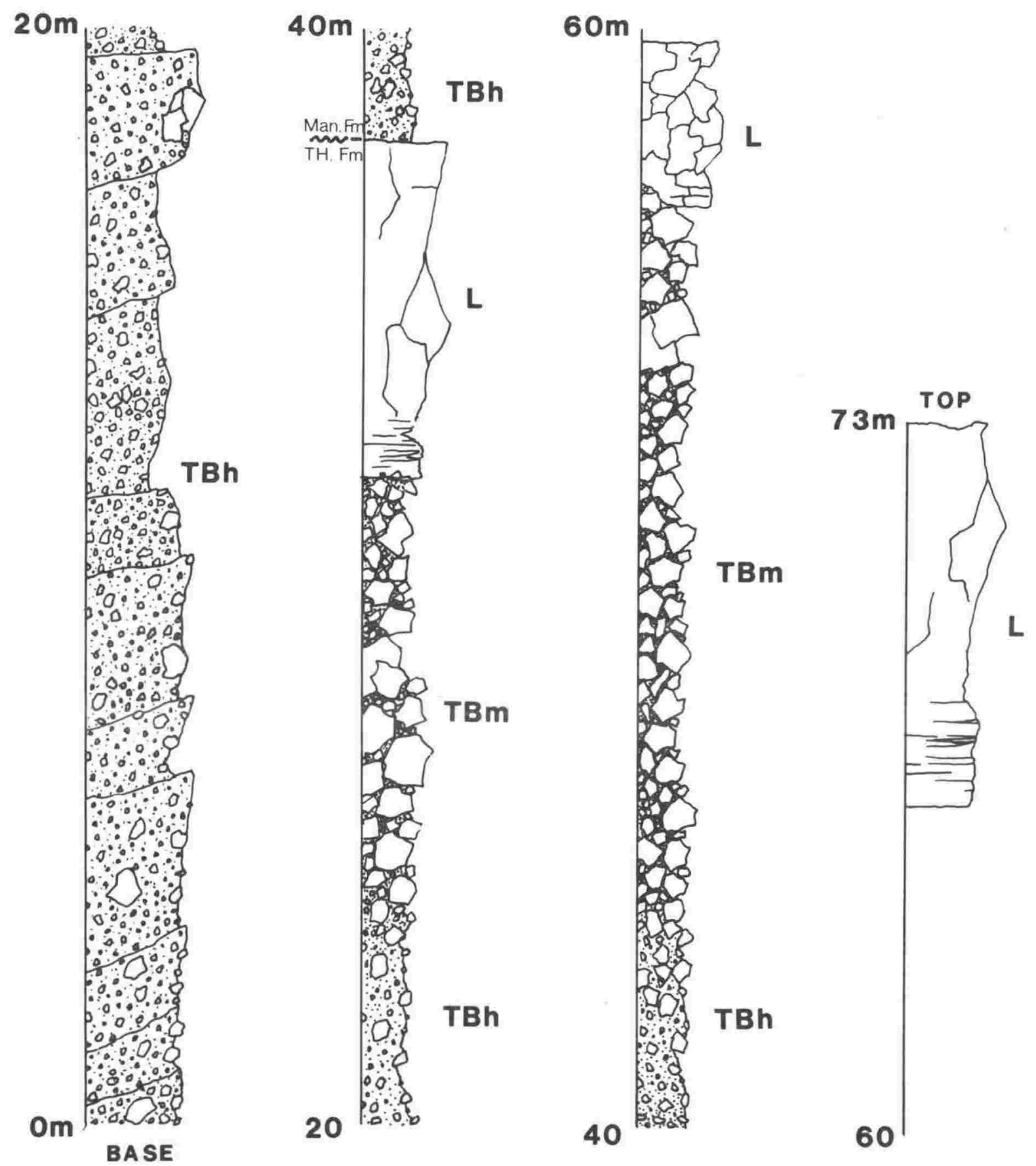

FIG. 16. Ruapehu Section 12. $73 \mathrm{~m}$ of Te Herenga and Mangawhero Fms exposed in Whakapapaiti Valley, west Ruapehu. The contact of these formations occurs at $38 \mathrm{~m}$, where tuff breccias of Mangawhero $\mathrm{Fm}$ rest unconformably on the glaciated surface of a Te Herenga Fm lava flow. Grid references for base of section are: S20/28315I (metric), N112/026700 (yard). 
the remainder of the deposits being heterolithologic tuff breccias (TBh), and minor bedded sand and gravel deposits. outcrop views of the major lithologies are given in Figure 17.

\section{Lava Flows}

Lava flows are present throughout the proximal facies but dominate the stratigraphy only in the upper portion of the cone complex (Ruapehu Section 2, Te Herenga Ridge, Fig. 15). The flows are lenticular in cross section and form an anastomosing outcrop pattern, where successive flows have infilled local topographic lows on the irregular surfaces of older flows. Fourteen measured flows range from 2 to 16 metres in thickness, and average 6.5 metres. Flow interiors are transected by blocky jointing, and platy jointing is nearly always developed near the bases. Flow banding is largely absent. Monolithologic tuff breccia (TBm) is almost invariably associated, and the transition from lava to breccia is abrupt but occurs along irregular contacts. Flows nearly always have spinose, irregular bases, but often exhibit non-blocky and distinctly planar top surfaces. However, weathering of the flow tops is weak or non-existent, suggesting that extrusion was punctuated by brief intervals of quiescence.

\section{Monolithologic tuff breccias (TBm, TBmw)}

These unsorted, oxidized tuff breccias are commonly associated with lava flows. Clasts usually do not exceed 0.4 metres, and are spinose and clinkery. The petrography of clasts is identical to that of lava flows, and complete size gradation exists down to lapilli and ash, where the latter consist of angular rock and crystal fragments. Most of these coarse deposits are clast-supported. Welding is not commonly developed.

The monolithologic tuff breccias were clearly produced by the autobrecciation of flowing lava. The flows and autobreccias closely resemble aa and block lava flows (Macdonald, 

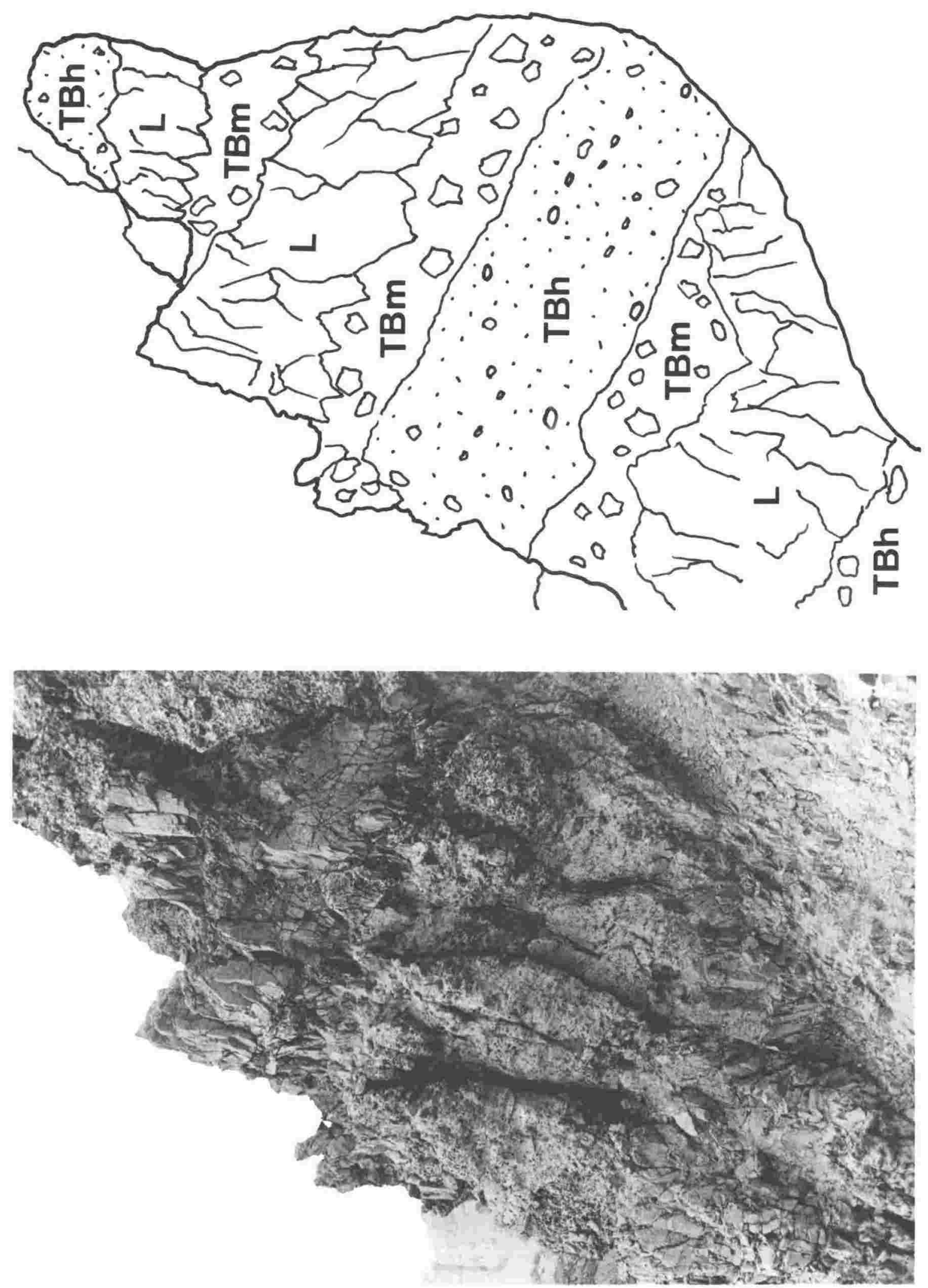

FIG. 17. Outcrop photograph of proximal facies lithologies of the Te Herenga Formation, upper Pinnacle Ridge. 
1953), where the outer margins of the flows cool and become relatively brittle, leading to fragmentation in response to stresses imposed by the still-fluid, plastic interior of the flow. Blocky jointing is developed, but the flows have not brecciated en masse, and the fragmentation is restricted to the outer rinds of the flows and to the development of shear planes (platy jointing) near their bases. These features are characteristic of relatively viscous basaltic to lowsilica andesitic lavas.

\section{Heterolithologic tuff breccias (TBh)}

Because of the great petrographic uniformity of essential magmatic material in the $\mathrm{Te}$ Herenga Formation, the TBh deposits are not strongly heterolithologic. The heterolithologic character is manifested by a clast population which exhibits only subtle variation in the abundance and relative proportions of phenocrysts; however, the clasts exhibit widely varying degrees of alteration, oxidation, and vesicularity in a given deposit. The most common TBh are massive or very weakly bedded, where poor stratification is produced by local horizons of angular, metre-sized blocks. These coarse, nearly monolithologic horizons are lenticular over lateral distances of tens of metres, and the angular clasts are unoxidized and petrographically identical to Te Herenga lava flows.

The host TBh for these local coarse horizons are more strongly heterolithologic. Angular to subrounded blocks of medium to light grey, dense, microvesicular, plag-cpx-opx phyric rock occur up to 0.5 metres but average 15 to 25 centimetres. Rounded, vesicular, palagonitized bombs are far subordinate to dense blocks. Clasts are supported by a massive tuffaceous matrix of angular to subrounded, dense, variably oxidized lapilli up to 2 centimetres, rounded yellowgrey pumice lapilli up to 2 centimetres, and coarse to medium crystal-vitric tuff. The tuffaceous matrix consists of rock and crystal fragments, and lacks glass shards. It is indurated but not welded. 
Complete size gradation exists from 0.5 metre angular blocks to medium ash, and the deposits are generally matrixsupported. In the lower 23 metres of Ruapehu Section 12 (Fig. 15), stratification is well developed between depositional units, which average 2.5 metres in thickness, exhibit crude internal bedding, and have primary dips on the order of $25^{\circ}$. In Ruapehu Section 1 (Fig. 13), depositional units are tens of metres thick, and primary dips are generally 10 to $20^{\circ}$.

On lithologic criteria alone, these deposits cannot be interpreted unambiguously. The Te Herenga Formation TBh units have all the characteristics of relatively cold mass flows (lahars or debris flows), but collapse of eruption columns during explosive volcanism could also generate massive, unsorted heterolithologic deposits with abundant tuffaceous matrix. In the latter situation, the heterolithologic character results from simultaneous ejection of dense, already solidified fragments of the pre-existing cone, as well as violently effervescing fresh magmatic material. The most cogent argument in favour of a pyroclastic flow mechanism (collapse of eruption columns) is the fact that the TBh exhibit no lithologic change as they are traced into the vent region, aside from secondary hydrothermal alteration. Arguments in favour of laharic origins include (i) the abundance of subrounded clasts (2) a general absence of lithologic features to suggest high-temperature emplacement, such as charred vegetation, gas escape pipes, and pervasive oxidation, and (3) the association of TBh with moderately well sorted and bedded sand and gravel (see below).

The coarse, lenticular, nearly monolithologic breccias which are intercalated with massive TBh are not likely to have originated as coarse ballistic ejecta, since impact structures are absent. These breccias also differ from autoclastic breccias in that the blocks are larger, more angular, less oxidized, and not directly associated with lava flows. The large, equant blocks closely resemble those which are produced by the blockly jointing of lava flow interiors or volcanic 
domes, suggesting that the coarse breccias originated by the gravitational collapse of solidified lavas on the upper slopes.

G.P.L. Walker (pers. comm., 1980) has suggested that if the TBh originated by major explosive eruptions, then the tuff matrix could be crystal-enriched, relative to lava flows, as a result of the glassy fragments having been blown away as fine dust. Such crystal enrichment is not evident either in the petrography, or in the chemistry: aside from secondary hydration and minor loss of silica and alkalis, the tuffaceous matrix is similar in bulk chemistry to the associated lava flows.

Since the TBh can be traced into the vent region without notable lithologic changes, question arises as to the mechanism of their generation. The answer relies more on structural than on lithologic criteria. At numerous localities along upper Pinnacle Ridge, within about $1 \mathrm{~km}$ of the vent region, thin lava flows and voluminous tuff breccias are observed to be oversteepened and often have dips between 60 degrees and vertical. In light of the numerous shallow intrusions that exist in the central facies, this oversteepening is strong evidence that the TBh were generated by gravitational collapse of the cone as a result of the deformation associated with the shallow intrusion of magma.

Most arguments therefore favour an origin for the Te Herenga TBh as secondary mass flows, generated largely by the gravitational collapse of unstable pyroclastic/autoclastic material on the steep upper slopes of the cone. The most probable mechanism was deformation associated with shallow intrusion of magma. The absence of primary airfall material in the stratigraphy probably also attests to the frequency of secondary processes, rather than to an original lack of primary airfall deposits during Te Herenga volcanism. 
In an attempt to resolve this issue, paleomagnetic cores were taken from ca. the 73 metre and 94 metre intervals of Ruapehu Section 1 (Fig. 14), and natural remanent magnetization (NRM) data for these samples are given in Figure 18. The NRM vectors are neither random nor oriented with respect to the present-day axial dipole. No precise statements on emplacement temperatures can be made from the existing data, except to say that the deposits were not emplaced at magmatic temperatures. The samples require alternating field or thermal demagnetization to resolve the thermal remanent magnetization (TRM) component from post-depositional viscous overprint components of magnetization.

Moderately sorted, bedded sand and gravel deposits (SG)

These deposits comprise a minor component of the stratigraphy, and are always associated with TBh. Examples occur at the 99.5, 100.4 and 103.2 metre intervals of Ruapehu Section 1 (Fig. 14), as well as at numerous localities on Pinnacle Ridge. Figure 19 is an outcrop view of some Pinnacle Ridge deposits. The sand- and gravel-sized material is conspicuously planar bedded on a centimetre to decimetre scale, and the clasts and tuffaceous matrix are petrographically identical to those of the associated TBh.

No sag structures are present beneath the larger clasts, and they are therefore unlikely to be of airfall origin. They are interpreted as fluvial/colluvial deposits derived by the reworking of heterolithologic tuff breccias on the steep slopes of the cone.

Intrusive igneous bodies (I)

Numerous north-trending dykes have intruded tuff breccias and lava flows of the Te Herenga proximal facies (Fig. 20). A single dyke is recorded at the 102 metre interval of Ruapehu Section 1 (Fig. 14), and the geologic map of Pinnacle Ridge (Fig. 2l) shows that numerous dykes traverse the ridge. The dykes range from about 0.5 to 3 metres in thickness, have similar petrographies to lava flows, and have not altered or 

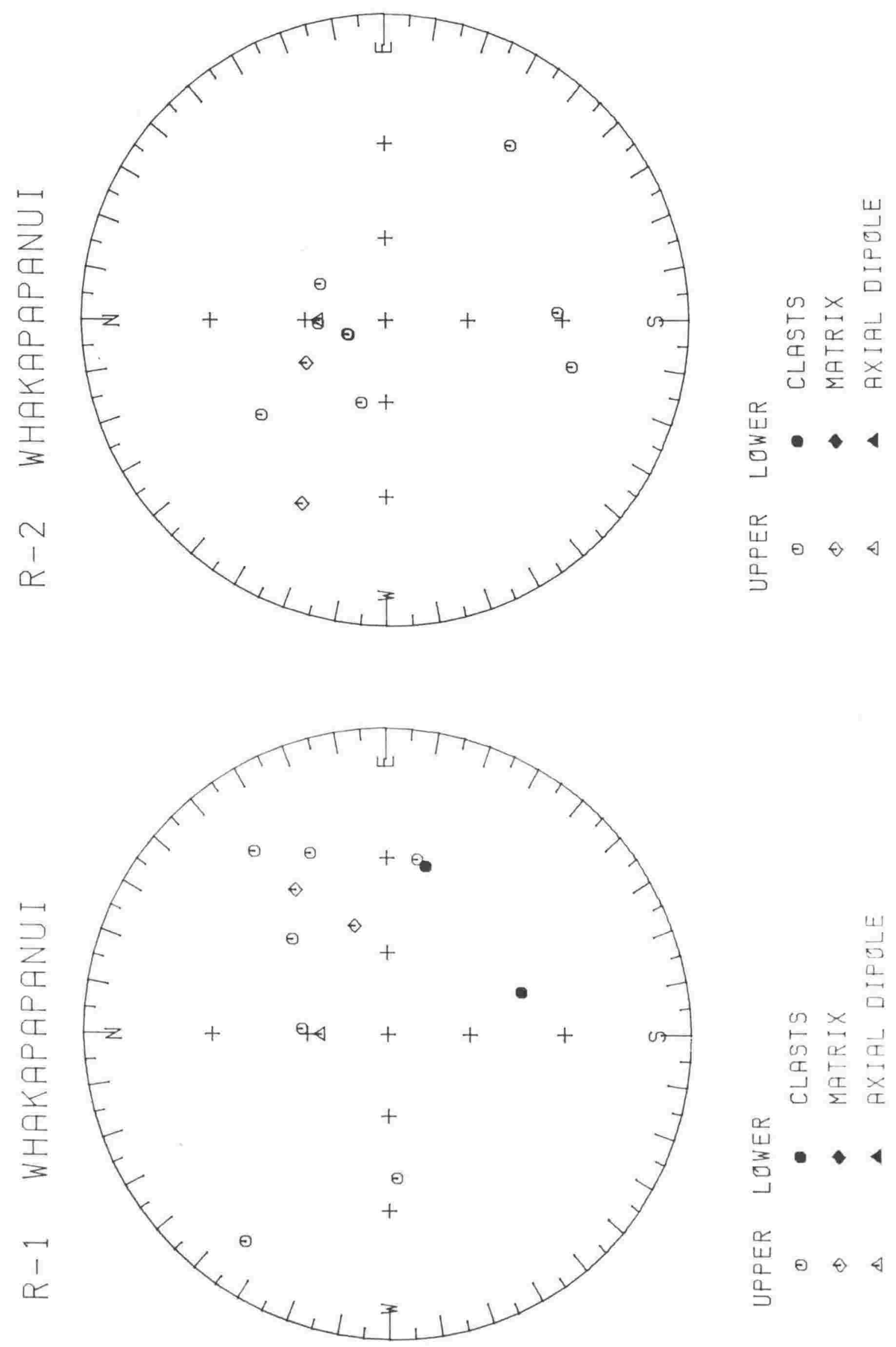


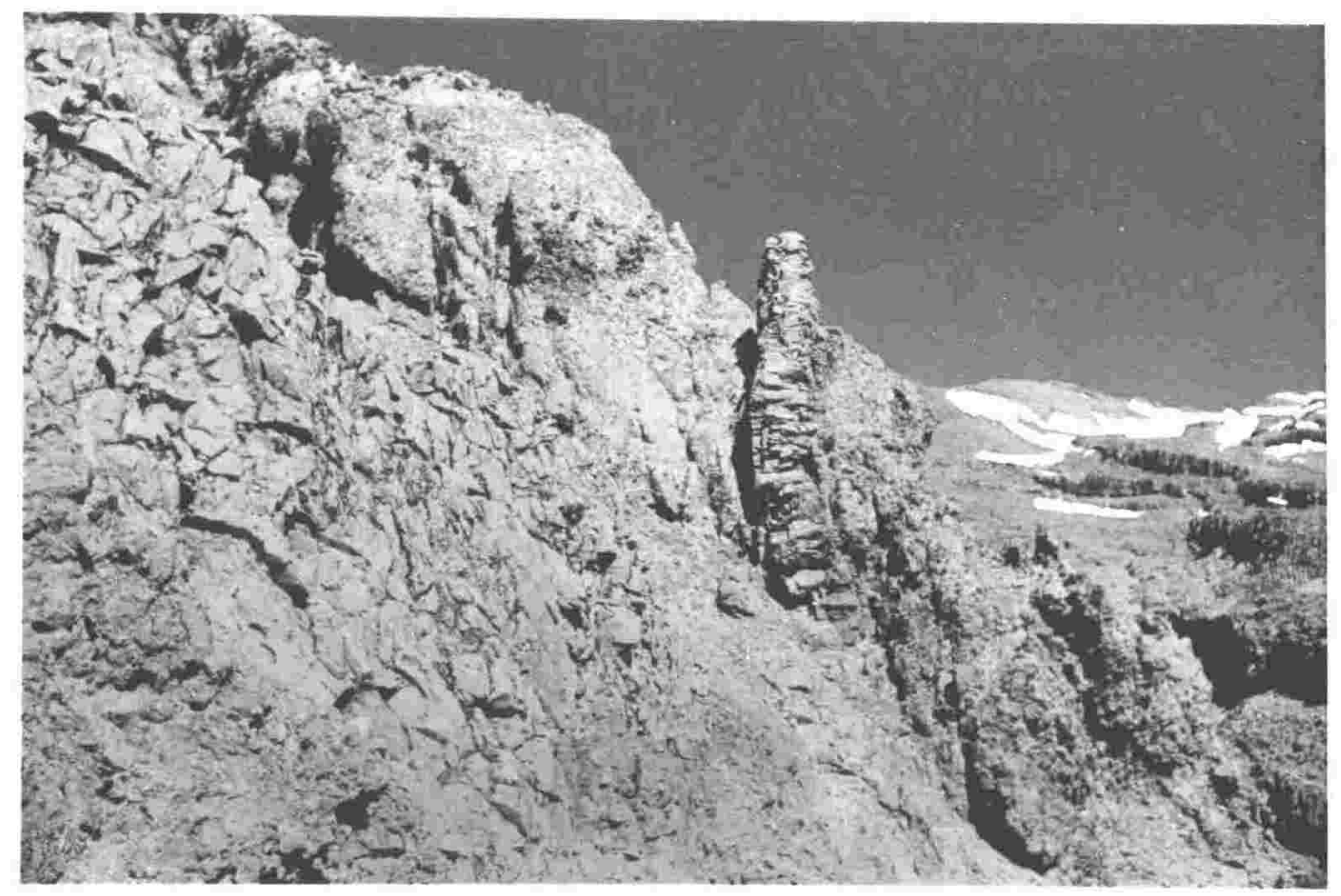

FIG. 20. North-trending dyke of Te Herenga Fm, Pinnacle Ridge. Note shear planes developed in the host tuff breccias.

FIG. 19. Colluvial deposits of Te Herenga Fm proximal facies, Pinnacle Ridge. This locality is denoted by "l" of Fig. 12.

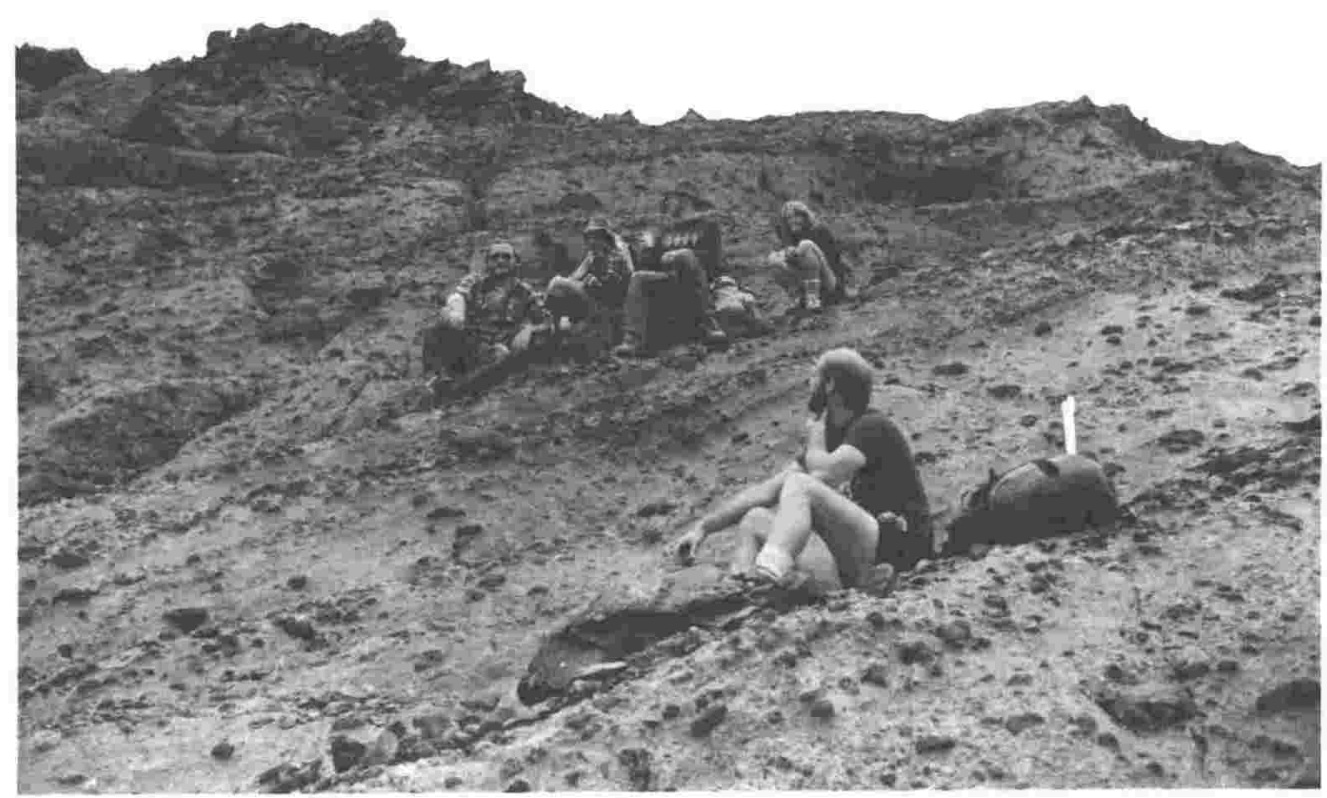




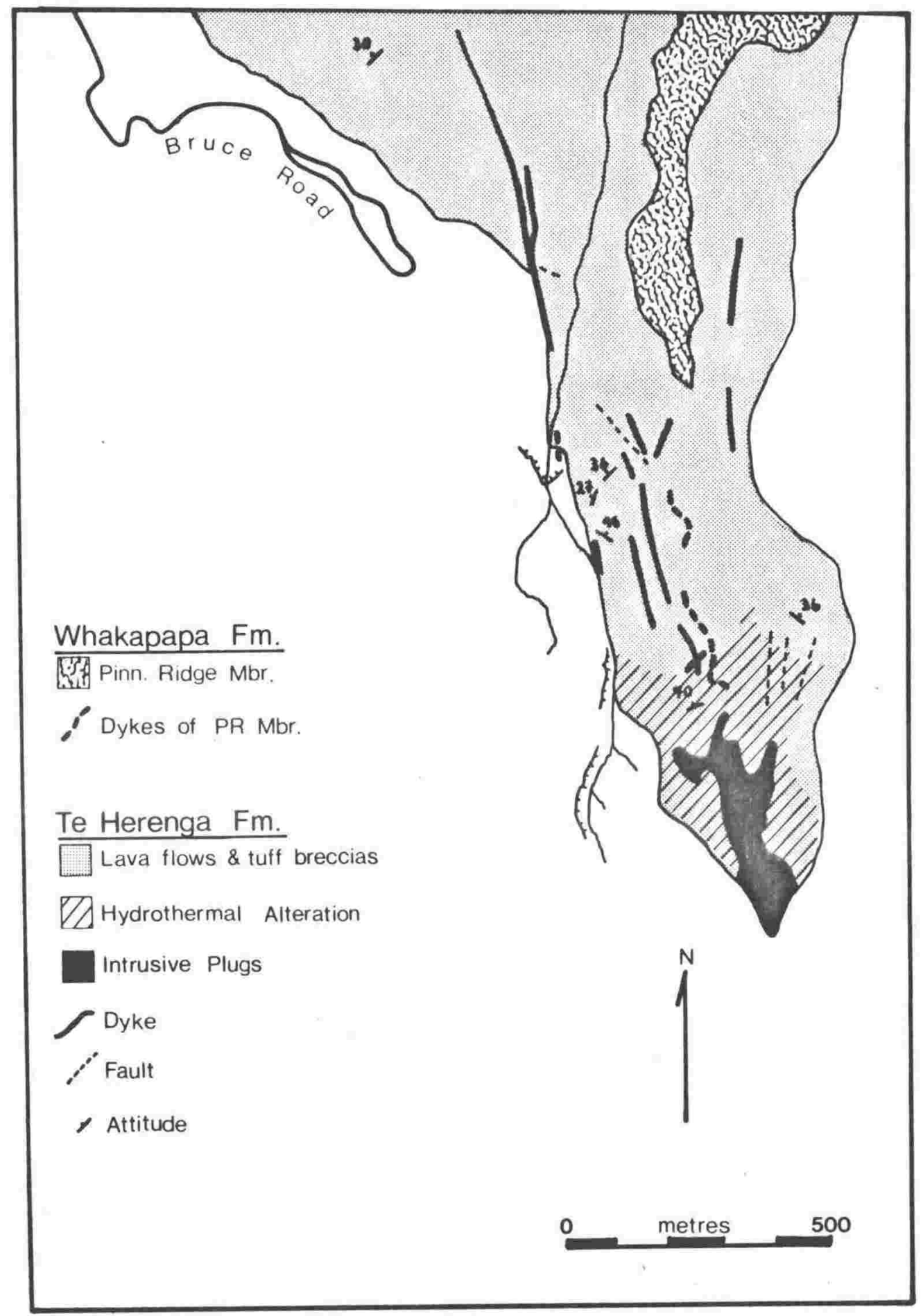

FIG. 21. Geologic Map of Pinnacle Ridge, northwest Ruapehu. 
deformed their host deposits except for the development of minor vertical shear planes in the surrounding tuff breccias. The dykes are prominent all along Pinnacle Ridge, but perhaps the most conspicuous example is Mead's Wall. Pinnacle Ridge was also the locus of fissure eruptions for the much younger Whakapapa Formation (see p. ).

Dykes of the Te Herenga Formation are the most conspicuous on the mountain, and their extensive exposure is due to the advanced dissection of the Te Herenga cone relative to younger formations. Dyke intrusion represents the latest stage of Te Herenga volcanism, and the petrographic similarities between dykes and lava flows suggests that the dykes were feeders for the upper sequence of flows.

\subsection{WAHIANOA FORMATION (New formation name) \\ DISTRIBUTION, THICKNESS AND VOLUME}

The Wahianoa Formation is named for the Wahianoa valley, a prominent glacial valley of the southeastern slopes of Ruapehu. The Wahianoa Formation is exposed at the southeastern quadrant of Ruapehu; in the Wahianoa and Whangaehu valleys, and on the broad planeze surface which separates them (Fig. 22). Additional exposures occur at Girdlestone Peak, and limited local exposure of the upper part of the formation occurs on north Ruapehu in a 70 metre deep fluvial valley (Fig. 30). The formation consists of voluminous lava flows and tuff breccias with variable lithologies, and subordinate finergrained tuffaceous deposits. These have been hydrothermally altered and intruded by several dykes and plugs in the nearvent region. The greatest thickness of Wahianoa Formation is exposed in the southern face of the upper Whangaehu valley, where 220 metres of near-vertical exposure have been described (Fig. 25). The initial volume of the formation cannot be established precisely. Assuming a simple cone-like geometry, and subtracting the post-erosional Te Herenga volume, the Wahianoa edifice was probably of the order $45 \mathrm{~km}^{3}$. 


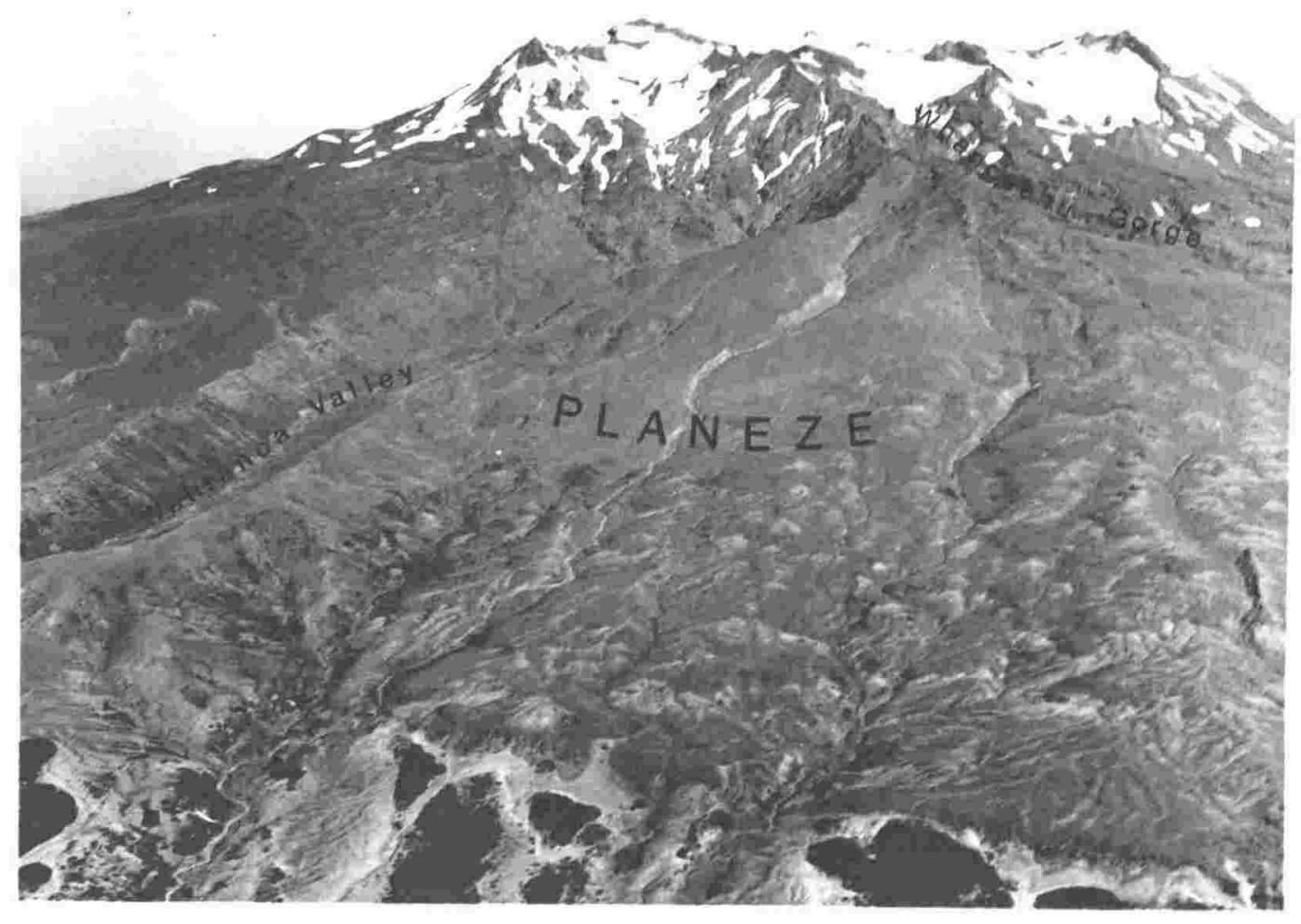

FIG. 22. Aerial photograph of southeastern slopes of Ruapehu. Wahianoa Fm is exposed in headwaters of Wahianoa and Whangaehu Rivers, and comprises the broad planeze surface between these valleys. Normal fault in the foreground is downthrown on the near side. 
TYPE AREAS: Southern face of upper Whangaehu Gorge, and upper Wahianoa Valley

\section{FORMATION BOUNDARIES}

The Wahianoa Formation is nowhere seen to overlie the Te Herenga Formation or the subvolcanic basement. Distinction from the Te Herenga Formation is therefore not based on contact relations, but rather on the lesser degree of dissection for the Wahianoa Formation, and on major lithologic and petrographic differences.

The upper formation boundary is defined at two localities. At Girdlestone Peak, olivine-bearing lavas of the Mangawhero Formation unconformably overlie olivine-free lavas and tuff breccias of the Wahianoa Formation (Fig. 23). At north Ruapehu (Fig. 30), heterolithologic tuff breccias of the Wahianoa Formation are unconformably overlain by olivinebearing lavas of the Mangawhero Formation. These exposures demonstrate that degradation of the Wahianoa cone occurred prior to deposition of Mangawhero lavas.

\section{LITHOLOGY AND PETROGRAPHY}

Deposits of the Wahianoa Formation exhibit great lithologic and moderate petrographic variation. All lithologic types are represented in the measured sections and in other outcrops, but monolithologic tuff breccias (TBm, TBmw) and associated lava flows are the most voluminous lithologies. Lava flows and clasts from the tuff breccias are generally porphyritic plag-cpx-opx andesites whose phenocryst contents vary from about 15 to 40 percent, and with light grey to black matrices. Some olivine-bearing lavas are present, but this mineral is not conspicuous.

$\underline{A G E}$

No absolute chronology exists for the Wahianoa Formation, but it is believed to be younger than the Te Herenga Formation. This inference is substantiated by the lesser degree of dissection of the Wahianoa Formation, relative to Te Herenga 


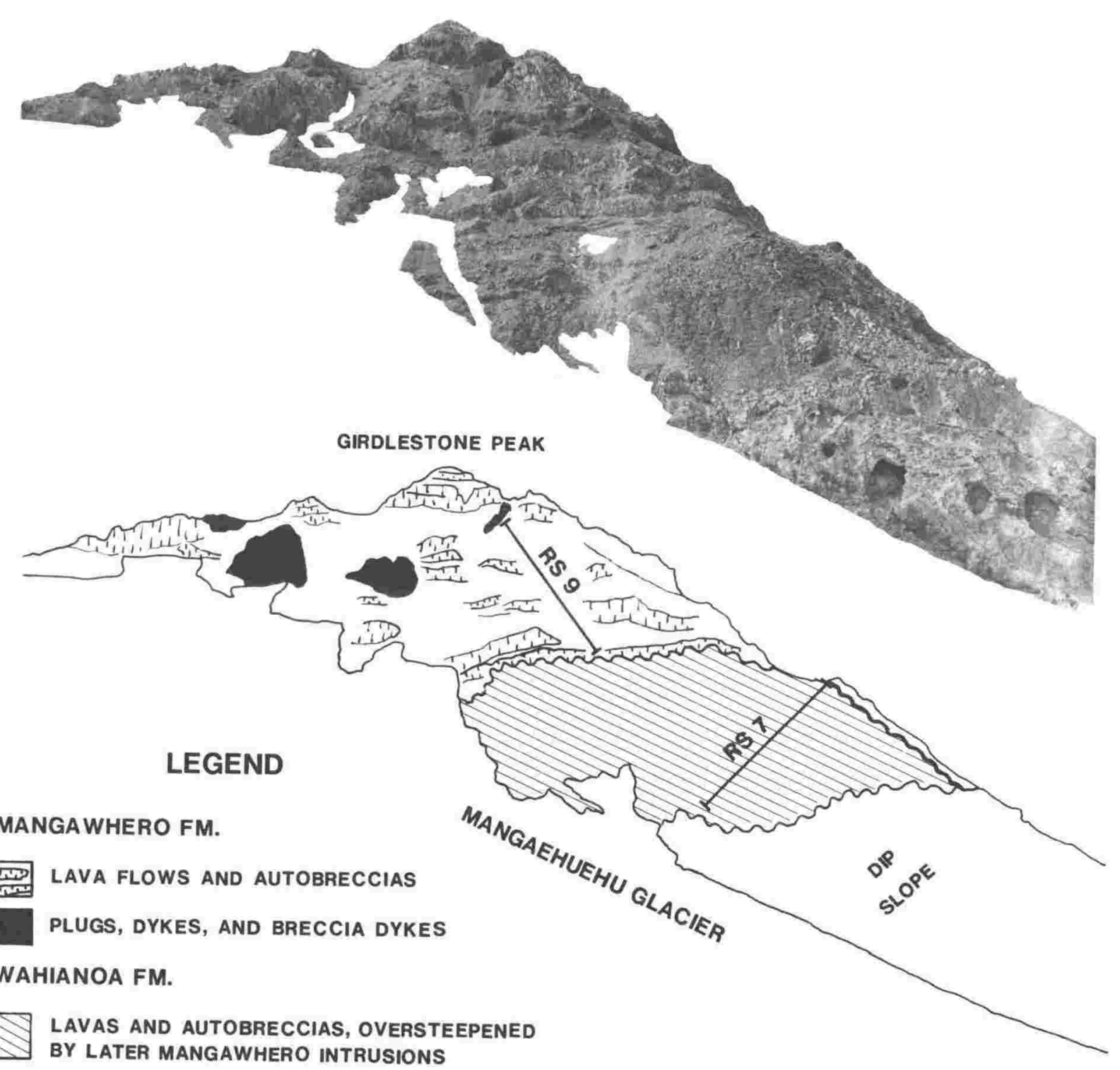

〜 UNCONFORMITY

FIG. 23. Geology of the southwest face, Girdlestone Peak. The unconformable contact of Wahianoa and Mangawhero Formations is exposed here. 
Formation. The wahianoa Formation is certainly older than Mangawhero Formation which unconformably overlies it, but neither the age of the base of the Mangawhero Formation nor the time span of the hiatus are known.

\section{VOLCANIC FACIES}

(i) Central Facies

Deposits of the central facies are not as well exposed as those of the Te Herenga Formation because erosion has not carved as deeply into the Wahianoa cone complex. Furthermore, the central facies is inaccessably exposed high in the headwaters of the Whangaehu River, a region of precipitous cliffs and unstable talus slopes. From the northern side of the Whangaehu valley and from the eastern summit region of Ruapehu, features are observed in the headwaters of the Whangaehu (Fig. 24) which appear analogous to those of the Te Herenga central facies. Pervasive hydrothermal alteration is evident in the yellow-brown discolouration of the deposits, and talus blocks of this material are abundant in modern fluvial deposits of the upper Whangaehu River. The deposits consist largely of altered tuff breccias with subordinate intercalated lava flows, and these are transected by several vertical, NW-trending dykes. The proportion of lava flows is decidedly less than for the proximal facies. Deep in the valley, podiform masses of lighter-coloured rock suggest the presence of intrusive bodies.

Although detailed lithologic descriptions of the tuff breccias were not obtained, the deposits are similar in overall lithology to the better-studied Te Herenga central facies. A central cone consisting largely of tuff breccias and lesser lava flows was invaded by several dykes. Attendant circulation of phreatic water produced an internal zone of hydrothermal alteration.

\section{Proximal Facies}

The proximal facies is well exposed on the scuthern wall 

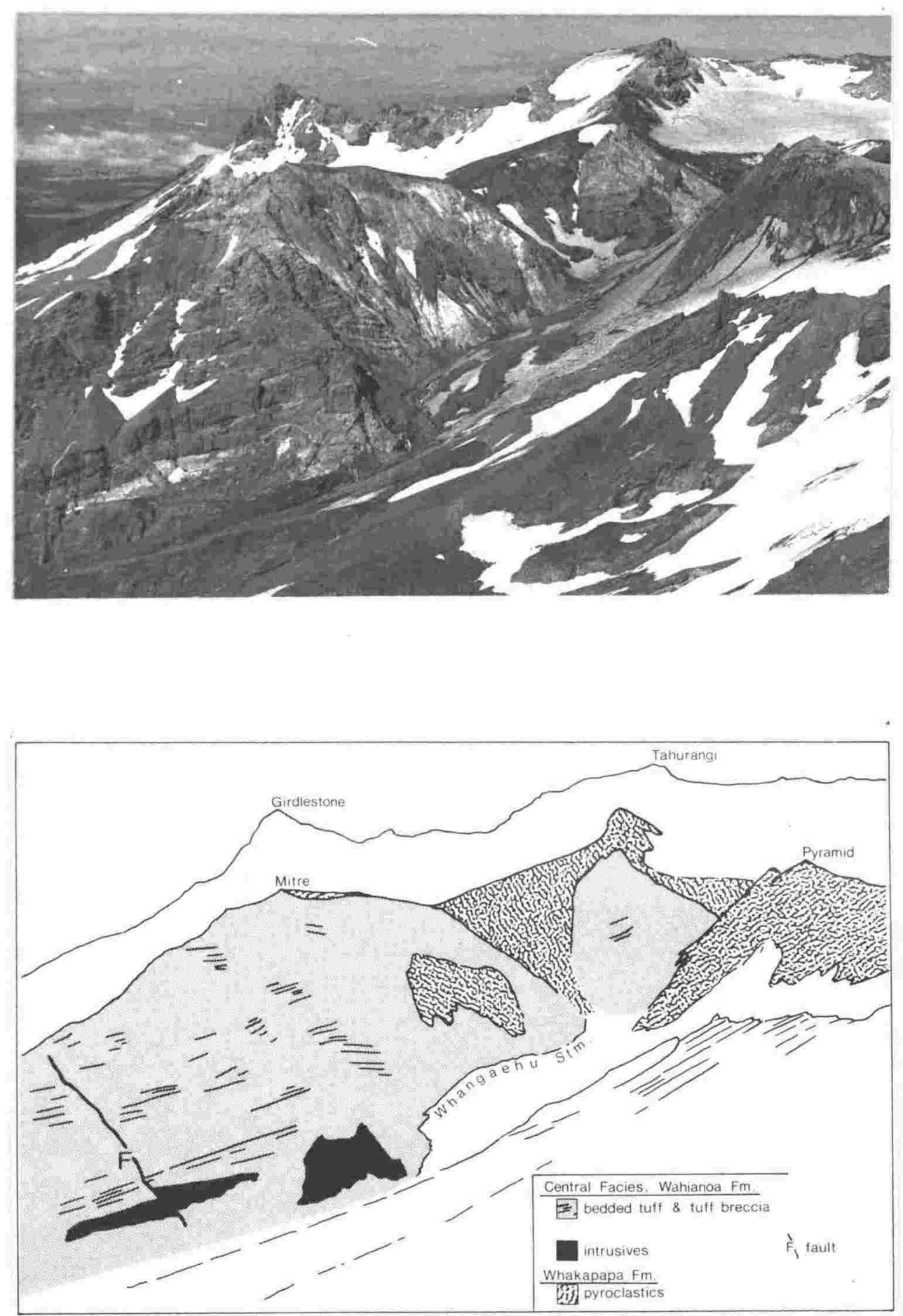

FIG. 24. Central facies of Wahianoa Fm exposed in headwaters of Whangaehu River, southeastern summit region of Ruapehu. Bulk of central facies consists of bedded tuffs and tuff breccias. Intrusive bodies are inferred only. Note the mantle of Crater Lake pyroclastics on Wahianoa Frm of Mitre Peak. 
of the Whangaehu Gorge (Fig. 25), in the upper reaches of the Wahianoa valley (Fig. 26), and at Girdlestone Peak (Fig. 23). Six measured sections are presented (Figs. 27-32), three from the Whangaehu Gorge, one from north Ruapehu, one from Girdlestone Peak, and one from Wahianoa Valley.

A wide range of lithologic types is recorded in the sections, but lava flows and associated monolithologic tuff breccias (TBM, TBMw) of autoclastic origin predominate, comprising about 75 percent of the deposits.

\section{Lava Flows:}

These are the most conspicuous component of most sections, forming protruding, steep bluffs. The flows are lensoid in cross section, and range from clearly valley-filling to nearly planar (see Fig. 25). Twenty flows measured on RS 3 range in thickness from 0.5 to 12 metres, with a mean of 4.5 metres. The flows are almost invariably associated with monolithologic tuff breccias. A rapid but gradational relationship is observed from massive, concordant lava, to irregular lava tongues intruding welded monolithologic tuff breccia, and then to unwelded tuff breccia.

Flow interiors are pervasively jointed to produce large, irregular, but generally equant angular blocks. Many flows exhibit intense, platy jointing which is often concentrated near the bases of flows. Conspicuous flow banding occurs in some flows, and near flow margins the banding is often tightly convolute. These features are displayed in Figures 33-35.

Most of the flows are broadly conformable and approximately flat lying, suggesting rapid effusion of successive flows with little opportunity for extensive intervening erosion. In a minority of cases time breaks were sufficient for erosion of major gullies, and the succeeding lava flows were confined to the valleys (Fig. 25). 


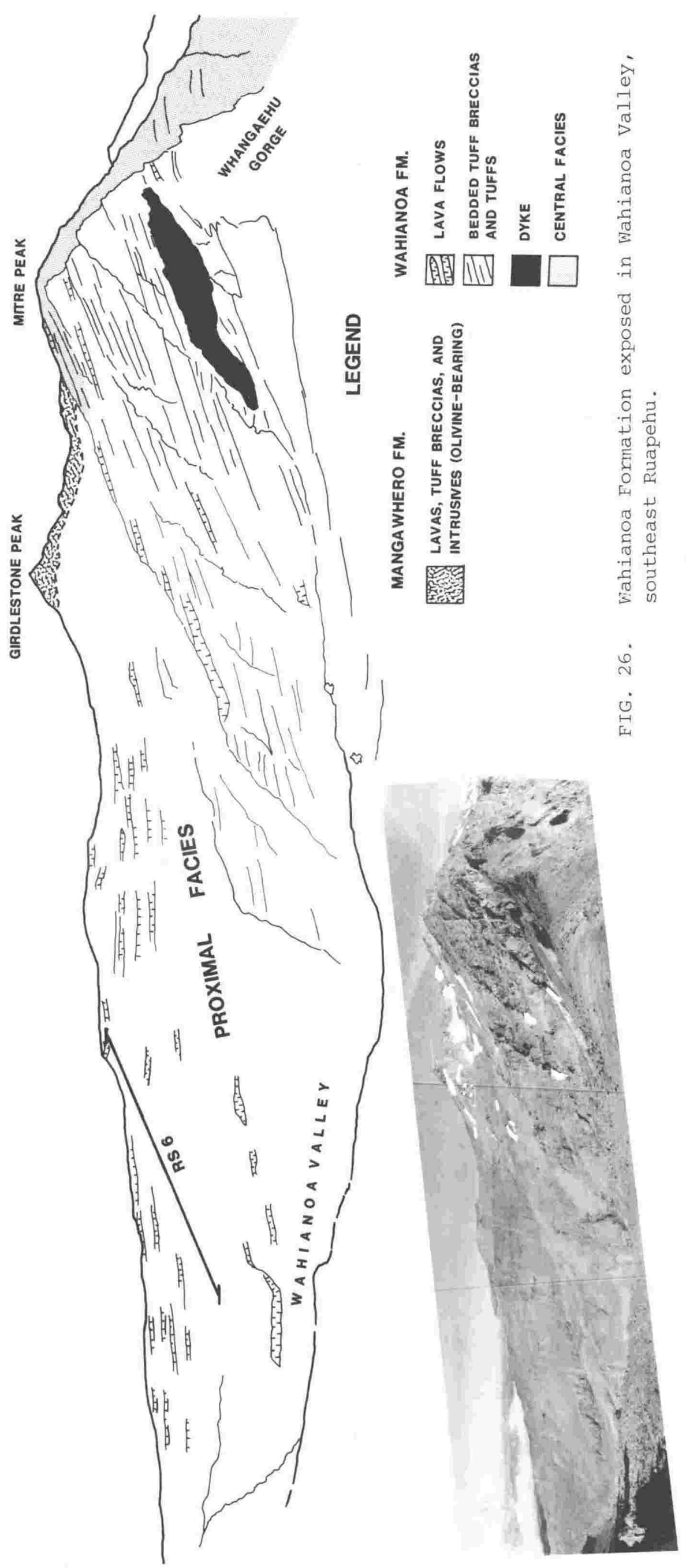


FIG. 27. Ruapehu Section 3. $223.5 \mathrm{~m}$ of Wahianoa Fm exposed in Whangaehu Gorge, southeast Ruapehu. Grid references for base of section are: T20/347094 (metric), N122/098646 (yard).

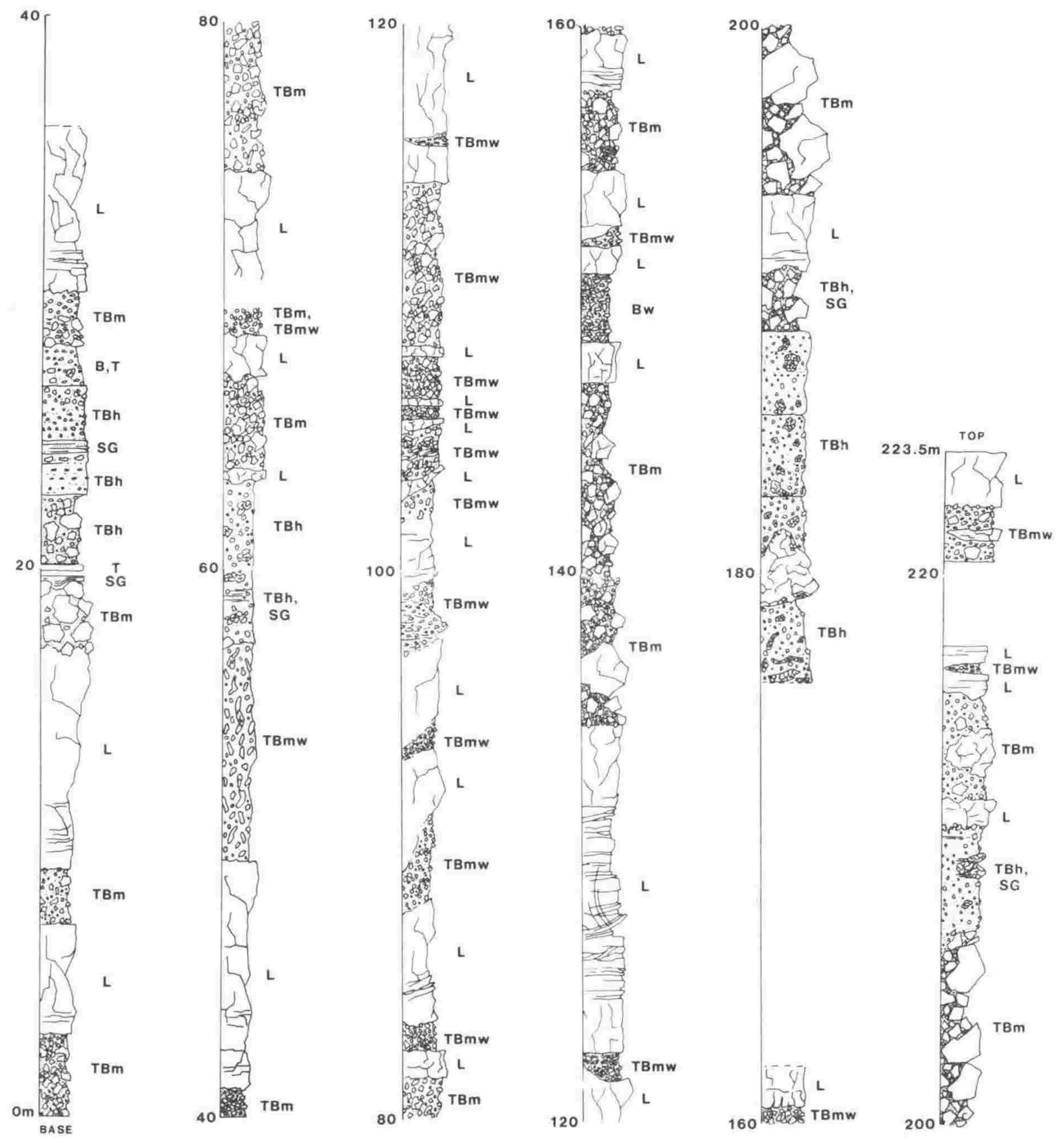




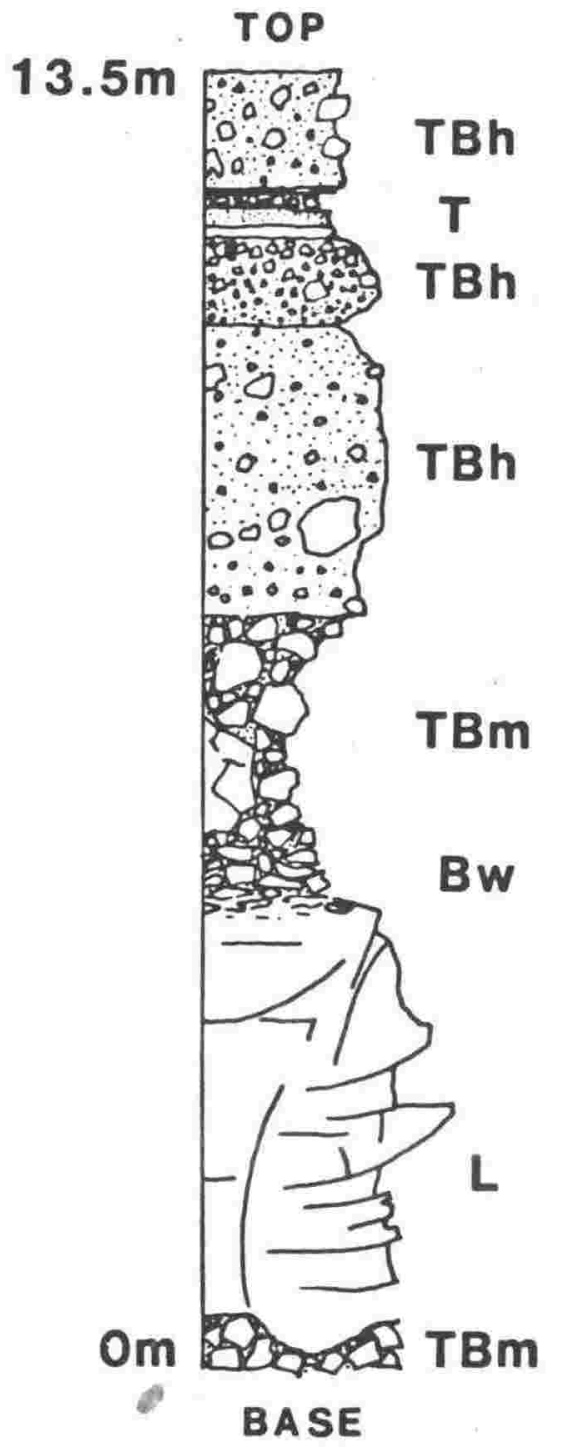

FIG. 28. Ruapehu Section $4.13 .5 \mathrm{~m}$ of Wahianoa $\mathrm{Fm}$ exposed in the Whangaehu Gorge, southeast Ruapehu. Grid references for base of section are: T20/353092(metric), N122/105643(yard). 

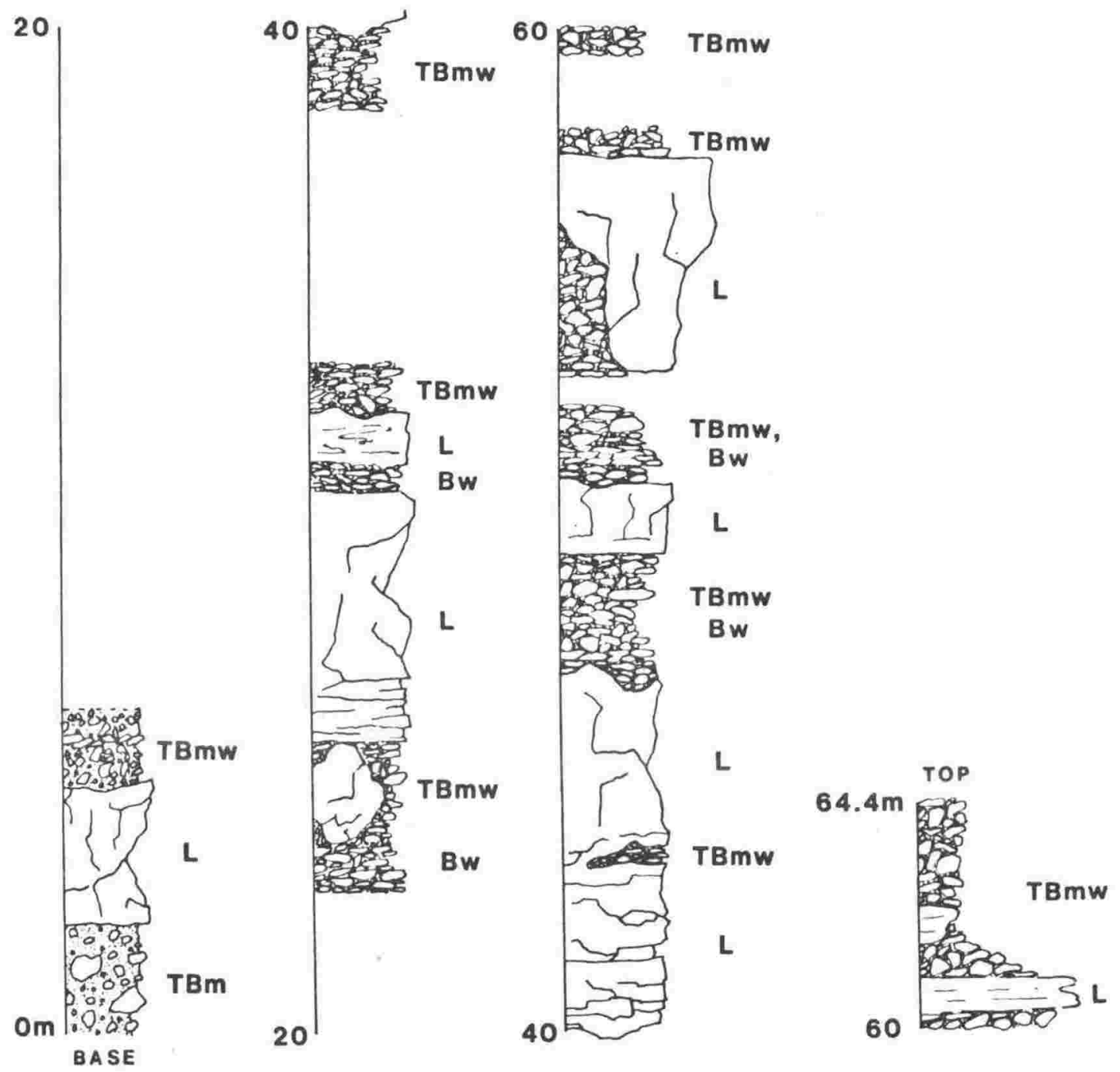

FIG. 29. Ruapehu Section 5. $64.4 \mathrm{~m}$ of Wahianoa Fm exposed in Whangaehu Gorge, eastern Ruapehu. Grid references for base of section are: T20/365093 (metric), N122/128640 (yard). 


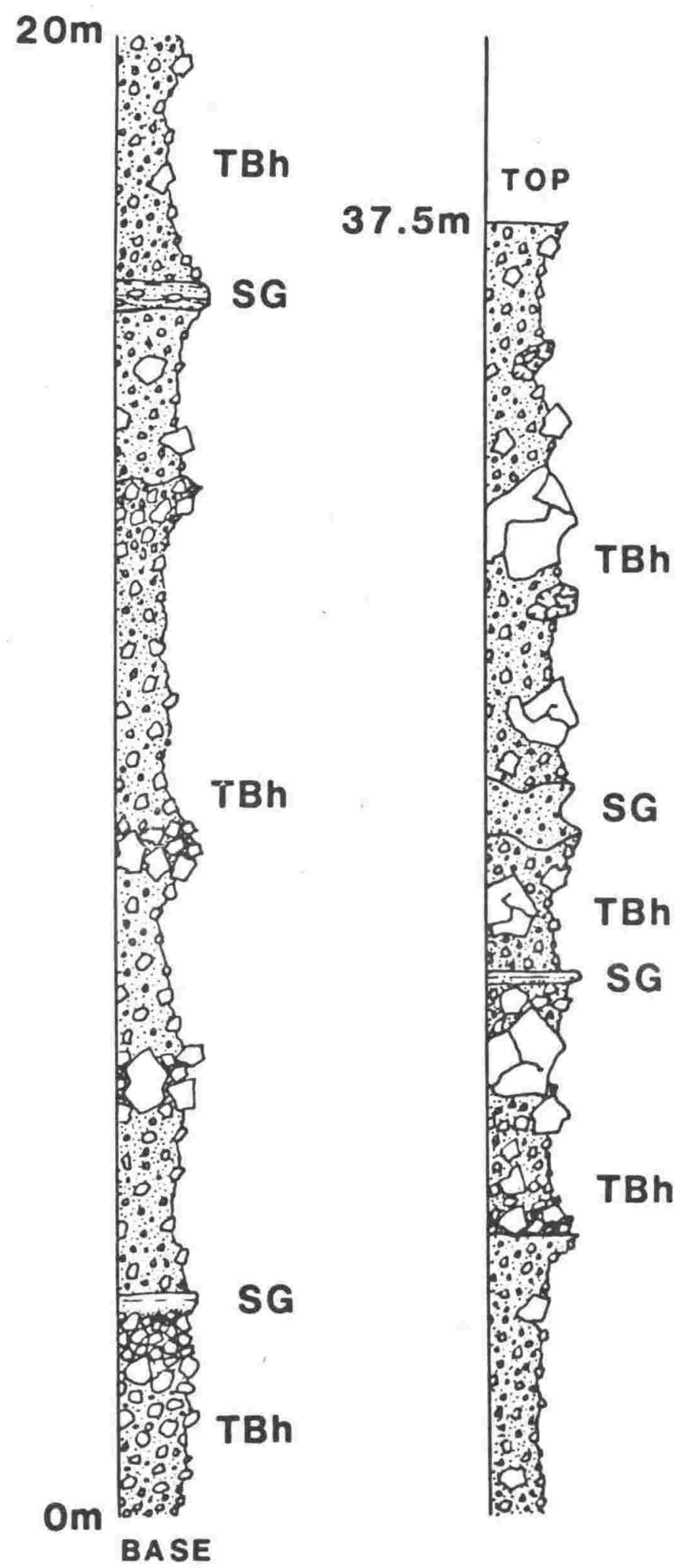

FIG. 30. Ruapehu Section 8. $37.5 \mathrm{~m}$ of Wahianoa Fm exposed in an unnamed stream valley of north Ruapehu. Grid references for base of section are: T20/342155(metric), N112/090712 (yard). 


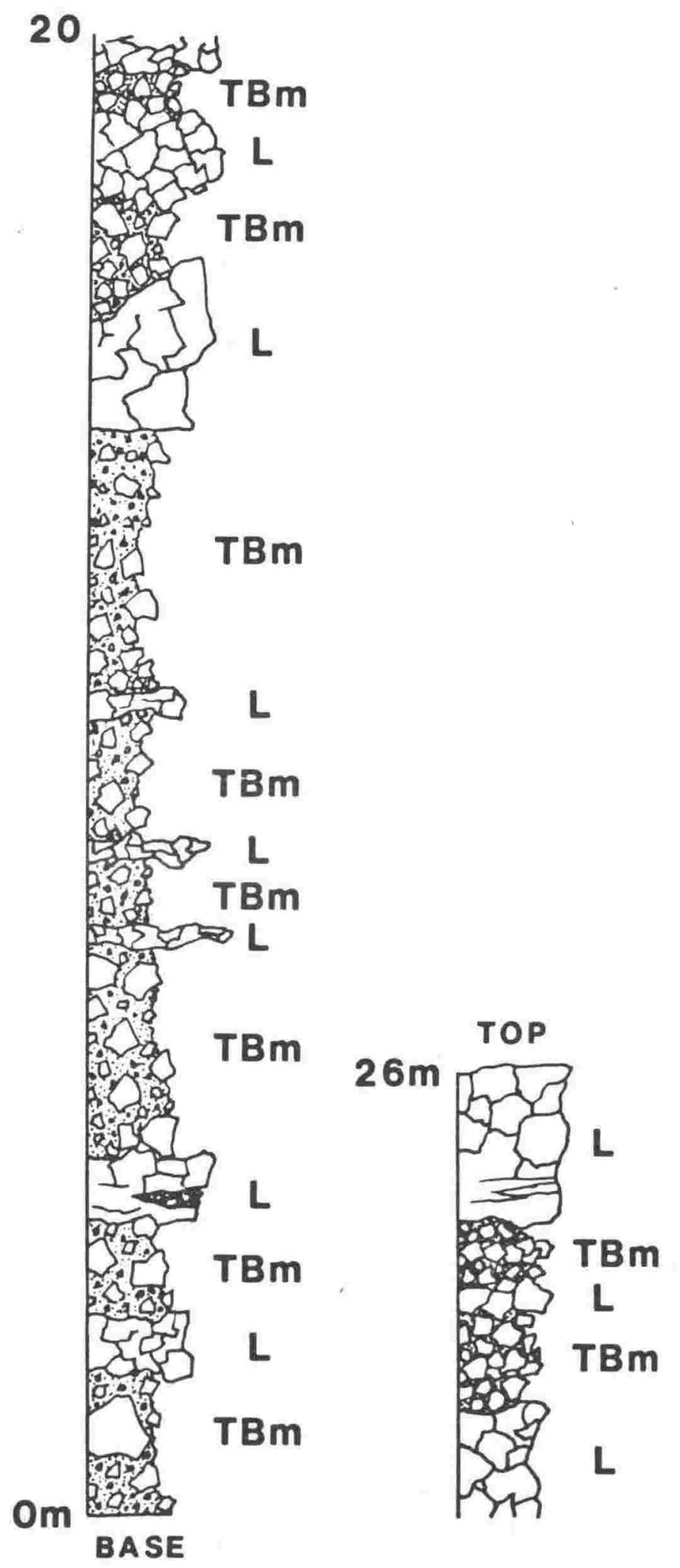

FIG. 31. Ruapehu Section 7. $26 \mathrm{~m}$ of Wahianoa Fm exposed at Girdlestone Peak (see: Fig. 23). Grid references for base of section are: T20/311086 (metric), N122/060636 (yard). 
FIG. 32. Ruapehu Section 6. $192 \mathrm{~m}$ of Wahianoa Fm exposed in Wahianoa Valley, southeast Ruapehu. Grid references for base of section are: T20/339073(metric), N122/090621 (yard).
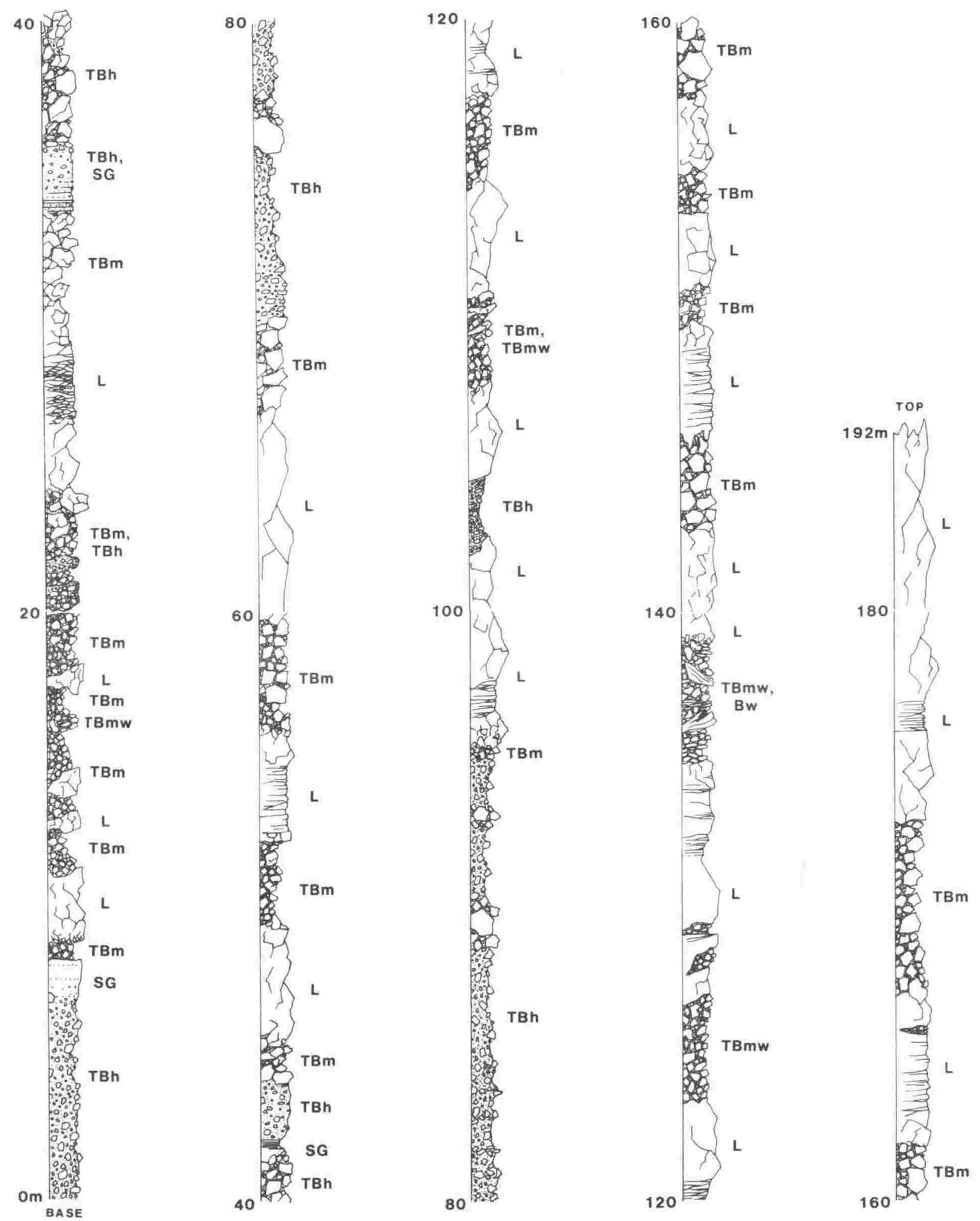
69
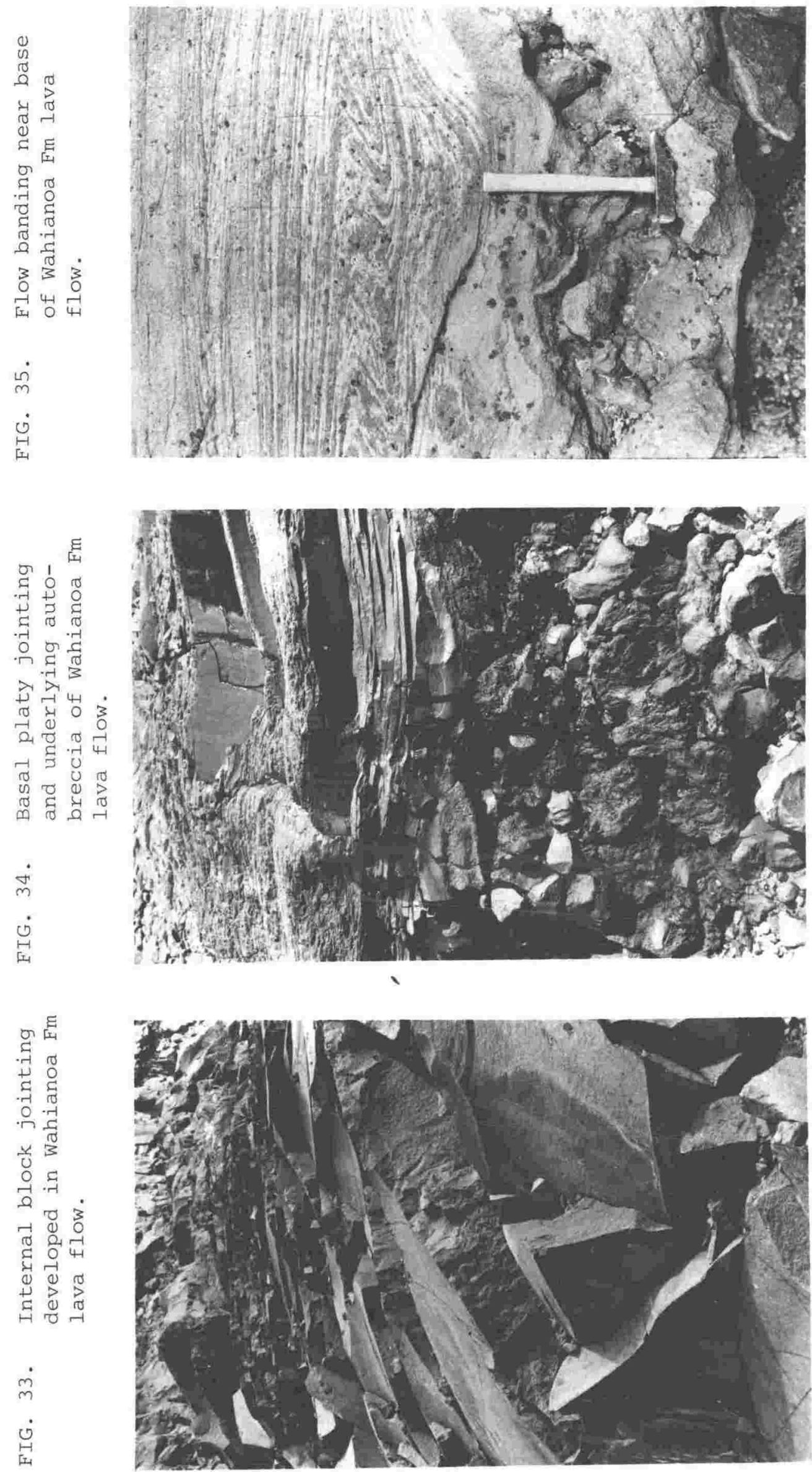
Monolithologic tuff breccias (TBm, TBMw):

The TBm units are invariably associated with, and petrographically identical to, lava flows of the wahianoa Formation. The breccias are chaotic, massive tuff breccias, containing generally blocky clasts of widely variable grainsize. Maximum clast size is generally less than 0.5 metres, with matrix material down to ash size. Clast roundness varies from angular to subrounded. A gradation from framework to matrix support is present. Large clasts and matrix almost invariably show strong oxidation to bright red colours.

Many units show a rapid gradational relationship to massive lava (Fig. 36). The lava flows possess irregular, rubbly, slaggy margins passing into welded, relatively coarse and angular breccia often intruded by thin discordant tongues of lava (RS 3, Fig. 27, 100-110metres). The welded breccia passes outwards into partially and then unwelded breccia which is more matrix-rich and with distinct rounding of the larger clasts. Thicker lava flows often contain lensoid internal pods of incipient brecciation (Fig. 37).

Excellent examples of these features occur in RS 7 (Fig. 31), where thin lenticular lava flows often pinch out into TBm and have internal zones of TBm, and in RS5 (Fig. 29), where lava flows are intercalated with TBmw and with coarse bomb beds of airfall origin.

Well sorted tuffs, and lapilli and bomb beds ( $T$; $B, B w$ ).

Shower bedded, well sorted beds of probable airfall origin are rare in the Wahianoa Formation. A $20 \mathrm{~cm}$ unit of shower bedded pumiceous andesitic lapilli occurs at 12.1 metres in RS 4 (Fig. 28). An unwelded bomb bed occurs 30 metres above the base of RS 3 (Fig. 39), separated by several graded TBh units from a 1 metre thick sequence of airfall lapilli and ash (Fig. 40) at 20 metres above section base. Common characteristics of these units are: shower bedding definea by subtle variations in grain size, a mantling of underlying relief, better sorting than all other clastic units, and a predominance 


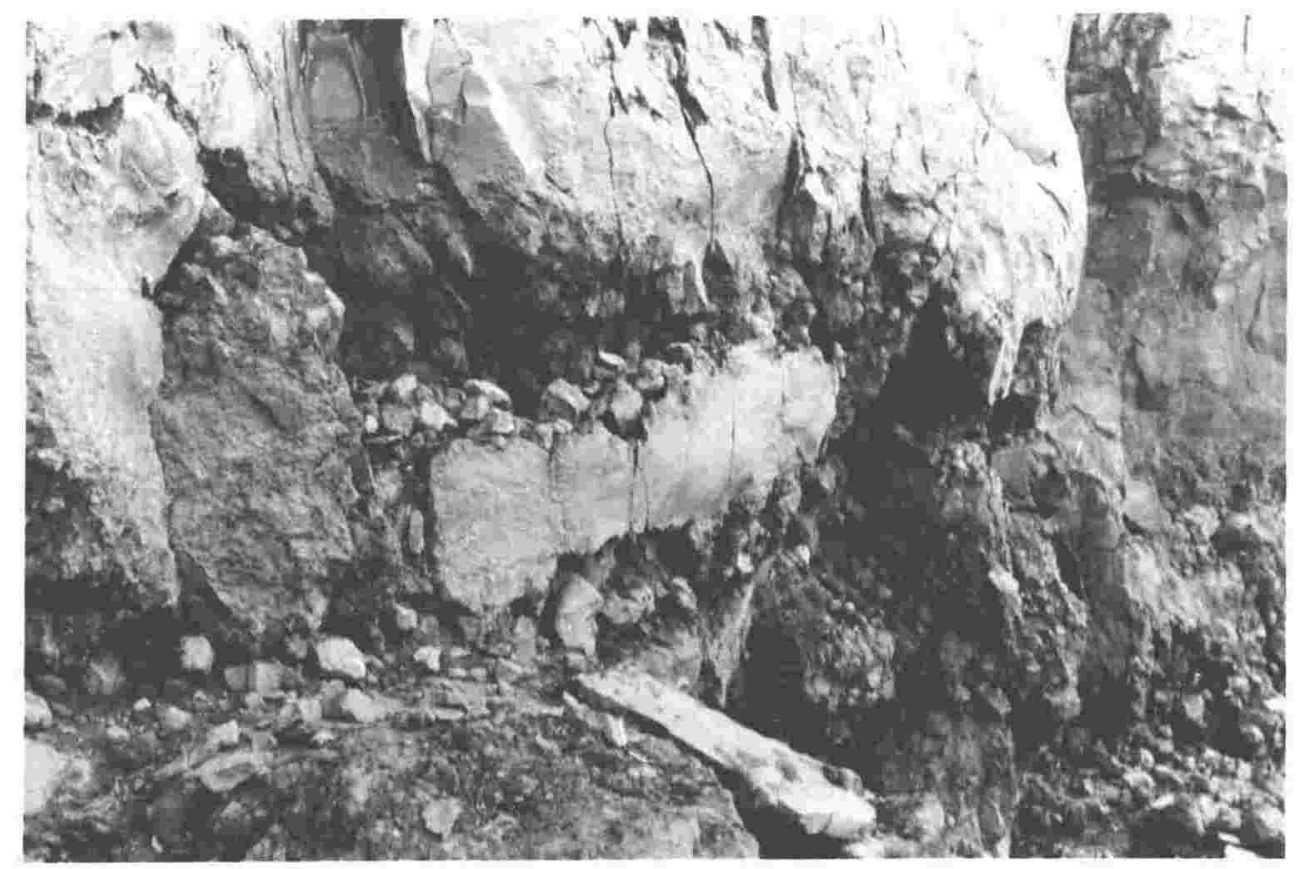

FIG. 36. Transition from lava flow to autobreccia in Wahianoa Fm, approx. $100 \mathrm{~m}$ interval of RS 3. Height of scene is $6 \mathrm{~m}$.

FIG. 37. Lenses of welded, incipient autobreccia in Wahianoa Fm lava flow, approx. $130 \mathrm{~m}$ interval of RS 3 . Height of scene is $4 \mathrm{~m}$.

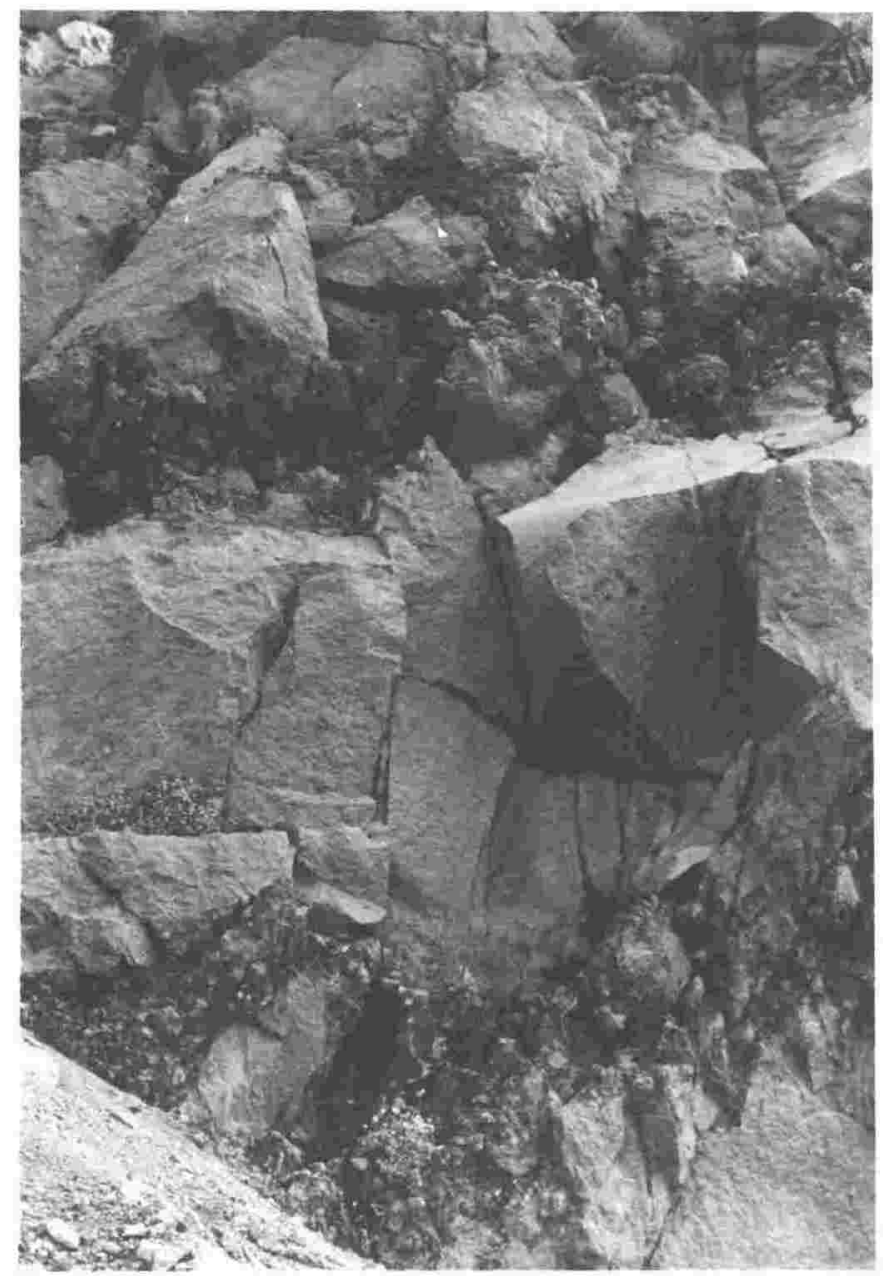




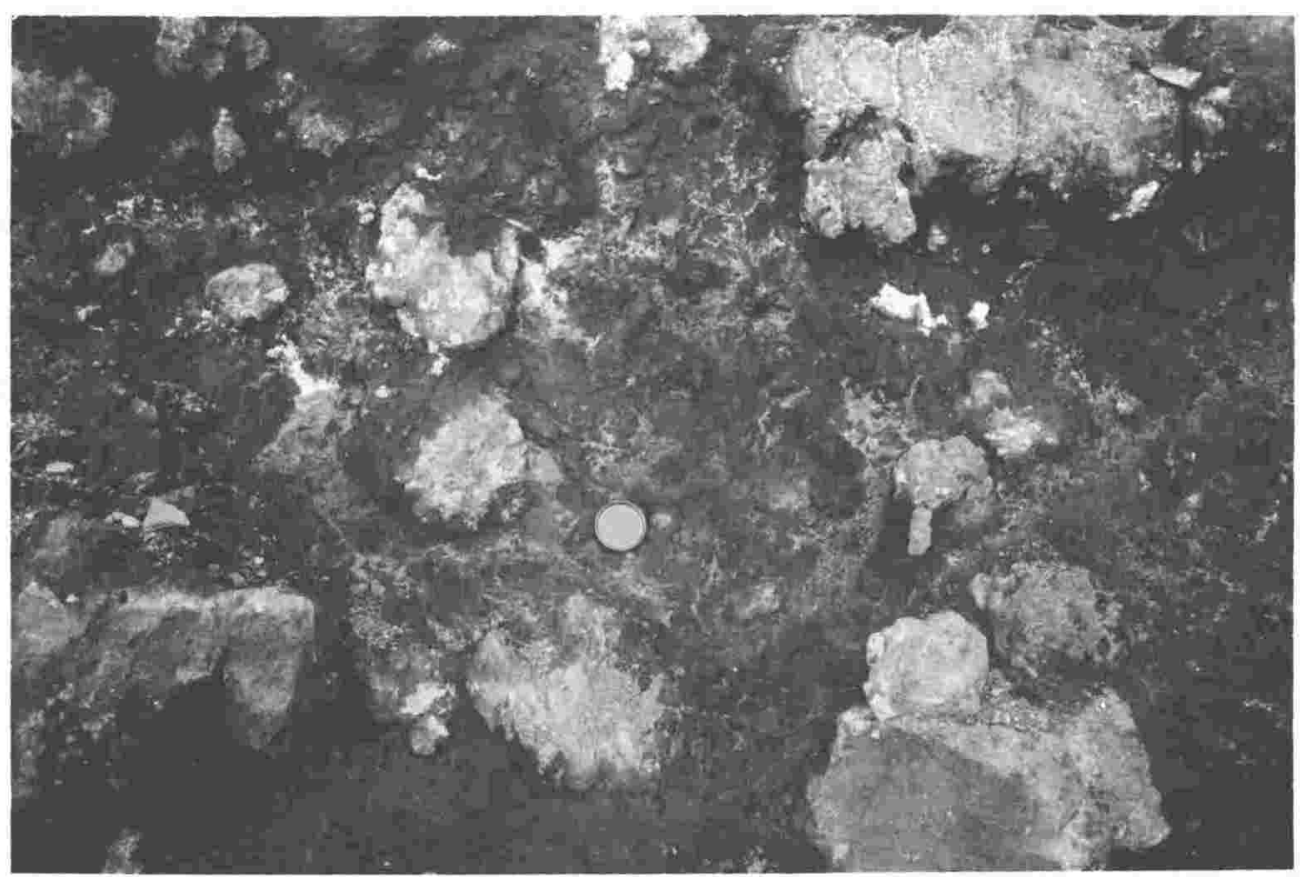

FIG. 39. Unwelded bomb bed, $30 \mathrm{~m}$ interval of RS 3 .

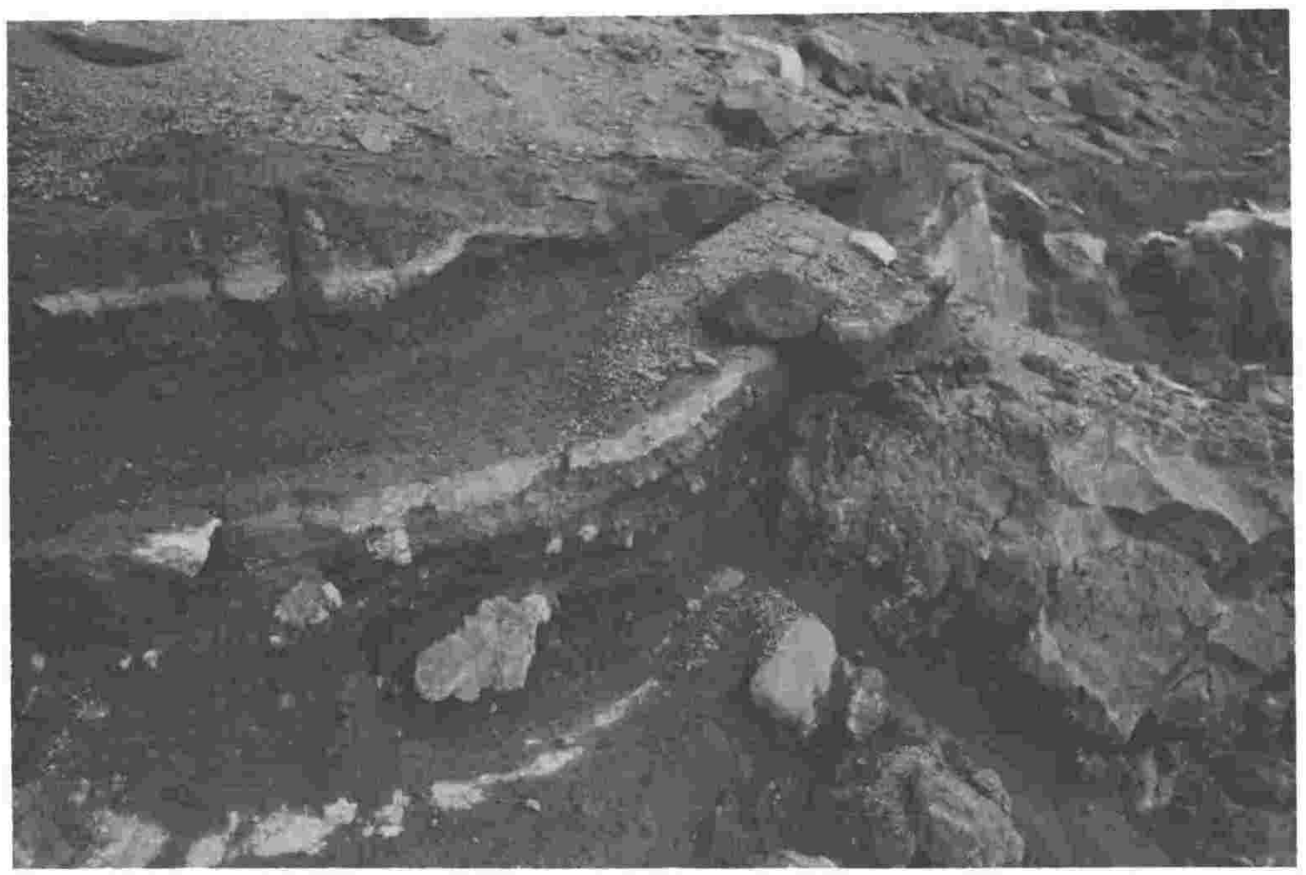

FIG. 40. Mantle-bedded airfall lapilli and ash, $20 \mathrm{~m}$ interval of RS 3 . 
of vesicular, scoriaceous or pumiceous essential clasts.

In RS 5 (Fig. 29), coarse agglutinate units (Bw) are interbedded with welded autobreccias (TBMw) and are distinguished from them only with difficulty. These Bw units are better sorted than the welded autobreccias and contain plastic, rounded, vesicular bombs as the major clast component. Thin, lenticular pods of dense, lava-like material are associated with BW. These are generally less than 1 metre thick and often exhibit striking, flamelike flow banding.

The characteristics of the unwelded deposits suggest they are airfall magmatic deposits. They resemble historic and other young airfall deposits of the Tongariro Volcanic Centre; e.g., Ngauruhoe 1975 (Nairn and Self, 1978), Poutu Lapilli (Topping, 1973), and Ohakune Andesite Formation (this volume). The Bw units are interpreted as welded airfall tuffs which were produced during eruptions from a nearby but unexposed vent. The thin, dense, lava-like units associated with $\mathrm{BW}$ are considered to be densely welded equivalents of $\mathrm{BW}$, where compactional welding has obscured the original bomb outlines. The contorted banding in many of these densely welded Bw units suggests secondary flowage, and they are interpreted as rheomorphic welded tuffs. During high rates of effusion, densely welded airfall can become mobilised by gravity and give rise to genuine lava flows; such a process has been observed during historic Hawaiian-type eruptions. Apparently, the welded airfall deposits were being generated concurrently with the effusion of lava flows and associated autobreccias. The flowing lava may have carried the airfall ejecta away from the vent region, in similar manner to that observed for the 1955 eruption of Kilauea (Macdonald, 1972, p.215).

Heterolithologic tuff breccias (TBh)

This diverse group contains several distinct types of units, ranging from nearly monolithologic to strongly heterolithologic, from matrix to framework supported, and from 
massive to graded bedding. Three types of unit are described here.

Type A consists of a range of large (0.1 to 1 metre diametre) clasts, which are framework supported and with interstitial ash matrices. Clasts include (1) fresh grey and black andesite, (2) red oxidised andesite, and (3) weathered brown andesitic pumice. Most clasts are subrounded to subangular, but some well-preserved bombs occur. The units possess planar, non-erosive bases and planar tops. Frequently, the basal $10-20 \mathrm{~cm}$ of beds is reversely graded, passing upwards into massive tuff breccia. An excellent example of such a unit is found $1.6-2.6$ metres below the top of RS 4 (Fig. 41).

Type B contains a similar clast population, but the clasts are floating in brown matrices of ash-to lapilli-sized material. The large clasts include black, breadcrusted blocks. Large clasts are sometimes restricted to the upper half of these deposits, yielding a reversely graded lithology. Weakly developed internal stratification is manifested by the alignment and relative concentrations of larger clasts. Two reversely graded units occur at the $22.6-26.6$ metre interval of RS 3 (Fig. 42). Similar matrix-supported but not reversely graded deposits comprise much of RS 8 (Fig. 30), and are common in RS 6 (Fig. 32; 0 - 7 metres, 70 - 95 metres).

Type $\mathrm{C}$ is an unusual variety of tuff breccia found in RS 3 (Fig. 27; 59.2 - 63.2 metre, 176 - 189 metre and 207 211 metre intervals). These are matrix-supported, crudely stratified deposits (Fig. 43) which are continuous across most of the southern wall of the Whangaehu Gorge. Large clasts, comprising approximately 25 percent of the deposits, are dominated by striking black volcanic bombs. The bombs, up to 3 metres in diameter, possess delicate breadcrusted exteriors and dense, nonvesicular interiors often cut by arcuate cooling cracks (Fig. 44). The cracks frequently divide individual bombs into a number of discrete, isolated fragments (Fig. 45). 

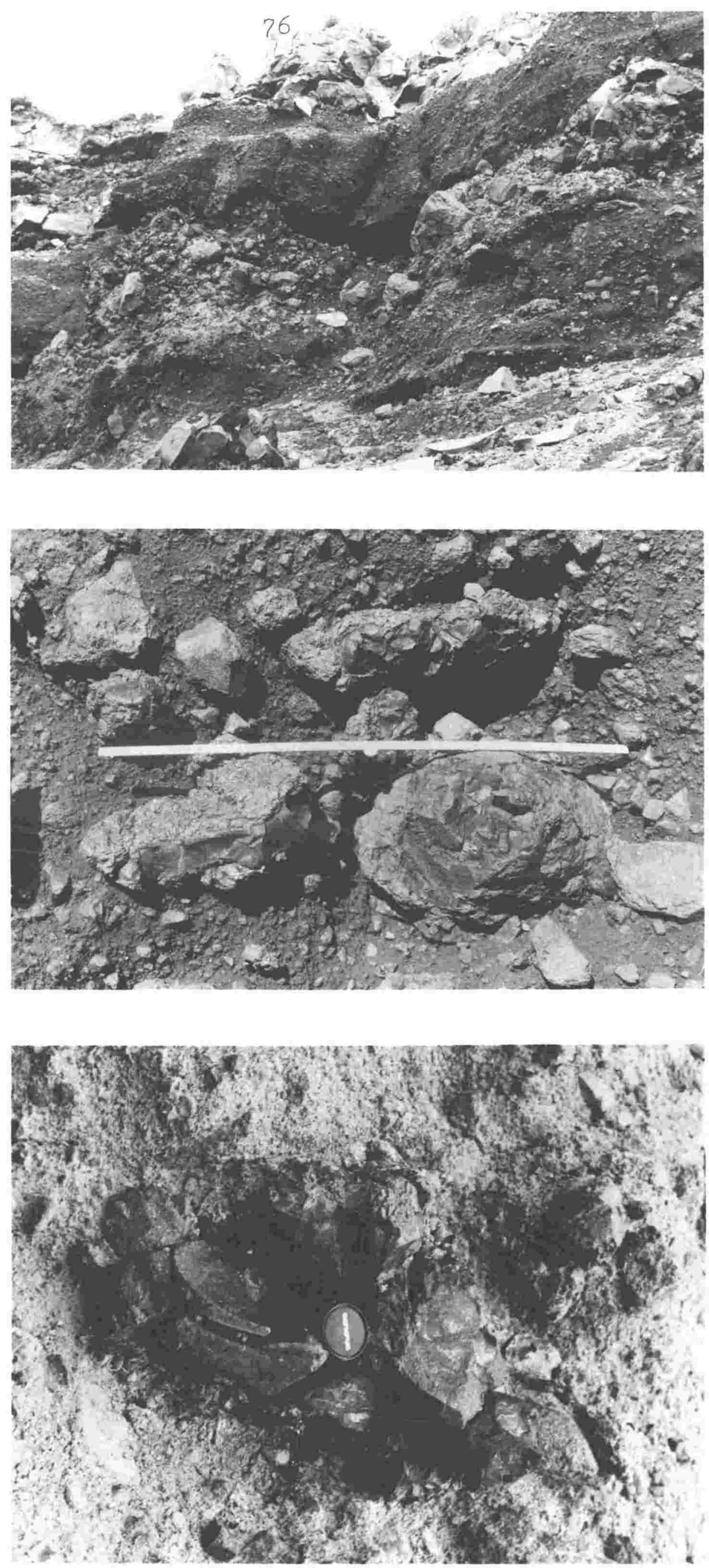
The remainder of the large clasts consist of subangular to subrounded blocks of dense, microvesicular or nonvesicular grey or oxidised red andesite up to $25 \mathrm{~cm}$ in size, and subordinate weathered brown andesite lapilli. Measurements of natural remanent magnetization (NRM) on cores drilled from large clasts indicate that the black breadcrusted bombs have a consistently aligned NRM, whereas dense subrounded blocks exhibit nearly random NRM (Fig. 46).

Type $\mathrm{A}$ and $\mathrm{B}$ tuff breccias are considered to be the products of lahars generated on the upper slopes of the Wahianoa cone. The deposits are clearly the products of mass flows, and the massive nature of the deposits and the abundance of matrix material suggest the transportation mechanisms were debris flows (Johnson, 1970; Middleton and Hampton, 1976) or slurry flows (Carter, 1975). In these mechanisms, large clasts are dispersed in and suspended by matrices consisting of slurries of fine particles and water, with finite yield strengths. Deposition is by mass emplacement or freezing, explaining the massive nature of the heterolithologic tuff breccias. Frequently the flow interiors move as rigid plugs with little internal movement of clasts (Middleton and Hampton, 1976). Plug flow explains transportation without abrasion of volcanic bombs having delicate surface features.

The dominance of a single lithology in many heterolithologic tuff breccias suggests the origin of the mass flows was often the failure or collapse of a single rock unit, be it either pyroclastic material or fragmented lava. A variety of factors combine to make the upper portions of composite volcanoes likely sites for mass collapse. These include (1) steep initial slopes, (2) rapid accumulation rates of often unstable pyroclastic material, (3) extrusion of gravitationally unstable spines, domes and flows of lava, and (4) a variety of possible mechanisms to trigger the collapse of unstable material. The latter includes (1) volcanic seismic events, (2) loading resulting from deposition of new material on an 


\section{R-4 WHANGAEHU}

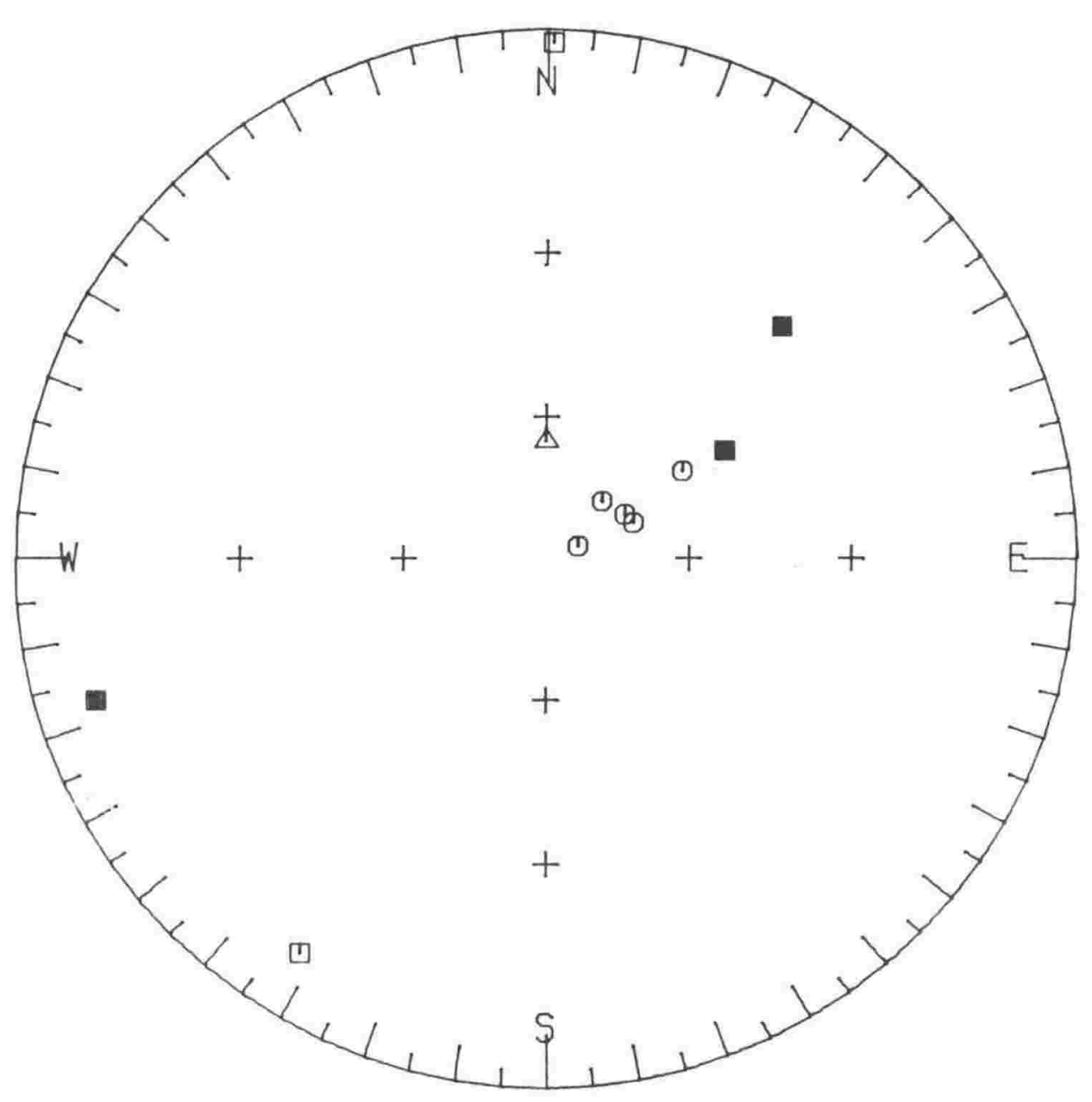

UPPER LOWER

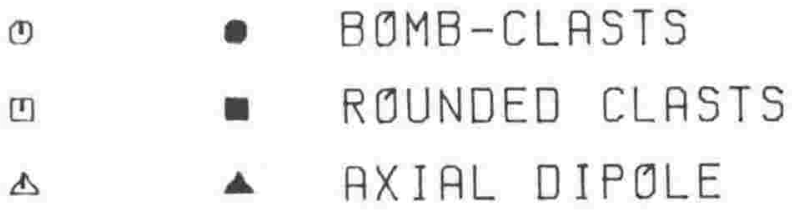

FIG. 46. NRM vectors for "Type C" heterolithologic tuff breccia. Five breadcrusted bomb clasts and five rounded clasts were cored at the $77 \mathrm{~m}$ interval of Ruapehu Section 3 (Fig. 27). "Upper, lower" refers to vectors in upper or lower hemispheres of the equal-area plot. Present-day axial dipole is noted. Vectors for bomb clasts are clustered, suggesting cooling from temperatures above average blocking temperature. Displacement of these from present axial dipole is consistent with down-dip rotation to the $\mathrm{SE}$, as a result of slumping after cooling. Other clasts display random vectors, consistent with emplacement below blocking temperatures. 
already unstable deposit, (3) explosions resulting from extrusion of lava onto snow, onto water-saturated ground, or into water courses, and (4) deformation associated with subterranean movement of magma.

The reversely graded bases of many tuff breccia units can be explained by the hypothesis of Naylor (1980), who suggested that the strongly sheared bases of debris flows are relatively weak and can therefore only support smaller clasts. Neall (1976) has subdivided lahars into volcanic mudflows ( 50 percent or more sand- and mud-sized material) and debris flows (less than 50 percent fine material). By these definitions, type $A$ and type $B$ tuff breccias correspond to debris flows and mud flows, respectively. However, in sedimentological terms the distinction has little meaning, since the two types of deposit were probably transported by similar mechanisms and can be regarded as parts of a continuous spectrum. Debris flow mechanisms have been described for flows with as little as 20 percent clay-sized material (Curry, 1966). Dispersal pressure between large clasts may also have some role in sediment transport for the most matrix-poor units.

Type $\mathrm{C}$ deposits require a more complex explanation because of the presence of large black volcanic bombs. It is likely that the bombs were transported and deposited in a hot and plastic condition and that the arcuate cooling cracks postdate deposition, because the bombs would not likely have survived any mode of transportation in their present highly fractured state. However, there is an absence of signs to indicate that the matrix was ever at an elevated temperature, such as charred vegetation, oxidation, or gas escape pipes. The magnetic measurements suggest that the bombs were deposited in their present positions at a temperature near the curie point, whereas the remaining clasts were closer to minimum blocking temperatures. In form, the bombs are strikingly similar to vulcanian deposits from the 1975 eruption of Ngauruhoe. 
Possible mechanisms are: (1) hot, plastic airfall ejecta falling onto a pre-existing volcaniclastic deposit, mobilizing it as a lahar, and becoming incorporated into the cold material, and (2) the hot bombs are one clast component of a generally cold lahar which was generated directly by explosive eruption. It is clear from experimental studies related to eruption columns (Wilson, 1976) that the slow rate of heat conduction through clasts severely limits heat exchange between large clasts and surrounding fluid, permitting hot large clasts to be transported finite distances in a cold medium without rapid cooling. One other example of this type of deposit, with mixed hot and cool clasts, has been described from Mt St Helens by Hoblitt and Kellogg (1979).

Bedded sand and gravel (SG)

Cross- and planar-bedded, well sorted sands and gravels are commonly associated with heterolithologic tuff breccias in the Wahianoa Formation, but comprise a minor component of the overall stratigraphy. Contact relations with TBh range from abrupt to gradational, and from irregular to nearly planar. SG units are nearly always less than a metre in thickness. A second mode of occurrence is as discrete pockets of high angle cross bedded sand in large interstices of coarse autoclastic and airfall breccias (Figs. 47, 48).

The good sorting, sedimentary structures, and heterolithologic character of these units indicate that they are fluvial deposits. Discrete SG beds with abrupt, planar to irregular contacts with over- and underlying units were probably the products of sheet wash during periods of high rainfall. Other SG units overlie TBh and are gradational into the TBh without changes in matrix colour or clast petrographies (e.g., the 6 - 8 metre interval of RS 6 ; Fig. 32). These SG may have been produced by de-watering of the underlying laharic TBh.

Interstitial cross bedded sands in coarse breccias are clearly not the products of a single depositional event since (1) large clasts sometimes exhibit welding at points of contact, 


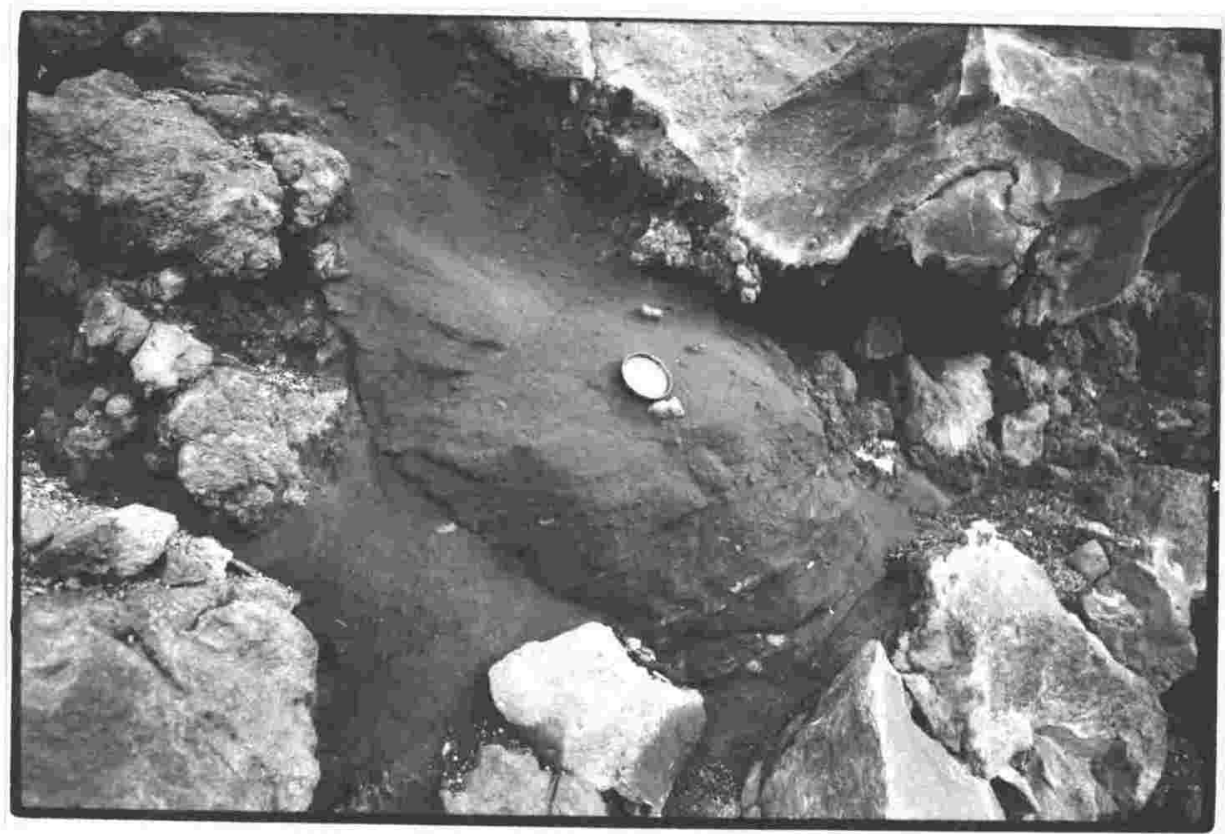

FIG. 47. Cross-bedded sand filling interstices of coarse breccia; $19.2-19.8 \mathrm{~m}$ interval of RS 3 (see: Fig.27).

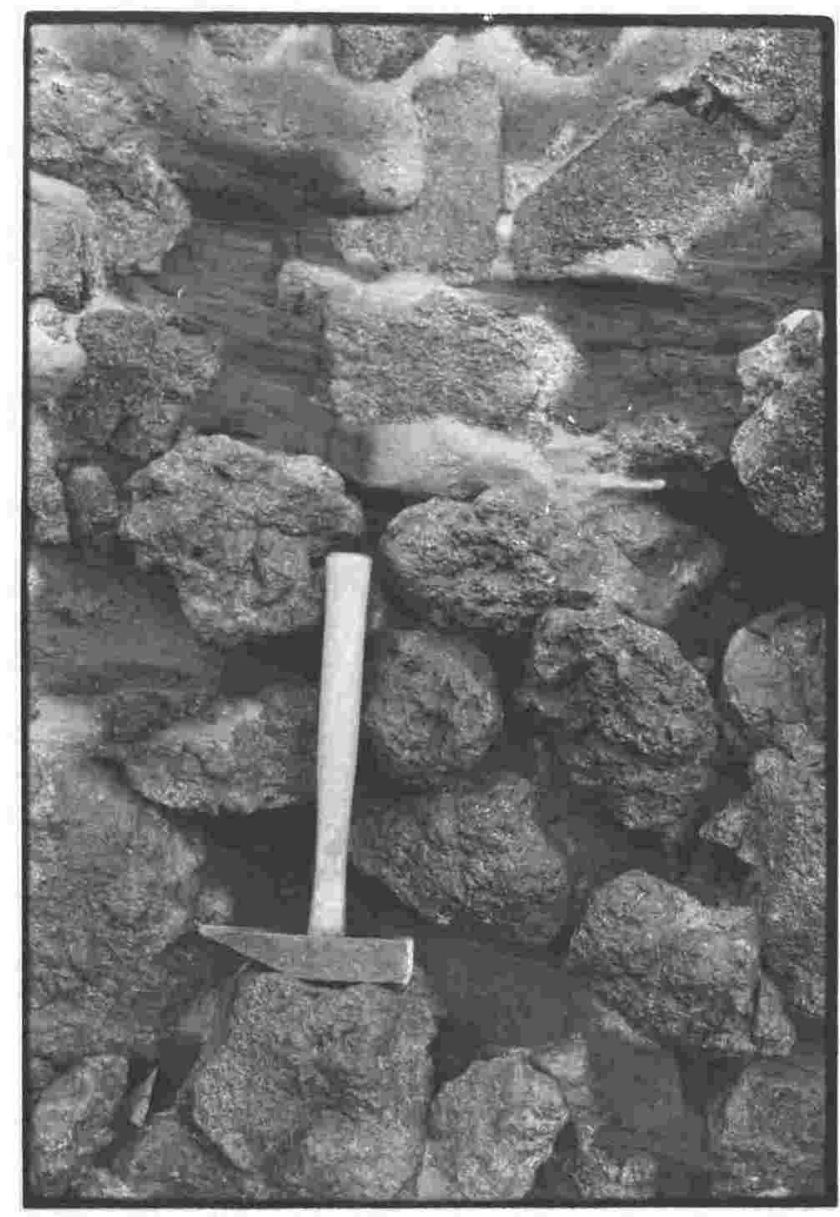

FIG.48. Cross-bedded sand in coarse breccia; Wahianoa Fm at T20/337093, N122/088644. 
which is indicative of emplacement at temperatures above the vapourization temperature of water, and (2) no aqueous fluid can transport metre-sized blocks and fine sand simultaneously. The cross bedded, fine matrices are clearly secondary fluviatile additions to coarse, primary, highly permeable pyroclastic or autoclastic deposits. Additional examples are found in Mangawhero Formation SG deposits. Modern analogues to these "mixed deposits" can be seen at a number of locations around Ruapehu where modern streams, in times of flood, have washed sand into open pore spaces in older coarse fluvial or pyroclastic/autoclastic deposits. The "mixed deposits" are considered to be analogous to sieve deposits decribed from alluvial fan environments (Hooke, 1967).

\subsection{MANGAWHERO FORMATION (New formation name)}

DISTRIBUTION, THICKNESS AND VOLUME

The Mangawhero Formation is named after the Mangawhero River, which drains part of the soutwestern flank of Ruapehu. The formation is extensively exposed over most of Ruapehu, except for the southeastern slopes, and its deposits form the present-day high peaks (except Te Heuheu, the northernmost summit region) and main cone of Ruapehu. Compared to older formations, the deposits have been less deeply incised by glacial and fluvial erosion (Fig. 49), but numerous local intraformational fluvial unconformities are present. The vast majority of the deposits are lava flows and associated autoclastic breccias, with a total exposed thickness of up to 120 metres and an estimated volume of $35 \mathrm{~km}^{3}$.

TYPE AREA: Headwaters of the Mangaturuturu River, southwest Ruapehu

\section{FORMATION BOUNDARIES}

Localities for the lower boundary have been described under Wahianoa Formation. An additional exposure of the basal contact occurs in the headwaters of the Whakapapaiti Stream (RS 12, Fig. 15), where black, plagioclase-phyric and grey olivine-bearing lavas of the Mangawhero Formation unconformably rest on the glaciated surface of a Te fierenga Formation lava 

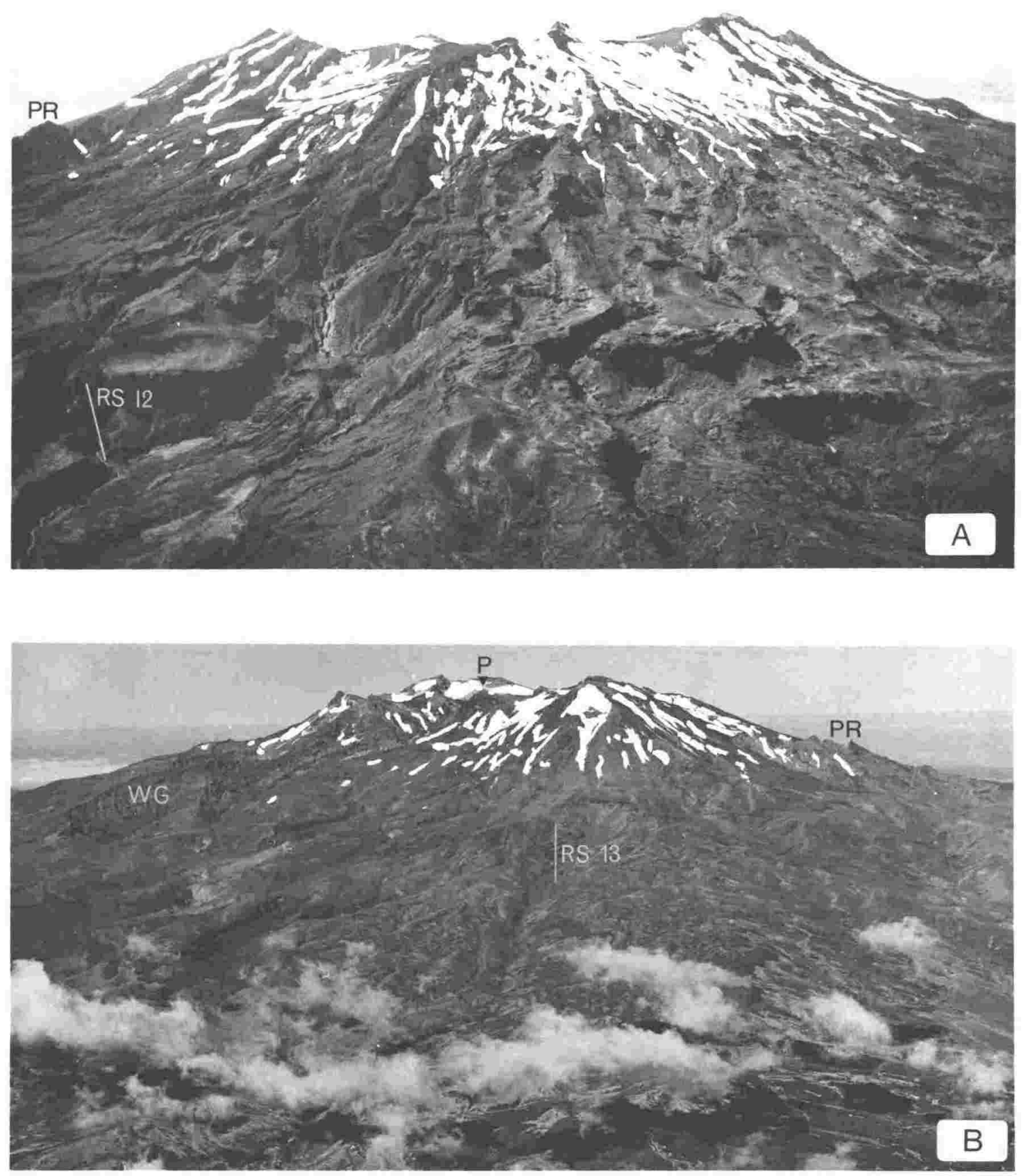

FIG. 49. A: Aerial photograph of southwestern slopes of Ruapehu, showing tabular lava flows and autobreccias of Mangawhero Fm.

B: Northeastern slopes, showing main cone of Mangawhero and Whakapapa Fms.

Pyramid Peak (P) coprises tephra of Whakapapa Fm. Remnants of older cones comprise Wahianoa Fm of Whangaehu Gorge (WG) and Te Herenga Fm of Pinnacle Ridge (PR).. Localities for stratigraphic sections in Mangawhero Fm are also shown. 
flow. The base of the formation is thus defined both by conspicuously unconformable relations with wahianoa and Te Herenga Formation deposits, and by an abrupt change in the phenocryst mineralogy of the deposits across the contact. The petrographic distinction is an important one, as numerous intraformational glaciofluvial unconformities exist within the Mangawhero Formation. Were it not for the abrupt change to olivine-bearing eruptives, the lower formation boundary would be far less confidently defined.

Mangawhero Formation is locally overlain by post-glacial eruptives of the Whakapapa Formation. The relation is clearly unconformable on the flanks of Ruapehu, but not in the western summit region. Whakapapa Formation of the northern summit region (Te Heuheu Ridge) is separated from upper Mangawhero deposits of Paretetaitonga, by the Whakapapa Glacier. No unconformity can be identified, and in the western summit region there is a suggestion that activity from summit vents was continuous across the Mangawhero/Whakapapa boundary.

$\underline{\mathrm{AGE}}$

On the basis of two $\mathrm{K}$-Ar dates from the middle of the formation (Stipp, 1968; Fig. 5, this volume), the numerous intraformational unconformities, and the overall degree of dissection, the writer speculates that Mangawhero volcanism occurred over a time interval between about 50,000 and 15,000 years ago. This encompasses the brief time at which parasitic volcanism occurred (see below).

\section{LITHOLOGY AND PETROGRAPHY}

Mangawhero deposits are present in RS 9 through 13 (Figs 15, and 50-53). About 96 percent of these deposits consist of lava flows and monolithologic tuff breccias (TBm), and the remainder are heterolithologic tuff breccias (TBh), sand and gravel (SG), and mantle- or shower-bedded tuffs (T). 

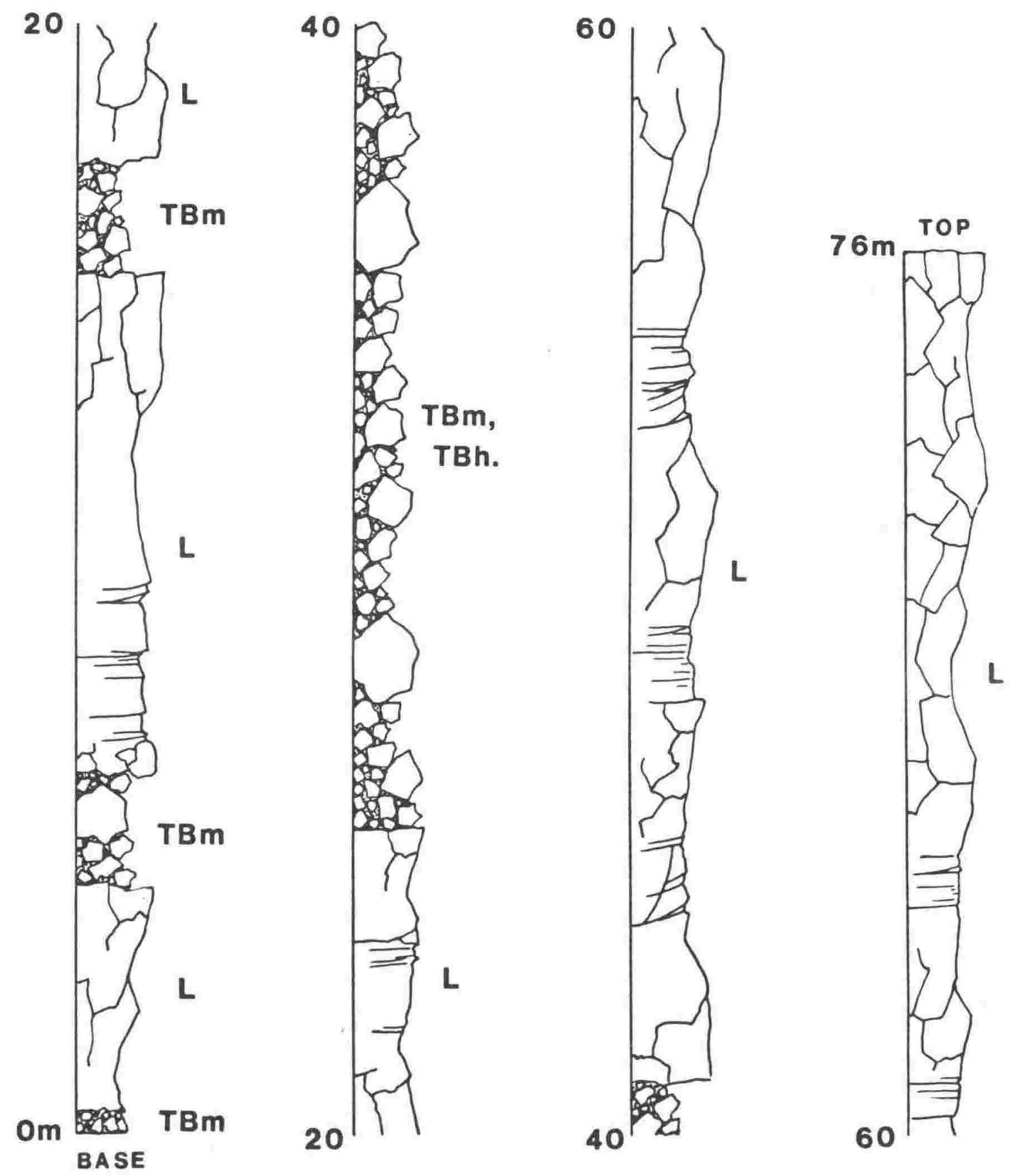

FIG. 50. Ruapehu Section 9. $76 \mathrm{~m}$ of Mangawhero Fm exposed at Girdlestone Peak, southeastern summit region of Ruapehu (see: Fig. 23). Grid references for base of section are: T20/313087 (metric), N122/062636 (yard). 

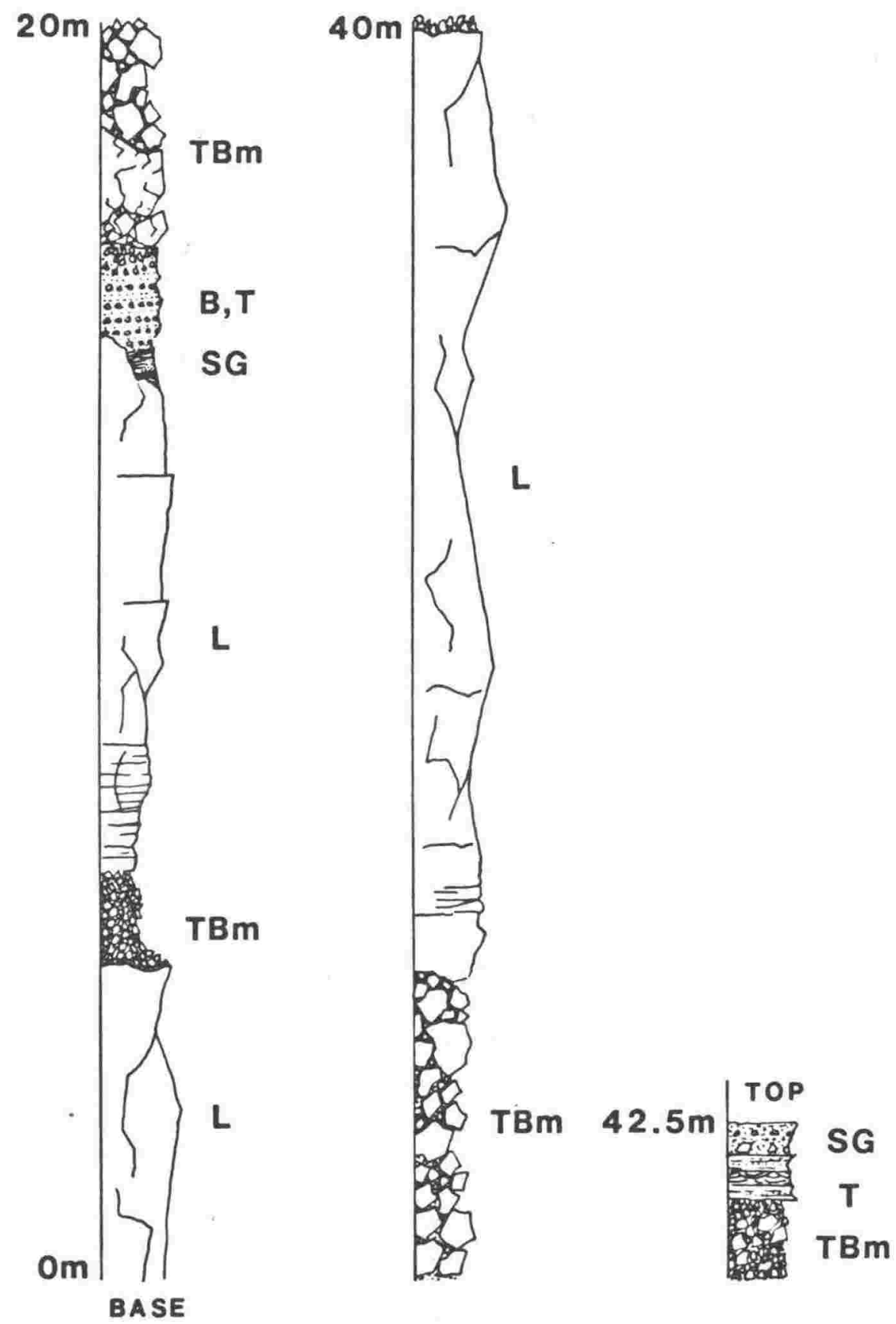

FIG. 51. Ruapehu Section 10. $42.5 \mathrm{~m}$ of Mangawhero Fm exposed beneath Tahurangi (see: Fig. 59), southern summit region of Ruapehu. Grid references for base of section are: T20/309098 (metric), N122/057647 (yard). 

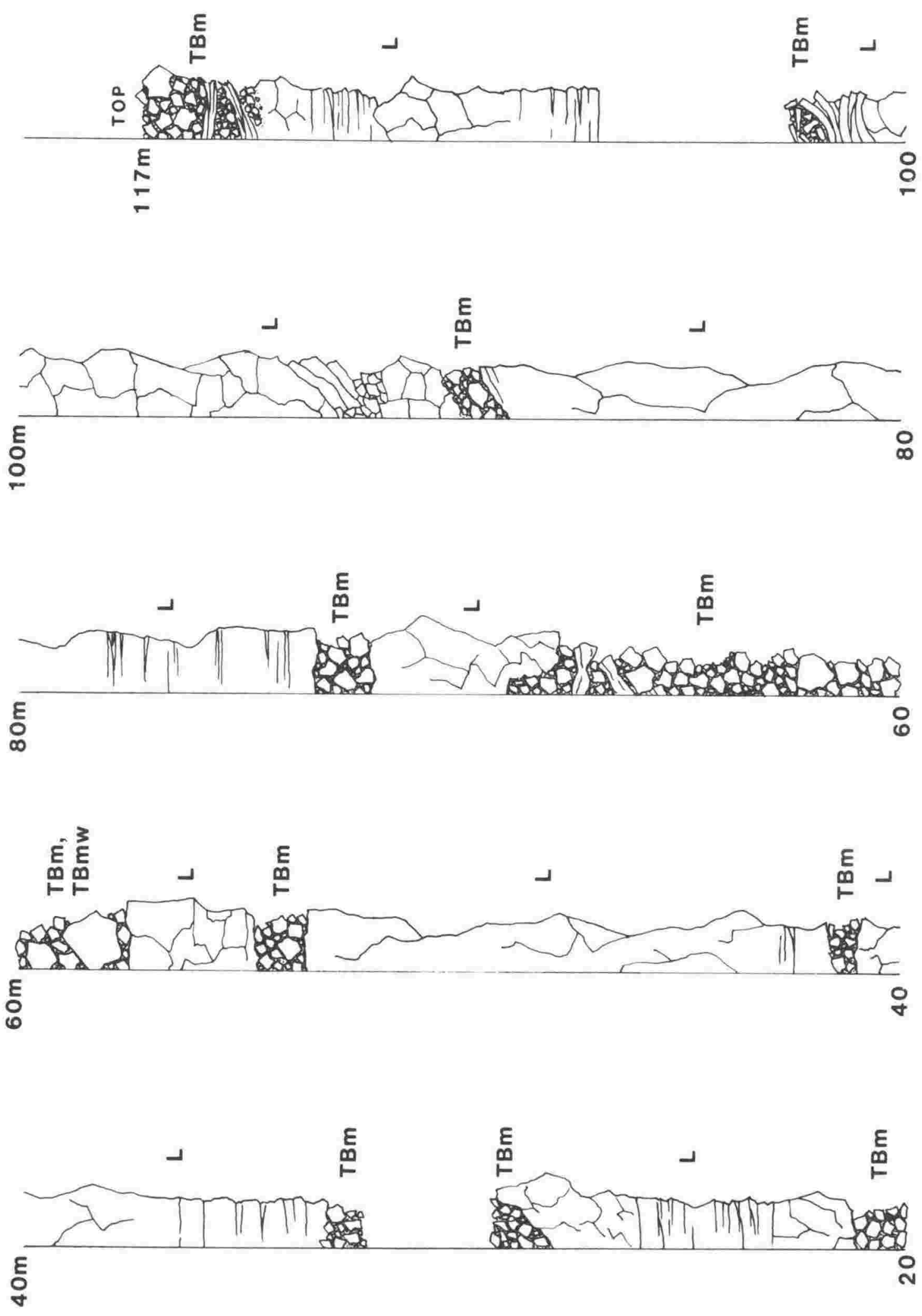

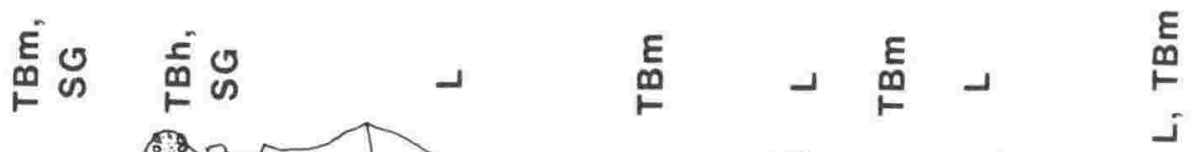

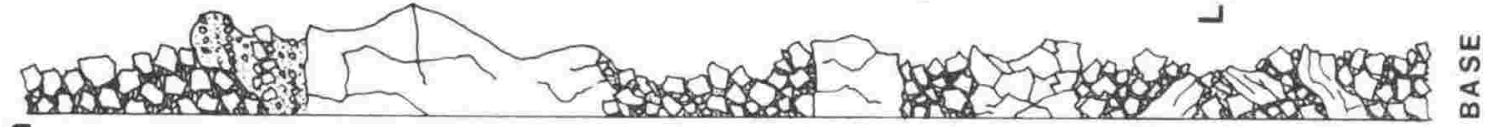
ํํำ 


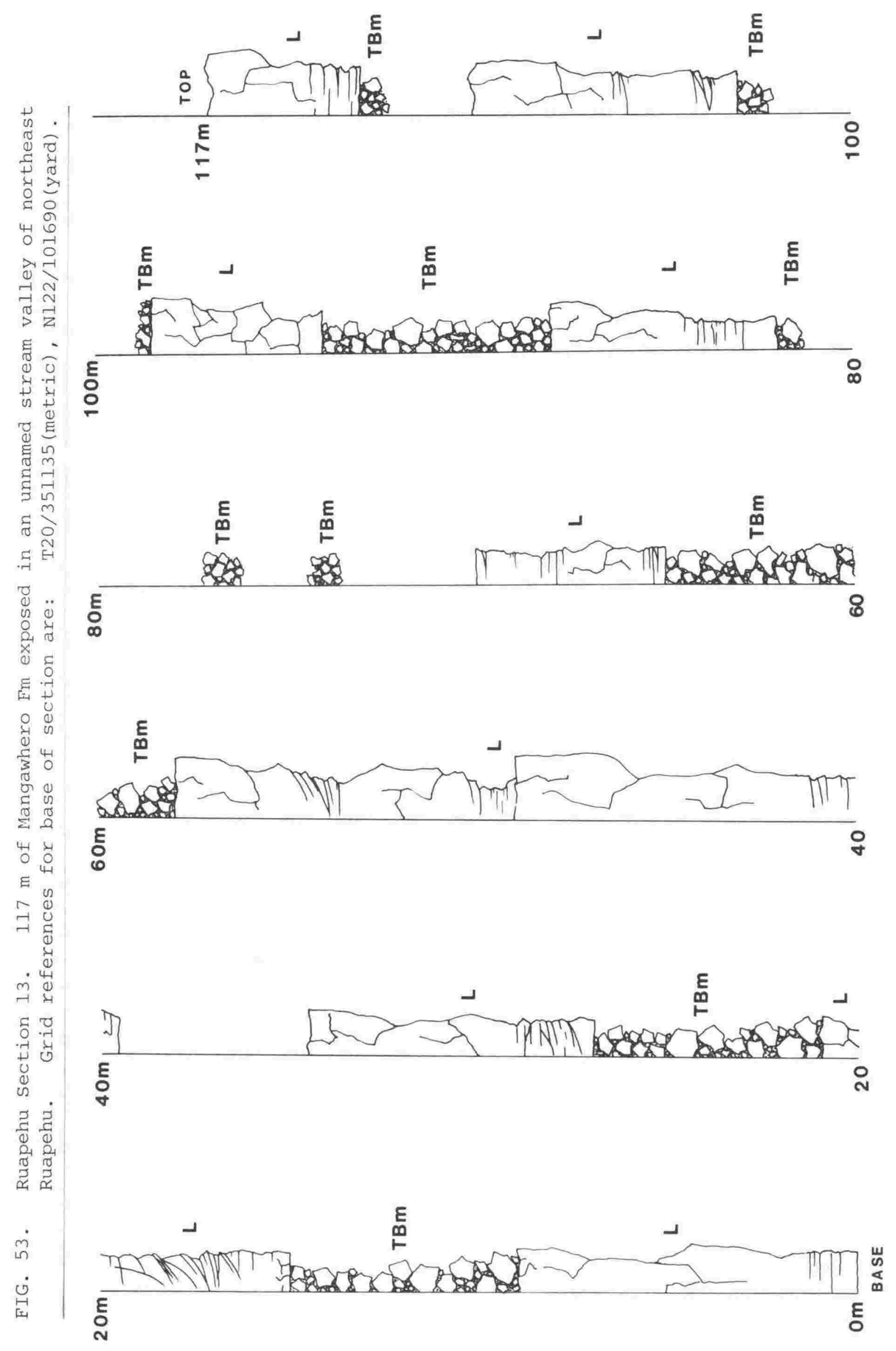


Lava Flows

Twenty-nine lava flows, measured from all Mangawhero sections, range from 1.5 to 35 metres, and average 8.4 metres in thickness. Flows are nearly always associated with TBm, and the transition from flow to breccia is abrupt. Most flows have rubbly margins, but nearly planar tops are present, suggesting brief erosion between flows. Blocky and platy jointing of the flow interiors is characteristic, but some glassy flows have well-developed columnar jointing.

The flows exhibit widely varying petrographies, from black, glassy dacites, to medium grey olivine basalt. Conspicuously olivine-bearing flows are particularly abundant at, but not restricted to, the base of the formation.

\section{Monolithologic tuff breccias (TBm)}

These incorporate all the characteristics of TBm deposits described perviously for other formations and are accordingly interpreted as autoclastic breccias formed by the fragmentation of flowing lava. A drawing of the often chaotic association among lava flows and TBm is presented as Figure 54.

\section{Heterolithologic tuff breccias (TBh)}

This lithology is not abundant in the Mangawhero Formation. In the measured sections, an example occurs at the 38 - 44 metre interval of RS 12 (Fig. 15). Rounded, strongly heterolithologic clasts are supported in indurated, yellow-brown tuffaceous matrices. Crude internal stratification is commonly developed as relatively coarse horizons in a generally finergrained deposit, and the TBh are commonly associated with SG deposits. TBh and SG occur throughout the formation as local, valley-filling deposits intercalated with the more voluminous lava flows and autobreccias. TBh are interpreted as fluviallaharic units, which are the depositional counterparts of the numerous intraformational fluvial unconformities. 


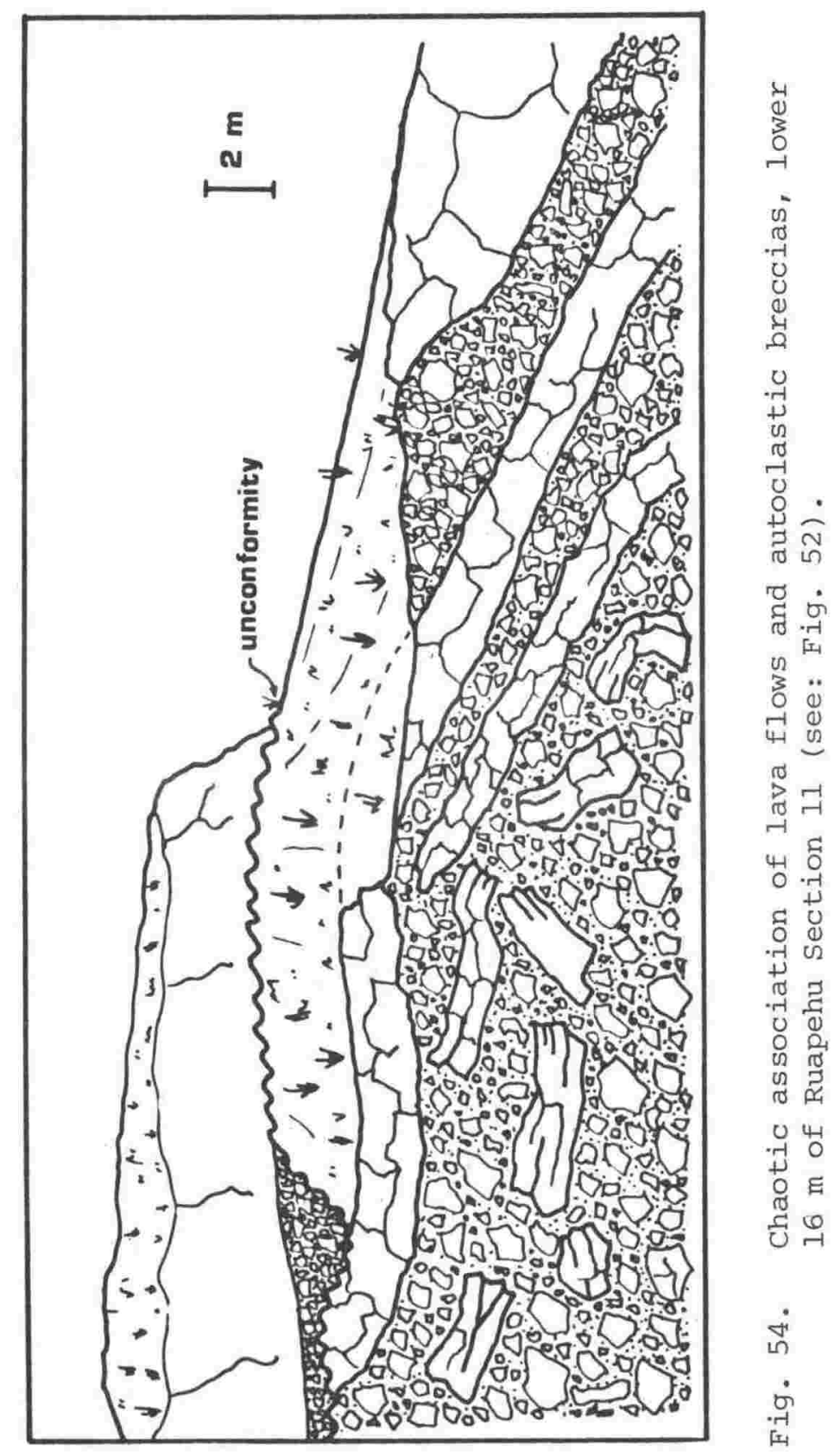


Bedded, sorted sand and gravel (SG)

Examples of these deposits occur at the $14.2-14.8$ and 41.5 - 42.5 metre intervals of RS 10 (Fig. 51), and at the 16 - 20 metre interval of RS 11 (Fig. 52).

The deposits in RS 10, and expanded view of which is given in Figure 55, range from crudely bedded sandy gravels to planar- and cross-bedded fine sand and mud. They are interpreted as fluvially reworked airfall material. Deposits in RS 11 (Fig. 56) include bedded, framework-supported coarse gravels which alternate with cross-bedded pebbly sands, and are interpreted as fluvial deposits. A second lithology occurs as coarse, clast-supported $\mathrm{TBm}$, where the interstices are filled with cohesive but uncemented, trough cross-bedded fine sand and silt. This is interpreted as being of identical origin to similar SG units of the Wahianoa Formation.

Well sorted, mantle- and shower bedded tuffs and lapilli tuffs $(\mathrm{T})$

These deposits are rare in the Mangawhero Formation. Two examples occur at the 14.8 - 16.5 and at the 41.5 metre interval of RS 10 (Fig. 51; expanded drawings in Fig. 57). Shower and mantle bedding are well developed, and the deposits are interpreted as primary magmatic and phreatomagmatic airfall units. At the 41.5 metre interval of RS 10, alternating coarse ash and fine ash laminae contain coarse lapilli with bomb sags.

\section{Intrusive bodies (I)}

Intrusive bodies are restricted to a few vertical dykes. None are recorded in the measured sections, but numerous conspicuous examples occur at Girdlestone Peak (Fig. 23). Many of these dykes are dark and olivine-bearing, and are petrographically similar to the associated lava flows. Several metres of the surrounding country rock are commonly altered to a deep brown colour. A few are breccia dykes having lithologies nearly identical to autoclastic tuff breccia, but differing from the latter in that they are not pervasively oxidized. These dykes 

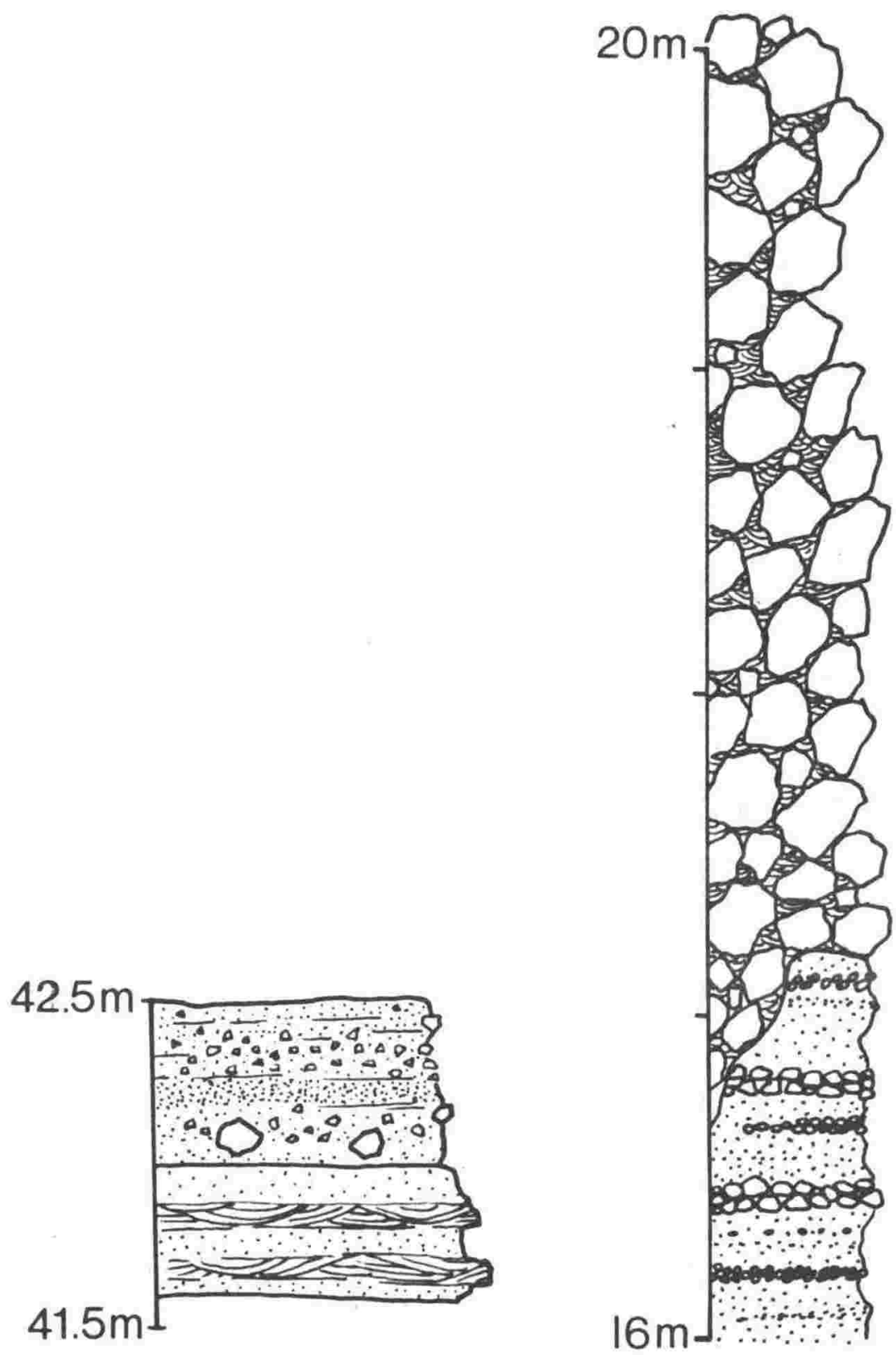

FIG. 55(left). SG deposits of Mangawhero Fm;

41.5-42.5 m interval of Ruapehu Section 10 (see: Fig. 51).

FIG. 56 (right). SG deposits of Mangawhero Fm; 16-20 m interval of Ruapehu Section 11 (see: Fig. 52). 

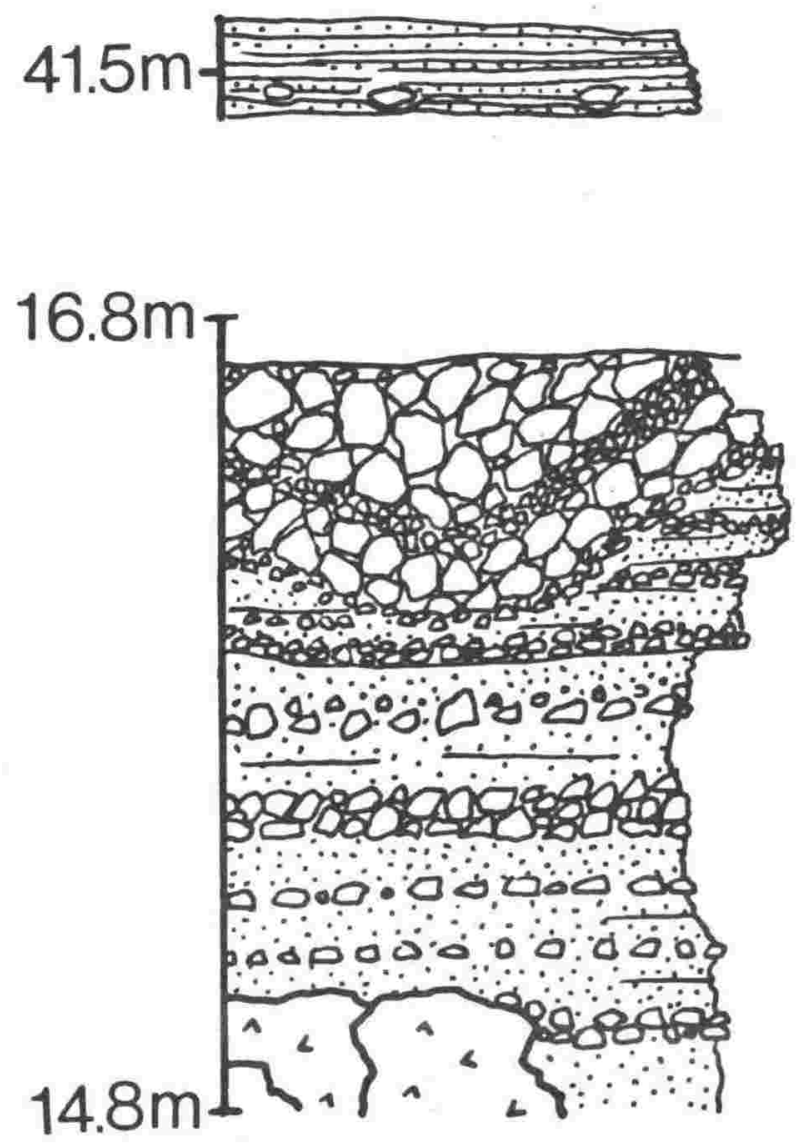

FIG. 57. Bedded tuffs and lapilli tuffs of Mangawhero $\mathrm{Fm} ; 14.8-16.8 \mathrm{~m}$ and $41.5 \mathrm{~m}$ intervals of Ruapehu Section 10 (see: Fig. 5I). 
exhibit clear intrusive relationships to the host deposits (Fig. 58), and surrounding deposits of the Wahianoa Fm are locally oversteepened. Park (1886) noted that: "On the north side of this peak (Girdlestone) there is a great boss or dome of dark smooth pitchstone in which the lines of fluxion are well marked". This intrusive body was not identified by the present writer but is almost certainly related to the dark, ol-bearing Mangawhero dykes described above.

\section{Discussion}

Because younger formations such as the Mangawhero are not deeply eroded and are exposed over large areas, they afford an opportunity to evaluate the areal distribution of vent regions and their eruptive products.

Most of the Mangawhero Formation was produced by subaerial effusion of lava as tabular flows, and a large quantity of autoclastic tuff breccia is associated with these flows. Local fluvial unconformities occur throughout the formation, as lava flows were emplaced onto previously dissected terrain. Perched terraces of heterolithologic tuff breccia (lahars) and fluvial deposits are observed in present-day stream courses, and similar deposits were intercalated between Mangawhero lava flows.

Eruptions issued from several centres in the summit region. In the southern part of this region, dips of Mangawhero deposits are radially disposed around a point between crater Lake and Tahurangi. Several intraformational unconformities are evident in the deposits beneath Tahurangi (Fig. 59), sometimes having broad, U-shaped outcrop traces, suggestive of alpine glaciation during the period of deposition. Many deposits beneath Tahurangi and in the cliffs between Tahurangi and Paretetaitonga exhibit hydrothermal alteration, confirming that a vent existed in the southern part of what is now the Crater Lake Basin.

Cathedral Rocks (Fig. 60) consist of hydrothermally altered heterolithologic and monolithologic tuff breccias of 


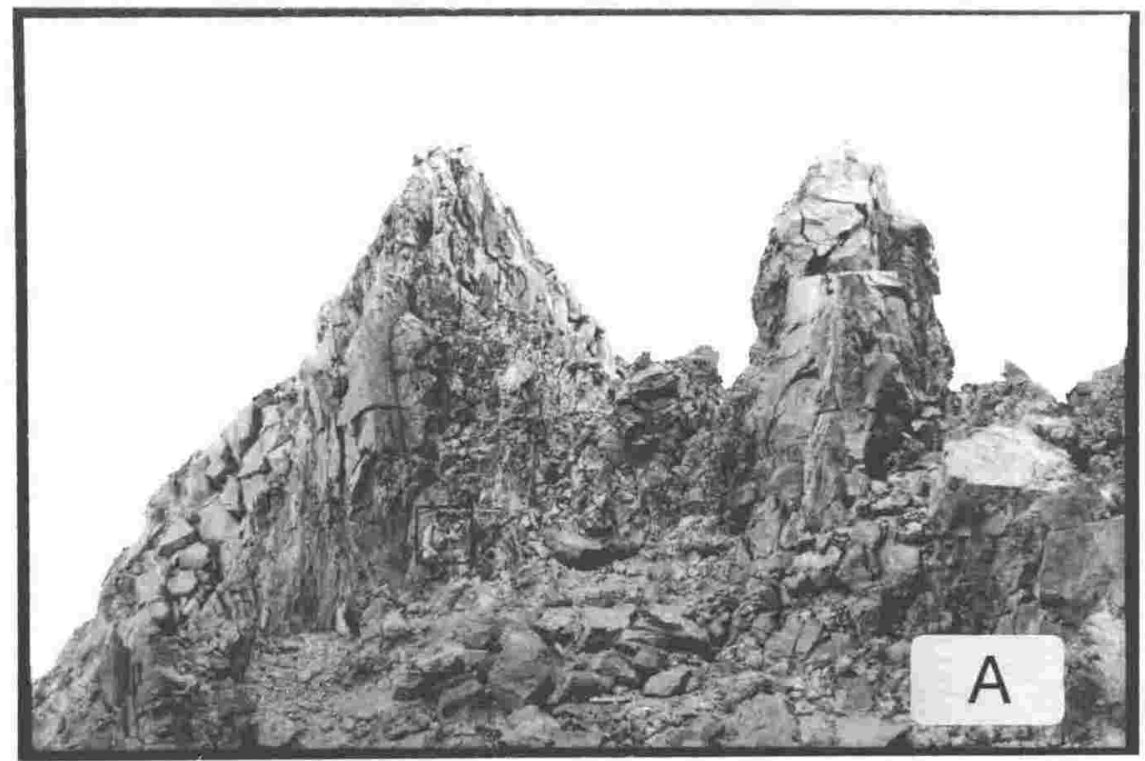

FIG. 58. Dykes of Mangawhero Fm at Girdlestone Peak. A: Intrusive breccia with unbrecciated margins.

B: Subvertical dyke cutting lava flows and autobreccias of Mangawhero Fm.

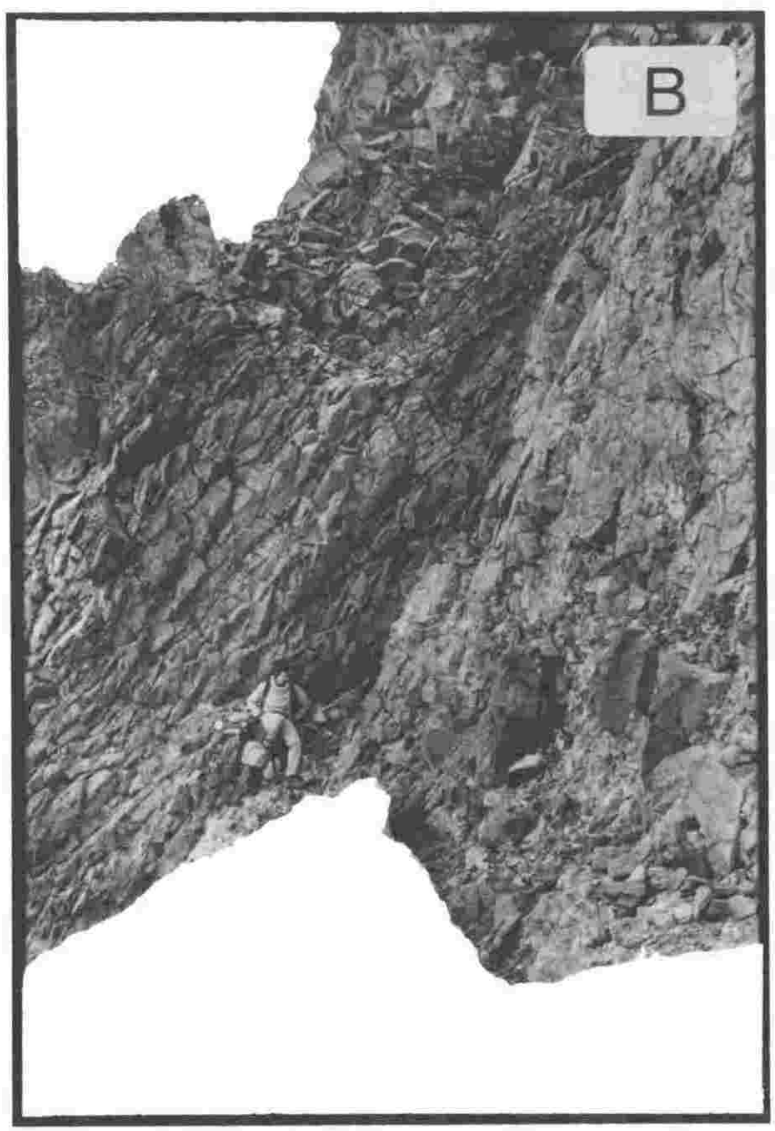



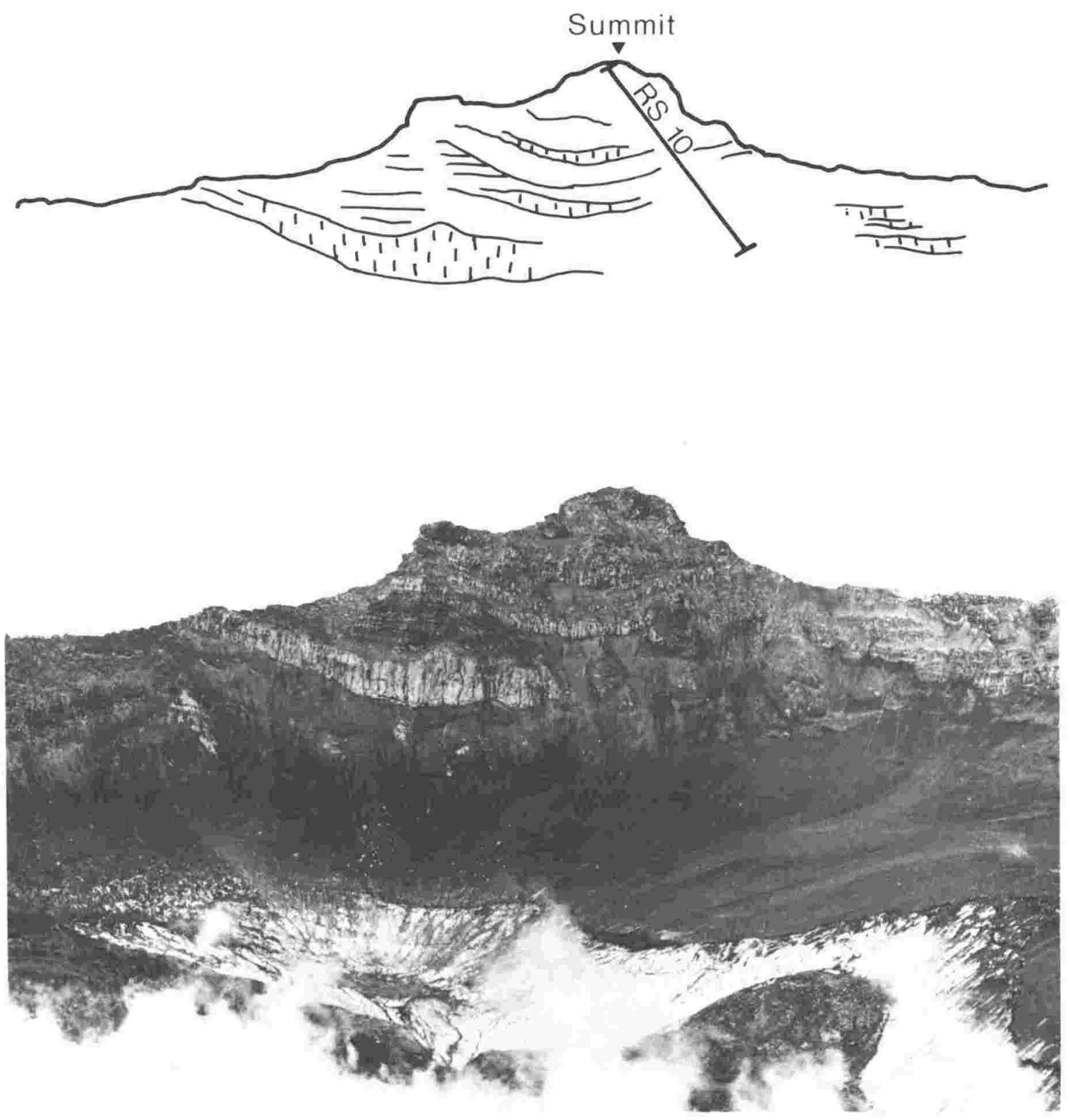

FIG. 59. Glacial unconformities developed in Mangawhero Fm beneath Tahurangi (Ruapehu summit). Crater lake in foreground. (NZGS photo by D.L. Homer). 


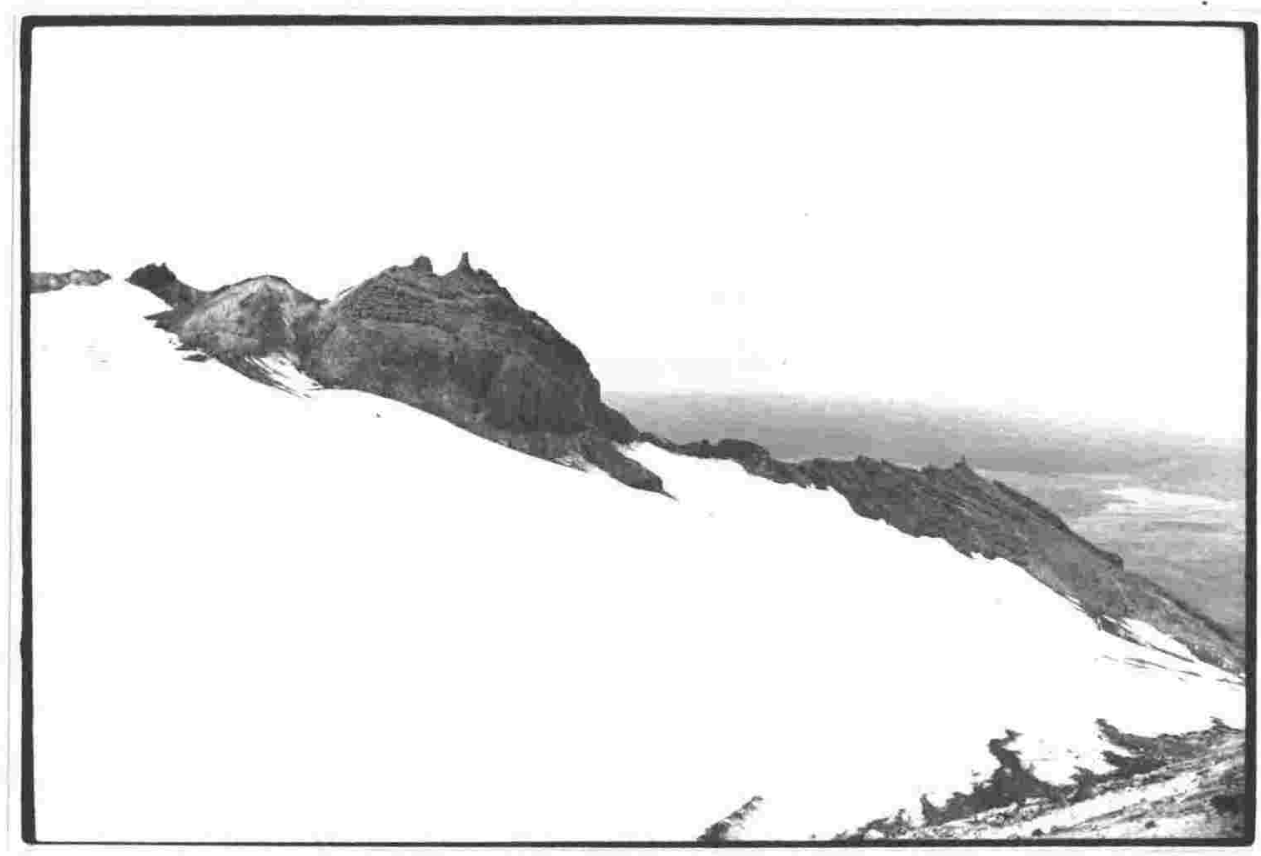

FIG. 60. Cathedral Rocks, western summit region of Ruapehu. The exposure comprises altered tuff breccias of Mangawhero Fm, erupted from a vent which occupied the Sumit Plateau(to the left of photograph). The dipping lavas and tuff breccias at the right of the photo form a small planeze surface.

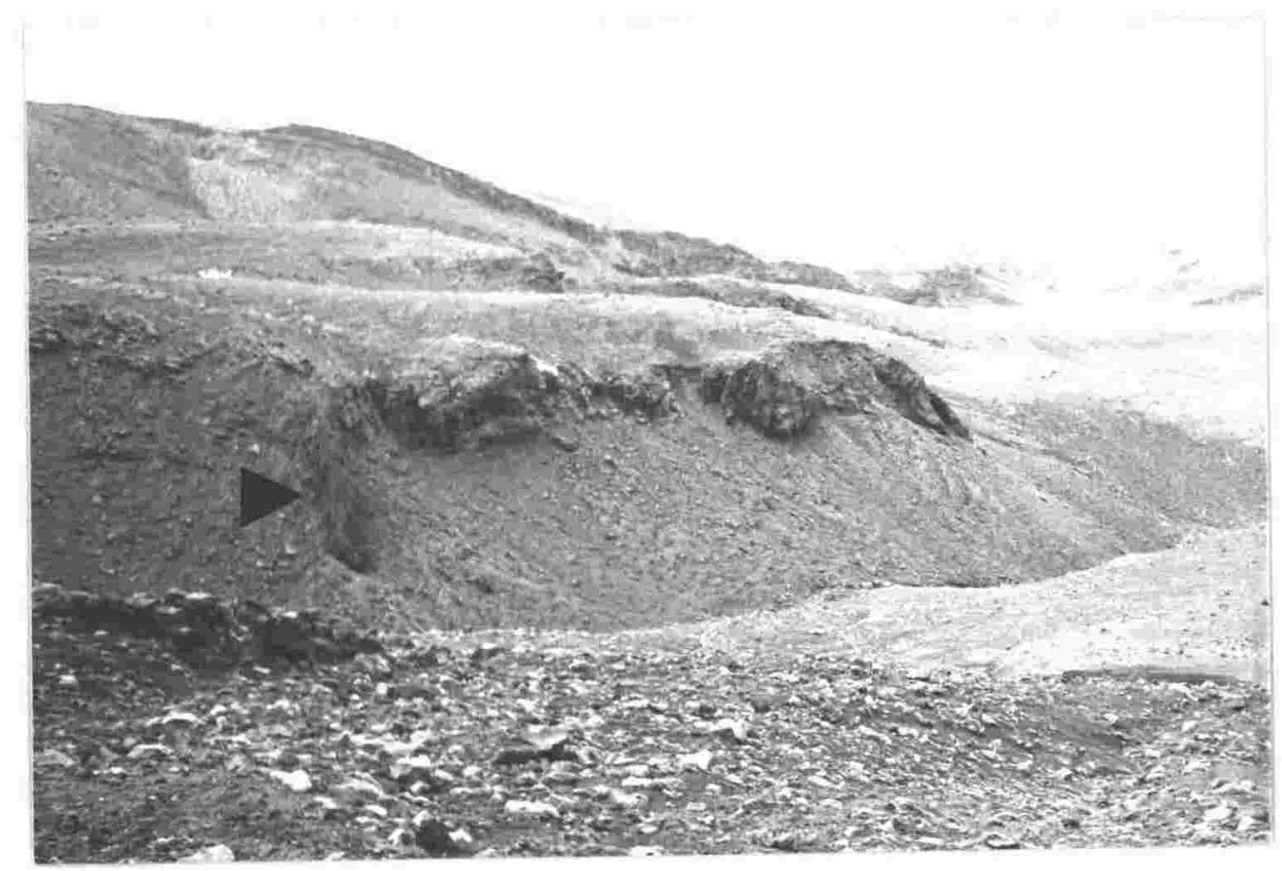

FIG. 61. Feeder dyke for northern Flank eruptions of Mangawhero Fm at locality T20/329156(metric), N112/077713 (yard). 
the Mangawhero Formation. Hydrothermal alteration intensifies northwestward, and individual depositional units are separated by bedding planes which dip to the southeast. These observations imply a source vent which occupied the region of the present-day summit Plateau.

Another apparent vent region is Girdlestone Peak. The Wahianoa-Mangawhero boundary is defined here, and some of the most complex geology on the mountain is exposed (Fig. 23). Both formations are intruded by irregular dykes of massive lava and breccia.

A single Mangawhero flank vent is documented on north Ruapehu, where a vertical dyke is observed to have fed a dacite flow (Fig. 61).

\subsection{WHAKAPAPA FORMATION (New formation name)}

\section{DISTRIBUTION, THICKNESS AND VOLUME}

The Whakapapa Formation is named after the Whakapapa skifield on the northwestern slopes of Ruapehu. The formation is defined as conspicuously young, post-glacial lava flows, autoclastic breccias, and pyroclastics which exhibit only minor fluvial erosion, although the deposits of the summit region have undergone minor erosion by Holocene alpine glaciers. Eruptions occurred from at least six discrete vents, and the deposits from each of these vents are given Member status. The Whakapapa lava field of northwest Ruapehu, the Taranaki Falls lava flow, and the lavas and pyroclastics of the Te Heuheu Ridge all erupted from a vent at the northern summit region of Ruapehu, and comprise the Iwikau Member. A second summit vent is the currently-active crater Lake vent, which erupted minor pyroclastics and lava flows that comprise the crater Lake Member. Flank eruptions occurred as well. Two lava fields and minor pyroclastics were produced during flank eruptions on the northern slopes of Ruapehu, comprising the Tama Member. Voluminous lava flows and lesser pyroclastics comprise the Rangataua Member, which erupted from a single flank 
vent on the southern slopes of Ruapehu. Welded airfall tuff and vertical dykes of the Pinnacle Ridge Member issued from fissures along this ridge.

The formation is neither thick nor voluminous. A maximum thickness of about 50 metres is exposed in the upper Whakapapanui Gorge, northwest Ruapehu, where the Whakapapa lava field has been deeply incised by fluvial erosion (Fig. 74). Summation of the volumes for individual Members yields a total volume of $2.6 \mathrm{~km}^{3}$ for Whakapapa Formation.

\section{FORMATION BOUNDARIES}

Lava flows and fragmental deposits of the Whakapapa Formation unconformably overlie those of all other formations, except in the region of Paretetaitonga, where Mangawhero and Whakapapa deposits do not exhibit unconformable relations. No upper formation boundary is defined, because modern eruptives from the crater lake vent are included in the formation definition.

TYPE AREAS: each defined member comprises its own type area.

\section{LITHOLOGY, PETROGRAPHY AND GENESIS OF MEMBERS}

\section{RANGATAUA MEMBER}

The lava flows and essential pyroclastic material are plag-cpx-opx andesites with dark grey to black matrices.

The vent region for these eruptives is a low, elongate mound of welded and unwelded pyroclastics (Fig. 62). A measured section of Rangataua lithologies, taken near the vent region, is shown in Figure 63. At the base of the section, angular blocks and lesser moderately vesicular bombs up to $15 \mathrm{~cm}$ are supported in a thoroughly welded, oxidized, microvesicular matrix. No sag structures are present beneath the large clasts, and the deposit is poorly sorted and lacks internal stratification. It is interpreted as a pyroclastic flow. Above this are shower-bedded lapilli tuffs. These are well sorted but contain some red scoriaceous bombs up to 


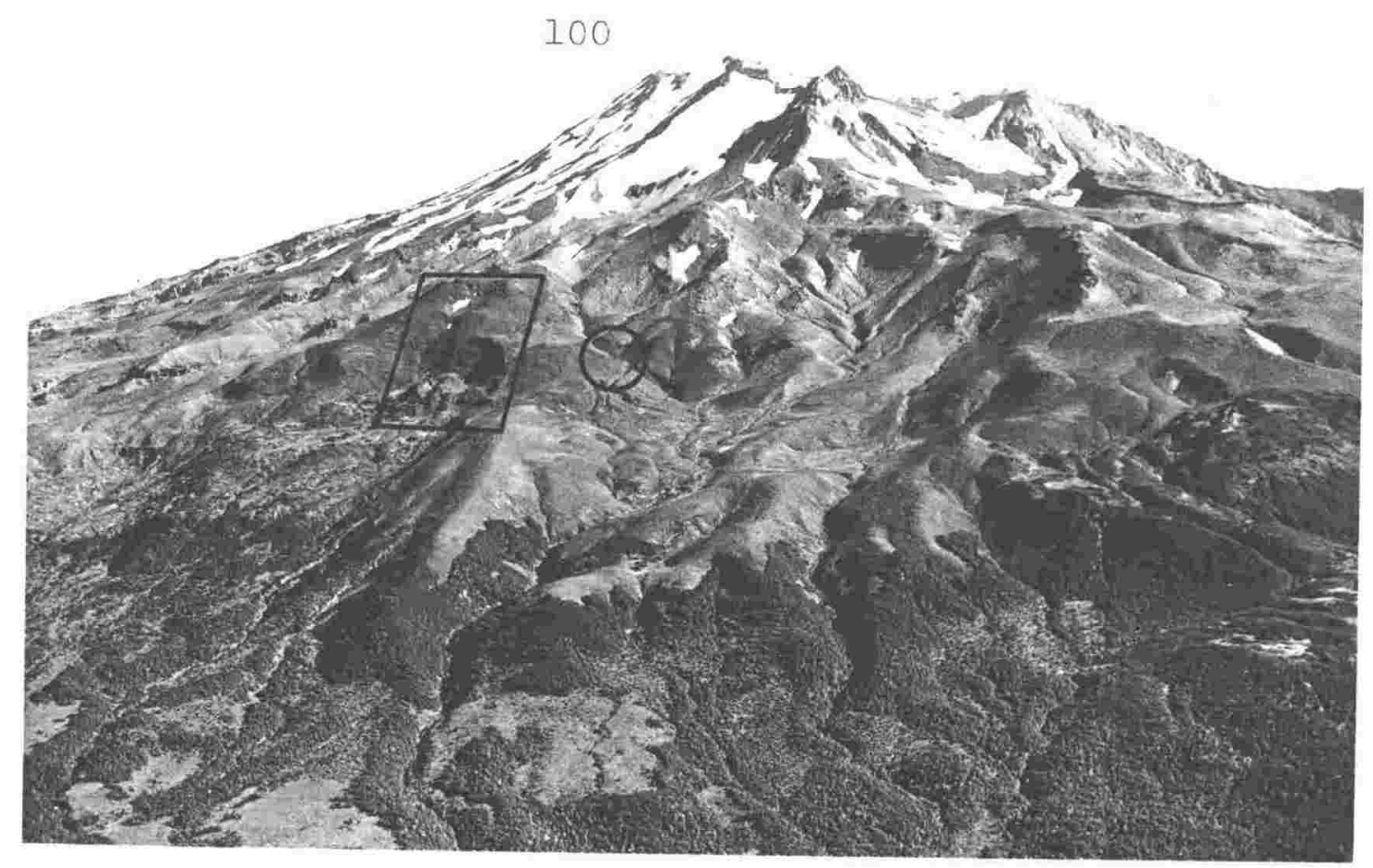

FIG. 62. Aerial photograph of the southern slopes of Ruapehu. Vent region for the Rangataua Member is enclosed in box outline. Lava flows travelled southward from this source. Gray ridge below vent region is lateral moraine covered by pyroclastics at the right of the vent region. Locality for RS 14 is circled.
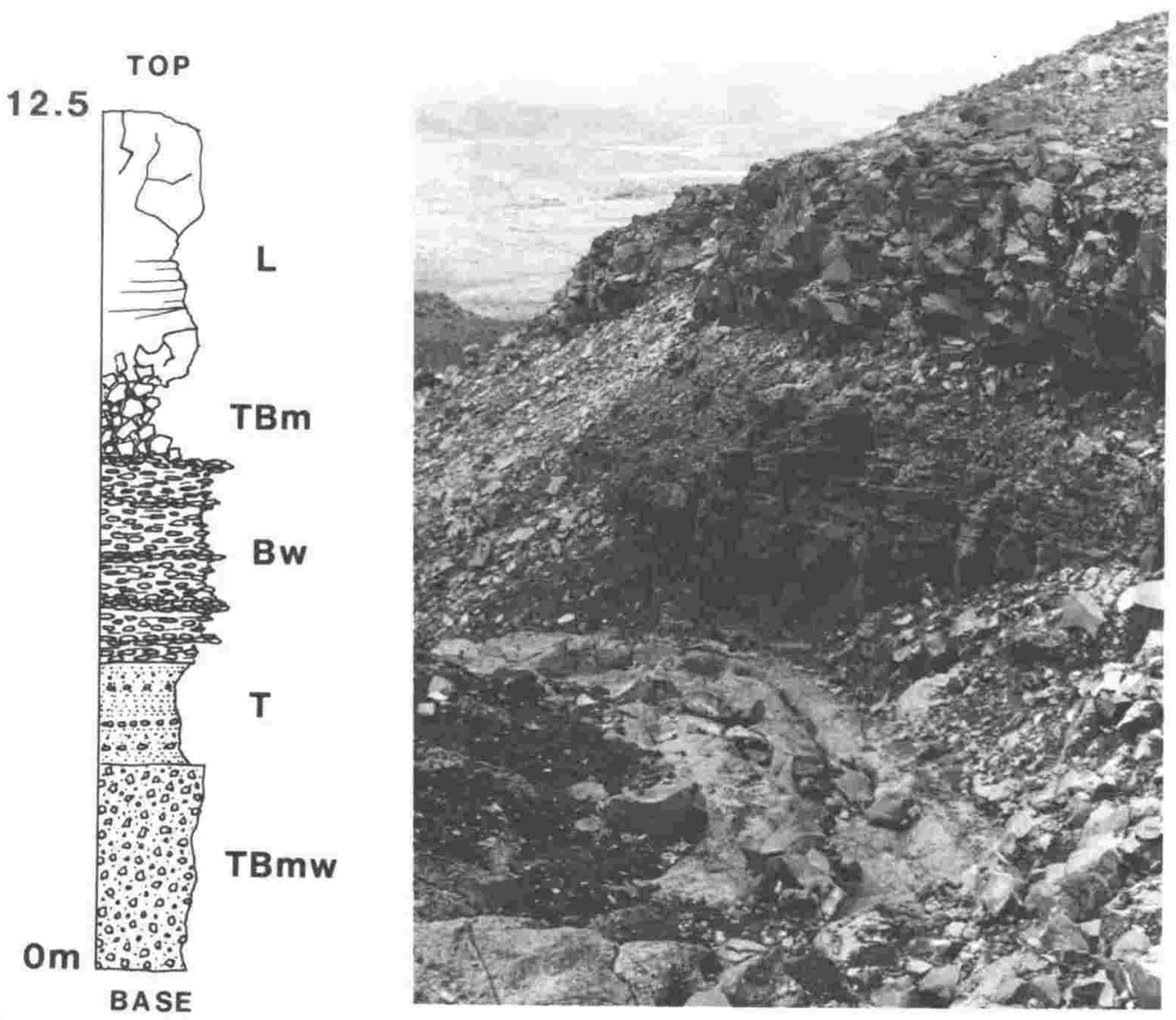

FIG. 63. Ruapehu Section 14. $12.5 \mathrm{~m}$ of Rangataua Member (Whakapapa Fm) exposed in a stream valley to the east of the vent region, south Ruapehu. Grid references for base of section are: T20/306065 (metric), N122/055612 (yard). 
$10 \mathrm{~cm}$. The sorting and shower bedding indicate an airfall origin. The welded unit above this exhibits excellent internal stratification and good sorting of the individual welded clasts. The deposit is interpreted as welded airfall (agglutinate). At the top of the section, a lava flow and autoclastic breccia are exposed.

In this section, the violence of eruptions is seen to have decreased with time, from emission of a small pyroclastic flow, to deposition of airfall pyroclastics, to the relatively mild effusion of lava flows. Such a stratigraphy is consistent with interpretation that the vapour-rich top of a magma chamber was first erupted, then followed by mild effusion of voluminous but relatively de-gassed lava flows. The Rangataua lava flows are the most extensive and voluminous on Ruapehu; They extend nearly $14 \mathrm{~km}$ from source, have an average aggregate thickness of about 60 metres, cover an area of $24.3 \mathrm{~km}^{3}$, and have an aggregate volume of $1.5 \mathrm{~km}^{3}$. The flows, of which there are at least two and a maximum of six, are excellent examples of block lava. The flows are narrow (about $\frac{1}{2} \mathrm{~km}$ ) to a distance of about $7 \mathrm{~km}$ from source, due to cooling of the margins and construction of high stopbanks of blocky debris. Subsequent drainage of the central channel has produced a trough-like cross section. Beyond $7 \mathrm{~km}$ from source, the flows have spread laterally on gentler topography of the ring plain, producing immense lobes with steep blocky flow fronts exceeding 30 metres in height.

\section{TAMA MEMBER}

This member consists of lava flows and minor pyroclastics which erupted from two flank vents on the northern slopes of Ruapehu (Fig. 64). No well exposed vertical sections through these deposits are known, but ground traverses have confirmed some of the same lithologies as are present for the Rangataua member. The northern lava field comprises two flows of block lava that issued from a single vent at the southern limit of the field. These cover an area of $6.5 \mathrm{~km}^{2}$ and have a volume of about $0.2 \mathrm{~km}^{3}$. The vent is evident as a low mound of coarse, locally welded airfall ejecta consisting largely of blocks 
(Fig. 65). The eruptives are dark grey andesites.

A second block lava flow of lesser volume and area is present on the northern slopes at about 1,900 metre elevation. This lava is black low-silica andesite. The vent region for this flow is an inconspicuous low mound of blocky debris at the southern limit of exposure.

Minor shower-bedded lapilli tuffs were produced during the early stages of activity from these vents (Fig. 66).

\section{PINNACLE RIDGE MEMBER}

Between about 1,550 and 1,900 metre elevation, the Te Herenga Formation of Pinnacle Ridge is unconformably mantled by welded breccias and tuffs (Figs. 21 and 67). The deposit is exposed over an area of about $0.8 \mathrm{~km}^{2}$ and has a volume of about $0.01 \mathrm{~km}^{3}$. Stratigraphic sections are presented in Figure 68. In distal sections at lower elevations, the deposit consists of internally stratified and well sorted pyroclastics exhibiting widely varying degrees of welding (RS 15A and B; Figs. 68 and 69). The deposit has a steep primary dip, and in the densely to moderately welded portions, moderately vesicular to pumiceous essential clasts are flattened parallel to the stratification, giving the appearance of ignimbrite (Fig. 70). A second clast component is present as accessory subangular to subrounded lithic blocks of the Te Herenga Formation which were derived from the underlying lateral moraine and colluvium (Fig. 71).

Higher on the ridge, the deposit still exhibits internal stratification (Figs. 72 and 73), but it is thicker, is overall more densely welded, and generally contains larger accidental lithics (RS 15C).

The welded character of the deposit led Parsons (unpub. map in files of N.Z. Geological Survey, Rotorua) to term it an ignimbrite. Although dense welding and eutaxitic texture are 

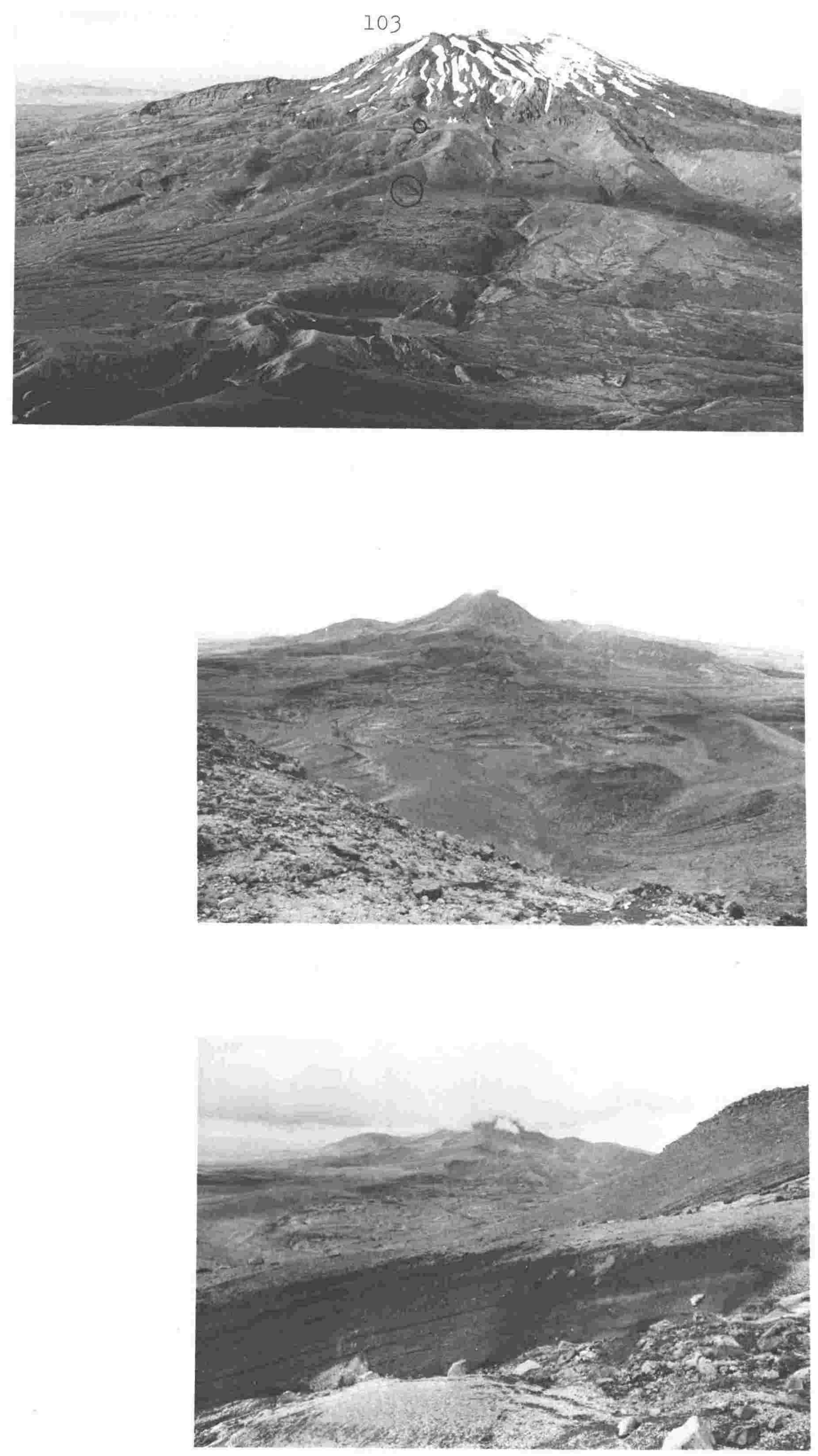


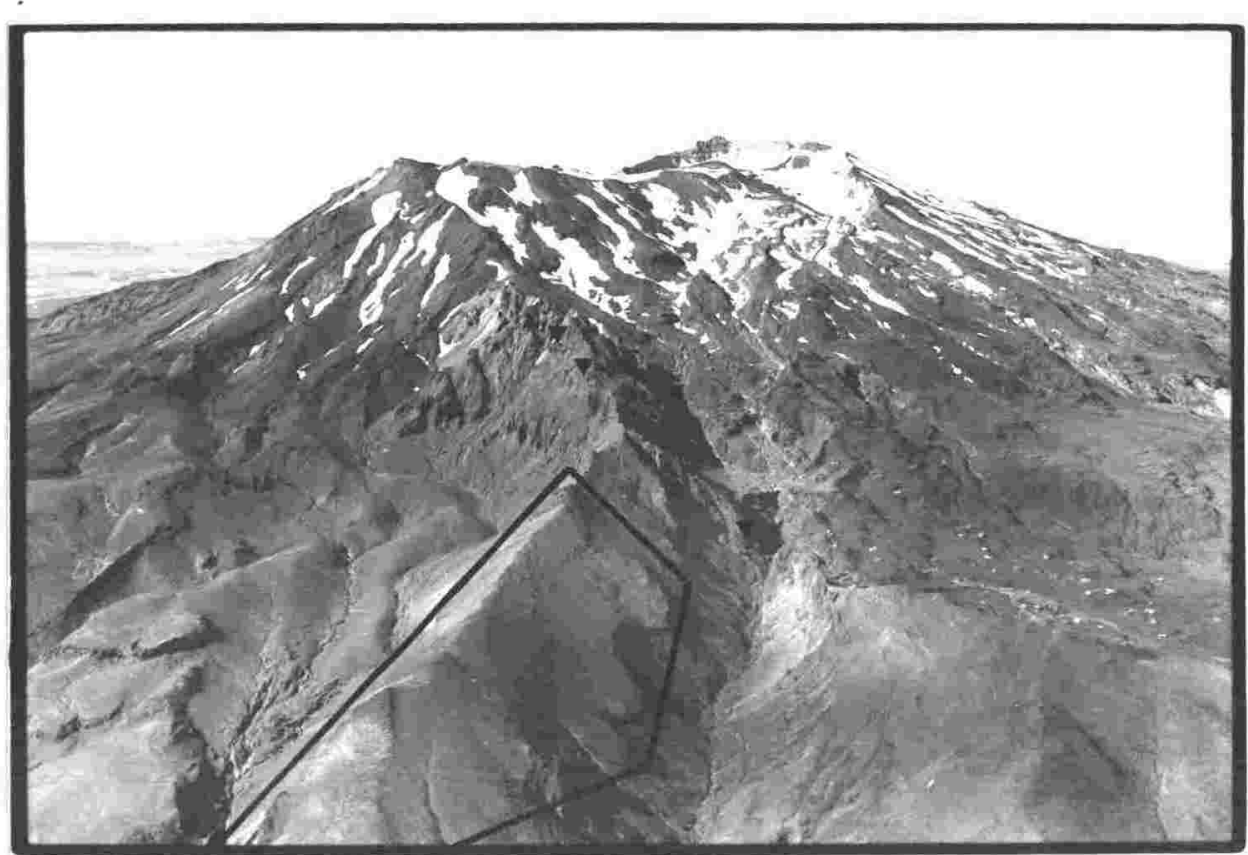

FIG. 67. Oblique aerial photograph of the northwestern slopes of Ruapehu. Welded airfall tuff of Pinnacle Ridge Mbr, Whakapapa Fm, is outlined. Locations of dykes for Pinnacle Ridge Mbr are shown with arrows. 

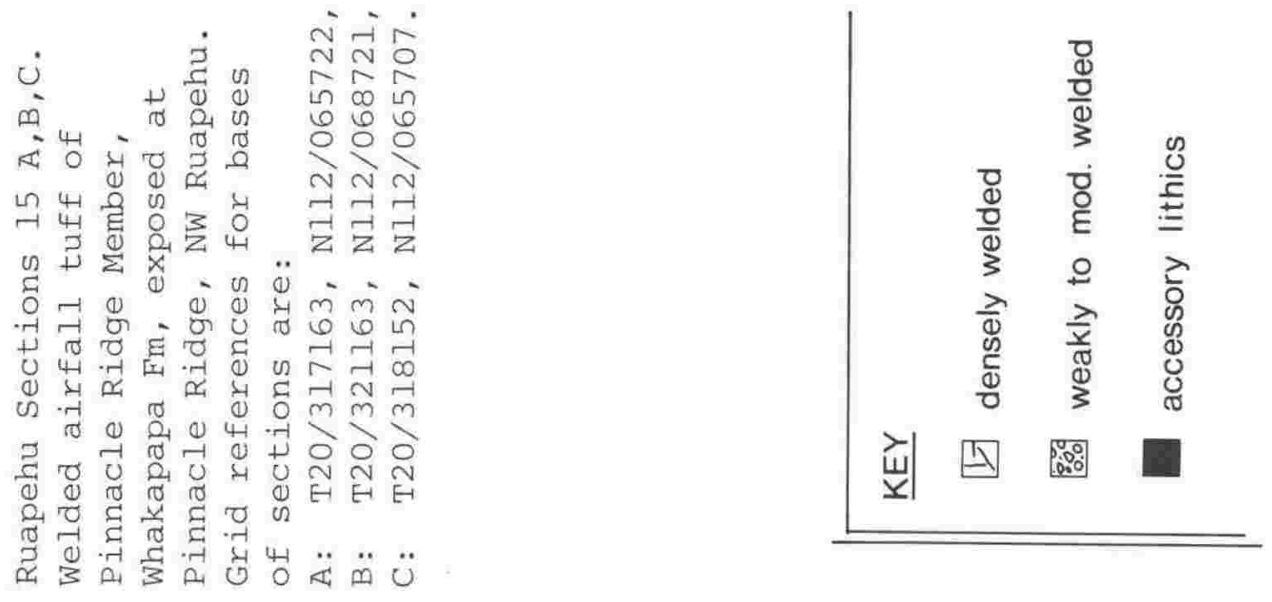

$\infty$
6
$\dot{0}$
$\dot{H}$
$\dot{1}=1$
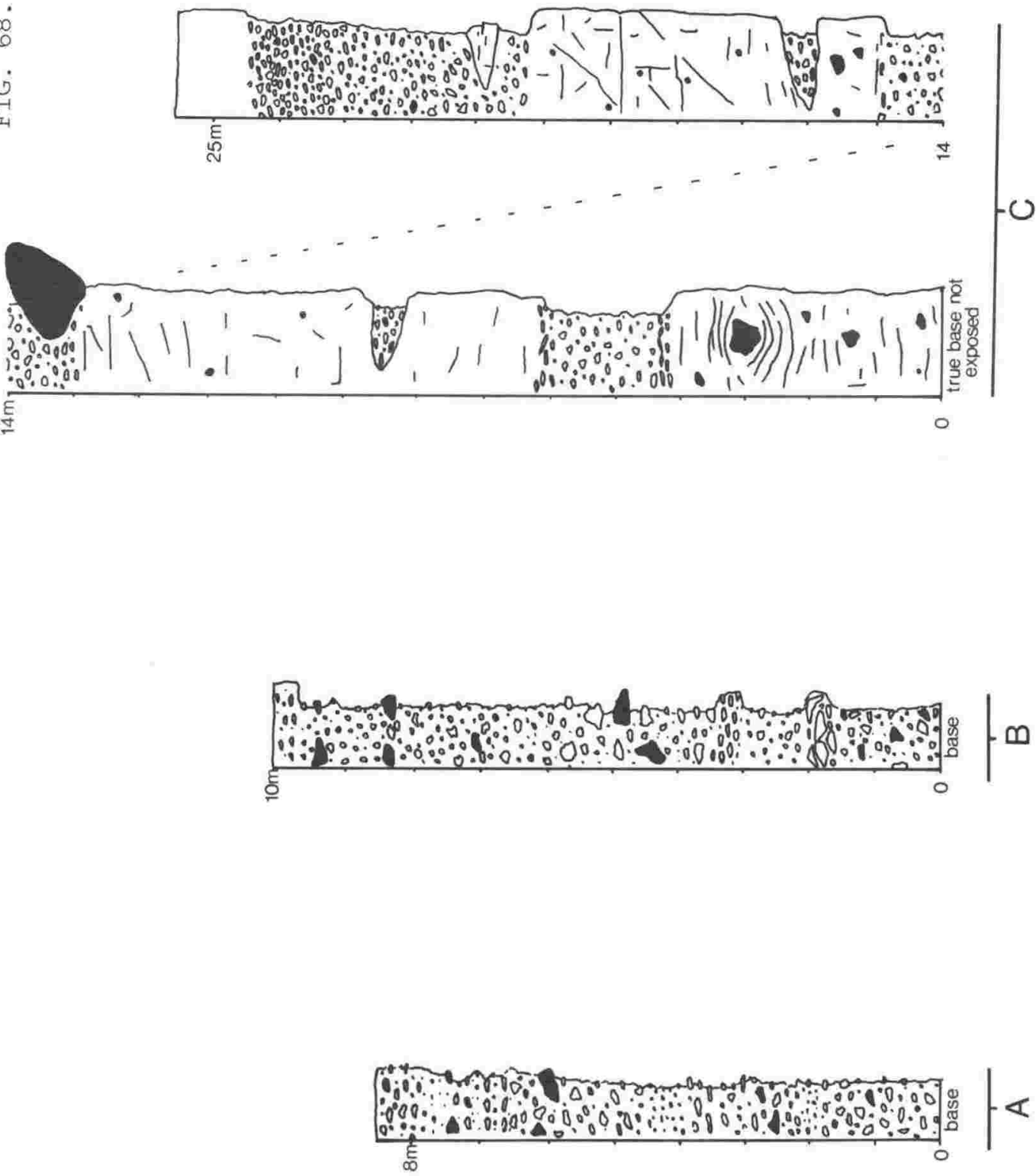

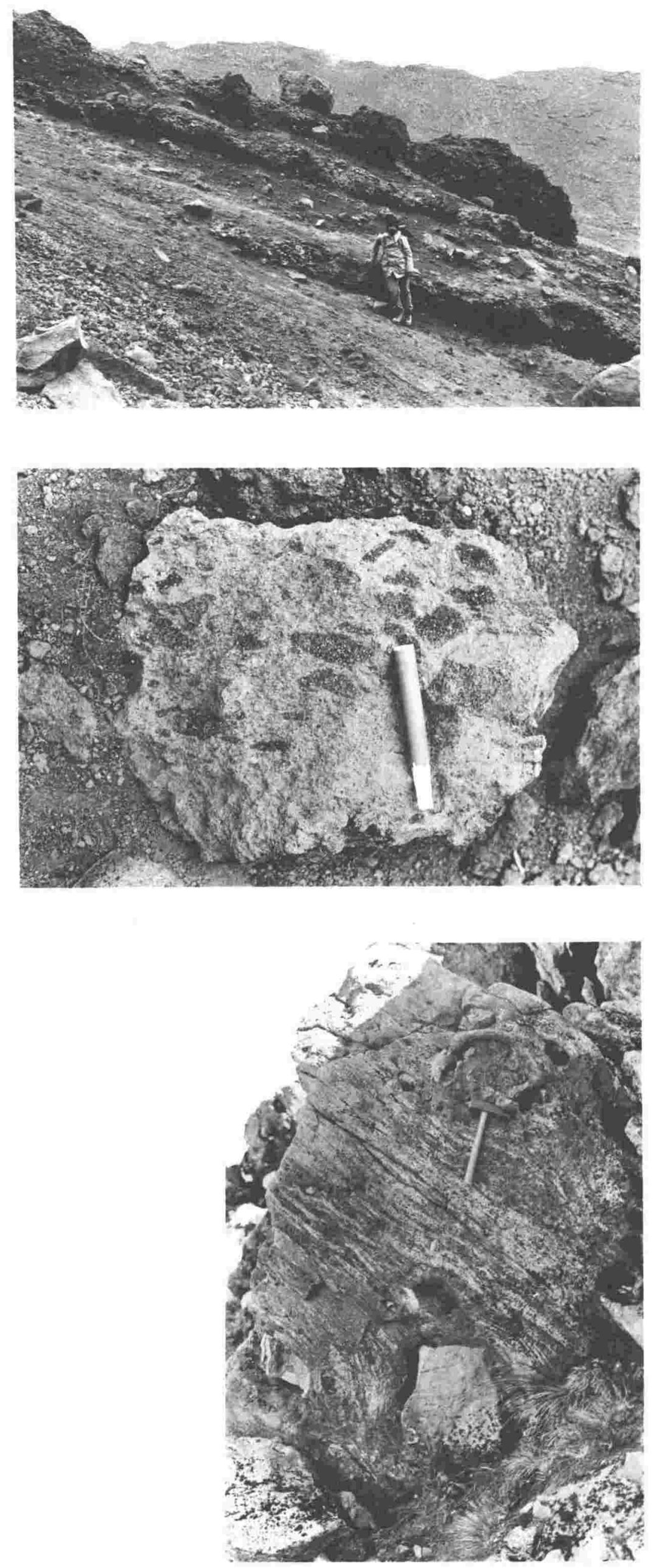


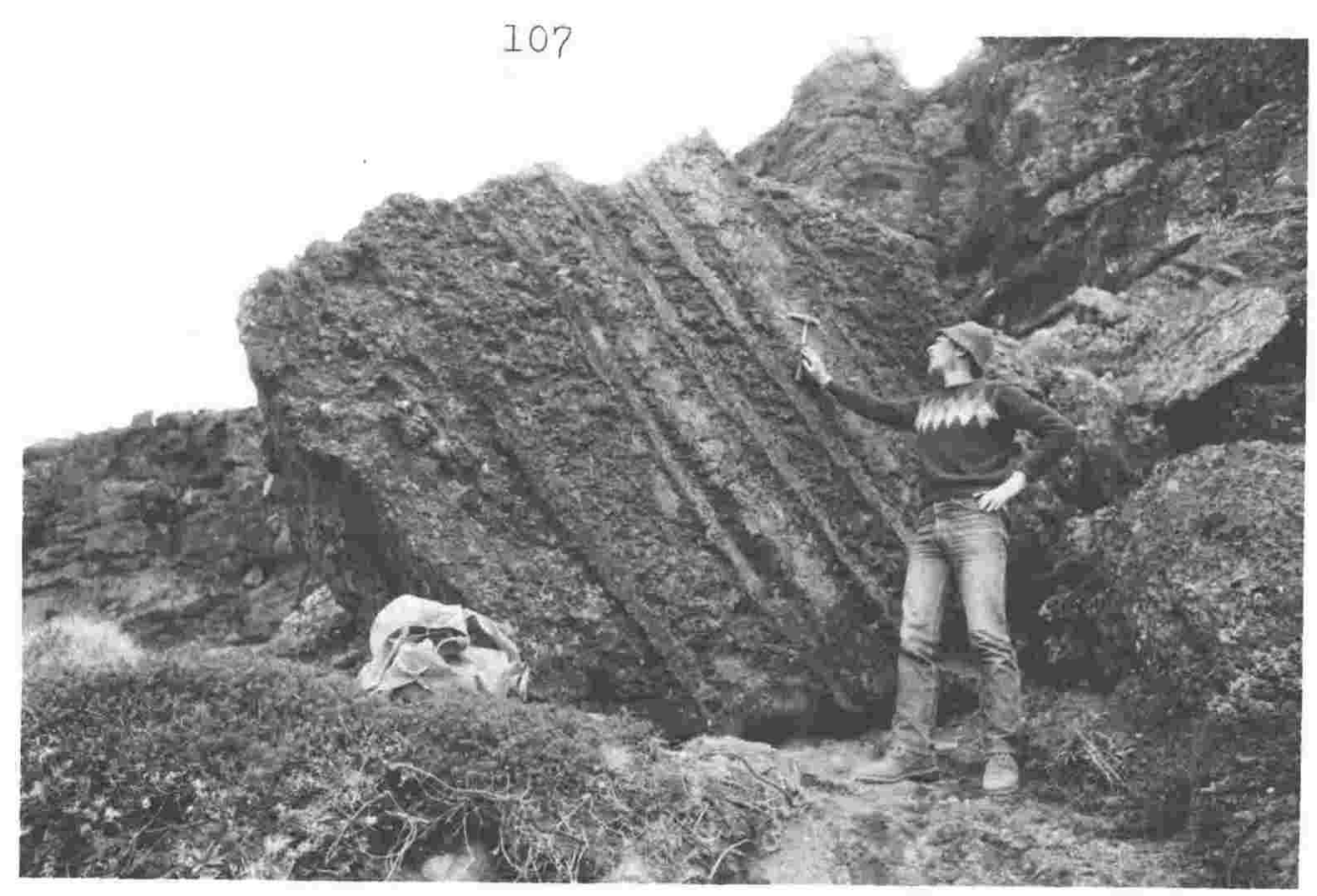

FIG. 72. Internal stratification in welded airfall tuff, Pinnacle Ridge Member.

FIG. 73. Thick, densely welded airfall tuff near the vent region for Pinnacle Ridge Member. Note the large lithic block from underlyjng Te Herenga Fm.

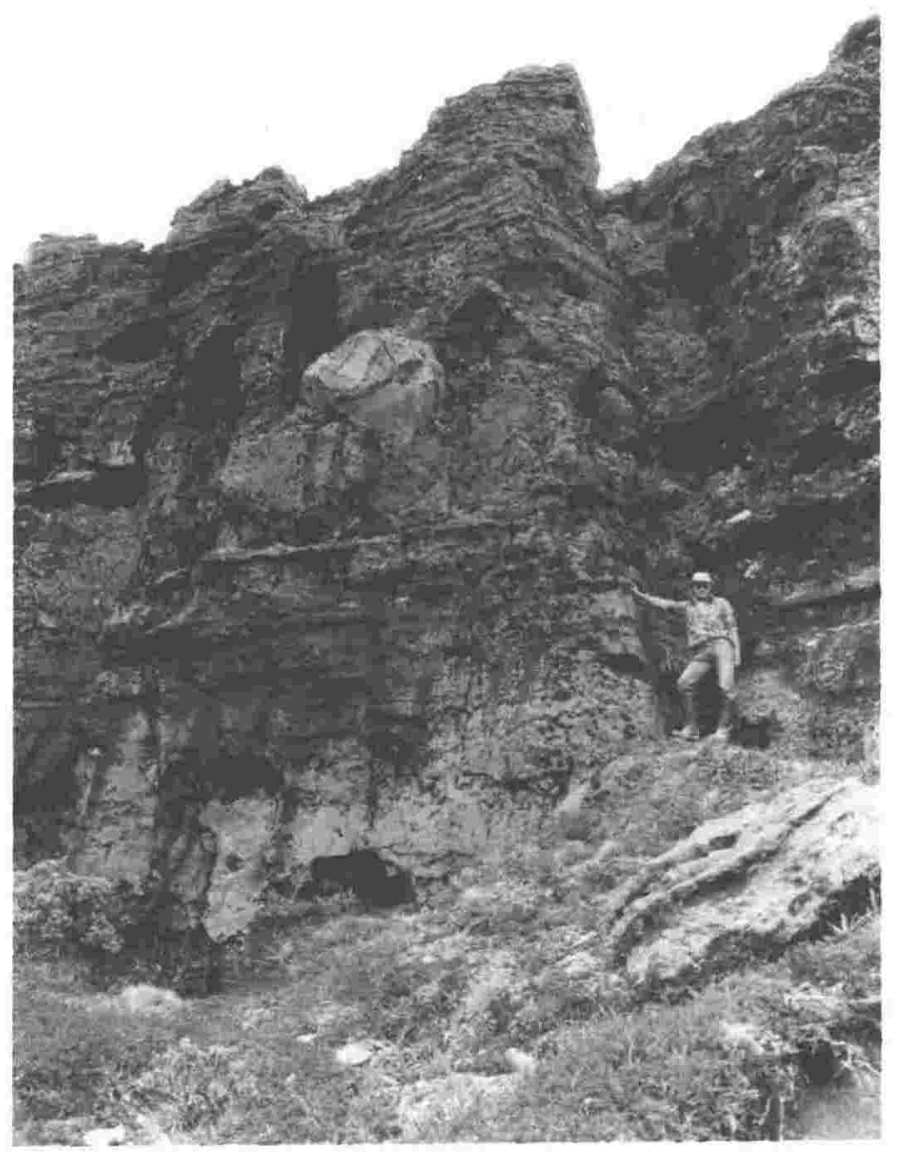


indeed well developed, the deposit as a whole does not exhibit regular zones of internal welding, such as are produced by compactional flattening of pumice clasts in welded pyroclastic flows. Rather, the degree of welding is irregularly developed in the vertical sense, and the deposit thins and grades laterally over short distances into poorly- and non-welded stratified equivalents.

These are precisely the characteristics of welded airfall tuffs (Sparks and Wright, 1979). If the Pinnacle Ridge welded airfall tuff did not undergo major secondary mass flowage (rheomorphism), as appears to have been the case, then thickness and maximum size of accidental lithics would be expected to increase toward the vent. Using these criteria, the vent region must have been in the vicinity of the upper-elevation limits of exposure. Indeed, a feeder dyke for these deposits parallels the ridge crest, and can be traced southward up the ridge for a distance of $1.2 \mathrm{~km}$ (Fig. 21). The dyke is irregular in trend, and varies from about 1.5 to 3 metres in thickness. At its southern limit of exposure, the dyke is overlain by its own welded airfall ejecta. The erosional remnant of a second dyke is present as a single outcrop in the headwalls of the Whakapapanui Gorge (see: O'Shea, 1957, p.59). Apparently, Pinnacle Ridge was the site of volcanism during both $\mathrm{Te}$ Herenga and Whakapapa times, although the character of the eruptions differed considerably.

The juvenile magmatic material of the Pinnacle Ridge Member is black andesite with conspicuous plagioclase phenocrysts.

\section{IWIKAU MEMBER}

Many eruptives of the Whakapapa Formation, including the voluminous andesite flows of the Whakapapa lava field, can be traced to the northern summit region of Ruapehu. The Iwikau Member is defined as all eruptives that issued from this northern vent during Whakapapa time. The original morphology of the vent region is obscured by the broad ice field of the Sumit Plateau, and Holocene alpine glaciers have modified the 
vent rim. Te Heuheu Ridge and its southwestward extension consist of thin lava flows, autoclastic breccias, and pyroclastics which dip radially away from the summit plateau. These deposits are well exposed on the high northern slopes beneath Te Heuheu. The most voluminous lithologies are thin (generally less than 2 metres) lava flows and autoclastic tuff breccias with variable degrees of welding. Other deposits are sorted and stratified, and contain essential pumiceous to moderately vesicular clasts. Vesicular clasts occur up to about $20 \mathrm{~cm}$, and the deposits are often weakly welded at clast contacts. These are interpreted as coarse airfall ejecta. In one coarse, oxidized airfall deposit on the northern slopes below Te Heuheu, the abundance of accidental metamorphic enclaves is remarkable, and approaches several volume percent of the deposit. The enclaves are largely granoblastic to foliated quartz-biotite-garnet rock fragments, which can exceed $10 \mathrm{~cm}$. A large area of the northern and northeastern flanks of Ruapehu is blanketed by primary and reworked pale brown andesite pumice lapilli which were erupted from this northern vent, as deduced from the coarsening and thickening of the airfall pumice as Te Heuheu is approached.

A valley-filling deposit of pervasively oxidized and moderately welded heterolithologic tuff breccia travelled eastward from the northern summit region into the headwaters of the Mangateoteonui Stream, NE Ruapehu. This is interpreted as a pyroclastic flow on the basis of its poor sorting, lack of internal stratification, heterolithologic character, valley-filling disposition, and evidence for high temperature emplacement. It is one of only a few pyroclastic flows which have been identified on Ruapehu.

Voluminous lava flows issued from the northern summit region onto the northwestern slopes. Both the Taranaki Falls lava flow and the Whakapapa skifield lava flows travelled about $8.5 \mathrm{~km}$ from source. The Whakapapa lava field (Fig.8) consists 
of at least six flows, covers an area of $10.5 \mathrm{~km}^{2}$, and has an estimated aggregate volume of $0.75 \mathrm{~km}^{3}$. The lavas and associated monolithologic tuff breccias are well exposed throughout the Whakapapa skifield (Fig. 74) and along the Bruce Road, to their termination at the Silica springs track. These exposures provide excellent opportunity to study the process of autobrecciation. Autoclastic breccias are commonly welded in the nearvent region, where flows are thin. As more distal regions are traversed, the character of the autobreccias changes from angular, clast-supported and welded, to angular, clast-supported and unwelded, to subrounded clasts floating in unwelded, mostly lapilli-sized matrices. The latter, especially, closely resemble lahars, except for their monolithologic character, and represent viable parent material for secondary mass flows (lahars and debris flows). Figure 75 illustrates these lithologies.

\section{CRATER LAKE MEMBER}

Crater Lake Basin (Fig. 76) is a topographic feature of complex origin. Today, much of the area is covered by small alpine glaciers that terminate at the margins of Crater Lake and occupy the headwaters of the Wahianoa. During Mangawhero eruptions, a vent certainly existed not far south of the modern crater Lake. Since that time, the basin has been greatly modified by glacial erosion and probably also by explosive volcanism. A larger basin, of combined erosional and explosive origin, and represented by the high peaks around Crater Lake, existed prior to the onset of activity from the present crater Lake vent. Pyramid Peak (Fig. 77), a tephra mound of about $0.002 \mathrm{~km}^{3}$ volume was constructed within this larger depression, obstructing the valley which previously drained Crater Lake Basin into the headwaters of the Whangaehu. Pyramid Peak consists of several lithologic types: thin lava flows with associated monolithologic tuff breccias; layers of oxidized scoriaceous bombs up to 0.5 metres, usually stratified and including subordinate dense, angular blocks; welded breccias and tuffs, some of which are well sorted; and shower-bedded 


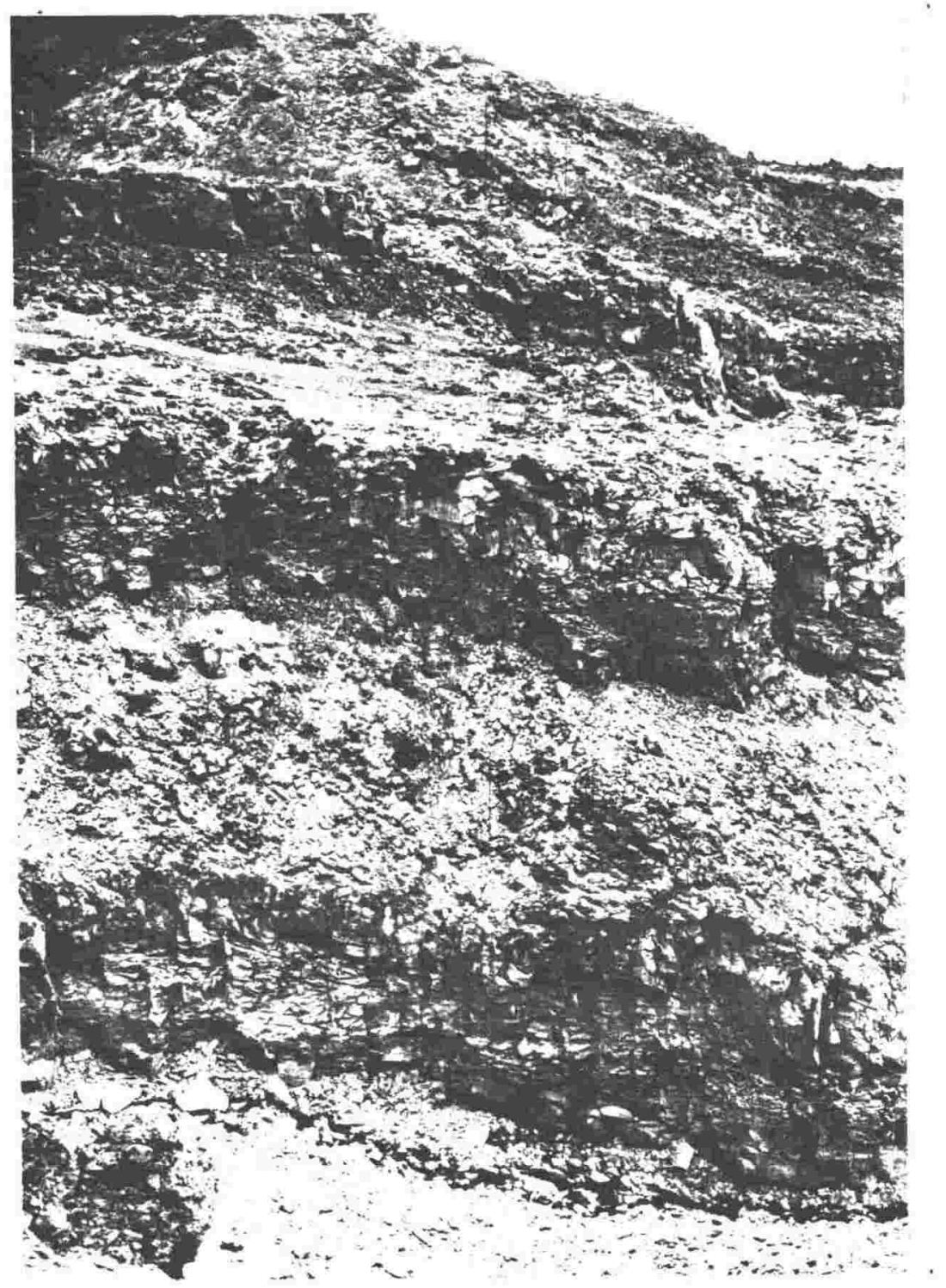

FIG. 74. Block lava flows and autoclastic breccias of Iwikau Mbr. Exposed at Whakapapa Skifield, NN Ruapehu, by fluvial erosion. Locality T20/314140 (Metric), N122/061695 (yard). 


\section{2}
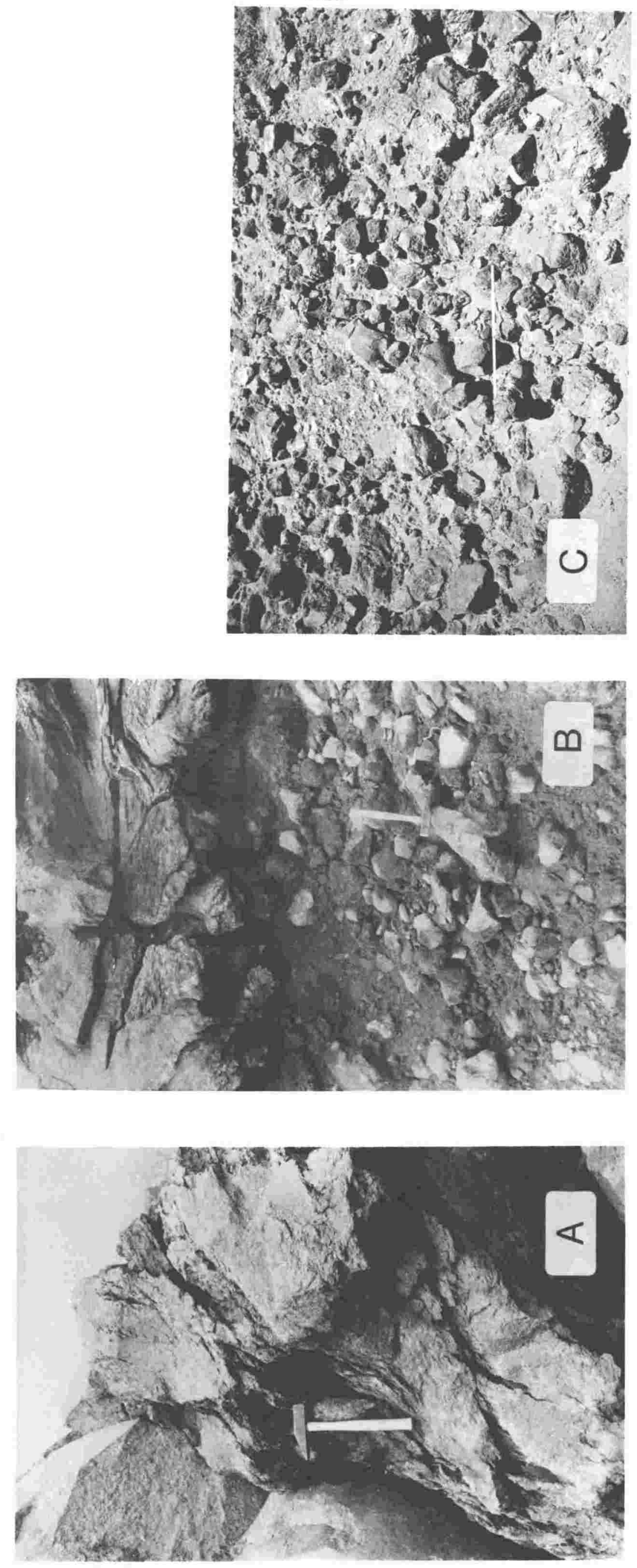

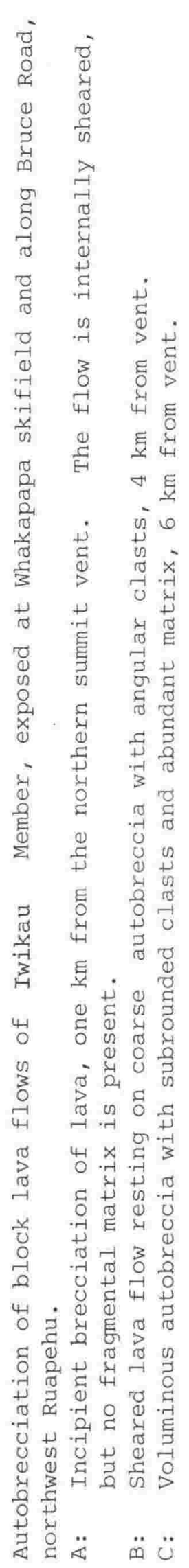



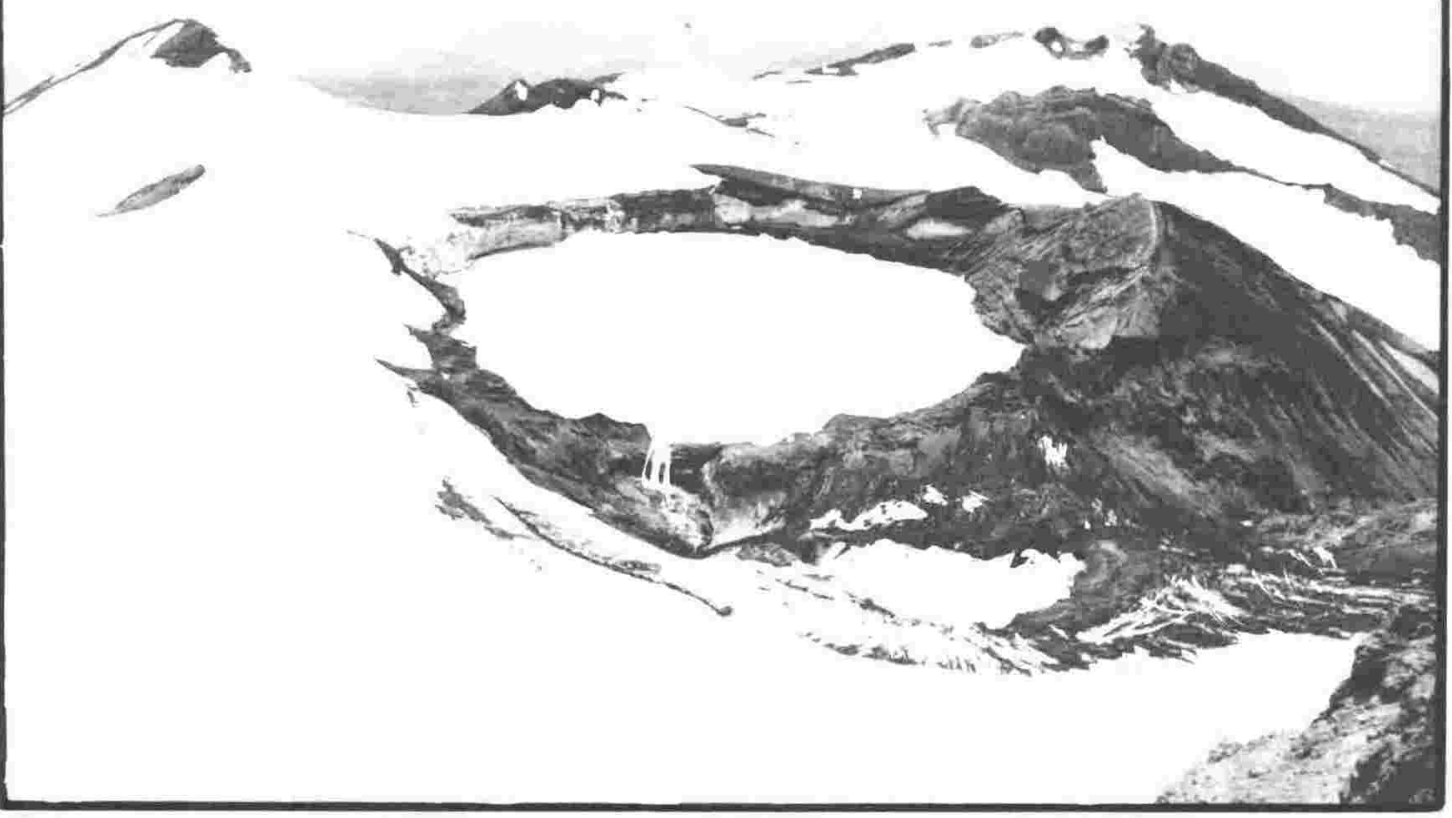

FIG. 76 .

Crater Lake basin, photographed from Ruapehu summit. Lake outlet at centre of photo. Pyramid Peak, a tephra mount, to the right.

FIG. 77. Mantle-bedded pyroclastics and subordinate lava flows of Pyramid Peak.

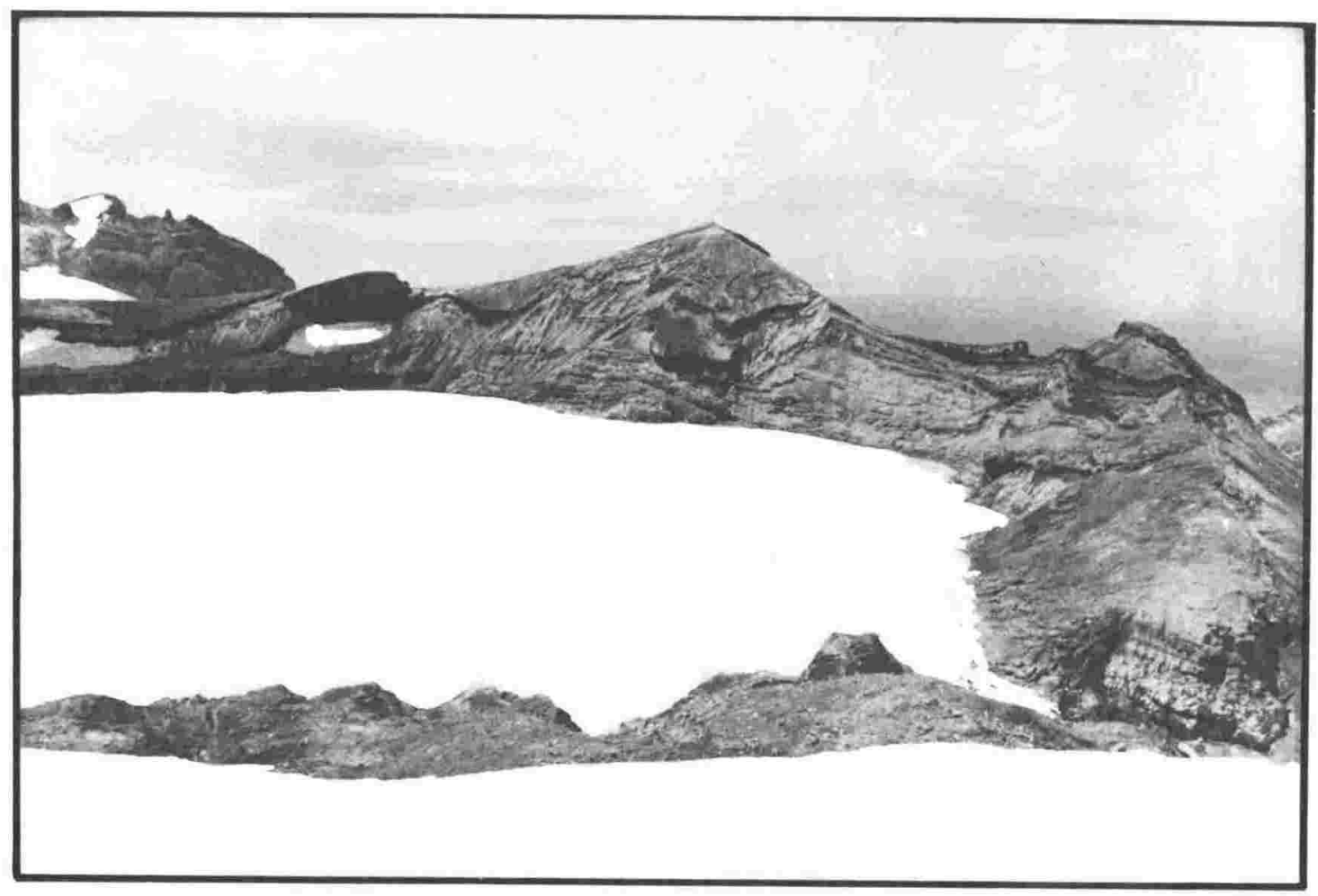


units which include block and ash with sag structures, and tuffs/lapilli tuffs. Local unconformities are common, and the deposits are mantle-bedded over the rim of the tephra cone.

Most of these deposits are coarse airfall and ballistic ejecta, with minor effusive activity represented by thin lava flows. Some of the airfall pyroclastics were ejected more than a kilometre from the vent; a mantle of welded pyroclastics covers the eastern slopes of Tahurangi and part of the arête between Girdlestone and Tahurangi. Mitre Peak, a hydrothermally altered erosional remnant of the Wahianoa cone, is mantled on its southwestern face by welded airfall pyroclastics from the crater lake vent.

Ejection of coarse airfall pyroclastics onto the outer flanks of Ruapehu has occurred during very recent times, as deduced from the above observations, and from observations on the outer slopes to the south of Tahurangi. Above 2,000 metres on the southern slopes (nearly $3 \mathrm{~km}$ from Crater Lake), highly vesicular, black, glassy cowdung bombs up to $75 \mathrm{~cm}$ are observed. They commonly contain inclusions of crater Lake mud, are very fragile, and are sometimes draped plastically over the substrate. These bombs have certainly not been re-deposited, and they indicate that coarse, hot, airfall ejecta have issued from Crater lake during magmatic eruptions, to a radius of nearly $3 \mathrm{~km}$ from source.

$\underline{A G E}$

Dating of some Whakapapa Formation deposits has been accomplished by Topping (1974) on the basis of tephra stratigraphy. Topping (1974) estimated that the Whakapapa lava field was erupted between 5,000 and 10,000 years ago, and that the large lava field on the northern flank of Ruapehu was erupted between 5,000 and 9,700 years ago. The northern crater of Ruapehu, which in the present study is considered to have been active during both Mangawhero and Whakapapa deposition, was considered by Topping (1974), to have emitted numerous 
tephra deposits between about 10,000 and 14,000 years ago, with sporadic activity continuing until about 5,000 years ago. Topping (1974) also considered that 2,500 years ago, little tephra were being emitted from Ruapehu, and that tephra eruped from Ruapehu since then probably came from the currently active Crater Lake vent. Most activity from this vent has occurred since 1,819 years ago (post Taupo eruption).

No quantitative age estimates exist for the Rangataua Member. These lavas have undergone only minor fluvial erosion and weathering, and morphologically appear to be of similar age as, or only slightly older than, the Whakapapa and Tama lava fields. A provisional age for the oldest whakapapa Formation deposits is therefore suggested as approximately 15,000 years before present, with the most recent activity (since 2,500 years ago) occurring at the crater Lake vent.

\section{TAWHAI FALLS LAVA FLOWS}

Two block lava flows form an isolated exposure in the Whakapapanui stream, northwest Ruapehu ring plain (N112/014787). These flows are dark grey, nearly aphyric andesites which have no petrographic analogues on NW Ruapehu. The flows overlie older block lavas with petrographic characteristics similar to those of the Whakapapa Mbr. The Tawhai Falls flows are therefore part of Whakapapa Fm, but are not given Member status. Their precise age is unknown. 
2.8 THE ORIGIN OF LAHAR MOUNDS DEPOSITS, NW RUAPEHU

The lahar mounds (Fig. 78) occur as part of Grindley's (1960) Murimotu Lahars Formation. Topping (1974) estimated the age of last emplacement of the deposits at 9,500 to 12,500 years ago, on the basis of their tephra cover. The exposures occur along SH 48 at a road cutting $4 \mathrm{~km}$ NW of the Chateau, and at another cutting 50 metres north of the junction of SH 47 and $\mathrm{SH} 48$.

These deposits have created interest not only from a volcanological perspective, but also from an historical one, for they have been variously interpreted since the late 1800's. Hill (1891) considered that the mounds were blisters on the surface of a lava flow that had travelled over water-saturated ground. Cowan (1927) considered them to be bubbles within lava, and Bossard (1928) speculated that the bubbles originated by explosions of volatiles from a gas-rich lava. Park (1926) considered the mounds as drumlin-like features which were deposited by a retreating glacier. Grange and Hurst (1929) were the first to suggest that the mounds were lahar deposits. Healy (1965) suggested that one or more lahars and one or more glowing avalanches came down the whakapapanui valley from the northern summit region of Ruapehu. Current opinion appears to favour an origin by eruptions of Ruapehu Crater Lake.

The bulk of the lahar mounds are probably debris flows, as deduced from the fact that little clay- or silt-sized material is present, and by the predominance of one clast type for individual depositional units. The mounds exhibit crude internal statification which is manifested by changes in the relative proportions of clast types, indicating several episodes of deposition. These observations suggest "dry" failure of sectors of the cone at different times and from several source areas. The source areas have been deduced through study of the clast petrographies. 


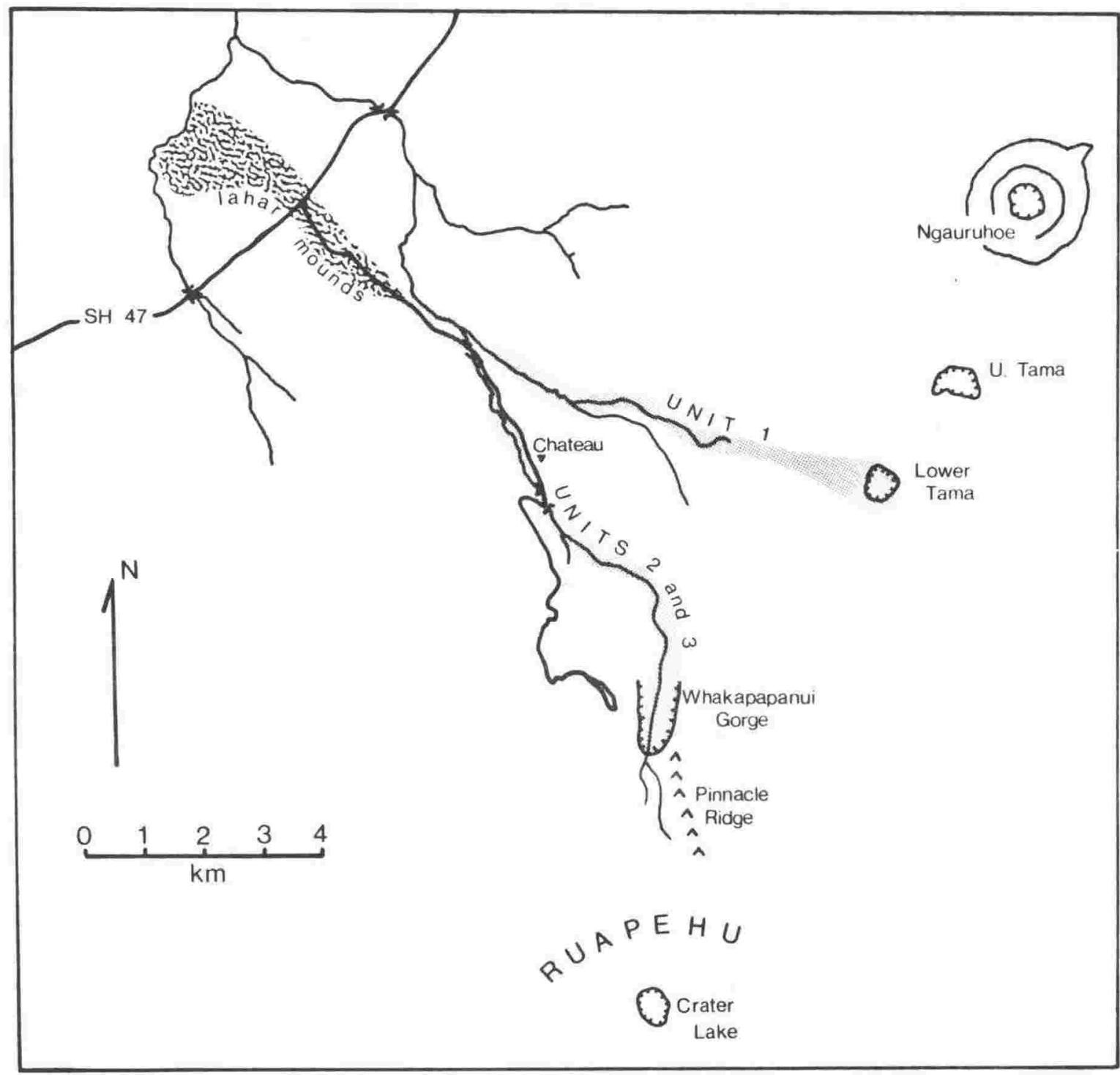

FIG. 78. Map of 'lahar mounds' deposits, their inferred source regions, and probable paths of the debris flows. Unit 1 probably came from the Tama Lakes area. Units 2 and 3 originated in the upper Whakapapanui Gorge, northwest Ruapehu. 
Clasts from the interior portion of the SH 48 lahar mound (Fig. 79) are predominantly of altered hornblende dacite. The present writer is confident that no lavas with this petrography occur on NW Ruapehu, and the only documented locality for hornblende-bearing lava is at the lower Tama Lake, in the saddle between Ruapehu and Tongariro. This depositional unit was probably generated during the phreatic eruptions that produced the Tama Lakes craters (ca. 10,000 years ago; Topping, 1974), and travelled down the wairere stream to the site of deposition. The mound morphology was developed in this initial deposit from the Tama region.

Later depositional units have mantled the hummocky topography and are thickened on the stoss side of the SH 48 lahar mound. Directly overlying the initial hummocky deposit is a second unit with three types of clast, which closely resemble the Pinnacle Ridge, and Iwikau Members of Whakapapa Fm, and Te Herenga Fm. The third and uppermost tuff breccia is oxidized, suggesting hot emplacement, and the clasts are largely of one petrographic type, similar to that of Whakapapa Member lava flows.

Thus, the clast types suggest that the two younger depositional units originated in the upper Whakapapanui Gorge, near the Top-o-the-Bruce, and travelled down the Whakapapanui Stream where they may have been further mobilized by water or steam. Similarly to the first deposit from the Tama area, the momentum of the debris flows apparently carried them over the stream bank at a bend in the course, leading to loss of momentum and deposition on flat topography.

Topping (1974) has suggested that Ruapehu Crater Lake has been active only for about the past 2,500 years. The present writer has found no evidence of the vesiculated bombs and fragments of metamorphosed lake mud which are characteristic of historic ejecta from crater Lake. Thus, neither the age of the mounds (greater than ca. 9,500 years b.p.) nor their clast petrographies indicate a Crater Lake source for these 

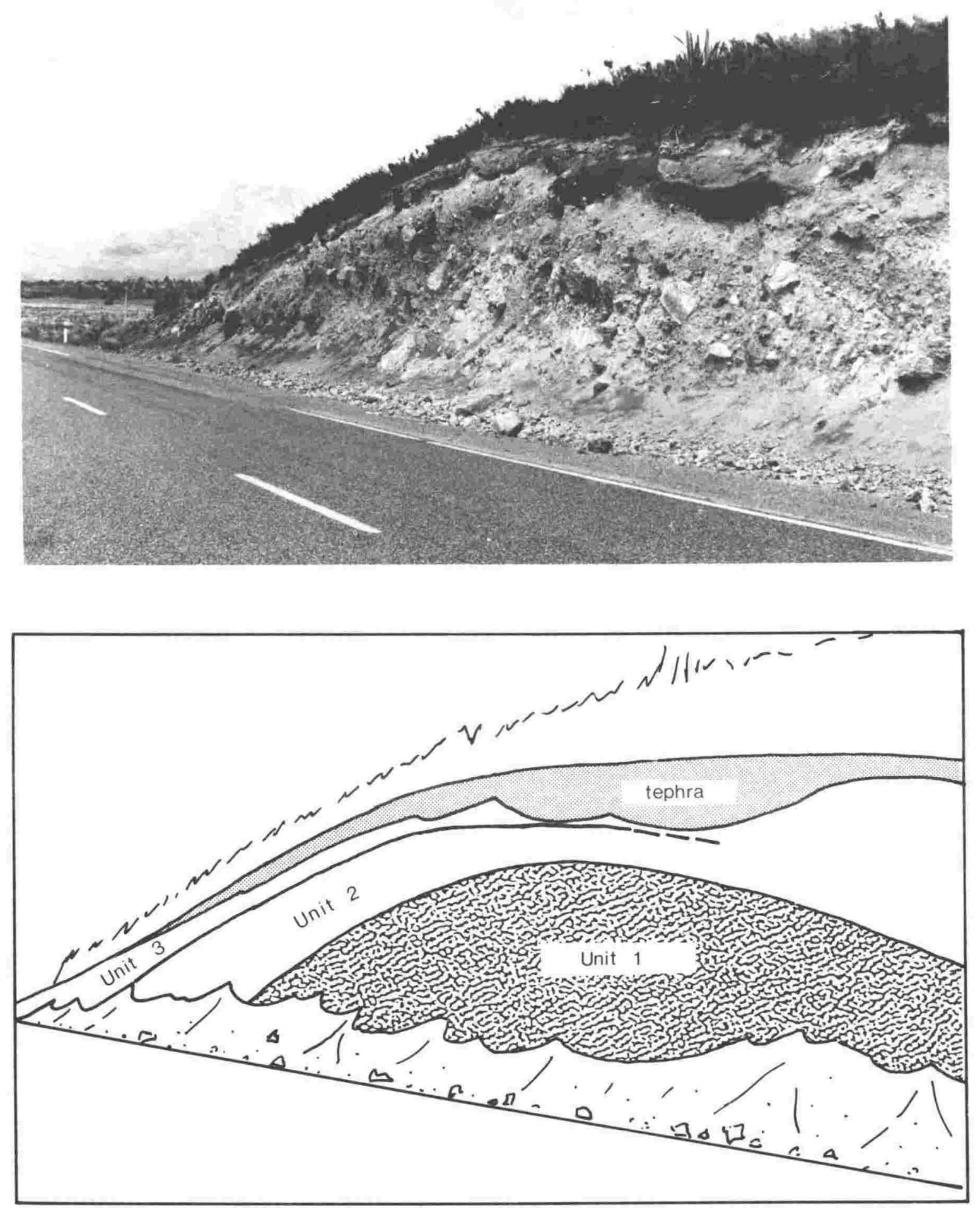

FIG. 79. Photograph and drawing of lahar mound exposed along SH 48. See Fig. 78 for provenance of depositional units. Lithologic descriptions of units are given in the text. 
deposits. Rather, the lahar mounds appear to have originated during phreatic eruptions of Lower Tama (ca. 10,000 years b.p.), and from slope failure in the Whakapapanui Gorge/Pinnacle Ridge area of NW Ruapehu. It is not known whether the upper debris flows from Whakapapanui were generated directly as a result of eruptions in this region, but it seems likely that the emplacement of welded airfall tuff and autoclastic breccias of the Whakapapa Fm contributed in some manner to slope instability.

\subsection{GLACIAL FEATURES OF RUAPEHU MASSIF}

Identification of glacial deposits in volcanic terrains is difficult since they so closely resemble lahars (Neall, 1976; Mathews, 1967). Both mechanisms produce diamictites, and no lithologic criteria can be considered reliable. In this study, the distinction has relied upon constructional morphology: lahar deposits fill valleys and are tabular in form whereas moraine deposition constructs parabolic ridges on the landscape.

The distribution of deposits considered to be of glacial origin is shown in Fig. 80. Aerial and ground photographs of glacial features are presented in Figures 81-83.

No precise statements can be made as to the chronology of glacial deposits on Ruapehu; only rarely can alpine glacial features be dated directly, as a result of near-absence of plant detritus and the uncertainty of its provenance in these regions. The most deeply incised glacial valleys of Ruapehu occur on the two oldest formations, and thus all glacial features must be younger than upper Te Herenga Fm (0.23 Ma). They can therefore only represent glaciations during the Waimean and Otiran Stages of the New Zealana Quaternary. Glacial features developed on Te Herenga Fm of NW Ruapehu are locally overlain by Mangawhero Fm, suggesting that these moraines and valleys were created during the Waimean stage. Moraines developed on Mangawhero Fm of SW Ruapehu must be younger than about 30,000 years, which implies construction during the 


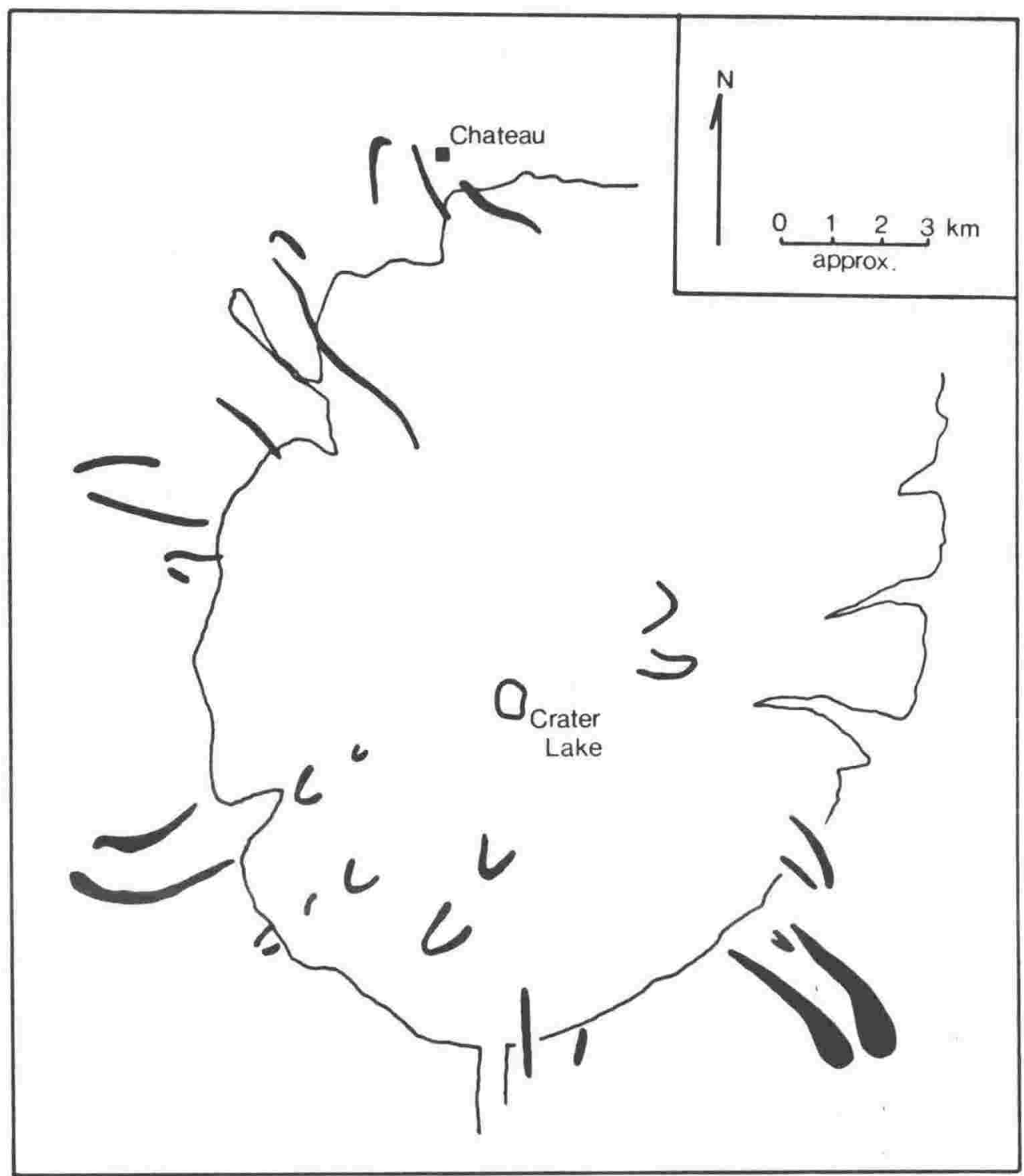

FIG. 80. Glacial moraines of Ruapehu massif. Mapped directly from vertical aerial photographs, using criterion of constructional morphology. 

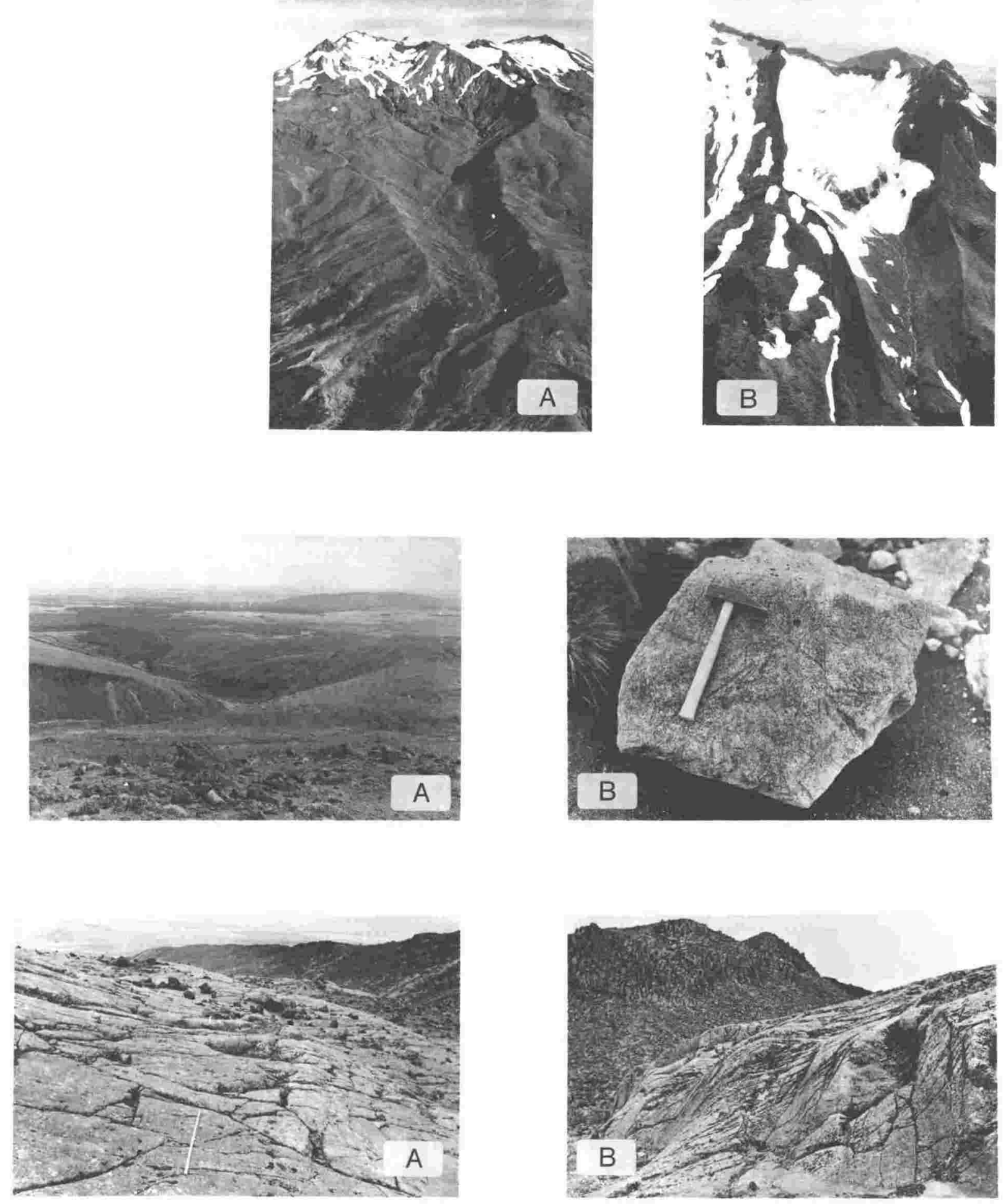
Otiran stage. There is good evidence for a minimum of three advances during otiran time, as deduced from the nested triads of moraine ridges in two valleys of SW Ruapehu. The Wahianoa Valley glacial features (SE Ruapehu) are probably also of Otiran age, since the terminal and lateral moraines have undergone only minor dissection, and since the Mangawhero Fm deposits have been incised as well as those of Wahianoa Fm. Finally, relatively minor glaciation of the summit region has occurred during the Aranuian Stage, as deduced from glacial features developed on Whakapapa Fm (post ca. 10,000 years) at high elevations. The present-day summit region is occupied by small alpine glaciers.

\subsection{FAULTING}

Faults on Ruapehu (Fig. 84) are those of the Taupo Fault Belt (Grindley, 1960), a system of high-angle NNE-trending normal faults which extends from the Tongariro Volcanic Centre to the Bay of Plenty. Vent locations at Ruapehu have clearly been controlled by regional faulting. The most conspicuous examples of these faults occur on the northern flanks of Ruapehu, where fault scarps exhibit vartical displacements of up to 4 metres. No horizontal component of displacement can be proved. None of the normal faults have displaced lava flows of the Whakapapa Formation.

Greater structural complexity is encountered on the southeastern and southern flanks of Ruapehu, where the faults progressively change trend from NNE to $E-W$. The $E-W$ faulting is characteristic of Wanganui Basin structures of the south, where Quaternary volcanism is absent. Downthrow occurs mainly on the southern sides of these faults, and several parasitic vents at ohakune are localized along an E-W fault scarp which aisplaces Pliocene marine sediments and deposits of the Ruapehu ring plain.

High on the massif, fault traces are generally not topographically expressed, as a result of cover by eruptives from summit vents. An exception occurs on the southern and 


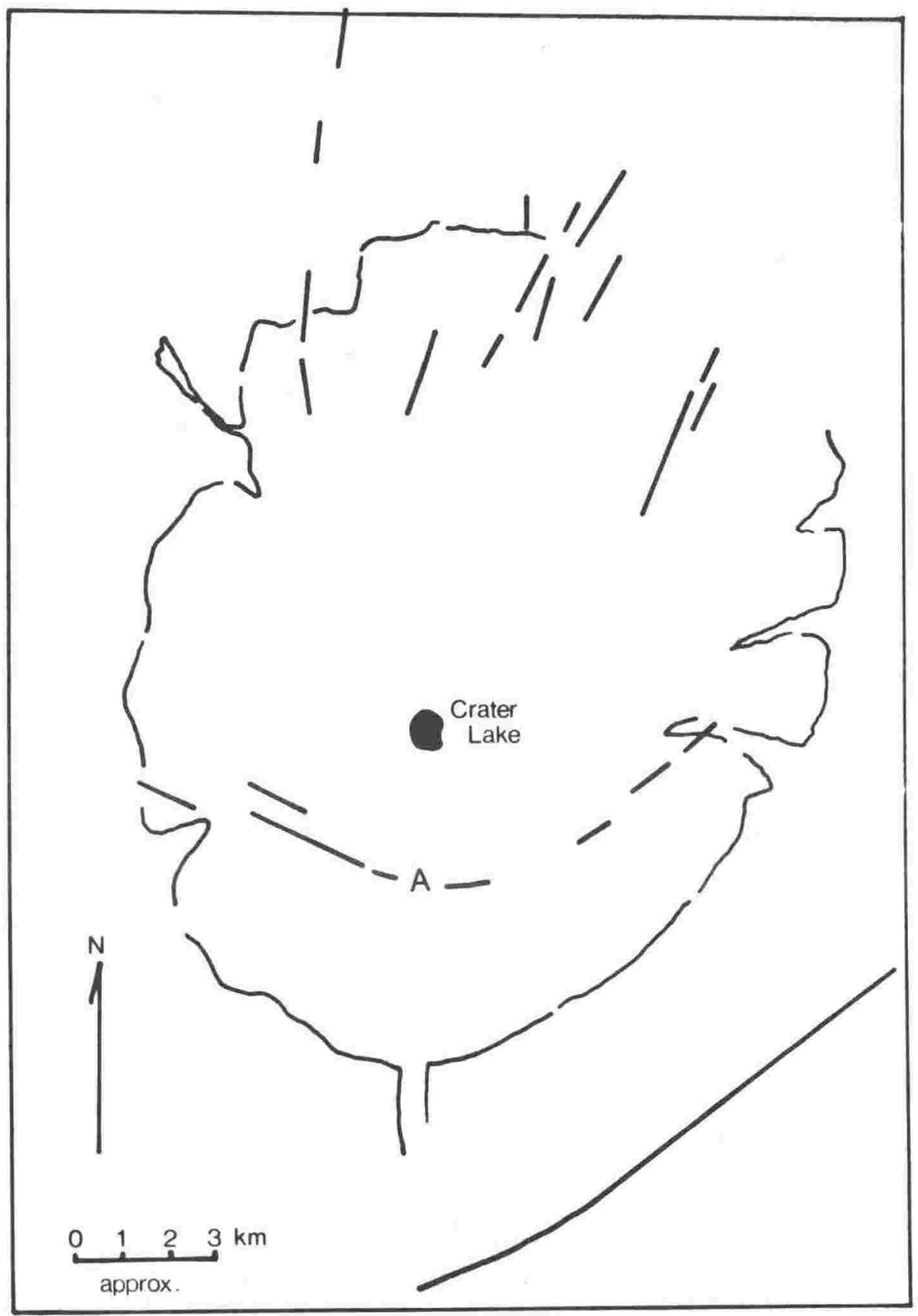

FIG. 84. Fault traces on Ruapehu massif. Mapped directly from vertical and oblique aerial photographs. 
southwestern flanks of Ruapehu (labelled "A" in Fig. 84), where the trace of a north-dipping fault traverses Mangawhero and Wahianoa Formations. The sense of displacement is unknown. This fault differs from most others in its relatively low dip angle.

\subsection{1}

IMPLICATIONS FOR VOLCANIC HAZARD ASSESSMENT AT RUAPEHU

Knowledge of the prehistoric record provides an opportunity to examine processes occurring at time scales of $10^{3}$ to $10^{5}$ years, in contrast to historic observations.

The most voluminous lithologies at Ruapehu are lava flows, autoclastic breccias, and secondary mass flows. These preserve a record of major, largely magmatic episodes which probably occurred over periods of $10^{2}$ to $10^{4}$ years. Lava flows themselves involve comparatively little hazard since they are slow-moving and their courses can be predicted. However, the associated production of voluminous autobreccias during lava extrusion presents a great hazard during major magmatic eruptions. If mobilized by gravity, hot autobreccias can become pyroclastic avalanches, and remain as unstable deposits long after effusion has ceased. Frequent failure of sectors of the cone is an expected consequence when a large proportion of the mountain consists of unstable fragmental deposits which are supported only by jointed and shattered lava flows.

On Ruapehu, the paucity of primary airfall units is remarkable. On steep and unstable terrain, poorly consolidated airfall units have low preservation potentials, and a geographic separation of lithologies results. While unconsolidated airfall deposits are rare on the massif, at distal exposures $10 \mathrm{~km}$ east of the mountain, Holocene airfall deposits are the rule and lava flows are exceptional. The geographic separation of lava flows and coarse tuff breccias from coeval airfall deposits is considered to be a result of secondary processes; unconsolidated airfall deposits being rapidly eroded and re-deposited as a component of the tuffaceous matrices in lahars and debris flows. Hazlett (1977) has made 
a similar deduction at San Cristobal Volcanic Complex, Nicaragua. In regions with relatively humid climates (New Zealand and Central America), this geographic separation may be a fundamental characteristic of steep-sided composite cones, and has two implications for hazards assessment. First, the geographic separation suggests a high frequency of lahar and debris flow generation on the massif. Second, if the frequency and volumes of tephra are to be evaluated for purposes of hazards assessment, the studies must be performed in distal regions where a relatively complete airfall stratigraphy is preserved.

Modern studies have justifiably emphasized present-day activity from the crater Lake, and have recognized the propensity of lahar generaticn from this vent (Fig. 85). The prehistoric record suggests that other mechanisms for lahar generation were also operative. For the Te Herenga Formation, voluminous secondary mass flows were probably generated by slope instability associated with intrusive deformation. For Wahianoa Formation, "Type C" heterolithologic tuff breccias indicate that lahars with a "hot" clast component were generated directly as a result of magmatic eruptions. In Mangawhero Formation, numerous valley-filling lahars and intercalated fluviatile sediments suggest frequent but local slope failures, perhaps during periods of heavy rainfall. The failure of unstable deposits in the upper Whakapapanui Gorge, NW Ruapehu, is suggested as a mechanism for lahar mounds deposition, which occurred during deposition of Whakapapa Formation.

These examples provide some justification for slope stability evaluation over a large portion of the upper slopes. In addition, studies of the Te Herenga and Waihianoa Formations suggest that deformation of the present-day summit region may herald not only magma intrusion and lahar generation from Crater Lake, but also an increased probability of "dry" slope failure on the upper flanks of Ruapehu. 


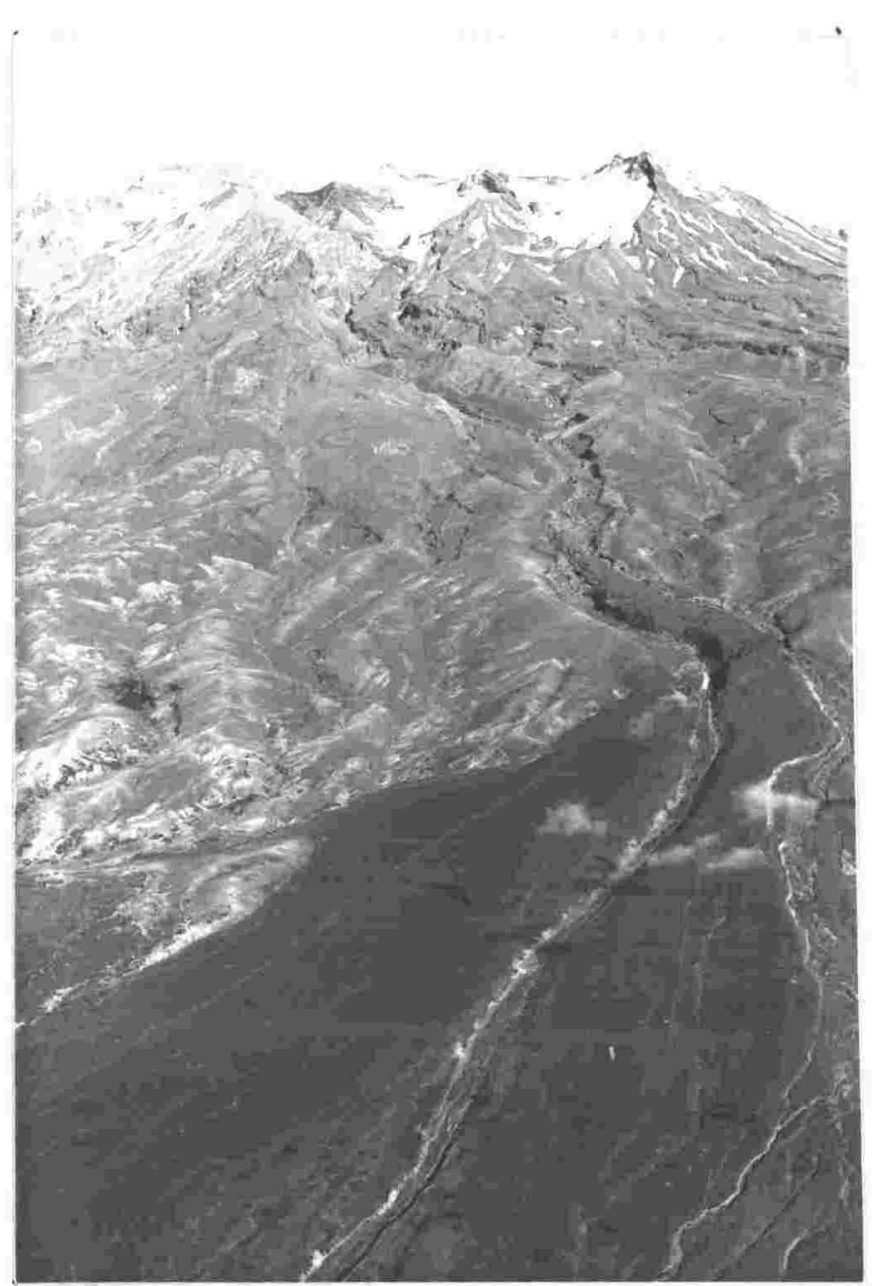

FIG. 85. Aerial Photograph of Whangaehu lahar fan, eastern ring plain of Ruapehu. The fan has resulted from eruptions of Crater Lake during $\mathrm{ca}$. the past 2500 years. 
No evidence for eruption of voluminous pyroclastic flows is found in the prehistoric record, in contrast to the situation at some other andesitic composite cones (e.g., Asama, Aramaki, 1963). Composite andesite cones commonly produce voluminous pyroclastic flows, and post-eruptive collapse of the vent regions is often associated with their effusion. I'his contrasts with Ruapehu, where no evidence for large collapse depressions is found. Furthermore, the mechanism for summit collapse, which commonly involves withdrawal of magmatic support subsequent to the extrusion of voluminous pyroclastics (Williams, 1941) is absent at Ruapehu: pyroclastic flows are neither abundant nor do they have large individual volumes. Small-volume "pyroclastic avalanches" occurred at Ngauruhoe to the north of Ruapehu in 1975 (Nairn and Self, 1978), and the prehistoric record of Ruapehu indicates that similar smallvolume pyroclastic flows also contributed to the whakapapa Formation (Rangataua and Iwikau Members), but only as a minor component. 
3. GEOLOGY OF RELATED VENTS

3.1

INTRODUCTION

Parasitic activity at the Tongariro Volcanic Centre is neither extensive nor voluminous, occurring at only two localities. These are the tephra cones and lava flows of Pukeonake, and numerous small craters in the vicinity of Ohakune. The total volume of parasitic eruptives is less than about $0.5 \mathrm{~km}^{3}$. The locations of these vents reflect structural trenais in the subvolcanic basement. Parasitic activity contrasts with that of the main massif: Short-lived eruptions have produced small, monogenetic tephra cones and minor lava flows, as opposed to the voluminous and long-continued effusion of pyroclastics and lava flows on the massif. Parasitic volcanism probably commenced within the last 25,000 years, and were thus late-stage eruptions, relative to Ruapehu massif.

Hauhungatahi is an additional eruptive centre which lies to the west of Ruapehu. This vent is not considered to be a parasitic centre, since its construction probably began prior to, or during the earliest stages of activity on Ruapehu massif.

\subsection{GEOLOGY OF THE PUKEONAKE VENTS \\ Topping (1974) has discussed the geology of Pukeonake} vents in detail. Most of his conclusions have been confirmed by this writer, and portions of the geologic discussion which follows are paraphrased after Topping (1974).

\section{PROPOSED RE-DEFINITION OF PUKEONAKE ANDESITE FORMATION}

This writer agrees with Topping's (1974) suggestion that Grindley's (1960) Pukeonake Andesite Formation should be re--defined. The formal definition given below incorporates both the observations of Topping (1974) and observations made during the present study. This definition differs from that of Grindley (1960) in that Pukeonake Andesite here includes both pyroclastics and lava flows, and the areal distribution is re-defined. In particular, several lava flows mapped by Grindley (1960) as Pukekaikiore Andesite are incluaed within Pukeonake Andesite. 


\section{DISTRIBUTION AND THICKNESS}

The formation is named after Pukeonake, a conspicuous, 143 metre high tephra cone to the west of Tongariro massif. The formation is defined as lava flows, autoclastic breccias, and pyroclastics which occur in this region and which are identified by their conspicuous olivine phenocrysts. Lava flows were confined to valleys and are now exposed only in road cuttings and stream courses over about a $55 \mathrm{~km}^{2}$ area to the west of Tongariro (Fig. 86). The deposits are covered by about 5 metres of rhyolitic and andesitic tephra. The formation thickness is highly variable, ranging from the 30 metres of pyroclastics exposed at Pukeonake tephra cone, to the 5 - 10 metre lava flows which travelled westward from their sources.

\section{FORMATION BOUNDARIES}

The base of the formation has not been observed, but Pukeonake Andesite almost certainly overlies dissected deposits of the Tongariro ring plain. Where a complete stratigraphy has been preserved (e.g., the exhumed crater of Pukeonake tephra cone), Pukeonake Andesite is overlain by the oruanui Formation, a conspicuous rhyolitic tephra which erupted from the Taupo region about 19,800 years ago.

\section{$\underline{\text { LITHOLOGY }}$}

Pukeonake Andesite Formation consists of both near-vent pyroclastics and associated tabular lava flows. The pyroclastics are well exposed by stream erosion and recent quarrying at Pukeonake tephra cone. The pyroclastics are mantle bedded over the rim of a central crater. Dark gray to black scoriaceous bomb and lapilli beds with bombs and blocks up to 1.5 metres are present. These alternate with beds in which the large clasts rest in matrices of more pumiceous yellowgrey lapilli and coarse ash. Although pyroclasts range from bomb to medium ash size, individual beds are moderately to well sorted. In the upper portion of the cone, coarse bomb and lapilli beds are locally welded, and an internal unconformity is present. 


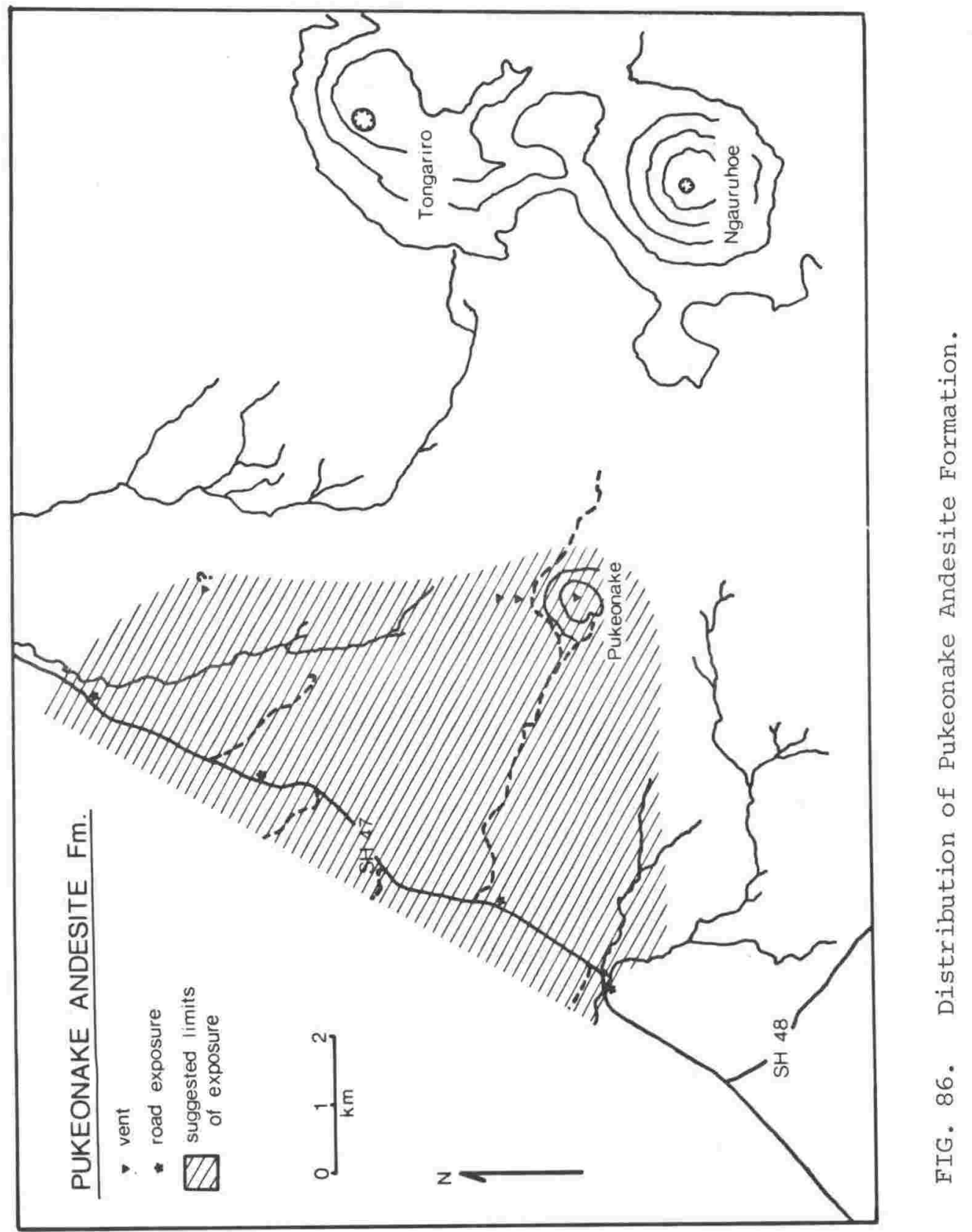


Associated valley-confined lava flows traversed much of the quadrant to the west of Pukeonake. Non-vesicular lava flows have medium grey matrices (e.g., Miahia Rapids), and vesicular flows are usually black. All of the tephra and lavas contain comspicuous olivine phenocrysts. Exposed thicknesses are on the order of 4- 10 metres, and often exhibit welldeveloped flow banding. Two smaller rounded hills to the north of Pukeonake consist of non-vesicular lava flows, and lava with abundant large irregular vesicles; no pyroclastics are found at these exposures.

$\underline{A G E}$

Pukeonake Andesite is overlain by Oruanui Formation (Topping, 1974), a rhyolitic tephra unit which erupted about 19,800 years ago. This provides a minimum age for the eruptions, and the absence of a conspicuous paleosol or erosional break at the Pukeonake-oranui contact suggests that Pukeonake Anaesite erupted not long before the Oruanui was emplaced.

\section{ORIGIN OF PUKEONAKE ANDESITE FORMATION}

Prior to 19,800 years ago, lava flows and coarse airfall ejecta issued from several parasitic vents to the west of Tongariro. Three mounds collectively define a N-S lineament which parallels the trend of vents on the main massifs, and is clearly related to regional faulting of the subvolcanic basement. Pukeonake tephra cone was the source of voluminous, coarse, locally welded and locally dispersed airfall deposits which were produced by relatively mild fire fountaining eruptions. Many of the finer ash- to lapilli-sized fall units exhibit palagonitization of the pumiceous fragments. The finer grain size and palagonitization indicate a minor component of phreatomagmatic activity, when water gained access to the vent. Two smaller mounds to the north of Pukeonake tephra cone consist of dense to vesicular lava flows; no airfall ejecta are associated with these, and no appreciable andesitic or rhyolitic tephra cover is present. These vents probably erupted mainly lava flows, and then underwent substantial erosion. 
TYPE AREAS

Pyroclastics of the vent region are well exposed in the quarry at Pukeonake tephra cone. Several of the lava flows are exposed in road cuttings along state Highway 47 between Taurewa and Mahuia Rapids.

\section{3}

GEOLOGY OF HAUHUNGATAHI

Twelve kilometres to the northwest of Ruapehu, the crescentic plateau Hauhungatahi (Fig. 87) consists of lava flows which cap a sequence of ash and breccia units, in turn resting on Miocene (Kapitean Stage) marine siltstones. A geologic cross section of Hauhungatahi is given in Figure 88.

DISTRIBUTION AND THICKNESS OF HAUHUNGATAHI ANDESITE FORMATION

Hay (1967) mapped Hauhungatahi Andesite Formation as "olivine-augite-hypersthene-Zabradorite andesite" but made no mention of its lithology or probable age in the accompanying map text. The formation is named after Hauhungatahi, the 1,519 metre apex of this broad plateau, and is only exposed over an $11 \mathrm{~km}^{2}$ area, on and around the margins of the plateau. It is defined as ol-bearing lava flows, autoclastic breccias, and pyroclastics which are exposed on the plateau of Hauhungatahi. Measured sections have not been obtained, but approximately 8 metres of lava flows overlie at least 50 metres of pyroclastics.

\section{FORMATION BOUNDARIES}

Hauhungatahi Andesite Formation rests on Kapitean Stage marine siltstones. The basal contact is poorly exposed, and probably occurs at between 1,100 and 1,200 metres elevation around the steep outer slopes of the plateau. A lower elevation limit for the basal contact is provided by documented fossil localities in the underlying marine sediments (Gregg, 1960 , p.34), which do not exceed 1,100 metres elevation. Hauhungatahi Andesite is overlain by weathered unnamed andesitic tephra, by weathered rhyolitic Oruanui Formation, and by weathered andesitic tephra of the Tongariro subgroup (Topping, 1974, section 242). 


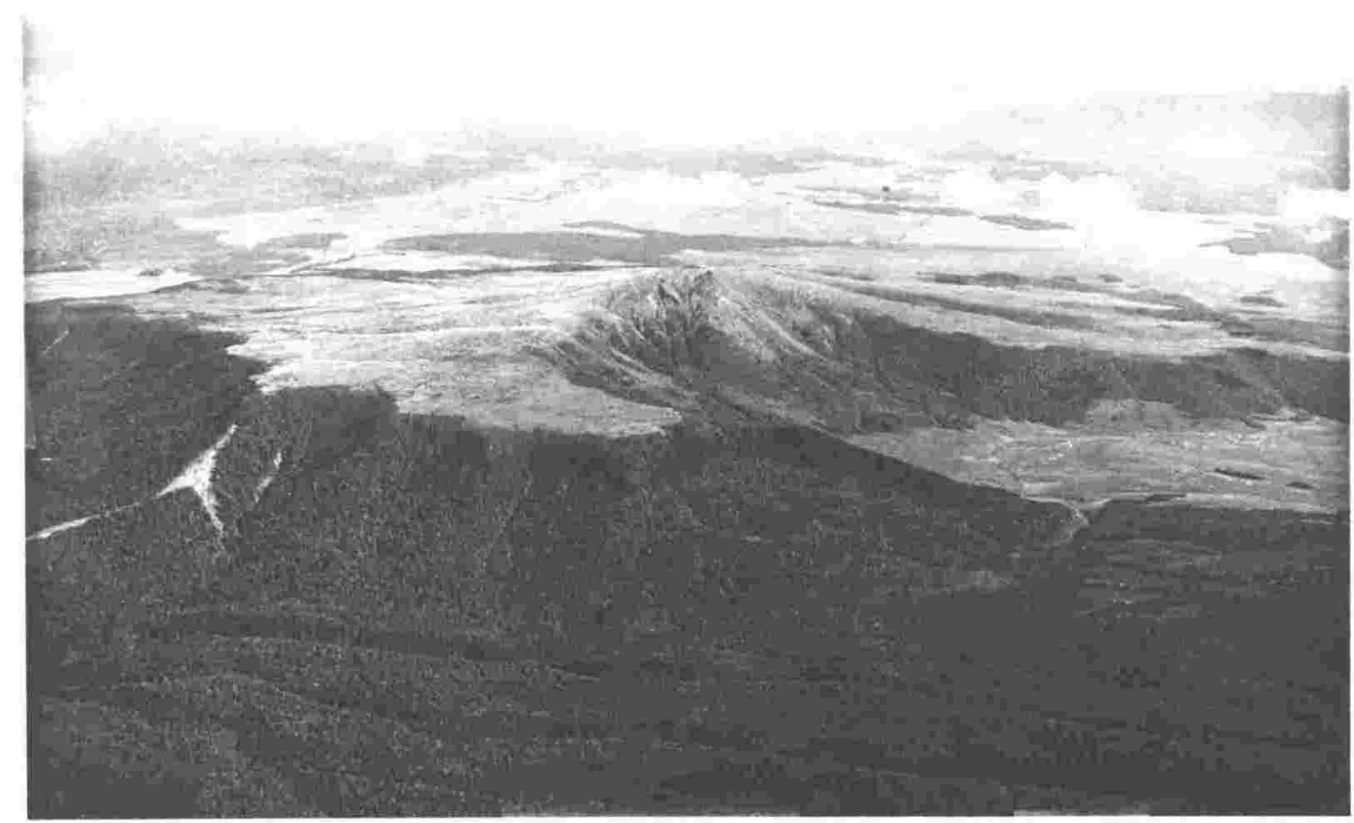

FIG. 87. Aerial photograph of Hauhungatahi, a deeply eroded volcano to the west of Ruapehu.

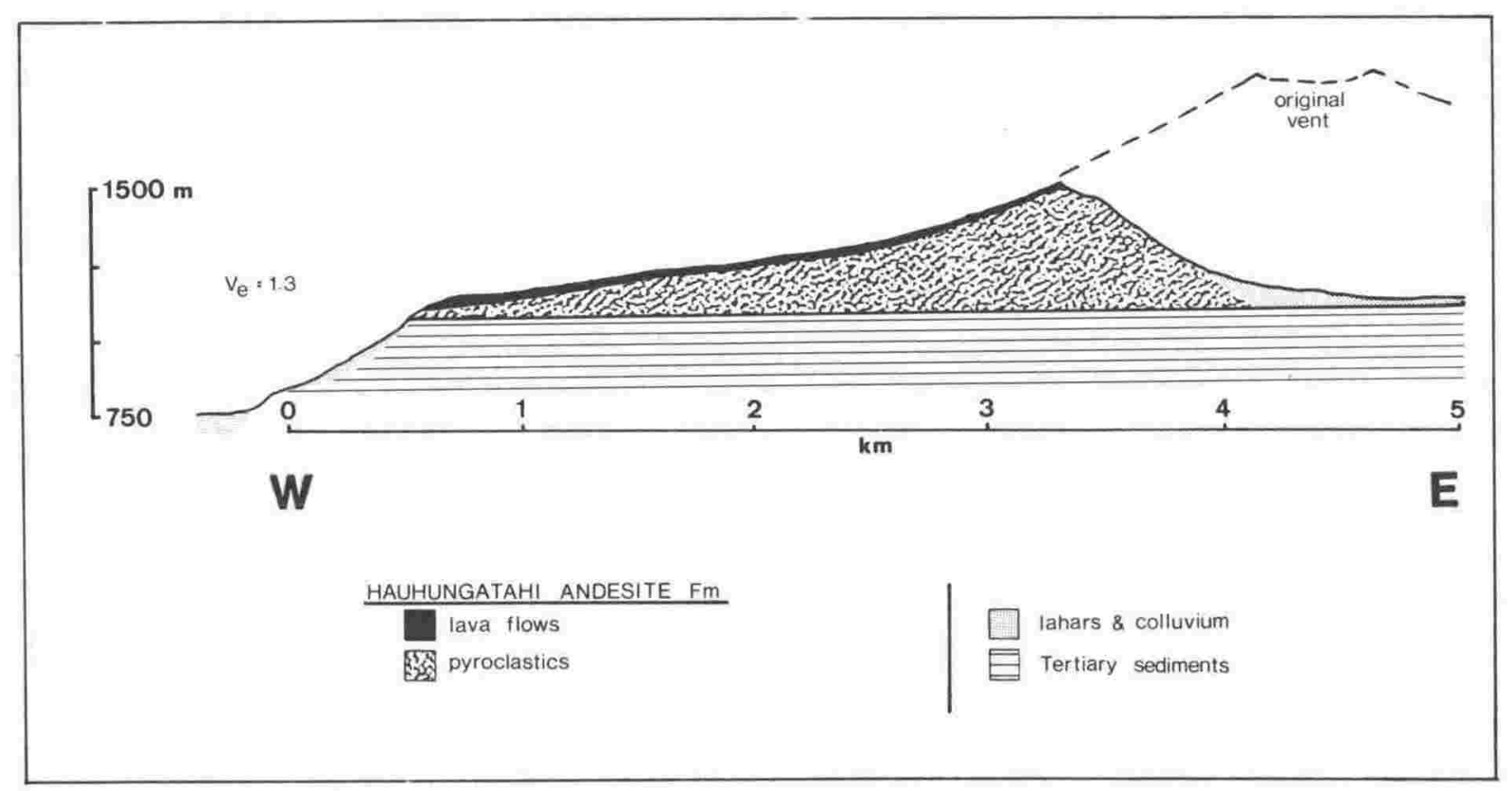

FIG. 88. Geologic cross-section of Hauhungatahi. 


\section{LITHOLOGY}

Several pale purple divine-bearing lava flows comprise the upper portion of the formation, and are responsible for the mesa-like topography. Near the summit, the lavas are highly frost shattered into vertical plates, but elsewhere they are massive. The lowest flow rests on weathered, monolithologic tuff breccia. Large, weathered talus blocks from these lavas commonly occur around the plateau, and are mixed with the overlying andesitic tephra to form a surrounding apron of colluvial deposits. Deeply weathered pyroclastics are well exposed beneath the upper lava flows in the steep concavity of the eastern plateau (Fig. 89). Here, alternating units of weathered block and ash (black, angular clasts in a green, clay-rich matrix), and weathered greenish yellow fine ash occur (well developed planar and cross stratification, and sag structures beneath rounded bombs). Welded tuff breccia occurs near the base of the formation (weathered green ash and lapilli matrix with grey subangular blocks up to $4 \mathrm{~cm}$ ). The entire pyroclastic sequence is transected by high-angle fractures which are filled with red and green clay. All clasts in the pyroclastic deposits have the same petrography as the overlying lava flows, except for some variation in the degree of vesicularity.

The lower welded tuff breccias probably represent pyroclastic flow deposits which issued from an unexposed but nearby vent region during the early stages of activity. The upper pyroclastics are largely airfall and re-worked airfall material, as deduced from the internal stratification and the presence of bomb sags. This early tephra cone was then armoured by several lava flows and minor associated autoclastic breccias. Assuming a 4 kilometre radius and a 400 metre height for the original cone, which are considered to be maximum probable dimensions, the original edifice did not exceed $10 \mathrm{~km}^{3}$ in volume.

AGE

Topping (1974, p.111) identified Oruanui Formation within the sequence of andesitic tephra which overlies Hauhungatahi 


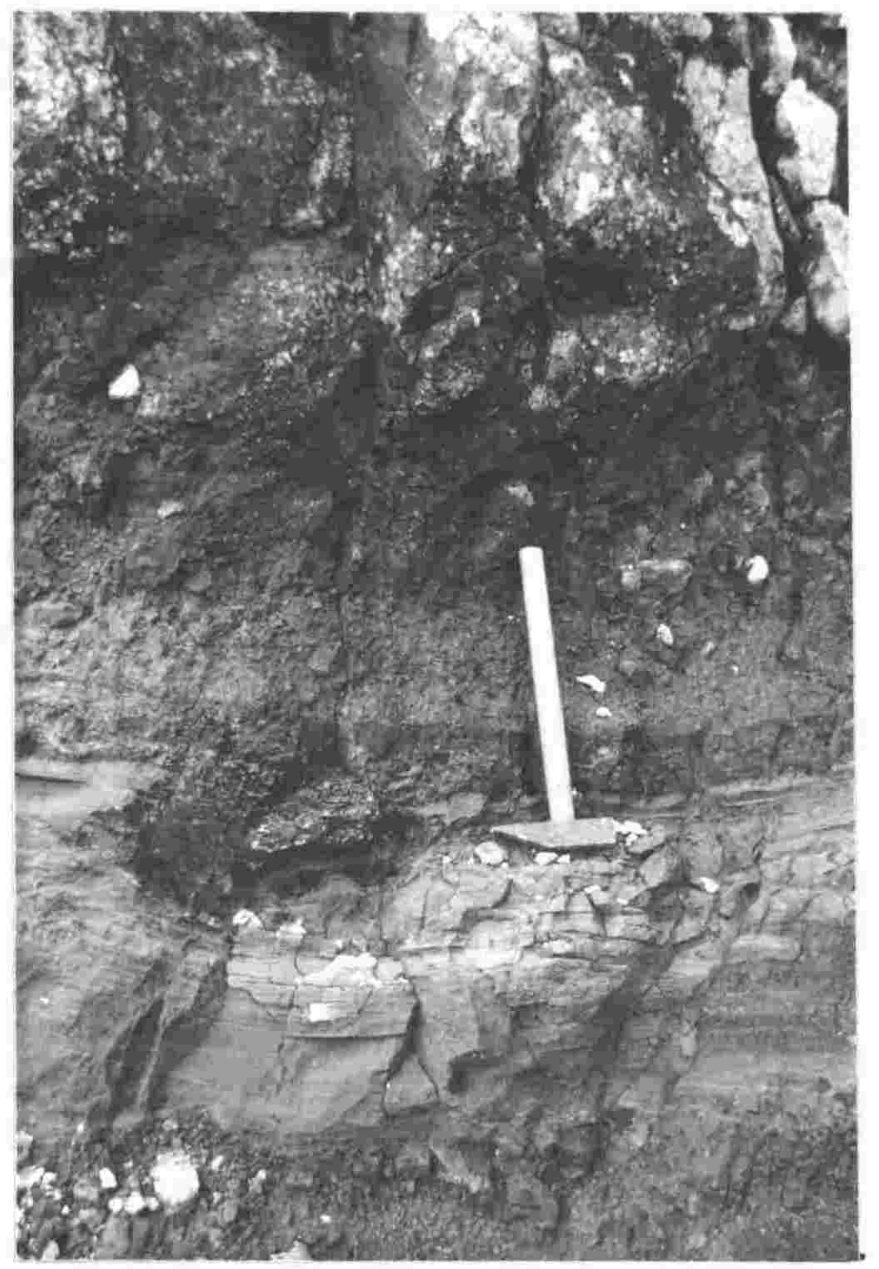

FIG. 89. Pyroclastics beneath upper sequence of lava flows, Hauhungatahi. Base of lowest lava flow is shown at top of photograph, resting on autoclastic breccia. Exposed in the steep gully of the eastern concavity. 
Andesite, providing a minimum age of 19,800 years for the formation. However, the Hauhungatahi Andesite is probably much older than this minimum age. The eroded morphology of the cone suggests that it is one of the oldest volcanic features of the Tongariro region. Furthermore, during the construction of Ruapehu massif, the surrounding area must have been a region of voluminous deposition, forming the Ruapehu ring plain. Yet Hauhungatahi Andesite rests on Tertiary marine sediments, about 200 metres above the encircling surface of the Ruapehu ring plain. This implies extensive erosion of Hauhungatahi Andesite and the underlying marine sediments, prior to advanced construction of Ruapehu massif and deposition of its ring plain. The Hauhungatahi deposits are also deeply weathered, suggesting antiquity relative to Ruapehu massif. Hauhungatahi was probably active prior to, or only during the earliest stages of construction of Ruapehu massif, and may have an age on the order of $0.5 \mathrm{Ma}$.

TYPE AREA

The best exposures of Hauhungatahi Andesite Formation exist in the precipitous gully of the eastern concavity. 


\subsection{GEOLOGY OF THE OHAKUNE VENTS}

A copy of the following research paper is presented:

Houghton, B.F., and Hackett, W.R., 1984. Strombolian and phreatomagmatic deposits of Ohakune Craters, Ruapehu, New Zealand: A complex interaction between external water and rising basaltic magma. Jour of Volcanology and Geothermal Res., 21, 207-231.

After initial reconnaissance by the present writer, detailed field work and laboratory studies were made jointly with Dr. B.F. Houghton of the New Zealand Geological Survey, Rotorua. The first draft was produced by Dr. Houghton, and subsequently modified by the present writer and by several other reviewers. 


\title{
STROMBOLIAN AND PHREATOMAGMATIC DEPOSITS OF OHAKUNE CRATERS, RUAPEHU, NEW ZEALAND: A COMPLEX INTERACTION BETWEEN EXTERNAL WATER AND RISING BASALTIC MAGMA
}

\author{
B.F. HOUGHTON ${ }^{2}$ and W.R. HACKETT ${ }^{2}$ \\ ' New Zealand Geological Survey, P.O. Box 499, Rotorua (New Zealand) \\ ${ }^{2}$ Department of Geology, Victoria University of Wellington, Wellington (New Zealand)
}

(Recejved January 18, 1983 ; revised and accepted December 22, 1983)

\section{ABSTRACT}

Houghton, B.F. and Hackett, W.R., 1984. Strombolian and phreatomagmatic deposits of Ohakune Craters, Ruapehu, New Zealand: a complex interaction between external water and rising basaltic magma. J. Volcanol. Geotherm. Res., 21: 207-231.

The Ohakune Craters form one of several parasitic centres surrounding Ruapehu volcano, at the southern end of the Taupo Volcanic Zone. An inner scoria cone and an outer, probably older, tuff ring are the principal structures in a nested cluster of four vents.

The scoria cone consists of alternating lava flows and coarse, welded and unwelded, strombolian block and bomb beds. The strombolian beds consist of principally two discrete types of essential clast, vesicular bombs and dense angular blocks. Rare finer-grained beds are unusually block-rich. The tuff ring consists of alternating strombolian and phreatomagmatic units. Strombolian beds have similar grain size characteristics to scoria cone units, but contain more highly vesicular unoxidised bombs and few blocks. Phreatomagmatic deposits, which contain clasts with variable degrees of palagonitisation, consist of less well-sorted airfall deposits and very poorly sorted, crystal-rich pyroclastic surge deposits.

Disruption by expanding magmatic gas bubbles was a major but relatively constant influence on both strombolian and phreatomagmatic eruptions at Ohakune. Instead, the nature of deposits was principally controlled by two other variables, vent geometry and the relative influence of external water during volcanism. During tuff-ring construction, magma is considered to have risen rapidly to the surface, and to have been ejected with out sufficient residence time in the vent for non-explosive degassing. Availability of external water principally governed the eruption mechanism and hence the nature of the deposits. Essentials clasts of the scoria cone are, by comparison, dense, degassed and oxidised. It is suggested that a change in vent geometry, possibly the construction of the tuff ring itself, permitted lava ponding and degassing during scoria cone growth. During strombolian eruptions, magma remaining in the vent probably became depleted in gas, leading to the formation of an inert zone, or crust, above actively degassing magma. Subsequent explosions had therefore to disrupt both this passive crust and underlying, vesiculating magma "driving" the eruption. Cycles of strombolian eruption are thought to have stopped when the thickness of the inert crust precluded explosive eruption and only recommenced when some of this material was removed, either as a lava flow or during phreatomagmatic explosions when external water entered the vent. Such explosions probably formed the unusually fine-grained and block-rich beds in the strombolian sequence. 
The Ohakune deposits are an excellent example of the products of explosive eruption of fluid, gas-rich basic magma vesiculating under very near-surface conditions. A complex interplay of rate of magma rise, rate and depth of formation of gas bubbles, vent geometry, abundance of shallow external water, wind velocity and accumulation rate of ejecta determines the nature of deposits of such eruptions.

\section{INTRODUCTION}

General processes of strombolian eruption and related phreatomagmatic activity are well-known, from detailed studies of short historical eruptions (Moore et al., 1966; Booth and Walker, 1973; Self et al., 1974; Guest et al., 1974; Kienle et al., 1980) and theoretical studies (Blackburn et al., 1976; Sparks, 1978; Wilson, 1980; Sheridan and Wohletz, 1981). Characteristics of grain size and clast morphology of such deposits are also well-established (Heiken, 1972; Walker and Croasdale, 1972). However, there are few published bed-by-bed investigations of entire scoria-cone or tuff-ring sequences documenting textural variations within single units and transitions between effusive, strombolian and phreatomagmatic deposits.

This paper attempts to document in detail one very well-exposed sequence with numerous transitions between effusive, strombolian, violent strombolian and phreatomagmatic activity and to draw general conclusions about transitions between these eruptive styles.

\section{REGIONAL SETTING}

The Ohakune Craters form one of several parasitic volcanic centres surrounding the andesitic composite volcano Ruapehu, at the southern extremity of the Taupo Volcanic Zone, in central New Zealand (Fig. 1). The monogenetic parasitic vents are typically strombolian or phreatomagmatic. Basement beneath Ruapehu is a sequence of Pliocene-Miocene marine sediments (Hay, 1967). South of Ruapehu these strata form fault-bounded blocks protruding through the laharic ring plain of the volcano (Fig. 2). The Ohakune Craters are located on the southern margin of one such fault block and magma probably reached the surface along the near-vertical east-west fault system associated with this block. The Ohakune deposits are immediately underlain by the laharic and alluvial fan which extends southwards from Ruapehu. The deposits are as yet undated but are overlain directly, without any indication of sustained erosion or weathering, by a 20,000 . year-old rhyolitic ash from Taupo Volcano. The Ohakune tephra is a distinctive two-pyroxene, olivine low-silica andesite contrasting with the strongly plagioclase-phyric andesites of the main cone of Ruapehu.

\section{OHAKUNE CRATERS}

The Ohakune Craters form a nested cluster of four well-defined eruptive centres. The two principal structures, an inner scoria cone and outer tuff 


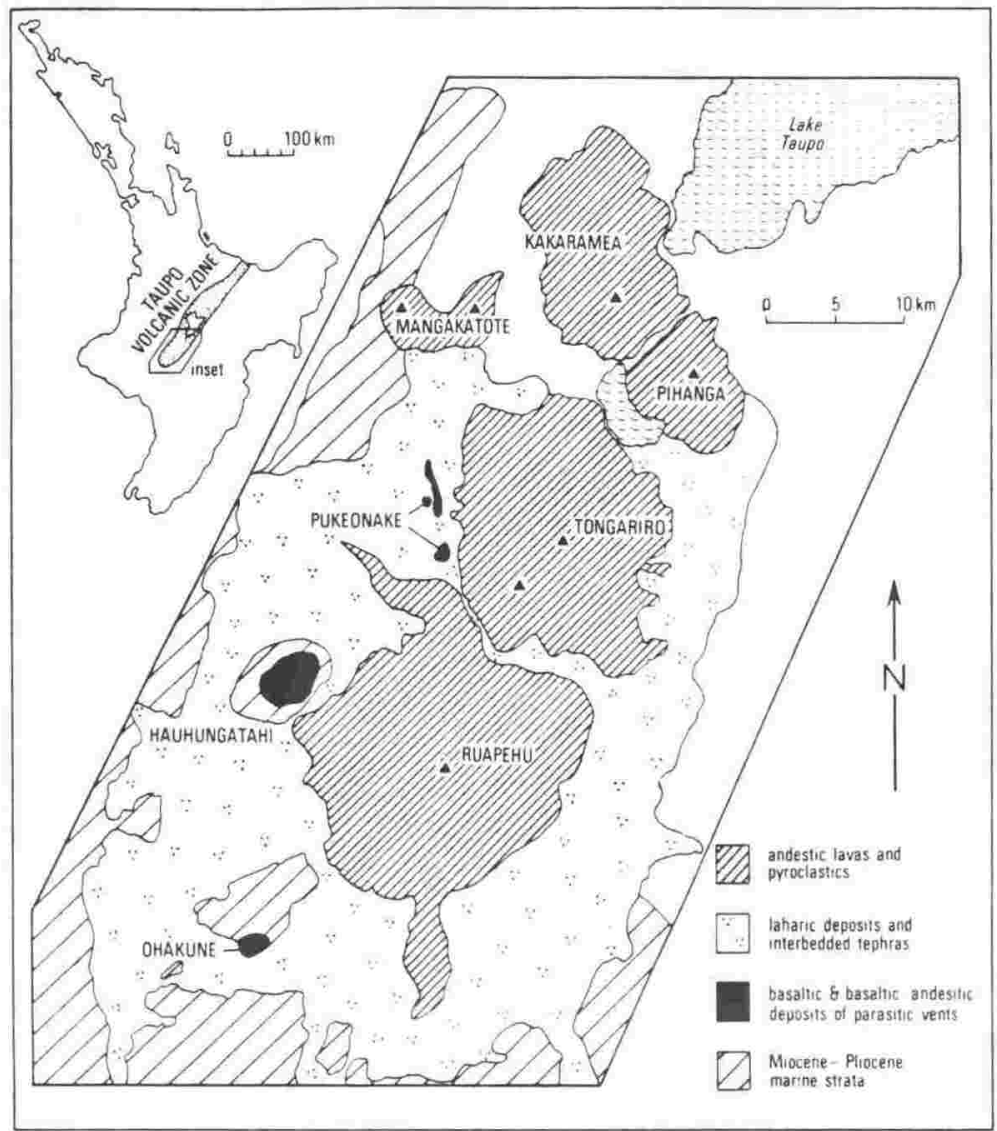

Fig. 1. General geology of southern Taupo Volcanic Zone modified after Grindley (1967) and Hay (1967).

ring, are concentric, with two smaller pits set on the eastern rim of the tuff ring (Fig. 2). A number of small, less well-defined crater forms are visible on aerial photographs of the surrounding area. The craters lie on the flat, gently sloping swampy surface of the Ruapehu lahar fan, which is cut by numerous minor streams, fed by springs discharging from the fault scarp to the north. It is clear that the region is now, and was probably at the time of eruption, one of abundant groundwater. The inner scoria cone is $500 \mathrm{~m}$ wide and rises $28 \mathrm{~m}$ above the moat separating it from the tuff ring. The southeastern floor of the cone is a north west-sloping planar surface, which drops abruptly into a steep-walled pit beneath the northwestern wall of the cone.

The outer tuff ring is asymmetrical and between 600 and $1000 \mathrm{~m}$ wide, and $20 \mathrm{~m}$ high. Surrounding the craters is a thin $(<2 \mathrm{~m})$ blanket of distal ejecta, extending eastward and southward for at least $2 \mathrm{~km}$. 


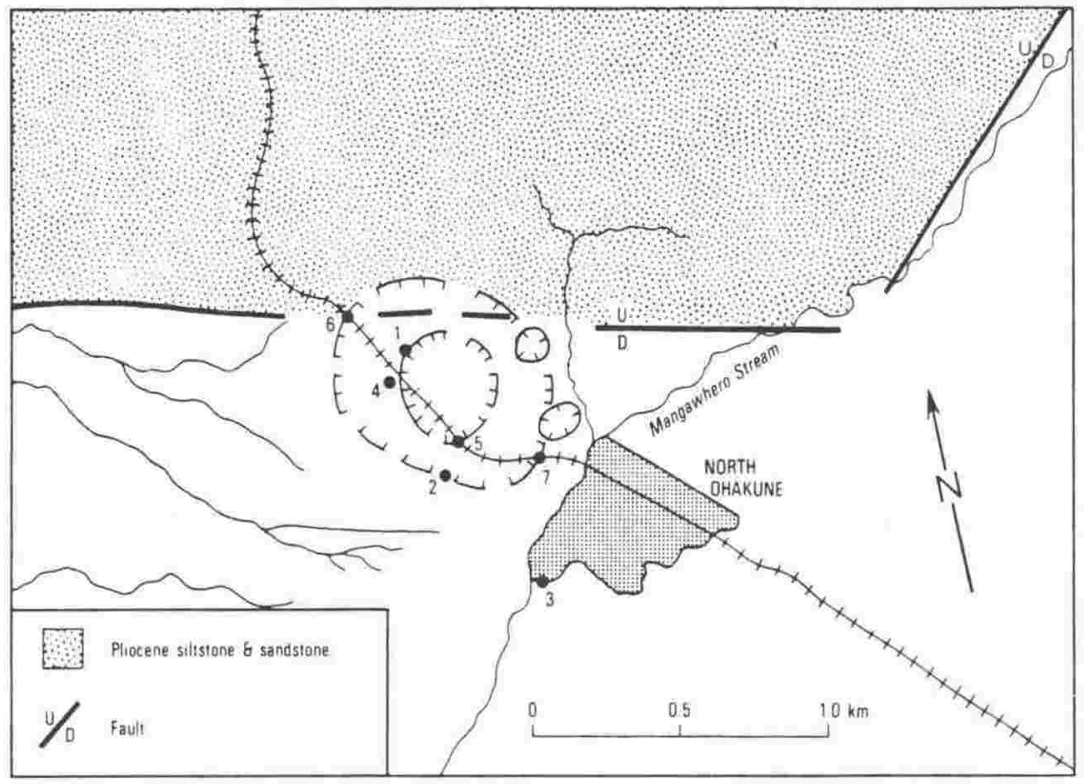

Fig. 2. Sketch map of the geology of Ohakune Craters. Localities 1, 2, 3 as in text. Localities 4 and 5 are railway cuttings through the western and southern margins of the scoria cone and localities 6 and 7 are cuttings through the northwestern and southeastern rim of the tuff ring.

\section{Scoria cone}

The scoria cone consists of an alternation of strombolian block and bomb beds and massive lava flows (Fig. 3). A quarry at location 1 in Fig. 2 provides an excellent near-radial section through the upper $16 \mathrm{~m}$ of the cone. The sequence can be subdivided into lava flows (L), and welded (W), and nonwelded (S) block and bomb beds (Fig. 4). Dips measured on the surfaces of $\mathrm{L}$ and $\mathrm{W}$ beds average $25^{\circ}$. A 1 -m unconformable mantle of phreatomagmatic ejecta is present on the inner wall of the cone at this locality.

The sequence at locality 1 is dominated by coarse-grained, relatively wellsorted, framework-supported $\mathrm{S}$ beds (Fig. 3). The $\mathrm{S}$ beds are superficially monotonous but contain crude bedding and variations in the proportions of clast types. Red oxidised clasts of essential, low silica andesite form 95-99\% of any sample of the deposits. The essential clasts have a unique, plagioclasepoor mineralogy not recognised in any other deposits in the Ohakune area. Essential clasts are of two distinct types: (1) well-formed fusiform to ovoid bombs, with moderately vesicular cores and "breadcrust" rinds; and (2) dense, angular non-vesicular to microvesicular essential blocks. Three types of accidental clast are present in minor amounts: quartzose xenoliths, baked sedimentary inclusions and well-rounded boulders of plagioclase-phyric Ruapehu andesite. The morphology of the latter suggests they are derived from laharic deposits and not primary volcanic material. 


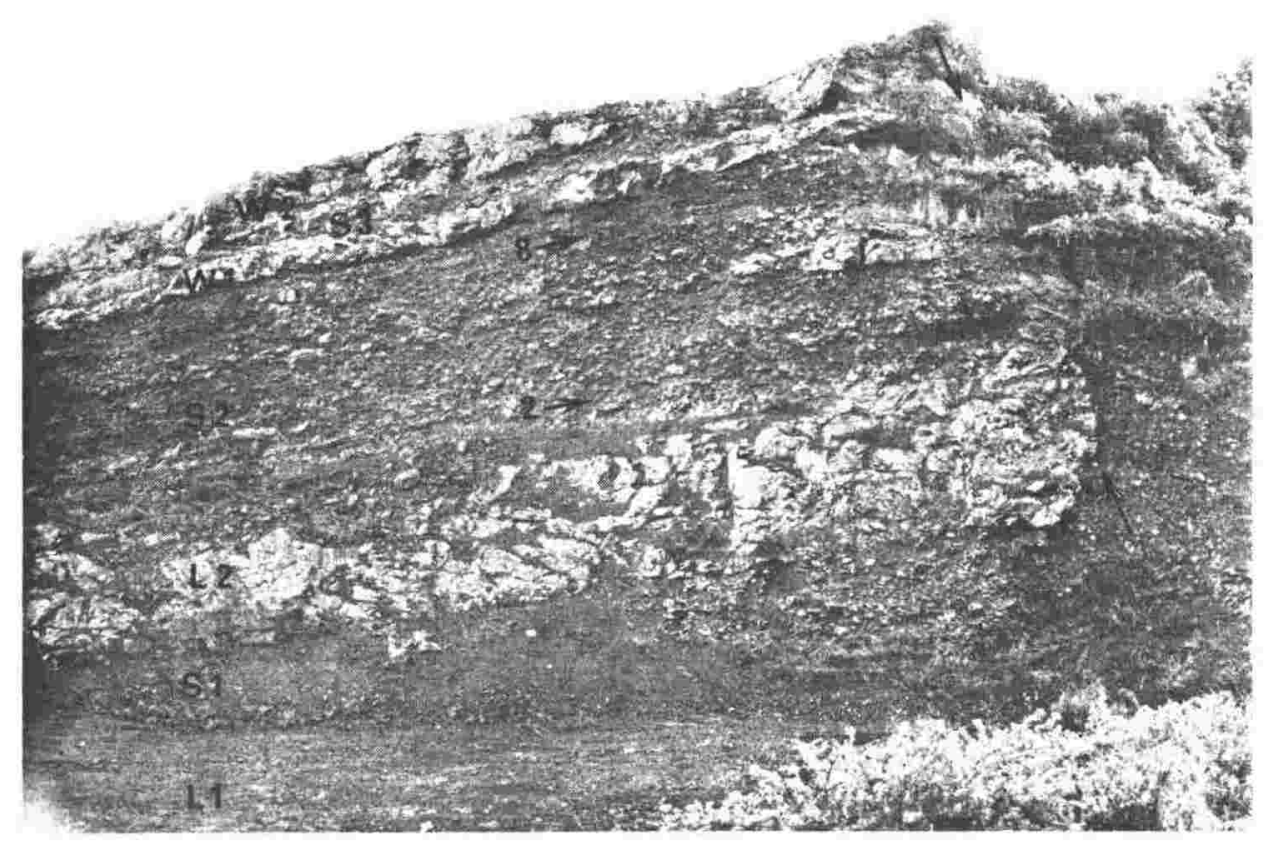

Fig. 3. Near-radial, $16 \mathrm{~m}$ section through the scoria cone at Locality 1, Fig. 2 (also Fig. 4). $L$ are lava flows, $S$ unwelded and $W$ welded strombolian block and bomb beds. Locations of unusually fine-grained horizons in the $S 2$ interval are shown (samples 2 and 8 ). The position of the scoria cone rim is arrowed.

The thick sequence (S2) between L2 and W1 is typical of the S beds and was sampled in detail. A sharp colour change corresponding to increased oxidation of the clasts occurs $5.0 \mathrm{~m}$ above $\mathrm{L} 2$ at the level of a prominent concentration of essential blocks. Two atypically finer-grained beds, containing a concentration of dense clasts, occur at $1.2 \mathrm{~m}$ and $6.5 \mathrm{~m}$ above the base of S2 (Fig. 3).

Welded block and bomb beds alternate with the unwelded $\mathrm{S}$ beds in the sequence. Two welded beds (W1, W2) are well exposed at the top of the sequence at locality 1 . The welded beds form resistant ridges, standing out from the more easily eroded $\mathrm{S}$ beds. Welding is dense, obscuring the primary pyroclastic texture of the beds. Scoriaceous partially welded lenses occur throughout the deposits, often around large dense essential or accidental clasts. Transitions upward and downward through partly welded material into $\mathrm{S}$ beds are gradational over distances of several centimetres.

\section{Tuff ring}

The best exposures of the deposits are on the southern margin of the tuff ring (locality 2) where several quarry faces are oriented both radially and tangentially to the ring (Fig. 5). The tuff ring consists entirely of pyro- 


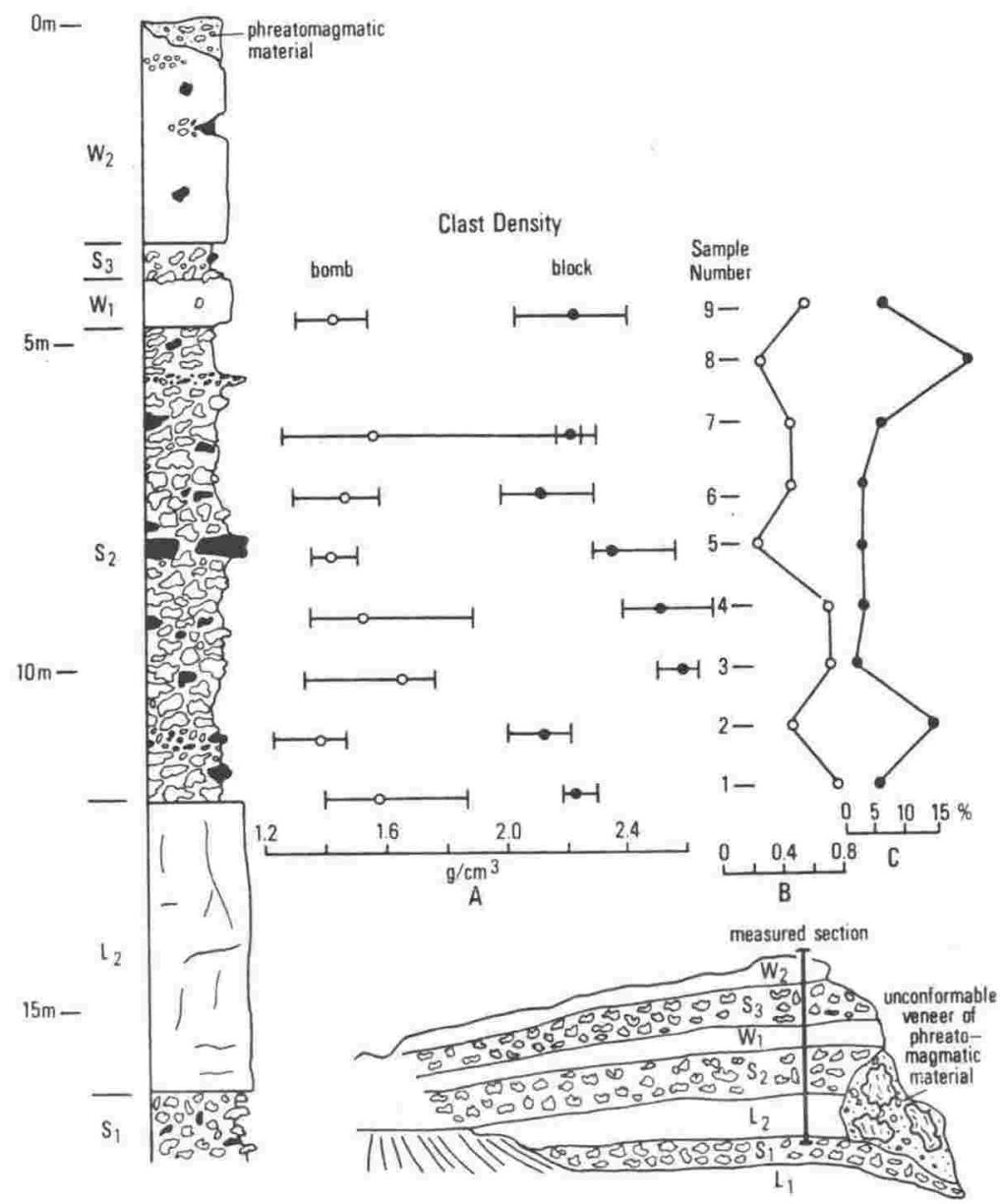

Fig. 4. Representative section through scoria cone at Locality 1 . White clasts are bombs, black clasts dense essential blocks. Plots of variation with stratigraphic height of (A) range $(\mapsto)$ and mean $(O)$ densities of bombs and blocks, (B) ratio of bombs to essential blocks, and (C) \% of sample finer than $1 \mathrm{~mm}$.

clastic beds. One major face (A) shows individual beds thinning markedly up the inner wall of the tuff ring before sloping gently down the outer wall (Fig. 6). A composite stratigraphic sequence for the quarry is given in Fig. 7. The sequence is readily subdivided into black, relatively well-sorted, bomb layers ( $\mathrm{S}$ beds), pale brown, less well-sorted block and bomb layers ( $\mathrm{Pb}$ beds) and dark brown, poorly sorted ash beds ( $\mathrm{Pa}$ beds)

$\mathrm{S}$ beds in the sequence contrast with the $\mathrm{S}$ beds of the scoria cone, in containing principally highly vesicular unoxidised bombs and only relatively minor proportions of dense, degassed essential clasts. The brown colouration of the $\mathrm{P}$ beds is due to variable palagonitisation of essential clasts. $\mathrm{Pb}$ beds contain internal bedding and often develop bedding sags at the contact to 


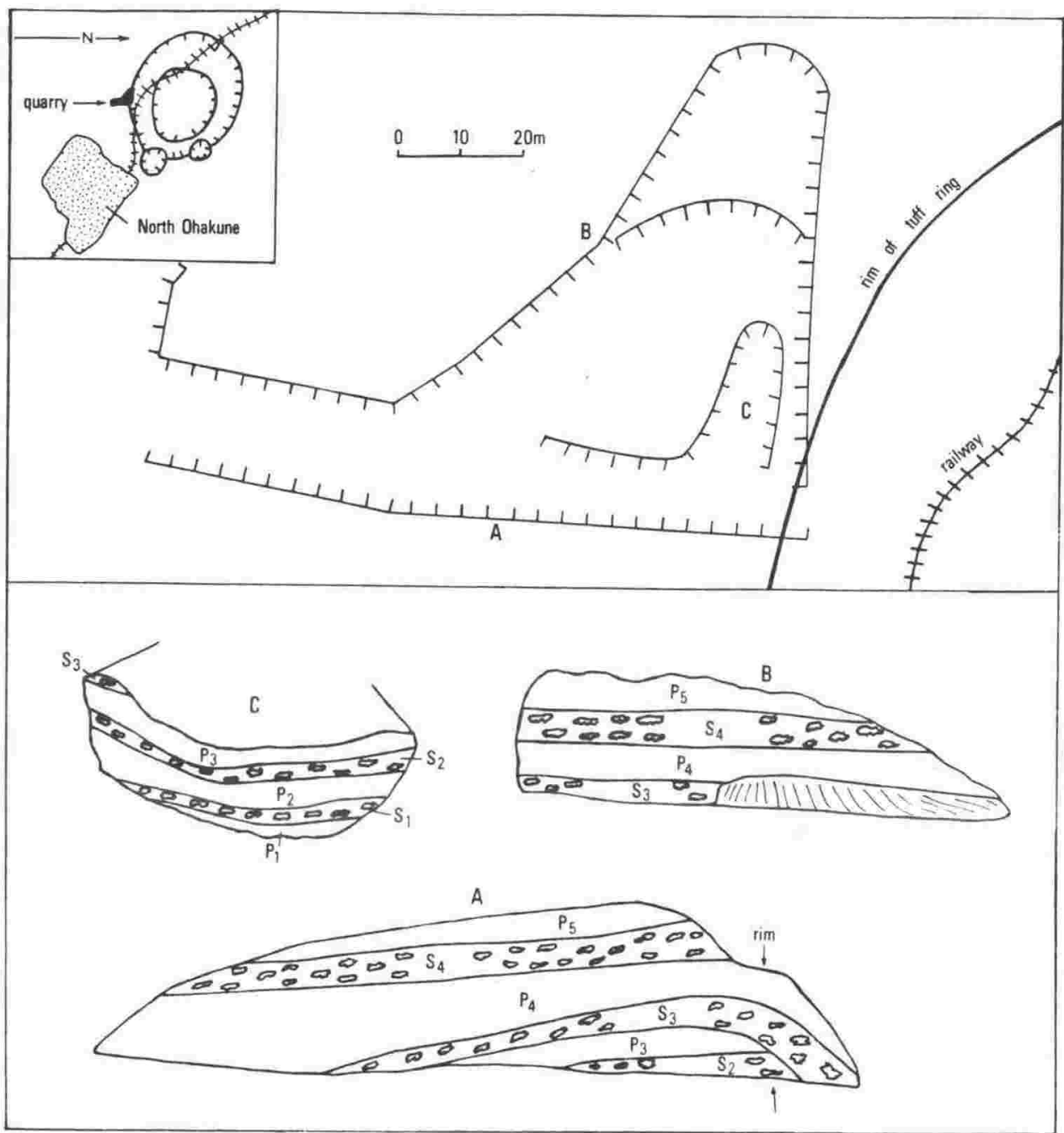

Fig. 5. Sketch of geometry and stratigraphy of quarry at Locality 2 of Fig. 2, Ohakune tuff ring.

underlying $\mathrm{Pa}$ beds. The Pa beds are massive or planar-bedded, but contain internal low angular unconformities, irregular thickness variations and planed erosional contacts (Fig. 8).

\section{Distal apron}

The distal apron of ejecta from Ohakune extends southwards and eastwards to North Ohakune township. An excellent exposure $1 \mathrm{~km}$ from the craters (locality 3, Fig. 2) contains $2.4 \mathrm{~m}$ of bedded tephra (Fig. 9). The 


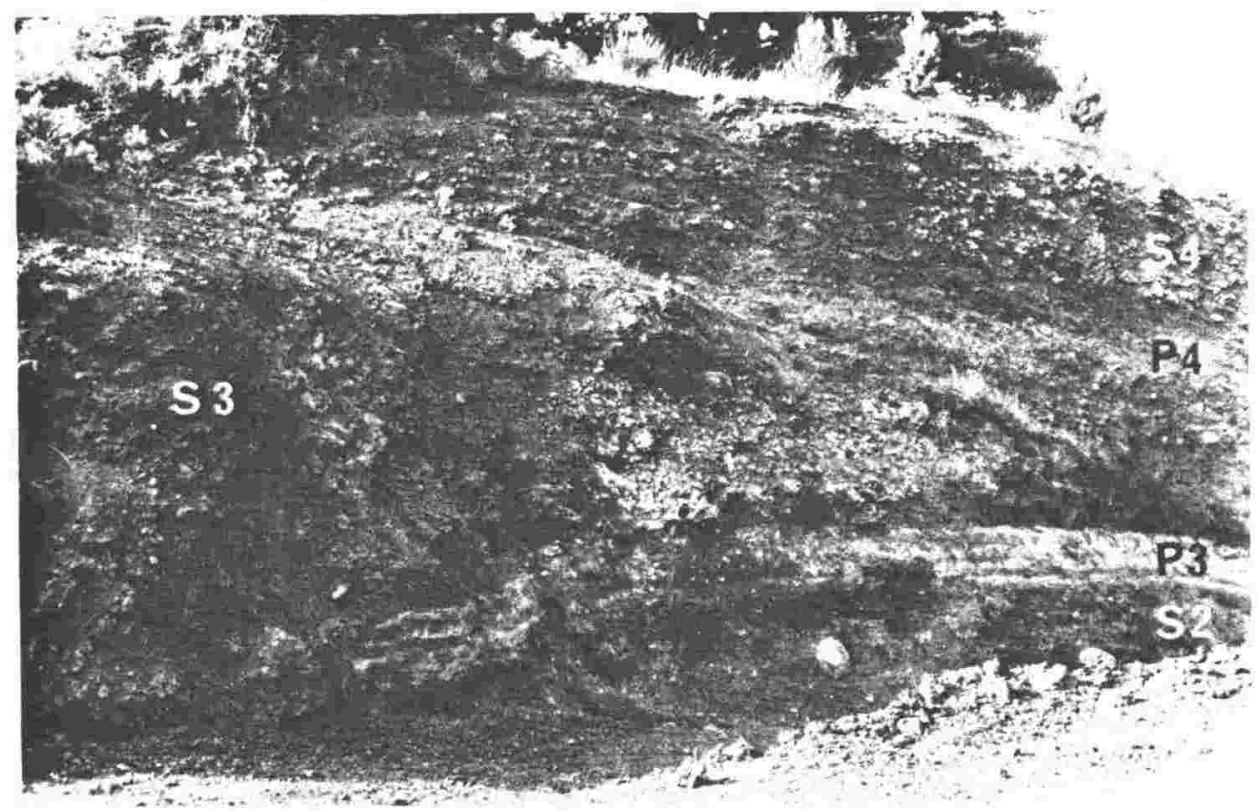

Fig. 6. Face A, locality 2 (see Fig. 8 ) oriented radially to tuff ring, vent to the left. Note thickening of black strombolian unit (S3) on inner wall of ring and rapid thinning of black $\mathrm{S}$ units relative to intervening lighter coloured $\mathrm{P}$ units.

deposits are of 3 types, coarse $\mathrm{Pb}$ beds, fine-grained $\mathrm{Pa}$ layers and isolated ballistic bombs.

The $\mathrm{Pb}$ and $\mathrm{Pa}$ beds may be correlated with the equivalent units with the tuff ring. Low angle cross bedding and dune bedforms are common in $\mathrm{Pa}$ beds at distal localities, and absent in the tuff ring. However, a similar transition, from massive sheet-like material with undulations in bed thickness into more distal material containing dune bedforms, occurs in the deposits of some historical cold, wet pyroclastic surges e.g. Taal Volcano, 1965 (Moore, 1967), or White Island volcano, 25 August, 1977 (Houghton et al., 1979), which are presumed to be analogues to the Ohakune deposits. Isolated ballistic blocks up to $1.0 \times 0.3 \mathrm{~m}$ are concentrated at two levels in the section (Fig. 9). These are probably correlative with $\mathrm{S}$ beds of the tuff ring, or possibly with $\mathrm{Pb}$ beds produced by the most violent explosive events.

\section{GRANULOMETRIC STUDIES}

\section{Introduction}

Samples of $10-20 \mathrm{~kg}$ weight were collected for grainsize analysis by drysieving. Sieves at $1 / 2 \phi$ intervals were used for clasts bigger than $2 \mathrm{~mm}$, because of the large sample size, whereas sieves at the normal $1 \phi$ interval were used for finer material. Size fractions for each sample were then split into the 


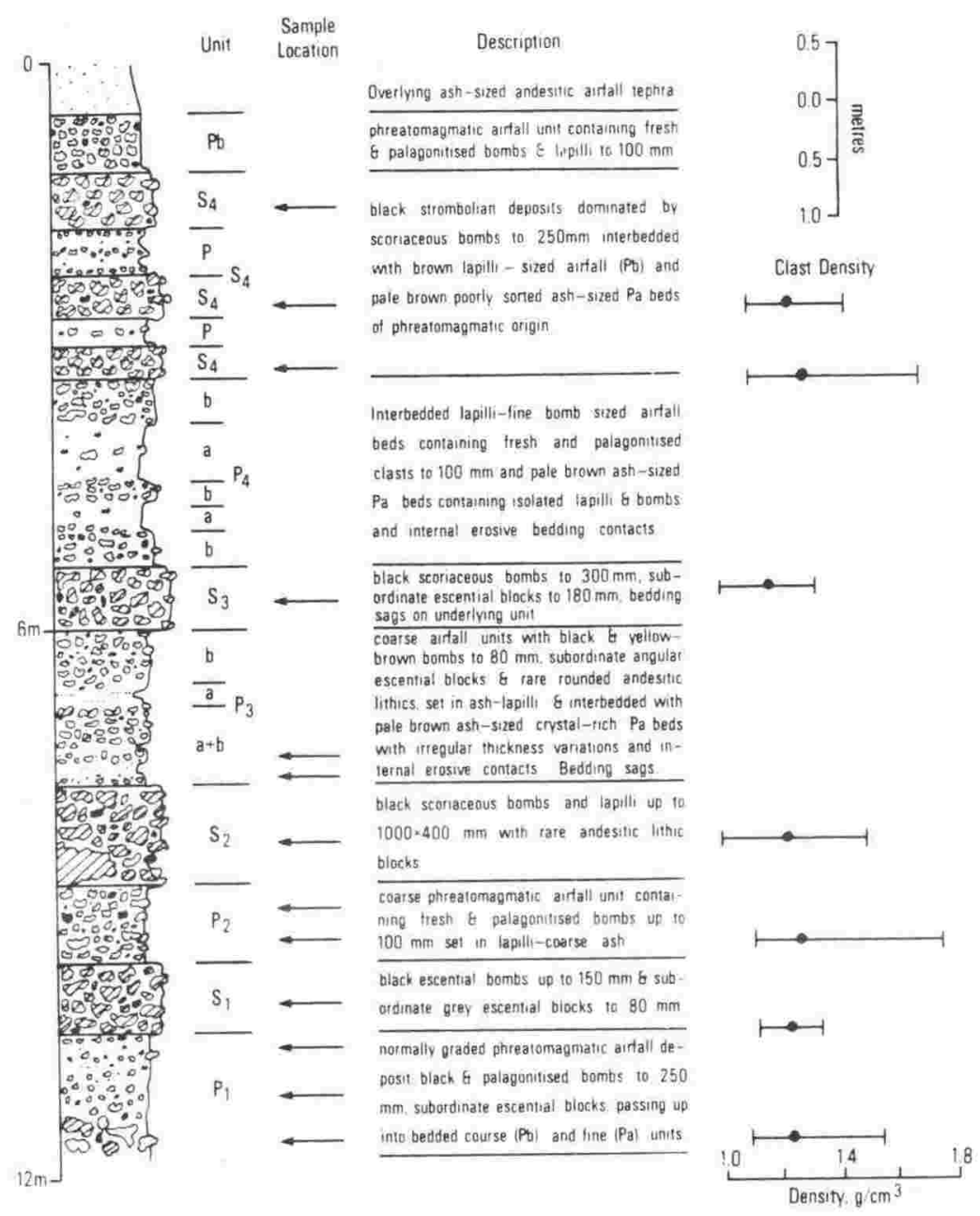

Fig. 7. Representative stratigraphic column through the tuff ring at Locality 2. Fresh, glass bombs are cross-hatched, palagonitised bombs white and dense essential blocks are black. Variation of mean clast density $(\bullet)$ and the range of clast density $(-)$ with stratigraphic depth shown on right.

following components: vesicular essential bombs, dense essential blocks, accidental lithic clasts and crystals. Density measurements were made for each sample by cutting cuboids from 8-10 large clasts and measuring their masses and dimensions. Samples were collected from localities 1 and 2 but not the distal apron where weathering of clasts precluded sieving. Granulometric data on the samples are summarised in Table I.

\section{Scoria cone}

Grain size. The majority of samples collected from $\mathrm{S}$ beds are coarse ( $M d$ $>32 \mathrm{~mm})$, relatively well-sorted $\left(\sigma_{\phi}=1.5-2.0\right)$ deposits containing less than 
216

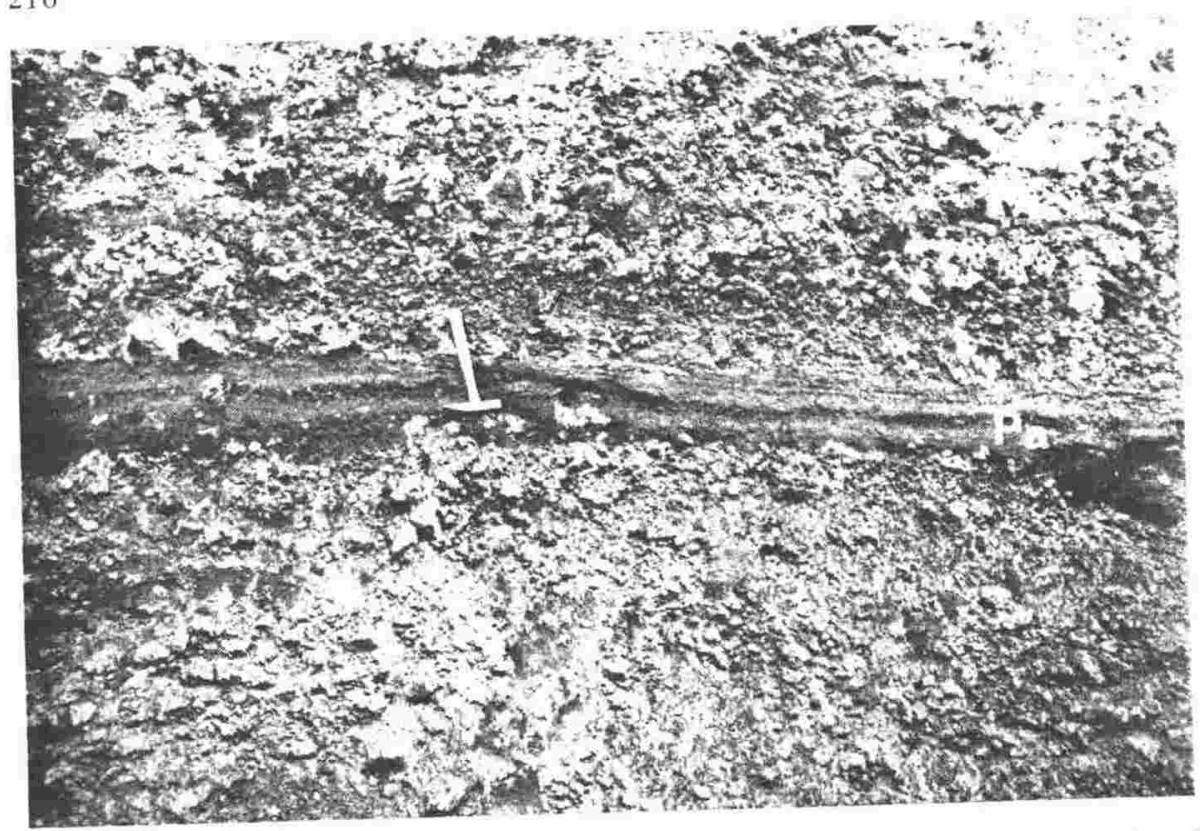

Fig. 8. Locality 2, Ohakune tuff ring. $\mathrm{Pb}$ bed in lower one third of frame and $\mathrm{Pa}$ bed at level of hammer, overlain by coarse-grained S2 bed. Note irregular thickness variations in $\mathrm{Pa}$ bed. Vent direction is away from the camera.

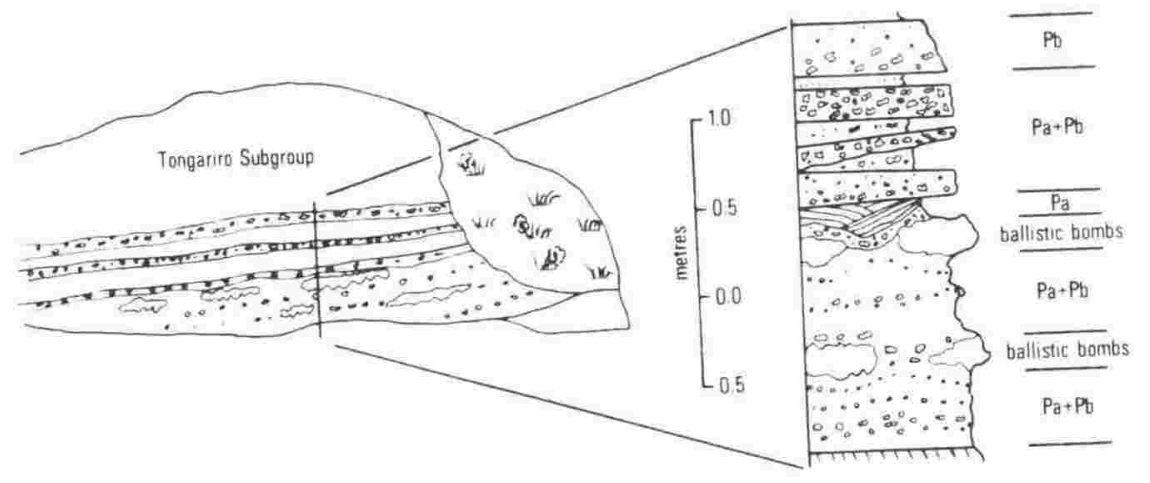

Fig. 9. Sketch of and stratigraphic column for section through distal apron at Locality 3 in Fig. 2. The Ohakune deposits are overlain by approximately $2 \mathrm{~m}$ of younger andesitic airfall ash erupted from the Tongariro volcanic centre.

$5 \%$ fine material and a high proportion (65-90\%) of scoriaceous bombs. The samples are comparable with, but rather coarser than, most of the strombolian samples (Fig. 10) of Walker and Croasdale (1972). The two samples from fine-grained beds in the S2 sequence are much less well-sorted, plotting in the surtseyian field.

The principal variation in proportion of clast types is between dense and vesicular essential clasts, as accessory lithics are never abundant and crystals 


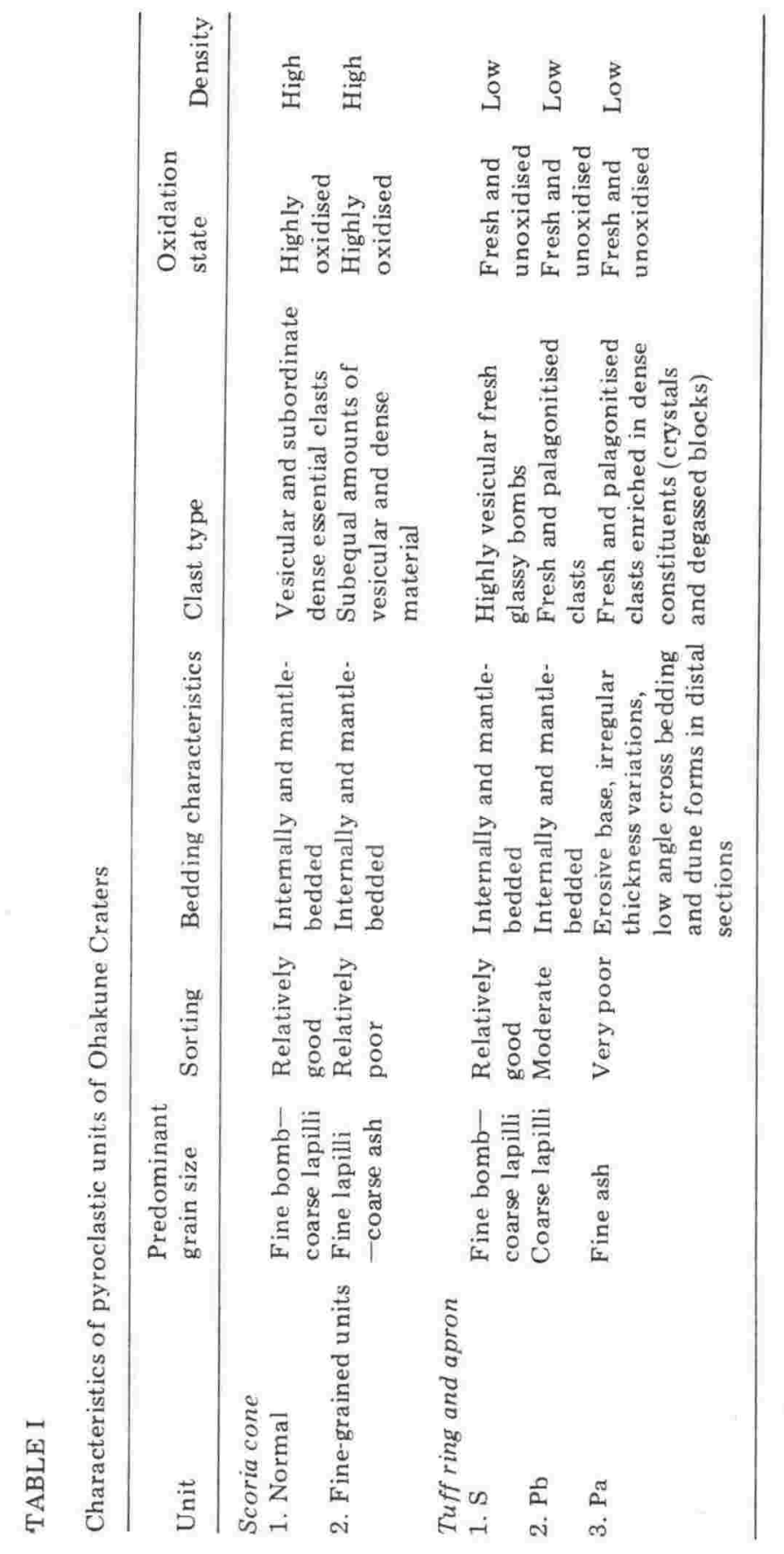


form only a small proportion of the sub- $2 \mathrm{~mm}$ size fractions. Three samples contain a high proportion of dense essential blocks (Fig. 4), the two finegrained samples mentioned previously and a sample collected at the level of the prominent parting and colour change in S2.

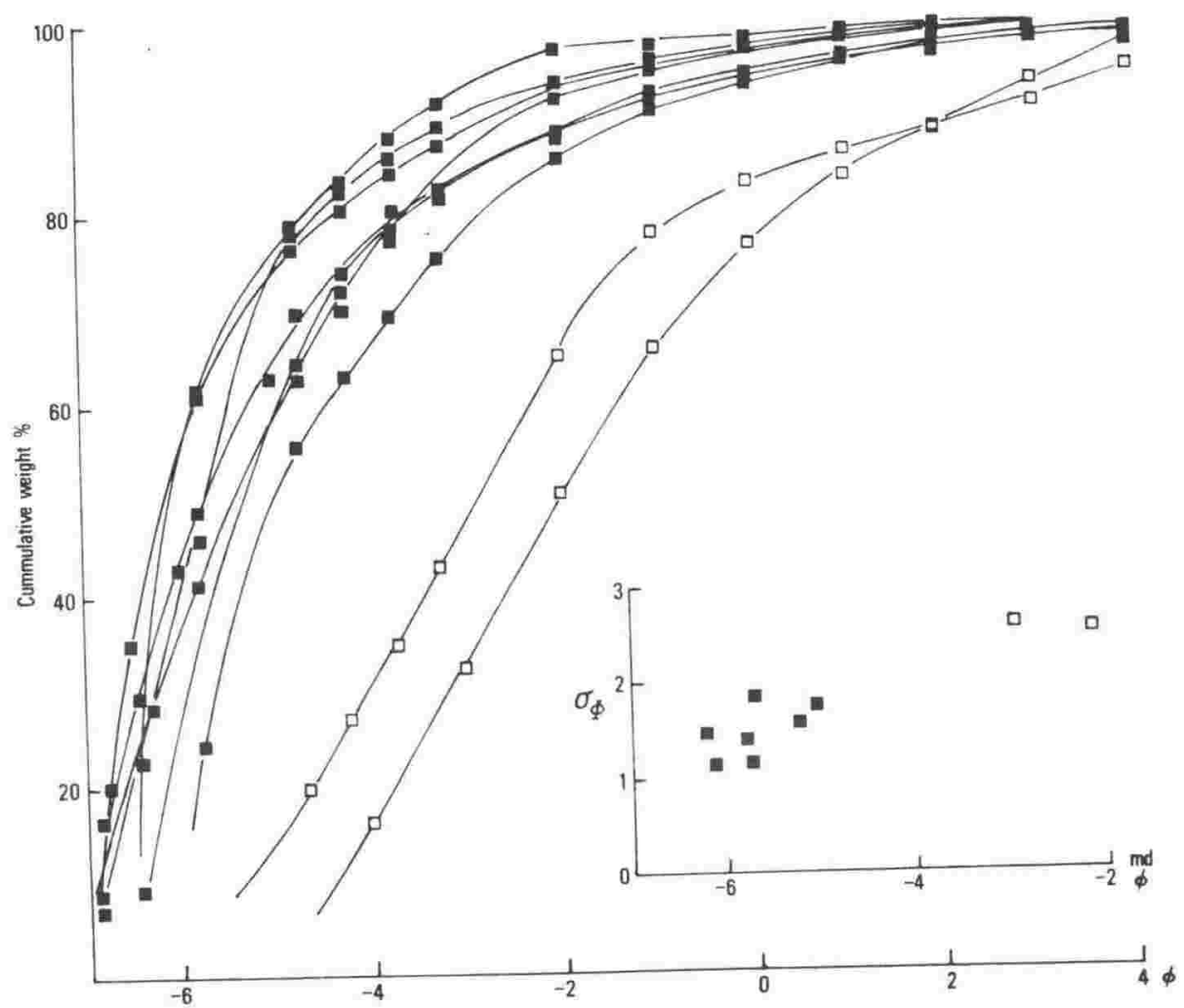

Fig. 10. Plot of grain-size distribution, by weight, for samples from the $\mathrm{S} 2$ interval of the Ohakune scoria cone. Closed symbols represent coarse-grained block and bomb beds, open symbols unusually fine-grained beds (see Fig. 3). Inset plot of median diameter versus Inman sorting coefficient.

Clast density. The calculated average densities and ranges of density for block and bomb populations in the $\mathrm{S}$ beds are shown in Fig. 4. Density averages for the two populations vary sympathetically through the sequence, and there is a clear separation between the block and bomb populations for all samples, except in one sample where one bomb with a dense core overlaps with the block population. Average densities of the block populations vary from 2.13 to 2.60 , the latter tending towards the value for samples from degassed, nonvesicular Ohakune lava flows or basaltic liquids (Macdonald, 1963; Carmichael et al., 1974). Average densities of the bomb populations vary from 1.39 to 1.59 . Density ranges are generally greater for bomb 


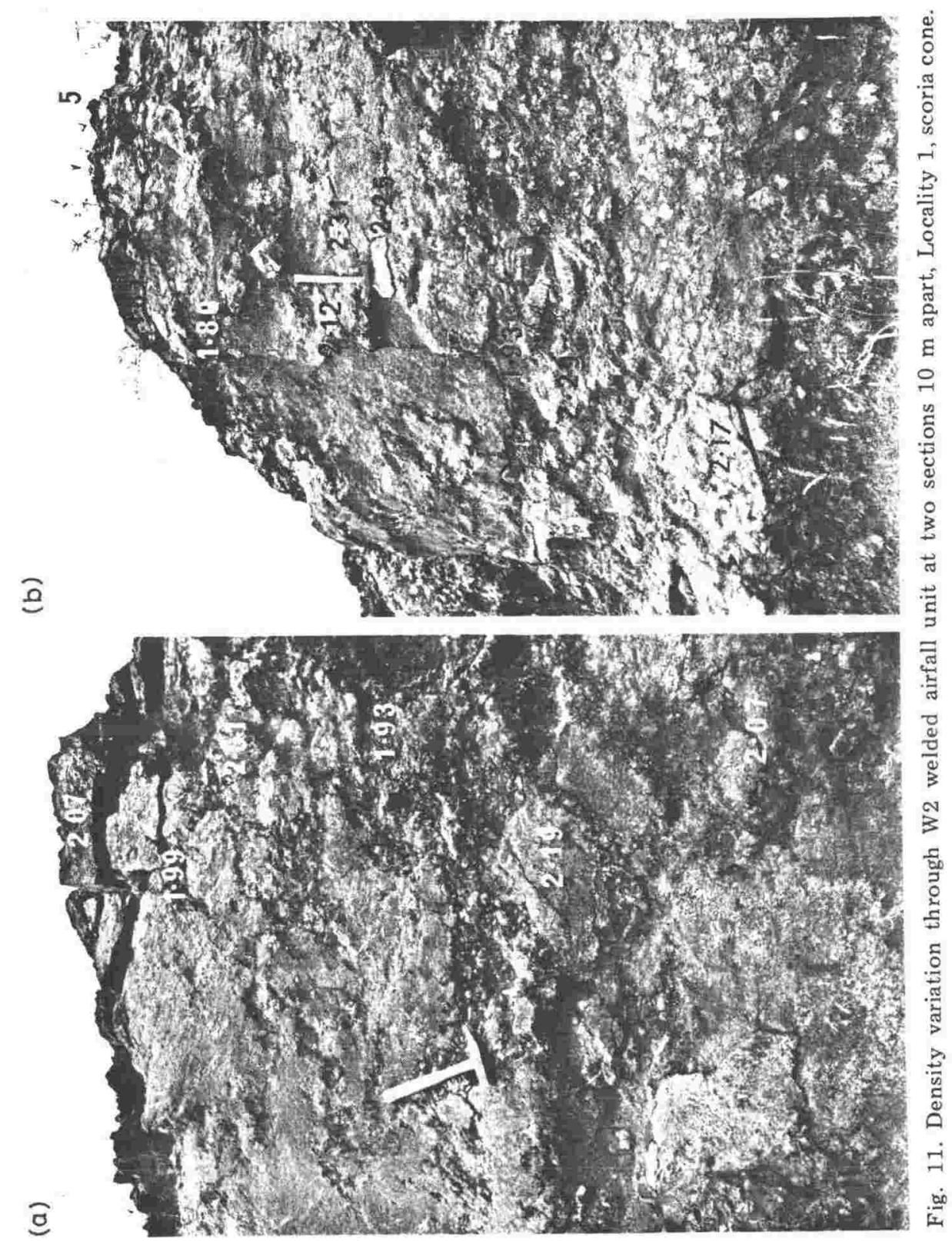


populations than for block populations, suggesting greater variability in the actively vesiculating material than in the degassed material disrupted by explosions.

Density of welded units. Difficulty in recognising clast boundaries precluded measurement of flattening ratios or determination of densities of individual clasts in the $\mathrm{W}$ beds. Bulk densities were determined on large $(100-200 \mathrm{~mm})$ cuboids for two sections through the thicker welded unit (Fig. 11). This figure shows the typical pattern of variation in welding and density through the units. The bulk of the deposit is densely welded, with no visible trace of clast boundaries and bulk densities of $2.1-2.3 \mathrm{~g} \mathrm{~cm}^{-3}$. Lenzoid zones within the deposit, either localised around large lithics or parallel to bedding are partly welded, show clear clast boundaries, and have densities of 1.7 to $1.9 \mathrm{~g} \mathrm{~cm}^{-3}$.

\section{Tuff ring}

Grain size. The $\mathrm{S}$ beds of the tuff ring are in general coarser and better sorted than the $\mathrm{Pb}$ beds ( $\mathrm{Fig} .12$ ). The $\mathrm{S}$ beds approximate to a straight line trend

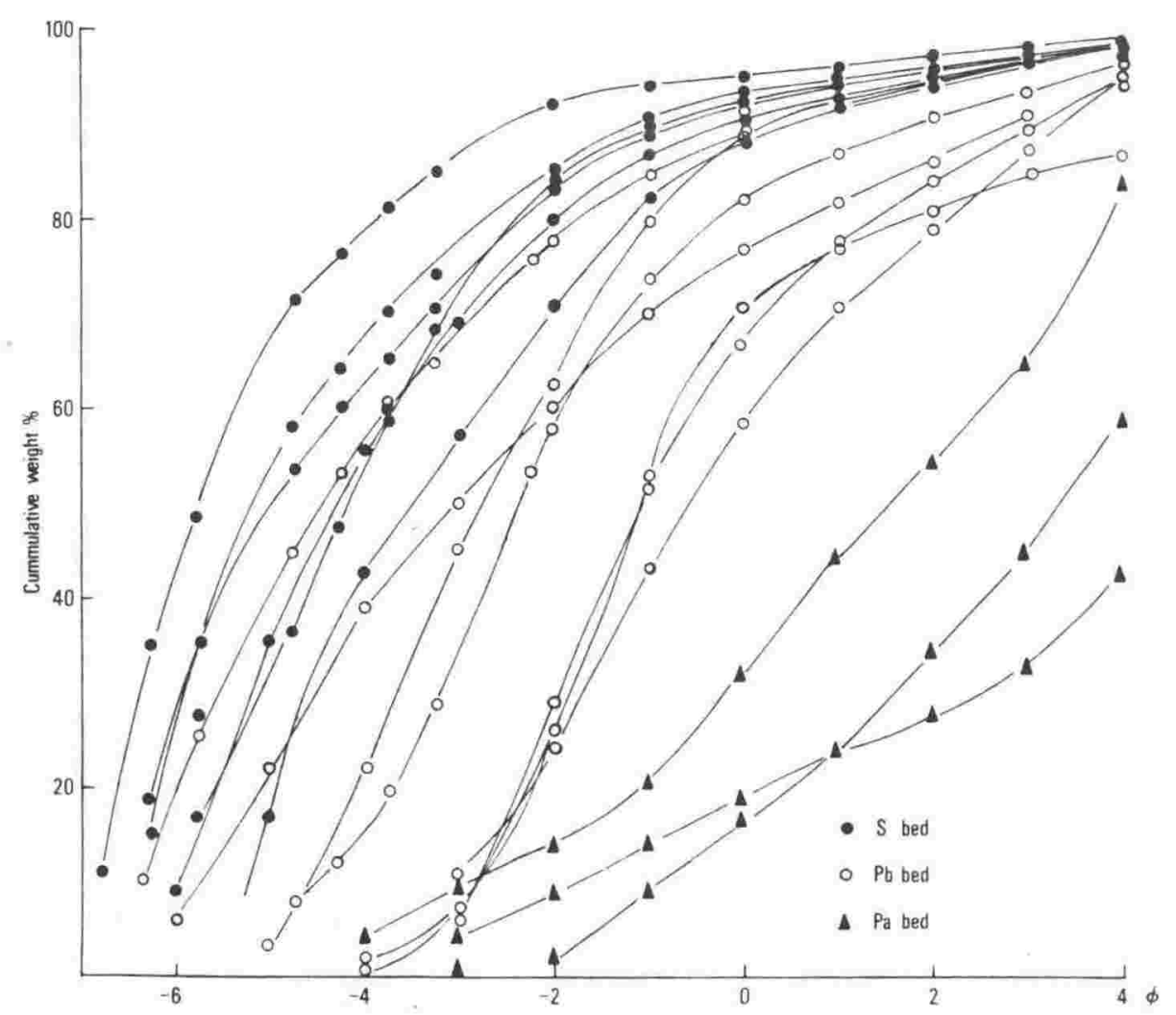

Fig. 12. Plot of grain-size distribution, by weight, for tuff ring samples. 
with positive gradient (Fig. 13), extending across the upper edge of the strombolian field on the $\sigma_{\phi} / M d$ diagram of Walker and Croasdale (1972). Three of the four $\mathrm{Pb}$ samples plot in the surtseyan field, with the fourth close to the field boundary. While all tuff ring samples contain an appreciably larger fine tail than the scoria cone deposits, this is generally more marked in $\mathrm{Pb}$ than $\mathrm{S}$ beds. Difficulties in disaggregating the indurated $\mathrm{Pa}$ beds prevented extensive sampling for grain-size analysis, but the 3 samples analysed are extremely poorly sorted and bimodal.

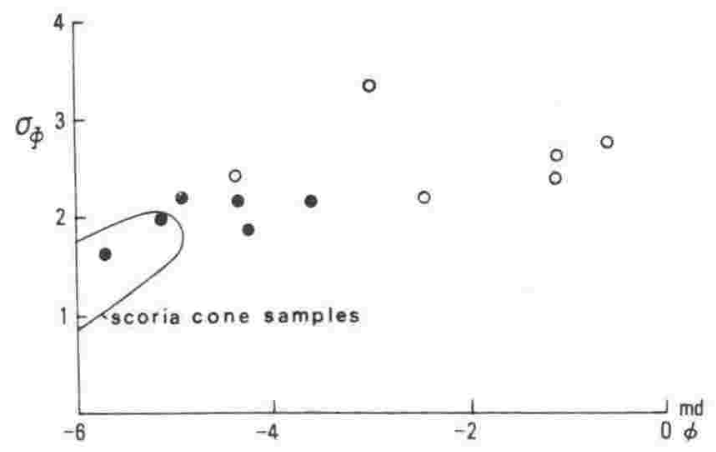

Fig. 13. Plot of median diameter versus Inman sorting coefficient for samples of airfall origin collected from tuff ring. Symbols as for Fig. 10. Field of strombolian samples from the scoria cone is circled.

When grain-size analyses for all the probable airfall units (i.e. $\mathrm{S}$ and $\mathrm{Pb}$ beds) are plotted on a $\sigma_{\phi} / M d$ diagram a near-linear trend of poorer sorting with decreasing grain size emerges. Normal $\mathrm{S}$ beds from the scoria cone are grouped at the coarse-grained, relatively well-sorted extremity and are separated from the poorly sorted $\mathrm{Pb}$ and fine scoria cone samples by the tuff ring $\mathrm{S}$ beds. There are major contrasts in the proportion of clast types between tuff ring and scoria cone samples. Tuff ring samples are dominated by highly vesicular bombs and contain few essential blocks. $\mathrm{S}$ beds generally contain $90-100 \%$ bombs and $\mathrm{Pb}$ beds $60-90 \%$.

Clast density. Densities of clasts in the tuff ring samples are appreciably lower than samples from the scoria cone. In any sample clast densities show a similar scatter about an average value, to the scoria cone but there is little or no variation in average density through the sequence (Fig. 7). Surprisingly, bombs in $\mathrm{S}$ and $\mathrm{Pb}$ samples show no significant contrast in density.

INTERPRETATION

\section{Model for scoria cone growth}

Activity during deposition of the Ohakune scoria cone alternated between effusive and explosive eruptions. The normal products of explosive vol- 
canism at Ohakune are relatively monotonous and very coarse grained, relatively well-sorted and only locally dispersed and hence of typically strombolian character. There were however, three types of departure from this pattern of behaviour to produce: (1) similarly coarse grained units unusually rich in degassed blocks; (2) finer-grained, less well-sorted blockrich beds; and ( 3 ) welded airfall units.

All clasts in the scoria cone deposits are dense and oxidised relative to the black, highly vesicular bombs of the strombolian beds in the tuff ring. However, with the exception of the oxidation state of iron, the clasts are chemically identical. This suggests that while magma rose freely and was discharged rapidly during the history of the tuff ring, scoria cone magma experienced a period of degassing prior to explosive eruption. The close chemical similarities suggest that the magma at depth remained constant in composition throughout construction of both tuff ring and scoria cone and it seems likely degassing during cone construction took place under near-surface conditions in the immediate vicinity of the vent. This is best accomplished by ponding in a small lava lake prior to eruption.

The degassed relatively dense nature of clasts and the low abundance of phreatomagmatic deposits, in the scoria cone relative to the tuff ring, may be explained by a single factor. This is the construction of some structure or barrier at the vent which both excluded water and permitted lava ponding. The tuff ring itself was probably this structure. Once this barrier existed, lava rose rapidly and ponded and eruptive activity was dominated by explosive eruptions powered by magmatic degassing, at or close to the lava:air surface. Lava ponding also supplies a mechanism to explain the two discrete types of essential clasts, vesicular bombs and dense blocks, found in the deposits. Gas segregation, during scoria cone growth, probably commenced some distance below the explosive foci and large bubbles grew (Fig. 14 ), removing additional gas from the magma as they rose (McGetchin et al., 1974; Blackburn et al., 1976). Bubble growth therefore scavenged and depleted gas in the lava pond (Sparks, 1978). Each explosion ejected the portion of surrounding magma disrupted by explosive expansion of the bubble at or near the surface, but left behind a gas-depleted region which contributed gas to the bubble but was not disrupted. The result was development of a zone or crust of degassed but hot lava above actively degassing material in the lava pond. Once this crust formed, any subsequent explosions had to disrupt both the actively degassing magma 'driving' the explosion and the overlying crust which played an essentially inert role in the explosion (Fig. 14).

In this model the vesicular volcanic bombs represent the actively degassing component of the magma and the dense, angular essential blocks the lava crust. Presumably the rate of magma supply or vent geometry varied such that at times unwelded block and bomb beds ( $\mathrm{S}$ beds) were deposited, whereas at other times the rate of accumulation was sufficiently high (Sparks and Wright, 1979) for welding to occur ( $W$ beds). The $W$ beds represent the 


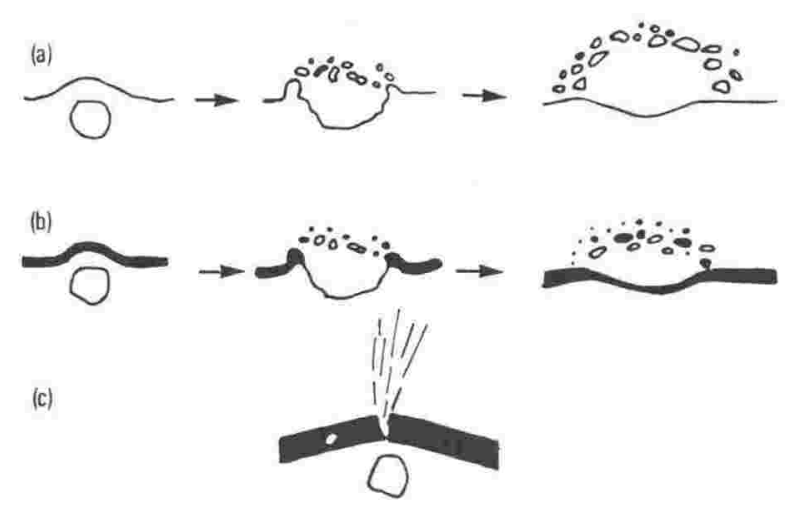

Fig. 14. Model for explosive expansion of gas bubbles during strombolian phases of construction of the Ohakune scoria cone modified after Wilson (1980). In (a) expansion of gas disrupts actively vesiculating magma-ejecting scoriaceous bombs. Such explosions deplete the remaining magma in gas. With time a degassed crust forms on the lava and explosions disrupt both this crust and the underlying vesiculating magma (b). Finally a critical crust thickness is reached which precludes explosive disruption by magmatic gas and only non-explosive degassing can oceur, through cracks and fractures in the crust.

products of periods of very rapid explosive fire fountaining, which presumably prevented formation of an extensive crust of degassed magma. Welding of these units was probably a combination of spattering and agglutination of individual bombs on landing, and deformation in response to loading by further ejecta, rather than purely spattering. This is shown by lenses of only partly welded bombs enclosing large dense blocks, in regions of decreased stress surrounding such blocks. Such zones would not be expected if spattering was the only welding mechanism. For any strombolian eruption to continue, the balance of rates of supply of fresh gas-rich magma and removal of magma must exceed the rate of depletion of gas in magma remaining in the vent. In some instances this is achieved by removal of degassed magma as lava flows, either immediately below the cone (e.g. Etna, 1974; Guest et al., 1974) or at considerably lower elevation (e.g. Etna, 1971; Booth and Walker, 1973). It is clear that at Ohakune the rate of depletion in gas exceeded the rate of magma removal from the lava pond. Thus a form of cyclic activity was established. With time, explosions depleted gas in the ponded magma, producing both an increase in clast density and an increase in the proportion of dense blocks to vesicular bombs. As the lava crust thickened, this deepened the foci of explosions and level of vesiculation and increased the minimum amount of work required to be done by gas expansion to disrupt a portion of the lava pond. A normal strombolian cycle of deposition therefore concluded when explosive gas release ceased or reached a level where ejecta no longer clears the crater rim.

An analogy to this exists in the 1976-1978 eruptions of White Island volcano (Houghton et al., 1979). Three cycles of strombolian eruptions alternating with phreatomagmatic eruptions were recorded. During strom- 
bolian phases, early eruptions ejected highly vesicular bombs produced by disruption of actively vesiculating magma, but the end of each strombolian phase was marked by a change to a clast population dominated by angular incandescent blocks and by a decreased frequency of explosions to as low as 1 per 15 to 100 minutes.

At Ohakune there appear to have been 2 distinct types of event which followed a strombolian cycle. If magma supply to the lava pond continued, the inert crust was rafted upwards until magma overtopped the scoria cone rim and a lava flow formed. Removal of degassed material with the flow presumably retriggered explosive activity and a return to strombolian eruption. The layer of blocky slabs in the centre of the section at locality 1 , probably formed when a lava flow overtopped another, lower, section of the cone.

The alternative sequence of events is where water appears to have gained temporary access to the vent. Although degassed, the crust was hot, molten and potentially capable of flashing water to steam. Such explosions would produce a clast population of fine grain size, rich in dense angular blocks, e.g. the fine-grained, poorly sorted units, within the $\mathrm{S}$ beds, which have the grain-size characteristics of phreatomagmatic deposits. A strong predominance of blocky, nonvesicular clasts also suggests that expansion of magmatic gas was not the only explosive mechanism in their generation. Such phreatomagmatic explosions presumably reduced the thickness of crust and hence promoted commencement of another strombolian cycle.

\section{Model for tuff ring formation}

Tuff rings are generally associated with phreatomagmatic eruptions and scoria cones with the strombolian style of eruption. The Ohakune tuff ring consists, however, of alternating strombolian and phreatomagmatic deposits. Such deposits are uncommon but not unknown e.g. Rothenberg volcano, East Eifel (Schmincke, 1977), Ukinrek Maars, Alaska (Kienle et al., 1980), Mt. Leura and Tower Hill, Victoria, Australia (J.V. Wright, pers. commun., 1982).

The $\mathrm{S}$ beds of Ohakune tuff ring are of magmatic airfall origin and are probably strombolian. The very vesicular nature of clasts, absence of angular degassed blocks and very consistent clast density through the sequence suggests that, during strombolian intervals, magma rose rapidly and continuously and was discharged quickly with little opportunity for near-surface degassing, cooling, oxidation, or reaction with wall material. Bombs in the $\mathrm{S}$ beds of the tuff ring are more expanded and less dense than scoria cone analogues. This probably means that fragmentation of the tuff ring magma took place at the peak of vesiculation, whereas fragmentation of scoria cone magma took place after the near-surface magma had already undergone substantial degassing. However the $\mathrm{S}$ beds of the tuff ring are less wellsorted and possess a distinct, finer than $1 \mathrm{~mm}$, tail suggesting that there was some limited involvement of water in the explosions. 
The $\mathrm{Pb}$ beds are clearly phreatomagmatic (abundance of palagonite, poor sorting and fine grain size relative to $\mathrm{S}$ beds) and also clearly airfall (presence of internal and mantle bedding, impact sags in underlying $\mathrm{Pa}$ beds). They contrast to many maar deposits (Lorenz, 1970, 1973; Schmincke, 1977; Kienle et al., 1980), and indeed to most basaltic deposits in the Taupo Volcanic Zone, in their very low abundance of accessory and accidental lithic clasts. This presumably indicates very shallow foci of explosion and vesiculation. The magma which rose along the fault line at Ohakune was gas rich and evidently reached near-surface levels before undergoing explosive vesiculation. It is therefore probable that explosive eruptions would have commenced without the presence of water, and clast morphology suggests vesiculation was generally already advanced when steam-generated explosions occurred. The role of water was therefore limited to modifying the form of the explosions rather than being their sole cause.

The $P$ intervals at Ohakune lack a number of typical features of many phreatomagmatic eruptions such as accretionary lapilli and vesiculated tuff (Lorenz, 1974; Schmincke, 1977). This probably reflects directly the abundance of water in the eruption column and surrounding atmosphere, and hence indirectly reflects the relative abundance of water and magma at the point of explosion. The model of tuff ring growth is one of very rapid and continuous flow of fluid magma towards the surface, with vesiculation commencing at very shallow levels. Conditions at the vent would have governed whether explosions during this relatively continuous flow of magma were driven by explosive expansion of vesicle gas bubbles ("dry" vent) or by steam explosions ("wet" vent) or by both. Removal of magma by either explosive mechanism always followed quickly on from arrival at the surface without extended ponding or non-explosive degassing.

It remains to invoke a mechanism for alternately permitting and denying access of water to the vent. Scoria cone growth is generally very rapid (Bullard, 1947; Self et al., 1974; Guest et al., 1974). Comparison with historical equivalents (Foshag and Gonzalez, 1956; Wood, 1980; White Island 1976-1978) suggests construction of the Ohakune deposit was probably achieved over a period of several weeks to several months. Hence discrete eruption intervals (S, P, etc.) were probably of the order of several days to several weeks. This level of frequency would be consistent with two possible explanations: (1) a direct correlation with precipitation, with phreatomagmatic eruptions following short duration, high intensity rainstorms; or (2) a "self-sustaining" process whereby the net discharge of heat through the adjacent country from the magma column periodically dried the near-vent area, permitting strombolian eruption.

The latter has the disadvantage of not supplying a mechanism to stop strombolian eruptions. The top of strombolian beds do not show marked enrichment in degassed essential blocks (implying crust formation) or accessory material (suggesting blocking of the vent by wall-collapse) and it therefore seems more likely that influence of sudden pulses of water abruptly ended strombolian periods. 
In explosive basaltic volcanism a wide spectrum exists, from volcanic explosions caused by reaction of magma with external water, through events where water is an influence, to eruptions where external water is not involved. The Ohakune deposits represent the middle ground where the role of water ranges from a minor to a controlling influence but where shallow vesiculation was probably always a factor in promoting the critical rapid transfer of heat. The Ohakune deposits are an excellent example of the range of products produced by explosive volcanism involving fluid, gas-rich basic magma vesiculating under very near-surface conditions. The late onset of vesiculation was presumably due to a very rapid rate of magma ascent.

Very near-vent processes governed the nature of explosions, and hence particle size and morphology, in the case of both scoria cone and tuff rings. The controlling factor during scoria cone formation was the influence and extent of lava ponding, degassing and crust formation. By contrast the tuff ring was constructed during rapid and free discharge of vesiculating magma and the determinant variable was the magma:water ratio.

\section{DISCUSSION}

\section{Criteria for recognising eruption type}

In many recent studies clast morphology reflects, or is taken to reflect, eruptive mechanism (Heiken, 1972; Walker and Croasdale, 1972; Gutman, 1976; Schmincke, 1977; Self et al., 1980). Strombolian explosions are con. sidered to produce clasts shaped by forces of surface tension, and phreatomagmatic explosions angular clasts bounded by fracture surfaces. The Ohakune study suggests particle morphology may, in some cases, be an equivocal and less reliable criterion than the earlier-established criteria of grain size, sorting and dispersal. Beds consisting entirely of expanded vesicular bombs are certainly the products of magmatic eruptions but dense blocky clasts may be phreatomagmatic or may reflect disruption of a degassed crust during magmatic explosions. Thus clast morphology reflects not necessarily the contrast between phreatomagmatic and magmatic explosions but whether the clast forms by expansion of an endogenous or an exogenous gas phase. The exogenous case includes not only generation of steam by heating of external water but also disruption of inert degassed magma by expanding magmatic gas generated by adjacent and generally underlying vesiculating magma.

\section{Factors governing explosive basaltic volcanism}

Explosive basaltic eruptions are small in terms of volume, discharge rate, dispersive power and violence. In addition most strombolian or phreato- 
magmatic eruptions are modelled as a sequence of innumerable small closely spaced explosions whereas plinian eruptions of more viscous magma approximate to a continuous 'steady state' gas blast. It is therefore not surprising that slight changes in a number of variables or small variations in very localised, near-vent processes have a much stronger influence on basaltic eruptions. Factors governing the form of basaltic volcanism include:

(1) rate of rise of magma,

(2) rate of rise and depth of formation of gas bubbles,

(3) depth of explosive expansion of bubbles,

(4) vent geometry,

(5) abundance of external water,

(6) wind velocity,

(7) rate of accumulation of ejecta.

Rate of magma rise has a major influence on eruption style. A very low rate may prevent phreatomagmatic eruption by excluding water from the vent by evaporation of groundwater by a thermal front preceding the magma (Schmincke, 1977), or by evaporation (Shepherd et al., 1979) or displacement of a crater lake (Gregg, 1960). Strombolian, or phreatomagmatic, eruption may occur if magma ascends more rapidly. The formation of welded or nonwelded layers during strombolian eruption is principally a function of rate of accumulation of ejecta. However, if other factors such as eruption column height, wind velocity, and violence remain effectively constant, accumulation rate probably varies directly with rate of magma rise. At velocities above a critical level strombolian activity is superseded by steady-state fire fountaining and production of lava flows (Wilson and Head, 1981).

Episodes of explosive basaltic volcanism are typically short-lived (Wood, 1980 ) and end abruptly with retreat of magma from the vent. It is hard to sustain strombolian eruption once the rate of magma ascent has declined and fresh actively vesiculating magma is no longer reaching the surface. However, if water can reach the retreating lava column, phreatomagmatic explosions may accompany column retreat, modifying and enlarging the subsurface conduit. Deposits of such waning events are often lithic-rich because the explosive foci are progressively deeper than earlier strombolian and phreatomagmatic events and because material from wall-rock collapse is re-ejected during the late stage events. It is not surprising therefore that late-stage aprons of lithic ejecta are associated with many events, e.g. Tarawera, 1886 (Cole, 1970), Ukinrek 1977 (Self et al., 1980), White Island March 1977 (Houghton et al., 1979). The deep portion of the crater within Ohakune scoria cone and the thin mantling of phreatomagmatic material at locality 1 presumably formed in this fashion. Fluctuations in magma column height is also common while eruption continues (Jagger and Finch, 1924; Kienle et al., 1980), with a major influence on eruptive style.

Rate of magma rise combines with the second and third factors to deter- 
mine the depth of magmatic explosions and hence to some extent the proportions of essential and accessory ejecta. They probably also strongly influence the depth of phreatomagmatic explosions in cases where abundant external water is present, because vesiculation is commonly held to be one means of increasing contact area between magma and water and hence rate of heat transfer (Colgate and Sigurgeirsson, 1973; Schmincke, 1977; Self and Sparks, 1978). Where vesiculation and explosions occur at very shallow depths a tuff ring rich in essential ejecta results. Higher proportions of accessory material and maar-like collapse structures are thought to be the products of deeper-seated explosion (Schmincke, 1977).

Vent geometry influences eruptive style in a number of ways. The overall configuration of vent location seems important in determining style and duration of eruptions. For extended strombolian eruptions as recorded at Northeast Crater Etna (McGetchin et al., 1974) it seems essential that degassed magma is removed as lava flows from either adjacent or flank vents. Eruptions from a single simple vent as at Ohakune are invariably of short duration and magnitude.

Changes in vent geometry during an eruption may also alter the eruptive style. The association of maars/tuff rings with valleys and depressions and adjacent strombolian cones with higher ground is well known (Heiken, 1971; Lorenz, 1975; Schmincke, 1977), but even ephemeral accumulation of ejecta about a vent may act to exclude water from the vent and change the course of an eruption. The pattern of discrete phreatomagmatic explosions during the early growth of Surtsey was altered several times by temporary formation of a tephra barrier prior to the final exclusion of seawater (Thorarinsson et al., 1964) and the onset of continuous strombolian eruption. A similar pattern seems to have occurred during construction of the Ohakune tuff ring. Construction of a ring or cone during eruption may also promote ponding of magma, permitting extensive degassing and cooling of the lava during the prolonged residence time at the vent. Such a process must inevitably alter the pattern of explosive activity. While blocky ejecta derived from degassed lava crust are not commonly described from basaltic scoria cones, they are probably misinterpreted as accessory material in instances where the magma petrography is not distinctly different from earlier phases.

Another possible change to vent geometry involves failure or removal of part of a newly constructed tuff ring or cone, either inwards partly blocking the vent and increasing the proportion of lithic ejecta (Booth and Walker, 1973 ), or outwards either permitting or in response to rafting by lava flows.

The effects of wind speed and direction, in governing the distribution of the products of explosive volcanism, if not their nature, are well documented.

The effects of the relative abundance of external water during basaltic volcanism are best considered through the water:magma ratio which reflects both rate of magma rise and availability of water. Several authors have sug- 
Sheridan and Wohletz, 1981). Deposits of water-rich systems show the typical features expected from phreatomagmatic explosions, pronounced bedding sags below ballistic clasts, adhesion of wet tephra on steeply inclined surfaces, extreme soft sediment deformation, accretionary lapilli and vesiculated tuffs. However, in the same way that magmatic gas may play a crucial role in such eruptions, by promoting rapid heat transfer, external water may play an important part in eruptions which show few signs of phreatomagmatic influence (Schmincke, 1977; Sheridan et al., 1981). External water probably played two important roles during essentially magmatic eruptions at Ohakune. Firstly, contact of the actively vesiculating magma with some external water during strombolian phases of tuff ring construction is the probable cause of more efficient magmatic disruption and hence fine grain size and poorer sorting relative to analogous deposits of the scoria cone. Secondly, steam explosions disrupting the degassed crust of the lava pond during scoria cone growth, to produce the fine grained block-rich beds, acted to promote strombolian eruption by reducing pressure on the underlying gas-rich magma.

The Ohakune deposits demonstrate only some of the complex controls on processes of explosive basaltic volcanism. Despite the widespread occurrence of cones and tuff rings and some excellent accounts of gross cone structure and analogous historical eruptions, there are few detailed bed-by-bed analyses of very proximal basaltic tephras. Coarse grain size and apparent monotony of such deposits are deterrents to detailed grain size analysis and study of clast morphology. However, it is these techniques which will offer further insights into explosive basaltic volcanism.

\section{ACKNOWLEDGEMENTS}

This work was carried out while one of the authors was the recipient of a New Zealand National Parks Board Scholarship. We would like to thank C.J.N. Wilson and J.V. Wright for invaluable discussions in the field, I.A. Nairn, H.-U. Schmincke, G.P.L. Walker, and J.V. Wright for their constructive criticism of the manuscript, and in particular S. Self and A.R. McBirney who reviewed the final manuscript.

\section{REFERENCES}

Blackburn, E.A., Wilson, L. and Sparks, R.S.J., 1976. Mechanisms and dynamics of strombolian activity. J. Geol. Soc. London, 132: 429-440.

Booth, B. and Walker, G.P.L., 1973. Ash deposits from the new explosion crater, Etna, 1971. Philos. Trans. R. Soc. London, 274: 147-151.

Bullard, F.M., 1947. Studies on Paricutin Volcano, Mexico, Bull. Geol. Soc. Am., 58: $433-450$,

CarmichaeI, I.S.E., Turner, F.J, and Verhoogen, J., 1974. Igneous Petrology. McGrawHill, New York, N.Y., 739 pp. 
Cole, J.C., 1970. Structure and eruptive history of Tarawera Volcanic Complex. N. Z. J. Geol. Geophys., 13: 879-902.

Colgate, S.A. and Sigurgeirsson, T., 1973. Dynamic mixing of magma and water. Nature, 244: 552-555.

Foshag, W.R. and Gonzalez, R.J., 1956. Birth and development of Paricutin Volcano. U.S. Geol. Surv. Bull., 965-D: 355-489.

Gregg, D.R., 1960. The geology of Tongariro subdivision. N.Z. Geol. Surv. Bull, 40.

Grindley, G.W., 1967. Geological Map of New Zealand, 1:250000 Sheet 8, Taupo. D.S.I.R. Wellington, New Zealand.

Guest, J.E., Huntingdon, A.T., Wadge, G., Brander, J.L., Booth, B., Carter, S. and Duncan, A., 1974. The recent eruption of Mount Etna. Nature, 250: 385-387.

Gutman, J.T., 1976. Geology of Crater Elegante, Sonora, Mexico. Geol. Soc. Am. Bull. 87: $1718-1729$.

Hay, R.F., 1967. Geological Map of New Zealand, 1:250 000. Sheet 7, Taranaki, D.S.I.R., Wellington, New Zealand.

Heiken, G., 1971. Tuff rings; examples from the Fort Rock-Christmas Lake Valley Basin, South-central Oregon. J. Geophys. Res., 76: 5615-5626.

Heiken, G., 1972. Morphology and petrography of volcanic ashes. Geol. Soc. Am. Bull., 83: 1961-1988.

Houghton, B.F., Nairn, I.A. and Lloyd, E.F., 1979. Eruption of White Island Volcano in 1977. Bull. Volcanic Eruptions, 17: 17-19.

Houghton, B.F., Clark, R.H. and Cole, J.W., 1981. Eruption of White Island Volcano in 1979. Bull. Volcanic Eruptions, 19: 13-14.

Jagger, T.A. and Finch, R.H., 1924. The explosive eruption of Kilauea in Hawaii, 1924. Am. J. Sci., 8: 353-374.

Kienle, J., Kyle, P.R., Self, S., Motyka, R.J. and Lorenz, V., 1980. Ukinrek Maars, Alaska. 1. April 1977 eruption sequence, petrology and tectonic setting. J. Volcanol. Geotherm. Res., 7: 11-37.

Lorenz, V., 1970. Some aspects of the eruption mechanism of the Big Hole maar, central Oregon. Geol. Soc. Am. Bull, 81: 1823-1830.

Lorenz, V., 1973. On the formation of maars. Bull. Volcanol., 37: 183-204.

Lorenz, V., 1974. Vesiculated tuffs and associated features. Sedimentology, 21: 273291.

Lorenz, V., 1975. Formation of phreatomagmatic maar-diatreme volcanoes and its relevance to kimberlite diatremes. Phys. Chem. Earth, 9: 17-27.

Macdonald, G.A., 1963. Volcanoes. Prentice-Hall, Englewood Cliffs, N.J. 510 pp.

McGetchin, T.R., Settle, M. and Chouet, B.H., 1974. Cinder cone growth modelled after Northeast crater, Mt. Etna, Sicily. J. Geophys. Res., 77: 3257-3272.

Moore, J.G., 1967. Base Surge in recent volcanic eruptions. Bull. Volcanol., 30: 337-363.

Moore, J.G., Nakamura, K. and Alcaraz, A., 1966. The 1965 eruption of Taal Volcano. Science, 151: 955-960.

Schmincke, H.-U., 1977. Phreatomagmatische Phasen in quartären Vulkanen der Osteifel. Geol. Jahrb., A, 39:3-45.

Self, S. and Sparks, R.S.J., 1978. Characteristics of widespread pyroclastic deposits formed by the interaction of silicic magma and water. Bull. Volcanol., 41: 196-212.

Self, S., Kienle, J, and Huot, J-P., 1980. Ukinrek Maars, Alaska II. Deposits and formation of the 1977 craters. J. Volcanol. Geotherm. Res., 7: 39-65.

Self, S., Sparks, R.S.J., Booth, B. and Walker, G.P.L., 1974. The 1973 Heimaey Strombolian scoria deposit, Iceland. Geol. Mag., 111: 534-548.

Shepherd, J.B., Aspinall, W.P., Rowley, K.C., Pereiru, J., Sigurdsson, H., Fiske, R.S. and Tomblin, J.F., 1979. The eruption of Soufriere volcano St. Vincent April-June 1979. Nature, 282: 24-28,

Sheridan, M.F., Barberi, F., Rosi, M. and Santacroce, R., 1981. A model for Plinian eruptions of Vesuvius. Nature, 289: 282. 
Sheridan, M.F. and Wohletz, K.H., 1981. Hydrovolcanic explosions: the systematics of water pyroclast equilibration. Science, $212: 1387-1389$.

Sparks, R.S.J., 1978. The dynamics of bubble formation and growth in magma: a review and analysis. J. Volcanol. Geotherm. Res., 3: 1-37.

Sparks, R.S.J. and Wright, J.V., 1979. Welded airfall tuffs. Geol. Soc. Am., Spec. Pap., 180: 155-166.

Thorarinsson, S., Einarsson, T., Sigvaldason, G. and Elisson, G., 1964. The submarine eruption off the Vestmann Islands, 1963-64. Bull. Volcanol., 27: 434-445.

Walker, G.P.L. and Croasdale, R., 1972. Characteristics of some basaltic pyroclastics. Bull. Volcanol., 35: 303-317.

Waters, A.C. and Fisher, R.V., 1971. Base surges and their deposits: Capelinhos and Taal Volcanoes. J. Geophys. Res., 76: 5596-5614.

Wilson, L., 1980. Relationships between pressure, volatile content and ejecta velocity in three types of volcanic explosion. J. Volcanol. Geotherm. Res., 8: 297-313.

Wilson, L. and Head, J.W., 1981. Ascent and eruption of basaltic magma on the earth and moon. J. Geophys. Res., 86: 2971-3000.

Wood, C.A., 1980. Morphometric evolution of cinder cones. J. Volcanol. Geotherm. Res., $7: 38 T-413$. 
Eruptions at Ruapehu probably commenced about 250,000 years ago from a vent near present-day upper Pinnacle Ridge (Fig. 90A). It is not known if Ruapehu was a multiple volcano at this time; present exposures indicate a central vent region with dykes radiating from it to the NNW. These early eruptions were petrographically uniform, and comprise the Te Herenga Formation. Early eruptions constructed a steep cone of tuff breccias and subordinate lava flows. The tuff breccias were probably originated by upper slope failure associated with shallow intrusion and deformation of the host cone. Hydrothermal alteration attended intrusion of microdiorite plugs in the central facies. Lava flows and autoclastic breccias were then emplaced onto the fragmental cone, and were probably fed by late-stage dykes.

A period of erosion then followed (Fig. 90B), involving glaciation(s) over unknown time interval(s). Degradation of the Te Herenga cone cannot confidently be attributed to any single glacial episode, and it was probably glaciated during several periods of ice advance.

The eroded morphology of Hauhungatahi suggests that this centre was active concurrently or prior to the earliest eruptions of Ruapehu. Hauhungatahi consists of basal pyroclastics with a capping of lava flows, and rests on Tertiary marine sediments.

Wahianoa Formation was apparently erupted from a central vent to the NW of Mitre Peak (Fig. 90C). The central facies is characterized by hydrothermal alteration, intrusion of several dykes, and the possible presence of intrusive plugs. A radially-dipping sequence of alternating lava flows, tuff breccias, and subordinate airfall and fluvial deposits comprise the proximal facies. The tuff breccias were emplaced as autoclastic breccias and secondary mass flows. Several tuff 
breccias have a clast component which was deposited at relatively high temperatures, implying generation of these deposits attendant with magmatic eruptions. Clasts and lava flows exhibit moderate hand specimen petrographic variation.

Degradation of the Wahianoa edifice (Fig. 90D) is indicated by erosion of the upper slopes (unconformity at Girdlestone Peak) and attendant deposition of secondary mass flows at lower elevations (RS 8, Fig. 30).

Mangawhero Formation was unconformably emplaced onto the eroded Wahianoa cone (Fig. 90E). The vast majority of the deposits are lava flows and associated autobreccias, with subordinate fluvial laharic material occurring as local valleyfilling deposits. Subordinate airfall material occurs in exposures of the summit region. Ruapehu was a multiple volcano during Mangawhero time. Eruptions were fed by dykes exposed at Girdlestone Peak and at one locality on north Ruapehu. Summit eruptions issued from several vents between Tahurangi and the northern summit Plateau. In the southern summit region, sufficient time passed between eruptive episodes for the establishment of small alpine glaciers. Eruptions may have spanned a period from about 50,000 to 15,000 years ago, but only two dates from the middle of the formation constrain this estimate. The base of the formation is marked by the appearance of conspicuously olivine-bearing lavas, including one basalt flow. Petrographic variation is great, ranging from olivine basalt to dacites.

During emplacement of later Mangawhero deposits $(20,000$ to 25,000 years ago), parasitic eruptions occurred at several isolated, monogenetic vents. The Ohakune and Pukeonake vents produced minor volumes of ol-bearing lava flows and airfall pyroclastics.

Whakapapa Formation erupted from four flank and two summit vents during post-glacial time (ca. 15,000 years ago to the present (Fig. 90F). Volcanism in the northestern summit 


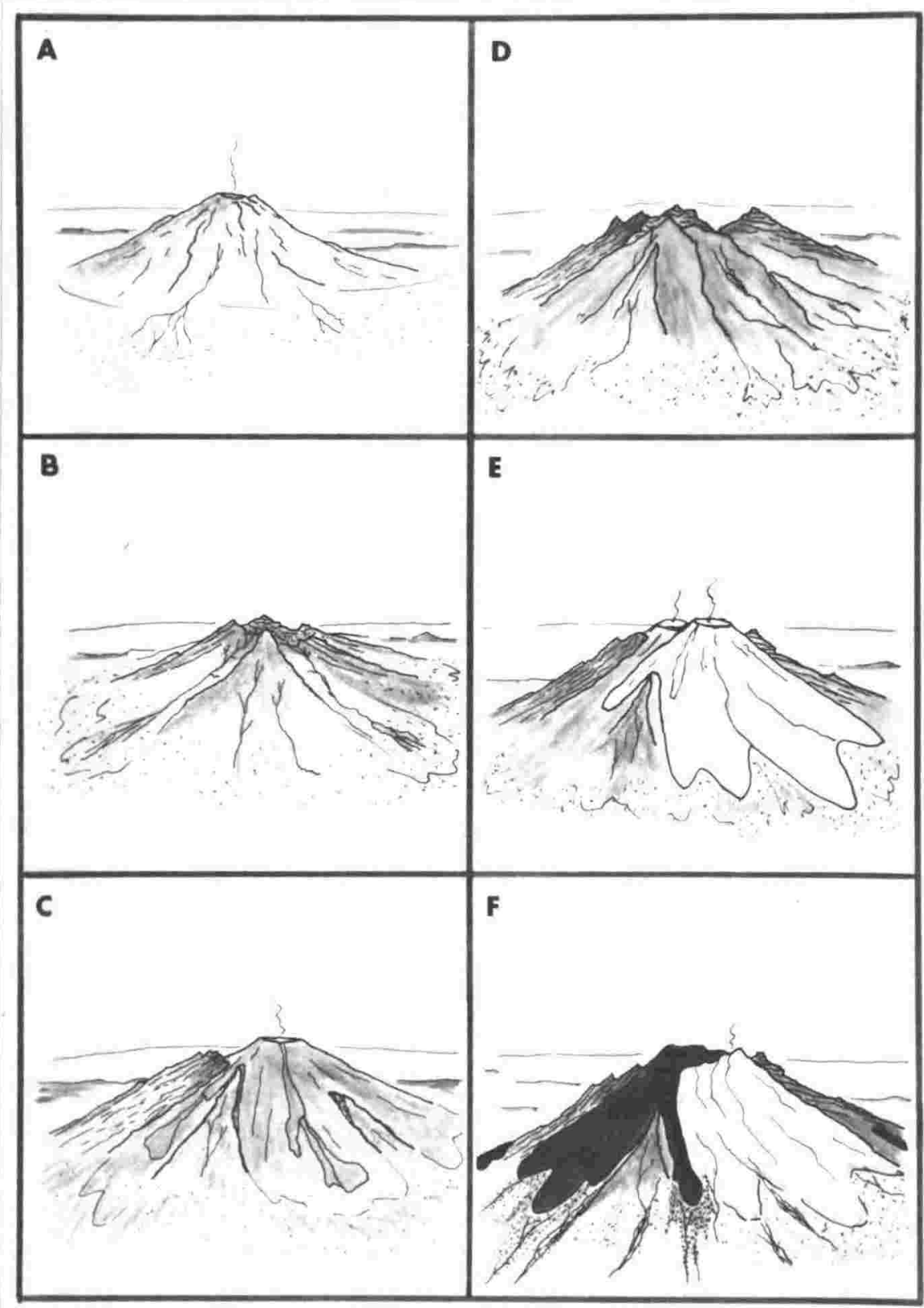

FIG. 90. Schematic drawings of Ruapehu history, viewed from the west.

A: Construction of Te Herenga cone.

B: Erosion of Te Herenga cone. Orange colours represent the hydrothermally altered interior.

c: Construction of Wahianoa cone, from sumit vent(s) to the southeast.

D: Erosion of Te Herenga and Wahianoa cones.

$\mathrm{E}$ : Construction of Mangawhero cone, largely from summit vents.

F: Erosion of Mangawhero cone and eruption of Whakapapa Fm from flank and summit vents.

See Fig. 6 for absolute chronology and inferred glacial stages. 
region may have been continuous across the Mangawhero/ Whakapapa boundary. The bulk of the deposits are andesite lava flows and autoclastic breccias, with subordinate airfall pyroclastics present at the vent regions. Welded airfall tuff (Pinnacle Ridge Member) and small pyroclastic flows (Rangataua and Iwikau Members) are also represented. Activity from the Crater Lake vent continues to the present day.

The present study indicates that Ruapehu was a multiple-vent volcano during at least ca. the past 30,000 years. Alpine glaciers have modified the vent morphologies of Mangawhero and Whakapapa Formations in the summit region. No evidence for major explosive or collapse events has been found anywhere on the mountain. The present writer therefore concludes that the broad, irregular summit results from multiple-vent eruptions and glacial erosion. In this writer's opinion, the only summit areas which exhibit vestiges of original vent structure and morphology are the Crater Lake, the larger depression encircling Crater Lake, and the summit Plateau. All other bowl-like depressions are considered to be cirques. 


\section{GEOLOGY OF WAIMARINO BASALT (new formation name)}

The following manuscript has been submitted for publication, and is currently awaiting editorial review:

Hackett, W.R., in press. The Waimarino Basalt: A new basalt locality from the Taupo Volcanic Zone, New Zealand.

(submitted to New Zealand Journal of Geology and Geophysics for publication as a note) 
THE WAIMARINO BASALT: A NEW BASALT IOCALITY FROM THE TAUPO VOLCANIC ZONE, NEW ZEALAND

William R. Hackett Department of Geology Victoria University Private Bag Wellington

$\underline{\text { ABSTRACT }}$

Waimarino Basalt (new formation name) is a previously unreported basalt occurrence in the Taupo Volcanic Zone (TVZ). Field relations, major element, and petrographic data show that the Waimarino Basalt is a primitive basalt magma type which erupted to the southeast of Lake Taupo about 15,000 years ago. In contrast to previously reported basalts from the TVZ, the petrography and chemistry are consistent with direct derivation from the mantle, involving little or no modification by differentiation processes. The age and composition of Waimarino Basalt suggest that it is a manifestation of Holocene volcanism in the Taupo Arc.

\section{KEYWORDS}

Waimarino Basalt; new formation name; primitive basalt; Holocene volcanism; modal mineralogy; major element data.

1Present address: William R. Hackett, Department of Geology, Idaho State University, Box 8072, Pocatello, Idaho, U.S.A., 83209 


\section{INTRODUCTION}

The Waimarino Basalt (new formation name), like most basalt exposures in the TVZ, comprises only a few outcrops. The type locality, at grid reference $\mathrm{N} 112414969$, is one of several local exposures within a radius of $0.5 \mathrm{~km}$ (Fig. 1). The basalt and overlying andesitic tephra are best exposed along the eastern side of the Waimarino River. The western side largely consists of Taupo Pumice Alluvium, but additional exposures of Waimarino Basalt colluvium occur in cuttings along Motiti Road.

The river has cut a deep and narrow gorge through the underlying Rangitaiki Ignimbrite, exposing at least $6 \mathrm{~m}$ of this unit at the base of the section (Fig. 2). The ignimbrite is unwelded, of medium gray colour, and holds conspicuous phenocrysts of quartz, plagioclase, and weathered ferromagnesian minerals. The contact with the overlying basalt is not exposed, but can be inferred within a metre of section. At all nearby exposures where the basalt is absent, andesitic tephra unconformably overlie the Rangitaiki Ignimbrite, and at the type section the andesitic tephra appear to conformably overlie the basalt. A non-conformable relation between the basalt and the Rangitaiki Ignimbrite is therefore inferred.

Approximately $10 \mathrm{~m}$ of basalt breccia occur above the ignimbrite, $5 \mathrm{~m}$ of which are well exposed in a road cutting. The breccia is strictly monolithologic, but clast types are gradational from dense, largely unoxidized angular lava 
fragments up to $2 \mathrm{~m}$, to variably oxidized, microvesicular, subangular to subrounded scoriaceous fragments of decimetre to centimetre size. The centimetre-sized microvesicular clasts are usually rounded, suggesting attrition. Dense, tabular clasts are present, similar to those produced by viscous shear at the bases of lava flows. No clasts with bomb-like morphologies are present. The deposit is very poorly sorted, unwelded, and clast-supported or nearly so. It is interpreted as an autoclastic breccia, formed by the fragmentation of flowing lava.

At the Waimarino River road cutting, modern humic soil is developed directly on the basalt breccia, but farther north along the same cutting, $2.5 \mathrm{~m}$ of bedded, yellow-brown, weathered andesitic tephra are exposed. These have a $0.5 \mathrm{~m}$ chocolate-coloured paleosol developed at the top, and represent distal equivalents of the Tongariro Subgroup (Topping, 1973). Taupo Pumice Alluvium occurs above the andesitic tephra.

\section{AGE OF THE WAIMARINO BASAIT}

The age of the basalt is certainly constrained between that of the underlying Rangitaiki Ignimbrite (ca. $300 \mathrm{Ka}$ ) and the overlying Taupo Pumice deposits (ca $1.8 \mathrm{Ka}$ ). Oruanui Breccia (19.8 Ka) is absent at the type locality, but overlies the Rangitaiki Ignimbrite at nearby exposures to the northwest (P. Froggatt, pers. comm., 1982). This rhyolite breccia was deposited throughout the region, but has subsequently been removed by erosion - probably the same period of erosion that 
planed the top of the Rangitaiki Ignimbrite. It is unlikely that the basalt breccia would have remained on the landscape after this extensive period of erosion, and it is highly probable that the basalt is younger than $19.8 \mathrm{Ka}$.

The base of the overlying Tongariro Subgroup has been dated at $13.8 \mathrm{Ka}$ (NZ 1559, Topping 1973). The thickness of these tephra near the type locality suggests a complete or nearly complete section of the Subgroup. The Waimarino Basalt therefore has a probable age between $19.8 \mathrm{Ka}$ (Oruanui Breccia) and $13.8 \mathrm{Ka}$ (base of the Tongariro Subgroup).

\section{PETROGRAPHY}

In hand specimen, the rock comprises conspicuous, light green, 2-3 mm phenocrysts of olivine and clinopyroxene, set in a dark gray aphyric matrix. Plagioclase is restricted to the groundmass.

The modal mineralogy and crystallization sequence are presented in Table 1. Euhedral to subhedral phenocrysts of forsteritic olivine and calcic clinopyoxene are set in a hyalopilitic matrix with calcic labradorite, orthopyroxene, titanomagnetite, rare subcalcic augite, and olivine (Fig. 3). Interstitial acid residuum is present, comprising dusty brown glass, plagioclase, and minor alkali feldspar. Magnesian olivine phenocrysts commonly contain microphenocrysts of translucent brown chrome spinel. Aggregates of olivine, 
clinopyroxene, brown glass, and chrome spinel form clusters up to $3 \mathrm{~mm}$ in diameter.

MAJOR ELEMENT COMPOSITION

A bulk rock major element analysis and normative mineralogy are presented in Table 2, along with an analysis of average high-alumina basalt from the MVZ (Cole, 1973). Additional bulk rock trace element and mineral data will be reported in a later publication.

\section{DISCUSSION}

The Waimarino Basalt is a subalkaline basalt, as deduced from the petrography (orthopyroxene and interstitial acid residuum in the groundmass), chemistry (low in alkalis with respect to silica: Macdonald and Katsura, 1964; Irvine and Baragar, 1971), and normative mineralogy (quartz tholeiite). The rock is properly termed a magnesian quartz tholeiite.

Waimarino Basalt represents a magma type which differs both petrographically and compositionally from high-alumina basalts of the TVZ. In contrast to high-alumina types (Cole, 1973), Waimarino Basalt lacks plagioclase phenocrysts, is low in alumina, and has a high $\mathrm{Mg} / \mathrm{Mg}+\mathrm{Fe}+$ ratio. The latter aspect suggests derivation from the mantle wedge beneath the TVZ, with little or no subsequent modification by crystal fractionation. 
Cole and Lewis (1981) have suggested that a Holocene volcanic arc occupies the eastern side of the TVZ, and has produced mainly olivine-bearing andesites. The age and location of Waimarino Basalt suggest that this magma type represents upper mantle anatexis, precursory to andesitic arc volcanism of the Taupo Arc. 


\section{ACKNOWLEDGEMVENTS}

I thank J. W. Cole and J. A. Gamble for discussion, and P. Froggatt and C. Vucetich for advice on stratigraphic relations. This basalt locality was first noted in 1974 by G. A. Hancox of the New Zealand Geological Survey. C. P. Wood brought the locality to my attention. This research was performed during the tenure of a scholarship from the New Zealand National Parks Authority, Department of Lands and Survey. 


\section{REFERENCES}

Cole, J. W., 1973, High-alumina basalts of the Taupo Volcanic Zone, New Zealand. Lithos, 6, 53-64.

Cole, J. W., and Lewis, K. B., 1981, Evolution of the Taupo-Hikurangi Subduction System. Tectonophysics, 72, $1-21$.

Irvine, T. N., and Baragar, W. R. A., 1971, A guide to the chemical classification of the common volcanic rocks. Canadian Journal of Earth Science, 8, 523-548.

Macdonald, G. A., and Katsura, T., 1964, Chemical composition of Hawaiian lavas. Journal of Petrology, 5, 82-133.

Norrish, K., and Hutton, J. T., 1969, An accurate x-ray spectrographic method for the analysis of a wide range of geological samples. Geochimica et Cosmochimica Acta, 33 , $431-453$.

Topping, W. W., 1973, Tephrostratigraphy and chronology of late Quaternary eruptives from the Tongariro Volcanic Centre, New Zealand. New Zealand Journal Geology and Geophysics, $16,397-423$. 


\section{LIST OF FIGURES}

Figure 1. Index map of North Island, and locality map for Waimarino Basalt Formation.

Figure 2. Measured stratigraphic section of Waimarino Basalt and associated units at the type locality, N112 414969.

Figure 3. Photomicrograph of Waimarino Basalt under plane polarized light, showing phenocrysts of olivine and clinopyroxene in a hyalopilitic matrix. Long dimension of photograph represents $4.2 \mathrm{~mm}$. 


\section{LIST OF TABLES}

Table 1. Modal mineralogy and crystallization sequence for Waimarino Basalt. Mode was determined by point counting two thin sections. Compositions of phenocryst and groundmass minerals were obtained using the electron microprobe.

Table 2. Bulk rock major element analysis and CIPW normative mineralogy of Waimarino Basalt. Average high-alumina basalt of the TVZ is given for comparison. 


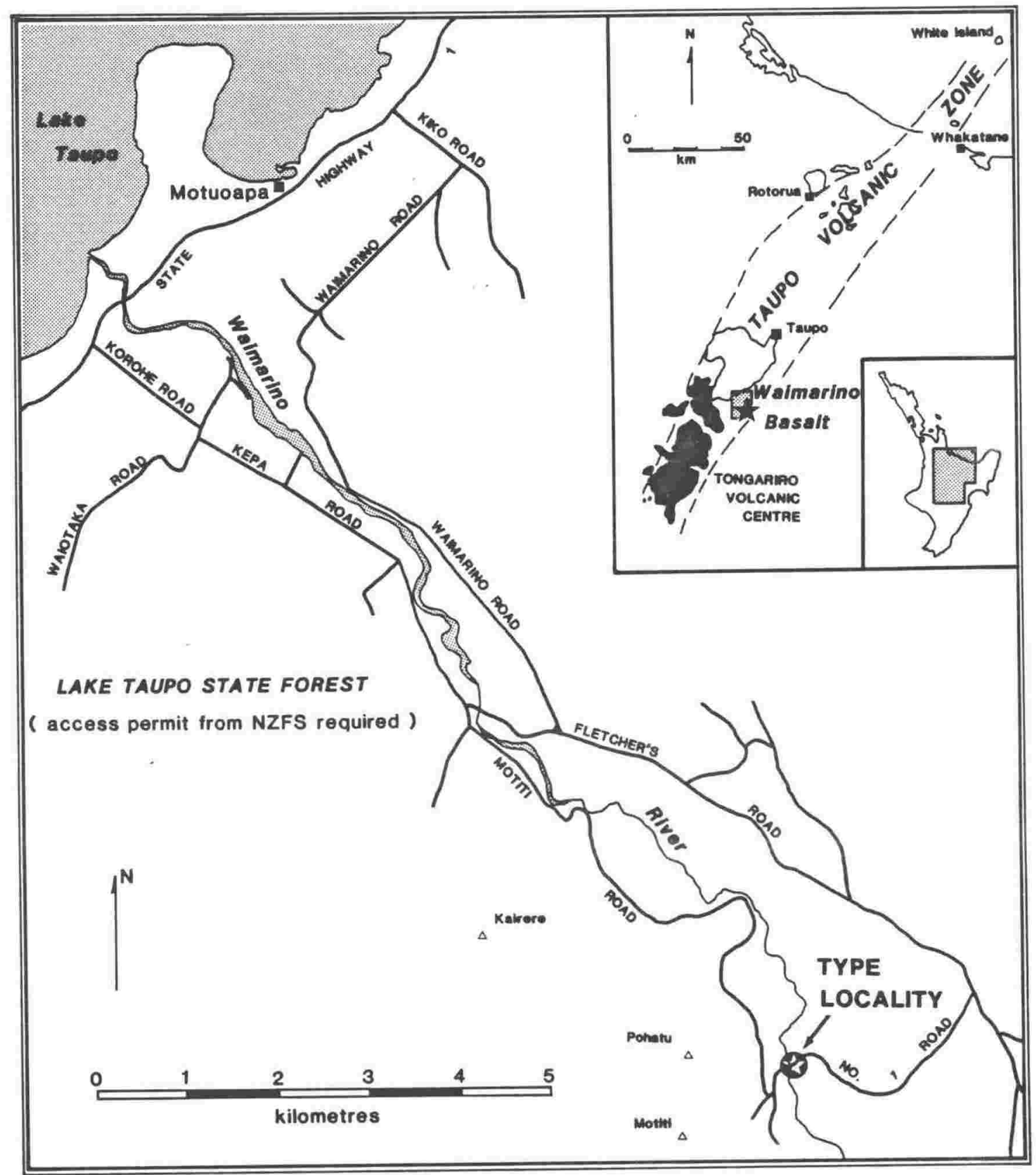

Fig. 1 


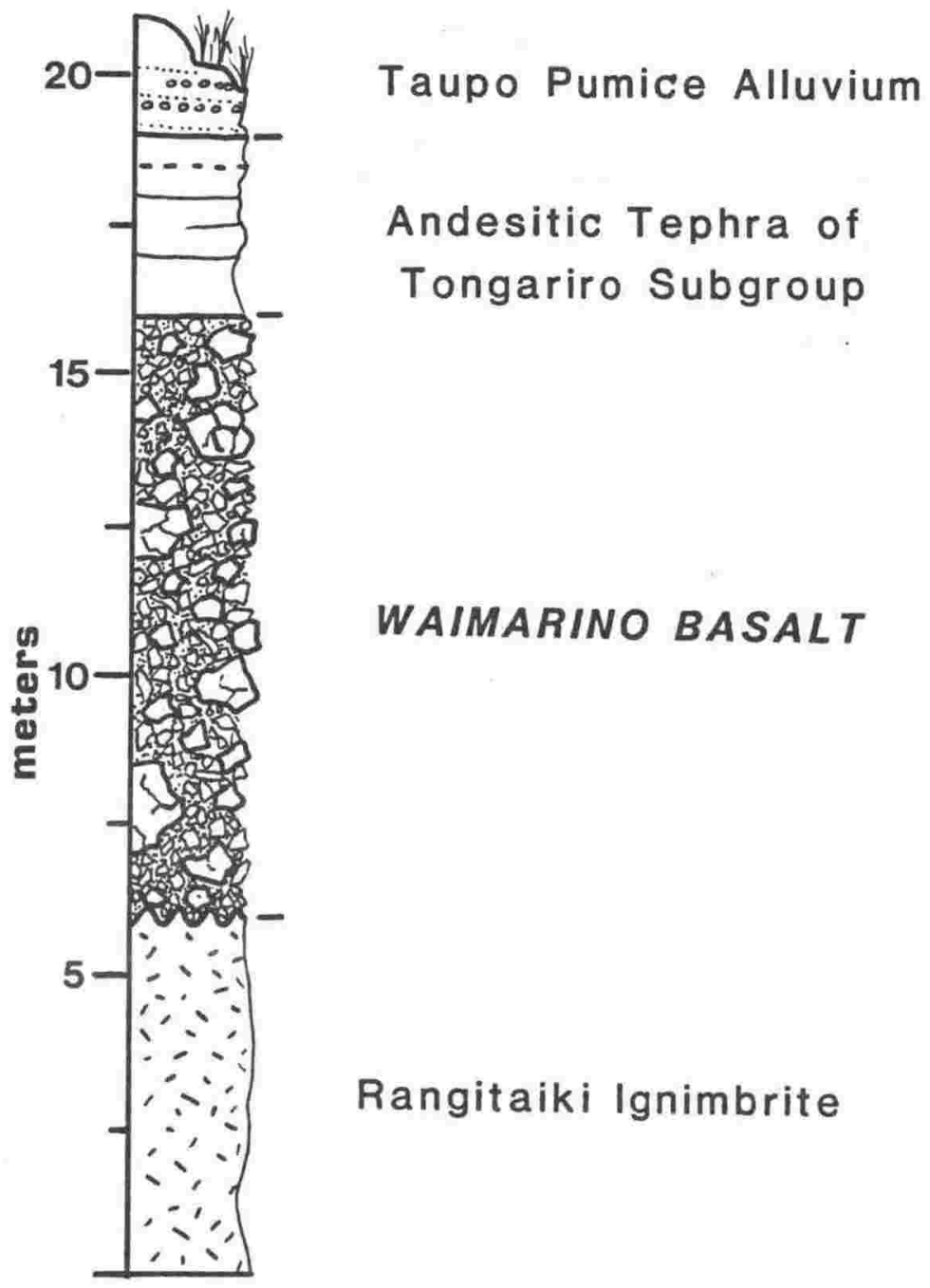

Fig. 2 


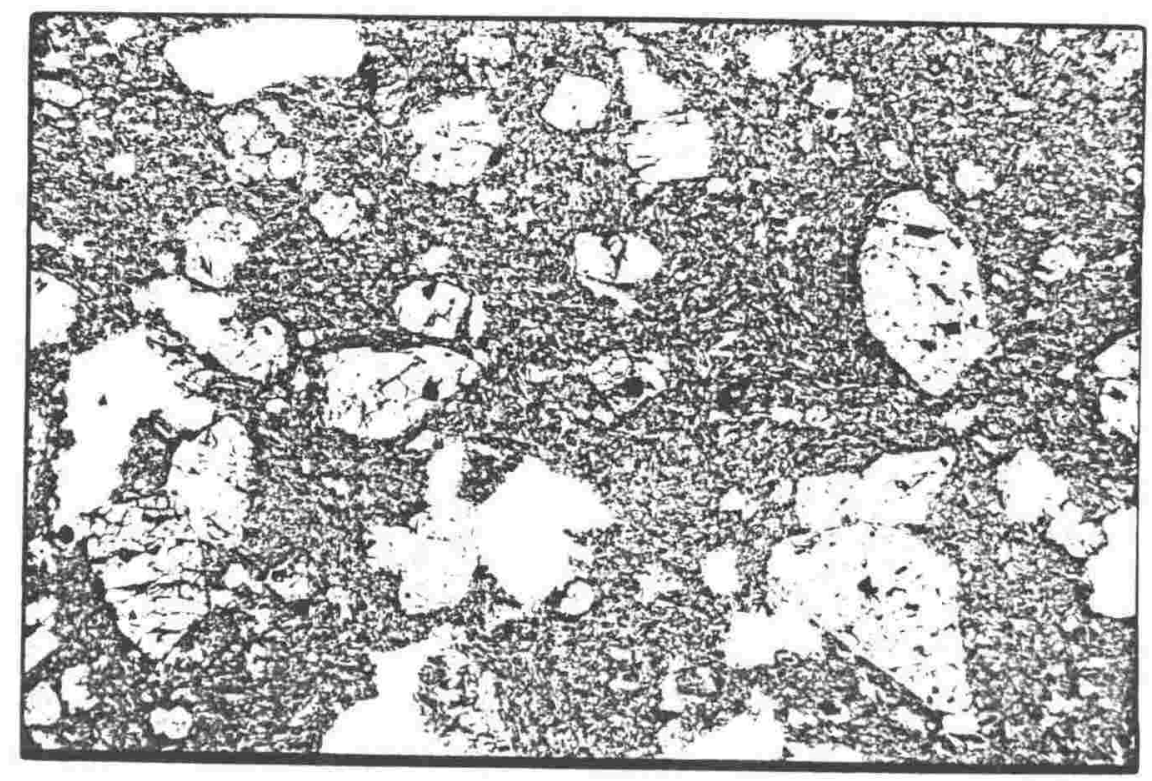

Fig. 3 
MODAL MINERALOGY

Phenocrysts

$\underline{\text { Groundmass }}$
olivine
16.1
clinopyroxene
7.4
spinel
$<1$
23.5
76.5

CRYSTALLIZATION SEQUENCE

\begin{tabular}{lll} 
& \multicolumn{1}{c}{ Phenocrysts } & Groundmass \\
spine1 & $100 \mathrm{Cr} / \mathrm{Cr}+\mathrm{Al}=80$ & $100 \mathrm{Cr} / \mathrm{Cr}+\mathrm{Al}=30$ to 40 \\
olivine & $\mathrm{F} 0 \mathrm{gl}$ & $\mathrm{Fo} 74$ \\
clinopyroxene & $100 \mathrm{Mg} / \mathrm{Mg}+\mathrm{Fe}=85$ & $100 \mathrm{Mg} / \mathrm{Mg}+\mathrm{Fe}=75$ \\
orthopyroxene & & $100 \mathrm{Mg} / \mathrm{Mg}+\mathrm{Fe}=74$ \\
plagioclase & & $\mathrm{An}_{80}$ to $\mathrm{An}_{55}$
\end{tabular}

Table 1. Modal mineralogy and crystallization sequence for Waimarino Basalt. Mode determined by point counting two thin sections. Phenocryst and groundmass mineral compositions obtained by EPMA. 


\begin{tabular}{|c|c|c|c|c|}
\hline \multicolumn{2}{|c|}{1} & 2 & \multicolumn{2}{|c|}{3} \\
\hline $\mathrm{SiO}_{2}$ & 52.18 & $q z \quad 1.04$ & $\mathrm{SiO}_{2}$ & 51.07 \\
\hline $\mathrm{TiO}_{2}$ & 0.47 & or 2.57 & $\mathrm{TiO}_{2}$ & 1.05 \\
\hline $\mathrm{Al}_{2} \mathrm{O}_{3}$ & 12.68 & $a b 14.03$ & $\mathrm{Al}_{2} \mathrm{O}_{3}$ & 17.50 \\
\hline $\mathrm{Fe}_{2} \mathrm{O}_{3}$ & 1.96 & an 26.26 & $\mathrm{Fe}_{2} \mathrm{O}_{3}$ & $9.64^{a}$ \\
\hline $\mathrm{FeO}$ & 6.58 & di 17.25 & $\mathrm{FeO}$ & \\
\hline MnO & 0.16 & hy 34.96 & $\mathrm{MnO}$ & 0.17 \\
\hline $\begin{array}{l}\mathrm{MgO} \\
\mathrm{CaO}\end{array}$ & $\begin{array}{r}13.15 \\
9.60\end{array}$ & mt 2.87 & $\begin{array}{l}\mathrm{MgO} \\
\mathrm{CaO}\end{array}$ & $\begin{array}{r}6.58 \\
10.57\end{array}$ \\
\hline $\mathrm{Na}_{2} \mathrm{O}$ & 1.64 & i1 0.90 & $\mathrm{Na}_{2} \mathrm{O}$ & 2.73 \\
\hline $\mathrm{K}_{2} \mathrm{O}$ & 0.43 & ap 0.12 & $\mathrm{~K}_{2} \mathrm{O}$ & 0.50 \\
\hline $\mathrm{P}_{2} \mathrm{O}_{5}$ & 0.05 & 100.00 & $\mathrm{P}_{2} \mathrm{O}_{5}$ & 0.27 \\
\hline LOI & 0.70 & & & \\
\hline Total & 99.60 & & & \\
\hline $\mathrm{Mg}^{*}$ & 78.08 & & & \\
\hline
\end{tabular}

$\mathrm{Mg}^{\star}=100 \mathrm{Mg} / \mathrm{Mg}+\mathrm{Fe}^{2+}$

a total iron expressed as $\mathrm{Fe} 0$

1. Waimarino Basalt. Average of ten $x$-ray fluorescence determinations, using method of Norrish and Hutton, 1969.

2. CIPW normative mineralogy of Waimarino Basalt.

3. Average high-alumina basalt of TVZ (Cole, 1973).

Table 2. Bulk rock major element analysis and CIPW normative mineralogy of Waimarino Basalt. Average high-alumina basalt of TVZ is given for comparison. 
PARI II: PEIROLOGY AND GEOCHEMISTRY 


\section{GENERAL INTRODUCTION}

\section{1.) PREVIOUS WORK}

Clark (1960) provided an excellent overview of the petrography of lavas from Tongariro Volcanic Centre, showing that the lavas are characteristically porphyritic, with ubiquitous labradorite- bytownite, bronzite- hypersthene, and augite phenocrysts set in intersertal, pilotaxitic or hyalopilitic groundmasses. Titanomagnetite is a common but minor constituent, occurring as microphenocrysts, inclusions in large phenocrysts, and as a groundmass phase. Olivine occurs in many rocks, usually as a minor constituent. Pigeonite rarely forms minute crystals and thin coronas surrounding hypersthene. Resorbed hornblende is rare. Apatite occurs as an accessory groundmass mineral and as inclusions in plagioclase. The details of mineral zonations in these rocks are complex, with both feldspar and ferromagnesian phenocrysts often showing resorbed cores, overgrowths, and oscillatory zonation.

Clark (1960) classified many specimens from Ruapehu as labradorite andesites (with plagioclase phenocrysts greater than twice the abundance of pyroxenes), but labradorite- pyroxene andesites were also noted (plagioclase less than twice the pyroxene abundance).

O'Shea (1957) described the detailed petrography for a few dykes and a sequence of lava flows on northwest Ruapehu. These correspond to Te Herenga Formation, and to the Iwikau and Pinnacle Ridge Members of Whakapapa Formation, in the present study. Lavas from Tawhai Falls (Whakapapa Fm, this study) and from Mahuia Rapids (Pukeonake Andesite $\mathrm{Fm}$, this study) were also described.

Cole (1978) described the mineralogy and petrography of andesites from Tongariro Volcanic Centre. Representative modal data were given, as well as partial chemical analyses for pyroxenes. 
Bulk rock chemical analyses from Ruapehu, Hauhungatahi, Pukeonake and Ohakune are given by Clark (1960), Topping (1974) and Cole (1978). Cole (1979) has compiled analyses of lavas of the Taupo Volcanic Zone to 1978, and descriptions and sample localities indicate that analyses from Ruapehu $(n=11)$ are labradorite or labradorite- pyroxene basic (53-57 wt \% $\mathrm{SiO}_{2}$ ) and acid (57-63 wt $\left.\% \mathrm{SiO}_{2}\right)$ andesites from Whakapapa $(n=8)$ and Mangawhero Formations $(n=2)$ defined in the present study. Analyses of olivine basic andesites from Pukeonake ( $n=5$; no trace elements), Hauhungatahi $(n=3)$ and the Ohakune vents $(n=3)$ are also given. No analyses from the older Ruapehu formations or of olivine- bearing Ruapehu lavas are given in Cole (1979). Thus, prior to the present study, about 25 bulk rock chemical analyses, ranging from $54-61 \& \mathrm{SiO}_{2}$, were documented from Ruapehu, Hauhungatahi, Pukeonake and Ohakune.

\section{NATURE AND SCOPE OF IHIS STUDY}

Specimens for petrographic and chemical analysis were collected during the field studies reported in Part I. The rock suite comprises spatially and temporally related lavas and enclaves that erupted from Ruapehu and related vents during about the past 0.5 m.y. Samples were collected from the outermost 100- 200 metres of the composite cone and its satellite vents, as this is the total depth of exposure. While coverage

therefore exists for only about the upper $20 \%$ of the estimated $110 \mathrm{~km}^{3}$ total volume, stratigraphic coverage of this portion is very thorough.

Because of their potential role as parental magmas to the voluminous andesites, olivine- bearing lavas were particularly thoroughly collected and analyzed, creating a sample bias. However, this exhaustive 
collection has allowed the identification of two basalt magma types, one from Ruapehu, and the other from an isolated occurrence $43 \mathrm{~km}$ to the northeast. Both of these basalts have great relevance to the petrogenesis of intermediate magmas.

Most specimens are from the fresh, relatively unoxidized interiors of lava flows, and the sample population is therefore lithologically biased. There are several practical reasons for this: Flows exhibit steplike erosional topography which facilitates sequential sampling, airfall material is rare and commonly oxidized on Ruapehu, and most tuf $f$ breccias are altered or oxidized.

The present work expands earlier observations in four respects: (1) The larger sample population ( 184 bulk rock chemical analyses; 200 thin sections) is considered representative of the subaerially exposed portion of Ruapehu Volcano and its related vents; "related vents" include the parasitic centres at Ohakune, the older cone of Hauhungalahi, and Waimarino Basalt. The latter is an isolated occurrence $40 \mathrm{~km}$ northeast of Ruapehu and outside the Tongariro Volcanic Centre, but the Waimarino Basalt magma type is relevant to petrogenesis of Ruapehu andesites. (2) A stratigraphic context for interpretation is provided in Part 1. Quantitative mineral analyses and detailed petrography are used to discuss the origins of entrained crystalline material, and (4) the data provide a base from which to evaluate petrogenetic processes.

Major goals of this section are to show the types, compositions and associations of minerals within the sample population, as well as the compositional diversity of bulk rocks. Some petrogenetic implications of the phenocryst and xenolith associations are given, but detailed discussion and quantitative models are presented in Part III, Petrogenesis. 


\subsection{RESULTS}

Modal mineralogy of selected whole rocks and igneous nodules is given in Tables 1-6. Photomicrographs of lavas, igneous nodules, and metamorphic xenoliths are presented in Figures 91-97. Mineral compositions were obtained by electron microprobe analysis and are listed in Appendices III, IV, and V for lavas, igneous nodules, and metamorphic xenoliths, respectively. Mineral analyses from selected lavas and igneous nodules are presented in graphical form as Figures 98-104.

Major element and trace element data for 144 fresh bulk rocks from Ruapehu and related vents are reported in Appendix II. In addition, 13 analyses are given for altered rocks, and 27 bulk rock analyses of igneous and metamorphic enclaves contained in the lavas. Strontium isotopic data (courtesy of Mr. Ian Graham) are given in Appendix II for 22 fresh bulk rocks, selected to span the entire compositional range from basalt to dacite, and also for seven xenoliths. Only major and trace element data from the 144 fresh bulk rocks are considered here; metamorphic xenolith compositions and isotopic data will be discussed under Part III, Petrogenesis. Results of the 144 unaltered bulk rock analyses are presented in Figures 105-109. 


\section{PETROGRAPHY}

\section{2.) TE HERENGA FORMATION}

Photomicrographs and modal data are given in Fig 91 and Table 1. The formation comprises petrographically and compositionally similar basic andesite lava flows, dykes and tuff breccia clasts. Specimens contain 30-55 \% phenocrysts of labradorite-bytownite, augite and bronzite-hypersthene, with ubiquitous but minor titanomagnetite phenocrysts (Fig 91A,B). A few specimens contain traces (2-4 grains per thin section) of resorbed olivine as groundmass microphenocrysts $\left(\mathrm{F}_{67}\right.$; Fig 91C). These olivines lack chrome spinel inclusions, are in equilibrium with coexisting pyroxene phenocryst cores, and represent the final stages of olivine crystallization from basic andesites. Groundmasses generally have higher plagioclase: total pyroxenes and higher orthopyroxene: clinopyroxene ratios than coexisting phenocryst assemblages: Table I, columns 2 and 7 are modes of groundmass only.

Microdiorite plugs (Fig 9ID,E; Table I, col 9) have the same crystal assemblage and similar bulk compositions as dykes and lava flows. As a consequence of advanced crystallization, the plugs have higher plagioclase: pyroxene ratios, and most are nearly holocrystalline. Portions of these hypabyssal intrusions are hydrothermally altered, as are surrounding lava flows and tuff breccias (Fig $9 \mid F, G, H)$. 


\section{FIG 91. PHOTOMICROGRAPHS FROM TE HERENGA FORMATION}

A. Basic andesite, Mead's Wall dyke. Large phenocrysts of labradorite ( $A n_{80-79}$ ), augite $\left(\mathrm{Mg}_{72-70}\right)$, bronzite $\left(\mathrm{Mg}_{73-70}\right)$, and microphenocrysts of titanomagnetite are set in a fine intergranular matrix of the same mineralogy. Crossed nicols (XN). Field width, $2.8 \mathrm{~mm}$. References: Appendix II, analysis 2; Appendix III; Table 1.

B. Basic andesite lava flow, Te Herenga Ridge. Same phenocryst assemblage as (A). This texture is representative of lava flows from Te Herenga Fm. XN. Width, $4.2 \mathrm{~mm}$. References: Appendix II, analysis 10; Appendix III.

C. Same lava as (B), but enlarged to show embayed olivine microphenocryst $\left(\mathrm{Fo}_{67}\right)$ with orthopyroxene corona. Plane polarized light (PPL). Width, $1.7 \mathrm{~mm}$. Reference: Appendix III.

D. Microdiorite intrusion, upper Pinnacle Ridge. Lineated subhedral phenocrysts of plagioclase, with subordinate clinopyroxene, orthopyroxene and opaque oxide are set in an intergranular matrix of the same minerals. PPL. Width, $2.8 \mathrm{~mm}$. Reference: Appendix II, analysis 9.

E. Microdiorite intrusion, upper Pinnacle Ridge. Hypidiomorphicgranular rock comprising plagioclase ( $\left.A n_{78-40}\right)$, hypersthene $\left(\mathrm{Mg}_{67}\right)$. augite $\left(\mathrm{Mg}_{71}\right)$ and opaque oxide. Patches of clouded mesostasis contain quartz and minor alkali feldspar. $X N$. Width, $2.8 \mathrm{~mm}$. References: Appendix II, analysis 12; Appendix III; Table I.

F. Altered hypabyssal intrusion, upper Pinnacle Ridge. Large phenocrysts of plagioclase, clinopyroxene and orthopyroxene are set in a fine intergranular matrix with disseminated pyrite. Clinopyroxene at centre has been partially replaced by pyrite. PPL. Width, $2.8 \mathrm{~mm}$. Reference: Appendix II, analysis 157.

G. Hydrothermally altered lava flow, upper Pinnacle Ridge. Original matrix and most pyroxenes have been replaced by pale green clay and by sulfides. PPL. Width, $2.8 \mathrm{~mm}$. Reference: Appendix II, analysis 148.

H. Hydrothermally altered microdiorite, upper Pinnacle Ridge. Pyroxenes exhibit alteration to clay and sulfides. PPL. Width, $2.8 \mathrm{~mm}$. References: Appendix II, analysis 153. 
FIG. 91 .

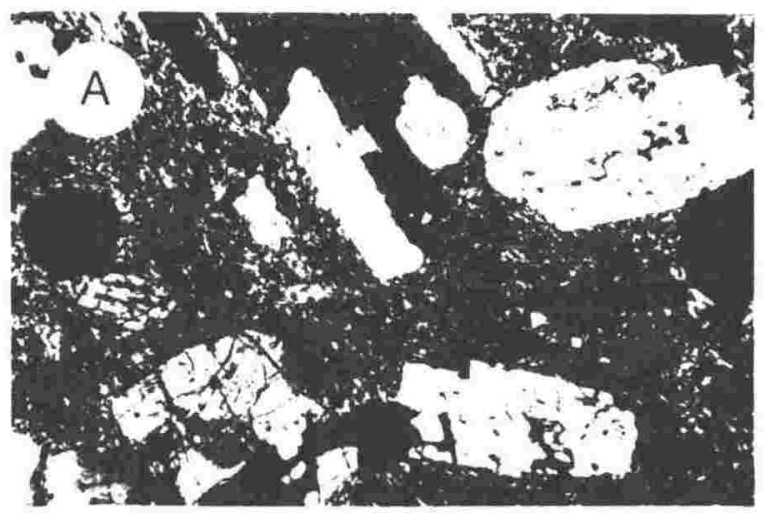

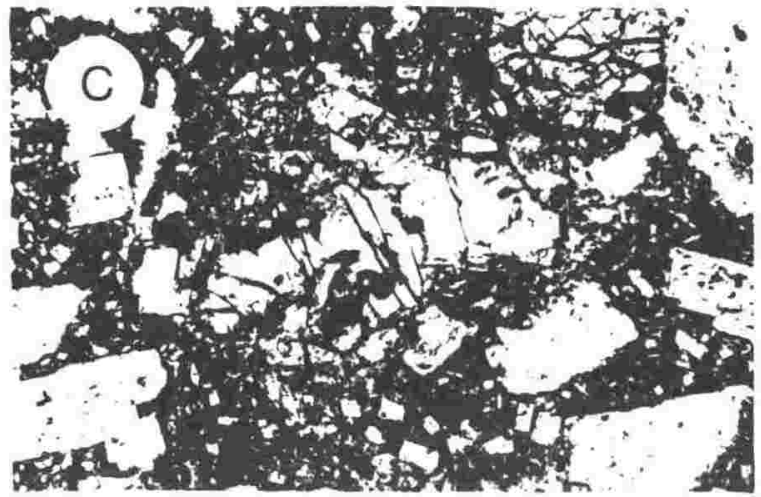

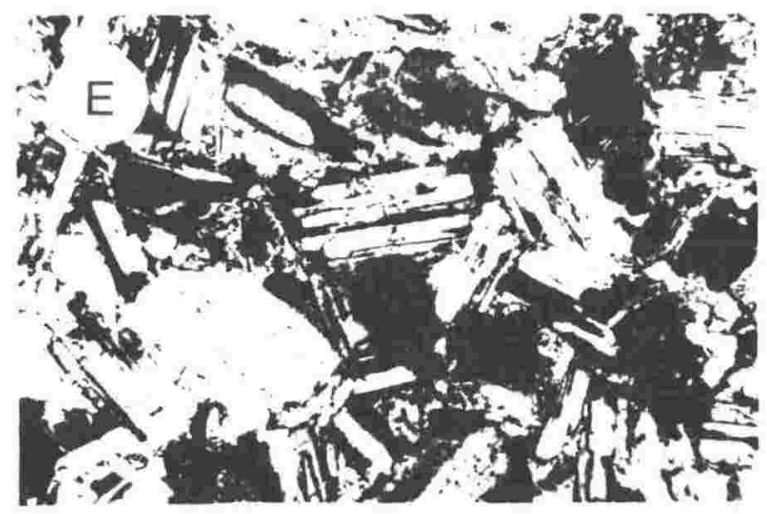

I G G A

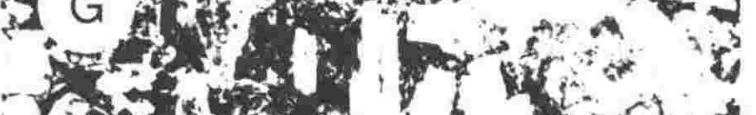

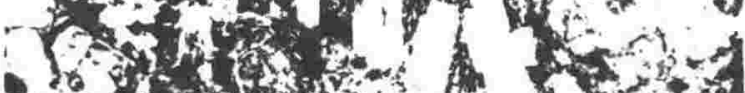

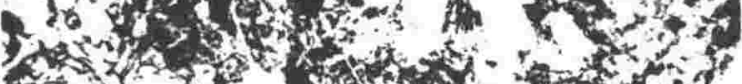

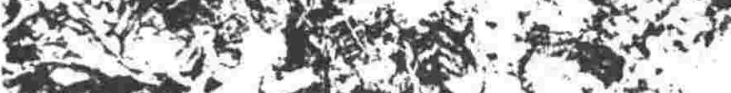

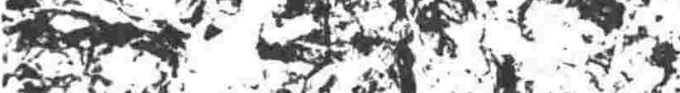

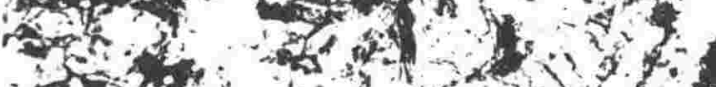

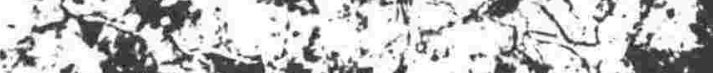

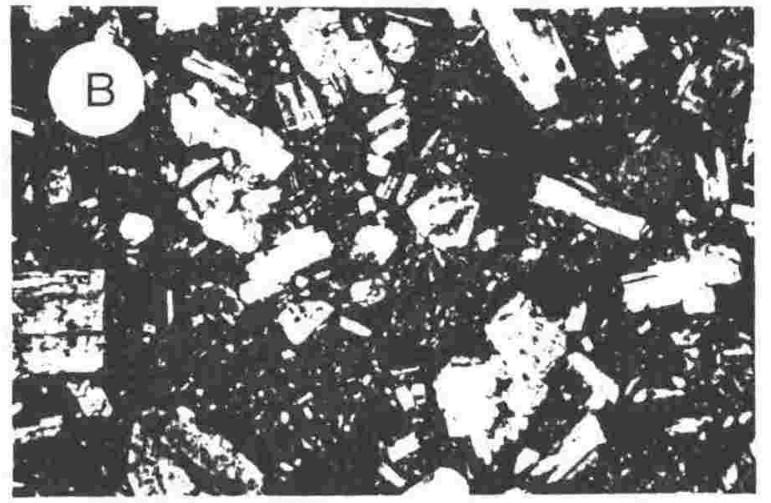

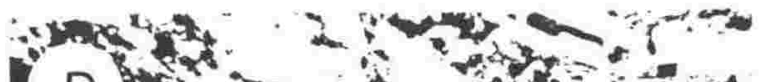

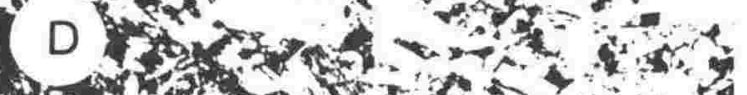

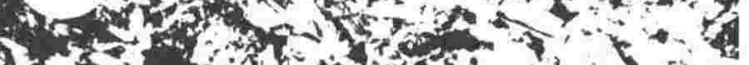

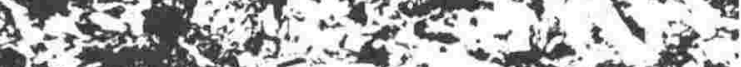

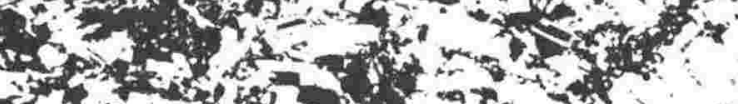

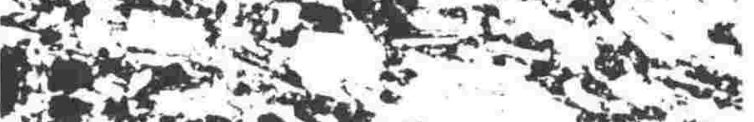

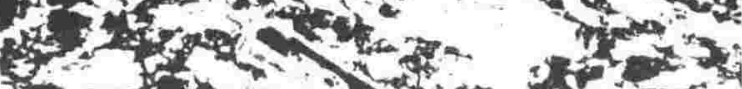

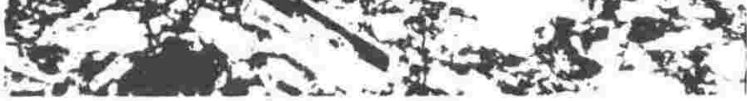

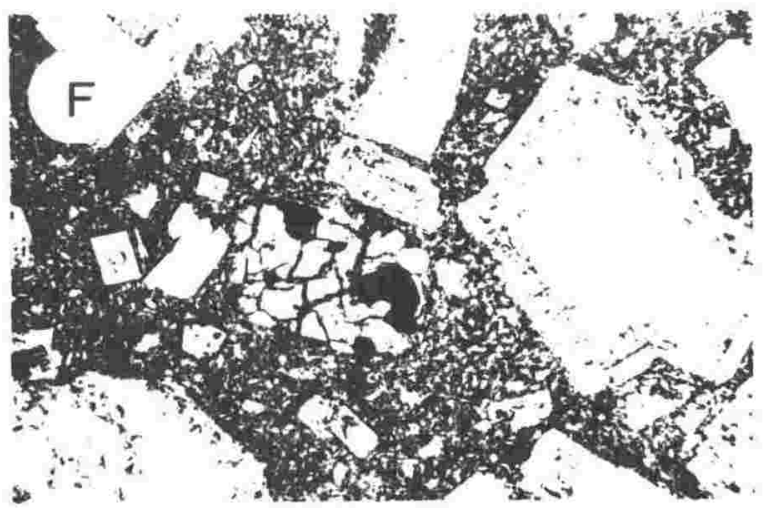

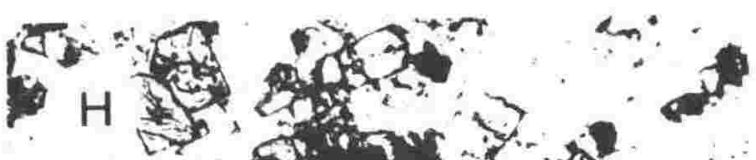
$\rightarrow 4$.

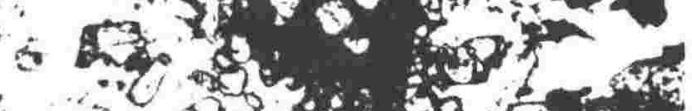
$A=\therefore$ as

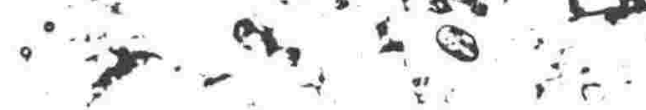




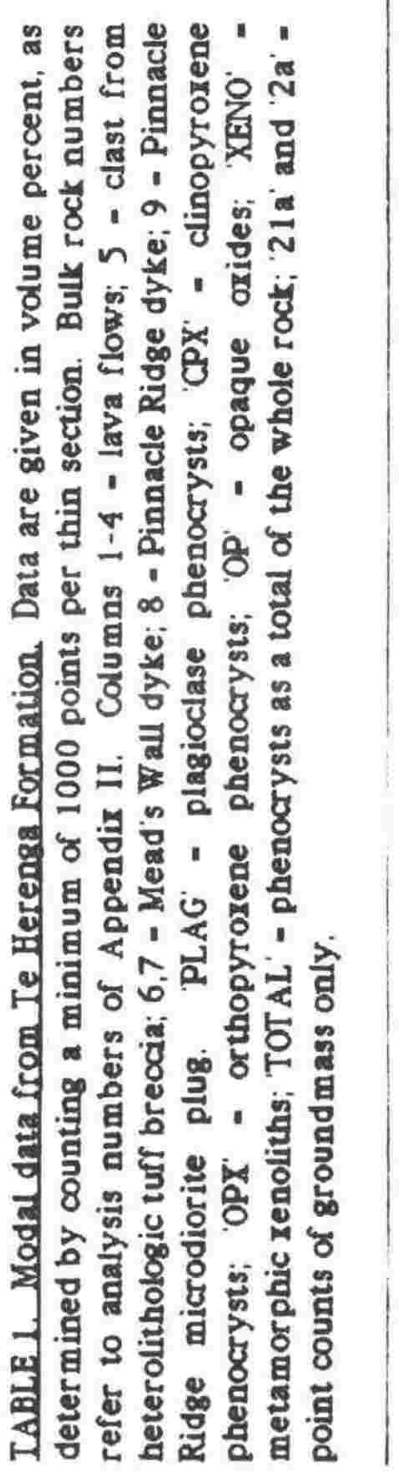

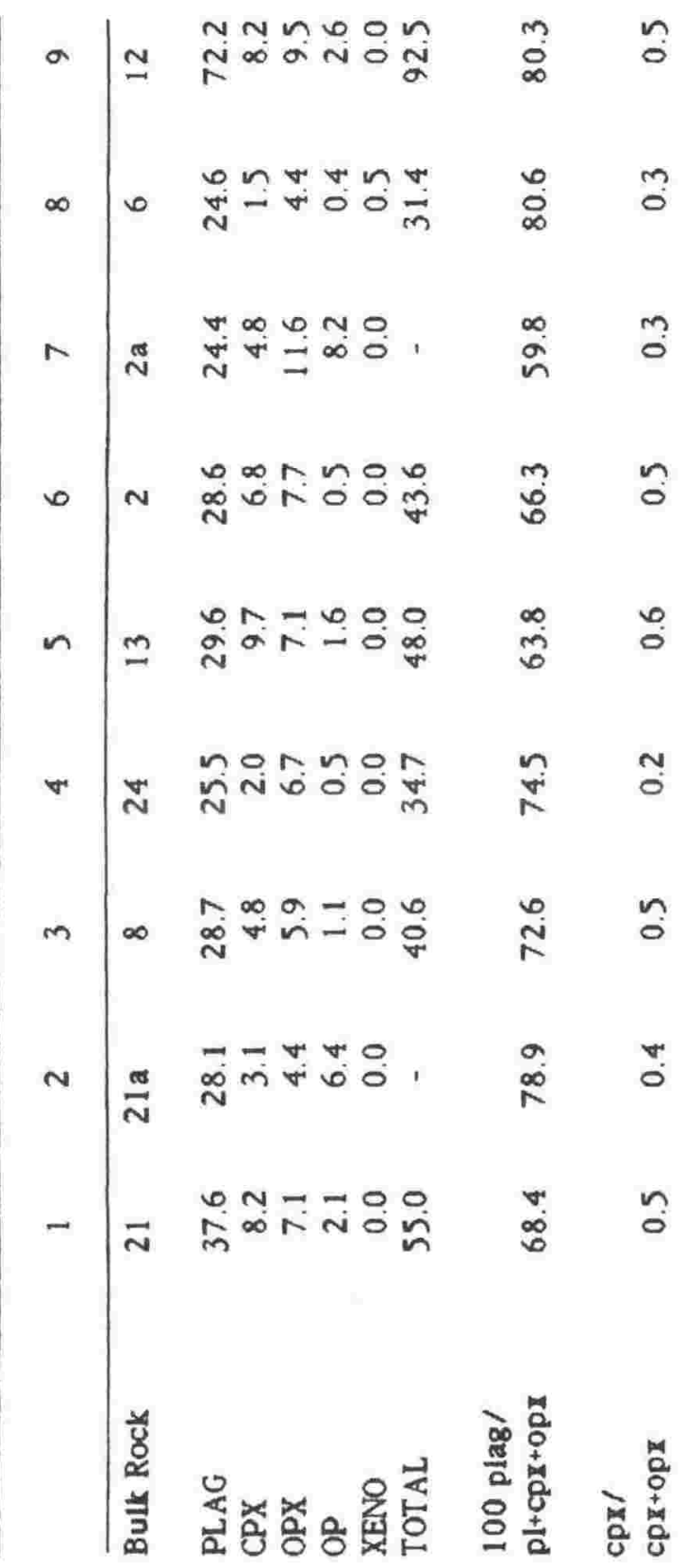




\section{WAHIANOA FORMATION}

Photomicrographs are given in Fig 92 and modal data are found in Table 2. Specimens have $14-39 \%$ phenocrysts, but most are about $30 \%$ phyric. Some specimens are texturally and mineralogically similar to Te Herenga $\mathrm{Fm}$, but overall there is greater compositional $\left(54-61 \% \mathrm{SiO}_{2}\right)$ and petrographic diversity. A few specimens (e.g., Table 2, bulk rock 50) contain traces of oxidized amphibole.

Petrographic diversity is shown by widely varying plagioclase: pyroxene ratios, clinopyroxene: orthopyroxene ratios, presence of resorbed olivine xenocrysts with chrome spinel inclusions, and complex zonation patterns and overgrowths, especially for pyroxenes. A few lavas are relatively "clean", and disequilibrium textures are not present for any minerals (Fig 92A). In others, phenocrysts are dominated by plagioclase aggregates (Fig 92B) or by pyroxene aggregates and discrete pyroxenes with internal resorption zones and overgrowths (Fig 92C-G). Resorbed and mantled plagioclase (Fig 92F), and resorbed forsteritic olivine with chrome spinel inclusions and orthopyroxene coronas sometimes accompany the pyroxene textures (Fig 92H-J).

It is noteworthy that only 6 of 32 thin sections examined lack significant amounts of crystal aggregates, or resorbed and mantled crystals. The hypidiomorphic-granular aggregates range in size from 3-5 $\mathrm{mm}$, to rare blocks approaching $8 \mathrm{~cm}$. The aggregates have anorthositicgabbroic- websteritic mineralogy, and they can comprise significant proportions of the total phenocryst assemblages in porphyritic rocks, producing substantial variations in plagioclase: pyroxene ratios and bulk compositions. Olivine is generally absent in these fragments and occurs instead as discrete, embayed, orthopyroxene-mantled, forsteritic crystals which seldom exceed a few volume percent. These are xenocrysts on the 
basis of petrography (chrome spinel inclusions, strong resorption and reaction) and composition (too forsteritic to be in equilibrium with host rocks). Pervasive mantling of pyroxenes, by coronas with about $10 \%$ greater $\mathrm{Mg}^{*}$ than cores, is characteristic of rocks with olivine xenocrysts. Details of these zonation patterns will be presented in Part III, Petrogenesis, but it is appropriate to state here that the mantled phenocrysts are interpreted as products of magma mixing and crystal accumulation. 


\section{FIG 92. PHOTOMICROGRAPHS FROM WAHIANOA FORMATION}

A. Acid andesite lava flow, south Ruapehu. Phenocrysts of labradorite ( $\mathrm{An}_{58}-56$ ), orthopyroxene (opx; $\mathrm{Mg}_{74-62}$ ), augite $\left(\mathrm{Mg}_{63}\right)$ and titanomagnetite are set in a pilotaxitic matrix. Disequilibrium textures are absent. PPL. Field width, $4.2 \mathrm{~mm}$. References: Appendix II, analysis 59; Appendix III; Table 2.

B. Acid andesite, Whangaehu Gorge. Phenocryst assemblage is dominated by bytownite ( $A n_{76}-73$ ), which occurs predominantly as $1-2$ $\mathrm{mm}$ hypidiomorphic-granular anorthosite fragments. Groundmass plagioclase is labradorite ( $\left(\mathrm{A} n_{55}\right)$. Interpreted as a plagloclaseaccumulative lava. Crossed nicols (XN). Width, $4.2 \mathrm{~mm}$. References: Appendix II, analysis 46; Appendix III; Table 2.

C. Basic andesite, Whangaehu Gorge. From left to right are: resorbed plagioclase ( $\mathrm{pl}$; $\left.\mathrm{An}_{65}-54\right)$, two reversely zoned augites (cpx; $M_{87-69}$ ), and a composite grain of twinned clinopyroxene and spongy orthopyroxene. XN. Width, $4.2 \mathrm{~mm}$. References: Appendix II, analysis 31; Appendix III; Table 2.

D, E. Same rock as (C), showing reversely zoned augite with $\mathrm{Mg}_{72-69}$ core and $\mathrm{Mg}_{87-76}$ rim. XN. Width, $1.3 \mathrm{~mm}$.

F. Ditto, showing resorbed plagioclase with $A_{64-59}$ core and thin, clear $\mathrm{An}_{65} \mathrm{rim}$.

G. Ditto, showing twinned clinopyroxene over fritted orthopyroxene.

H. Olivine basic andesite, Whangaehu Gorge. Phenocrysts of labradorite $\left(\mathrm{An}_{66}\right)$, augite $\left(\mathrm{Mg}_{78-68}\right)$, orthopyroxene $\left(\mathrm{Mg}_{77-68}\right)$ and olivine are set in an intersertal matrix. Resorbed olivines (0l; $\mathrm{F}_{90}{ }_{90}{ }_{87}$ ) contain chrome spinel inclusions and have orthopyroxene coronas. XN. Width, 4.2 mm. References: Appendix II, analysis 27; Appendix III; Table 2.

I. Same rock as $(\mathrm{H})$, showing embayed forsteritic olivine $\left(\mathrm{F}_{90}\right)$ with chrome spinel and orthopyroxene corona at upper left, clinopyroxene cluster at bottom centre, and mantled clinopyroxene $\left(\mathrm{Mg}_{68}\right.$ core; $\left.\mathrm{Mg}_{76} \mathrm{rim}\right)$ at lower right. XN. Width, $1.6 \mathrm{~mm}$.

J. Ditto, showing twinned cpx jacket enclosing spongy opx. 
FIG. 92.
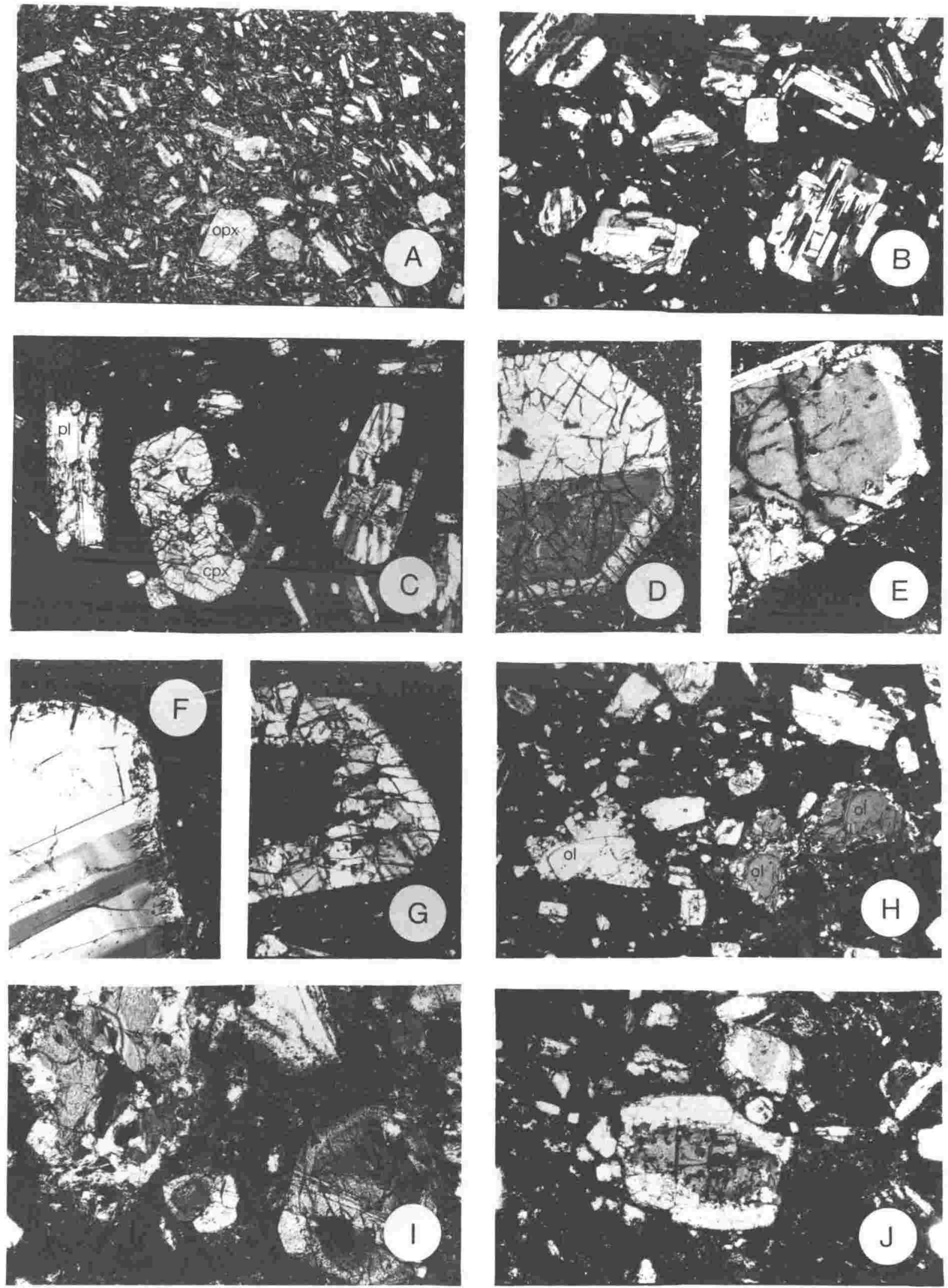


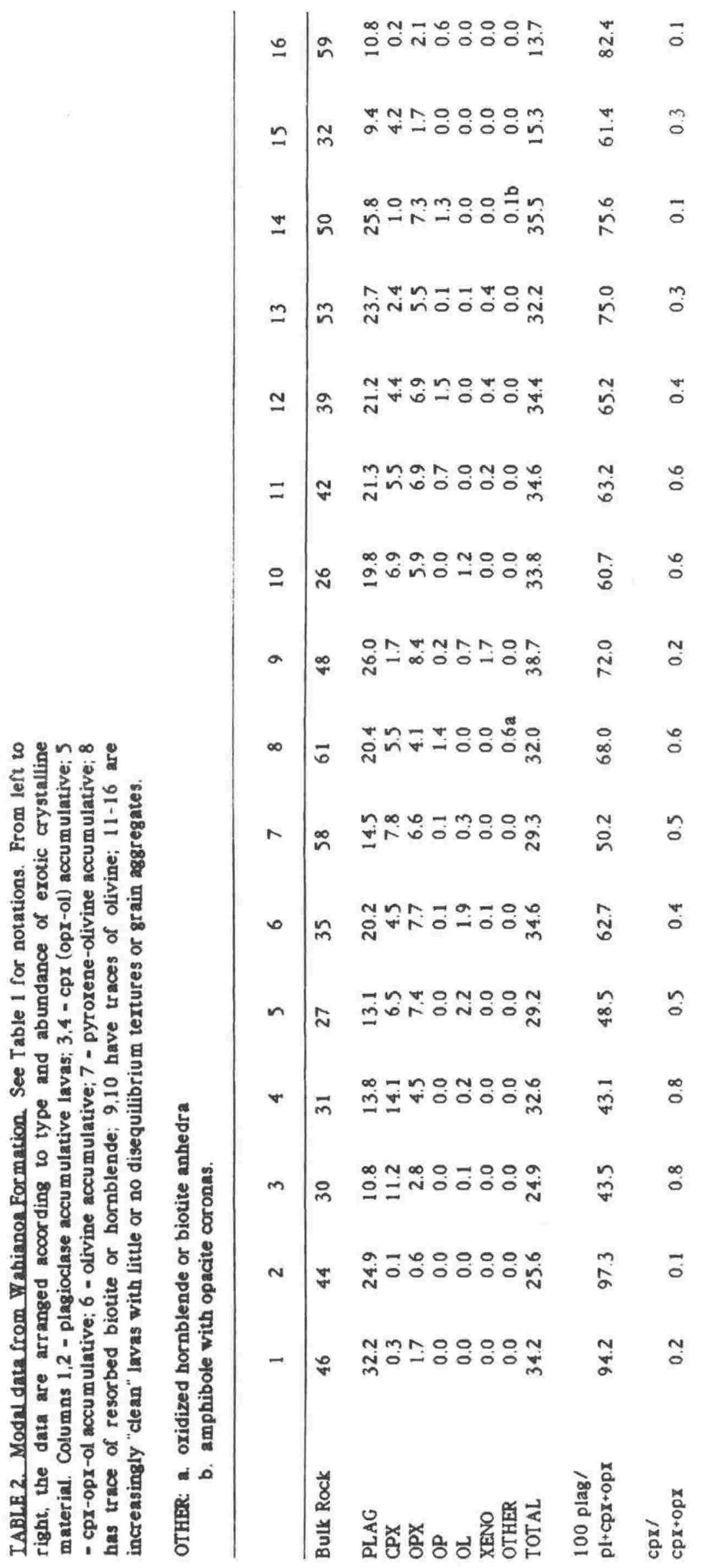




\section{MANGAWHERO FORMATION}

Photomicrographs are given in Fig 93 and modal data are found in Table 3. Phenocrysts are the same plagioclase + two pyroxene + opaque oxide \pm olivine \pm apatite assemblage as reported for other formations, but Mangawhero $\mathrm{Fm}$ is characterized by great compositional $\left(52-63 \% \mathrm{5iO}_{2}\right)$ and textural diversity.

Petrographic features previously described for Wahianoa Fm are even more pronounced here: Igneous rock fragments and high-temperature overgrowths on phenocrysts are common. Igneous fragments range in size from 2-5 mm, and are hypidiomorphic- granular pieces of pyroxenite (Fig 931) to anorthosite (Fig 93J). These involve substantial proportions of the total phenocryst assemblages in some specimens, as shown in Table 3 , cols 2 and 4 , where small igneous fragments comprise 19 and $15 \%$ of bulk rocks, and in both rocks they account for half of the total "phenocryst" abundances.

Olivine is present in significant amounts (up to $7 \mathrm{vol} \mathrm{\% )} \mathrm{in} \mathrm{many} \mathrm{of}$ these accumulative rocks, as well as in specimens that are relatively free of igneous inclusions. Olivine is an essential phenocryst in basic rocks, but with increasing silica content of bulk rocks, olivine gradually disappears until only 1-2 rounded microphenocrysts are observed in the groundmass of rocks with up to $58 \mathrm{x} \mathrm{SiO}_{2}$. The proportions of plagioclase and orthopyroxene, and the orthopyroxene: clinopyroxene ratio systematically increase as olivine disappears. These petrographic trends from basalt to dacite are shown in Table 2, cols 19-25, and Fig 93 A-F. Olivines from these specimens are in equilibrium with coexisting pyroxene cores and with bulk rocks, precluding xenocrystic origin. Olivine xenocrysts do occur in trace amounts for other lavas (e.g., Fig 93H).

Though of ten present in only trace amounts, forsteritic olivine is a 
nearly ubiquitous component of specimens with strongly developed disequilibrium textures (Fig 93M-R; Table 2, cols 11-15). These specimens include basic and acid andesites with forsteritic olivine up to $\mathrm{F}_{90}$, and with conspicuous mantled phenocrysts having high-temperature jackets over resorbed cores. Euhedral microphenocrysts of magnesian orthopyroxene (up to $\mathrm{Mg}_{90}$ ) are invariably present.

In summary, olivine occurs in three petrographic associations: (1) as trace forsteritic xenocrysts in pyroxene-accumulative rocks whose main petrographic feature is the presence of pyroxenite and gabbro fragments, (2) as a primary phenocryst of basalt and basic andesites, but progressively disappearing with increasing bulk rock acidity as a consequence of olivine-liquid reaction, and (3) as forsteritic crystals in mixed magmas whose signature is the presence of internally resorbed phenocrysts with high temperature jackets. These petrogenetic hypotheses will be quantitatively evaluated in Part III, Petrogenesis. 
A. Olivine basalt, north Ruapehu. Phenocrysts of plagioclase ( $\mathrm{pl}$; An $81-49$ ), clinopyroxene (cpx; $\mathrm{Mg}_{80-69}$ ), olivine (ol; $\mathrm{F}_{90}-79$ ) and minor orthopyroxene $\left(\mathrm{Mg}_{80-69}\right)$ are set in a felted, microvesicular matrix. Largest clinopyroxenes of ten have thin clear rims $\left(\mathrm{Mg}_{80}\right)$ on pale green cores $\left(M_{69}\right)$. Some plagioclase has resorbed cores $\left(A n_{71}\right)$ and thin, clear rims $\left(A n_{80}\right)$. Olivine lacks orthopyroxene coronas and contains chrome spinel inclusions. PPL. Width, $4.2 \mathrm{~mm}$. References: Appendix II, analysis 63; Appendix III; Table 3.

B. Olivine basic andesite, north Ruapehu. Similar petrography as (A), but with less olivine $\left(\mathrm{F}_{78}-68\right)$ and clinopyroxene $\left(\mathrm{Mg}_{84-69}\right)$, and more plagioclase $\left(\mathrm{An}_{65}\right)$ and orthopyroxene $\left(\mathrm{Mg}_{73}\right)$. PPL. Width, $4.2 \mathrm{~mm}$. References: Appendix II, analysis 64; Appendix III; Table 3.

C. Groundmass olivine (ol; $\mathrm{F}^{0} 70-68$ ) in lava (B), exhibiting rim oxidation but not orthopyroxene coronas; olivine has not yet reacted with liquid. PPL. Width, $1.7 \mathrm{~mm}$.

D. Olivine-bearing acid andesite, north Ruapehu. Euhedral plagioclase $\left(A n_{77-50}\right)$, lesser pyroxenes $\left(\mathrm{Mg}_{69-67}\right)$, and opaque oxide microphenocrysts are set in a felted matrix with rare oivine microphenocrysts $\left(\mathrm{Fo}_{67}\right)$. XN. Width, $4.2 \mathrm{~mm}$. References: Appendix $\mathrm{II}_{\text {, }}$ analysis 88; Appendix III; Table 3.

E. Rare groundmass olivine $\left(\mathrm{Ol} ; \mathrm{Fo}_{67}\right)$ in lava (D), surrounded by orthopyroxene (opx) and titanomagnetite corona. Olivine has now reacted with liquid to form orthopyroxene. XN. Width, $0.6 \mathrm{~mm}$.

F. Dacite, Mangaturuturu Valley, SW Ruapehu. Phenocrysts of plagioclase $\left(A n_{53}\right)$, orthopyroxene $\left(M_{67}\right)$, rare clinopyroxene, and opaque oxide microphenocrysts are set in a felted matrix. No olivine or igneous fragments are present. PPL. Width, $4.2 \mathrm{~mm}$. References: Appendix II, analysis 107; Appendix 1II; Table 3. 
G. Dacite lava flow, north Ruapehu. Apatite microphenocryst (ap; $0.2 \mathrm{~mm}$ ) is associated with orthopyroxene $(0 p x)$ and plagioclase. Note opaque, rod-like inclusions parallel to c-axis, and tabular habit. PPL. Reference: Appendix II, analysis 109.

H. Dacite, Whakapapaiti Valley, W Ruapehu. Phenocrysts of plagioclase, hypersthene $\left(\mathrm{Mg}_{61-59}\right)$ and augite are set in a felted matrix with abundant plagioclase and opaques. Olivine xenocryst $\left(\mathrm{Fo}_{85}\right)$ with chrome spinel inclusions and orthopyroxene corona is circled. Aggregate of two pyroxenes, plagioclase, oxides and glass occurs at left. PPL. Width, $4.2 \mathrm{~mm}$. References: Appendix II, analysis 108; Appendix III.

I. Olivine-bearing basic andesite, Girdlestone Peak. Total pyroxenes exceed plagioclase, comprising abundant large clinopyroxene crystals and two- pyroxene aggregates. Interpreted as a pyroxene- accumulative lava. XN. Field width, $4.2 \mathrm{~mm}$. References: Appendix II, analysis 72; Table 3.

J. Acid andesite, north Ruapehu. Plagioclase crystals (An $83-73$ ) greatly exceed pyroxenes $\left(\mathrm{Mg}_{73}-\mathrm{70}\right)$, and occur predominantly as hypidiomorphic- granular anorthosite fragments. Interpreted as a plagioclase-accumulative lava. XN. Field width, $4.2 \mathrm{~mm}$. References: Appendix II, analysis 100; Appendix III; Table 3.

K. Olivine-bearing basic andesite, north Ruapehu. Clinopyroxene and plagioclase commonly occur as hypidiomorphic-granular aggregates and as embayed crystals. XN. Field width, $4.2 \mathrm{~mm}$. Reference: Appendix II, analysis 73 .

L. Olivine-bearing basic andesite, showing oscillatory-zoned clinopyroxene megacryst. PPL. Field width, $4.2 \mathrm{~mm}$. Reference: Appendix II, analysis 68 .

M. Olivine basic andesite, $\mathrm{N}$ Ruapehu. Phenocrysts of labradorite $\left(A n_{58-50}\right)$, augite $\left(\mathrm{Mg}_{86-61}\right)$, orthopyroxene $\left(\mathrm{Mg}_{85-64}\right)$ and olivine (ol; $\mathrm{F}_{85}$ ) are set in a pilotaxitic matrix. Large olivine at upper left, mantled augite at lower right. XN. Field width, $4.2 \mathrm{~mm}$. References: Appendix II, analysis 69; Appendix III; Table 3.

$\mathrm{N}$. Same rock as (M), showing mantled augite with $\mathrm{Mg}_{61}$ core and $\mathrm{Mg}_{85}$ jacket. XN. Field width, $1 \mathrm{~mm}$. 
0. Same rock as (M). Mantled augite at centre, jacketed orthopyroxene (core $=M_{64}$, jacket $=M g_{85}$ ) at extreme right. XN. Field width, $0.5 \mathrm{~mm}$.

P. Olivine acid andesite, Girdlestone Peak. Phenocrysts of orthopyroxene, clinopyroxene, olivine, and subordinate plagioclase are set in an intersertal matrix. Pyroxenes are strongly jacketed or zoned. Compare to Fig 106E,F; these are also hybrid magmas. Clinopyroxene (cpx) at upper right has $\mathrm{Mg}_{72}$ core and $\mathrm{Mg}_{85}$ mantle. Olivine (ol; $\mathrm{Fo}_{92}-91$ ) at bottom centre has chrome spinel inclusions and orthopyroxene corona. Resorbed hypersthene (hy; $\mathrm{Mg}_{70}$ core), jacketed by spongy bronzite $\left(\mathrm{Mg}_{88}\right)$, lower right. The abundant grey, medium-relief microphenocrysts are enstatite $\left(\mathrm{Mg}_{90}\right)$. XN. Field width, $4.2 \mathrm{~mm}$. References: Appendix II, analysis 81; Appendix III; Table 3

Q. Olivine acid andesite, Girdlestone Peak, showing spongy orthopyroxene jacketed by clear, magnesian clinopyroxene. XN. Field width, $4.2 \mathrm{~mm}$. References: Appendix II, analysis 87; Appendix III; Table 3.

R. Same rock as (P), showing resorbed hypersthene (hy), jacketed by spongy bronzite $(b r)$, in turn overgrown by clinopyroxene $(c p x)$. XN. Field width, $0.8 \mathrm{~mm}$. 
FIG. 93.
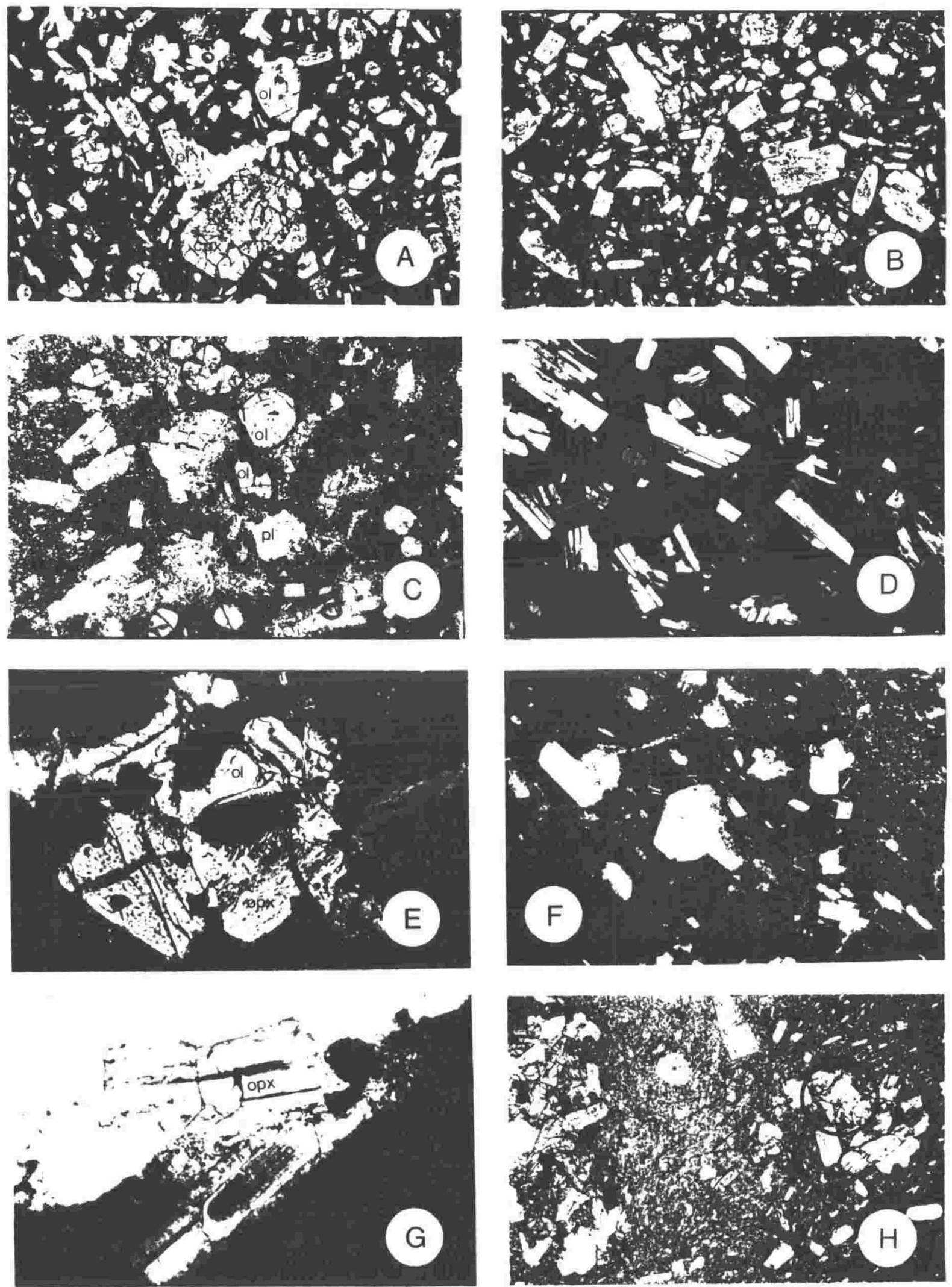
FIG. 93.
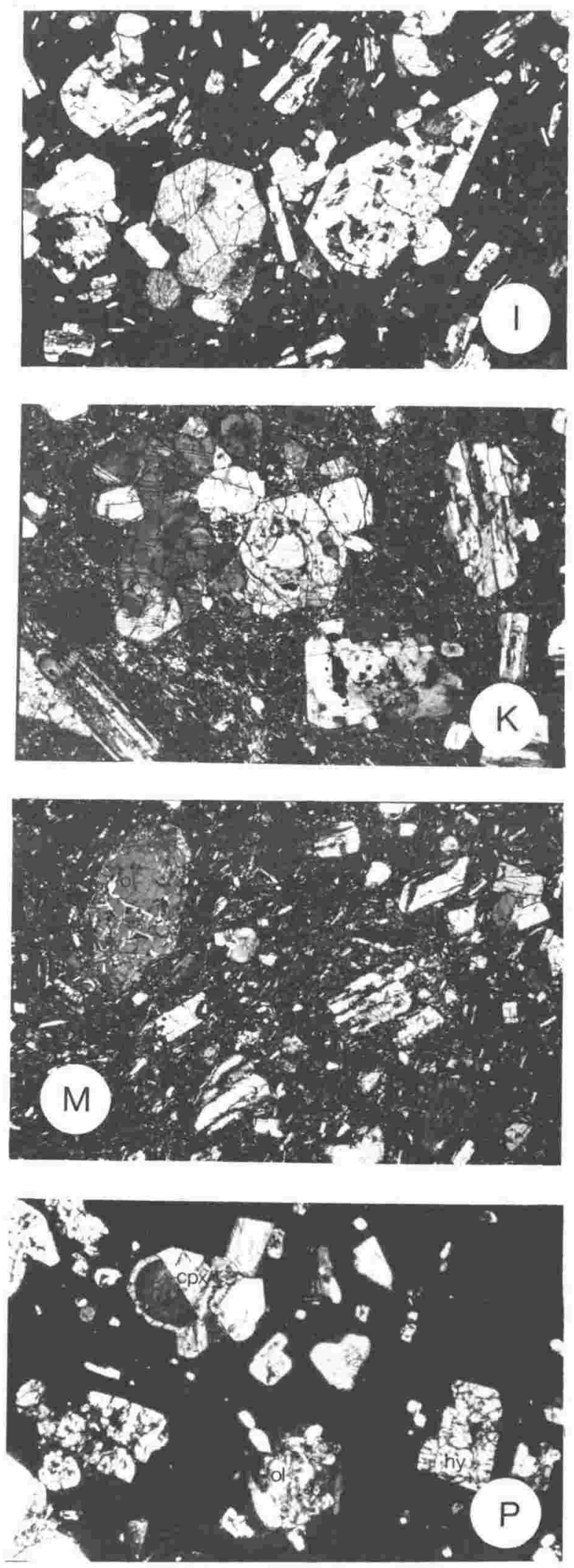
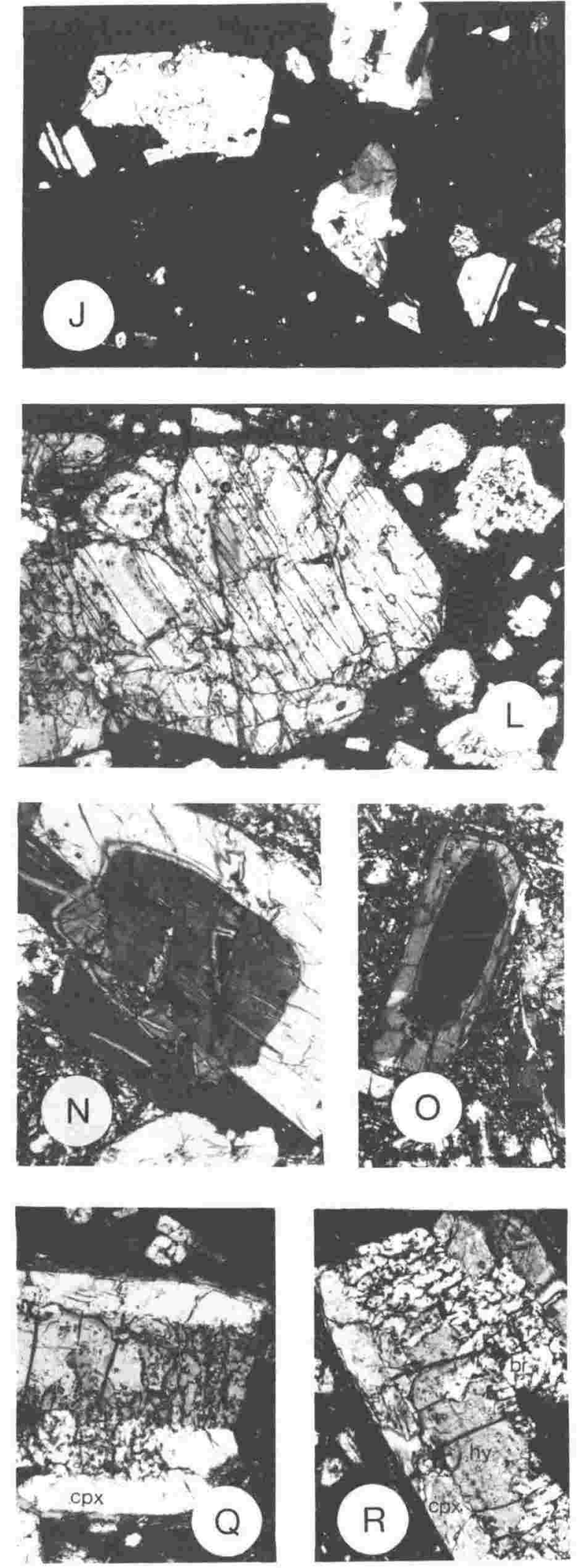


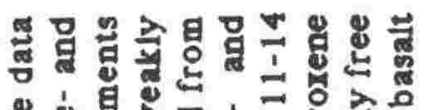

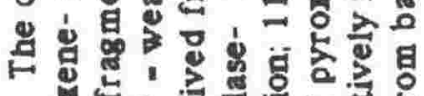

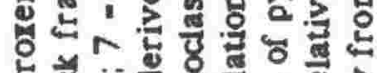
녕영

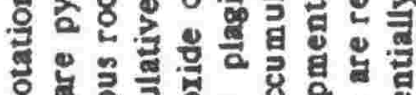
영

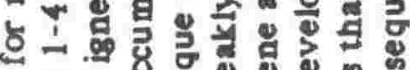
10.

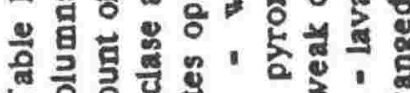

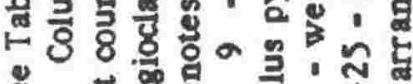

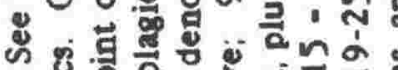
\%

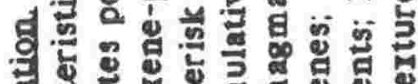

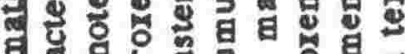

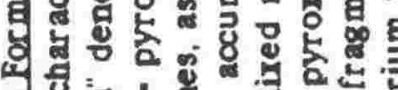
웡 열

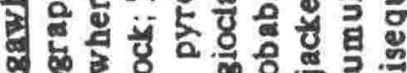
잉 능

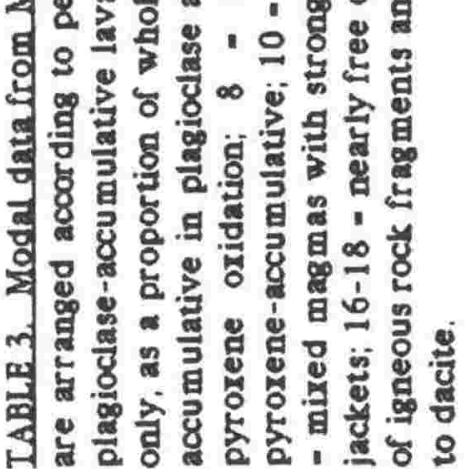

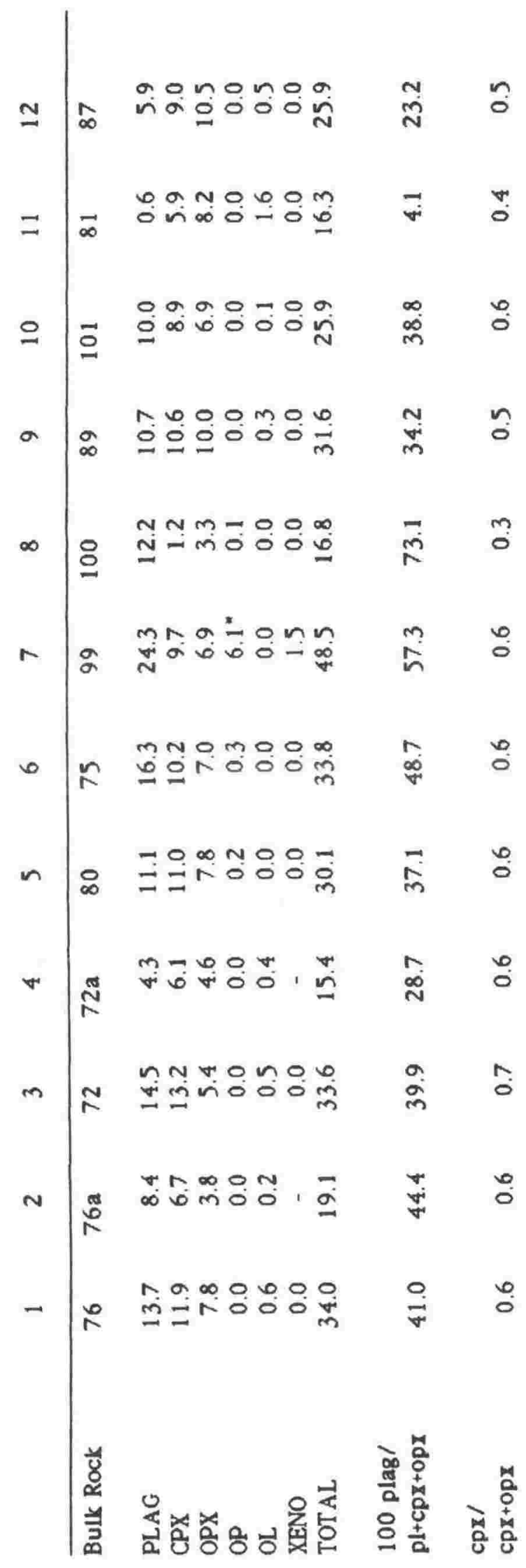




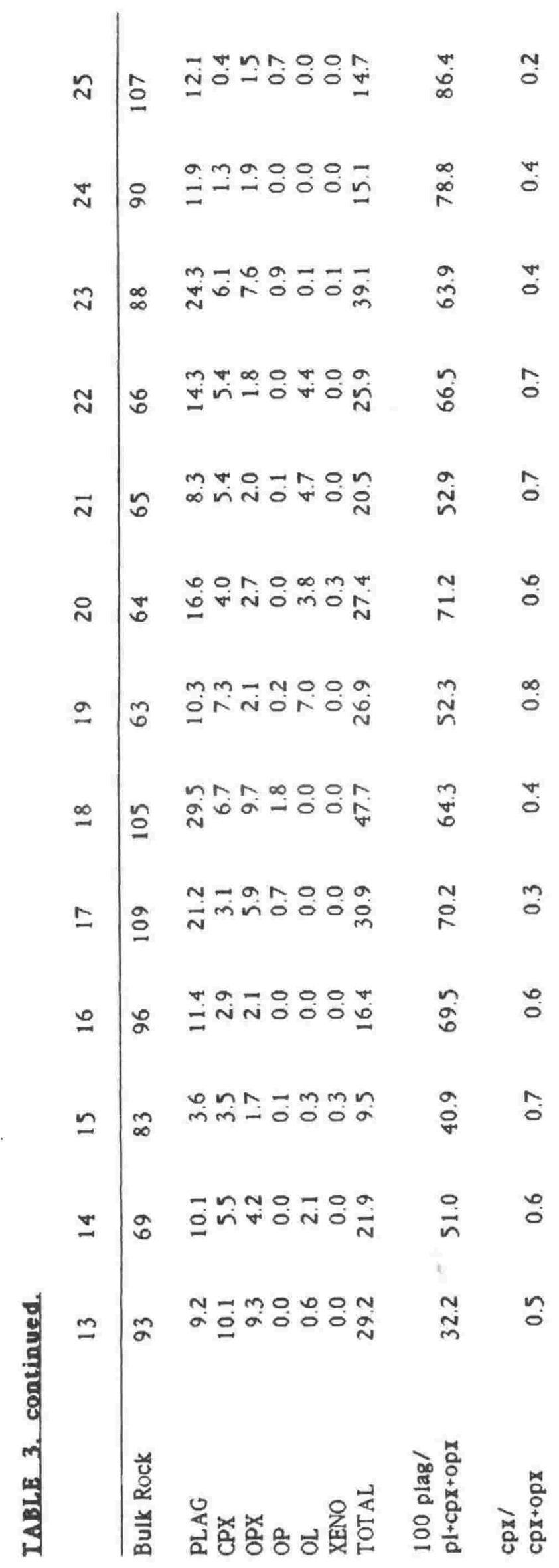




\section{WHAKAPAPA FORMATION}

Photomicrographs are presented in Fig 94 and modal data are found in Table 4. Most specimens are plagioclase + orthopyroxene + clinopyroxene + opaque oxide acid andesites, with one basic andesite and three dacites also documented. The acid andesites exhibit some of the crystalaccumulation features described for other formations, as shown in Fig 94A-G. Hypidiomorphic- granular fragments of websterite, gabbro and anorthosite are common in these lavas, occurring as 3-8 $\mathrm{mm}$ clusters but occasionally exceeding 1 centimetre. Olivine is rare in nodules and as discrete crystals in lavas. Opaque oxides are a ubiquitous accessory, occurring as discrete subhedral microphenocrysts, as inclusions in pyroxenes, and as a component of the nodules. Hornblende occurs as a resorbed accessory mineral in one lava (Table \&, col 7).

Petrographic features of Pinnacle Ridge Member (Fig 94D-F) are consistent with its origin as welded airfall tuff (see: $p$ 102-108). This deposit is mineralogically and texturally heterogeneous; e.g., some specimens lack olivine microphenocrysts. 


\section{FIG 94. PHOTOMICROGRAPHS FROM WHAKAPAPA FORMATION}

A. Basic andesite, upper lava field of Tama Member, $N$ Ruapehu. Phenocrysts of plagioclase, orthopyroxene, clinopyroxene and minor opaque oxide microphenocrysts are set in a hyalopilitic matrix. Nearly all plagioclase is internally fritted, with clear rims. Much spongy bronzite is present, some of it forming aggregates of large crystals. Noritic gabbro fragments (opx-cpx-plag) up to $6 \mathrm{~mm}$ are present. PPL. Field width, 4.2 $\mathrm{mm}$. References: Appendix II, analysis III; Table 4.

B. Acid andesite, Iwikau Member, exposed along Bruce Road. Phenocrysts of plagioclase, clinopyroxene, orthopyroxene and minor opaque oxide microphenocrysts are set in a pilotaxitic matrix. Most large plagioclase are internally fritted. Small gabbro fragments (centre) are commonly present in lavas of Iwikau Mbr. PPL. Field width, $4.2 \mathrm{~mm}$. References: Appendix II, analysis 117; Table 4.

C. Acid andesite, Rangataua Member, S Ruapehu. Plagioclase, orthopyroxene, clinopyroxene, and minor opaque oxide occur in a hyalopilitic matrix. Two varieties of plagioclase are present; one clear and euhedral, the other rounded and internally sieved or clouded. Gabbro fragments (not shown) are also present. Rangataua Member is the only known occurrence of amphibole- bearing igneous nodules (see: Fig $96 \mathrm{M}, \mathrm{N}, 0)$. References: Appendix II, analysis 126; Table 4.

D. Acid andesite, densely welded airfall tuff of Pinnacle Ridge Member, NW Ruapehu. Plagioclase, clinopyroxene and orthopyroxene phenocrysts with minor opaque oxides and a trace of olivine are set in an opaque, non-vesicular matrix of oxidized glass and crystallites. Olivines (ol; centre) rarely contain chrome spinel inclusions, and have orthopyroxene coronas. Gabbro fragments are common. PPL. Field width, $4.2 \mathrm{~mm}$. References: Appendix II, analysis 120; Table 4.

E. Moderately welded airfall tuff of Pinnacle Ridge Member. Irregular bands of non-vesicular, oxidized glass alternate with cryptocrystalline bands, producing a texture that appears eutaxitic in hand specimen (see: Fig 70, p 106). PPL. Field width, $4.2 \mathrm{~mm}$.

F. Weakly welded airfall tuff, basal $0.5 \mathrm{~m}$ of Pinnacle Ridge Member. Irregular vesicles $(V)$ are only partially collapsed. 
G. Acid andesite dyke of Pinnacle Ridge Member, Whakapapanui Gorge. Large, hypidiomorphic- granular anorthosite fragments $\left(A n_{80}\right)$ are the only conspicuous crystals, and the rock is interpreted as being plagioclaseaccumulative. The fragments are set in a pilotaxitic matrix with plagioclase $\left(\mathrm{An}_{80-53}\right)$, bronzite $\left(\mathrm{Mg}_{77}\right)$, augite $\left(\mathrm{Mg}_{77}\right)$ and opaque oxide microphenocrysts. XN. Field width, $4.2 \mathrm{~mm}$. References: Appendix II, analysis 118; Appendix III; Table 4.

H. Acid andesite, Tawhai Falls, NW Ruapehu. The nearly aphyric texture is atypical of Ruapehu lavas. Rare phenocrysts comprise plagioclase, with subordinate orthopyroxene and clinopyroxene. XN. Field width, $4.2 \mathrm{~mm}$. References: Appendix II, analysis 122; Table 4. 
FIG. 94.
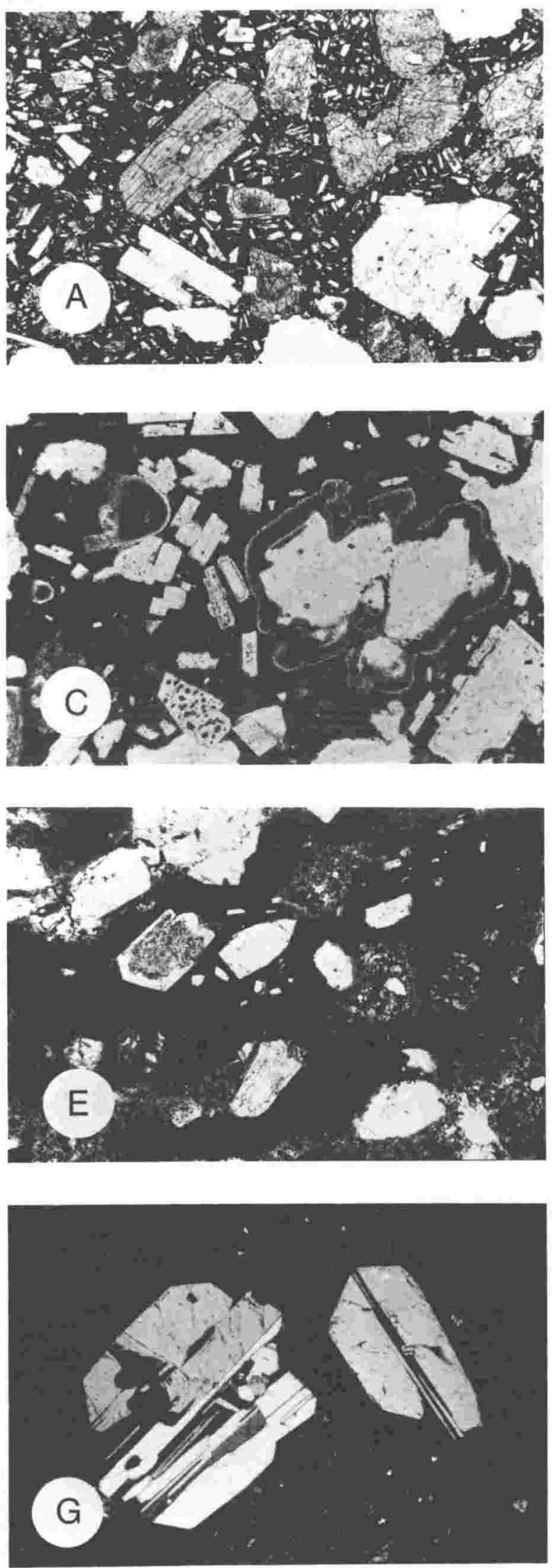
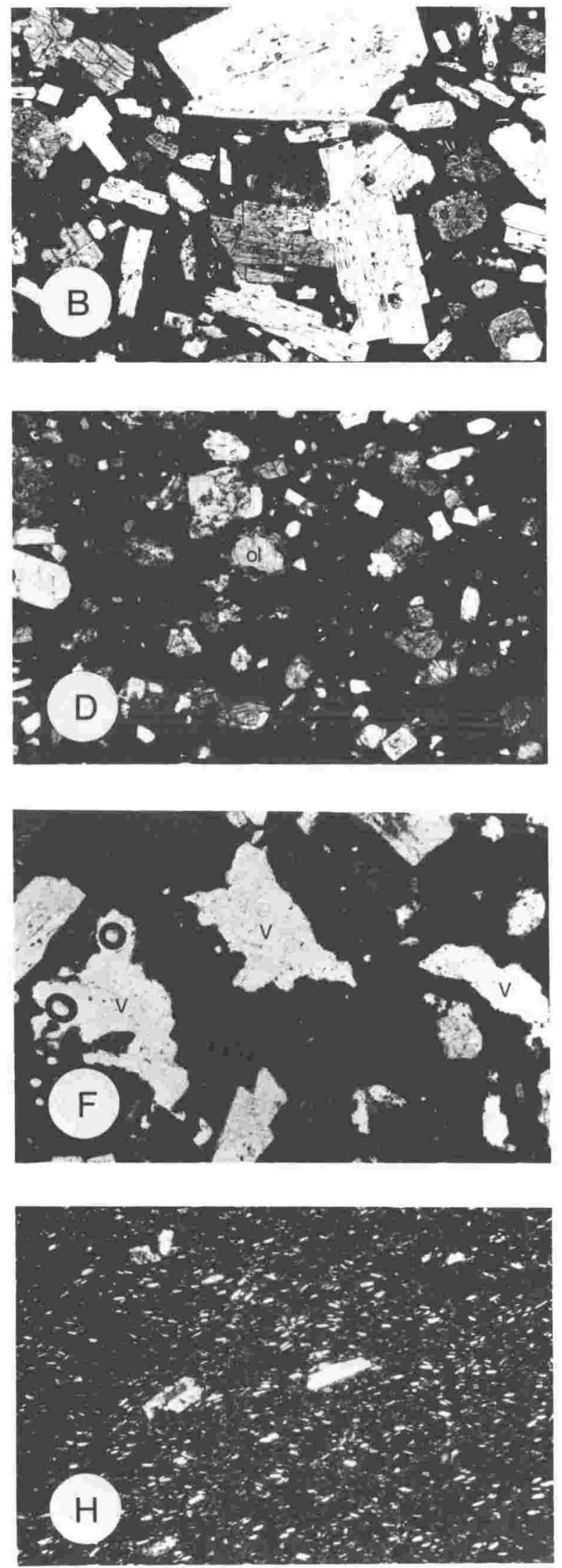


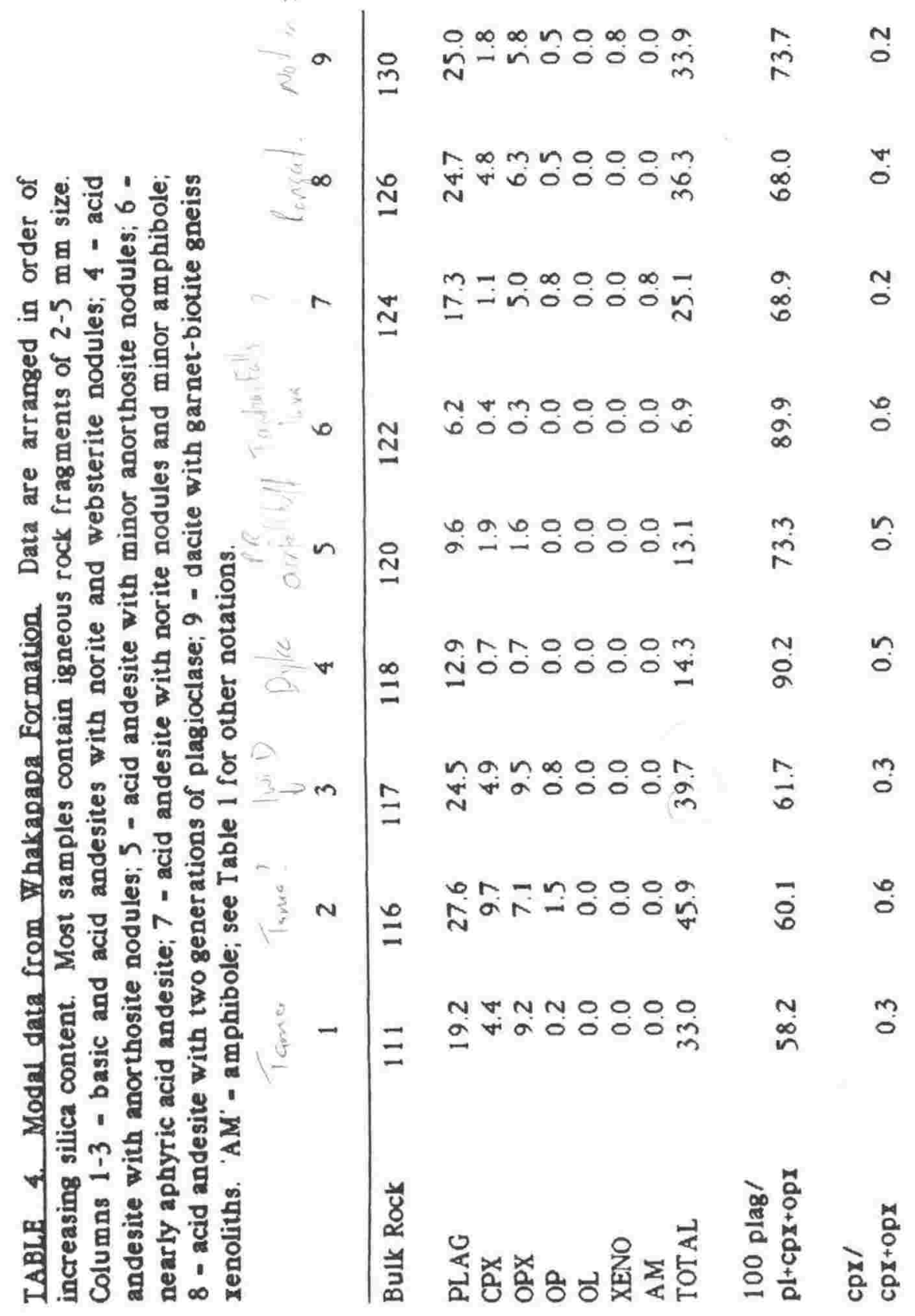




\section{LAVAS FROM SOURCES OTHER THAN RUAPEHU}

\subsection{Waimarino Basalt Formation}

Though Waimarino Basalt is not geographically related to Ruapehu, this primitive magma type is an end member for hybrid magmas that are found at Ruapehu and its satellitic vents. Waimarino Basalt has already been described in Part I, but a photomicrograph and modal data are given here as Fig 956 and Table 5, column 1.

\subsubsection{Hauhungatahi Andesite Formation}

Specimens from Hauhungatahi are coarsely crystalline, as shown in Fig 95A. Clinopyroxene is present as glomerophenocrysts up to $6 \mathrm{~mm}$, where it sometimes coexists with minor orthopyroxene and olivine Orthopyroxene occurs only as small ( $<0.6 \mathrm{~mm}$ ) phenocrysts. Olivine comprises sub- to anhedral phenocrysts that seldom exceed $1 \mathrm{~mm}$. The largest grains contain chrome spinel inclusions, and many olivine grains are rimmed by clino- or orthopyroxene. Accessory opaque oxides occur as microphenocrysts. Groundmasses range from felty to intergranular, and minor zeolite is present in some specimens.

These lavas are more coarsely crystalline than those of Ruapehu, and appear to be largely free of igneous rock fragments. Some clinopyroxene accumulation is possible, on the basis of the abundant glomerophenocrysts.

\subsubsection{Pukeonake Andesite Formation}

Basic andesite lava flows and pyroclastics from Pukeonake have uniform and distinctive composition and texture. Characteristic petrographic features are shown in Fig $95 \mathrm{E}, \mathrm{F}, \mathrm{G}$. Large (up to $1.5 \mathrm{~mm}$ ) forsteritic olivine crystals and dunite nodules, with chrome spinel inclusions and orthopyroxene coronas, are a diagnostic petrographic 
feature. Clinopyroxene occurs as phenocrysts up to $2 \mathrm{~mm}$ and as glomerophenocrysts; this mineral commonly has thin, clear outer mantles which are optically continuous with, but more Mg-rich than grain interiors. Two varieties of orthopyroxene are present: Large grains comprise embayed hypersthene core regions with spongy bronzite jackets, and the jackets are of ten optically discontinuous with cores. Small phenocrysts and microphenocrysts of spongy or clear bronzite form a second variety, and are normally zoned. Large plagioclase phenocrysts often contain inclusions of hypersthene and augite, and have clear bytownite jackets over clouded labradorite core regions. Titanomagnetite occurs as rare microphenocrysts and inclusions. Matrix textures vary from hyalopilitic in quenched tephra, to finely intergranular in thick lava flows.

\subsubsection{Ohakune Andesite Formation}

Basic andesite tephra from the Ohakune vents differs from Ruapehu lavas and tephra, in that plagioclase is absent as large phenocrysts and rarely exceeds $0.4 \mathrm{~mm}$ (Fig $95 \mathrm{~B}$ ). Clinopyroxene-orthopyroxene-olivine nodules up to $8 \mathrm{~mm}$ are conspicuous, comprising several percent of hand specimens. Large forsteritic olivines in these nodules commonly contain chrome spinel inclusions and are partially mantled by orthopyroxene. The groundmass assemblage comprises plagioclase, clinopyroxene, orthopyroxene, opaque oxides and olivine $\left(\mathrm{F}_{75}\right)$ microlites in brown, microvesicular, silicic glass.

\subsubsection{Core of Lahar Mound, State Highway 48. NW Ruapehu}

Lithology and genesis of the Lahar Mounds have been discussed on pages 116-120. The core of one of these mounds comprises hornblende dacite, having no known petrographic or compositional equivalent from Ruapehu Massif. Textural features are shown in Fig 95 C,D, and modal data 
are given in Table 5, column 5 .

Phenocrysts are plagioclase, brown hornblende and minor titanomagnetite microphenocrysts. Some hornblendes reach several millimetres and can be distinguished in hand specimens. Ferrohypersthene crystals are present (Fig $95 \mathrm{D}$ ), and hypersthene jackets suggest these are xenocrysts. 


\section{FIG. 95. PHOTOMICROGRAPHS OF NON-RUAPEHU LAVAS}

A. Olivine-bearing basic andesite lava flow, Hauhungatahi. The coarse texture is typical of lava flows from Hauhungatahi. Phenocrysts of plagioclase (An $89-69$ ), clinopyroxene $\left(\mathrm{Mg}_{84}\right)$, orthopyroxene $\left(\mathrm{Mg}_{84-76}\right)$, olivine $\left(\mathrm{F}_{87-81}\right)$ and opaque oxide microphenocrysts are set in a sparse intergranular matrix with minor zeolite. PPL. Field width, $4.2 \mathrm{~mm}$. References: Appendix II, analysis 135; Appendix III, bulk rock 133; Table 5 .

B. Olivine-bearing basic andesite, Ohakune vents. Large (to $4 \mathrm{~mm}$ ) aggregates of augite ( $\left.\mathrm{cpx} ; \mathrm{Mg}_{84-82}\right)+$ bronzite (opx; $\left.M g_{83-80}\right)+$ olivine $\left(01 ; \mathrm{F}_{88}-85\right)+$ chrome spinel are set in a hyalopilitic matrix. Groundmass contains plagioclase $\left(\mathrm{An}_{78-68}\right)$, orthopyroxene $\left(\mathrm{Mg}_{76}\right)$, clinopyroxene $\left(\mathrm{Mg}_{72}\right)$ and minor olivine $\left(\mathrm{F}_{78}\right)$. XN. Width, $4.2 \mathrm{~mm}$. References: Appendix II, analysis 137; Appendix III; Table 5.

C. Hornblende dacite, core of Lahar Mound on Highway 48. Phenocrysts of plagioclase $\left(\mathrm{An}_{44-40}\right)$, orthopyroxene $\left(\mathrm{Mg}_{70}\right)$, clinopyroxene $\left(\mathrm{Mg}_{73}\right.$ ), brown hornblende (circled; $\mathrm{Mg}_{60}$ ) and opaque oxide microphenocrysts are set in a felsitic matrix. PPL. Width, $4.2 \mathrm{~mm}$. References: Appendix II, analysis 144; Appendix III; Table 5.

D. Same rock as (C), but enlarged to show rare ferrohypersthene (fhy; $\mathrm{Mg}_{43}$ ) with hypersthene jacket (hy; $\mathrm{Mg}_{60}$ ) and a few opaque oxide grains. PPL. Field width, $0.6 \mathrm{~mm}$.

E. Olivine-bearing basic andesite, glassy tephra of Pukeonake Scoria Cone. Phenocrysts comprise clinopyroxene, orthopyroxene, plagioclase and olivine in a hyalopilitic matrix. Plucked dunite nodule $\left(\mathrm{Fo}_{94-87}\right)$ with chrome spinel inclusions and bronzite corona at right. Embayed plagioclase $\left(A n_{56-52}\right)$ at upper left. Hypersthene $\left(M_{70}\right)$ with acid glass inclusions and spongy bronzite jacket $\left(\mathrm{Mg}_{83}\right)$, lower left. PPL. Field width, $4.2 \mathrm{~mm}$. References: Appendix II, analysis 136; Appendix III, bulk rock 139; Table 5. 
F. Same rock as (E), showing characteristic textures of phenocrysts, considered to have resulted from magma mixing. Embayed and euhedral plagioclases at left. Mantled clinopyroxene with M977-70 core and $\mathrm{Mg}_{84-79}$ rim zone, at lower centre. Jacketed orthopyroxene with embayed hypersthene core and spongy bronzite mantle, upper right. Numerous euhedral bronzite microphenocrysts $\left(\operatorname{Mg}_{87-70}\right)$ are also present. $\mathrm{XN}$. Field width, $4.2 \mathrm{~mm}$.

G. Lava of Waimarino Basalt Formation. Phenocrysts are forsteritic olivine ( $\left.\mathrm{Fo}_{92}-74\right)$ with chrome spinel inclusions, and clinopyroxene (Mg $86-82)$ in a hyalopilitic matrix. PPL. Field width, $4.2 \mathrm{~mm}$. References: Appendix II, analysis 132; Appendix III; Table 5. 
FIG. 95.

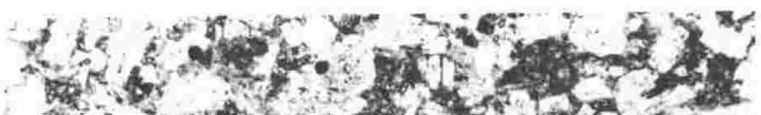

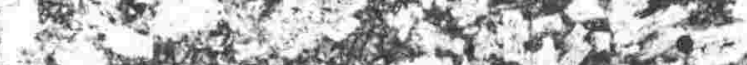

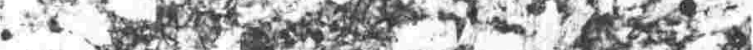

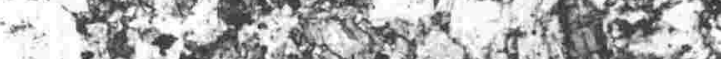

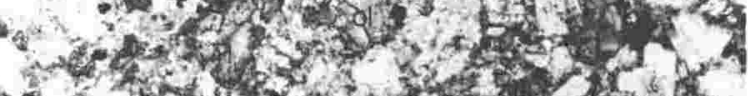

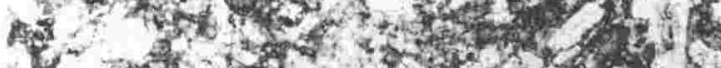

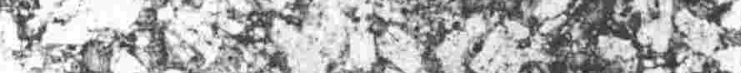

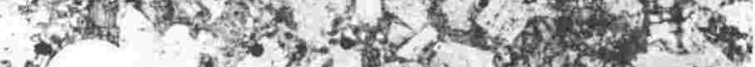

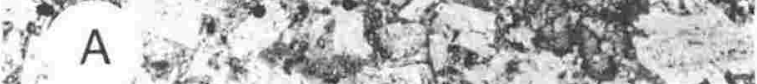

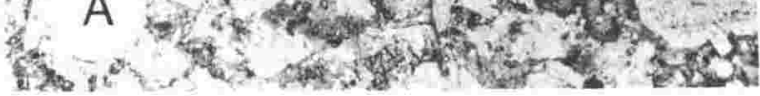
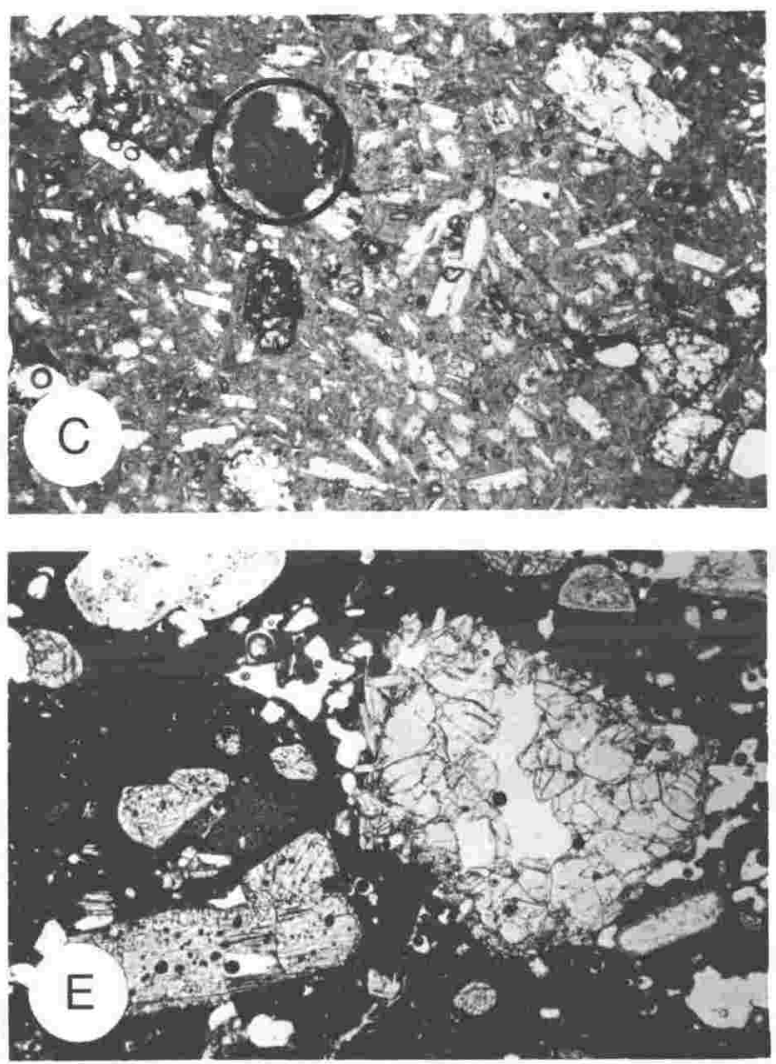
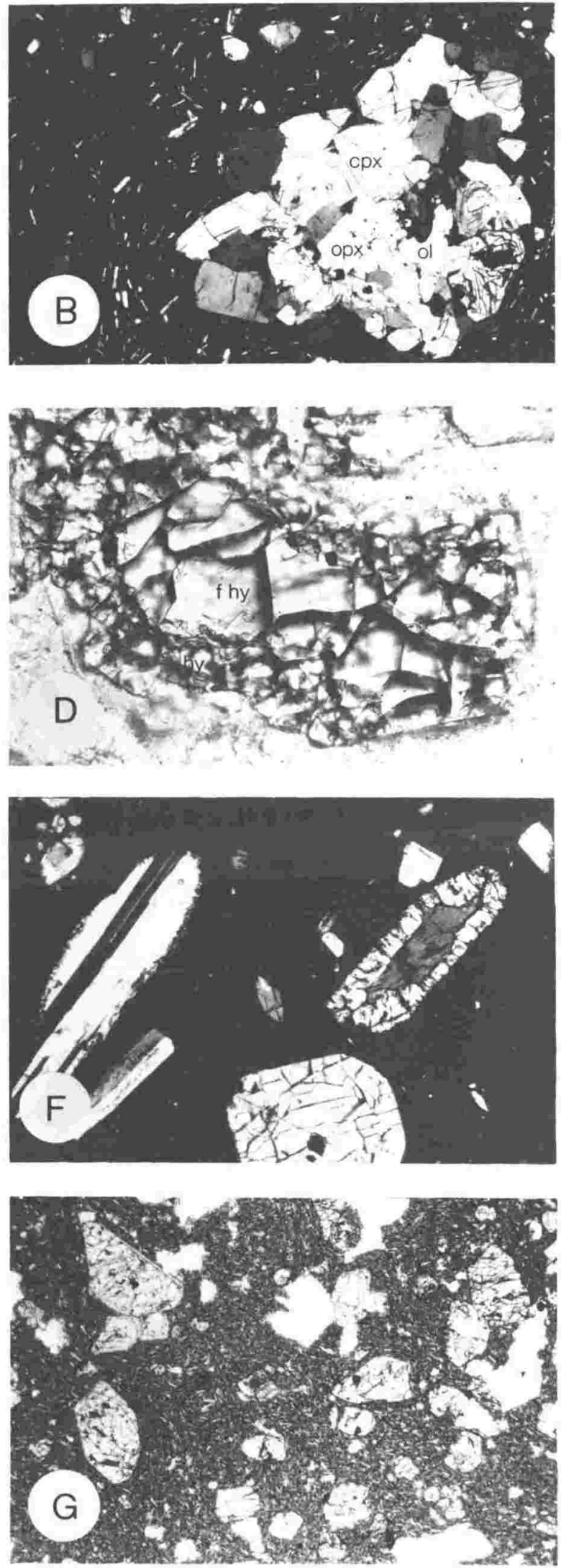


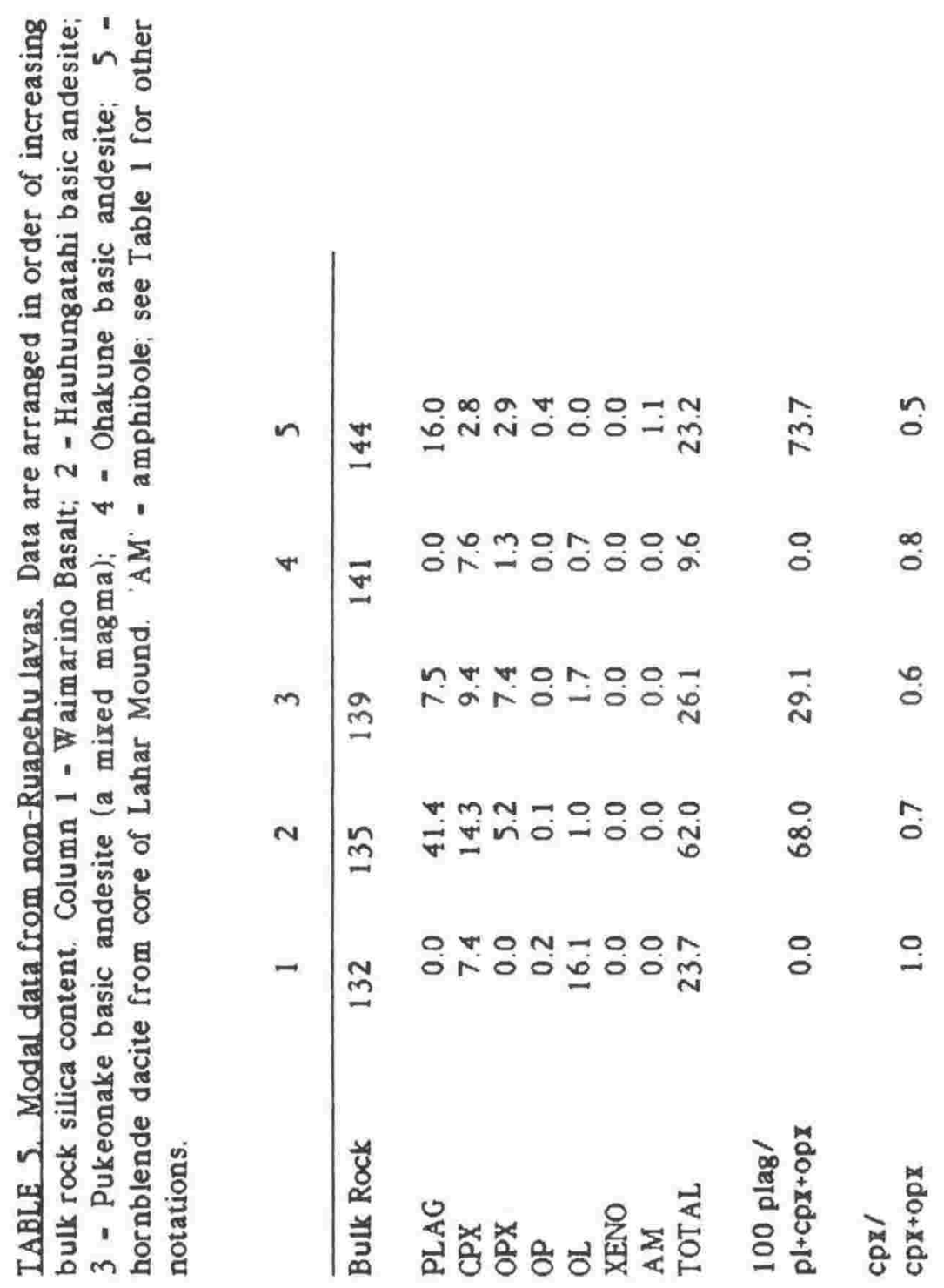




\subsection{IGNEOUS NODULES}

Numerous examples of millimetre-sized "glomerophenocrysts" and "grain aggregates" of three or more crystals have been shown in Figs 91-95. These comprise a significant proportion of the phenocryst assemblage in many specimens, and they can exert major control on plagioclase: pyroxene and clinopyroxene: orthopyroxene ratios, as well as total phenocryst content. The 2-5 mm fragments almost certainly represent smaller equivalents of centimetre-sized igneous nodules derived from magma freezing or crystal accumulation in the subvolcanic or plutonic environment.

Nodules are defined by the present writer as igneous-appearing rock fragments. Diagnostic criteria for deducing igneous origin include hypidimorphic- granular rock texture, together with oscillatory zonation of constituent minerals. Many inclusions have an overall metamorphic appearance, with xenoblastic to poikiloblastic textures, but if relict igneous textures are locally preserved, the present writer considers them to be igneous nodules in spite of the fact that they have undergone slight metamorphism. Thus, there is some textural overlap between rock fragments that are called igneous nodules and those that are called metamorphic xenoliths (section II-2.7).

The photomicrographs of Fig 96 illustrate the textural and mineralogical diversity of nodules. The textural effects of thermal metamorphism and cataclasis are apparent in Figs $96 \mathrm{E}, \mathrm{G}, \mathrm{H}, \mathrm{I}, \mathrm{J}$, the major consequences being local development of xenoblastic texture, destruction of oscillatory zonation, and formation of aluminous spinel and glass. Other nodules are largely unaf fected by metamorphism (e.g., Figs 96A,C).

Nodules have diverse mineral assemblages comprising dunite (Fig 95E), harzburgite (Fig 96K,L), pyroxenites (Figs 92I, 93I, 95B), websteritic to anorthositic gabbros and diorite (Fig 96A-J), and anorthosite (Figs 92B, 
93J, 946). Nodules with amphibole ( $\mathrm{Fig} 96 \mathrm{~N}, 0$ ) occur at only one locality.

The plagioclase + orthopyroxene + clinopyroxene + opaque oxide diorite nodules with interstitial glass probably represent liquid compositions, since their mineralogy and mineral proportions are comparable to the basic andesite hypabyssal intrusions: Compare Figs $91 \mathrm{E}$ and 96A. Nodules dominated by one mineral (anorthosites, websteritic gabbros, hornblendites) are almost certainly crystal cumulates from basic to acid andesite parent magmas.

Igneous lamination, as would be shown by alignment of tabular plagioclase and orthopyroxene, is absent in these nodules (except for Fig $96 \mathrm{~K}$, harzburgite), suggesting that gravitative settling of crystals to form rhythmically layered cumulates was not a common process. More likely, draughts of basaltic to acid andesitic magma were injected along highangle normal faults of the upper crust. Magma batches could nucleate crystals onto conduit walls, producing variolitic textures (Fig 96B), could become sheared after solidification ( $F$ ig $96 \mathrm{H}$ ), and could be filter-pressed to yield gabbroic rocks with little interstitial residuum. Repeatedly occupied, vertical, planar conduits would also imply high surface area to volume ratios for magma batches in the upper crust, providing opportunity for thermal alteration and entrainment of country rocks.

Especially noteworthy is the occurrence of peridotite nodules (Figs 95B,E; 96K,L), which are rarely associated with calc- alkaline volcanics. These nodules are found in basic andesite tephra and lava flows from Pukeonake, where they comprise abundant millimetre- sized fragments, and rarely reach centimetre size. Primary minerals in these peridotites are refractory, suggesting that they are upper mantle fragments or cumulates from primitive basaltic magma. 


\section{EJG 96. PHOTOMICROGRAPHS OF IGNEOUS NODULES}

A. Diorite in dacite host lava, Mangawhero Formation, $N$ Ruapehu. Labradorite $\left(\mathrm{An}_{57}\right)$, hypersthene $\left(\mathrm{Mg}_{64}\right)$, minor augite $\left(\mathrm{Mg}_{68}\right)$, rare titanomagnetite and ilmenite, and interstitial brown glass are present. PPL. Field width, $4.2 \mathrm{~mm}$. References: Host rock in Appendix II, analysis 105; nodule minerals in Appendix IV.

B. Gabbro in acid andesite lava of Iwikau Member, NW Ruapehu. Plagioclase, orthopyroxene, clinopyroxene and minor opaque oxides comprise this hypidiomorphic- granular nodule. Plagioclase and orthopyroxene locally form variolitic textures, with interstitial xenomorphic- granular plagioclase, pyroxenes and oxides. XN. Field width, $4.2 \mathrm{~mm}$. Reference: Host rock is Appendix II, analysis 114 .

C. Websteritic gabbro in acid andesite lava of Iwikau Member, NW Ruapehu. The mineral assemblage is clinopyroxene + orthopyroxene + plagioclase. PPL. Field width, $4.2 \mathrm{~mm}$. Reference: Host rock is Appendix II, analysis 114 .

D. Coarse clinopyroxene + plagioclase gabbro in acid andesite of Wahianoa Formation. PPL. Field width, $4.2 \mathrm{~mm}$. Reference: Host rock is Appendix 11 , analysis 143 .

E. Gabbro nodule in stream boulder derived from I wikau Member, NW Ruapehu. Minerals are plagioclase, orthopyroxene, clinopyroxene and opaque oxide. Textures range from coarse hypidiomorphic- granular to fine xenomorphic- granular. In the latter situation, recrystallized pyroxenes poikilitically enclose opaque oxides. Interpreted as an incipiently metamorphosed gabbro, since igneous textures are preserved. Crossed nicols (XN). Field width, $4.2 \mathrm{~mm}$. No cross-references.

F. Gabbro nodule in welded airfall tuff, Pinnacle Ridge Member, NW Ruapehu. Plagioclase, two pyroxenes and opaque oxides comprise this hypidiomorphic- granular fragment. PPL. Field width, $4.2 \mathrm{~mm}$. References: Host rock is Appendix II, analysis 120.

G. Anorthositic gabbro from acid andesite lava flow, Iwikau Member, NW Ruapehu. Subhedral bytownite $\left(A n_{77}\right)$ is the dominant mineral, with lesser bronzite $\left(\mathrm{Mg}_{76}\right)$, augite $\left(\mathrm{Mg}_{78}\right)$ and opaque oxide (not analyzed). Oxides are poikilitically encased in plagioclase and pyroxenes. XN. Field width, $4.2 \mathrm{~mm}$. References: Host rock is Appendix II, analysis 117; mineral analyses from nodule in Appendix IV. 
H. Sheared gabbro from Te Herenga Formation lava flow, NW Ruapehu. Most of the rock exhibits mortar texture, and is a dense mass of finely comminuted pyroxenes and plagioclase (upper left half of photo). Large sheared plagioclase (not analyzed), clinopyroxene $\left(\mathrm{Mg}_{82}\right)$ and orthopyroxene $\left(\mathrm{Mg}_{76}\right)$ are locally present (lower right of photo). References: Bulk nodule in Appendix II, analysis 172; minerals from nodule in Appendix IV.

I. Gabbro nodule from tephra of Pukeonake Scoria Cone. Local xenomorphic- granular patches are present (circled) in this plagioclasetwo pyroxene- opaque oxide rock. Interpreted as a weakly metamorphosed gabbro. XN. Field width, $4.2 \mathrm{~mm}$. No cross-references.

J. Diorite from tephra of Pukeonake Scoria Cone. The rock comprises labradorite $\left(\mathrm{An}_{58}\right)$, hypersthene $\left(\mathrm{Mg}_{69}\right)$, augite $\left(\mathrm{Mg}_{69}\right)$ and Al-Fe-Mg spinel. Textures include coarse hypidiomorphic- granular, fine xenomorphic-granular, and plagioclase poikilitically enclosing pyroxenes and spinel. Anhedral spinel (circled) is hercynite. Interstitial pools of brown silicic glass ( $\mathrm{gl} ; 62 \% \mathrm{SiO}_{2}$ ) are present. The rock is probably a metamorphosed diorite. PPL. Field width, $4.2 \mathrm{~mm}$. Reference: Appendix IV, analyses $136-3,6,8,9,11$.

K. Harzburgite nodule from tephra of Pukeonake Scoria Cone. Olivine $\left(\mathrm{ol} \mathrm{Fo}_{88}\right)$ comprises most of the rock. Irregular bands of orthopyroxene (opx; $\left.\mathrm{Mg}_{87}\right)$, and rare clinopyroxene $\left(\mathrm{Mg}_{84}\right)$ are present. Chrome spinel is an accessory. Rare inclusions of plagioclase $\left(A_{70}\right)$ are present in olivine. Veins of aluminous, intermediate $\left(54 \% \mathrm{SiO}_{2}\right)$, pale brown vesicular glass are present. Origin is uncertain. Coexisting olivine and plagioclase require pressure $<9 \mathrm{~kb}$; the rock is either depleted plagioclase peridotite of upper mantle origin, or a cumulate from basaltic magma that crystallized orthopyroxene as well as olivine. PPL. Field width, $4.2 \mathrm{~mm}$. Reference: Appendix IV, analyses 136$1,6,9,10,16,17,38,50,59$.

$\mathrm{L}$. Same rock as (K), showing vein of vesicular glass ( $\mathrm{gl} ; 54 \% \mathrm{SiO}_{2}$ ) with euhedral $\mathrm{Cr}-\mathrm{Fe}-\mathrm{Mg}-\mathrm{Al}$ spinel (picotite). The chrome spinel in glass is overgrown by, and coexists with, rare discrete euhedra of Al-Mg-Fe spinel. The aluminous spinel is a crystallization product of the glass, whereas the chrome spinel has similar composition to inclusions in olivine and is probably a residual phase after partial melting of the host rock. PPL. Field width, $0.6 \mathrm{~mm}$. 
M. Norite from lava flow of Rangataua Member, South Ruapehu. The rock comprises bytownite $\left(\mathrm{An}_{87}\right)$, bronzite $\left(\mathrm{Mg}_{75}\right)$ and minor augite $\left(\mathrm{Mg}_{80}\right)$, with a trace of pargasitic hornblende $\left(\mathrm{Mg}_{71}\right)$, brown silicic glass $\left(68 \% \mathrm{SiO}_{2}\right)$ and pyrrhotite (conf irmed by EPMA but analysis not reported). Hornblende is present only as $0.1-0.3 \mathrm{~mm}$ anhedral inclusions in orthopyroxene. Rangataua Member contains the only known hornblende- and pyrrhotite-bearing igneous nodules. PPL. Field width, $2.3 \mathrm{~mm}$. References: Bulk nodule in Appendix II, analysis 167; mineral analyses in Appendix IV.

$N$. Same rock as (M), enlarged to show hornblende inclusion (am; circled) in bronzite. PPL. Field width, $0.3 \mathrm{~mm}$.

0. Igneous amphibolite nodule from Rangataua Member. Pargasitic hornblende $\left(\mathrm{Mg}_{67}\right)$ poikilitically encloses bytownite $\left(\mathrm{An} \mathrm{n}_{79}\right)$, bronzite $\left(\mathrm{Mg}_{70}\right)$ and ilmenite, and is surrounded by strongly oxidized, pseudo-opaque glass $\left(\begin{array}{lll}68 & \mathrm{SiO}_{2}\end{array}\right)$. The glass contains plagioclase and pyroxene microphenocrysts. This nodule has the same mineralogy as rock (M), but hornblende is much more abundant, and the ferromagnesian crystals are slightly more iron-rich. Reference: Appendix IV, analyses $167-3,4,6,9,11,12,17$. 
FIG. 96 .
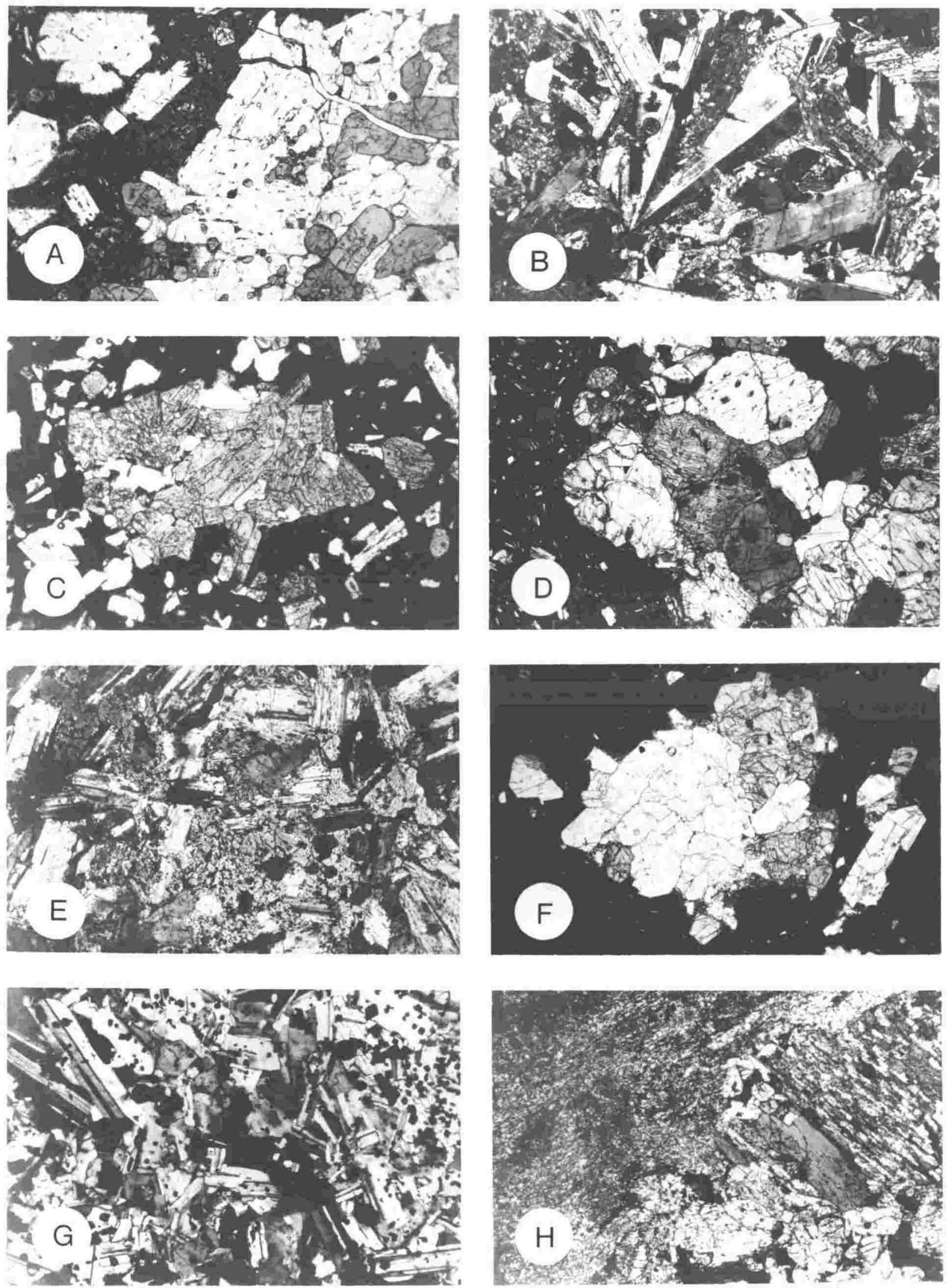
FIG. 96.

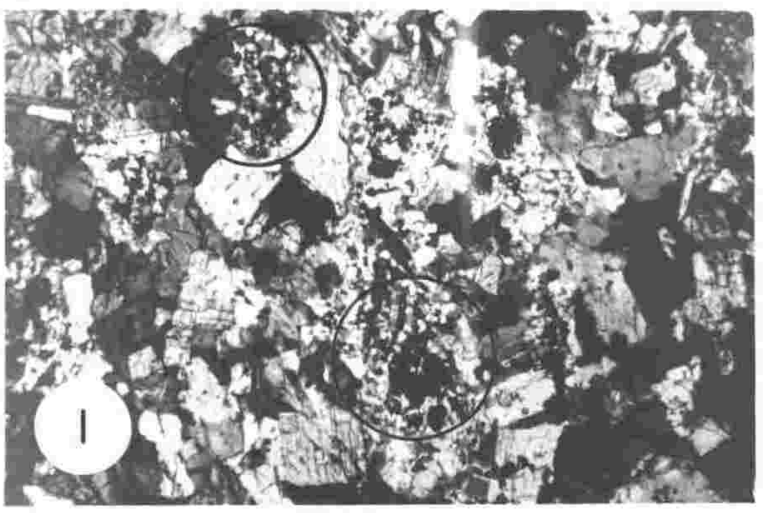

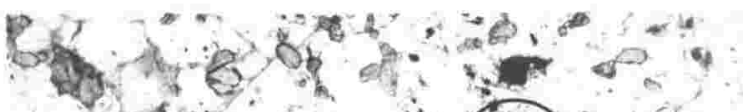

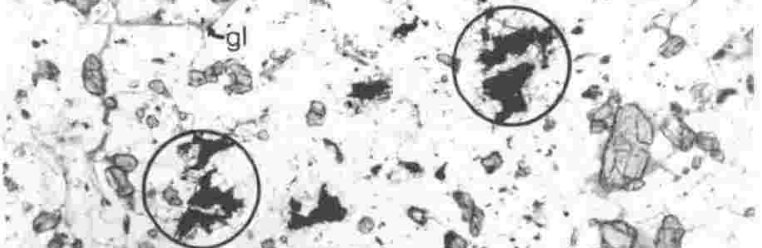

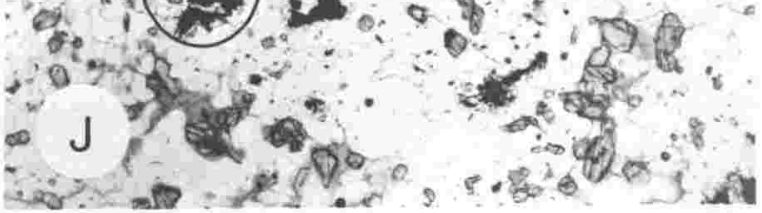
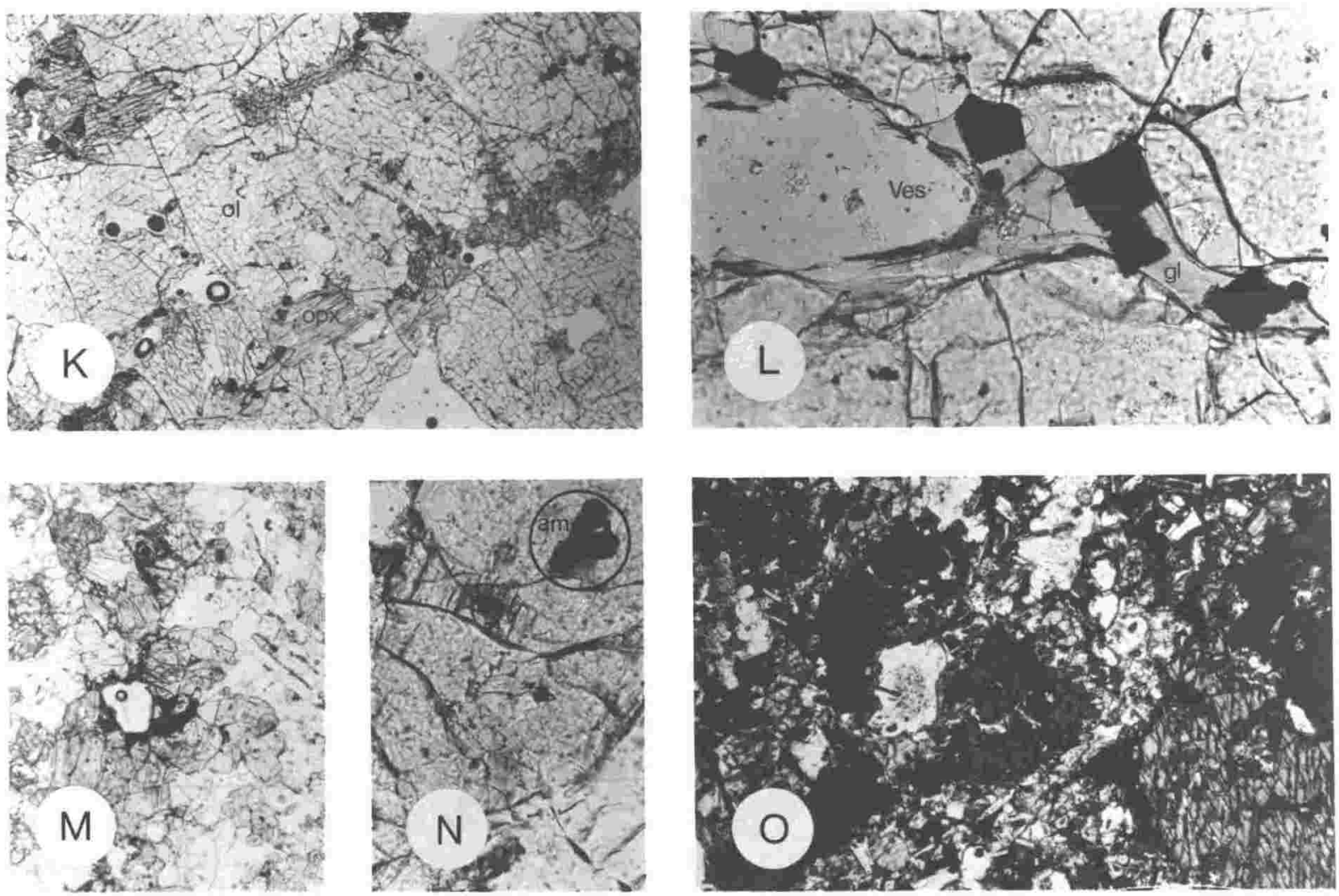


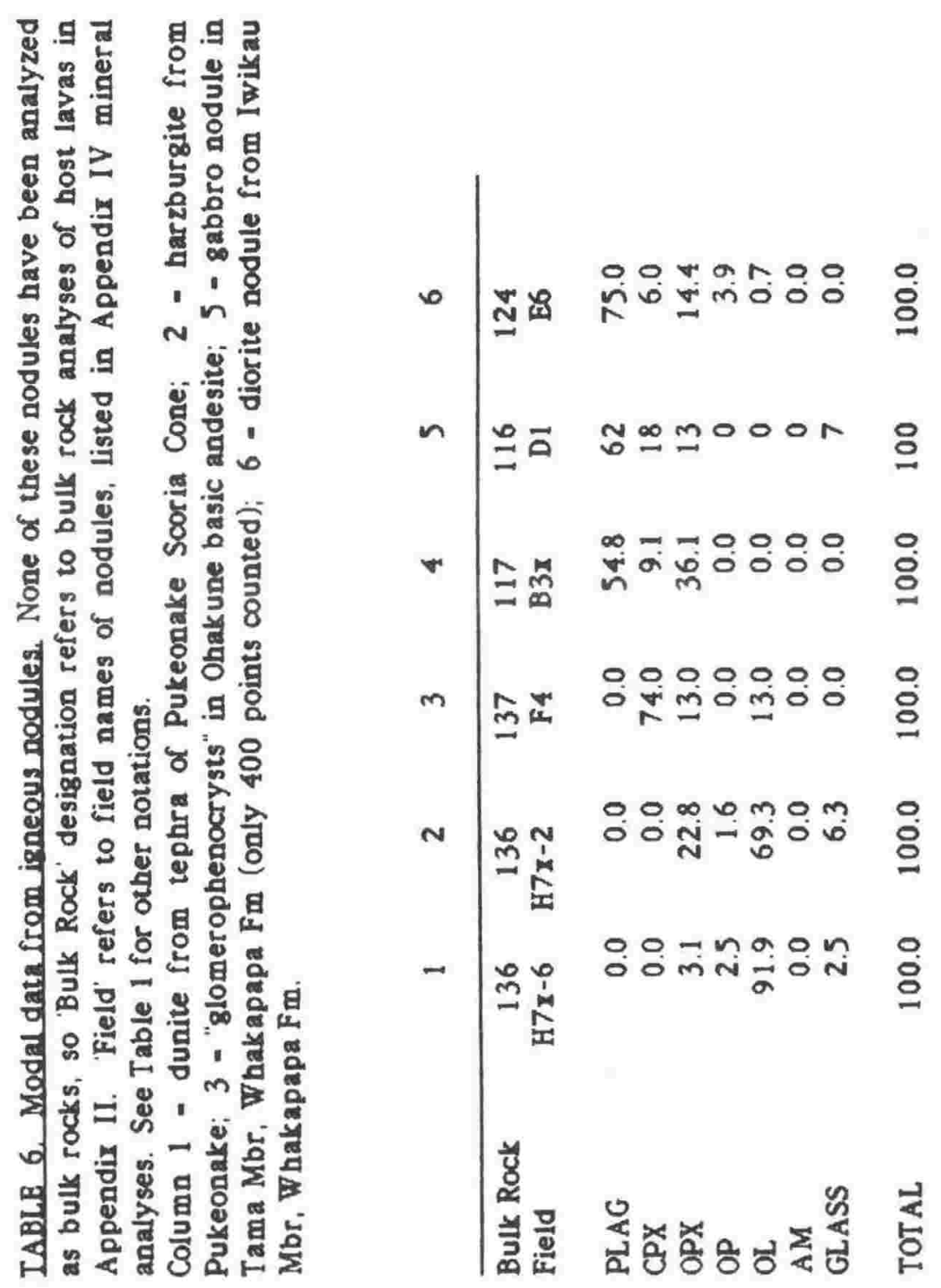




\subsection{METAMORPHIC XENOLITHS}

\subsubsection{Introduction}

Metamorphic xenoliths are rock fragments derived from the subvolcanic basement. Excluded in the present discussion are igneous nodules with recognizable hypabyssal or plutonic igneous textures, even though these are often partially overprinted by metamorphism. Metamorphic xenoliths are ubiquitous in lava flows and pyroclastics of Ruapehu and related vents. They are conspicuous in outcrop and generally range from 0.5 to $3 \mathrm{~cm}$ in size, although blocks of greywacke up to $70 \mathrm{~cm}$ have been found. Xenoliths are texturally and mineralogically diverse, reflecting a variety of metamorphic conditions and protoliths.

\subsubsection{Petrography and Mineralogy}

Photomicrographs are given in Fig 97 . Xenoliths comprise both foliated and non- foliated metamorphic rocks with textures of regional and contact metamorphism. Many have been strongly overprinted by pyrometamorphism during transport in host magmas, as shown by breakdown of biotite and garnet, and the presence of silicic glass and accessory sanidine in some specimens. Discussion is given by listing specif ic rock types and referring to the photomicrographs.

Metaquartzites (Fig 97A) are nearly monomineralic rocks, but biotite is present in variable quantities. Biotite gneisses of ten have quartzose bands, suggesting a genetic link between quartzites and gneisses. When biotite is abundant in quartzites, it forms irregular decussate bands, and is of ten associated with Al- Fe spinel and hematite, or rarely with alkali feldspar.

Hornfelses are finely xenomorphic-granular rock fragments of basic to intermediate composition, with light to medium grey colour and ranging in size from 0.5 to $1.5 \mathrm{~cm}$. Two varieties are present. The first is basic 
to intermediate in bulk composition (see: section III-6.3 and Fig 121 for discussion of xenolith bulk compositions) and is dominated by anhydrous minerals comprising poikiloblastic to xenoblastic andesine-labradorite, hypersthene with up to 6 wt \% Al203, minor Al-Fe spinel, titanomagnetite, ilmenite, clinopyroxene and apatite, and rare alkali feldspar. Quartz is absent. Mineralogically, these rocks vary from norites and gabbros to anorthosites (Fig 97 B,C). Many have been affected by pyrometamorphism, with crystals floating in pale brown silicic glass.

The second hornfels type is more aluminous and silica- poor in bulk composition, and contains almandine- pyrope garnet, anhedral cordierite with traces of fibrolite inclusions, Al-Fe spinel, and oligoclase (Fig $97 \mathrm{~F}$ ). Titaniferous biotite and traces of alkali feldspar are sometimes present.

Biotite- plagioclase- spinel schists and gneisses (Fig $97 \mathrm{G}, \mathrm{H}$ ) comprise brick red to dark grey fragments up to 8 centimetres. Essential minerals are titaniferous biotite, andesine which is of ten reversely zoned up to $10 \mathrm{~mol} \%$, and $\mathrm{Al}-\mathrm{Fe}$ spinel, where the latter mineral is locally a product of biotite breakdown. Other minerals that are commonly but not always present include: Quartz, garnet with opacite and hypersthene coronas, cordierite, sanidine, aluminous hypersthene, apatite, ilmenite, hematite, graphite, and silicic glass. Hypersthene is present in nearly all specimens, both as discrete grains and as partial coronas on almandinepyrope garnet. In spite of the presence of biotite, most specimens are only weakly foliated, due to the decussate texture of this mineral. Contorted, macroscopic banding is developed by alternating biotite- spinel- (garnetcordierite- hypersthene) and andesine- quartz- (sanidine- hypersthene) layers. Specimens with sanidine and glass do not contain cordierite.

Low- grade metagreywackes have outcrop equivalents in the surrounding main ranges of North Island. Some specimens are mylonitic (Fig $97 \mathrm{D}$ ) and unaffected by pyrometamorphism. The mineral assemblage is chlorite, quartz, albite, muscovite and epidote. Millimetre- wide veins 
of finely granoblastic quartz are common.

Tertiary siltstones (Fig $97 \mathrm{E}$ ) are found only at the Ohakune vents, where they comprise yellow- orange porcellanite blocks in volcanic ejecta. Sintering of the clay matrix has occurred, and the blocks were almost certainly entrained from shallow levels since Tertiary sediments form outcrops near the Ohakune vents.

Hydrothermally altered andesites (not illustrated), though not derived from the subvolcanic basement, are described here. They form yellow- brown, centimetre- sized blocks in lava flows and pyroclastics. Many blocks are flinty, due to sintering of their clay- rich matrices. Pyroxene and plagioclase phenocrysts are replaced by clays, leaving a relict porphyritic texture. Microscopically, these rocks are structureless masses of greenish- brown or pale tan clay, with minor disseminated white mica and sulfides.

\subsubsection{Relative Abundances and Stratigraphic Trends}

Xenoliths are ubiquitous and are found in all eruptive units, regardless of stratigraphic position. They approach $1 \%$ of some lava flows, as judged by visual inspection of planar outcrop faces, but most flows contain only 10-20 millimeter- to centimeter- sized fragments per 10 square metres of surface. White, saccharoidal quartzites are the most conspicuous and probably also the most abundant variety. Nearly equal to these, though generally smaller and less conspicuously grey-coloured, are the fine grained pyroxene hornfelses with intermediate plagioclase as the dominant mineral. All other types are rare. Of these, the most abundant are cordierite- garnet hornfelses and biotite- plagioclase- (quartzgarnet) gneisses.

Quartzites and feldspathic hornfelses exist at all stratigraphic levels, but gneiss fragments have not been found in Te Herenga Formation (earliest cone-building period) and they seem to be more common with 
increasing stratigraphic height. Quartzose and gneissic fragments achieve maximum abundance in a coarse airfall deposit of Iwikau Member (youngest eruptive period; see p. 109). The Whakapapa Skifield is a prime area for collecting, where lava flows of I wikau Member are freshly exposed in the Whakapapanui streambed and in road cuttings. 


\section{FIG 97. PHOTOMICROGRAPHS OF CRUSTAL XENOLITHS}

A. Saccharoidal quartzite, Ohakune vents, consisting of clouded, strained quartz with seriate grain boundaries. Grains are elongate and of varied sizes. Some quartzites contain significant amounts of biotite, suggesting a genetic link to schists and gneisses. Many specimens have clear, interstitial glass. Quartzites are the most abundant xenolith type. Crossed nicols $(X N)$. Field width, $1.7 \mathrm{~mm}$. References: Appendix II, analysis 184.

B. Coarse pyroxene hornfels, from lava flow of Iwikau Member, NW Ruapehu. This xenoblastic rock contains andesine-labradorite, hypersthene, augite and opaque oxide, and is probably a metamorphosed igneous rock. Pyroxene hornfelses are the second most abundant xenolith type, ranging from norites to anorthosites. Plane polarized light (PPL). Field width, $4.2 \mathrm{~mm}$. Reference: Appendix II, analysis 170.

C. Banded pyroxene hornfels, Iwikau Member, NW Ruapehu. This fine xenoblastic rock comprises labradorite, aluminous bronzite, titanomagnetite, Al-Fe spinel, and minor titaniferous biotite and alkali feldspar. PPL. Field width, $4.2 \mathrm{~mm}$. Reference: Appendix $\mathrm{V}$, under field name "B3x".

D. Metagreywacke, $70 \mathrm{~cm}$ block in I wikau Member pyroclastics, high northern slopes of Ruapehu. The rock has the same mineral assemblage (chlorite- quartz- albite- muscovite- epidote) and cataclastic texture as greenschist facies metagreywackes from the Kaimanawa Range to the east of Ruapehu. PPL. Field width, $4.2 \mathrm{~mm}$. References: Appendix II, analysis 181; Appendix $V$, under field name "NI12C".

E. Tertiary siltstone, in e jecta from Ohakune vents. Clouded grains of clastic quartz are set in a matrix of partially fused clay. Blocks of Tertiary sediment are rare on Ruapehu but are common at the Ohakune vents, where they have been baked to yellow- orange porcellanites. XN. Field width, $1.7 \mathrm{~mm}$. No cross- references.

F. Hornfels inclusion from accessory lithic block of Ruapehu andesite, contained in ejecta from Ohakune vents. The rock contains xenoblastic oligoclase, cordierite (cord), aluminous ferrohypersthene $(o p x), A l-F e$ spinel, and almandine- pyrope garnet. The garnet has opacite and orthopyroxene coronas. PPL. Field width, $1.7 \mathrm{~mm}$. Reference: Appendix $\mathrm{V}$, under field name " $\mathrm{XC}$ ". 
G. Gneiss fragment in microperlitic dacite block, N Ruapehu. The rock is irregularly banded, with decussate titaniferous biotite and $\mathrm{Al}-\mathrm{Fe}$ spinel bands (left) alternating with andesine- rich xenoblastic layers (plag; right). Minor alkali feldspar and a trace of ilmenite are also present. Note garnet (gar) with corona of opacite and aluminous ferrohypersthene. PPL. Field width, $4.2 \mathrm{~mm}$. References: Host dacite is Appendix II, analysis 130; mineral analyses from xenolith in Appendix $V$, under field name "NI12A".

H. Gneiss, from coarse airfall tephra of Iwikau Member, upper northern slopes of Ruapehu. The rock contains quartz, titaniferous biotite, Al-Fe spinel, almandine- pyrope garnet, aluminous ferrohypersthene, sanidine, minor ilmenite, and hematite. Banding is developed by alternating quartzofeldspathic and biotite- spinel- garnet layers. PPL. Field width, $4.2 \mathrm{~mm}$. References: Appendix V, under field name "B10xi". 
FIG. 97.
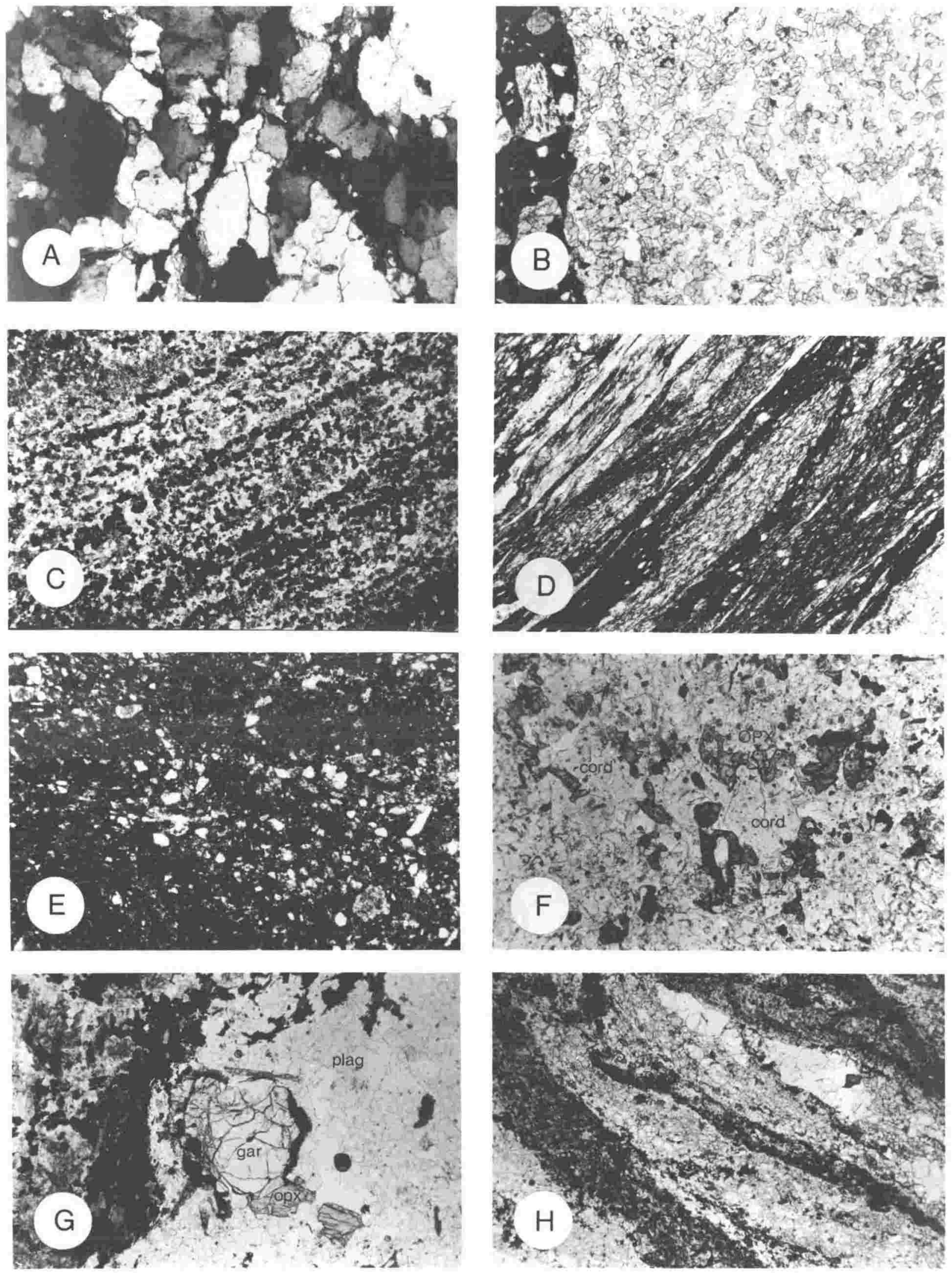


\section{SURVEY OF MINERAL CHEMISTRY IN LAVAS}

\subsection{OLIVINE}

Olivine occurs in lavas spanning the entire compositional range from basalt to dacite (Fig 98), though it exceeds $1 \%$ only in basalts and basic andesites. Together with clinopyroxene, it is an essential phenocryst in basalts (Figs 93A, 95G), and occurs as conspicuous, 1-3 mm subhedral crystals. In basalts, the cores of olivine phenocrysts are $\mathrm{F}_{85}-92$ and commonly contain chrome spinel inclusions. Olivine also occurs in the groundmass of basalts, and basic and acid andesites (Figs 91C; 93A,B,C,D,E; 95A,B,G), where it represents the final stages of crystallization during reaction with liquid:

$$
\begin{aligned}
(\mathrm{Mg}, \mathrm{Fe})_{2} \mathrm{SiO}_{4}+\mathrm{SiO}_{2} & =2(\mathrm{Mg}, \mathrm{Fe}) \mathrm{SiO}_{3} \\
\text { (olivine) })+(\text { melt }) & =\text { (orthopyroxene) } .
\end{aligned}
$$

Where olivine-liquid reaction has formed orthopyroxene in basic andesites, the forsterite content of olivine phenocryst rims equals the appropriate enstatite content of orthopyroxene cores, according to the olivineorthopyroxene equilibrium study of Medaris (1969). Olivine crystallization is terminated at forsterite contents ranging from $\mathrm{Fo}_{68}$ to $\mathrm{F}_{82}$, in groundmass liquids of bulk rocks having 53 to $58 \% \mathrm{SiO}_{2}$. Thus, olivineliquid reaction does not occur at an identical forsterite- or bulk rock silica content for all specimens. Several explanations can be given for this: (1) According to equation 1, olivine- liquid reaction is influenced by the activity of silica in liquids from which olivine is crystallizing. Silica activity in turn is controlled by temperature, pressure, and fugacity of 


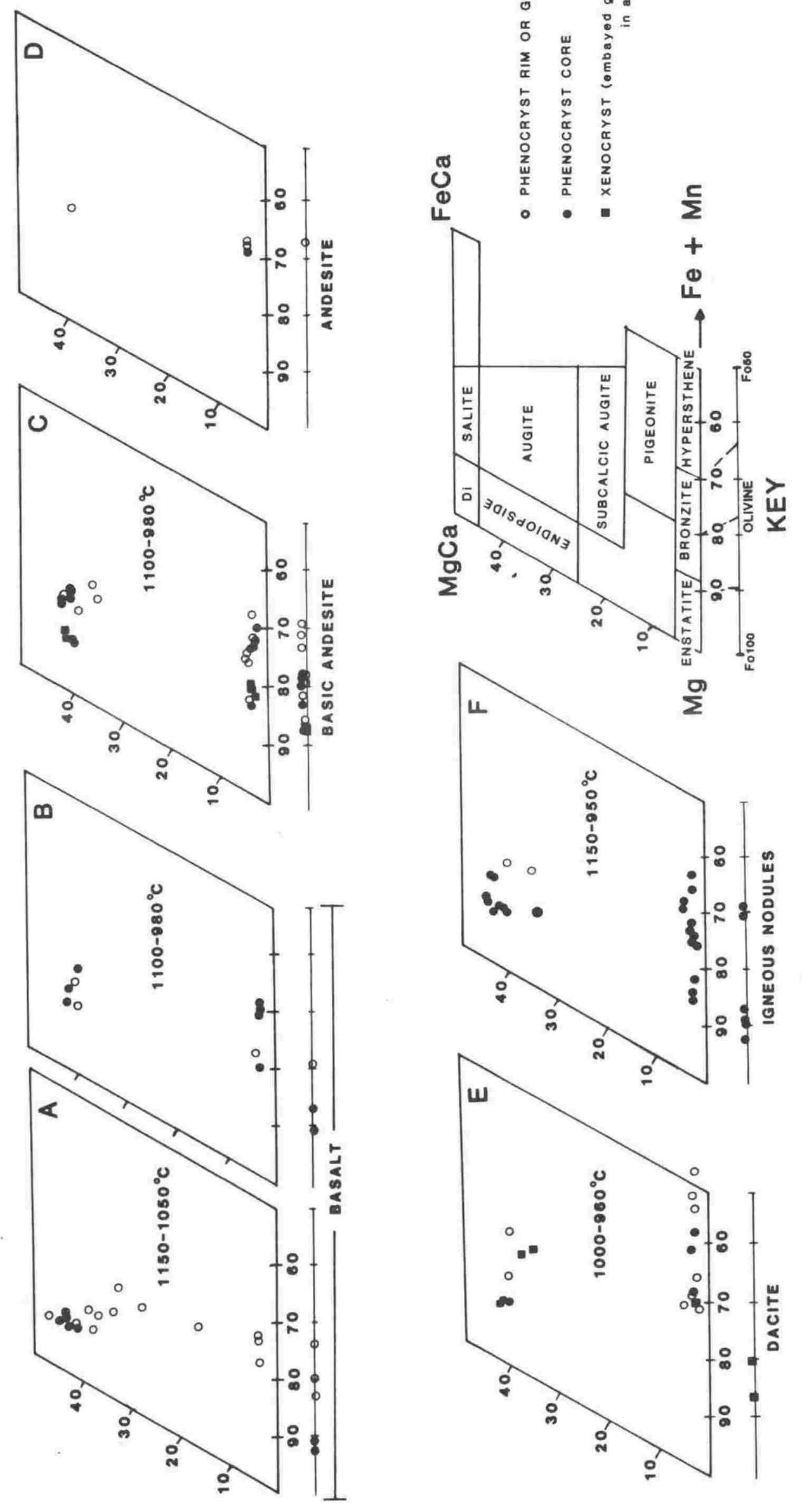


$\mathrm{H}_{2} \mathrm{O}$, all of which are expected to vary from rock to rock, according to the reservoir and eruptive histories of individual magma batches. (2) Bulk rock silica contents do not reflect residual liquid compositions because quenching occurs at different stages of crystallization for individual magma batches, and because bulk rock compositions ref lect the influence of accumulated xenocrysts and igneous rock fragments.

Olivine crystals are common in acid andesites and in a few dacites (Figs $92 \mathrm{H}, \mathrm{I} ; 93 \mathrm{H}, \mathrm{I}, \mathrm{K}, \mathrm{L}, \mathrm{M}, \mathrm{N}, \mathrm{O}, \mathrm{P}, \mathrm{Q}, \mathrm{R} ; 94 \mathrm{D} ; 95 \mathrm{~B}, \mathrm{E}, \mathrm{F}$ ). Most of these are certainly xenocrysts, on petrographic grounds (coexistence with orthopyroxene phenocrysts, corroded olivine margins with orthopyroxene coronas, presence of chrome spinel inclusions in forsteritic olivine), and on the basis of olivine- liquid equilibrium calculations, using either $K_{d}=$ 0.3 (Roeder and Emslie, 1970) or $K_{d}=0.4$ (Nicholls, 1974). These olivines probably originate from entrainment of the crystallization products of basaltic magma or from magma mixing, and are discussed further in Part III, Petrogenesis.

Within the entire rock suite, olivine composition ranges from $\mathrm{Fo}_{94}$ to $\mathrm{F}_{67}$. In single rocks and individual crystals, the variation is less than 15 mol percent forsterite.

CaO contents of olivine crystals in lavas and nodules lie between 0.07 and 0.20 wt \%, average 0.13 wt \%, and in single crystals are constant from cores to rims (i.e., within analytical uncertainty of the microprobe). The role of pressure as a control on Ca in olivine is arguable (Stormer, 1973 ) but absence of detectable Ca zonation in olivine and its coexistence with plagioclase suggest low pressure $(<9 \mathrm{~kb})$ olivine crystallization. Indeed, the observed range of $\mathrm{CaO}$ values in olivine is consistent with 1 atmosphere crystallization of olivine from melts having the $6-10$ wt \% Ca0 appropriate for basalts and basic andesites (Watson, 1979). 


\subsection{PYROXENES}

Pyroxenes (Fig 98) are second only to plagioclase in phenocryst abundance; hence, most lavas are two pyroxene acid or basic andesites. Augite and bronzite/hypersthene are the most commonly observed compositions. The modal ratio of clinopyroxene: orthopyroxene is usually near 1:1 for basic andesites, but varies substantially from basalts ( $c p x$ > $o p x)$ to dacites $(c p x<o p x)$. Orthopyroxene always exceeds clinopyroxene abundance in the groundmass of lavas. The proportion of total pyroxene to plagioclase phenocrysts also varies widely. General increase of plagioclase: pyroxene, and orthopyroxene: clinopyroxene ratios with increasing silica contents of bulk rocks is considered to be a result of fractional crystallization, while aberrant ratios (e.g., andesites with clinopyroxene $\gg$ plagioclase, or with plagioclase $\gg$ total pyroxenes) are considered to result from accidental entrainment of igneous rock fragments from the plutonic environment.

\subsubsection{Clinopyroxene}

Clinopyroxene is an essential phenocryst mineral in all lavas, though it decreases in proportion relative to orthopyroxene with increasing silica contents of bulk rocks. In basalts, it co-precipitated with olivine (+ chrome spinel) as early phenocrysts, and in more evolved rocks it crystallized with orthopyroxene, plagioclase and $\mathrm{Fe}-\mathrm{Ti}$ oxides. Most clinopyroxene phenocrysts are smoothly and normally zoned, and lack zoning reversals or overgrowths. However, in some lavas augite phenocrysts have $\mathrm{Mg}$-rich jackets up to several hundred microns wide (e.g., Figs 92C,D,E,I; 93M,N,O,P; 95E,F) and/or overgrowths of one pyraxene on another, where the overgrowths are of ten more magnesian than the cores (e.g., Figs $92 \mathrm{C}, \mathrm{D}, \mathrm{E}, \mathrm{J} ; 93 \mathrm{Q}, \mathrm{R})$. These compositional reversals and 
overgrowth patterns are attributed to the ef fects of magma mixing and to entrainment of exotic crystals.

All analyses are augites, except for Waimarino Basalt which contains diopside and endiopside phenocrysts ( $\mathrm{Fig} 98 \mathrm{~A}$ ). The limited $\mathrm{Mg} / \mathrm{Fe}$ compositional range is a mineralogical reflection of the weak iron enrichment trend of bulk rocks (Fig 107). Clinopyroxene analyses (Appendix III) show that the non-quadrilateral components $\mathrm{Ti}, \mathrm{Al}, \mathrm{Fe}^{3+}$ and $\mathrm{Na}$ together comprise only 2 to 5 atom \% of total cations. Aluminium is nearly always sufficient to fill tetrahedral sites with Si, and the remaining octahedrally coordinated $\mathrm{Al}$ is generally less than $1 \%$ of total cations. No consistent trends of $\mathrm{Al}$ and $\mathrm{Ti}$ zonation are apparent, and weak sector zonation with respect to $\mathrm{Al}$ and Ti probably accounts for most individual-grain variations. Cation totals generally preclude significant amounts of $\mathrm{Fe}_{2} \mathrm{O}_{3}(\mathrm{O} \times \mathrm{x}$ wt \%), and for this reason pyroxene analyses have not been re-calculated for $\mathrm{Fe}^{3+}$.

\section{Subcalcic Augite and Pigeonite}

Clark (1960) has reported rare pigeonite as rims on augite phenocrysts and in the groundmass of intermediate lavas from the Tongariro Volcanoes. The present writer has observed pigeonite in the groundmass of only one Ruapehu lava (Appendix III, 59-5). Subcalcic augite has been identified in only one rock (Fig 98A), where it occurs as 20 - 50 micron groundmass crystals. These are interpreted as metastable quench crystals.

\subsection{Orthopyroxene}

In basic andesites, orthopyroxene gradually replaces olivine as the 
major calcium-poor ferromagnesian phenocryst (see section 3.1). Most analyses (Fig 98) are bronzite or hypersthene. Ferrohypersthene occurs in one dacite (Fig 95D) and enstatite microphenocrysts occur in some hybrid magmas having primitive basalt as an end-member (e.g., Fig 93P). Orthopyroxene is normally zoned, but in some lavas fritted cores are overgrown by Mg-rich jackets. These jacketed orthopyroxenes coexist with similarly zoned augites and with jacketed plagioclase (Fig 95E,F), and are interpreted as being the products of magma mixing.

Since orthopyroxene has no 8-fold site, $\mathrm{Al}$ and $\mathrm{Na}$ are lower than in coexisting clinopyroxene. $\mathrm{Al}_{2} \mathrm{O}_{3}$ generally ranges between $\mathrm{I}$ and $3 \mathrm{wt} \%$, most of it tetrahedrally coordinated. No consistent core-to-rim Al zonation is apparent.

\subsection{FELDSPARS}

Plagioclase is ubiquitous and the most abundant mineral of the rock suite. It is the only phenocryst feldspar phase and is a major constituent of the groundmass in all rocks. Only two specimens, Waimarino Basalt (Figs 99A and 956), and Ohakune basic andesite (Fig 95B) lack plagioclase phenocrysts.

Analyses are presented in terms of $\mathrm{Ab}-\mathrm{An}-\mathrm{Or}$ end members in Fig 99. The compositional range is $A n_{89-40}$, but the majority of crystals are labradorite. Plagioclase is more calcic than the corresponding normative feldspar of bulk rocks, suggesting that potassium and to a lesser extent sodium are concentrated in the finely crystalline to glassy matrices.

Plagioclase is often complexly zoned. Phenocrysts are nearly always oscillatory zoned, especially in their outer portions, and a general trend of normal zonation is superposed. Thin, clear rims are present on most phenocrysts, and these are compositionally similar to groundmass 

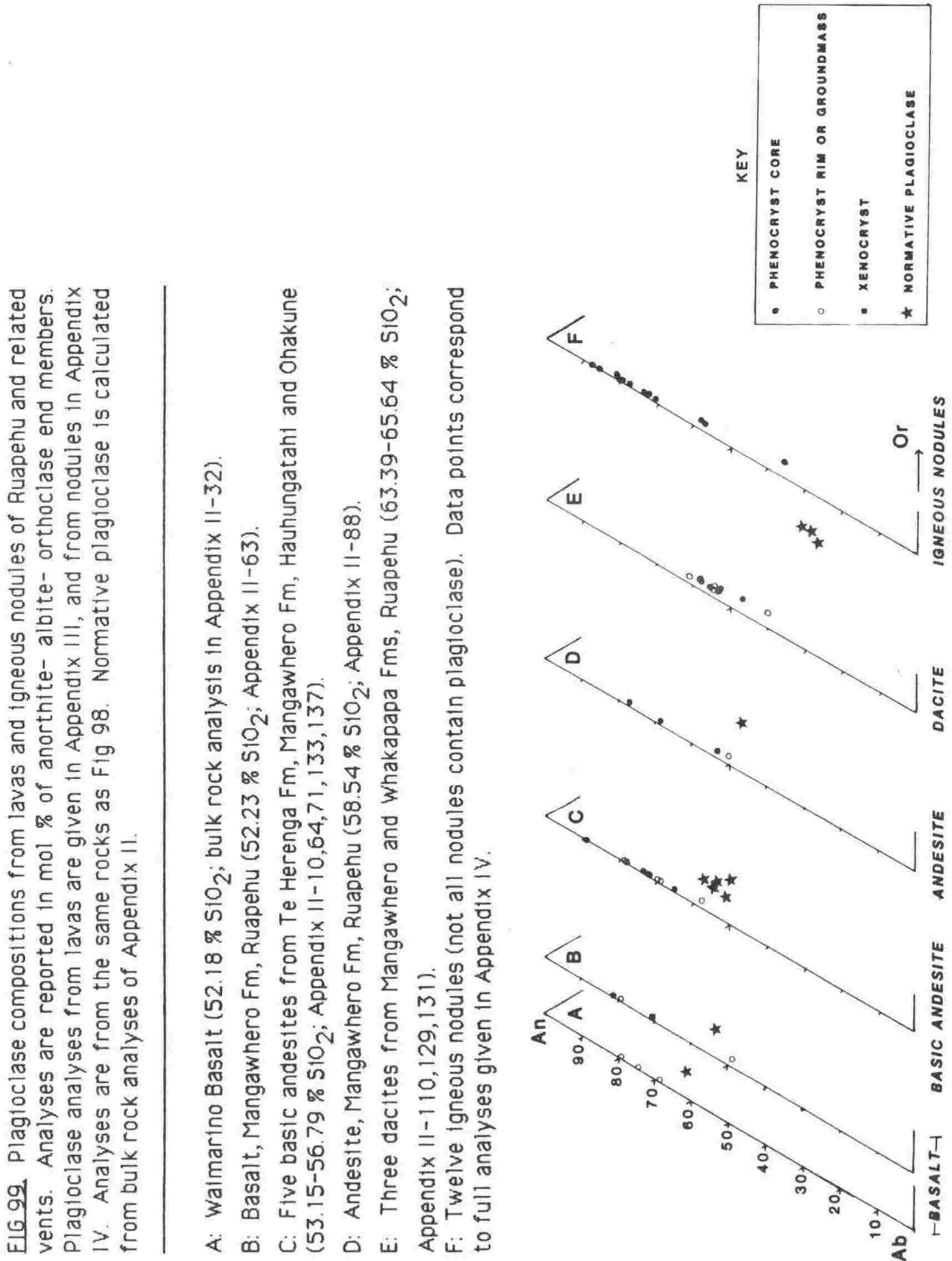
crystals. Inclusions of glass, cryptocrystalline material, pyroxenes and titanomagnetite are common. Apatite inclusions are occasionally present in plagioclase of acid andesites and dacites. Plagioclase can be internally fritted and clouded, or clear and euhedral, of ten in the same rock. Synnuetic phenocrysts and grain aggregates are common. In some specimens, plagioclase dominates the phenocryst assemblage and consists of hypidiomorphic- granular anorthosite fragments (Figs 92B, 946). Abrupt, calcium-rich jackets sometimes occur over fritted core regions (Fig 95E,F), and these crystals are found in association with jacketed pyroxenes. Thus, the zonation and textural features of plagioclase record one or more of three petrographic phenomena: Closed- system crystallization, together with pyroxenes and oxides, from melt whose residue comprises the groundmass; entrainment of exotic crystalline material, or mixing of magmas. For individual lavas, plagioclase phenocrysts are of ten polygenetic (e.g., Fig 94C) and reflect two or more of the above processes.

Alkali feldspar is rare as microlites in hyalopilitic groundmasses, and occurs as quartz- orthoclase intergrowths in the mesostasis of intrusive rocks (Fig $9 \mid \mathrm{E}$ ).

\subsection{OXIDES}

Oxide minerals form ubiquitous microphenocryst inclusions in silicate phenocrysts and in groundmasses. Three oxides occur as primary minerals: Chrome spinel, titanomagnetite, and rare ilmenite.

Chrome spinel occurs as microscopic sub- to euhedral inclusions in forsteritic olivines, and rarely in magnesian clinopyroxenes associated with these olivines. It is restricted to olivine of $\mathrm{F}_{85}$ or greater, and so is effectively limited to basaltic rocks or to olivine xenocrysts in evolved 
rocks. The inclusion crystals are generally homogeneous (Figs 100, 101, 102), are poor in $\mathrm{TiO}_{2}-\mathrm{FeO}-\mathrm{Fe}_{2} \mathrm{O}_{3}$, rich in $\mathrm{Cr}_{2} \mathrm{O}_{3}-\mathrm{MgO}^{-}-\mathrm{Al}_{2} \mathrm{O}_{3}$, and have compositions similar to refractory chrome spinels from boninites, peridotite nodules, alpine peridotites and layered basic intrusions (Fig 103). By contrast, discrete groundmass crystals are of ten strongly zoned, with outer mantles similar in composition to discrete groundmass titanomagnetite (Fig 100). This indicates reaction (and oxidation) between early-formed chrome spinel and liquid, involving enrichment of spinel rims in total $\mathrm{Fe}, \mathrm{Fe}^{3+}$ and $\mathrm{Ti}$, and depletion in $\mathrm{Cr}, \mathrm{Mg}, \mathrm{Al}$. Chrome spinel precipitation terminates when olivine reaches about $\mathrm{Fo}_{85}$, and is thereafter replaced by titanomagnetite as the oxide phase (Figs 101, 102). This is generally coincident with the onset of clinopyroxene crystallization, suggesting that the appearance of clinopyroxene as the $\mathrm{Cr}$ sequestering phase may be a control on spinel- liquid reaction (Irvine, 1967), together with the effects of oxidation and silica enrichment of residual liquids (Haggerty, 1976).

In basic andesites to dacites, titanomagnetite (Fig 104) forms ubiquitous microphenocrysts included in all silicate minerals except olivine, and in groundmasses. Titanomagnetites range between 6 and 20 wt \% $\mathrm{TiO}_{2}$ (29 to $58 \%$ ulvospinel), while stoichiometry permits up to 33 wt $\% \mathrm{TiO}_{2}$. This, together with the rarity of coexisting ilmenite, reflects the Ti-poor bulk compositions of host rocks (Buddington and Lindsley, 1964), as well as the effects of increasing acidity and oxygen fugacity during groundmass crystallization (Haggerty, 1976).

Umenite occurs sporadically in acid andesites and dacites. Crystals vary between 49 and 31 wt $\% \mathrm{TiO}_{2}$, and $\mathrm{TiO}_{2}$ of ten exceeds $\mathrm{FeO}$, suggest ing subsolidus oxidation (Buddington and Lindsley, 1964).

Several factors preclude the use of coexisting titanomagnetite and 

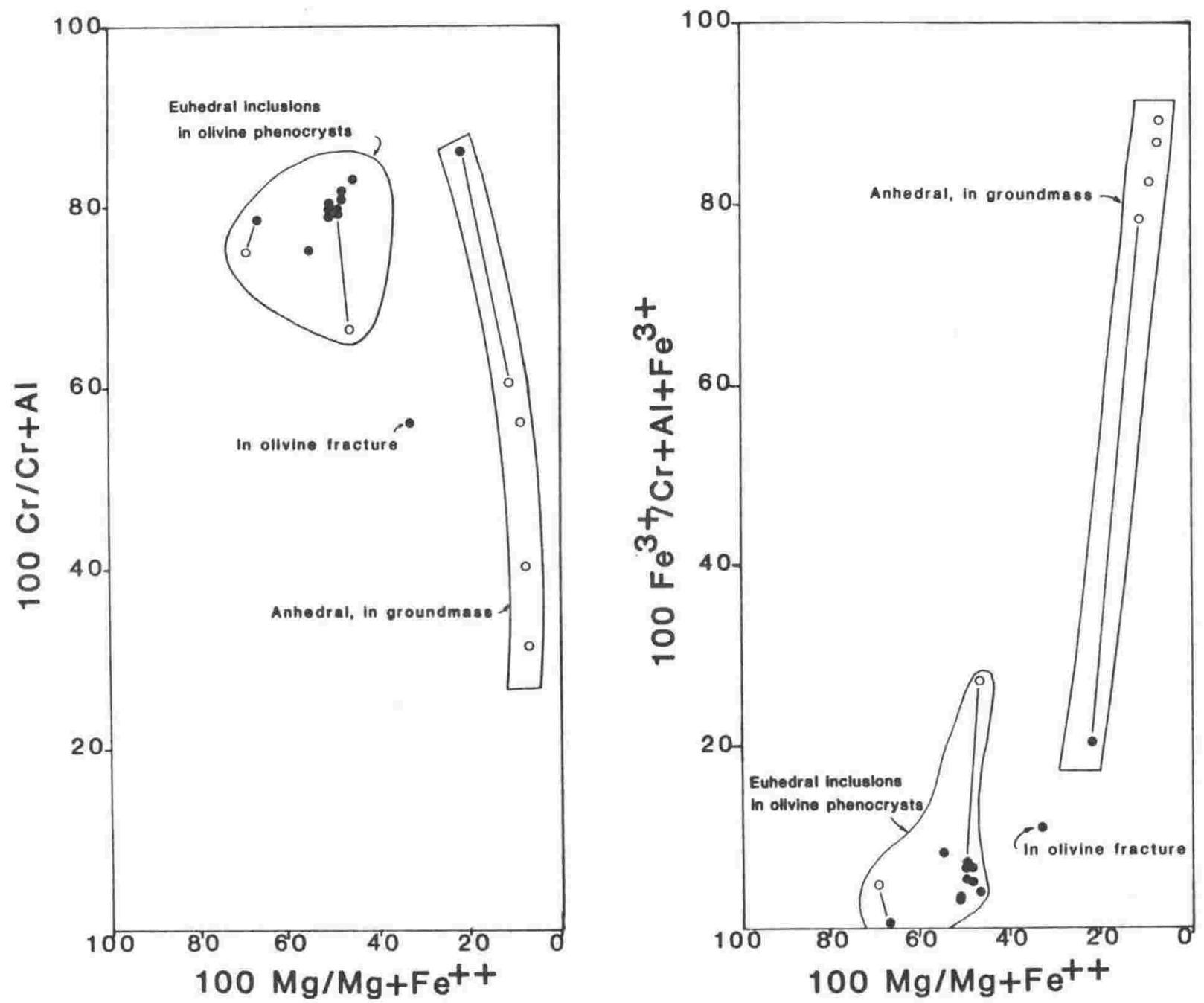

ElG 100. Oxide mineral compositions from Waimarino Basalt (bulk rock is Appendix II, analysis 132). Complete mineral analyses are given in Appendix III: 132. Inclusions in forsteritic olivine phenocrysts are homogeneous $\mathrm{Cr}-\mathrm{Al}-\mathrm{Mg}$ spinels (picotites) with $52-59 \mathrm{\&} \mathrm{Cr}_{2} \mathrm{O}_{3}$ and $0.2 \% \mathrm{TiO}_{2}$. Groundmass crystals are strongly zoned chromian titanomagnetites with 2-8 $\% \mathrm{Cr}_{2} \mathrm{O}_{3}$ and $4-6 \% \mathrm{TiO}_{2}$. Tielines link cores (filled circles) and rims (open circles) of single grains. Compare with Figs 101 and 102. 

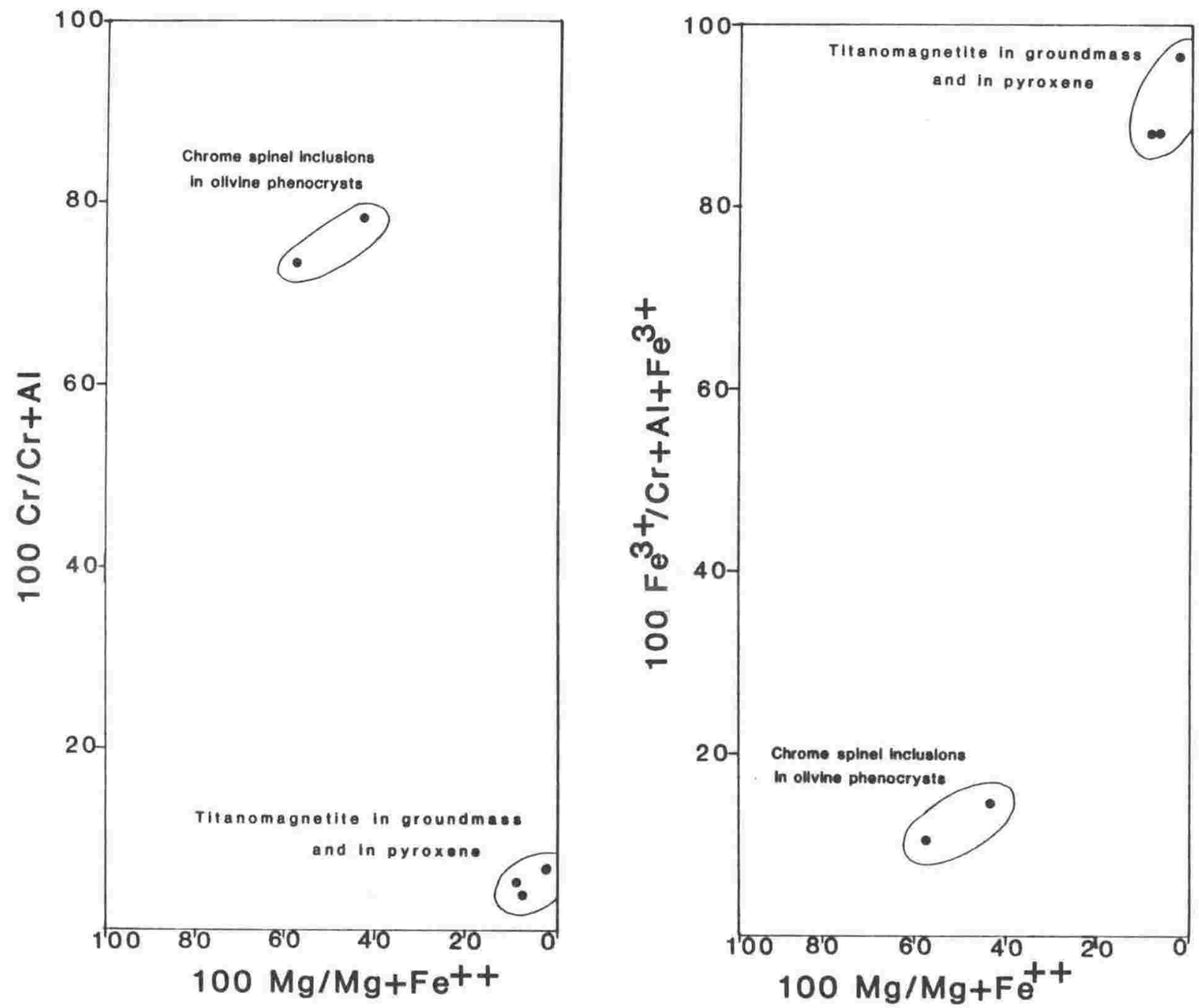

EIG 10L Oxide mineral compositions from basalt of Mangawhero Fm, Ruapehu. Complete mineral analyses are given in Appendix III, under bulk rock 63 . Inclusions in olivine phenocrysts are $\mathrm{Cr}-\mathrm{Al}-\mathrm{Mg}$ spinels (picotites) with $48-50 \% \mathrm{Cr}_{2} \mathrm{O}_{3}$ and $0.5 \% \mathrm{TiO}_{2}$. These are slightly less refractory than inclusion spinels from the more primitive Waimarino Basalt (Fig 100). Groundmass crystals and inclusions in pyroxene phenocrysts are titanomagnetites with $0.1-0.3 \% \mathrm{Cr}_{2} \mathrm{O}_{3}$ and $7-13 \% \mathrm{TiO}_{2}$. 

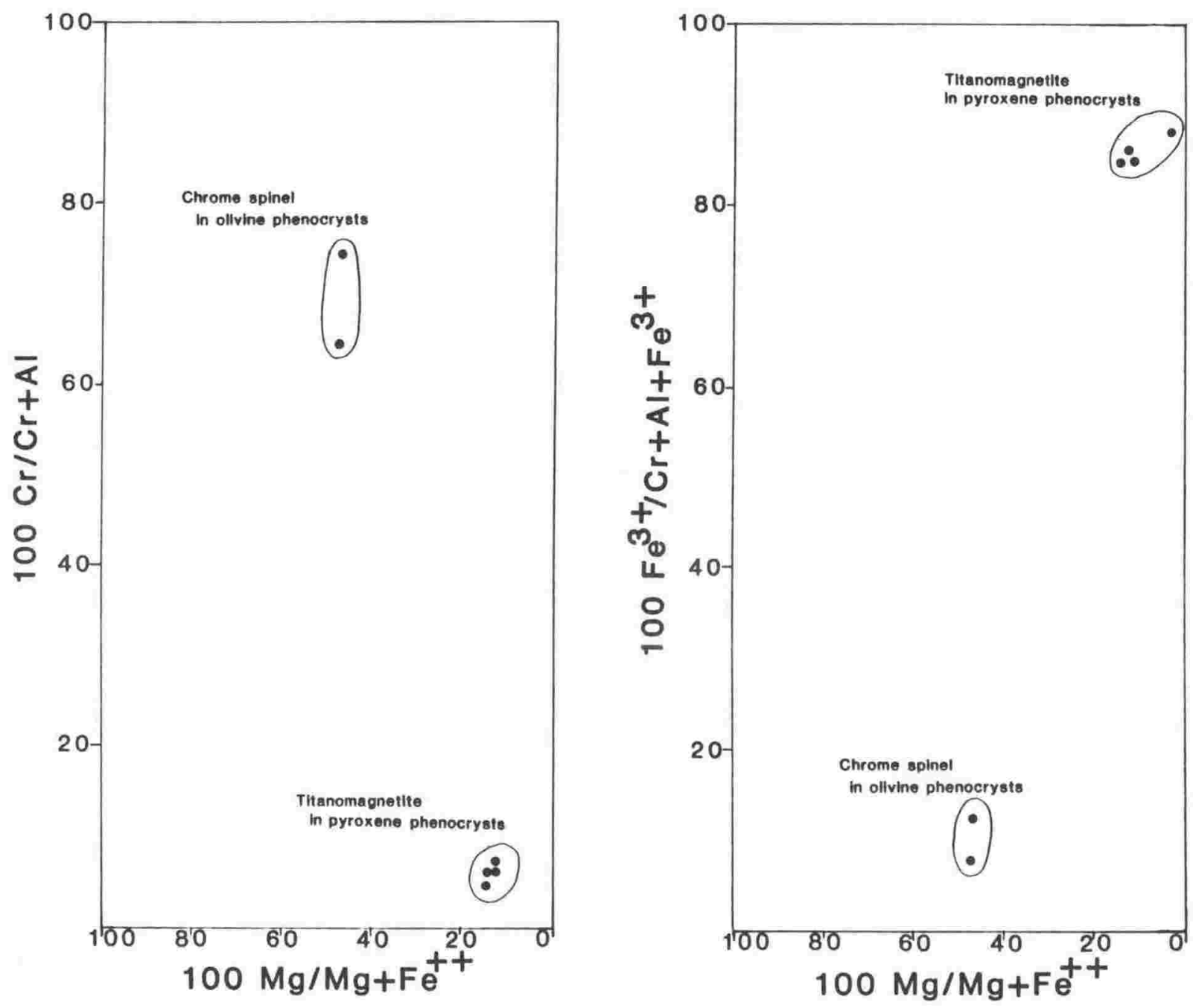

EIG 102 Oxide mineral compositions from two basic andesites of Mangawhero $\mathrm{Fm}$ and Hauhungatahi. Complete mineral analyses are given in Appendix III: 71,133 . Inclusions in olivine phenocrysts are $\mathrm{Cr}-\mathrm{Al}-\mathrm{Mg}$ spinels (picotites) with $45-47 \mathrm{~F} \mathrm{Cr}_{2} \mathrm{O}_{3}$ and $0.5 \% \mathrm{TiO}_{2}$. These picotites are less refractory than basaltic chrome spinels, but similarity of composition suggests a genetic link to basaltic parent magmas. Inclusions in pyroxenes are titanomagnetites with $0.5 \% \mathrm{Cr}_{2} \mathrm{O}_{3}$ and $9-10 \% \mathrm{TiO}_{2}$. 

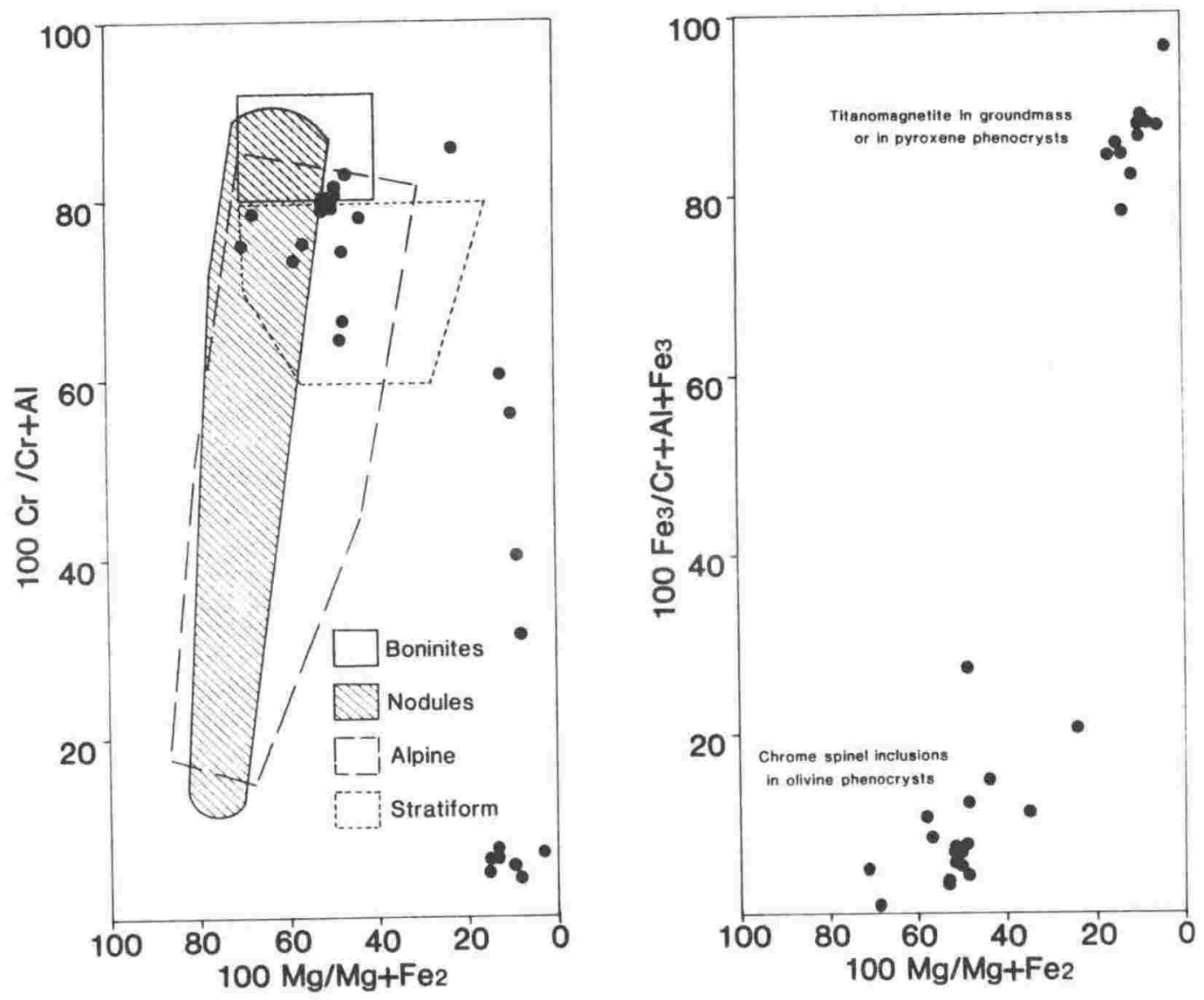

ElG 103. Composite diagram of all oxide compositions from basalts and basic andesites of Figs 100-102. Labelled fields are from Crawford (1980). Refractory chrome spinels of the present study are similar to spinels from boninites, peridotite nodules in alkali olivine basalts, Alpine- type harzburgites and stratiform basic intrusions. However, chrome spinels in lavas of the present study are succeeded by titanomagnetite, and oxide compositions diverge from those of boninites, intrusions and nodules. 


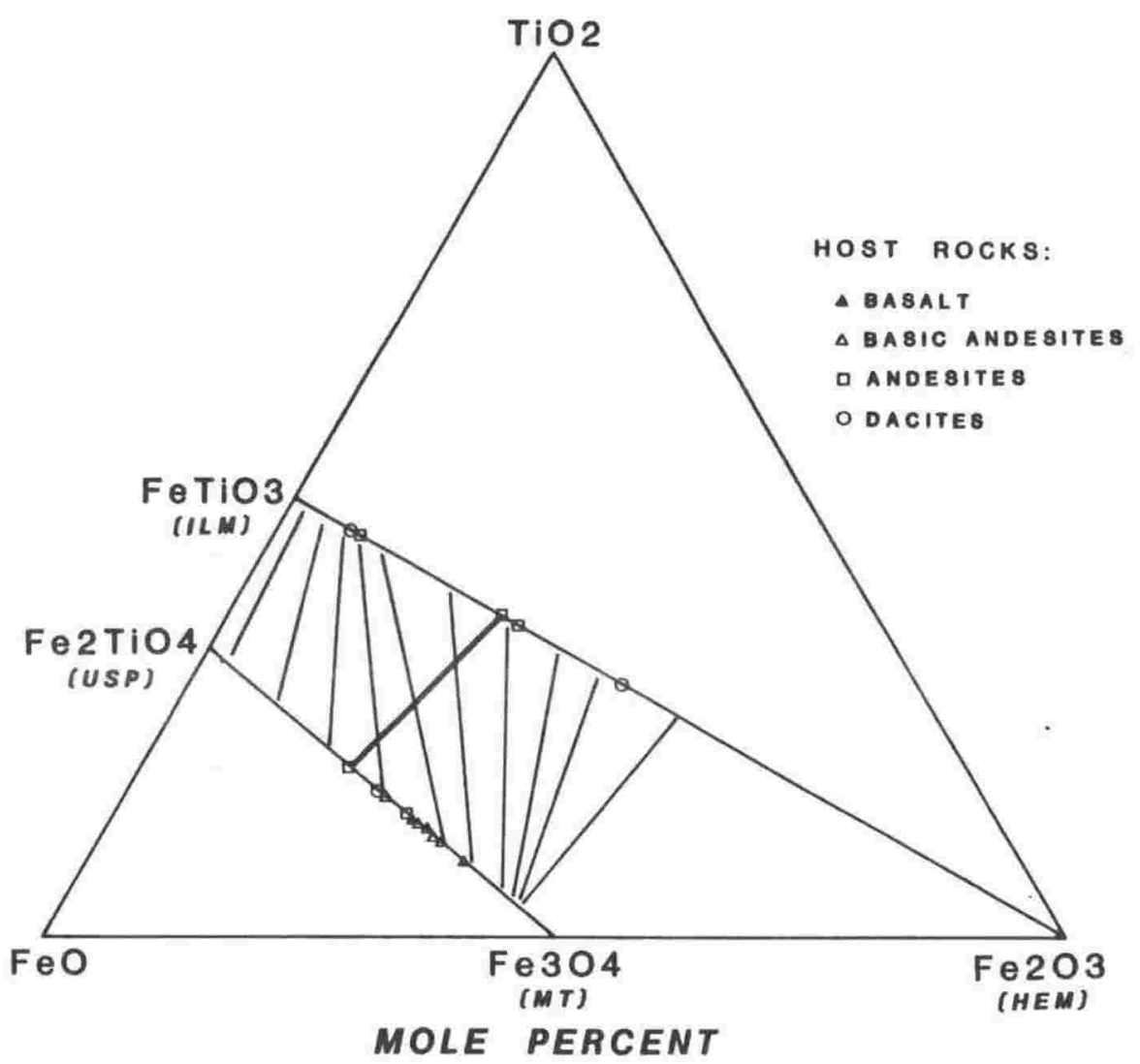

ElG 104 Composition diagram for iron-titanium oxides from lavas of Ruapehu and related vents. Equilibrium tielines at $900 \mathrm{C}$ are taken from Haggerty (1976). Single bold line is for coexisting oxides in bulk rock 105 (dacite), the only documented titanomagnetiteilmenite pair. This crosses equilibrium tielines, probably as a consequence of subsolidus oxidation. Complete analytical data are given in Appendix III. 
ilmenite as indicators of magmatic temperature and oxygen fugacity. First, ilmenite rarely coexists with titanomagnetite, due to Ti-poor melt compositions. Second, titanomagnetite compositions are well outside the limits of Buddington and Lindsley's (1964) calibrated temperature- oxygen fugacity curves.

\subsection{AMPHIBOLE}

Amphibole is very rare, and occurs as an accessory constituent in only three lavas; two acid andesites and a dacite. Analyses from two of these occurrences are reported in Appendix III, and a photomicrograph of hornblende dacite is given in Fig $95 \mathrm{C}$. Crystals are small (0.1-0.3 mm), acicular, and pleochroic brown or green. In lavas, they always exist as discrete microphenocrysts and never as inclusions in other silicates. Coronas of opaque material (opacite) are always present. All three analyses of Appendix 111 are silica- undersaturated, ferroan pargasitic hornblendes according to the classification of Leake (1978). These limited data indicate that amphiboles are slightly less magnesian than coexisting pyroxenes.

\subsection{APATITE}

Apatite is an accessory mineral ( $2-4$ grains per thin section) in about half of all rocks $>60 \% \mathrm{SiO}_{2}$. It forms stubby microphenocrysts (0.1-0.3 mm) with weak grey or brown pleochroism and opaque, rod-like inclusions parallel to the c-axes (Fig 93G). It is present as inclusions in plagioclase and hypersthene as well as in groundmasses, indicațing coprecipitation with silicates and oxides in evolved magmas. Mertzman (1977, p. 225) has described apatites with similar petrographic features 
from orogenic andesites of the Medicine Lake Volcano. The inclusion crystals are characteristically oriented parallel to host mineral zonation, suggesting apatite crystallization in response to local concentration gradients adjacent to growing silicate minerals, particularly plagioclase, and low diffusivity of phosphorus in silicate melts, as suggested by Green and Watson (1982). These authors further suggest that calc alkaline magma series do not achieve apatite saturation until andesite- dacite compositions are reached, and this is confirmed by petrographic data reported here.

\subsection{OTHER MINERALS}

Microscopic tridymite prisms occur as linings to lenticular shear cavities in some lava flows. Occasional quartz anhedra or fine xenomorphic- granular quartz aggregates up to $4 \mathrm{~mm}$ are found in some lavas. Tridymite forms from vapour phase crystallization, but quartz is certainly xenocrystic and derived from quartzites of the subvolcanic basement (see: 2.7 Crustal Xenoliths). Strongly resorbed, oxidized biotite and garnet occur in some dacites (Fig 122 A,B), as well as hercynite microlites (Appendix III, analysis 91-4). These three minerals are certainly xenocrysts, since they occur in the assemblage of gneissic xenoliths found in the lavas. Pyrite and clay minerals occur as secondary minerals in some intrusive rocks and lava flows, as a consequence of hydrothermal alteration (Fig $91 \mathrm{~F}, G, H$ ). Pyrrhotite has been identified in one igneous nodule (Fig 96M).

\section{SUMMARY OF MINERALOGY AND PETROGRAPHY}

The principal phenocryst minerals in lavas are the anhydrous silicates plagioclase, clinopyroxene, orthopyroxene and olivine, with 
subordinate opaque oxides. Ilmenite, hornblende and apatite are rare accessory minerals. With increasing acidity from basalts to dacites, changes occur in the types, relative proportions and compositions of phenocryst minerals. In basalts, the dominant minerals are forsteritic olivine and magnesian clinopyroxene, with subordinate bytownite/labradorite, bronzite and chrome spinel. In basic andesites, olivine is replaced by orthopyroxene as a consequence of reaction with silicic liquid, chrome spinel ceases to crystallize and titanomagnetite appears, and the phenocryst ratios orthopyroxene: clinopyroxene and plagioclase: total pyroxenes increase. Phenocryst minerals of basic and acid andesites are labradorite, hypersthene and augite, with minor titanomagnetite microphenocrysts. In acid andesites and dacites, labradorite/andesine dominates the phenocryst assemblage, with lesser pyroxenes, minor opaque oxides, and a trace of apatite.

Textures and zonation of plagioclase and pyroxenes are complex, suggesting polygenetic origins for phenocrysts in many lavas. Mantled phenocrysts with high temperature overgrowths \pm internal resorption indicate magma mixing, while other zonation patterns may reflect crystal accumulation.

Igneous nodules contain the same types and compositional ranges as minerals in host lavas, cornmonly exhibit hypidiomorphic- granular textures that are partially overprinted by xenoblastic metamorphic textures, and form 2-5 mm sized crystal aggregates in many lavas. Nodules and xenocrysts derived from them exert major influence on the "phenocryst" assemblages of many lavas. These observations suggest that the nodules are co-genetic igneous rock fragments from the hypabyssalplutonic environment, entrained within batches of erupting magma as they rose along previously occupied conduits. No pervasive evidence is found in the nodules for polybaric crystallization involving hydrous phases (e.g., hornblende, biotite) in the plutonic environment. 
Millimetre- to centimetre- sized metamorphic xenoliths from the subvolcanic basement are very common in lavas and pyroclastics. The most common varieties are saccharoidal quartzite and feldspathic hornfels, with subordinate garnet-biotite-plagioclase gneiss. 


\section{PETROGENESIS}

Some qualitative evaluations of pressure, temperature, water content and oxygen fugacity during crystallization are possible, using the observed mineral compositions and assemblages. The results of olivinespinel and two-pyroxene thermometry indicate crystallization temperatures ranging from $1150^{\circ} \mathrm{C}$ for basalt, to $960^{\circ} \mathrm{C}$ for dacite.

Low pressure crystallization $(<7 \mathrm{~kb}$ ) in crustal reservoirs is suggested by abundant metamorphic inclusions and by the following aspects of mineralogy: (1) The coexistence of olivine and plagioclase in andesite lavas and igneous inclusions (including ultramafic nodules; Fig 96K) requires crystallization pressures $<7 \mathrm{~kb}$, since at higher pressures these phases will react to form aluminous pyroxenes + spinel (Green and Hibberson, 1969). (2) The calcium content of olivine is low and nearly constant from cores to rims, suggesting low pressure, nearly isobaric olivine crystallization. (3) The observed concentrations of $\mathrm{Al}, \mathrm{Na}$ and $\mathrm{Ti}$ in pyroxenes, although dependent not only on pressure but also on temperature, cooling rate, silica activity, and coexisting minerals, are low enough to at least preclude pressures > $10 \mathrm{~kb}$ (cf.: high pressure pyroxenes crystallized from andesite by Green, 1972).

Comparison with the experimental results of other studies suggests that Ruapehu andesites were water- undersaturated, but not completely anhydrous, during phenocryst mineral growth: To achieve agreement between observed eruption temperatures and experimentally determined andesite liquidus temperatures, $2-5 \mathrm{wt} \% \mathrm{H}_{2} \mathrm{O}$ is required in the melt (Gill, 1981, Table 4.1, Fig 4.1). In addition, Eggler (1972) concluded that most andesite magmas must contain $<3$ wt $\% \mathrm{H}_{2} \mathrm{O}$ because plagioclase 
phenocrysts are common. These deductions are generally applicable to the present study, given the estimated crystallization temperatures reported here, and the ubiquity of plagioclase phenocrysts in lavas. That is, Ruapehu lavas probably contained only a few wt \% water during phenocryst precipitation.

Quantitative estimates of oxygen fugacity during crystallization are precluded by the rarity of coexisting titanomagnetite- ilmenite pairs. Using coexisting $\mathrm{Fe}-\mathrm{Ti}$ oxides from andesites, other authors have estimated $\mathrm{fO}_{2}$ ranging from Ni-NiO buffer conditions to $1-2 \log$ units above $\mathrm{Ni}-\mathrm{NiO}$, at temperatures of $900^{\circ}-1100^{\circ} \mathrm{C}$ (Gill, 1981, Fig 5.9). 


\section{BULK ROCK MAUOR AND TRACE ELEMENT COMPOSITION}

\subsection{INTRODUCTION}

Major goals of this section are: (1) to illustrate compositional limits of the rock suite, (2) classify rocks to provide a basis for terminology, (3) show the relative abundances of rock lypes, and (4) use variation diagrams to suggest differentiation processes. Although fractional crystallization has not yet been rigorously demonstrated as a differentiation mechanism, petrography, mineralogy and bulk rock chemical variation strongly imply that fractional crystallization of basaltic magma has produced much of the chemical variation. However, petrography also indicates that most rocks are porphyrilic and may not represent liquid compositions; other samples have features that suggest magma mixing. Considering these observations, deviation from expected liquid lines of descent, and scatter on interelement variation diagrams is anticipated.

Chemical analyses for 144 unaltered whole rocks from Ruapehu and related vents are presented as summary diagrams in Figs 105-109. The $\mathrm{SiO}_{2}$ histogram of $\mathrm{Fig} \mathrm{lOS} \mathrm{shows} \mathrm{that} \mathrm{specimens} \mathrm{vary} \mathrm{from} \mathrm{basalt} \mathrm{to}$ dacile, but most are basic or acid andesites. The MgO histogram (Fig 105) illustrates the unlinking of $\mathrm{MgO}$ and $\mathrm{SiO}_{2}$; these oxides usually behave antithetically during differentiation. As a consequence of crystal accumulation and magma mixing, rocks varying only between $8-9 \% \mathrm{MgO}$

are as diverse as basalt to acid andesite on the basis of their silica contents. Similarly, rocks varying only between 3-4\% MgO include basic andesite to dacite.

In view of these observations, the petrogenesis of andesites cannot be a simple process that involves closed-system fractional 


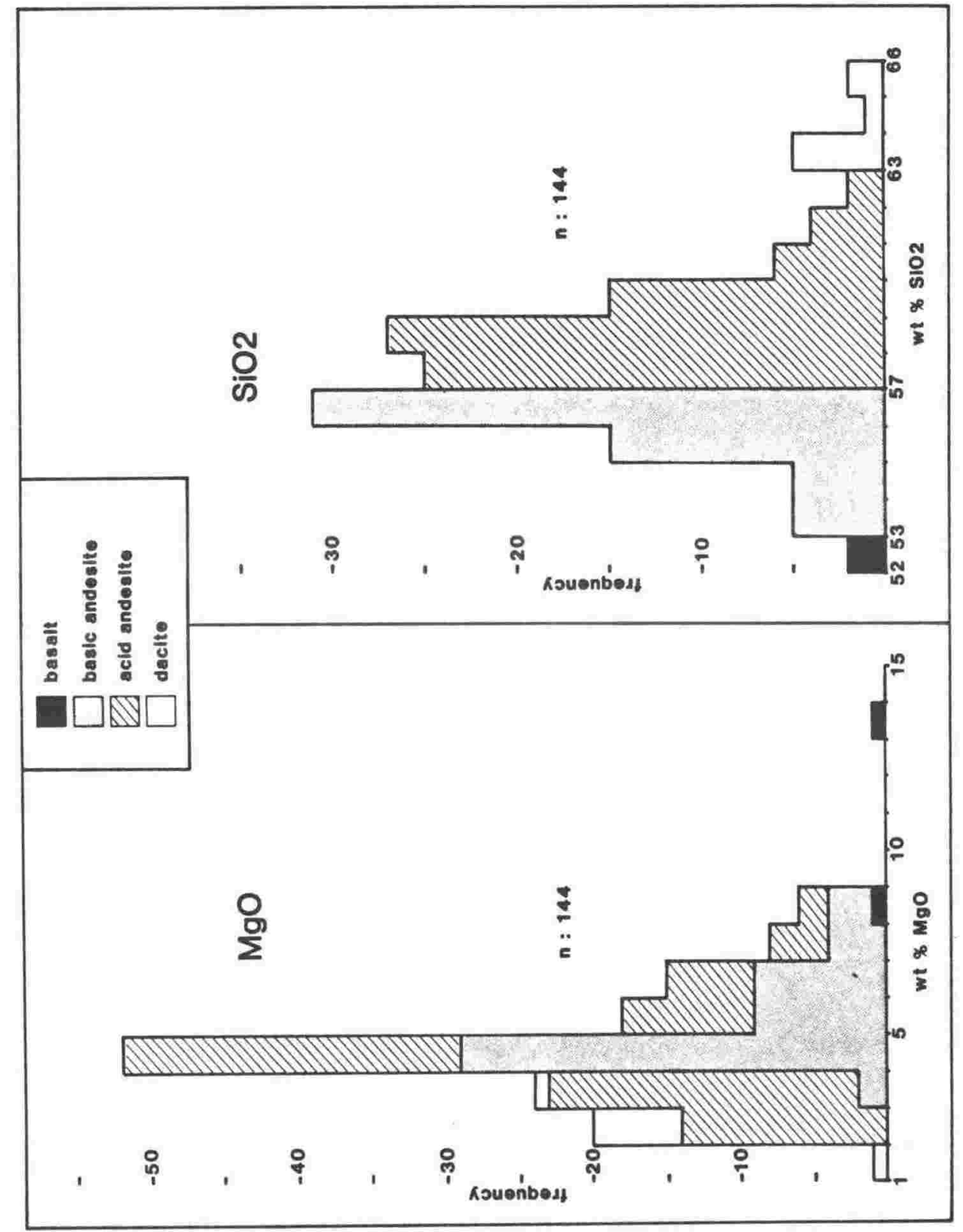

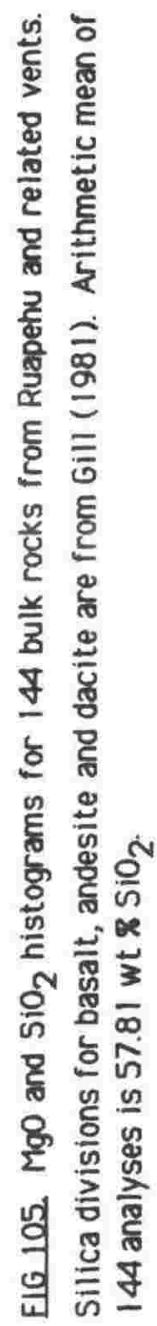


crystallization. Quantitative assessment of differentiation processes will be undertaken in Part III: Petrogenesis, but first a synopsis of chemical traits for the sample population is given.

\subsection{CLASSIFICATION}

Gill (1981) has proposed a classification of intermediate volcanic rocks on the basis of silica and potash contents. The central trapezoid of Fig 106 defines the compositional limits for "orogenic andesites". Basic and acid andesites are distinguished at $57 \% \mathrm{SiO}_{2}$; the terms 'basic-' and 'low silica andesite' are used interchangeably by the present author. 134 of the 144 bulk rocks are some variant of orogenic andesite. Most are medium- $K$ andesites, and all rocks meet Gill's additional criteria that $\mathrm{TiO}_{2}$ be less than $1.75 \%$ and be hypersthene- normative. All rocks, including the two basalts, are quartz-normative.

Peacock (1931) proposed a classification based on the silica content at which $\mathrm{CaO}$ and $\mathrm{Na}_{2} \mathrm{O}+\mathrm{K}_{2} \mathrm{O}$ trends intersect on Harker diagrams. According to this criterion, the rock series is calcalkalic ("calcalkaline", in current useage), since $\mathrm{CaO}=\mathrm{Na}_{2} \mathrm{O}+\mathrm{K}_{2} \mathrm{O}=5.8 \%$, at $61 \% \mathrm{SiO}_{2}$.

Calcalkaline rock series characteristically exhibit weak iron enrichment, relative to tholeiitic series. The rock series of Ruapehu and related vents is calcalkaline according to the criteria of Fig 108.

In summary, the 144 rock analyses range from basalts (2) to dacites (8), but are dominated by medium- $K$ acid and basic, andesites (120). All rocks contain less than $1 \% \mathrm{TiO}_{2}$ and are quartz- normative. The rock series is calcalkaline according to the original definition of Peacock (1931), and also according to later derinitions based on trends of iron enrichment. 


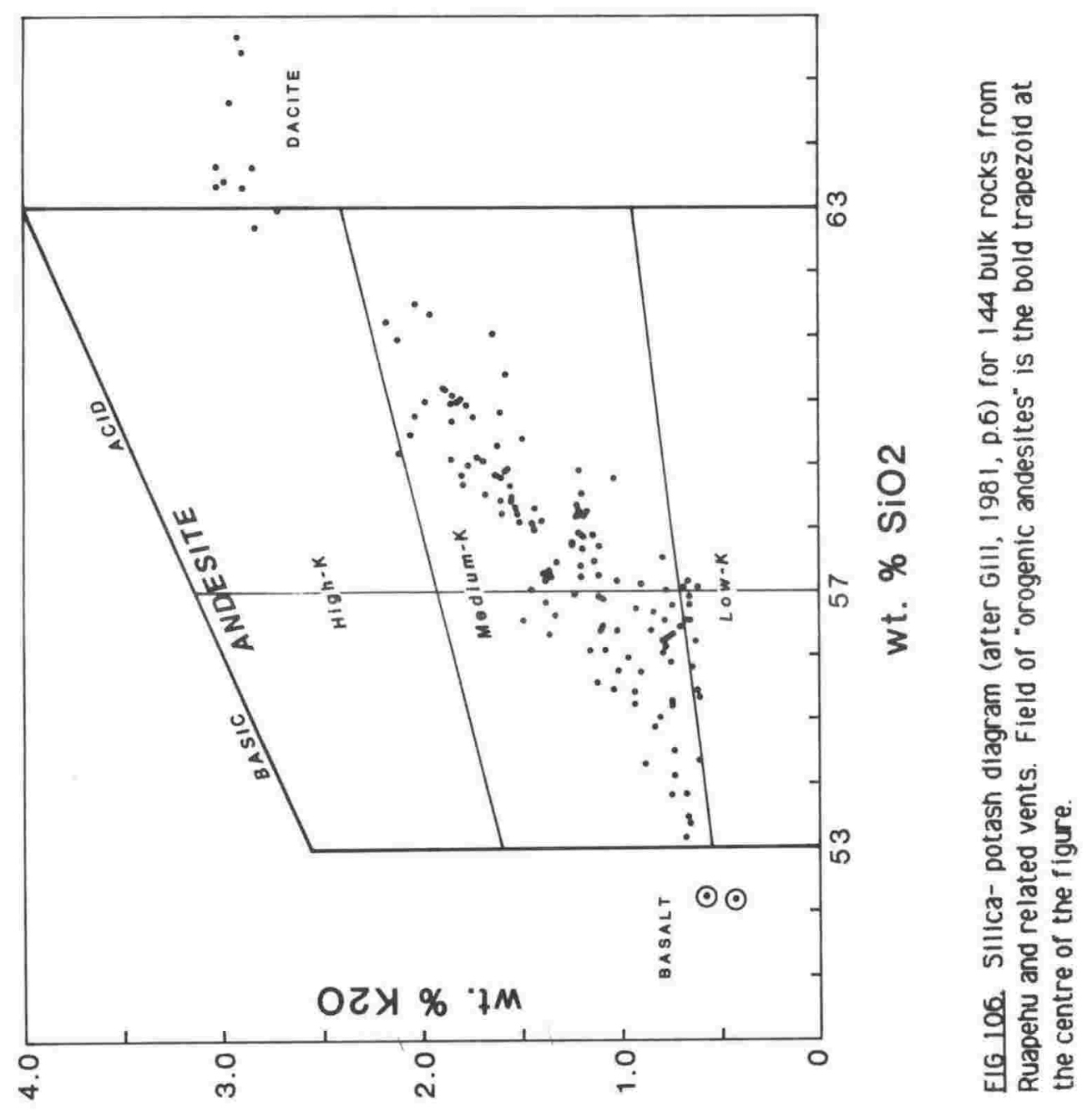




\subsection{MANORELEMENTS}

Silica (Fig 107) exhibits nearly continuous variation from basalts to dacites, but a compositional gap is apparent at $61.5-63 \% \mathrm{SiO}_{2}$ and is especiaily distinct on tine potasn diagrams (ífigs ior, iUT). The niatus is not a result of sclective sampling, and suggests that acid andesites and dacites may differ petrogenetically. Most data points cluster between 56$60 \% \mathrm{SiO}_{2}$, which reiterates the histogram of $\mathrm{Fig} 105$ and reflects domination of the sample population by andesites. For andesites, considerable scatter is apparent on all diagrams, but particularly for $\mathrm{Al}_{2} \mathrm{O}_{3}, \mathrm{MgO}$, and $\mathrm{Mg}$ number. The major mineral phases in andesitic rocks are plagioclase and pyroxenes, with subordinate olivine and opaque oxides. These phenocryst minerals are lower in silica than host liquids, and fractionation will produce silica enrichment, as well as pronounced effects for $\mathrm{Al}_{2} \mathrm{O}_{3}, \mathrm{MgO}$, and $\mathrm{Mg}$ number. Considering the high phenocryst contents of lavas and the petrographic evidence for crystal accumulation and magma mixing, it is likely that accumulation and magma mixing have acted concurrently with fractional crystallization, producing considerable deviation from possible liquid lines of descent on variation diagrams.

Alumina provides an illustration of this open-system behaviour, and several impressions emerge from the $\mathrm{Al}_{2} \mathrm{O}_{3}-\mathrm{SiO}_{2}$ diagram: (1) Both basalts are low- alumina types but differ substantially in wt $\% \mathrm{Al}_{2} \mathrm{O}_{3}$.

The horizontal "string" of data points at $16-18 \% \mathrm{Al}_{2} \mathrm{O}_{3}$ and $53-60 \% \mathrm{SiO}_{2}$ may represent a liquid line from Ruapehu basalt. If so, alumina reaches a maximum at $55 \% \mathrm{SiO}_{2}$ and then decreases slightly; this would require increasing plagioclase: pyroxene ratios in fractionating mineral 

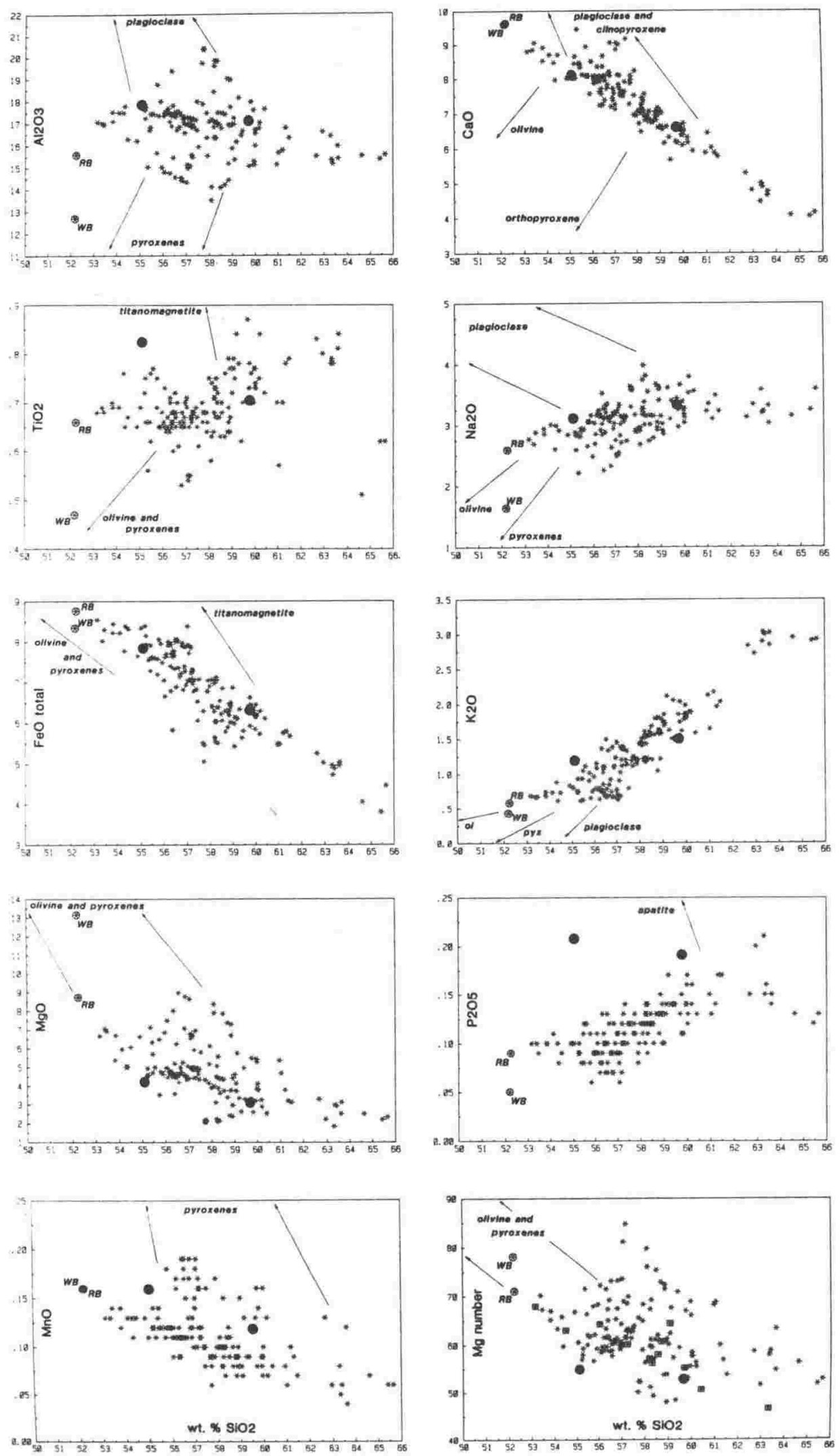

EIG 107 Silica variation diagrams for 144 bulk rocks from Ruapehu and related vents. The two basalts are circled; 'WB' is Waimarino Basalt, 'RB' is Ruapehu basalt. Open squares in Mg- number diagram denote 13 relatively aphyric rocks ranging from basic andesite to dacite. Large filled circles denote average medium- $K$ basic and acid andesites of Gill (1981, p.99). Vectors to phenocryst minerals are based on analytical data of Appendix III, and are generalized to allow for solid solution in minerals. 

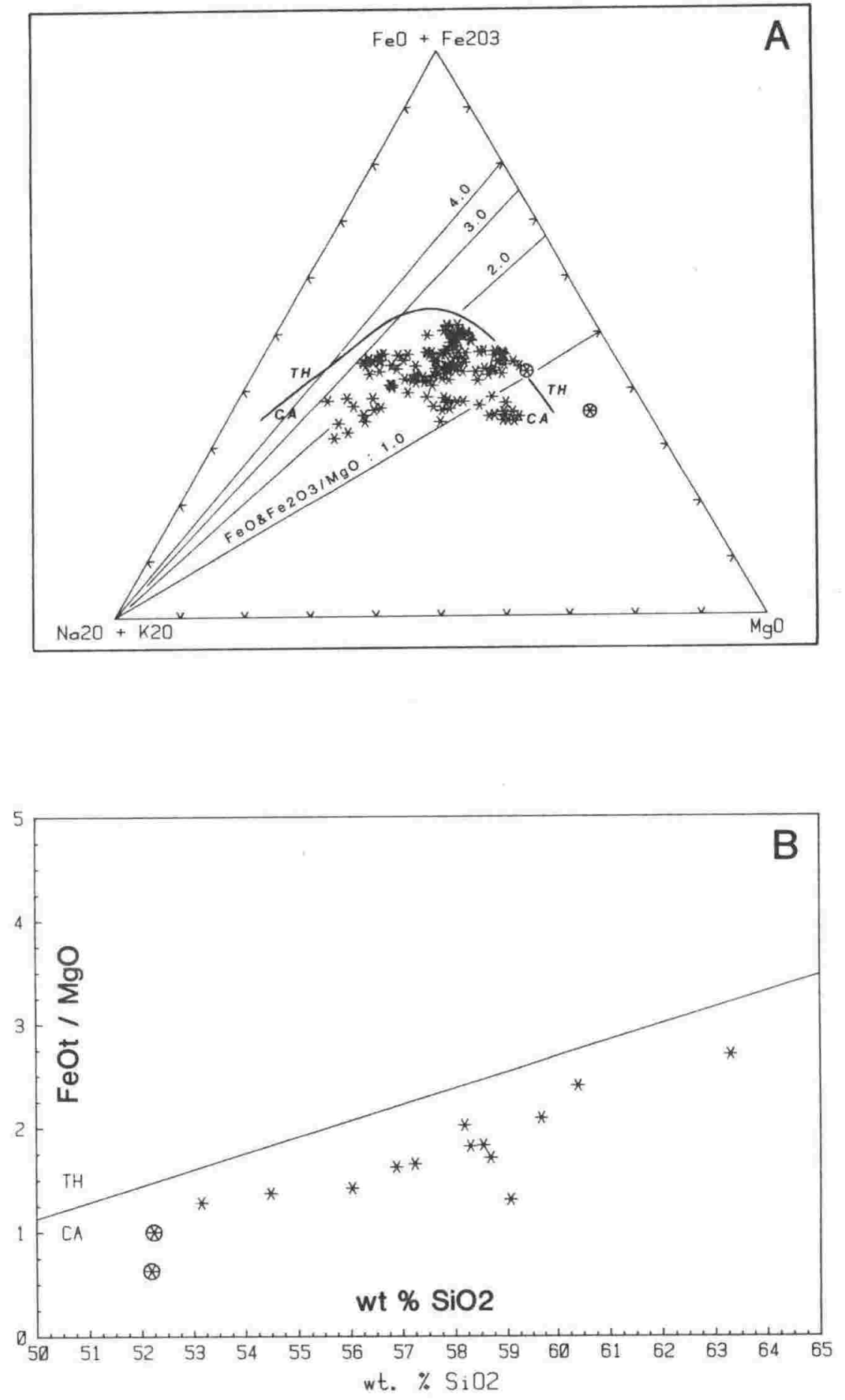

EIG 108 . Trends of iron enrichment for bulk rocks from Ruapehu and related vents. The two basalts are circled.

A. AFM diagram. Curve separating tholeilitic (TH) from calcalkaline (CA) fields is that of Irvine and Baragar (1971). Weak iron enrichment in basalts and basic andesites is indicated by crossing of $\mathrm{Fe} / \mathrm{Mg}$ ratio lines, but no absolute iron enrichment occurs (Fig 107). Acid andesites and dacites have nearly constant $\mathrm{Fe} / \mathrm{Mg}$. Considerable scatter is evident, reflecting the influence of crystal accumulation and magma mixing.

B. Tholelitic ( $\mathrm{TH}$ ) and calcalkaline (CA) volcanic rocks, as defined by Miyashiro (1974). Only 15 analyses are plotted: Two basalts and 13 relatively aphyric specimens, ranging from basic andesite to dacite. 
assemblages, which is consistent with petrographic trends from basalts to acid andesites. (3) On the basis of petrography, other data points of lower $\mathrm{Al}_{2} \mathrm{O}_{3}$ (13.5-15.5 \%) that roughly trend toward Waimarino Basalt probably reflect magma mixing between Waimarino Basalt and acid andesites/dacites. (4) Specimens with >19\% $\mathrm{Al}_{2} \mathrm{O}_{3}$ have anorthosite fragments and high plagioclase: pyroxene ratios, suggesting plagioclase accumulation.

Calcium correlates negatively with silica, a strong indication that clinopyroxene and plagioclase fractionation are mechanisms of differentiation. High CaO values above the main trend are produced by accumulation of plagioclase.

Magnesium falls rapidly in basic rocks and then decreases less rapidly in rocks > $55 \% \mathrm{SiO}_{2}$, producing a convex- downward curvature. This trend would be expected from fractional crystallization of basalt, with early olivine + pyroxene removal, followed by plagioclase + pyroxene removal from intermediate magmas. Data points above this possible liquid line have petrographic features suggesting pyroxene \pm olivine accumulation, or magma mixing.

Manganese behaves similarly to magnesium, and relatively high MnO values of many andesites can be attributed to pyroxene $(0.2-0.7 \%$ MnO) accumulation.

Iotal iron correlates negatively with silica and does not go through a maximum. This, together with $\mathrm{FeO}^{\mathrm{t}} \approx \mathrm{CaO}$, is typical of calc alkaline volcanic suites (Gill, 1981, p. 107). Petrography suggests that fractionation of pyroxenes (ca. 7-25 \% FeOt), olivine $\left(8-28 \% \mathrm{FeO}^{\mathrm{t}}\right.$ ), and minor opaque oxides $\left(25-80 \% \mathrm{FeO}^{\mathrm{t}}\right)$ is the mechanism for suppression of iron enrichment.

Mg number shows considerable scatter and negative correlation with silica. The negative correlation is explained by the same arguments 
as given for MgO variation. Overall, Mg numbers are significantly higher than for the average medium-K andesites of Gill (1981), although relatively aphyric samples approximate Gill's averages and probably define a liquid line of descent.

The high Mg numbers of some intermediate rocks are a consequence of several factors: (1) Since $\mathrm{Mg}$ number is $100 \mathrm{Mg} / \mathrm{Mg}+\mathrm{Fe}^{2+}$, the oxidation state of iron will be influential. As an example, the two andesites with $M g^{*}>80$ are oxidized bombs from the Ohakune vents, with $\mathrm{Fe}_{2} \mathrm{O}_{3} / \mathrm{FeO}>2$. When three visibly oxidized samples (with $\mathrm{Fe}_{2} \mathrm{O}_{3} / \mathrm{FeO}>1$ ) are eliminated, the entire rock suite ranges $0.19-0.78$ and averages $0.44 \mathrm{Fe}_{2} \mathrm{O}_{3} / \mathrm{FeO}$. This is higher than the $0.25-0.35 \mathrm{Fe}_{2} \mathrm{O}_{3} / \mathrm{FeO}$ range found by Fudali (1965) for medium-K andesites at 1 atmosphere, $1200 \mathrm{C}$, near $\mathrm{Ni}-\mathrm{NiO}$ buffer conditions. Thus, Gill (1981, p. 109) used $\mathrm{Fe}_{2} \mathrm{O}_{3} / \mathrm{FeO}=0.3$ when calculating Mg* for orogenic andesites, but stated there is no rigorous way to choose this ratio. $\mathrm{Fe}_{2} \mathrm{O}_{3} / \mathrm{FeO}$ ratios have not been changed from measured values by the present writer when calculating Mg numbers. Therefore, Mg numbers are generally higher than those of Gill's average medium- $\mathrm{K}$ andesites, and the average measured $\mathrm{Fe}_{2} \mathrm{O}_{3} / \mathrm{FeO}=0.44$ reported here can probably be attributed to slight subaerial oxidation of lava flow interiors, from which the samples were largely taken. As an indication of the extent of oxidation, $44 \%$ of samples have $\mathrm{Fe}_{2} \mathrm{O}_{3} / \mathrm{FeO}<0.4$, and these average $0.32 \mathrm{Fe}_{2} \mathrm{O}_{3} / \mathrm{FeO}$. (2) Since olivine and pyroxenes have higher $\mathrm{Mg} *$ than coexisting liquids, accumulation of ferromagnesian minerals influences Mg* of bulk rocks, producing scatter at higher Mg* than for relatively aphyric samples. (3) Two basalts with high Mg* are identified, and petrography indicates magma mixing between these basalts and evolved magmas. As a consequence of linear mixing trends, hybrid magmas 
will have higher $M g^{*}$ than magmas on a convex- downward liquid line, at equivalent silica contents.

Only the two basalts have $\mathrm{Mg}^{*}$ high enough to be in equilibrium with mantle olivine: If mantle olivine is $2 \mathrm{~F}_{87}$ (Sato, 1977) then primary melts must have $M g^{*} 267$ if $\mathrm{K}_{d}=0.3$ (Roeder and Emslie, 1970). However, if fusion occurs at lower temperatures $(\approx 1100 \mathrm{C})$ and hydrous conditions, then $K_{d} \approx 0.4$ (Nicholls, 1974) and Mg* of primary melts will be 273 . Other than the basalts, samples with high Mg* result from magma mixing, ferromagnesian mineral accumulation, and/or secondary oxidation.

Low titanium $\left(<1.3 \% \mathrm{TiO}_{2}\right)$ is characteristic of rocks at convergent plate boundaries, and $\mathrm{TiO}_{2}$ and $\mathrm{Fe}^{\mathrm{t}}$ contents usually correlate positively with each other and negatively with silica in orogenic andesites (Gill, 1981, p. 1II). Ruapehu specimens are low in $\mathrm{TiO}_{2}$, but much scatter and a weak positive correlation with silica is evident, in contrast to iron variation. Petrography and trace element geochemistry (see vanadium discussion) suggest fractionation of titanomagnetite, and negative correlation of $\mathrm{TiO}_{2}$ with silica could be anticipated. However, opaque oxides are minor phases, and the effects of titanomagnetite fractionation on $\mathrm{TiO}_{2}$ of bulk rocks must be weighed against the effects of co-precipitating silicate minerals. Pyroxenes contain only about $0.2-0.7 \%$ $\mathrm{TiO}_{2}$, and olivine and plagioclase concentrations are below the EPMA detection limit for $\mathrm{TiO}_{2}$. Hence, silicates in general have lower $\mathrm{TiO}_{2}$ than bulk rocks, and their fractionation will tend to negate the decrease of $\mathrm{TiO}_{2}$ associated with titanomagnetite fractionation.

Phosphorous contents in orogenic andesites are characteristically low, between 0.05-0.30 wt $\% \mathrm{P}_{2} \mathrm{O}_{5}$ (Gill, 1981, p. 112). Values reported 
here vary from $0.05-0.20$ wt $\% \mathrm{P}_{2} \mathrm{O}_{5}$, have a weak positive correlation with silica in the range $52-62 \% \mathrm{SiO}_{2}$, and then decrease in bulk rocks > 62 $\mathrm{S} \mathrm{SiO}_{2}$. This is consistent with petrography, since apatite is found as a trace mineral in about half of all rocks $>60 \% \mathrm{SiO}_{2}$, and could be a fractionating phase only in acid andesites and dacites.

Alkalies correlate positively with silica. No significant K- bearing phenocrysts (hornblende, biotite, $\mathrm{K}$-feldspar) have been identified in the lavas, and potassium is strongly incompatible through the entire compositional range. Sodium is contained in plagioclase (2-6 wt $\% \mathrm{Na}_{2} \mathrm{O}$ ), is therefore more compatible than potassium, and has a weaker positive correlation with silica for rocks with $52-59 \% \mathrm{SiO}_{2}$. In bulk rocks > $59 \%$ $\mathrm{SiO}_{2}$, sodium is rather constant; this probably reflects the increasing role of plagioclase fractionation relative to pyroxenes in evolved liquids, and the increasing albite component of plagioclase during fractionation. Some scatter is produced by crystal accumulation and magma mixing.

\subsection{TRACE ELEMENTS}

Selected trace elements are plotted against rubidium in Fig 109. Rubidium is strongly incompatible during differentiation and increases 6-fold over the range $53-63 \% \mathrm{SiO}_{2}$. The bulk distribution coefficient for $\mathrm{Rb}$ is probably close to zero through the entire compositional range, since no phenocryst minerals are $\mathrm{Rb}$ - sequestering phases. If $\mathrm{D}_{\mathrm{bulk}}, \mathrm{Rb}=0$ and perfect fractional crystallization is assumed, then application of the Rayleigh Law shows that about $80 \%$ fractional crystallization of basaltic magma is required to produce acid andesites with $60 \% \mathrm{SiO}_{2}$. The 

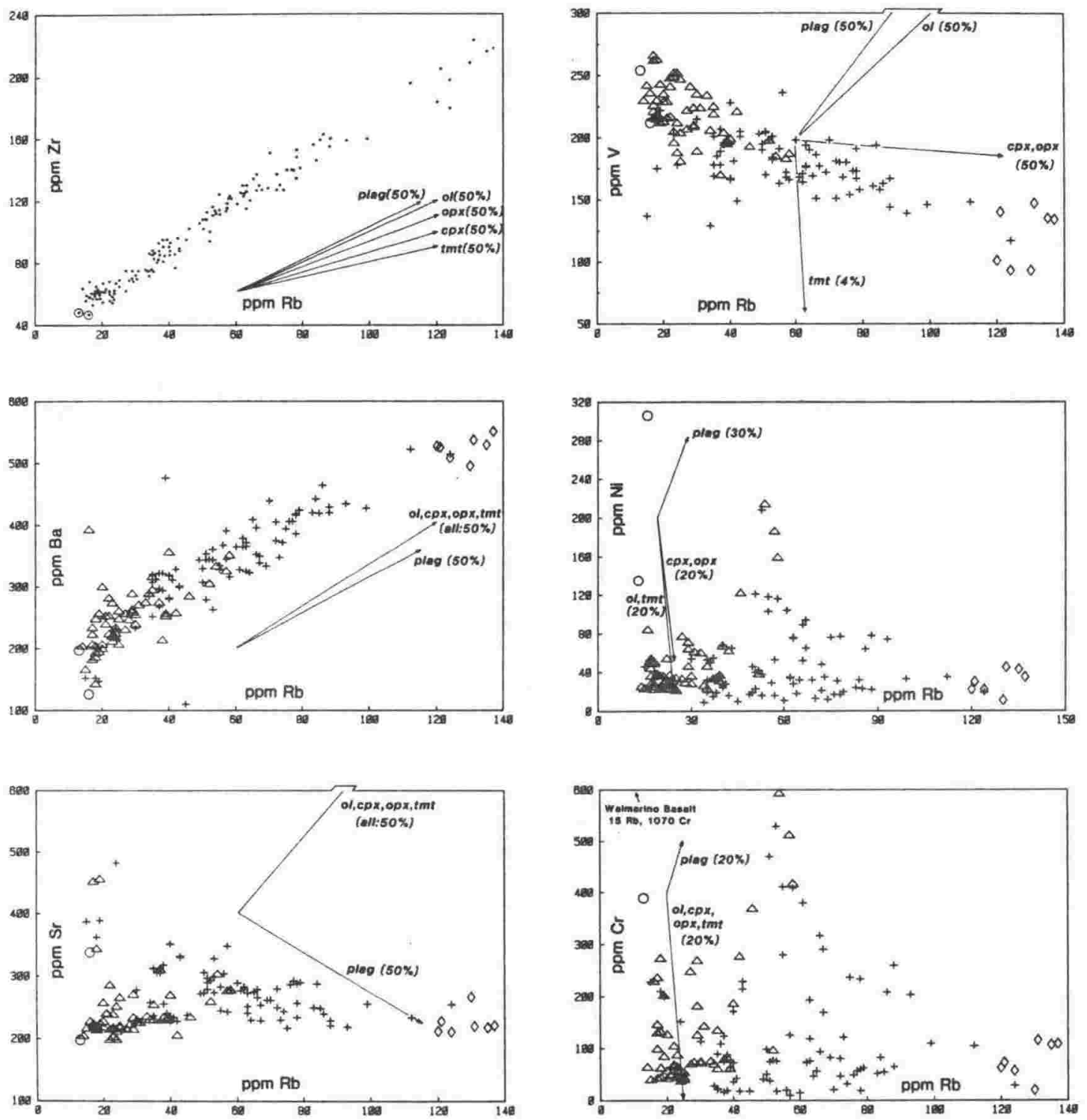

EIG 109. Rubidium variation diagrams for 144 bulk rocks from Ruapehu and related vents. Basalts, circles; basic andesites, triangles; acid andesites, crosses; dacites, rhombs. Note the minor abscissa scale change on the Ni-Rb diagram. Vectors indicate liquid lines generated by perfect fractional crystallization of individual phenocryst minerals, and the percentages crystallized are shown in parentheses. Vectors that continue off scale are not terminated by arrows. Calculation of vectors assumes Rayleigh Law behaviour, and mineral-melt distribution coefficients of Gill (1981, Table 6.3). 
compositional gap at $100-120 \mathrm{ppm}$ Rb corresponds to the $\mathrm{SiO}_{2}$ hiatus between acid andesites and dacites, a further indication that dacites may not be genetically related to andesites by fractional crystallization alone.

Zirconium is an incompatible, high field strength cation and shows a positive linear correlation with rubidium. Barium also correlates positively with $\mathrm{Rb}$, and high Ba values are characteristic of the rock suite: Even basalts have $100-200 \mathrm{ppm} \mathrm{Ba}$, which is 2-10 times the abundances reported for oceanic tholeiites (Basaltic Volcanism Study Project, 1981).

Strontium varies largely between 200-300 ppm for most rocks. This near- constancy is typical of orogenic andesites (Gill,1981), and suggests that $D^{S r}$ bulk $\approx 1$ during differentiation. A cluster of values at 15-20 ppm Rb and 300-500 ppm Sr includes Waimarino Basalt, a primitive quartz tholeiite with relatively high $\mathrm{Sr}$, together with its proposed differentiates (see: Part III, Petrogenesis). The high $\mathrm{Sr}$ of Waimarino Basalt (348 ppm) is a useful geochemical fingerprint and will be used later to identify hybrid magmas that mixed with it. In the range 30-90 $\mathrm{ppm} \mathrm{Rb}$, many lavas with $\mathrm{Sr}>280 \mathrm{ppm}$ are plagioclase- accumulative or hybrids produced by mingling of Waimarino Basalt and evolved magmas.

Vanadium decreases regularly with increasing $\mathrm{Rb}$, and follows the trend of $\mathrm{FeO}^{\mathrm{t}}$. This suggests fractionation of vanadium- bearing phase(s) throughout the compositional range, and petrographic evidence indicates that opaque oxides (with $\mathrm{V}^{3+}$ substituting for $\mathrm{Fe}^{3+}$ ) and pyroxenes are influential. If $\mathrm{D}^{\mathrm{RD}}$ bulk $=0, \mathrm{DV}_{\text {plagioclase }}=0, \mathrm{DV}_{\text {pyroxenes }}=1.1$, $D V_{\text {titanomagnetite }}=30$ and plagioclase:pyroxenes $=1$, then calculations using the Rayleigh equation show that $\mathrm{D}_{\text {bulk }} \approx 1.3$ to produce the observed $\mathrm{V}$ - $\mathrm{Rb}$ variation, and $\approx 0.02$ weight fraction titanomagnetite is required in the fractionating mineral assemblage. This small but necessary amount of titanomagnetite agrees with petrography. 
Nickel and Chromium are strongly compatible elements during fractionation of olivine, pyroxenes and opaque oxides. In basalts and basic andesites with 15-30 ppm Rb, fractionation of olivine, pyroxenes and chrome spinel is suggested by the rapid decrease of $\mathrm{Ni}$ and $\mathrm{Cr}$ concentrations. Acid andesites and dacites with $\mathrm{Rb}>30 \mathrm{ppm}$ achieve relatively constant values of around $20 \mathrm{ppm} \mathrm{Ni}$ and $\mathrm{Cr}$, again suggesting efficient removal by early fractionation of ferromagnesian minerals from parental magmas. The net result is a convex-downward trend on compatible-incompatible element diagrams (e.g., $\mathrm{Ni}-\mathrm{Rb}, \mathrm{Cr}-\mathrm{Rb}$ ); this trend can be reproduced using the Rayleigh equation, assuming $\mathrm{D}^{\mathrm{Rb}}{ }_{\text {bulk }} \approx 0$ and $\mathrm{D}^{\mathrm{Ni}, \mathrm{Cr}}$ bulk $>1$. Thus, the trend is highly suggestive of fractional crystallization of basaltic magma. However, considerable scatter at high $\mathrm{Cr}$ and $\mathrm{Ni}$ occurs, similarly to $\mathrm{MgO}$ and $\mathrm{Mg}^{*}$ diagrams, and concurrently high compatible-incompatible element values cannot be explained by closed-system fractional crystallization alone. Possible reasons for this scatter include open-system accumulation of ferromagnesian crystals and mixing of basic and acid magmas. As an indication of the pervasive influence of magma mixing and ferromagnesian mineral accumulation, it is instructive to note that nearly all samples contain > $10 \mathrm{ppm} \mathrm{Ni}$ and $\mathrm{Cr}$. Even some dacites contain $>50 \mathrm{ppm} \mathrm{Ni}$ and $>100 \mathrm{ppm} \mathrm{Cr}$, and these rocks have small xenocrysts of forsteritic olivine with chrome spinel inclusions (Fig 93H). 


\section{PART 11: PETROGENESIS}

"... apparently as many roads lead to andesite as to Rome."

Gill (1981, p. 314) 


\section{INTRODUCTION}

\subsection{GENERAL STATEMENI}

The field, geochemical and petrographic data of Parts I and II will now be applied toward constructing petrogenetic hypotheses. It is shown in Part I that lavas from Ruapehu and related vents are spatially (except Waimarino Basalt, which lies $45 \mathrm{~km}$ NE of Ruapehu) and temporally related. This, together with the nearly continuous but scattered compositional variation of bulk rocks shown in Part II, strongly implies consanguinity of the rock series, at least in the range of basalts to acid andesites. It has been demonstrated that samples are characteristically porphyritic, suggesting that many lavas do not represent liquid compositions. The minerals of lavas and nodules are anhydrous, and their mineral chemistry indicates low pressure crystallization, presumably in crustal reservoirs. Many lavas appear to be accumulative in igneous xenocrysts or rock fragments. Others exhibit petrographic features, such as mantled and reversely zoned phenocrysts, that are best explained by magma mixing; still others contain high- grade metamorphic xenoliths in various stages of assimilation, providing circumstantial evidence for crustal contamination and reservoiring in crustal magma chambers.

The major goal of Part III is to examine petrogenetic hypotheses that explain within- suite chemical and petrographic diversity. While no single path leads to andesite, fractional crystallization of basaltic magma is the principal process that explains compositional and mineralogical diversity. This follows the POAM (plagioclase- orthopyroxene/olivineaugite- magnetite) model of Gill (1981). Two time-transgressivé basalt magma types are identified as parental to Ruapehu andesites. These magma types are exemplified by two unique field occurrences of basaltic 
lava: Waimarino Basalt and Ruapehu basalt (from Mangawhero Fm).

Operating concurrently with fractional crystallization are the second-order processes crystal accumulation, magma mixing and assimilation of crustal material. Thus, diversity of rock composition and texture can be explained only by 'integrated models', as suggested by Gill (1981) and T.H. Green (1980).

\section{NATURE OF THE NORTH ISLAND PLATE BOUNDARY}

Cole and Lewis (1981) and Cole (1984) discuss the major structural features of North Island. The features shown in Fig 110 are considered to result from right- lateral oblique convergence between the Pacific and Indian Plates. The Hikurangi Trough (or Trench) to the east of North Island is regarded as a structural trench that marks the Indian- Pacific plate boundary and is the topographic expression of the suture marking plate collision. West of the trench is a $150 \mathrm{~km}$ - wide accretionary prism characterized by imbricate thrust faults in thick Upper Cretaceous to Quaternary turbidites. The accretionary prism is bounded on the west by a frontal ridge of Upper Paleozoic- Mesozoic greywacke, which forms the main axial ranges of North Island. The North Island Shear Belt (Cole, 1984) is a zone of dextral transcurrent fau!ts that cuts obliquely across the frontal ridge. Thus, oblique convergence is manifested by compressional features to the east (thrust faults of the accretionary prism) and dextral strike- slip features to the west (North Island Shear Belt). The Taupo Volcanic Zone (TVZ; also see Fig 1 and accompanying discussion) comprises a young andesite- dacite volcanic arc along its eastern side (Taupo Arc; Cole and Lewis, 1981), and a western volcano- tectonic depression (Taupo-Rotorua Depression; Grindley, 1960) involving' normal faulting and rhyolitic graben fill. The depression is interpreted by cole and Lewis (1981) and Cole (1984) as an ensialic marginal basin. Ruapehu 


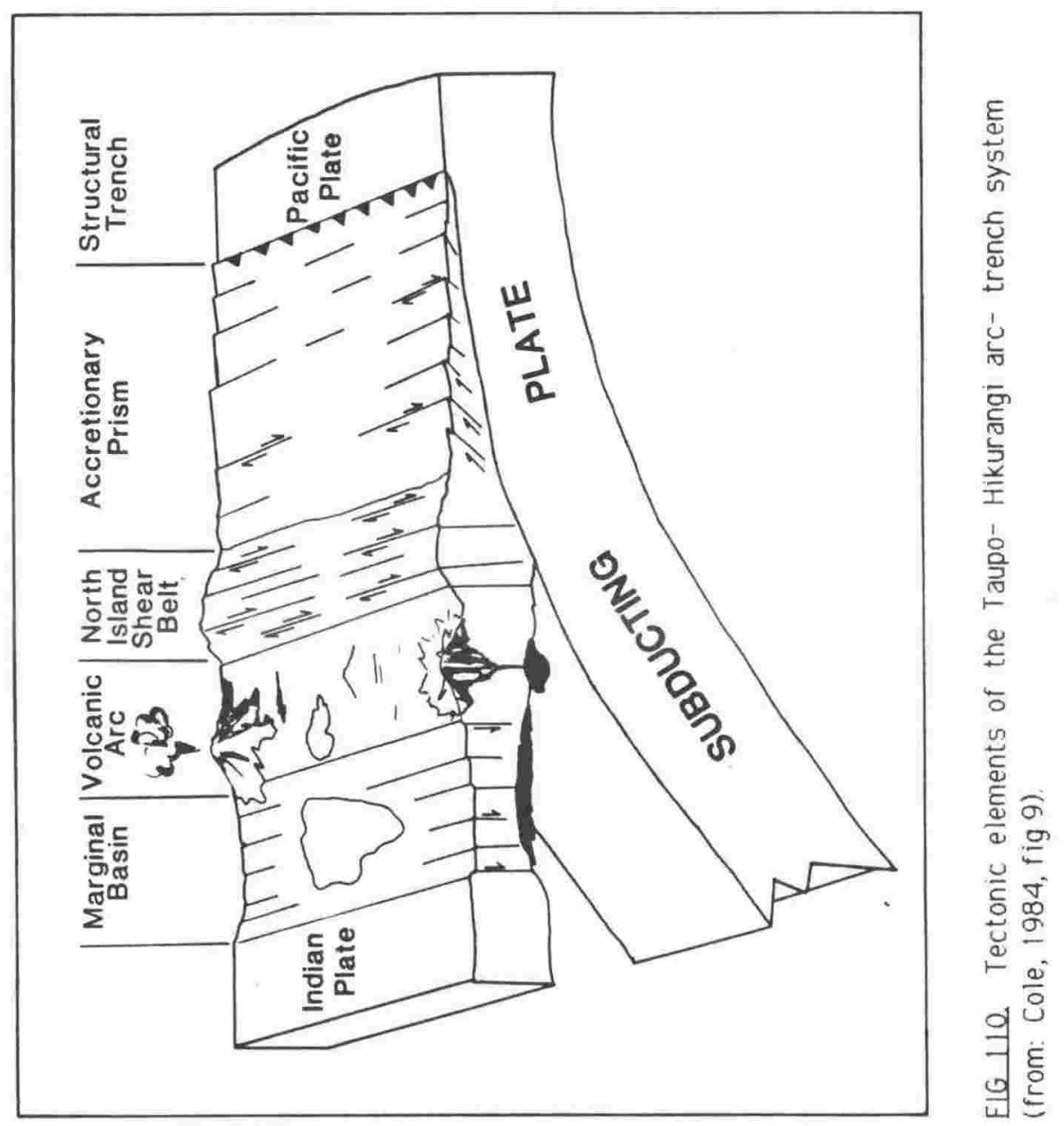


is at the southern limit of the TVZ and can be considered as part of the Taupo Arc, but neither the marginal basin nor its associated rhyolitic volcanism extend this far south (see Fig 1).

Geophysical studies have led to the recognition of tectonic features that are germane to discussion of andesite petrogenesis. Current geophysical interpretations are synthesized in Fig 111 . Perhaps the most speculative aspect of Fig 111 is the inferred shallow depth to the asthenosphere (ca. $30 \mathrm{~km}$ ) beneath Ruapehu. Although this interpretation is only inferred by published geophysical data, it is consistent with those data and has been supported during discussion with colleagues. Furthermore, as will be shown later, petrogenesis of quartz- normative basalts requires melting of the upper mantle at depths less than about 60 $\mathrm{km}$, implying the presence of shallow asthenosphere beneath the TVZ. Although the depth to asthenosphere beneath the TVZ is not well constrained, the following features are implied by geophysical data: (1) The existence of a westward- dipping seismic zone that reaches $80 \mathrm{~km}$ depth beneath Ruapehu, (2) the presence of anomalous (low- Q) mantle above the seismic zone and occurring only beneath the TVZ region, and (3) thin crust and lithosphere beneath the TVZ, in contrast to surrounding regions with about $35 \mathrm{~km}$ crustal thickness.

\subsection{PREVIOUS WORK ON PETROGENESIS OF TVZ ERUPTIVES}

Steiner (1958) and Clark (1960) are the first to use petrography and bulk rock major element chemistry to discuss the origins of TVZ magmas. Three distinct groups of volcanic rocks are recognized by these authors: (1) A "Main Basic Series", showing continuous variation from basalt to dacite, is considered to result from combined fractional crystallization and crustal assimilation, involving a contaminated high- Al basalt parent 


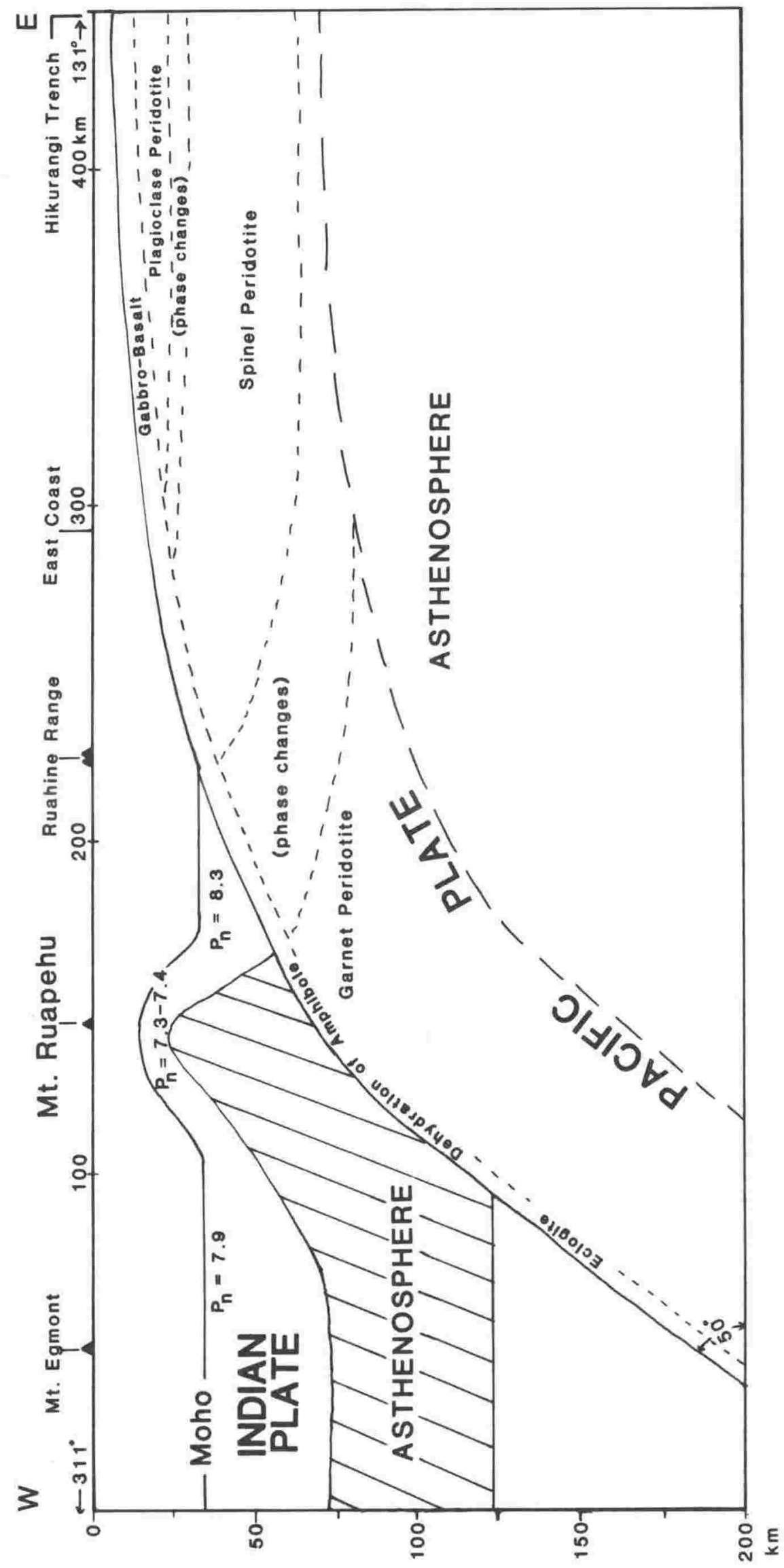


magma. (2) An "Accumulative Series" of basic andesites $\left(53-57 \% \mathrm{SiO}_{2}\right.$, with relatively low $\mathrm{Al}_{2} \mathrm{O}_{3}$ and high $\mathrm{MgO}$ ) is aberrant from chemical trends of the Main Basic Series and is petrographically characterized by " ... a notable amount of olivine phenocrysts" (Steiner, 1958). The Accumulative Series is considered to have originated by gravitational accumulation of early- crystallized olivine \pm clinopyroxene, in combination with limited fractional crystallization of olivine basalt magma. (3) A "Continuous Acid Series" of rhyolites and ignimbrites is excluded from being derived by fractional crystallization of the contaminated basaltic magma. Rather, the rhyolites and ignimbrites are viewed as having been "... derived from an acid magma resulting from transfusion of acid gneiss in prolonged contact with basaltic magma at great depth" (Steiner, 1958). Thus, two parent magmas are postulated for TVZ eruptives- one basaltic and one rhyolitic- and these in turn produced three distinct magma series. Fractional crystallization of basaltic magma, accumulation of earlyformed igneous crystals and selective crustal assimilation are considered by Steiner (1958) and Clark (1960) to be petrogenetic processes in basic to intermediate volcanics of the TVZ.

Ewart and Stipp (1968) use K, U, Th and ${ }^{87} \mathrm{Sr} /{ }^{86} \mathrm{Sr}$ to infer petrogenesis of TVZ lavas. They conclude that TVZ rhyolites are derived by widespread partial fusion of eugeosynclinal greywacke-argillite sediments. Data for andesites are interpreted as being inconsistent with their derivation by fractional crystallization of outcropping high- $\mathrm{Al}$ basalts, or by direct mantle derivation involving a single-stage process. Andesite data are interpreted as being most consistent with crustal assimilation by basalt or by a primary andesitic magma, with greywacke-argillite sediments acting as the contaminant.

Duncan (1970) rules out andesite origin by assimilation as being inconsistent with bulk rock major and trace element compositions, and 
shows that neither mixtures of (high- Al basalt) + (rhyolite) nor (high- Al basalt) + (greywacke/argillite) can approximate the major and trace element composition of average andesite. Duncan (1970) therefore proposes an origin from a subducting lithospheric plate by a two-stage process similar to that proposed by Taylor (1969).

Cole (1973) compiles field data, petrography and bulk rock chemical analyses from high- Al basalts of the TVZ; all high-Al basalt localities are shown to be associated with rhyolitic eruptive centres. Cole and Teoh (1975) describe the petrography and bulk rock chemistry of Pureora andesite volcano (an older volcanic centre to the NW of the Tongariro volcanoes), and argue that the lavas are pyroxene- accumulative basic andesites.

Cole (1978) provides the first major research paper dealing only with andesites of the Tongariro Volcanic Centre. Bulk rock major and trace element analyses, modal data and partial mineral analyses are given. Tongariro, Ngauruhoe and Ruapehu lavas are shown to be "normal" calcalkaline andesites (57-63 wt \% $\mathrm{SiO}_{2}$ and corresponding to acid andesites of the present study) and low-Si andesites (53-57\% SiO 2 and corresponding to basic andesites of the present study). Some low-Si andesites are regarded as phenocryst- rich cumulates. A model is presented in which subducted oceanic crust tectonically assimilates sediments at the eastern side of North Island, and eventually produces amphibolite at depth. Breakdown of amphibolite leads to hydration of the overlying mantle and lower crust, and eventually phlogopite eclogite is produced at depths of about $90 \mathrm{~km}$. Then, a multistage mechanism of magma genesis is envisaged (Green and Ringwood, 1968; Ringwood, 1975), involving partial melting of phlogopite eclogite and subsequent fractionation of this magma in the upper mantle or lower crust, producing "normal" and low-Si andesites. Crustal contamination of TVZ andesites is 
suggested by Cole (1978), after comparing Tongariro andesites (with relatively high $\mathrm{Na}_{2} \mathrm{O}, \mathrm{K}_{2} \mathrm{O}, \mathrm{RD}, \mathrm{Ba}$ and $\mathrm{Zr}$ ) with island arc andesites such as those of Tonga (Ewart and Bryan, 1973). Cole (1978) considers the contaminant to be sediments of the accretionary prism that became tectonically mixed with basalt at the top of the downgoing slab.

Cole (1979) reviews the structure, petrology and genesis of TVZ volcanics and presents a modified version of the multistage magma genesis model, with several changes from the earlier phlogopite eclogite melting model (cf.: Cole, 1978). New seismic interpretations by Adams and Ware (1977) led Cole (1979) to place the depth to the top of the subducting slab beneath the Tongariro volcanoes at about $80 \mathrm{~km}$ and not $170 \mathrm{~km}$ as suggested earlier by Hamilton and Gale (1968). Cole (1979) proposes that amphibolite (and not phlogopite eclogite) would break down at 80-100 km depth, generating intermediate magma that would subsequently fractionate to produce the Tongariro andesites. Rare earth element data given in Cole (1979) are shown to be non- supportive of eclogite melting. Pyroxene andesites are regarded as accumulative lavas, while olivine low-Si andesites are considered to be a separate, more basic magma. Cole (1982) reviewed andesites of the Tonga- Kermadec- New Zealand region and maintained the same multi-stage hypothesis as Cole (1979).

Cole, Cashman and Rankin (1983) present rare earth element data for andesites and basalts of the TVZ. Least squares mixing models indicate that neither high-Al nor low-Al basalts (specifically, the low-Al Red Crater Basalt, Tongariro; Cole 1978) are likely parents for labradorite or labradorite- pyroxene andesites. However, the Red Crater basalt is thought to be directly related to olivine low-silica andesites and olivine andesites of the Taupo Arc by fractionation. The source region of andesites is inferred to be garnet- free, due to flat heavy rare earth 
element patterns on chondrite- normalized plots, but the authors concede that the source could be either the top of the subducting plate or a hydrated lower portion of the mantle wedge. All lavas are believed to have undergone crustal contamination, on the basis of light rare earth element enrichment, though the composition and source of the contaminant is not specified by Cole, et al (1983).

Reid and Cole (1983) discuss the origin of TVZ dacites (63-68\% $\mathrm{SiO}_{2}$ ) and use quantitative petrologic models to conclude that a number of processes have operated on a local scale to produce dacite. These processes include: Fractional crystallization of andesite, andesite fractionation plus crustal contamination, partial melting of greywacke, and partial melting plus magma mixing. Thus, TVZ dacites are shown by Reid and Cole (1983) to be a minor $\left(5 \mathrm{~km}^{3}\right.$ total volume) but petrogenetically diverse group.

Reid (1983) discusses the origin of rhyolitic rocks of the TVZ. Major element, trace element and rare earth element analyses for the greywacke basement surrounding the TVZ are presented, as well as new rare earth element analyses for rhyolites. Least- squares mixing calculations and Rayleigh fractionation models are used to show that the rhyolites are not likely to have been derived through fractional crystallization of basaltic or andesitic parents. Rather, non- modal melting of granulite with a bulk composition equivalent to the Western Basement can reproduce most geochemical features of the rhyolites.

\subsubsection{Comments on Previous Work}

In the 25 years since the origins of TVZ lavas were first studied, major petrogenetic hypotheses for andesitic rocks have included fractional crystallization of basaltic magma (Steiner, 1958; Clark, 1960) 
and slab melting (Cole 1978, 1979, 1982). Some basic intermediate lavas were considered to be accumulative in phenocryst minerals, and all andesitic lavas were considered by all authors to have undergone crustal contamination, though no consensus exists as to the nature of the contaminant. Most quantitative modelling of andesite genesis has been simplistic, involving mixtures of high- Al basalt + greywacke/argillite or rhyolite, and compositions used in modelling were averages of published analyses. The inability of high- Al basalt fractionation to produce andesites (Ewart and Stipp, 1968; Cole, et al, 1983) is consistent with the complete geographic separation of high-Al basalts and andesites (Cole, 1973). The existence of a second, low-Al basalt magma type, in geographic association with andesitic lavas, was first recognized by Cole (1978; Red Crater basalt, Tongariro), but attempts to model "average labradorite and labradorite-pyroxene andesite" as a derivative of this lowAl basalt were unsuccessful (Cole, et al, 1983), implying yet another parental magma type for these andesites. At present, no satisfactory quantitative petrogenetic model exists for andesites of the TVZ.

The present writer will argue that fractional crystallization of low-Al, quartz- normative basaltic magmas, together with phenocryst accumulation, magma mixing and crustal contamination, can explain diversity of composition and texture. With the exception of magma mixing, these are not new to discussion of TVZ andesite genesis; however, the present data base is more extensive and quantitative modelling is therefore better constrained. 


\section{THE ROLE OF THE MANTLE WEDGE}

As shown in Fig 111, the "low-Q upper mantle zone" of Mooney (1970) implies the existence of an asthenosphere wedge beneath North Island. The wedge may be shallower beneath TVZ relative to surrounding regions in order to explain the very high heat flow, which requires efficient heat transfer to the surface and implies shallow asthenosphere convection beneath TVZ. The depth to the top of the slab is ca. $80 \mathrm{~km}$ beneath Ruapehu (Reyners, 1980) and this has several petrogenetic implications: (1) The mantle wedge can comprise only plagioclase- and spinel peridotite, since garnet peridotite is stable only at depths $>80-90$ km (D.H. Green and Ringwood, 1970; and assuming oceanic geotherm of D.H. Green and Ringwood, 1967). (2) At $80 \mathrm{~km}$ depth, the hydrated upper portion of the slab will have achieved an amphibolite mineral assemblage, and amphibolite dehydration is probably near completion by the time the slab has reached 75-100 km depth (Anderson, et al, 1976; Delaney and Helgeson, 1978). This would liberate water and possibly other volatile constituents ("IRS fluid" of Gill, 1981) into the overlying mantle wedge, significantly lowering its melting point. Only at depths $>80-100 \mathrm{~km}$ would the anhydrous slab achieve eclogite mineralogy (Ringwood, 1974); therefore, the slab is not assumed to be eclogitic beneath Ruapehu.

Whether the slab melts or not is a matter of speculation, and depends on the assumed degree of slab heating as it subducts (e.g., thermal models of Toksoz, et al, 1971; Griggs, 1972). The present writer considers that subsolidus slab dehydration, and not slab melting, occurs beneath Ruapehu, fluxing the overlying mantle wedge and allowing hydrous partial melting of peridotite in the wedge. Reasons for this conviction include: (1) Presence of anomalous mantle beneath TVZ, which can be interpreted as partially molten or perhaps veined peridotite, (2) Basalts, axiomatically the products of peridotite anatexis, are parental magmas to 
andesites at Ruapehu. The doctrine of simplicity is applied by the present writer: If basaltic magma, even in minor volume, is found in geographic association with calc- alkaline andesites and if basalt can quantitatively be demonstrated as the parent magma of andesites, then more complex petrogenetic hypotheses (e.g., the multi-stage model of Ringwood, 1974) become less viable.

Two new basalt magma types have been identified during the present study. Waimarino Basalt, though it is a unique, isolated occurrence that is geographically unrelated to Ruapehu, represents a magma type that is important in petrogenesis of Ruapehu lavas. Ruapehu basalt is also a unique occurrence, but is associated spatially and temporally with andesitic lavas of Mangawhero Fm, Ruapehu. These two basalts have many compositional traits in common (e.g., both are quartznormative), but are sufficiently different to be considered as separate magma types. Bulk rock analyses of these basalts, together with other basalt magma types, are given in Table 7 .

\subsection{PRIMITIVE NATURE OF WAIMARINO BASALI}

Quartz- normative basalts and basic andesites can originate by differentiation of parental basalts, and porphyritic lavas with high $\mathrm{Mg}^{*}$ can originate by accumulation of refractory ferromagnesian crystals. It is therefore necessary to argue that Waimarino Basalt (with $23.5 \%$ phenocrysts) is: (1) a liquid composition; i.e., not accumulative in olivine and clinopyroxene, and (2) a primary magma of the upper mantle that has not undergone significant modification by fractionation processes.

Texture and mineral compositions suggest that the Waimarino Basalt (hereafter, WB) is not accumulative. If forsteritic olivine crystals were added to a basic andesite magma (whose composition is represented by the WB groundmass), we would expect an abrupt compositional change 


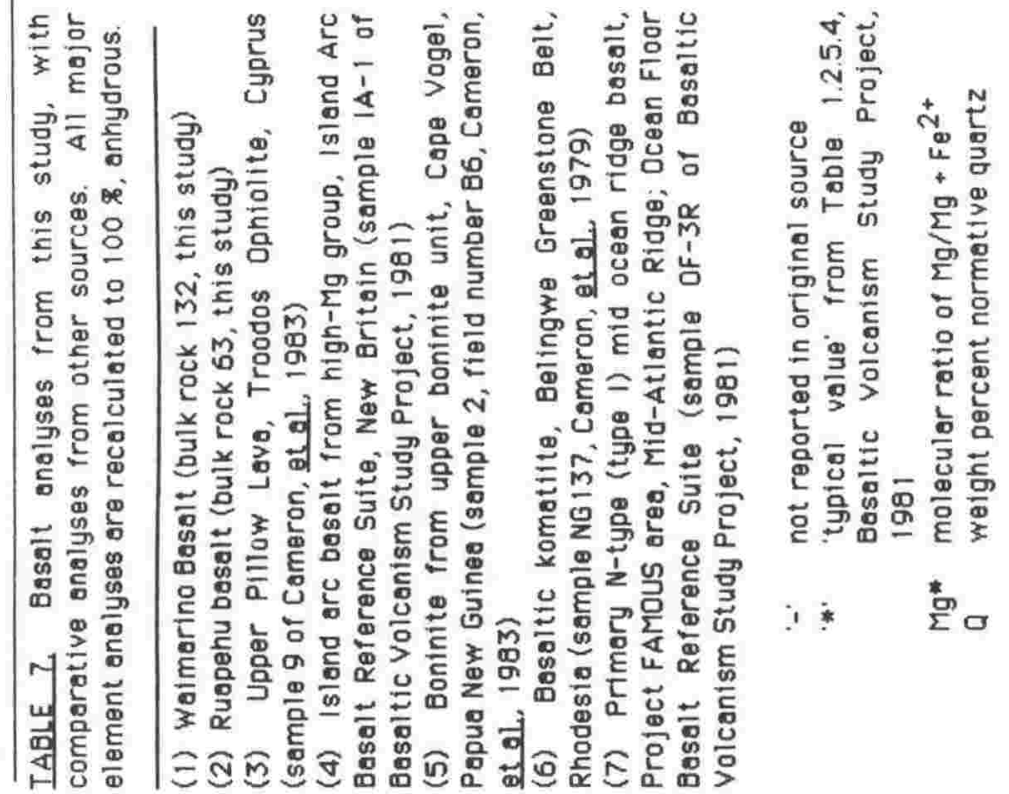


within the olivine crystals, since the groundmass liquid is in equilibrium with $\mathrm{F}_{74}$. This is not observed; olivine phenocrysts are always smoothly

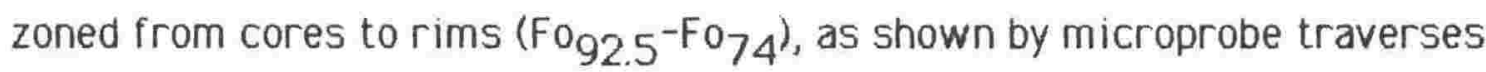
across several large grains. Furthermore, olivine microphenocryst cores reach $\mathrm{F}_{89}$ and are also smoothly zoned. Clinopyroxene crystals exhibit similar zonation patterns. These features suggest heterogeneous nucleation and growth of olivine and clinopyroxene from an evolving liquid whose residue comprises the groundmass, not addition of exotic ferromagnesian crystals into a basic andesite liquid.

Sparse olivine-clinopyroxene glomerophenocrysts do not have hypidiomorphic- granular texture and contain abundant interstitial glass with similar composition to groundmass glass. Thus, they are not interpreted as accidental nodules, but rather as cognate phenocrysts that nucleated and grew in close proximity.

We now test whether the forsteritic olivine cores $\left(\mathrm{Fo}_{92.5-90.8}\right)$ are in equilibrium with the bulk rock, when the bulk rock composition is assumed to represent the primitive liquid from which these olivines grew. Application of the Roeder and Emslie (1970) distribution coefficient:

$$
(\mathrm{Fe} / \mathrm{Mg})^{0 l} /(\mathrm{Fe} / \mathrm{Mg})^{\mathrm{liq}}=0.3
$$

indicates that the liquid that crystallized $\mathrm{F}_{0} 92.5-90.8$ had an $\mathrm{Mg} / \mathrm{Mg}+\mathrm{Fe}^{2+}$ (mol) ratio of $0.78-0.75$. This is within the observed bulk rock limits of $\mathrm{Mg} / \mathrm{Mg}+\mathrm{Fe}^{2+}=0.78$ (calculated using the titrimetric $\mathrm{FeO}$ ) and 0.74 (calculated using total iron as $\mathrm{Fe}^{2+}$ ). Hence, the bulk rock, if regarded as a liquid composition, is in equilibrium with its olivine phenocryst cores when $\mathrm{K}_{\mathrm{D}}=0.3$.

Olivine phenocryst cores are nickeliferous (0.3-0.4 wt \% NiO) and a 
distribution coefficient $\mathrm{D}_{\mathrm{Ni}}{ }^{\text {ol-liq }}=[\mathrm{ppm} \mathrm{Ni}$, olivine cores/ ppm Ni, bulk rock $=7.0-7.8$ is calculated. This is comparable to published olivine-liquid distribution coefficients for $\mathrm{Ni}$ in basaltic magmas having the 13 wt \% MgO of Waimarino Basalt [cf.: Fig. 2 of Irving's (1978) review of experimental trace element partitioning], and is a further suggestion of olivine-liquid equilibrium.

Having used petrography and mineral chemistry to show that WB was probably once entirely liquid, it remains to argue that WB is a primitive magma. Clarke and O'Hara (1979) have noted that if a lava is a primary magma, then the calculated or observed olivine composition should approximate to that of the residual mantle source region. Upper mantle olivines, particularly those from depleted peridotites, lie in the range $\mathrm{Fo}_{94-89}$ (Sato, 1977). Waimarino Basalt, with $\mathrm{Fo}_{92.5-90.8}$, meets Clarke and O'Hara's (1979) criterion for primitive status. The observed abundances of $\mathrm{MgO}(13.15$ wt \%), $\mathrm{Ni}(310 \mathrm{ppm})$ and $\mathrm{Cr}(1070 \mathrm{ppm})$ are also appropriate for primitive magrnas.

As a final argument for primitive status, Waimarino Basalt plots within the primary melt field of Hanson and Langmuir's (1978) MgO-FeO pyrolite melting grid at 1 atmosphere under anhydrous conditions. Conditions indicated by the grid are $30 \%$ melting at $1300 \mathrm{C}$, with $\mathrm{Fo}_{92}$ and minor pyroxene left in the residue.

\subsection{PRODUCTION OF QUARTZ NORMATIVE MAGMAS IN THE UPPER MANTLE}

Since Waimarino Basalt is interpreted as a primitive magma type, comparison with some experimentally- derived liquids is worthwhile. Liquids with normative compositions near the plane of silica saturation (quartz tholeiites and olivine- poor tholeiites) have been generated experimentally by anatexis of pyrolite and natural inerzolite. Quartz 
tholeitites have been generated from peridotite under both watersaturated (Green, 1973, and the complementary study of Nicholls and Ringwood, 1973) and anhydrous conditions (Jaques and Green, 1980). Anhydrous melting at low pressure is generally considered appropriate for the source regions of mid ocean ridge basalts (MORB), whereas hydrous melting of the mantle wedge is probably more likely for subductionrelated basaltic magma (Nicholls and Ringwood, 1973), with hydrous fluid derived from subducted oceanic lithosphere. The pressure- percent melting grid of Fig 112 is based on water- saturated, waterundersaturated and anhydrous melting experiments. The grid indicates that anhydrous melting of peridotite (or pyrolite) can yield quartz normative liquids only to pressures $<7 \mathrm{~kb}$, with degrees of melting on the order 15-35\% (Jaques and Green, 1980). Quartz normative liquids can be generated to pressures of about $18 \mathrm{~kb}$ under water-saturated conditions (Green, 1973). The extension of quartz normative melts to higher pressures under hydrous conditions is attributed to expansion of the stability field of olivine (Kushiro, 1972), permitting mantle olivine to be in equilibrium with silica- saturated melts. Other important features of the grid are: (1) The high pressure limit of the hydrous melt field implies a $60 \mathrm{~km}$ maximum depth of melting beneath Ruapehu. (2) Partial melting in the upper mantle is restricted to the plagioclase peridotite and Al-pyroxenes + spinel peridotite stability fields. [This is confirmed by REE studies on TVZ lavas (e.g., Cole, et al 1983); that is, a garnet-free residuum is suggested by REE patterns of TVZ basalts and andesites.] (3) Quartz tholeiites are produced to greatest depths (ca. $60 \mathrm{~km}$ ) under watersaturated conditions and when the percentage of melting is 25-30\%. It is appropriate to consider the slab as a source of hydrous fluid, since dehydration of amphibole is expected to occur at depths between 60 and $100 \mathrm{~km}$ (Delaney and Helgeson, 1978).

As a comparison to Waimarino Basalt, Green (1973) reports that 


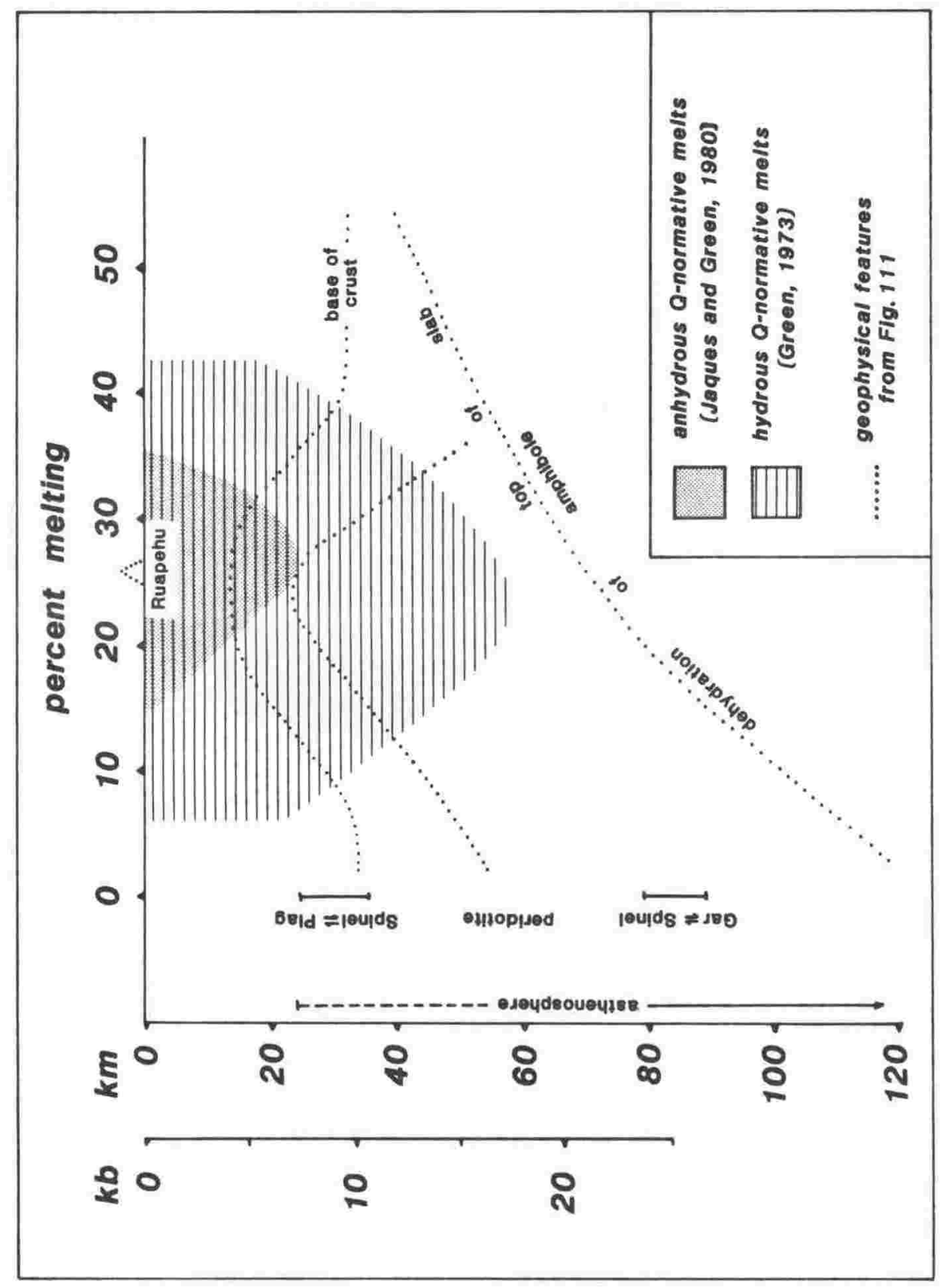

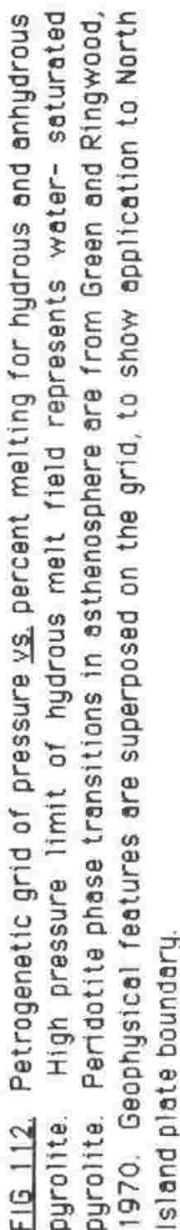


magnesian quartz tholeiite ( $5 \%$ normative quartz) is produced by $32.5 \%$ melting of pyrolite under water-saturated conditions, $10 \mathrm{~kb}, 1200^{\circ} \mathrm{C}$. This melt has $\mathrm{Mg}^{*}=75$, and the following mineral assemblages are observed at $10 \mathrm{~kb}$ : Olivine alone $\left(\mathrm{Fo}_{93}\right)$ is present as an equilibrium crystalline phase at $1200^{\circ} \mathrm{C}$, clinopyroxene and olivine are present at $1100^{\circ} \mathrm{C}$, and orthopyroxene first appears at $1050^{\circ} \mathrm{C}$. These experimentally determined features are remarkably similar to those calculated or observed for WB, and lend strong support to the hypothesis that WB was generated by 30-35 percent partial melting under hydrous conditions, in the spinel- or plagioclase peridotite stability field.

\subsection{COMPOSITION OF RUAPEHU BASALT AND RELATIONSHIP TO WAIMARINO BASALI}

Ruapehu basalt of Mangawhero $\mathrm{Fm}$ (hereafter, RB) has $\mathrm{Mg}^{*}=71$, suggesting that it, too is a primitive magma. Although RB bulk rock is in equilibrium with its $\mathrm{Fo}_{90}$ olivine phenocrysts, the bulk rock probably does not represent a primary liquid because petrography and mineral chemistry suggest accidental entrainment of igneous crystals from intermediate magma: Mantled pyroxene and feldspar crystals are present (Fig 93A). The cores of these grains have compositions appropriate for basic andesite liquids, but the outer mantles are in equilibrium with basaltic magma. These features are not likely to have resulted from magma mixing with an evolved end member (i.e., basic- or acid andesite) because bulk rock incompatible element concentrations are too low; for example, RB has only $12 \mathrm{ppm}$ rubidium. In spite of the evidence for crystal accumulation, the present writer has nonetheless used RB as a parental magma in mixing calculations to derive andesites, since it is the only basaltic lava known from Ruapehu. 
Relative to WB, RB has higher concentrations of $\mathrm{Ti}, \mathrm{Al}, \mathrm{Fe}, \mathrm{P}$ and alkalies, and lower concentrations of compatible elements such as $\mathrm{Mg}, \mathrm{Cr}$ and $\mathrm{Ni}$ (Table 7). This suggests RB may be a differentiate of the more primitive WB, but least- squares calculations (not reported) disprove olivine + clinopyroxene fractionation from WB to derive RB. Inspection of the bulk rock analyses provides confirmation: RB has much lower strontium and slightly lower rubidium than WB; this would require $D^{S r}$ bulk $\gg 1$ and $D^{R b}$ bulk $>1$ during early fractional crystallization of WB, which is inconsistent with petrography. In addition, incompatible element ratios such as $\mathrm{K} / \mathrm{Rb}$ and $\mathrm{Ba} / \mathrm{Zr}$ are substantially different between the two basalts; these ratios would not be affected by fractional crystallization, implying different sources and/or melting processes. Consequently, they must be thought of as different magma types.

\subsection{COMPARISON OF WAMMARINO BASALI WITH OTHER BASALT MAGMA IYPES}

Waimarino Basalt (Table 7) is very similar to some of the Upper Pillow Lavas from the Troodos Ophiolite, the only notable differences being the higher Ti, Sr, Ba, $\mathrm{Zr}$ and LREE of WB. Sun and Nesbitt (1978) referred to these pillow lavas as "low-Ti ophiolitic basalts" and concluded that they were produced by hydrous melting of a depleted mantle source in an interarc basin or young island arc setting. Similarly, WB is believed to reflect young volcanism in the Taupo Arc (Hackett, in press). In terms of major elements, WB is also similar to basaltic komatiite, an Archaean magma type that has Phanerozoic analogues in the silica- oversaturated but highly compatible element- rich "boninite series" of primitive arc volcanism (Meijer, 1980). Cameron, et al (1979) have shown that Phanerozoic boninite petrographically resembles Archaean basaltic 
komatiite, and the range of boninite compositions overlaps that of basaltic komatiites. Waimarino Basalt does not meet the strict petrographic definition of boninite, since it is neither glassy nor does it have orthopyroxene phenocrysts; the former is due to subaerial extrusion of WB (as opposed to submarine boninite), and the latter reflects the more silica-poor bulk composition of WB relative to boninites. However, WB has many of the same major and trace element features that Meijer (1980) proposed as characteristic of "boninite series" volcanic rocks (Fig 113).

Moderate to high degrees of peridotite melting (ca. $30 \%$ ) characterize WB and tholeites in general, so a comparison of WB with other tholeiites is undertaken. Relative to 'primary' ocean ridge (MORB) and island arc tholeiites (IAT), WB is enriched in the incompatible elements $\mathrm{K}, \mathrm{Rb}, \mathrm{Sr}, \mathrm{Ba}$ and LREE, and has higher ${ }^{87} \mathrm{Sr} /{ }^{86} \mathrm{Sr}, \mathrm{MgO}, \mathrm{Mg}^{*}, \mathrm{Cr}$ and $\mathrm{Ni}$ (Table 7). It also differs from MORB and IAT in having a lower Ti/Zr ratio (Fig 113). The concurrently high compatible element abundances ( $\mathrm{Mg}$, $\mathrm{Cr}, \mathrm{Ni}$ ) and low $\mathrm{Ti}$ and $\mathrm{P}$ of Waimarino Basalt suggest melting of previously depleted mantle or retention of residual phases (ilmenite, rutile, sphene, apatite?) in the source. However, the degree of partial melting that is implied by the bulk composition and by comparison with experimental results seems to preclude residual phases other than olivine + orthopyroxene in the source of WB.

The present writer therefore favours melting of a depleted source, but this cannot explain the LIL element- enriched character of WB, relative to other tholeiites. Although data for Waimarino Basalt are incomplete, the MORB- normalized pattern of WB is similar to that of island arc tholeiites (Fig 114), where continental crust is absent in the overriding plate. Depletion of $\mathrm{Ta}$ to $\mathrm{Yb}$ in WB and IAT relative to MORB can be attributed to higher degrees of partial melting and/or lower degrees of fractionation than MORB (Pearce, 1984). Enrichment of Sr to Th in WB and IAT relative to MORB must result from enrichment processes affecting 

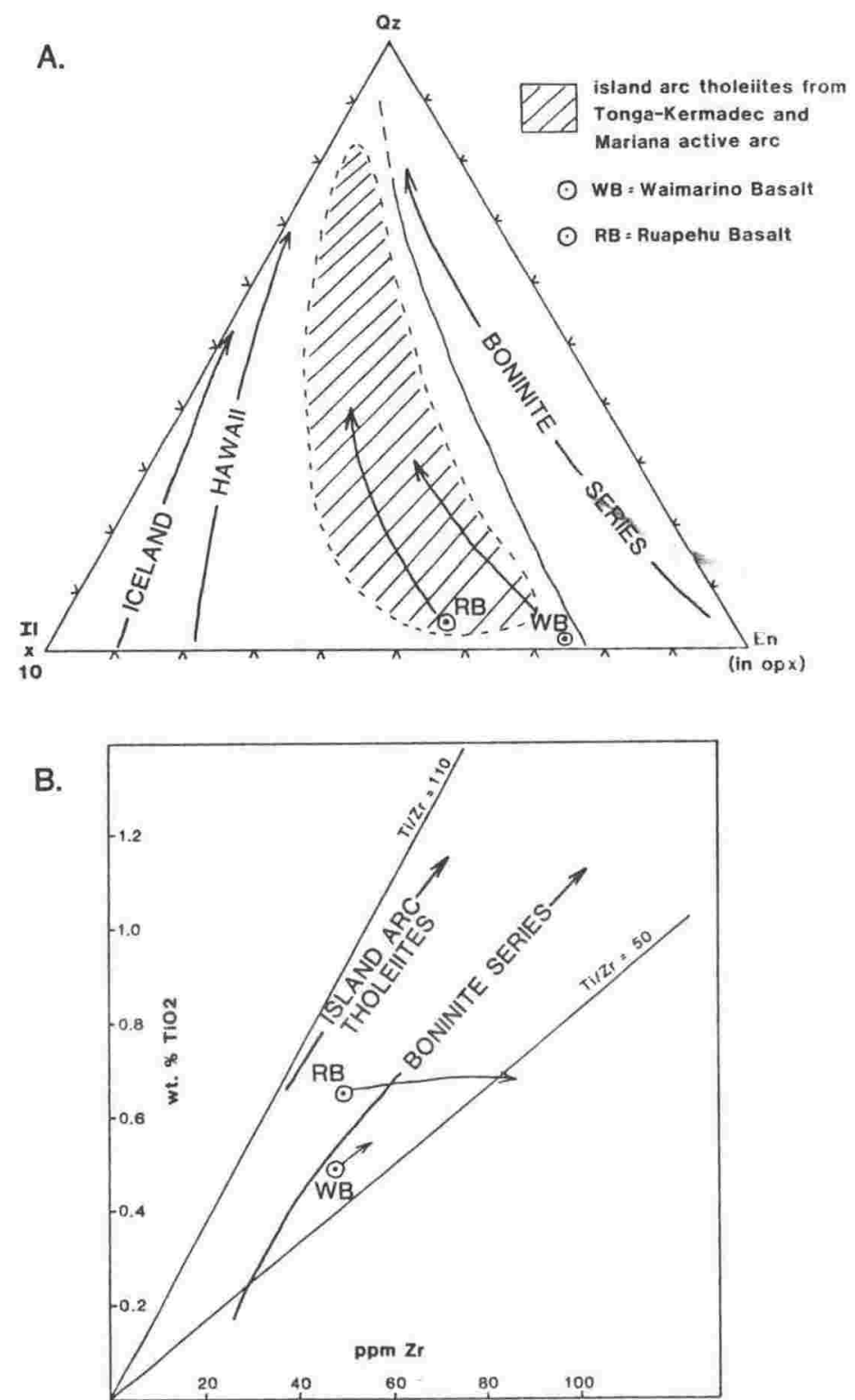

EIG 113. Major and trace element characteristics of 'boninite series' volcanic rocks and island arc tholeiites (from: Meijer, 1980, figs 4 and 6).

A. Plot of normative components enstatite (in orthopyroxene), quartz and ilmenite $x$ 10. Boundary curve separating boninite series from other series is drawn by Meijer (1980) on the basis of mineralogy, texture and other chemical components (e.g, high $\mathrm{Mg}, \mathrm{Cr}, \mathrm{Ni}$ in boninite). Bold arrows show differentiation trends of volcanic rock series; boninite series rocks are generally silica- oversaturated and have low concentrations of h.f.s. elements such as $\mathrm{Ti}, \mathrm{Zr}$, and $\mathrm{Y}$, so they plot at the extreme right of the diagram. Differentiation trends of basalts of this study (WB, RB; see section III-3 for modelling of fractional crystallization) are similar to those of island arc tholeiites, but WB appears transitional between boninite series and arc tholeiites, using criteria of this plot.

B Plot of $\mathrm{TiO}_{2}$ versus $\mathrm{Zr}$. Note boninite series rocks have $\mathrm{Ti} / \mathrm{Zr}$ ratios substantially less than the average chondritic value of 110 , in contrast to arc tholeiites. Basalts of the present study have $\mathrm{Ti} / \mathrm{Zr}$ ratios similar to boninite series, but differentiation trend of RB does not parallel that of boninite series. 


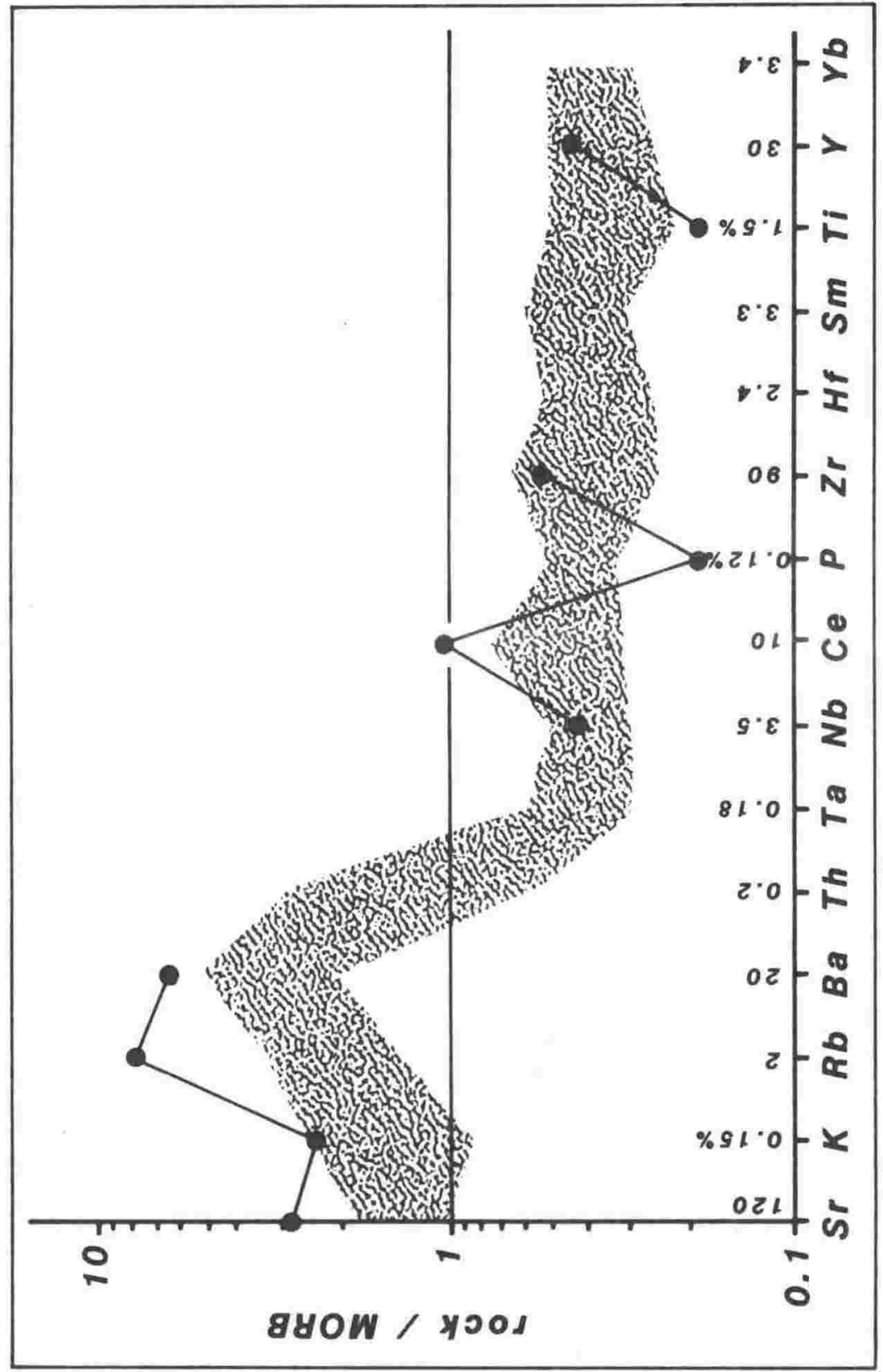

응 옳 닌

立章

몽

몰ㄴ

额造造

(1) क 듕

는른

일 है

总 든믄

元范

통 둥

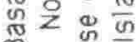

(⿻)

은

范它的

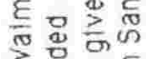

3 品

응

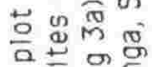

무은

당

है

论的空

1.

ह

굳ㄴㄷㄴㄷㅗ

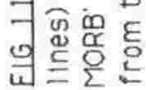


their source regions or from contamination during ascent through the crust (Pearce, 1984). Although the data of Fig 114 do not permit discrimination of the source of LIL element enrichment for WB, the present writer emphasizes the similarity with IAT and suggests that the enrichment of WB at least partially owes to metasomatism of the mantle source region. The origin of metasomatic fluids is suggested to be the subducting slab.

Other workers have attributed the enrichment of incompatible elements in TVZ lavas to contamination by continental crust; e.g., Ewart and others' (1977) comparison of Tonga- Kermadec with New Zealand volcanic rocks. Minor crustal contamination of WB is likely, since WB contains rare mm-sized quartzite xenoliths. However, mineralogy and bulk rock chemistry strongly suggest that WB is a primitive magma type that erupted after little or no fractionation (section 11-2.1). It therefore seems likely to the present writer that incompatible element enrichment of WB at least partially owes to enrichment of its mantle source region, and not entirely to the effects of crustal contamination. Orogenic andesite derivatives must inherit these characteristics; i.e., some measure of the LIL- and LREE-enriched character of TVZ andesites is probably due to parental (and primary) magma characteristics, and not solely to the effects of crustal contamination of andesite during its rise and storage in the upper plate.

The present writer concludes that the role of the mantle wedge beneath Ruapehu is to produce basaltic magma, by anatexis of the asthenosphere and/or the subcontinental lithosphere. This process is probably catalyzed by hydrous, metasomatic fluids from the subducting slab. The resulting melts include quartz-normative but primitive basalt that is depleted in $\mathrm{P}$ and $\mathrm{Ti}$, and enriched in Sr, LIL, LREE and radiogenic strontium, relative to MORB and IAT. The origin of the LIL- LREE- ${ }^{87} \mathrm{Sr}-$ enriched component in parental basalts is arguable, but probably reflects both mantle metasomatism (slab component) and contamination during rise 
and storage of magma (crustal component).

\subsection{ULTRAMAFIC NODULES AS POSSIBLE SAMPLES OF UPPER MANTLE}

Most igneous nodules found in Ruapehu lavas are pyroxeneplagioclase rocks, but rare, $\mathrm{cm}$-sized nodules of dunite and harzburgite (Fig $96 \mathrm{~K}, \mathrm{~L}$ ) are found in tephra of Pukeonake Scoria Cone. It will be argued later that the lavas of Pukeonake are hybrid in origin, involving mixing of primitive basalt and dacite. The ultramafic rock fragments were undoubtedly brought up as a component of the primitive basalt, but their interpretation remains uncertain: They could represent either crystal cumulates from primitive basalt, or accidental upper mantle fragments. At present, they raise more questions than they answer.

Whatever their origin, the mineralogy is refractory: harzburgite (Fig $96 \mathrm{~K}, \mathrm{~L}$ ) contains $\mathrm{F}_{88}$, dunite nodules contain $\mathrm{Fo}_{92}-88$ (no photomicrographs, but see analyses in Appendix IV-136-2,5), and one olivine crystal in a Pukeonake lava flow is $\mathrm{F}_{94}$ (Appendix 111-139-7). All dunites and harzburgites contain refractory chrome spinel with 52-53 wt $\% \mathrm{Cr}_{2} \mathrm{O}_{3}$

The dunite nodules are equigranular-polygonal in texture, but harzburgite (Fig $96 \mathrm{~K}, \mathrm{~L}$ ) has bands of orthopyroxene that suggest penetrative deformation, perhaps as a result of upper mantle diapirism. Veins of silicic, aluminous, alkali- and volatile-rich glass are present in the ultramafic nodules (see Appendix IV-136-50,16 for glass analyses), the Mg-numbers of which are far too low for the glass to be in equilibrium with olivine of the host nodules. Nor is the glass likely to derive firom the enclosing andesitic host magma, since the host magma can only react with, but not melt, such refractory nodules. The possibility exists that 
these nodules represent depleted mantle with volatile-rich metasomatic veins, the latter having melted during decompression. 


\section{THE ROLE OF BASALT FRACTIONATION}

Bowen (1928) argued persuasively that fractional crystallization is a common process in nature and can explain much of the compositional diversity of igneous rocks. Gill (1981) presents previously published quantitative fractionation models from diverse regions of orogenic andesite volcanism, and argues that fractional crystallization of basaltic magma is "...by far the most common and extensive process" that produces orogenic andesites. Gill (1981) refers to this as "POAM" (plagioclase + orthopyroxene/olivine + augite + magnetite) fractionation.

The bulk rock compositional variation shown in Figs 107 and 109 suggests that removal of the phenocryst minerals olivine, pyroxenes, plagioclase and opaque oxides may be an important differentiation mechanism for the Ruapehu rock suite. Accordingly, quantitative modelling of fractional crystallization has been undertaken: Summarized results of least squares mixing calculations are given in Tables 8 and 9, and calculated vs, observed mineral proportions are compared in Fig 115.

\subsection{CRITERIA FOR CHOICE OF SAMPLES REPRESENTING LIQUID}

COMPOSITIONS

It has been shown in Part II that nearly all lavas are porphyritic, and petrographic evidence for crystal accumulation and magma mixing exists in many samples. Therefore, the present writer has been selective in choosing samples for quantitative modelling of fractional crystallization. The essential criterion for choosing rocks that approximate to liquid compositions is not total phenocryst content, but rather the textural relations of phenocrysts. As far as possible, the writer has' chosen samples that are free of crystal aggregates and mantled phenocrysts. 


\section{DISCUSSION OF LEAST SOUARES MODELLING}

Fractional crystallization of Ruapehu and Waimarino basalt magma types, and their possible derivative liquids has been modelled in stepwise fashion; i.e., from basalt to basic andesites, then basic to acid andesite, then acid andesite to dacite. This is necessary because the types and proportions of phenocryst minerals change significantly from basalt to dacite. The reported calculations are the results of extensive trial and error on selected samples.

Calculated and observed phenocryst assemblages are compared in Fig 115. The reader is reminded that the calculated fields show the mineral proportions that are removed in order to achieve a match with the parent magma, therefore the calculated and observed proportions for a given rock should not be compared directly. For example, in Fig 115B, the small amount of plagioclase removal required by calculation is consistent with the observed large amount of plagioclase in rock $11-135$ because the parent magma does not contain plagioclase phenocrysts at all. That is, the calculated mineral proportions in derivative magmas ideally should fall somewhere between the proportions observed in the parent and derivative magmas. The following features of Fig 115 are worthy of mention: (1) The observed assemblages from basalt to dacite in Fig 115A summarize the petrographic information of Part $11-2.1$ to 2.5. That is, opaque oxides are minor but ubiquitous in lavas, the proportion of plagioclase phenocrysts and the orthopyroxene: clinopyroxene ratio increase with bulk rock acidity, and olivine disappears in basic andesites as a consequence of reaction with liquid. (2) The calculated mineral assemblages are generally in excellent agreement with the observed assemblages. Especially noteworthy is the requirement of minor opaque oxide fractionation, which was suggested earlier by major and trace element trends for the rock suite (Figs 107-109). (3) The calculated mineral proportions for dacite do 
A.
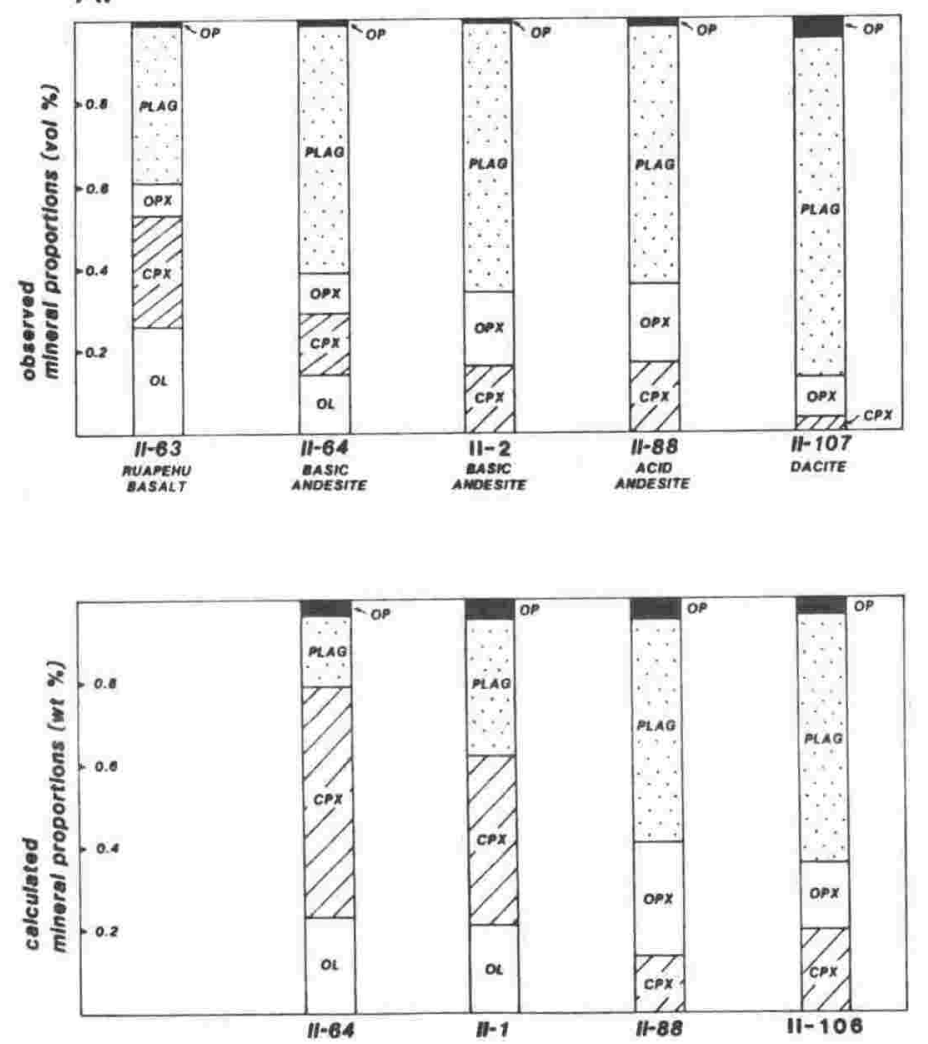

B.
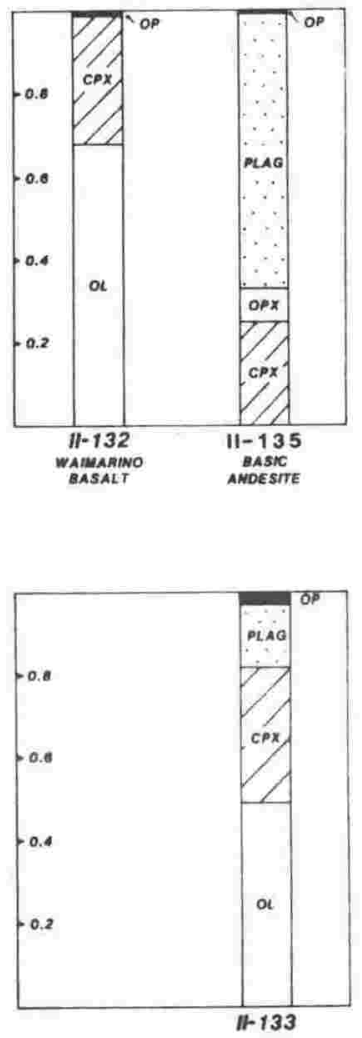

EIG 115 Comparison of calculated and observed mineral proportions during fractional crystallization. Calculated mineral proportions are from least squares mixing models of Tables 8 and 9. Observed mineral proportions are from modal data of Tables 1, 3 and 5 ; since modes have not been obtained for rocks $11-1,11-106$ and $11-133$, rocks of nearly identical petrography from the same formations have been used $(11-2,11-107$ and $11-135)$. ${ }^{\prime} O L^{\prime}=$ ollvine, $^{\prime} C P X X^{\prime}=$ clinopyroxene, ${ }^{\prime} O P X=$ orthopyroxene, ${ }^{\prime} P L A G '=$ plagtoclase, $O P{ }^{\prime}=$ opaque oxides.

A. Fractional crystallization of Ruapehu basalt magma type to yield andesites and dacite B. Fractional crystallization of Waimarino Basalt magma type to yield basic andesite of Hauhungatahi 
not agree with petrography, since the calculated total pyroxenes and clinopyroxene: orthopyroxene ratio are excessively high.

In Table 8 , the calculated and observed bulk rock compositions are in good agreement for the steps: (Ruapehu basalt) - (minerals) $=$ (basic andesites), and: (Basic andesite) - (minerals) = acid andesite. 5mall discrepancies in compatible elements such as $\mathrm{Cr}$ can be explained by minor pyroxene \pm opaque oxide accumulation, in spite of careful sample selection. Substantial discrepancies involving incompatible elements occur in several calculations of Table 8 , where the observed incompatible element concentrations of derivative lavas are too high to be explained by fractional crystallization alone. Barium, $\mathrm{Rb}, \mathrm{Zr}$ and $\mathrm{K}_{2} \mathrm{O}$ are components that would be affected by contamination processes, and the calculations suggest that fractional crystallization has acted concurrently with crustal contamination (see: Part III-6 for further discussion of the role of the crust). Incompatible element discrepancies for the step: (Acid andesite $)-($ minerals $)=($ dacite $)$ are so large that the simple fractional crystallization model (Table 8, VI-6) must be rejected, even though these rocks differ by only 5 wt $\% \mathrm{SiO}_{2}$. The writer has modelled several acid andesite-dacite combinations, and this calculation has the lowest residuals; no amount of manipulation will improve the major discrepancies for the incompatible elements $\mathrm{K}_{2} \mathrm{O}$ and $\mathrm{Rb}$ since no $\mathrm{K}$ - or $\mathrm{Rb}$ bearing phenocrysts are present in these rocks. The failed dacite calculation implies that process(es) in addition to fractional crystallization operate during dacite petrogenesis, and a mechanism is required for increasing the $\mathrm{K}$ and $\mathrm{Rb}$ values above the concentrations allowed by simple fractional crystallization of acid andesite. The writer proposes two hypotheses: (1) Since major discrepancies exist only for the incompatible elements, fractional crystallization may indeed operate, but in combination with selective assimilation of crustal material. The 

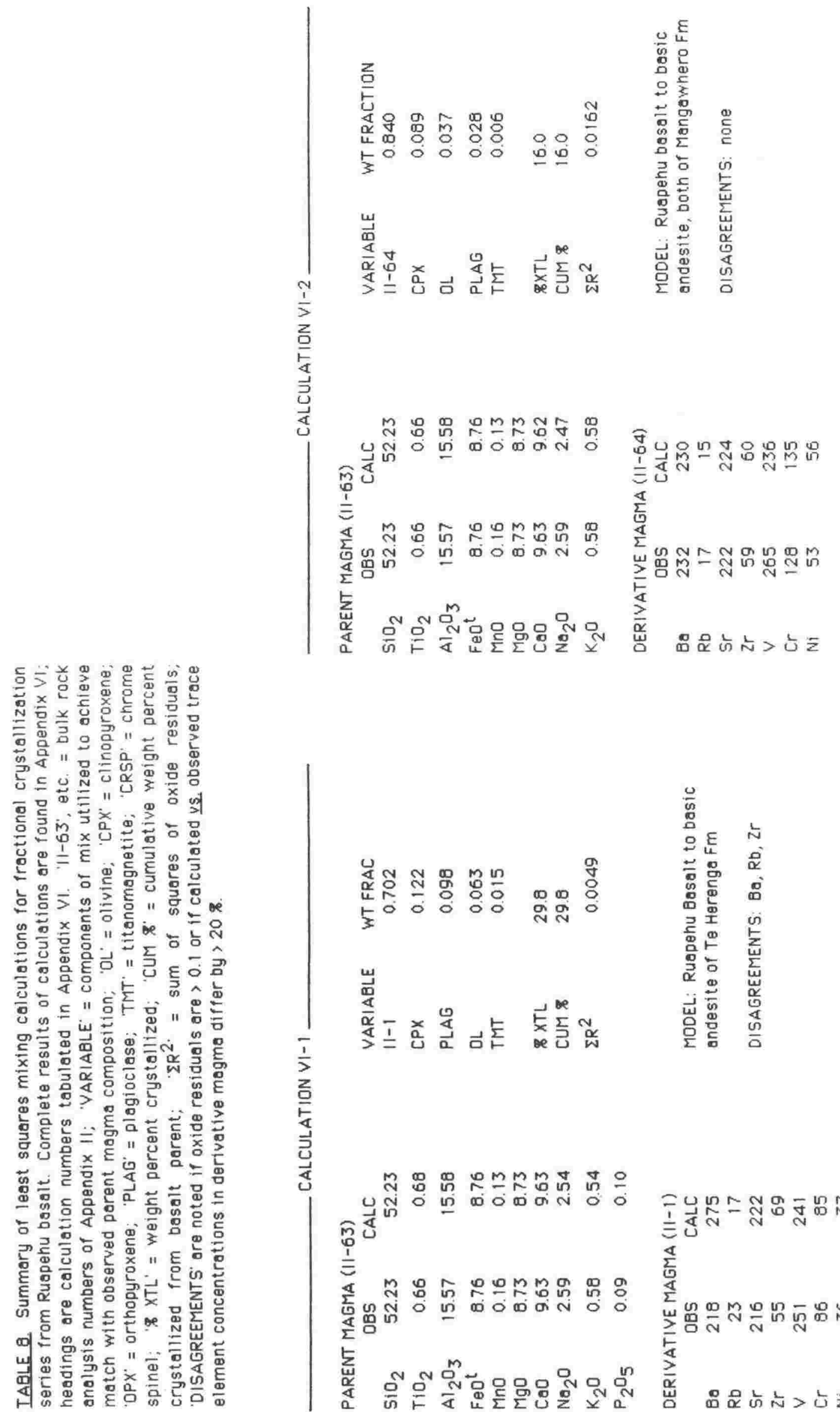

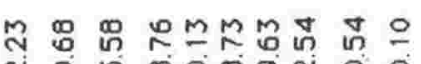

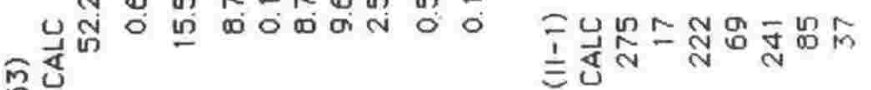
尊

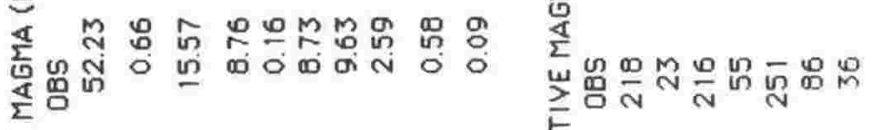

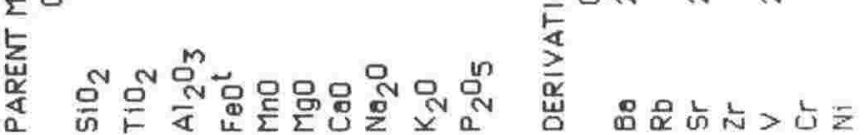



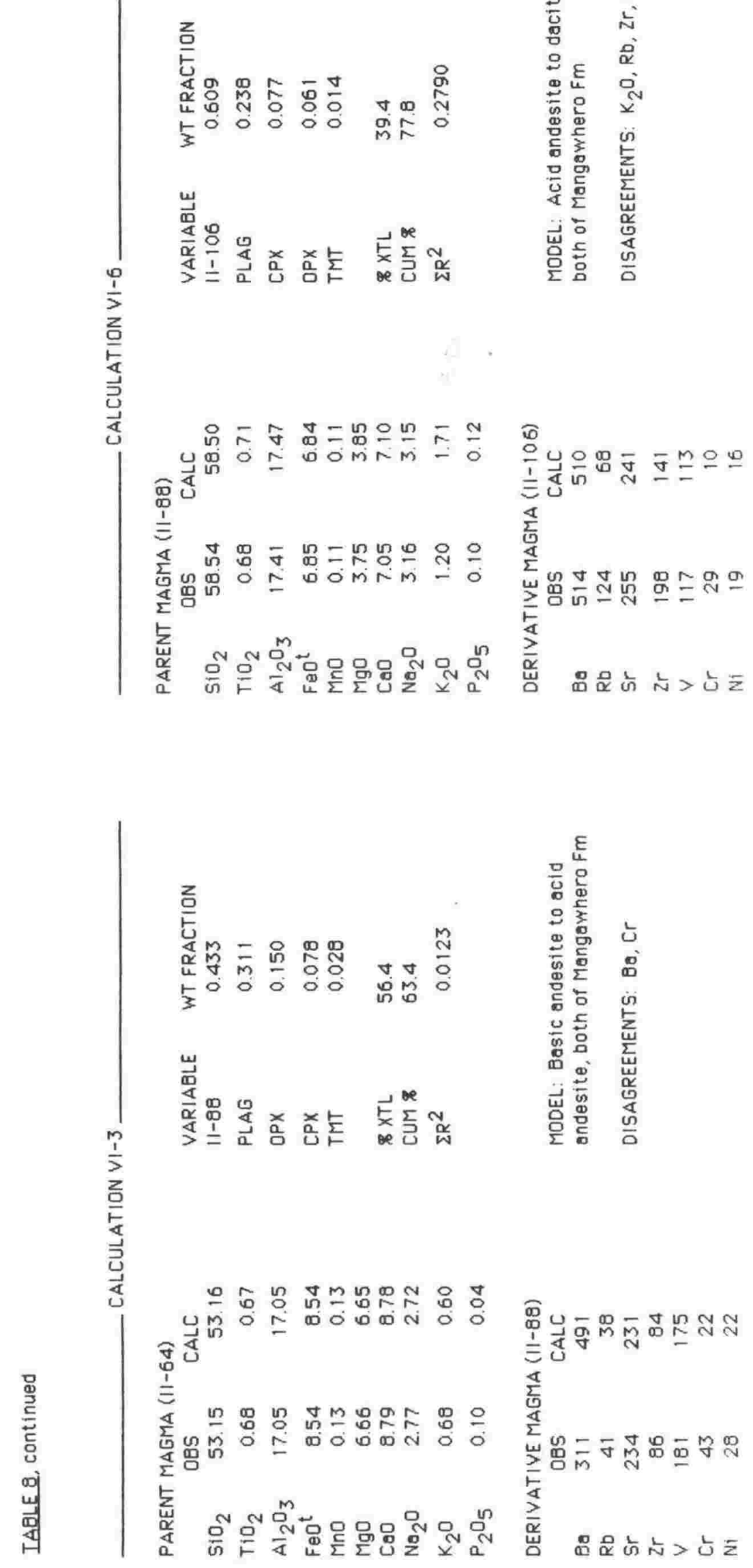
contaminant would need to be rich in incompatible elements, and may originate by anatexis of metamorphic xenoliths. (2) While acid andesites can largely be explained by protracted fractionation of parental basaltic magma, the Ruapehu dacites may be more closely related to TVZ rhyolites, in the sense that they are the products of crustal melting (cf: Reid and Cole, 1983). This possibility is supported by the compositional gap that exists between acid andesites and dacites on interelement variation diagrams (Figs 107, 109).

It is also noteworthy that the RB magma type has produced not only intraformational andesitic differentiates, but also differentiates in the much older Te Herenga Fm. This implies that the RB magma type, represented by a single basalt lava flow in Mangawhero Fm., is timetransgressive in the magma system of Ruapehu.

Calculations for fractionation of Waimarino Basalt magma type are presented in Table 9. In part, potential derivative magmas of the WB magma type were chosen on the basis of their high $\mathrm{Sr}$ concentrations relative to other basic andesites, since WB is characterized by high $5 r$. Waimarino Basalt lacks plagioclase phenocrysts, and $\mathrm{Sr}$ should therefore be incompatible during the early stages of fractionation, prior to major plagioclase crystallization. Calculated and observed results are in excellent agreement for Hauhungatahi basic andesite (Fig 115B, and Table 9, VI-4). The discrepancy for chromium can be explained by minor clinopyroxene accumulation, and this is consistent with the petrography of Hauhungatahi samples. Though not accounted for in the calculation, $\mathrm{Sr}$ isotopic ratios also differ between WB (0.70448) and Hauhungatahi (0.70423), suggesting significant isotopic differences between batches of WB magma type as a consequence of mantle source heterogeneity and/or varying degrees of crustal contamination. A further implication of this calculation concerns the stratigraphic context of the lavas: The WB magma type (age of WB at type locality is $14-20 \mathrm{Ka}$ ) has apparently 
冢

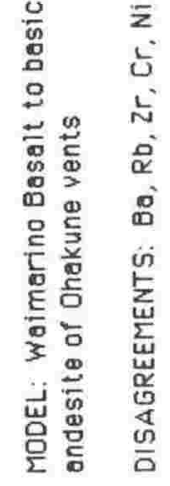

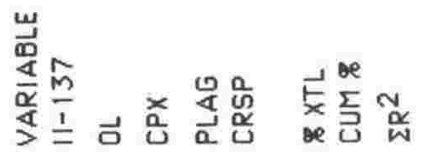

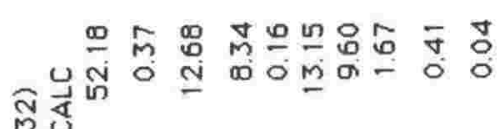

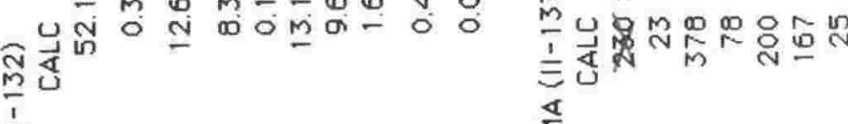

紊

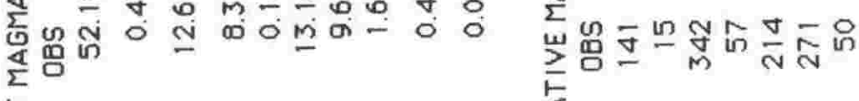

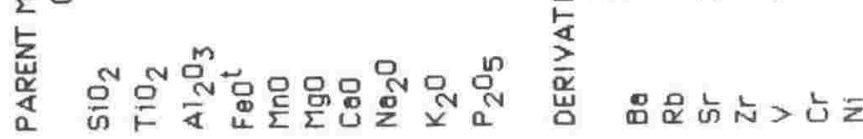

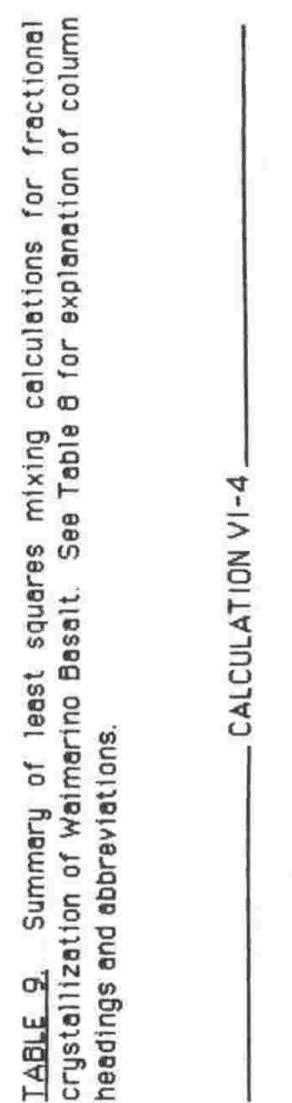

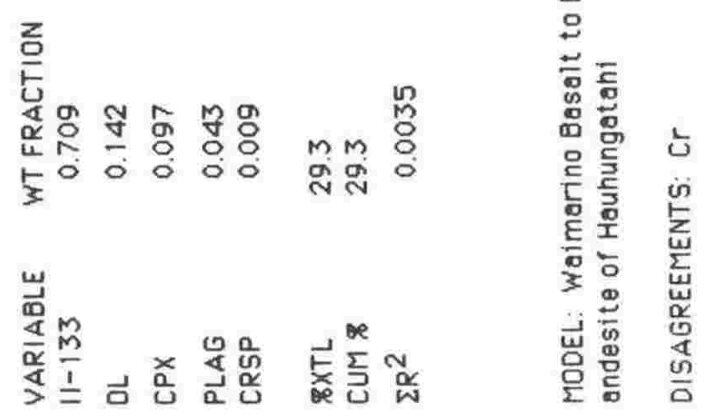

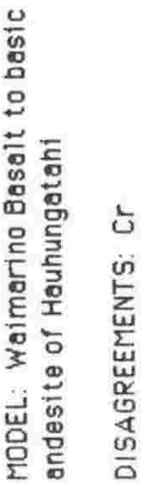

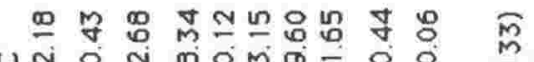

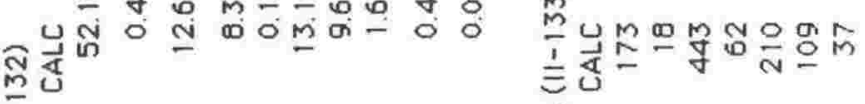

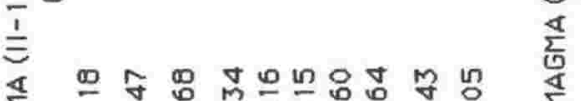

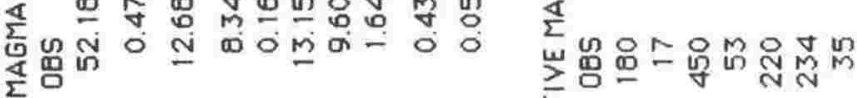

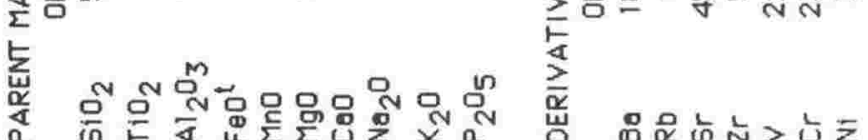


fractionated to produce Hauhungatahi basic andesites, which are among the oldest eruptives of the Tongariro Volcanic Centre. Clearly, single magma batches cannot have been involved and the calculations imply that magmas of the WB type may have been time transgressive.

A calculation to derive Ohakune basic andesite from Waimarino Basalt is given in Table 9, VI-5. The high bulk rock Sr of Ohakune lavas (ca. $340 \mathrm{ppm}$ ) relative to Ruapehu basic andesites (ca. $220 \mathrm{ppm}$ ) cannot be a result of accidental plagioclase entrainment, since Ohakune lavas contain only minor, euhedral plagioclase microphenocrysts. Rather, the high bulk rock $\mathrm{Sr}$ of Ohakune basic andesites suggests that these lavas may be differentiates of a high-Sr parental basalt that fractionated predominantly ferromagnesian minerals. The WB magma type is a probable parent for Ohakune basic andesite because WB at its type locality has high bulk rock $\mathrm{Sr}$, lacks plagioclase phenocrysts, and erupted nearly synchronously with the Ohakune vents. However, large trace element disagreements are present in the calculation to derive Ohakune basic andesite from the WB parent. Discrepancies for $\mathrm{Cr}$ and $\mathrm{Ni}$ can be explained by accumulation, since the Ohakune lavas contain small peridotite nodules; these nodules could be construed as cumulate fragments from the WB parent since the major nodule minerals are olivine and clinopyroxene. The disagreements for $\mathrm{Ba}, \mathrm{Rb}$ and $\mathrm{Zr}$ cannot be explained in this manner. The calculation suggests that the Onakune basic andesite may be: (1) The fractionation product of a parental basaltic magma type that is similar to Waimarino Basalt, but richer in $\mathrm{Ba}, \mathrm{Rb}$ and $\mathrm{Zr}$, or (2) the combined result of WB fractionation, accumulation and crustal contamination. The latter hypothesis is supported by the presence of small peridotite nodules and crustal rock fragments in Ohakune lavas, as well as slight enrichment of Ohakune lavas in radiogenic strontium $\left({ }^{87} \mathrm{Sr}_{\mathrm{r}}{ }^{86} \mathrm{Sr}_{\mathrm{S}}=0.70456\right)$ relátive to the proposed WB parent $\left({ }^{87} \mathrm{Sr} /{ }^{86}{ }_{5 r}=0.70448\right)$.

The preceding results and discussion show that simple fractional 
crystallization cannot entirely explain the petrographic and bulk rock chemical variation of Ruapehu lavas, even after careful sample selection. In a general way, fractional crystallization of basaltic magma is consistent with the petrographic and bulk rock chemical variation of andesites, but few individual mixing calculations of parent-derivative lavas are entirely satisfactory. This is true for several reasons: (1) Parental basalts may not be well characterized. Two basalt magma types, represented by two unique field occurrences, have been identif ied and used in quantitative modelling. There may be other basalts that produce different liquid lines from those calculated here (e.g., Red Crater basalt, Tongariro; Cole, et al, 1983). (2) Models that assume simple fractional crystallization are seldom satisfactory because fractional crystallization is apparently contemporaneous with other differentiation processes such as accumulation of igneous crystals, magma mixing and crustal contamination. In the following sections, these processes are examined more closely. 


\section{4.) INTRODUCTION}

Accumulation of igneous crystals in TVZ eruptives was first proposed by Steiner (1958) and Clark (1960), who considered an "Accumulative Series" of basic andesites that originated by accumulation of olivine and pyroxene into host liquids that were derived by fractional crystallization of a basaltic parent. Cole and Teoh (1975) demonstrated that the basic andesites of Pureora Volcano, TVZ, are pyroxeneaccumulative, and Cole (1979) suggested that some varieties of pyroxenerich basic andesites from the TVZ are accumulative in pyroxenes.

Ewart (1982) shows that significant statistical correlations exist between phenocryst modes and bulk rock compositions of basic to intermediate lavas from the southwestern Pacific: Plagioclase correlates with $\mathrm{Al}_{2} \mathrm{O}_{3}$; olivine with $\mathrm{MgO}, \mathrm{Ni}$, and $\mathrm{Cr}$; and augite with Mgo. These correlations, together with the phenocryst-rich textures of most orogenic lavas, are considered by Ewart (1982) to reflect both phenocryst accumulation and extraction during low pressure fractional crystallization processes. Arculus, et al (1983) describe andesites from the 1951 cumulodome of Mount Lamington; these were contaminated by olivine and orthopyroxene from harzburgites of the underlying Papuan UItramafic Belt. Mertzman (1977) documents an accumulative basalt from the Medicine Lake Highland, California, which is a linear mixture of basic andesite and olivine + plagioclase. Thus, recent studies from other regions of orogenic volcanism imply that "open system" differentiation is a common process, and that crystal accumulation is a natural corrollary to fractional crystallization. Accumulation can be anticipated at polygenetic volicanoes such as Ruapehu, where fresh influxes of intermediate magma continually 
re-occupy old conduits and accumulate igneous crystals from earlier episodes of magma consolidation.

Bowen (1928) and McBirney (1979) have shown that exotic crystals will exhibit one of three relationships with liquid. (1) If the added crystals are mineral(s) that the host magma could have precipitated at an earlier stage of differentiation, then the host magma cannot melt the crystals but will react with them to form mineral(s) that are equilibrated with the host magma. An example is a forsteritic olivine xenocryst in dacite host magma (Fig 93H): The host magma is in equilibrium with orthopyroxene, and has reacted with the exotic olivine to form an orthopyroxene corona. (2) The added crystals are of similar types and compositions to those the host magma is actively precipitating (Fig 96A): In this situation no reaction occurs, the exotic crystals simply add to the existing phenocryst assemblage, and would be virtually indistinguishable from cognate phenocrysts. (3) The added crystals are minerals that the host magma could precipitate at later stages of differentiation (Fig 122 $A, B)$ : In this situation, the added minerals can be congruently or incongruently melted, with the heat of fusion being supplied by latent heat of crystallization of phenocrysts from the host magma.

In schemes 1 and 2, no new melt is produced when igneous crystals are added to host magmas; this process is defined as accumulation, and is the subject of the present section. Scheme 3 involves the production of melt and/or vapour, with possible addition of these mobile phases to host magmas. This is defined as an assimilation process, and is the subject of section $111-6$.

\subsection{EFFECTS OF ACCUMULATION}

Igneous nodules from Ruapehu lavas are generally gabbroic in mineralogy and the products of their disaggregation are pyroxenes, 
plagioclase and olivine. Pyroxenite and anorthosite fragments are also found. Most nodules probably are not cognate in the strict sense; i.e., they are derived from previous magma batches and not from the host lavas in which they are entrained, as judged by compositional and zonation differences between nodule minerals and discrete, euhedral phenocrysts. Nonetheless, nodules and discrete crystals derived from them are broadly co-genetic with the suite of lavas, since the nodules are cumulates or frozen liquids from magmas of basaltic to dacitic composition.

Lavas with significant amounts of hypidiomorphic-granular igneous rock fragments and/or disequilibrium phenocryst mineral assemblages (e.g., forsteritic olivine in dacite; Fig 93H) are certainly accumulative and do not represent liquid compositions. The habit of crystals and crystal clusters is thus of greater importance than phenocryst abundances; for example, a clinopyroxene- rich lava would not necessarily be considered accumulative since basic andesites and basalts characteristically have substantial amounts of clinopyroxene phenocrysts. However, if most clinopyroxene occurs in mm-sized websterite or gabbro fragments, then textural evidence for accumulation exists. In addition to texture, bulk rock chemistry is also an important criterion, although entrainment of igneous rock fragments or crystals does not necessarily lead to deviation from liquid compositions and fractional crystallization curves on variation diagrams. For example, if the accumulated crystals comprise a mineral assemblage that is similar to a previous crystal extract assemblage from the host lava, then the solid- liquid mixture will fortuitously have a bulk composition near the liquid line of descent since fractionated minerals are being added back into the host magma. However, if the accumulated crystals are nearly monomineralic, then major deviations from "POAM-type" liquid lines can occur. In Fig 116, "phenocryst" mineral abundances in accumulative lavas are compared with phenocryst abundances in non- accumulative lavas, where the latter are 
suggested in section $111-3$ to approximate liquid lines of descent from parental basalts. Thus, the ability to compare with fractional crystallization series is essential for identification of accumulative lavas: Figure 117 illustrates some of the effects of accumulated crystals on bulk rock compositions.

Mineral chemistry and zonation patterns are additional criteria for recognizing accumulative lavas, although the relationship between added crystals and host liquid is not necessarily that of disequilibrium: Reaction or zonation depends on the types and compositions of the added crystals, relative to the equilibrium phenocrysts of the host magma, as well as residence time of the added crystals in host magma. Continued growth of the added crystals is possible only in situation (2), where the added crystals are of the same mineralogy as cognate phenocrysts. Several zonation patterns may result. The first is normal zonation, as when magnesian augite is added to acid andesite in equilibrium with a more iron-rich augite; here, the added crystals would be difficult to distinguish from cognate phenocrysts. The second is development of a more refractory overgrowth or jacket (Fig 93A) around the added crystals, as when intermediate augite $\left(\mathrm{Mg}_{69}\right)$ is added to basaltic magma in equilibrium with magnesian augite $\left(\mathrm{Mg}_{80}\right)$.

An example of reaction with refractory crystals is provided by Ohakune basic andesite (Fig 95B): The groundmass liquid is in equilibrium with its ferromagnesian microphenocrysts, which have $\mathrm{Mg}^{*} \approx 75$ (assuming $\mathrm{K}_{\mathrm{d}}=0.3$ ). By contrast, the augite, bronzite and olivine of the crystal clusters have $M g^{*}=88-80$, and are most likely derived from basaltic magma. Bronzite in the crystal clusters is anhedral and surrounds forsteritic olivine; it is interpreted as a reaction product of olivine and liquid. 


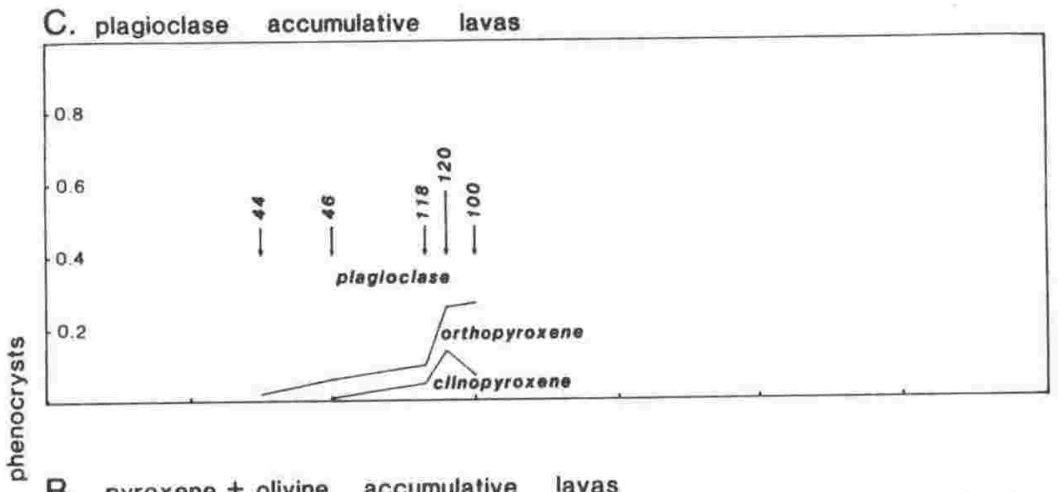

B. pyroxene \pm olivine accumulative lavas
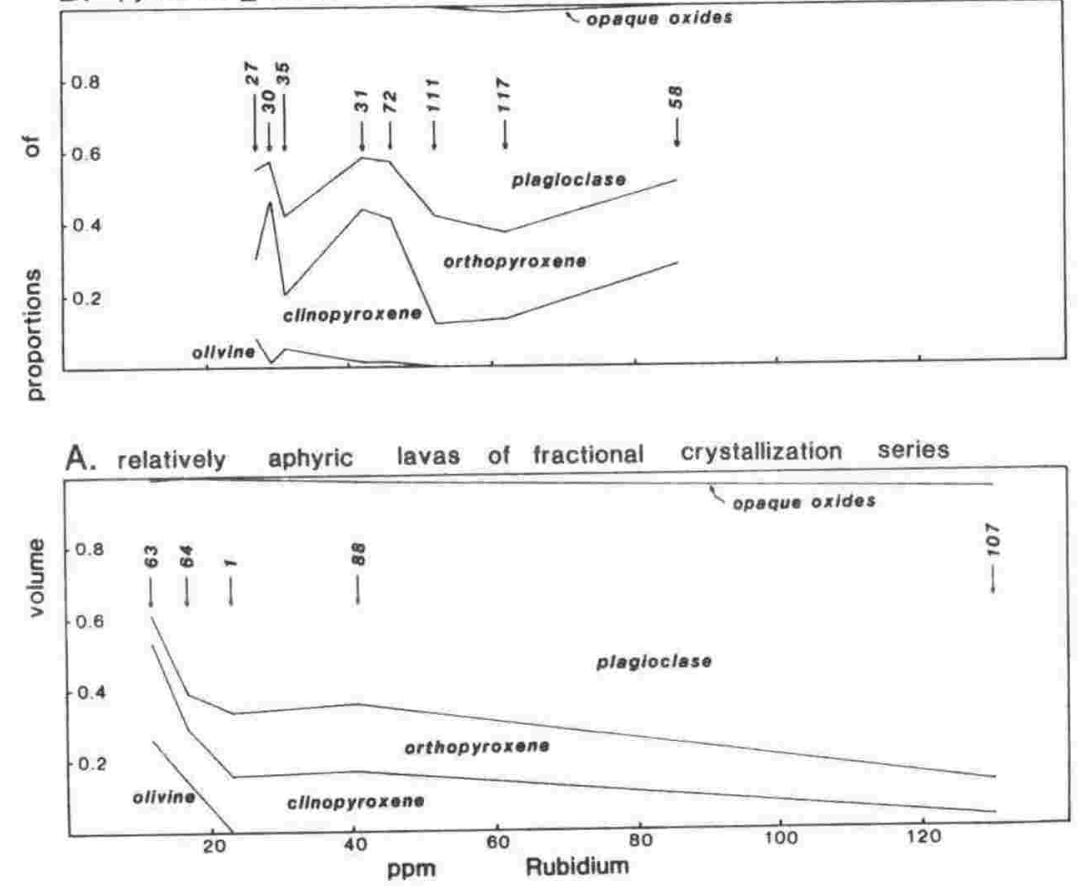

FIG 116 Phenocryst mineral proportions for accumulative and nonaccumulative lavas. Rubidium is used as a differentiation index. Total phenocryst minerals for each lava have been normalized to a volume fraction of 1 . Complete modal data are found in Tables 1-5. Numbers with arrows correspond to bulk rock analysis numbers of Appendix II.

A. Fractional crystallization series from Ruapehu Basalt to acid andesite; dacite (107) is not a simple fractional crystallization product of acid andesite but is nonetheless relatively aphyric and free of exotic crystals [see Fig $93 \mathrm{~A}-\mathrm{F}$ for photomicrographs]. Compare these regular mineralogical trends with $B$ and $C$.

$B$. Lavas that are judged to be accumulative in ferromagnesian minerals, note the high ferromagnesian mineral abundances and the irregular variations in mineral abundances, as compared with A [see Figs $92 \mathrm{C}, \mathrm{H}$ and 931 for photomicrographs].

C. Lavas that are judged to be accumulative in plagioclase; the major feature, when compared with $A$ and $B$, is domination of the mineral assemblages by plagioclase [see Figs 92B, $93 \mathrm{~J}, 940,6$ for photomicrographs; calculations VI-14,15 of Appendix VI show bulk rocks 46 and 118 are linear mixtures of non-accumulative acid andesite and bytownite] 


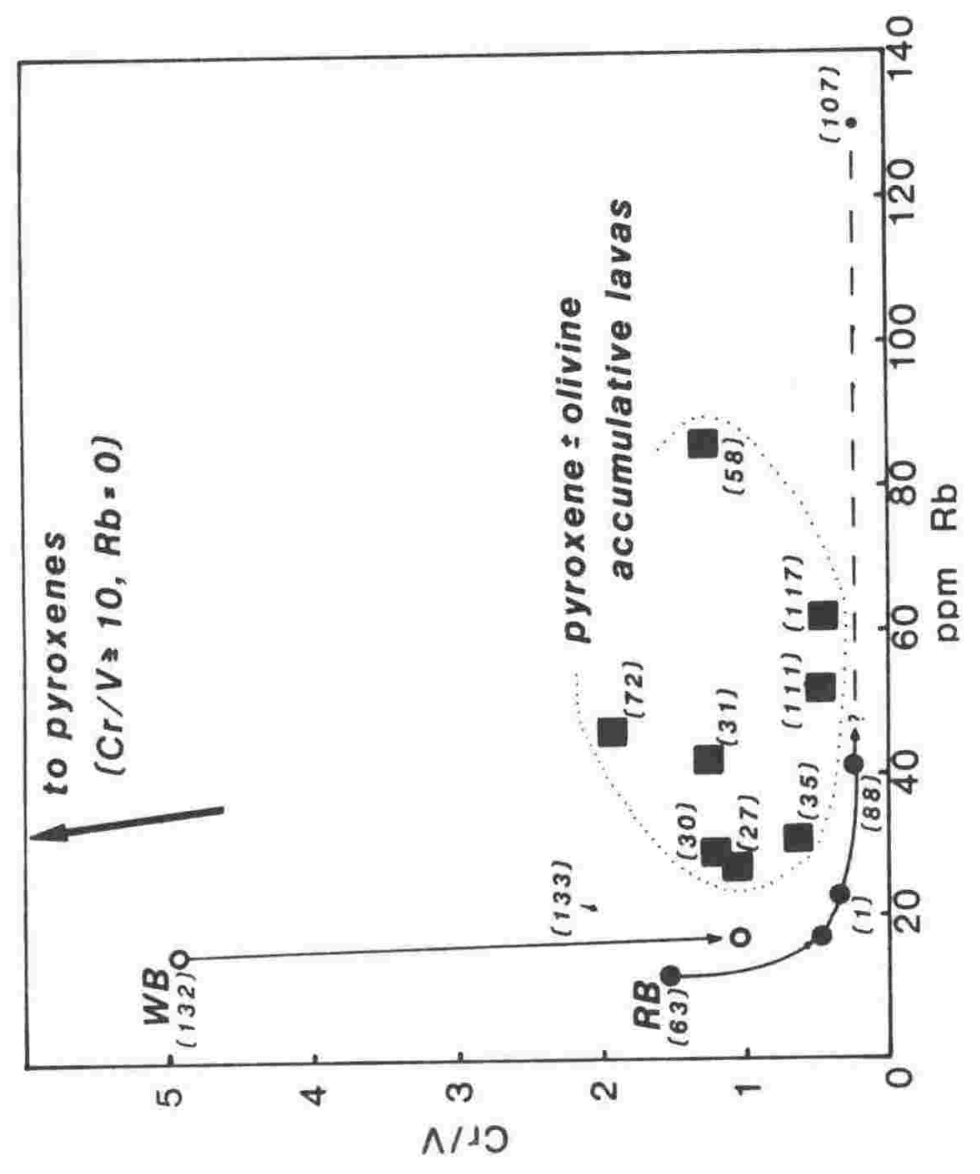

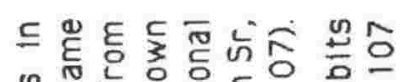
๓

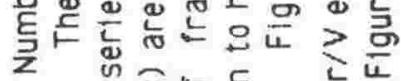

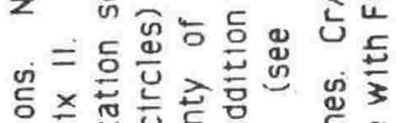

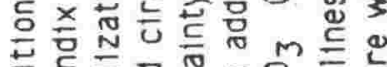

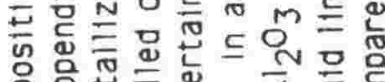

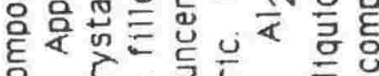
¿

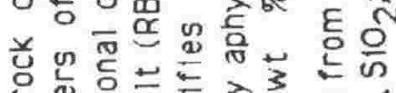

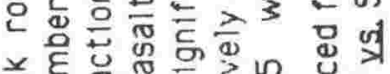

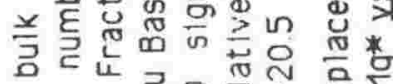
든

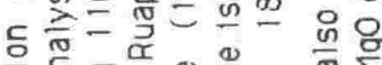

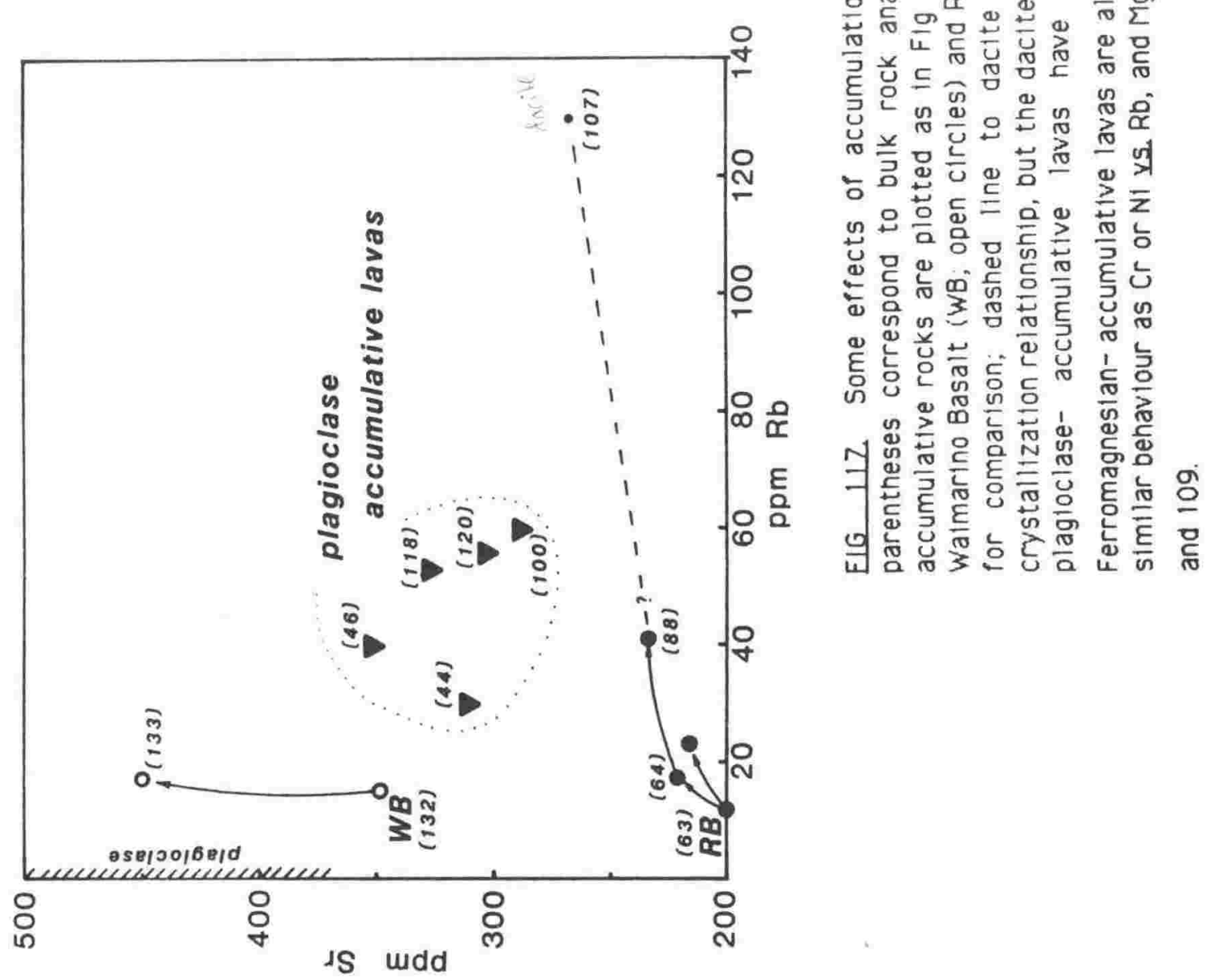




\subsection{SUMMARY OF MAJOR POINTS CONCERNING THE ROLE OF ACCUMULATION}

(1) Accumulation is a pervasive process, affecting lavas of all compositions. This contrasts with the narrower view of previous workers, who recognized only basic andesites as examples of accumulative lavas.

(2) Accumulation involves addition of plagioclase as well as ferromagnesian minerals, in contrast to the views of earlier workers who identified only olivine and pyroxenes as accumulative minerals.

(3) Accumulation of igneous crystals and rock fragments is commonplace, and most lavas do not represent liquid compositions. Beneath polygenetic composite volcanoes such as Ruapehu, the accumulation process is considered to be a natural corollary of fractional crystallization, involving entrainment of previously congealed magma, as repeated influxes of new magma re-occupied old conduits. 


\section{THE ROLE OF MAGMAMIXING}

\subsection{INTRODUCTION}

The claimed significance of magma mixing in orogenic lavas ranges from major (i.e., as an alternative to crystal-liquid fractionation; Eichelberger, 1975) to minor (i.e., back-mixing of magmas that are related by fractional crystallization; Mc Birney, 1980; Green, 1980). Published references to magma mixing have proliferated in the past ten years, and most examples are from volcanic arc settings. Sakuyama (1981) describes $\mathrm{R}$-type and $\mathrm{N}$-type rocks from two Japanese volcanoes, according to the presence or absence of reversely zoned mafic phenocrysts. Sakuyama (1981) considers that the chemical trends and petrographic features of $\mathrm{R}$-type rocks (reversely zoned) result from magma mixing, and that magma mixing is common in calc-alkaline (hypersthenic series of Kuno, 1950) volcanic rocks of Japan. Grove, et al. (1982) and Gerlach and Grove (1982) have identified hybrid lavas from the Medicine Lake Highland, California, ranging in composition from basic andesite to rhyolite. These authors propose an integrated model of calc-alkaline magma genesis, involving fractionation, assimilation and mixing.

Petrographic and chemical evidence of magma mixing is uncommon at Ruapehu and its satellite vents; only about 6 specimens of the 144 total bulk rocks are considered to have originated by magma mixing. Hybrid magmas are largely restricted to the upper cone complex (Mangawhero Fm) and young satellite vents (Pukeonake). Field relations suggest that these massif and satellite vents erupted synchronously, probably $20-30 \mathrm{Ka}$.

The present writer considers that mixing is a second-order process, involving back-mixing of magmas whose individual compositions were largely predetermined by fractional crystallization. Like crystal 
accumulation, this process is viewed as another manifestation of open-system magma evolution beneath polygenetic Ruapehu volcano, involving mingling of magmas in common conduits.

\subsection{MINERALOGICAL EFFECTS OF MAGMA MIXING}

The lavas of Ruapehu and related vents are characteristically porphyritic, and magma mixing is best recorded in zonation patterns of the phenocryst minerals. Examples of mineral zonation patterns in hybrid magmas from Pukeonake (a parasitic vent of Ruapehu and Tongariro) and from a lava flow of Mangawhero Fm are given in Fig 118 . Crystals in these lavas have four origins: (1) Phenocrysts that were originally present in the basic end member include, most notably, forsteritic olivine and chrome spinel These minerals are rưritiaiiy zoned, and crystallization was terminated by reaction with the hybrid liquid after mixing occurred: Forsteritic olivine has bronzite coronas, and discrete chrome spinel in the groundmass has rims of titanomagnetite. (2) Phenocrysts that were originally present in the evolved (andesitic to dacitic) end member include augite, hypersthene and intermediate plagioclase. As a consequence of heating during magma mixing, these minerals underwent resorption, producing anhedral and internally fritted grains. (3) New minerals, precipitated from the hybrid liquid after mixing, occur in two habits. First, they occur as high temperature mantles on resorbed cores of hypersthene, augite and plagioclase. The mantled phenocrysts are characteristic of the "R-type" (reversely zoned) lavas of Sakuyama (1981). Second, minerals were precipitated from the hybrid liquid as microphenocrysts and groundmass grains. These discrete crystals are highly significant because they demonstrate the presence of a hybrid liquid whose residue comprises the quenched groundmass. They have 

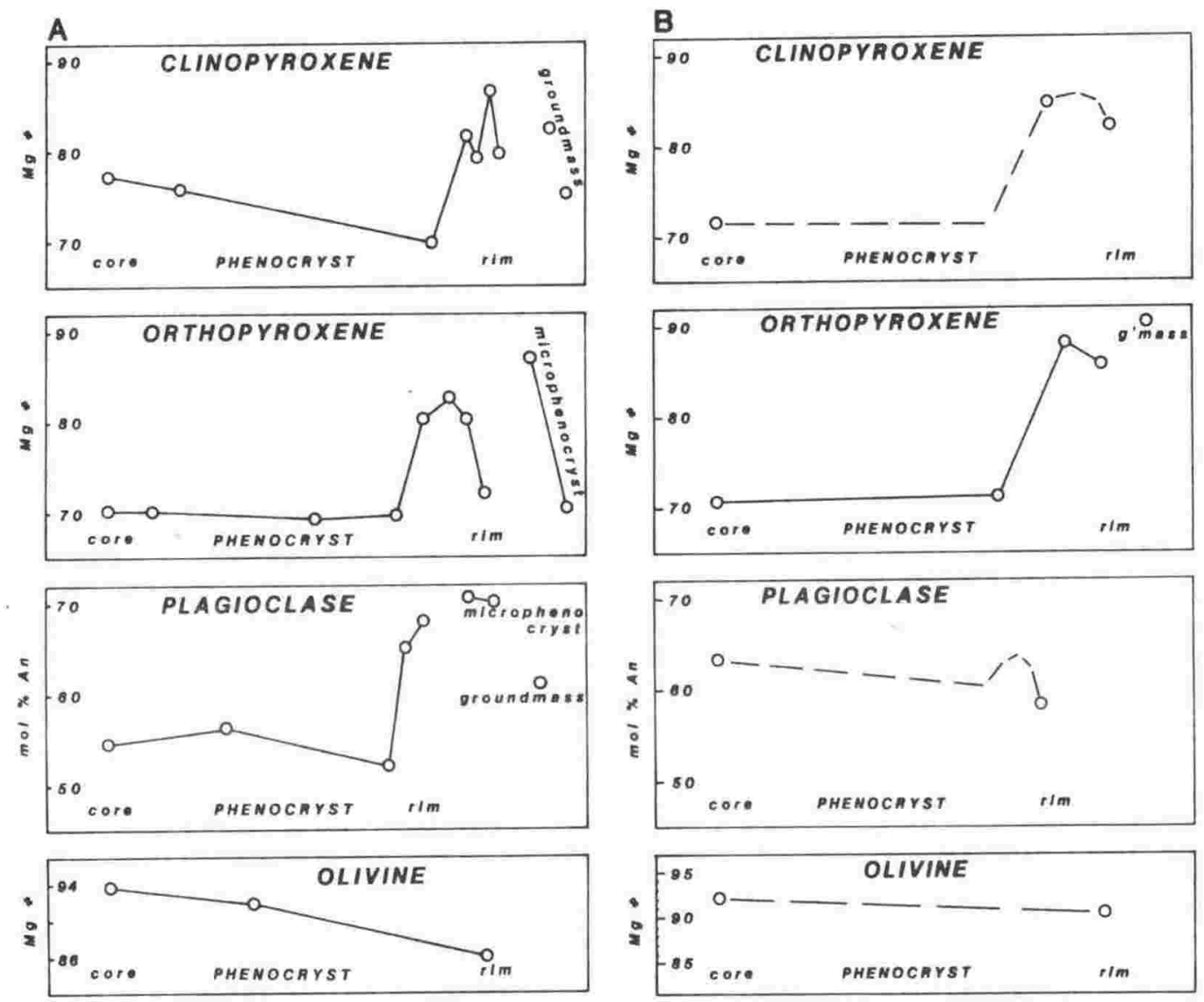

EIG 118. Mineral zonation patterns in two hybrid magmas. Zonation patterns are based on electron microprobe spot analyses; complete EPMA data are found in Appendix III

A. Bulk rock 139, high-Mg basic andesite of Pukeonake. All silicate phenocrysts show evidence of reaction with liquid (olivine with orthopyroxene coronas), or have high temperature mantles (pyroxenes and plagioclase). Note the presence of microphenocrysts and groundmass crystals with compositions similar to phenocryst mantles. Photomicrographs from this rock are given in Fig $95 \mathrm{E}, \mathrm{F}$

B. Bulk rock 81, high-Mg acid andesite of Mangawhero Fm, Ruapehu. Mineral zonation patterns similar to ' $A$ ' are present. For grains with few data points, dashed lines show zonation patterns inferred from optical examination. Photomicrographs from this rock are given in Fig $93 P, R$. 
refractory cores that are similar in composition to the most magnesian/calcic portions of phenocryst mantles, and are normally zoned due to fractional crystallization of the hybrid liquid. (4) Accidental crystals and fragments of igneous and metamorphic rock are present. At Pukeonake, these include dunite, harzburgite, gabbro, diorite, and a variety of hornfelsic to gneissic metamorphic rock fragments that were initially present in the end member magmas (e.g., ultramafic nodules were almost certainly a component of the basaltic end member) or were entrained af ter mixing and during eruption (e.g., metamorphic rock fragments that bear little overprinting by pyrometamorphism).

Phenocrysts that were initially present in the end member magmas (i.e., types 1 and 2) are petrogenetically significant because they enable the characterization of end members to form the hybrid. For example, the forsteritic olivines and chrome spinels in the hybrid lavas of Fig 118 suggest that one end member was primitive basalt. The augite, labradorite and hypersthene cores of resorbed and mantled phenocrysts have similar compositions to phenocrysts in Ruapehu acid andesites and dacites, implying that the second end member was andesitic to dacitic in bulk composition. The preservation of phenocrysts from both end members suggests that magma mixing occurred just prior to eruption and quenching; indeed, the mixing events may have triggered the eruptions (cf.: Sparks, et al, 1977).

\subsection{DISCUSSION OF LEAST SQUARES MODELLING, AND GEOCHEMICAL} EFFECTS OF MAGMAMIXING

Six least squares mixing calculations, deriving hybrid lavas as linear mixtures of two end members, are given in Table 10. All of the potential hybrid lavas were chosen on the basis of clear petrographic evidence for 
zo

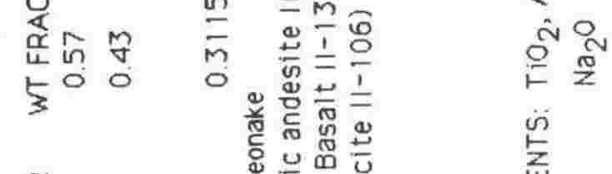

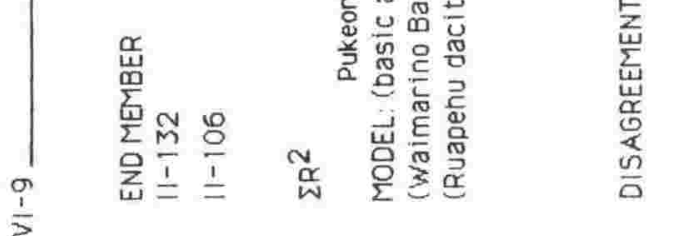

욤

I

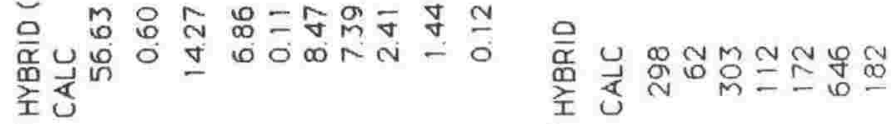
o

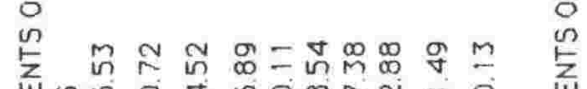

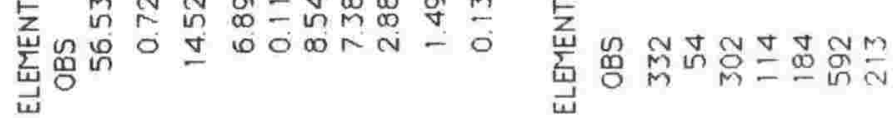

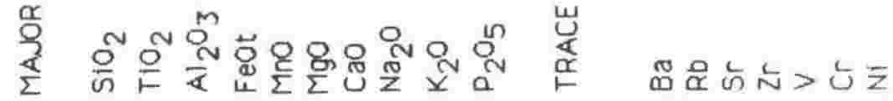

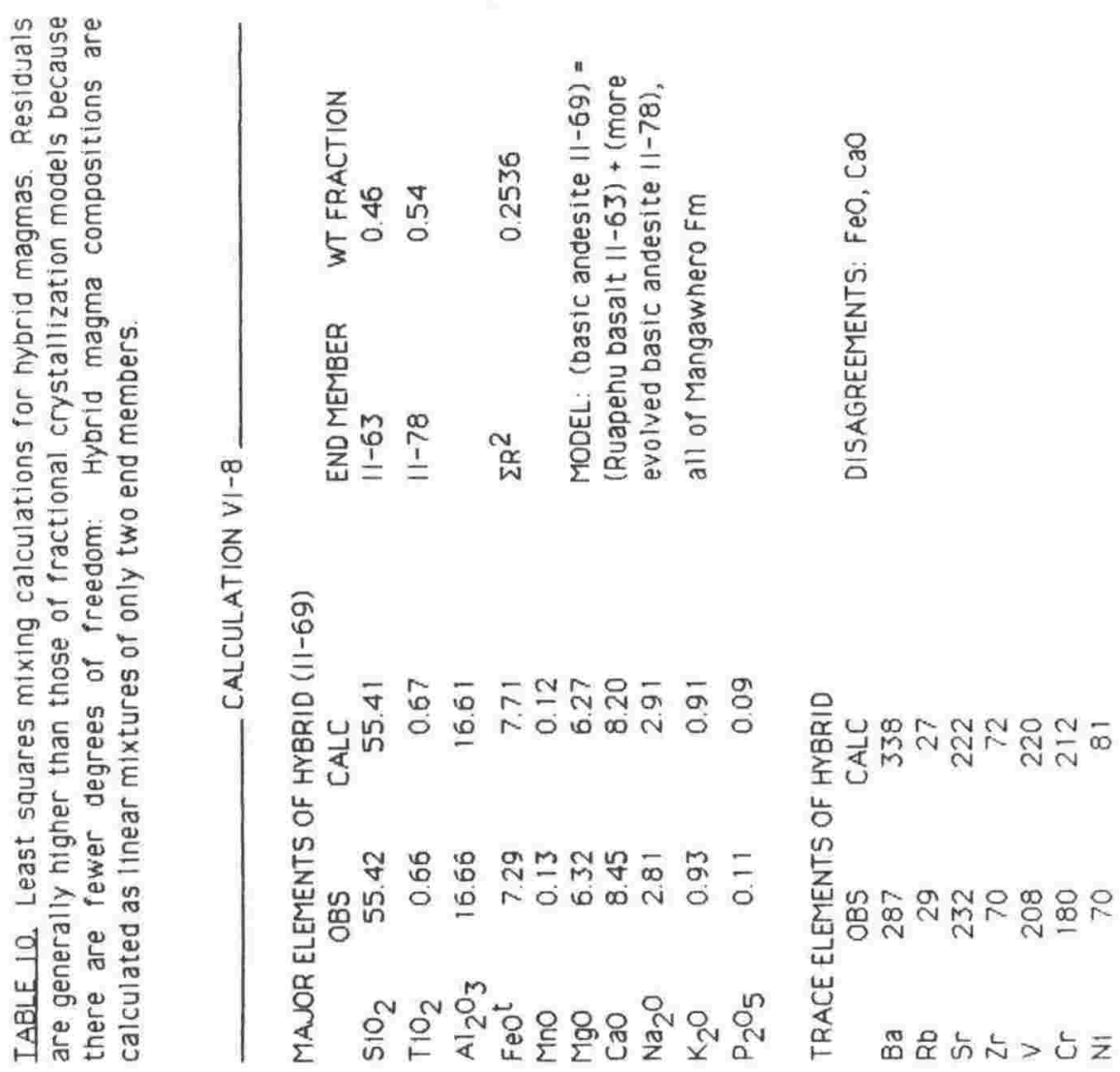



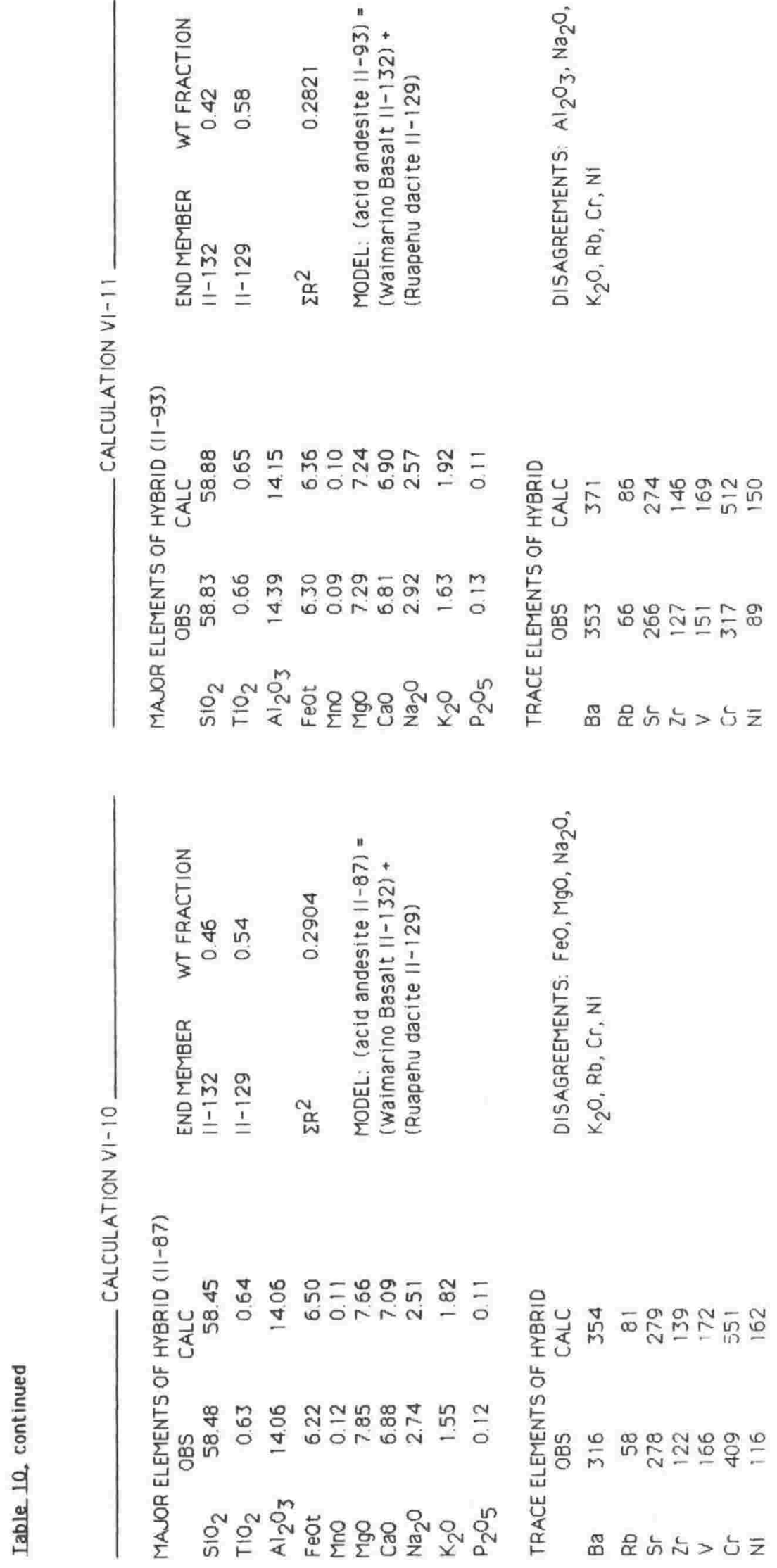


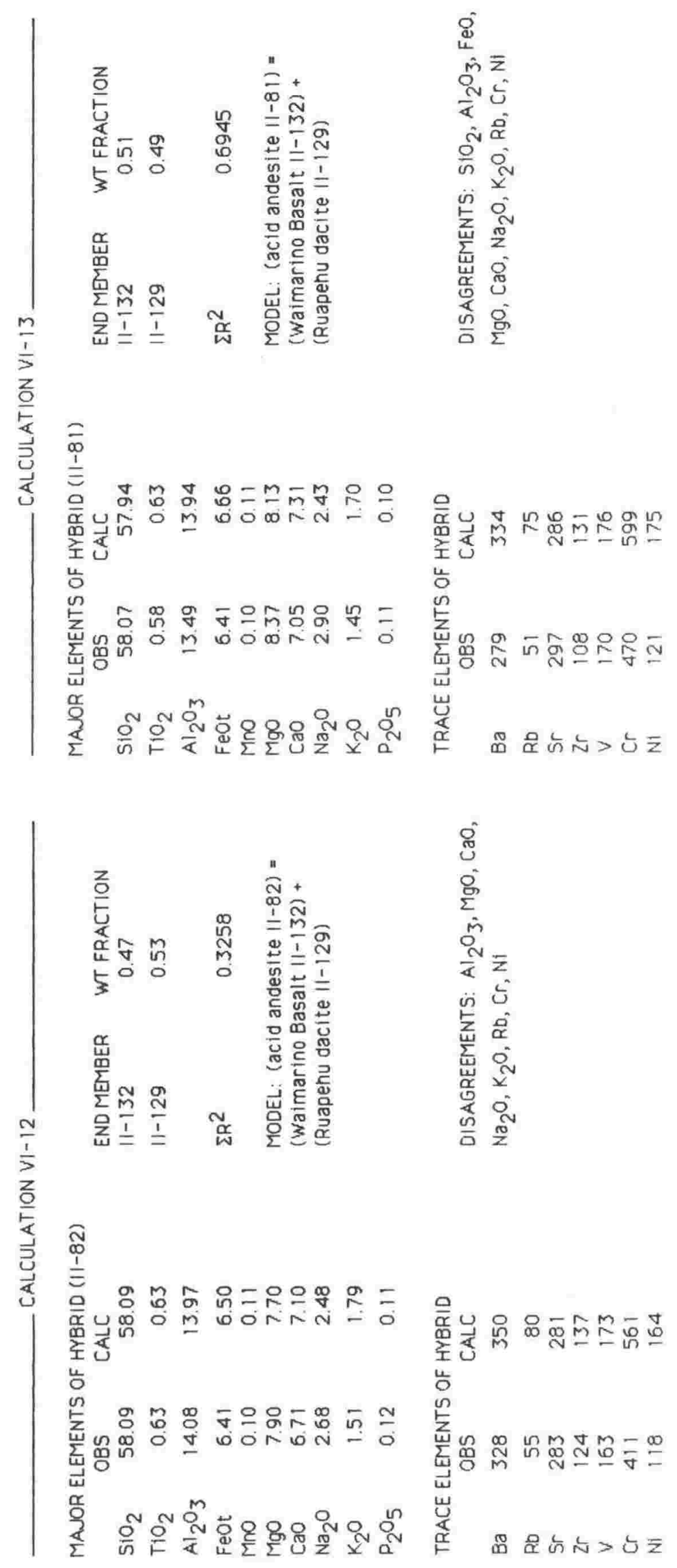


magma mixing. Disagreements are more numerous and squared residuals are nigher than in fractional crystallization calculations, because the hybrids are calculated as linear mixtures of only two end members. The calculated trace element abundances are unconstrained and should therefore give a good indication of the viability of the mixing process. In this regard, there is good agreement for the first four calculations ( VI-8 to VI-11). The calculations have several implications: (1) Basaltic magma is an end member of all hybrids. The present writer acknowledges that this is partly a matter of recognition; i.e., mixtures of basalt and acid andesite/dacite are easily recognized, whereas mixtures of compositionaliy similar lavas could be easily overlooked because the petrographic and geochemical effects are more subtle. (2) In all calculations, basalts and evolved magmas have mixed in approximately equal proportions. Again, this is partly a matter of recognition; e.g., if a small amount of dacite mixed with a large amount of basalt, the dacite phenocrysts would likely be destroyed. (3) Both RB and WB magma types apparently have mixed with more evolved magmas.

Representative bulk rock analyses of hybrid lavas are given in Table 11, with an acid andesite of the Ruapehu basalt fractional crystallization series given for comparison. In the variation diagrams of Fig 119, comparison is made between hybrid lavas and lavas of the fractional crystallization series from WB and RB. Deviation of hybrid lavas from mixing lines suggests that the end member lavas are not well characterized, or that other processes (such as crystal accumulation) have acted concurrently with magma mixing. The main geochemical effects of magma mixing are to produce lavas with concurrently high compatible and incompatible element abundances (see Ni-Rb plot of Fig 119). Magma mixing has produced several chernically (and petrographically) distinctive high-magnesium andesites; those that mixed with Waimarino Basalt have 
inherited not only the high MgO, $\mathrm{Ni}$ and $\mathrm{Cr}$ of this magma type, but also its high $\mathrm{Sr}$. 
IABLE $\|$ Representative bulk rock analyses of hybrid lavas. Columns 1-3 are hybrid lavas; for comparison, column 4 is acid andesite of fractional crystallization series from Ruapehu basalt.

(1) Basic andesite, Mangawhero Fm (bulk rock 69; see calculation 8 of Table 10)

(2) Acid andesite, Mangawhero Fm (bulk rock 81; see calculation 13 of Table 10)

(3) Basic andesite, Pukeonake (bulk rock 136; see calculation 9 of Table 10)

(4) Acid andesite, Mangawhero Fm (bulk rock 88; not a hybrid lava)

\begin{tabular}{|c|c|c|c|c|}
\hline & 1 & 2 & 3 & 4 \\
\hline $\mathrm{SiO}_{2}$ & 55.42 & 58.07 & 56.53 & 58.54 \\
\hline $\mathrm{TiO}_{2}$ & 0.66 & 0.58 & 0.72 & 0.68 \\
\hline $\mathrm{Al}_{2} \mathrm{O}_{3}$ & 16.66 & 13.49 & 14.52 & 17.41 \\
\hline $\mathrm{Fe}_{2} \mathrm{O}_{3}$ & 1.75 & 2.91 & 1.12 & 2.25 \\
\hline $\mathrm{FeO}$ & 5.71 & 3.79 & 5.88 & 4.82 \\
\hline MnO & 0.13 & 0.10 & 0.11 & 0.11 \\
\hline MgO & 6.32 & 8.37 & 8.97 & 3.75 \\
\hline $\mathrm{CaO}$ & 8.45 & 7.05 & 7.38 & 7.05 \\
\hline $\mathrm{Na}_{2} \mathrm{O}$ & 2.81 & 2.90 & 2.88 & 3.16 \\
\hline $\mathrm{K}_{2} \mathrm{O}$ & 0.93 & 1.45 & 1.49 & 1.20 \\
\hline $\mathrm{P}_{2} \mathrm{O}_{5}$ & 0.11 & 0.11 & 0.13 & 0.10 \\
\hline LOI & 0.78 & 0.82 & 0.66 & 1.05 \\
\hline Sum & 99.73 & 99.64 & 100.39 & 100.12 \\
\hline $\mathrm{mg*}$ & 66.4 & 79.7 & 73.1 & 58.1 \\
\hline $\mathrm{Ba}$ & 287 & 279 & 332 & 311 \\
\hline $\mathrm{Rb}$ & 29 & 51 & 54 & 41 \\
\hline $\mathrm{Sr}$ & 232 & 297 & 302 & 234 \\
\hline $\mathrm{Zr}$ & 70 & 108 & 114 & 86 \\
\hline V & 208 & 170 & 184 & 181 \\
\hline $\mathrm{Cr}$ & 180 & 470 & 591 & 43 \\
\hline $\mathrm{Ni}$ & 70 & 121 & 213 & 28 \\
\hline
\end{tabular}



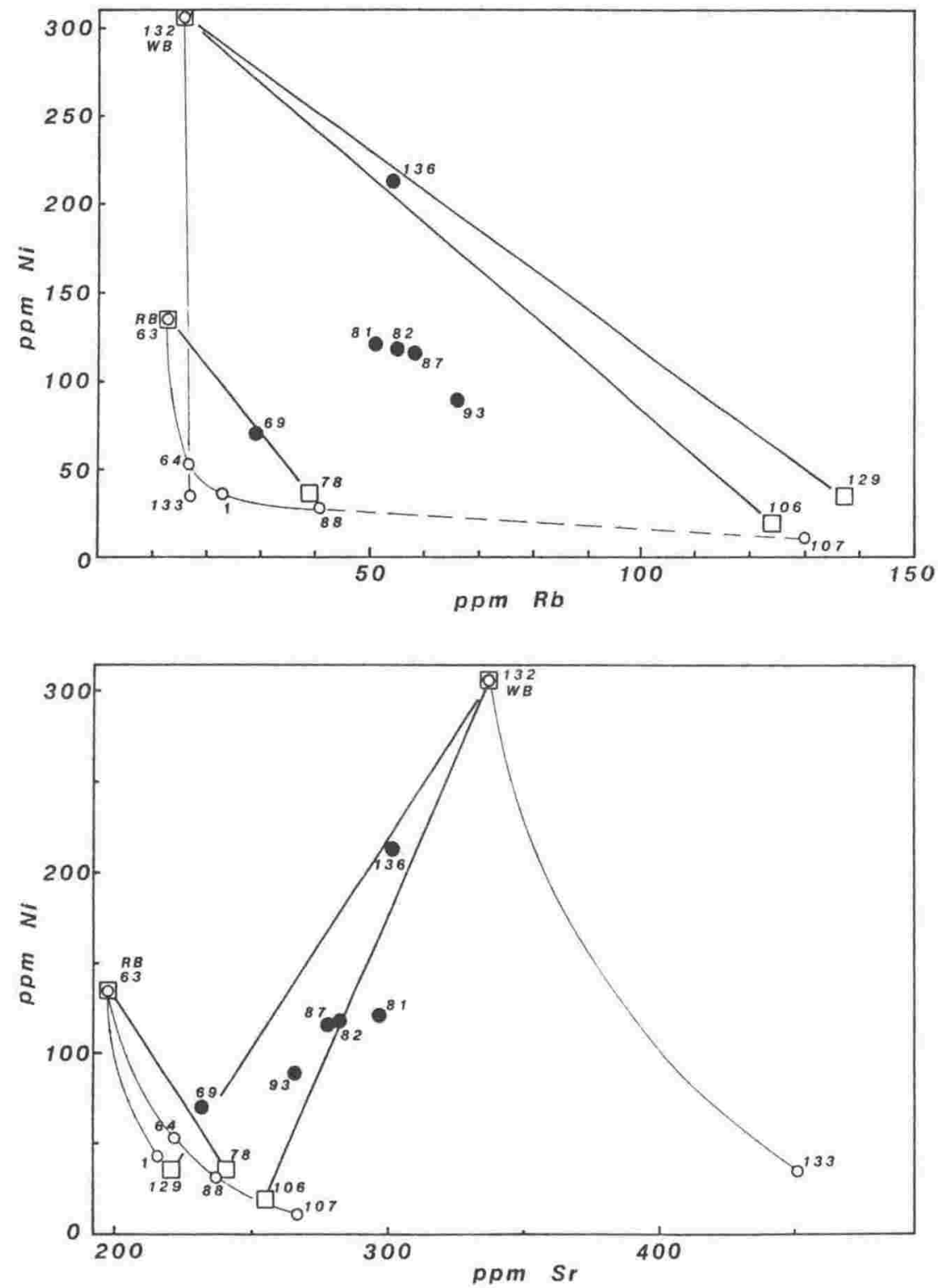

EIG U1. Variation diagrams comparing hybrid lavas with those of fractional crystallization series. Numbers within diagram correspond to bulk rock analysis numbers of Appendix II. Lavas of fractional crystallization series from Waimarino Basalt (WB) and Ruapehu basalt (RB) are shown as open circles connected by thin curves. Hybrid lavas are shown as filled circles. End member magmas to form hybrids are shown as open squares, and bold lines denote linear mixtures of end members. See Table 10 for least squares mixing calculations to derive hybrid magmas. 


\section{THE ROLE AND NATURE OF THE CRUST}

\section{6.) INTRODUCTION}

Geophysical studies, field mapping and xenolith studies are three methods that can be used to infer crustal cornposition, and the thermal and deformational history of the crust (Kay and Kay, 1981). Geophysical studies of crustal structure and composition beneath the TVZ are lacking, and results of the unreversed Wellington Crustal Refraction Profile (Eiby, 1955) are controversial (Garrick, 1968). Thus, geophysical interpretations of crustal structure, composition and thickness are equivocal, although TVZ heat flow and $P_{n}$ velocities suggest thin crust and lithosphere, as summarized in Fig 111.

Mesozoic greywacke forms much of the surface outcrop of North Island, and the Axial Range of North Island is composed almost entirely of this rock type, although it is the least known area of greywacke in New Zealand (Korsch and Wellman, 1985). Hay (1967) and Grindley (1960) mapped respective areas to the west and east of Ruapehu, where the surrounding ranges comprise low grade metagreywackes and argillites. South of Ruapehu, the greywacke is veneered by unmetamorphosed Tertiary marine sediments (Fleming and Steiner, 1950). While Mesozoic greywacke and Tertiary mudstones do occur as xenoliths (see: section 11-2.7), it is significant that most crustal fragments have no clear outcrop equivalents in the surrounding terrain. Thus, xenoliths are interpreted with difficulty because geophysical and outcrop constraints are lacking.

Magmas have sampled a great variety of fragments from the subvolcanic basement. These are important petrogenetically because they suggest mechanisms of crustal contamination, and are also valuable toward deducing the mineralogy and composition of the crust. However, 
xenolith studies seldom allow construction of an accurate crustal cross section (Kay and Kay, 1981). At Ruapehu, this is true for several reasons: (1) There is no reliable way to depth-order crustal xenoliths since the mineral assemblages of ten preclude P-T calculations, and since there is pervasive evidence for mineralogical disequilibrium, particularly overprinting by pyrometamorphism. (2) It cannot be assumed that lavas have representatively sampled wall rocks along their paths. (3) Some xenoliths may be more easily destroyed than others. In spite of these limitations, a discussion of inferred metamorphic conditions, compositional variation of xenoliths, and petrogenetic implications is given below. General petrographic and mineralogical data for xenoliths have already been reported in section II-2.7.

\subsection{METAMORPHIC CONDITIONS IN THE CRUSI}

A summary of metamorphic conditions inferred from xenolith mineralogy is given in Fig 120. Evidence for high temperature metamorphic conditions is varied and consistent: (1) plagioclase has intermediate compositions (andesine- labradorite), (2) biotite has high $\mathrm{TiO}_{2}$ content in the presence of ilmenite and spinel, (3) muscovite is absent (except in a few albite- epidote metagreywacke xenoliths with outcrop analogues), which suggests high grade metamorphism, (4) garnets are almandine-pyrope solid solutions, where the pyrope component is indicative of high temperature, (5) sillimanite, though it occurs rarely as fibrolite inclusions in cordierite, is the only aluminosilicate polymorph observed, and (6) results of garnet-biotite geothermometry (Goldman and Albee, 1977) indicate equilibration temperatures of $650-750^{\circ} \mathrm{C}$ for schists and gneisses.

Inappropriate mineral assemblages and textural disequilibrium 


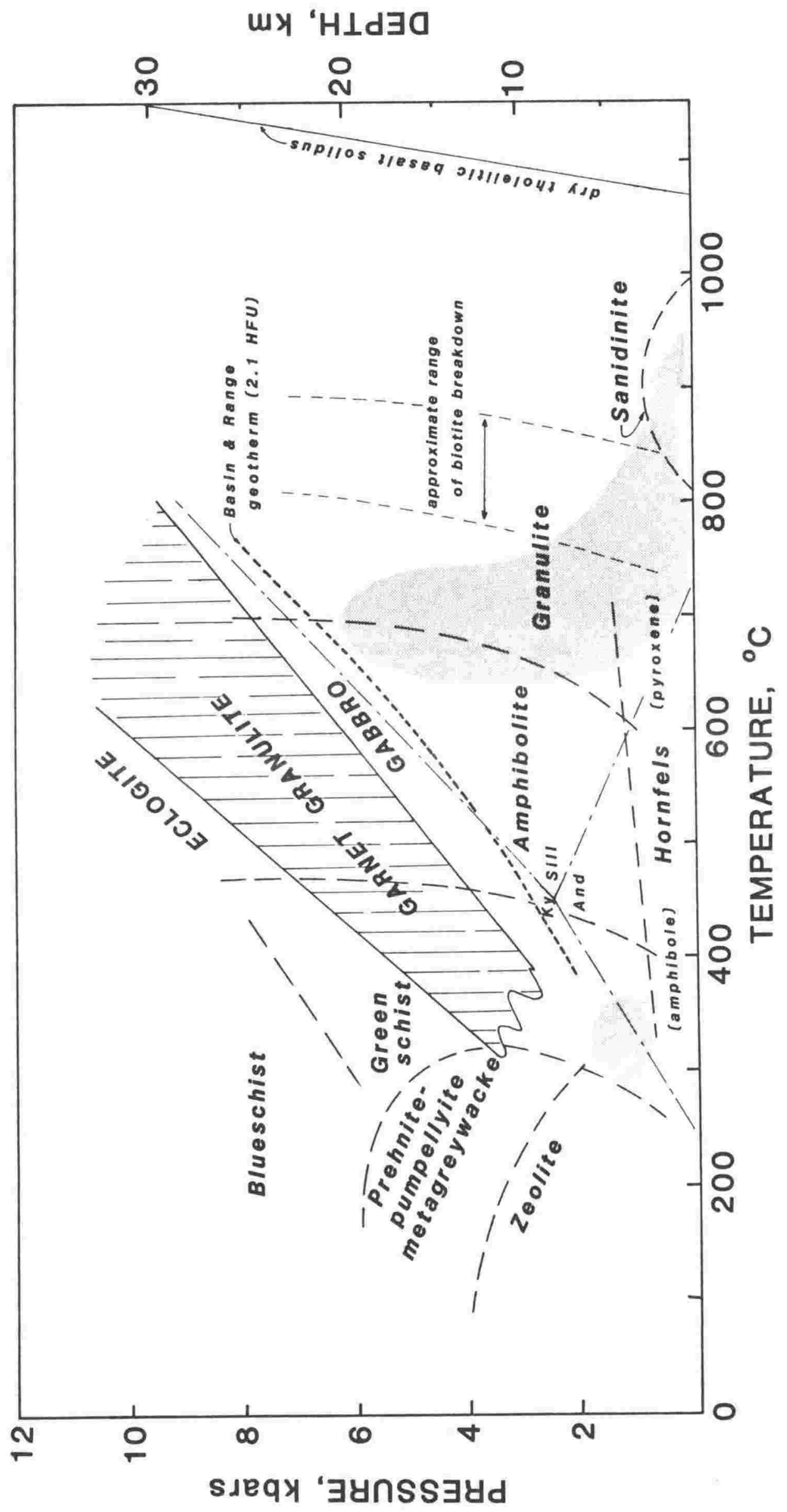


generally prohibit accurate pressure estimates, but qualitative estimates suggest low to moderate pressures appropriate to crustal depths: Metamorphosed basic igneous rocks are garnet- free, and plagioclaseorthopyroxene or plagioclase- olivine reactions to form garnet or spinel, respectively, are absent. The garnet- free, gabbroic mineralogy of metabasites suggests $P-T$ conditions lower than those necessary to produce a garnet granulite mineralogy (Fig 120).

Some hypersthene- bearing pelitic schists and hornfelses contain coexisting cordierite and almandine. Winkler (1979, p. 234) states that

the pair cordierite plus almandine is restricted to a specif ic P-T range in high grade regional metamorphism and in the regional hypersthene zone (granulite facies)". The experimental data of Currie (1971) suggest pressure limits of 4-7 kilobars for coexisting cordierite + almandine + sillimanite + quartz. This pressure range corresponds to crustal depths of $10-20 \mathrm{~km}$.

The presence of crystalloblastic hypersthene in many xenoliths and the virtual absence of amphibole indicate metamorphic conditions in the regional hypersthene zone (granulite facies) (Winkler, 1979). No specific P-T range is implicit, the essential requirement for hypersthene being $\mathrm{P}_{\mathrm{H} 2 \mathrm{O}} \ll \mathrm{P}$ total In regional metamorphic terrains, this condition is usually met only in the deep crust, where rocks have undergone protracted metamorphism and loss of volatiles. However, "dry" conditions can also be attained beneath magmatic belts, where rocks have been subjected to high temperatures at moderate to low pressures (e.g., high $T$ - low P facies series of Miyashiro, 1974). Depth of origin of xenoliths therefore remains an unsolved problem, but the hypersthene- bearing rocks certainly originated at high temperatures and under nearly anhydrous conditions.

The textures and mineralogy of primary regional metamorphism have been overprinted by secondary processes, operating on two different time 
scales. First, high grade regional metamorphic rocks seem to have undergone progressive regional metamorphism during a rising geothermal gradient. This process was operative over a relatively long time span (perhaps on the order of $10^{6}$ years), but rates were not slow enough to maintain equilibrium. The major effects of progressive regional metamorphism are smooth reverse zoning of plagioclase and garnet (increasing pyrope molecule outward), plus the development of aluminous orthopyroxene as coronas on garnet and as disseminated crystals. These features suggest increasing temperature, and progression from upper amphibolite facies conditions to regional hypersthene (granulite facies) conditions. The presence of hypersthene is the essential mineralogical criterion for granulite facies, but titaniferous biotite is still present.

Second, xenoliths underwent the brief but intense effects of pyrometamorphism during transport in host magmas. These effects include: (1) breakdown of biotite to Al-Fe spinel and other, as yet unidentified, reaction products, (2) thermal alteration of garnet, forming opacite coronas, (3) crystallization of sanidine (perhaps as a product of biotite breakdown) from rocks of appropriate composition, and (4) the production of interstitial silicic- alkaline glass, or even complete melting. These features indicate progression to sanidinite facies conditions, as metamorphic rock fragments were transported in host magmas having temperatures of $\mathrm{ca} .900$ to $1000^{\circ} \mathrm{C}$.

Overall, mineral assemblages suggest high temperature metamorphic conditions, in the low to moderate pressure region of the granulite, pyroxene hornfels and sanidinite facies.

\subsection{XENOLITH BULK COMPOSITIONS}

Important major element characteristics of xenoliths are summarized in Fig 121, and Table 12 gives representative major and trace element 


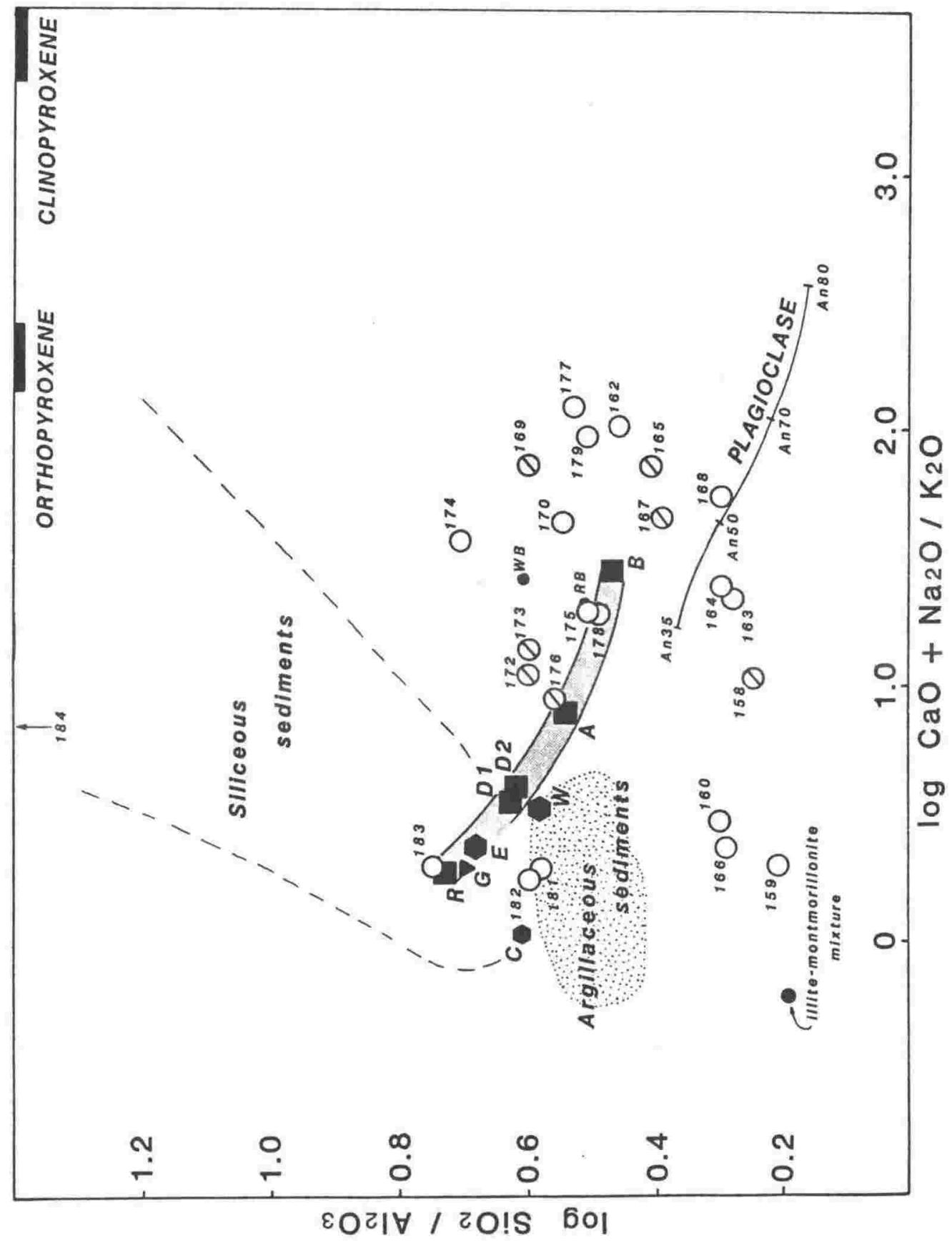




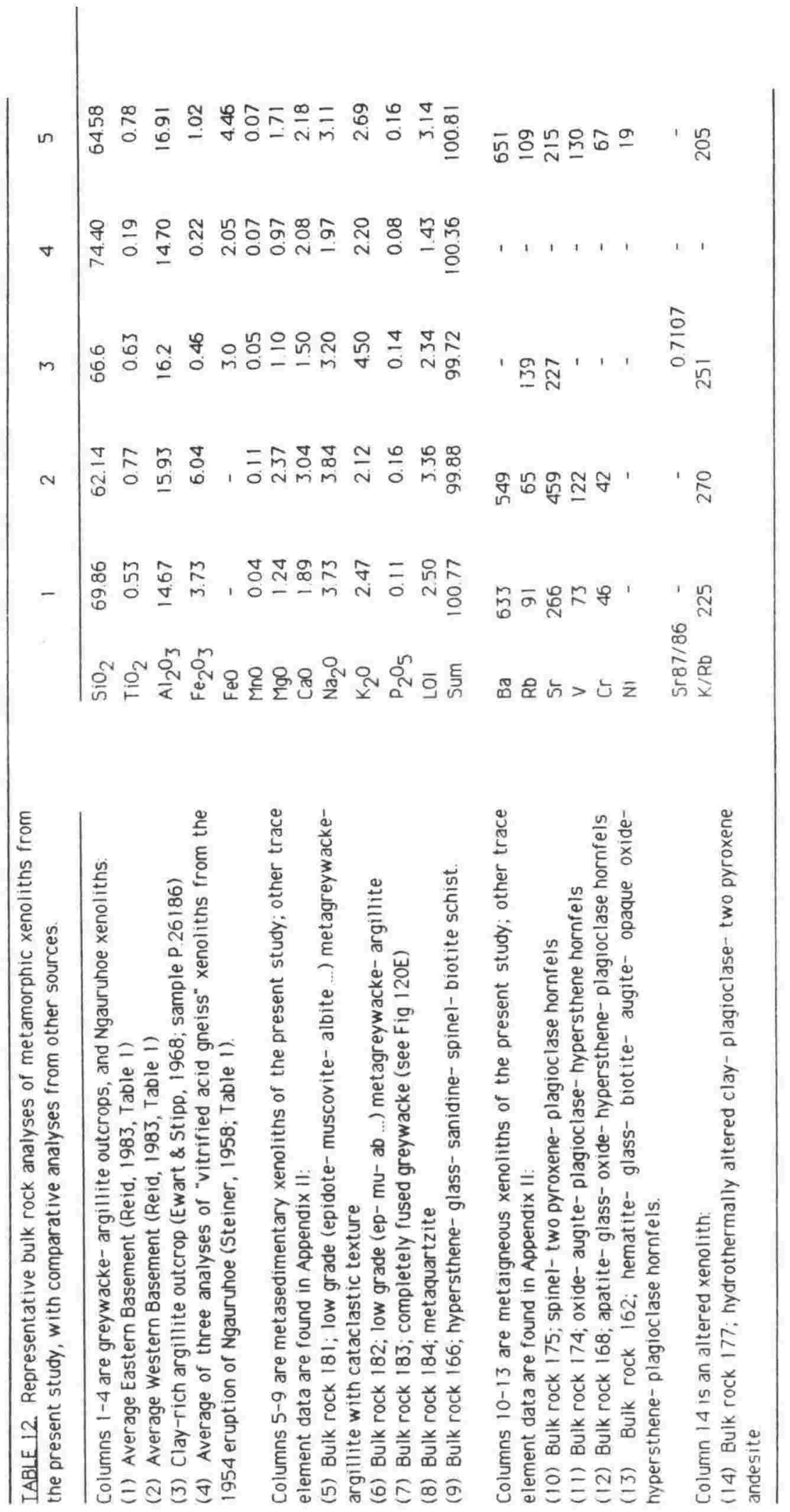




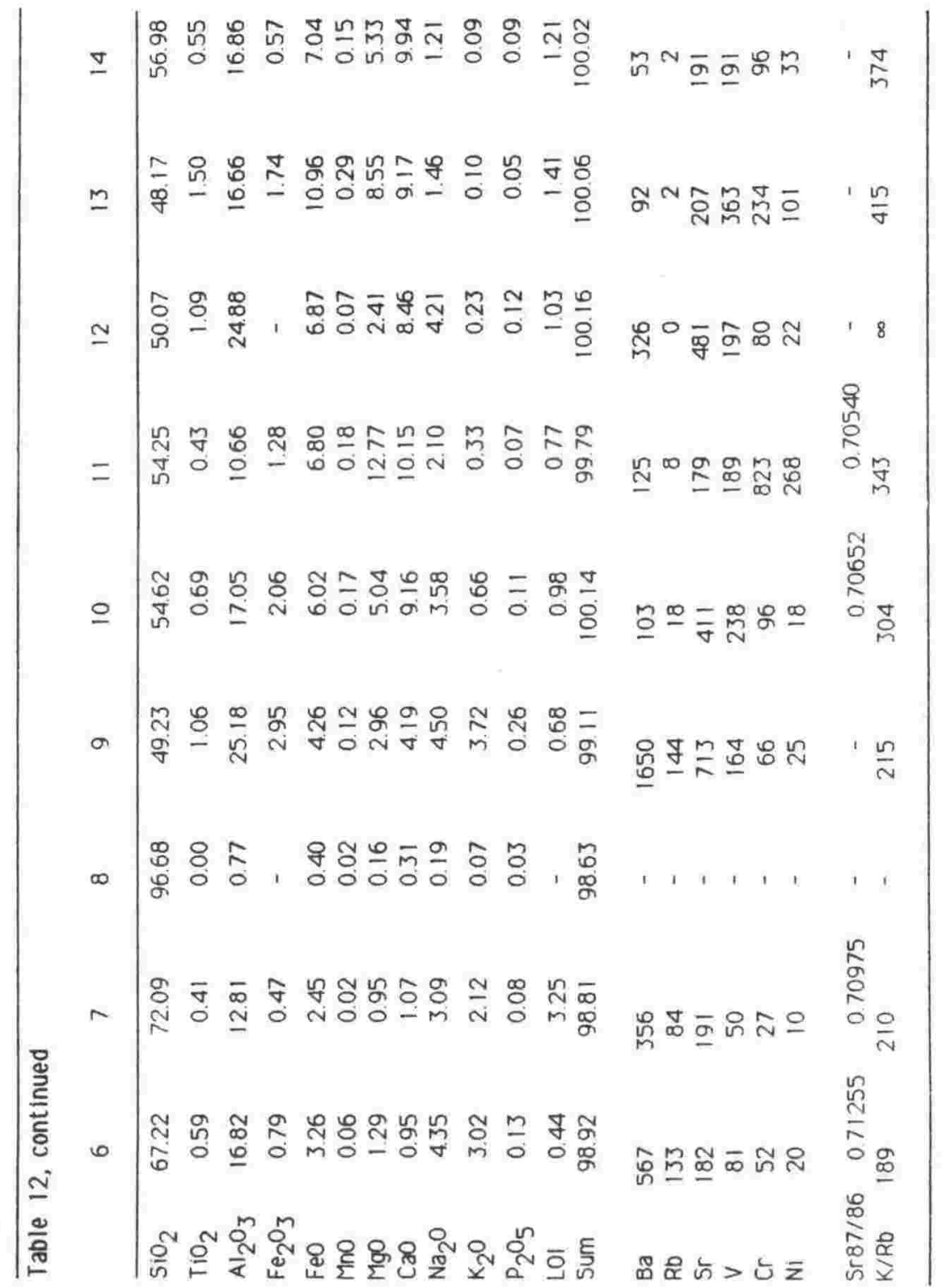


data for xenoliths. Some xenoliths are texturally and compositionally similar to subaerially exposed greywacke-argillite, but most are basic to intermediate in bulk composition and have quartz- free, anhydrous mineral assernblages, suggesting derivation from unexposed metabasites within or beneath the greywacke. Using the criteria of Fig 121, three compositional groups (and numerous subgroups) are recognized.

GROUP 1: Metasedimentary xenoliths (analyses 159, 166, 181, $182,183,184)$ plot on the left side of Fig 121. The great variation in $5 \mathrm{SiO}_{2} / \mathrm{Al}_{2} \mathrm{O}_{3}$ ratios reflects the varying quartz/clay ratios in the original sediments. Several subgroups are distinguished.

la: Metaquartzites are nearly pure silica and were probably quartz arenites prior to metamorphism, or quartz segregation veins produced during metamorphism. Although represented by only one analysis (184; Table 12), this is a very abundant xenolith type.

1b:-Metagreywackes/argillites (analyses 181, 182, 183) have compositions similar to greywacke/argillite outcrops. Rock 183 is a completely fused greywacke (Fig 121, Table 12, Fig 120E) with a bulk composition nearly identical to Steiner's (1958) "vitrified acid gneiss". Although it appears similar to average TVZ rhyolite on Fig 121, rock 183 is compositionally similar to average Eastern Basement, as shown by its $\mathrm{Rb}, \mathrm{Sr}$ and $\mathrm{V}$ abundances (Table 12). Rocks 181 and 182 are more argillaceous than average Eastern or Western Basement. This is reflected by their higher values of $\mathrm{Rb}$ (Table 12), which are similar to the $\mathrm{Rb}$ concentration of Ewart and Stipp's (1968) argillite outcrop.

Strongly argillaceous metasediments (analyses 159,166 ) plot at the extreme lower left of Fig 121. The extremely $\mathrm{K}$ - and Al-rich bulk compositions (Table 12) of these fine grained, high grade schists are reflected by normative corundum, and the presence of modal sanidine, 
cordierite ( \pm fibrolite inclusions), aluminous spinel (hercynite) and biotite. High LIL element abundances suggest that these rocks are metamorphosed claystones, and not residues after partial melting of greywacke/ argillite basement.

Strontium isotopic ratios for three metasedimentary xenoliths (159, 182, 183) are uniformly high, ranging from 0.70975 to 0.71255 (Mr. Ian Graham, analyst).

GROUP H: Metaigneous xenoliths have fine- grained crystalloblastic textures, vary from basic to intermediate in silica content, and plot on the right side of Fig 121. Representative analyses are given in Table 12. Most are basic to intermediate hornfelses with compositions displaced to the right of the TVZ igneous trend, toward pyroxene and plagioclase. This suggests that the metabasites may represent metamorphosed subvolcanic TVZ igneous rocks that are accumulative to varying degrees in plagioclase, pyroxenes ( \pm olivine in original rocks), and opaque oxides. Note that the crystalloblastic metaigneous xenoliths are compositionally similar to nodules with igneous textures, where the latter are shown in Fig 121 as open circles with diagonal slashes.

Metaigneous rock compositions (Fig 121, Table 12) are gradational from those that plot close to the TVZ igneous trend (rock 175), to those that probably represent metamorphosed pyroxene cumulates (rock 174, with high $\mathrm{MgO}, \mathrm{Cr}, \mathrm{Ni}$ ), plagioclase cumulates (rock 168 , with high $\mathrm{Al}_{2} \mathrm{O}_{3}$ and $\mathrm{Sr}$ ), and opaque oxide \pm pyroxene cumulates (rock 162, with high total FeO and $\mathrm{V}$ ). Strontium isotopic ratios of three metaigneous xenoliths range from 0.70540 to 0.7063 (Mr Ian Graham, analyst).

Rock 172 (sheared gabbro; Fig 96H) is compositionally and texturally an unusual xenolith. High compatible element concentrations 
suggest a cumulate rock, but it is also rich in $\mathrm{Ba}$ (373 ppm) and $\mathrm{Rb}$ (47 ppm). Given the cataclastic texture of the rock, the bulk composition suggests that it may be a tectonic mixture (fault gouge) of basic igneous rock and greywacke/argillite.

The wide range in chemical composition of the metaigneous rocks and the divergence of their compositions from those of TVZ magrna types is strong evidence against many xenoliths being simply frozen basic to intermediate magmas, although they could be crystal cumulates from these magmas. The temporal relationship between metaigneous rock fragments and their host lavas is largely unknown: The metabasites could represent metamorphosed frozen magmas and crystal cumulates associated with Quaternary TVZ volcanism, or samples of the eugeosynclinal, subgreywacke basement prior to TVZ volcanism. Distinction between (1) older crust and (2) metamorphosed cogenetic igneous rock fragments cannot be made using the present data. However, such a distinction would be important because (1) implies that the metaigneous xenoliths may be of regional significance and therefore useful in geophysical studies of crustal structure and composition, and in studies of rhyolite genesis, whereas (2) implies that the metaigneous rocks may occur only beneath Ruapehu, and are therefore only of local geophysical and petrogenetic significance. Additional mineralogical and geochemical studies of Ruapehu xenoliths are currently being done by Mr Ian Graham, and may resolve this question.

GROUP W:-Altered xenoliths contain clay as a common feature, suggesting subsurface hydrothermal alteration. Rock 177 (Table 12) is extremely low in LIL elements and is interpreted as a hydrothermally altered andesite. Rock 158 is an altered diorite with abundant plagioclase, hypersthene, opaque oxide and interstitial clay. Rock i60 is a fine grained, massive aggregate of cryptocrystalline clay. 


\subsection{ROLE OF THE CRUST IN PETROGENESIS OF RUAPEHU LAVAS}

\subsubsection{Physical Role of the Crust}

Kuno (1968) first suggested that the crust beneath orogenic volcanic belts can be considered as a "density filter" that af fects the buoyant rise of magmas, and Gill (1973) used this concept to explain the greater relative abundance of silicic volcanic rocks in continental anorogenic provinces, as compared with oceanic provinces. Ewart, et al. (1977) suggest that crustal thickness and composition may partially control along-strike abundance patterns of magmas in a single zone of orogenic volcanism: The Tonga-Kermadec island arc is situated on thin oceanic crust and has abundant basalts, while New Zealand has thicker continental crust, fewer basalts and abundant andesites. Ruapehu is a fine example of andesite dominance: In spite of the parental relationship that has been demonstrated between mantle- derived basalts and their andesitic derivatives, only one basalt flow has been found on the entire mountain. The present writer believes there are three reasons why basaltic magma rarely arrives on the surface at Ruapehu: (1) Parental quartz tholeites are generated under hydrous conditions, and "wet" basalts are expected to fractionate at least olivine prior to eruption, due to the negative slopes of solidus and liquidus curves (Nicholls and Ringwood, 1973); (2) the buoyant rise of dense basalts from their mantle source regions is slowed or halted by the lighter continental crust, increasing the probability of fractionation (and assimilation) in crustal magma chambers; and (3) fresh influxes of basaltic magma are likely to encounter evolved magma (andesites, dacites) from previously emplaced batches, leading to basalt consolidation or magrna mixing within the crust. 


\subsubsection{Geochemical Role of the Crust}

In the central portion of the Taupo Volcanic Zone, voluminous rhyolite is considered to result from partial melting of greywacke granulite basement (Reid, 1983). Therefore, in adjacent regions it is to be expected that the crust might contribute to the compositions of basaltic magmas and their derivatives. The ubiquity and small size of metamorphic xenoliths in Ruapehu lavas suggest that the ratio of xenolith surface area to magma mass is high, increasing the possibility of contarnination. The high grade mineral assemblages of xenoliths show that crustal rocks beneath Ruapehu were subjected to high temperatures even before entrainment in magma, so relatively little heat is needed to achieve anatexis under sanidinite facies conditions. The breakdown of xenoliths in host magmas (Fig 122) is strong physical evidence for contamination, since the production of melt or vapour in xenoliths will greatly increase chemical exchange between xenoliths and host magmas.

Some geochemical effects of assimilation are shown in Figs 123 and 124. In section $111-3$ it was suggested that andesites are the fractional crystallization products of basalts, but fractional crystallization alone cannot explain the $\mathrm{Sr}$ isotopic heterogeneity shown in Fig 123. The high ${ }^{87} 5 r / 865$ r ratios of metasedimentary xenoliths imply that xenoliths have contributed radiogenic Sr to host lavas. The present writer considers that fractional crystallization and assimilation of crust are concurrent processes, since the heat needed to melt xenoliths is supplied by latent heat of crystallization of phenocrysts from host magmas (Bowen, 1928); this is supported by the positive correlation of $87 \mathrm{Sr} / 86 \mathrm{Sr}$ with $\mathrm{SiO}_{2}$ in lavas, where dacites may be the most contaminated because they are also the most fractionated. Considering the Sr isotopic data, the successful fractional crystallization calculations show that these calculations can accommodate the geochemical effects of concurrent fractionation and 
FIG 122. PHYSICAL EVIDENCE FOR ASSIMILATION OF CRUSTAL MATERIAL

A,B. Gneiss fragment in microperlitic dacite block; same deposit and locality as Fig $97 \mathrm{G}$. Note clouding and portial melting of andesine. Gornet (left) and biotite (right) are both breaking down to opaque material. xenoliths of the gneiss are found throughout the hast rack, from individual crystals to $\mathrm{cm}$ - sized fragments. A: Crossed nicols. B: Plane palarized light, with gneiss fragment outlined. Field width, $4.2 \mathrm{~mm}$. References: Hast dacite is Appendix 11 , analysis 131; mineral analyses from a similar xenolith in Appendix $V$, under field name "N112A".

C. Quartz- biotite- spinel gneiss from Iwikau Member airfall, N Ruapehu. Much of the biotite has broken down to opaque material; mineral analyses from similar frogments show this to be Al-Fe spinel (hercynite). Glass vein with biatite relicts is present at lower left. PPL. Field width, $4.2 \mathrm{~mm}$. (No analytical dato; xenalith is field name "B10 $\mathrm{xf}$.)

D. Gneiss, from dacite lava flow of Mangawhero Formation, W Ruapehu. Minerals are andesine, titaniferous biatite, olmandine- pyrope gornet, aluminous hypersthene and apatite. Clouding of feldspars, and breakdown of biotite and garnet are advanced. Disaggregation and invasion by magma is attended by axidation of ferromognesion phenocrysts in the host lava. PPL. Field width, $4.2 \mathrm{~mm}$. References: Appendix $V$, under field name "Jlx". Host lava is Appendix II, analysis 110.

E. Reticulite xenolith, from tephra of Pukeonake Scoria Cone. This is a buff-caloured, completely melted greywacke (as deduced from bulk chemistry), camprising clear vesicular gloss $\left(72.8 \mathrm{SiO}_{2}\right)$ with cordierite and spinel microlites. PPL. Field width, $4.2 \mathrm{~mm}$. References: Bulk xenolith is Appendix II, analysis 183. Analyses of glass and cardierite in Appendix $V$, under field name " $\mathrm{H} 7 \mathrm{x}-20$ ".

F. Web texture in pyroxene hornfels from lava flow of Rangataua Member, 5 Ruapehu. Labradorite, hypersthene and titanomagnetite are floating in pale brown silicic $\left(71 \% \mathrm{SiO}_{2}\right)$ glass. Note daughter crystal of acicular apatite with surrounding pleachroic halo. PPL. Field width, 0.6 mm. Reference: Appendix $V$, under field name " $G x$ ". 
FIG. 122 .
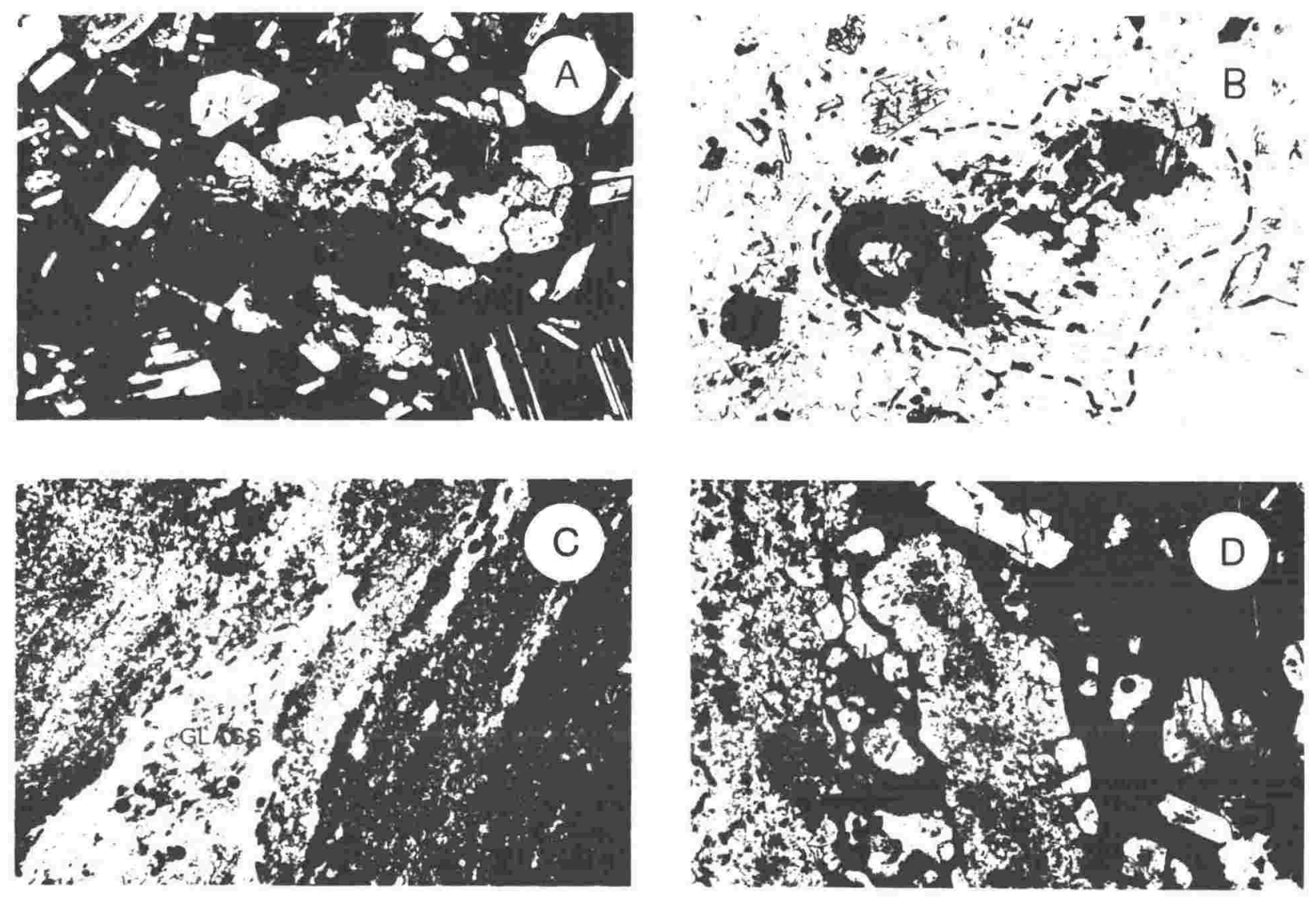

7 .

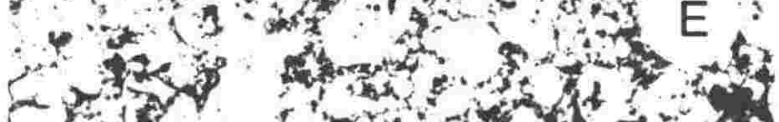

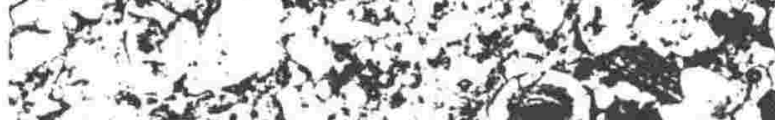

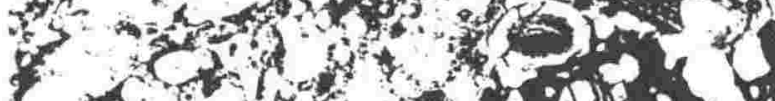

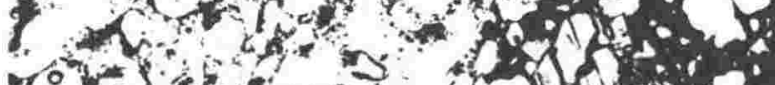
(1)

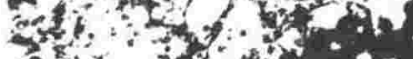
S.

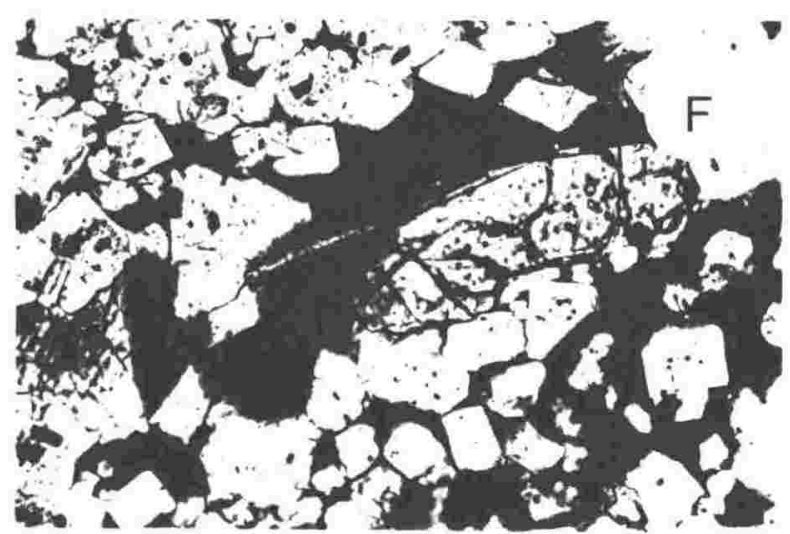


A. METAMORPHIC XENOLITHS

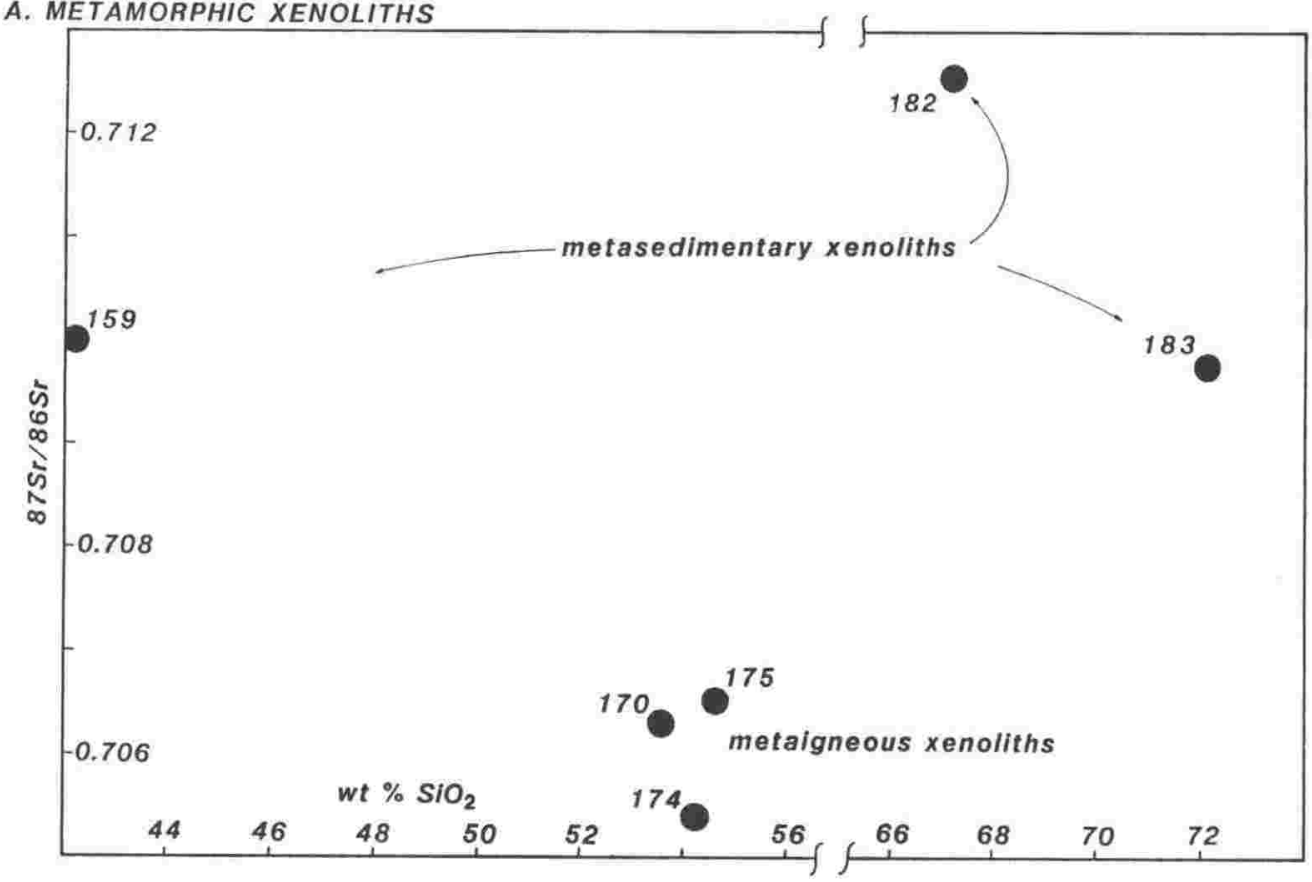

B. LAVAS

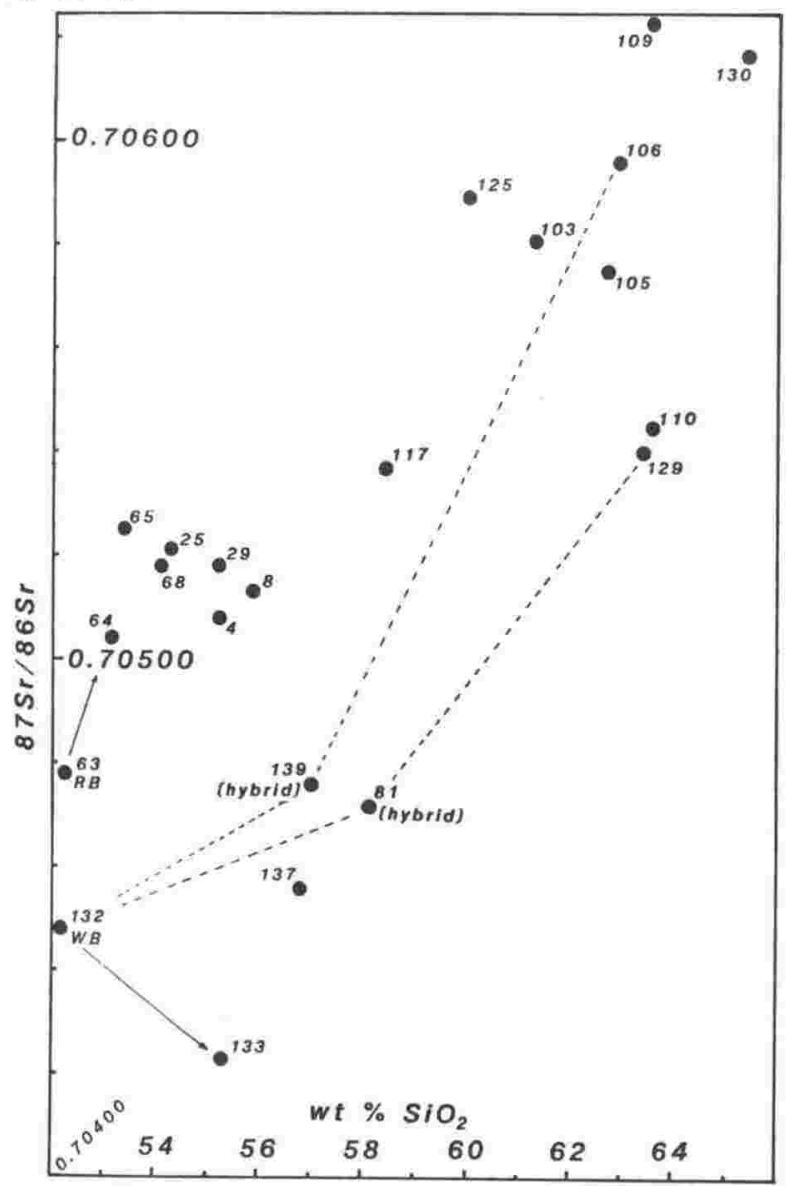

E16 12J Strontium isotopic data from metamorphic xenoliths and lavas, using $\mathrm{SIO}_{2}$ as a differentiation index All $\mathrm{Sr}$ isotopic determinations are courtesy of $\mathrm{Mr}$ lan Graham Numbers within diagrams correspond to bul rock analysis numbers of ApDendix 11

A Metamorphic xenoliths include highly radiogenic metasediments and less radiogenic metargneous rocks Reler to $\mathrm{Fig} 121$ and accompanying discussion for criteria used to distinguish igneous from sediment ary

B. Lavas of Ruapetw and related vents exnibit positive correlation of ${ }^{87} \mathrm{Sr}^{86} \mathrm{Sr}$ with $\mathrm{SiO}_{2}$, suggesting concurrent fractional crystallization and contamination by radiogenic $5 r$ from crustal sources. Arrows from Ruapehu basall (RB) and Warmarino Basalt (WB) indicate successful fractional crystallization calculations to socrm basic andesite derivatives: less raciogentc derivative 1133; Hathungatan) of wamarino Basatt can De explainec only if wi magma type is isotoptcaly ce expores ly heter geneds though time. Dashed is isolopicaly hybrid (see Table 10 for mixing calculations) 
crustal assimilation in basalts to acid andesites. However, attempts to model dacite by simple fractional crystallization of acid andesite have failed because the geochernical effects of assimilation are too great (Table 8, calculation VI-6). Major elements and compatible trace elements are in good agreement (except $\mathrm{Cr}$, which can be explained by accumulation of a few grains of pyroxene or spinel), suggesting that fractional crystallization is indeed operative. The calculation fails because the observed incompatible element concentrations in dacite $(\mathrm{K}, \mathrm{Rb})$ are too high for the degree of fractionation allowed, suggesting selective assimilation of these elements from a crustal source. The failed calculation suggests that the contaminant would be high in $\mathrm{K}$ and $\mathrm{Rb}$, and would have a low $\mathrm{K} / \mathrm{RD}$ ratio:

$$
\begin{aligned}
& K_{\text {obs }}-K_{\text {Calc }}=0.51 \text { wt \% } K_{2} O=4233 p p m K \\
& R_{\text {obs }}-R_{\text {calc }}=124-68=56 p p m R b \\
& K / R_{\text {contaminant }}=4233 / 56=76 .
\end{aligned}
$$

Variation of $\mathrm{K} / \mathrm{Rb}$ for the rock suite is shown in Fig 124. The smooth and regular variation of $\mathrm{K} / \mathrm{Rb}$ suggests consanguinity of samples, and the decrease of $\mathrm{K} / \mathrm{Rb}$ with differentiation can be explained in part by fractionation of plagioclase, olivine and pyroxenes since $\mathrm{Rb}$ is more incompatible than $K$ in these silicate phases. However, $K / R b$ decreases more rapidly than Shaw's (1968) Main Trend; petrographic evidence from lavas and nodules shows that this cannot be the result of amphibole fractionation. The present writer considers that the deviation from Shaw's Main Trend is a result of crustal assimilation: Metasedimentary xenoliths have bulk rock $K / R b$ of $189-215$, the high grade metasediments contain biotite (low $K / R b \approx 80$; Shaw, 1968), and biotite in these xénoliths is observed to break down during pyrometamorphism (Figs 120, 122). Microprobe and optical results show that biotite breakdown is not simple 


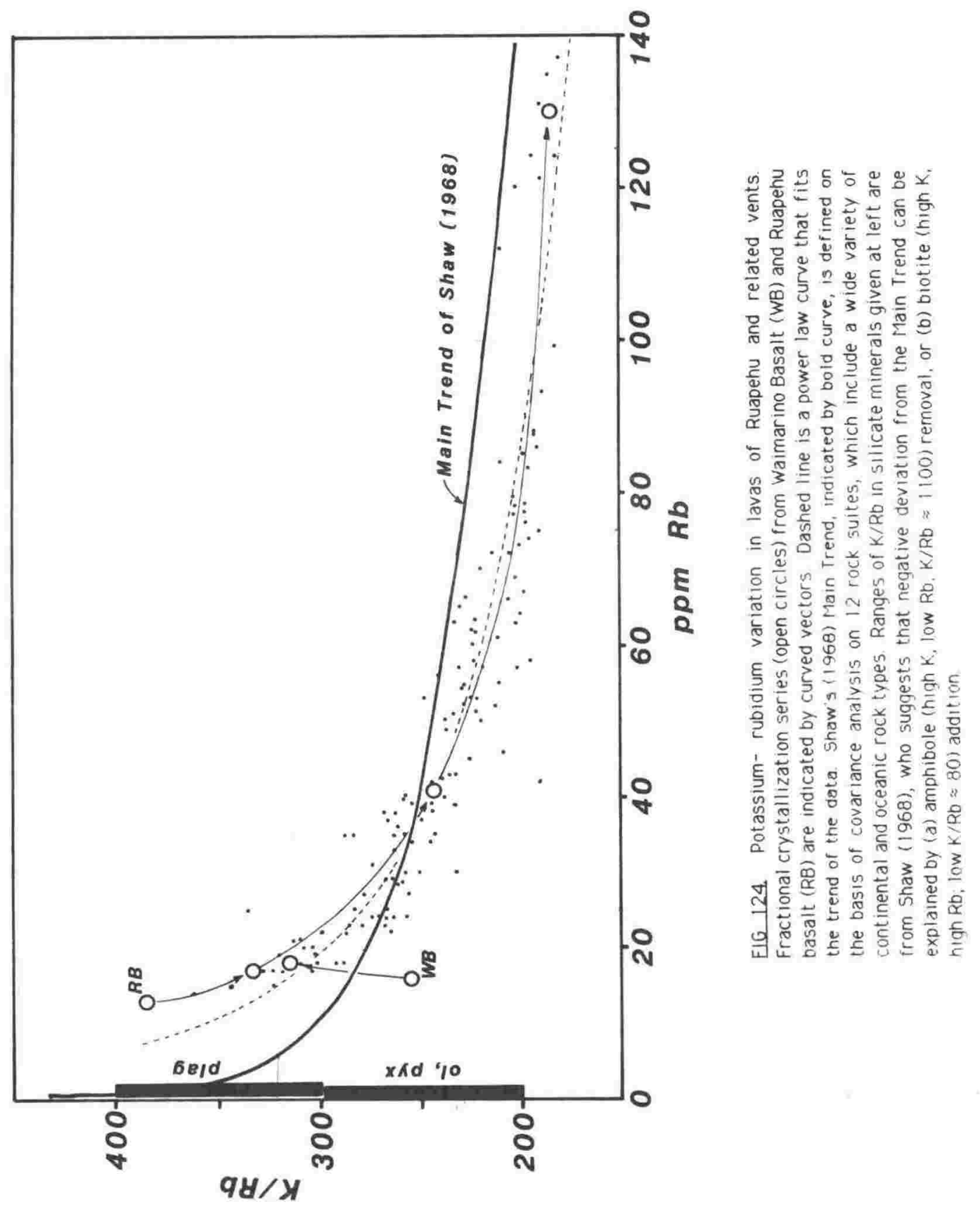


dehydration, but involves incongruent melting of biotite to form hercynite. Mass balance suggests that the other, as yet unanalyzed, reaction products are probably liberated in the form of a mobile, hydrous fluid rich in $\mathrm{SiO}_{2}$, $\mathrm{K}_{2} \mathrm{O}$, and $\mathrm{Rb}$. Nedelec and Paquet (1981) report a similar occurrence, involving incongruent melting of biotite in high grade gneisses, to produce uncharacterized "metallic oxides", glass, and a "mobile hydrous phase". The glass and hydrous fluid produced by biotite melting probably have ${ }^{87} \mathrm{Sr} /{ }^{86} \mathrm{Sr} \gg{ }^{87} \mathrm{Sr} /{ }^{86} \mathrm{Sr}$ bulk xenolith. This is because biotite is a Rbrich phase, and ${ }^{87} \mathrm{Sr}$ is produced by decay of ${ }^{87} \mathrm{Rb}$. Pushkar and Stoeser (1975) report anatectic glass in a quartz monzonite xenolith, where the bulk xenolith has ${ }^{87} \mathrm{Sr} / 86_{\mathrm{Sr}}=0.7058$, and the glass has ${ }^{87} \mathrm{Sr} / 86_{\mathrm{Sr}}=$ 0.7229 , leading these authors to state (p. 671): "... the high ratio in the glass supports the supposition that the glass has a large component of biotite-derived strontium".

The preceding arguments support the idea that crustal assimilation is a selective process, involving the addition of incompatible elements (particularly $\mathrm{K}$ and $\mathrm{Rb}$ ) and radiogenic $\mathrm{Sr}$ to host magmas. One mechanism of this selective contamination is inferred to be incongruent melting of biotite, the only major hydrous, LIL- rich phase that is present in xenoliths. In regard to selective assimilation, Watson (1982) states:

"If basalt magma induces local melting of crustal rocks, the assimilation process becomes one of liquid- state interdiffusion. In this case, the varying diffusivities of ions and the ir differing preferences for silicic relative to basaltic melts can produce marked selective contamination effects. Selective contamination of ascending basaltic magmas is particularly likely in the case of $\mathrm{K}_{2} \mathrm{O}$, which may be introduced in substantial amounts even when other elements remain unaffected." (from the Abstract) 
Thus, experimental evidence supports the idea of selective assimilation, as proposed by Steiner (1958) and by the present writer. Assimilation is a process that should be modelled concurrently with fractional crystallization, and the nature of the contaminant should be constrained by the observed meiting relations in xenoliths, not by simply adding bulk xenoliths to bulk magmas. 


\section{MAGMAEVOLUTION IN TIME AND SPACE: A RETURN TO THE STRATIGRAPHIC CONTEXI}

A synopsis of compositional diversity for Ruapehu formations and related vents is given in Fig 125 . Hauhungatahi ( 0.5 m.y.?) is probably the oldest vent of the Tongariro Volcanic Centre, and the lavas are rather uniform in petrography and bulk composition. Least squares mixing calculations suggest that the basic andesite of Haunungatahi may be a differentiate of the Waimarino Basalt magna type. If so, the WB magma type is remarkably time transgressive.

Lavas of the Te Herenga Fm represent the oldest known eruptives on Ruapehu. The lavas are petrographically uniform, olivine- free basic andesites and a few acid andesites (range: 53.8-58.8\% $5 \mathrm{SO}_{2}$ ). Least squares mixing calculations suggest that the most basic Te Herenga sample may be a differentiate of the Ruapehu basait magma type, although the only known exposure of this basalt is in the younger Mangawhero Fm Most basic andesites of Te Herenga Fm have similar compositions to lavas on the liquid line of descent from Ruapehu basalt, and the limited intraformational compositional variation can be explained by continued fractionation of pyroxenes and plagioclase to produce rare acid andesite. A few samples may be mildly accumulative in pyroxenes, as suggested by pyroxene clusters and bulk rock $\mathrm{Cr}$ up to $97 \mathrm{ppm}$.

Lavas of the Wahianoa Fm include basic and acid andesites in about equal abundance (range: 54.3-61.2\% $\mathrm{SiO}_{2}$ ), and there is greater compositional diversity than in the older Te Herenga Frn. Many lavas are petrographically similar to Te Herenga Fm, and most have compositions near the liquid line of descent from Ruapehu basalt, suggesting they are differentiates of this magma type. Some lavas are unequivocally accurnulative in pyroxenes \pm olivine (bulk rocks $27,30,31,57,58,60$ ), on 


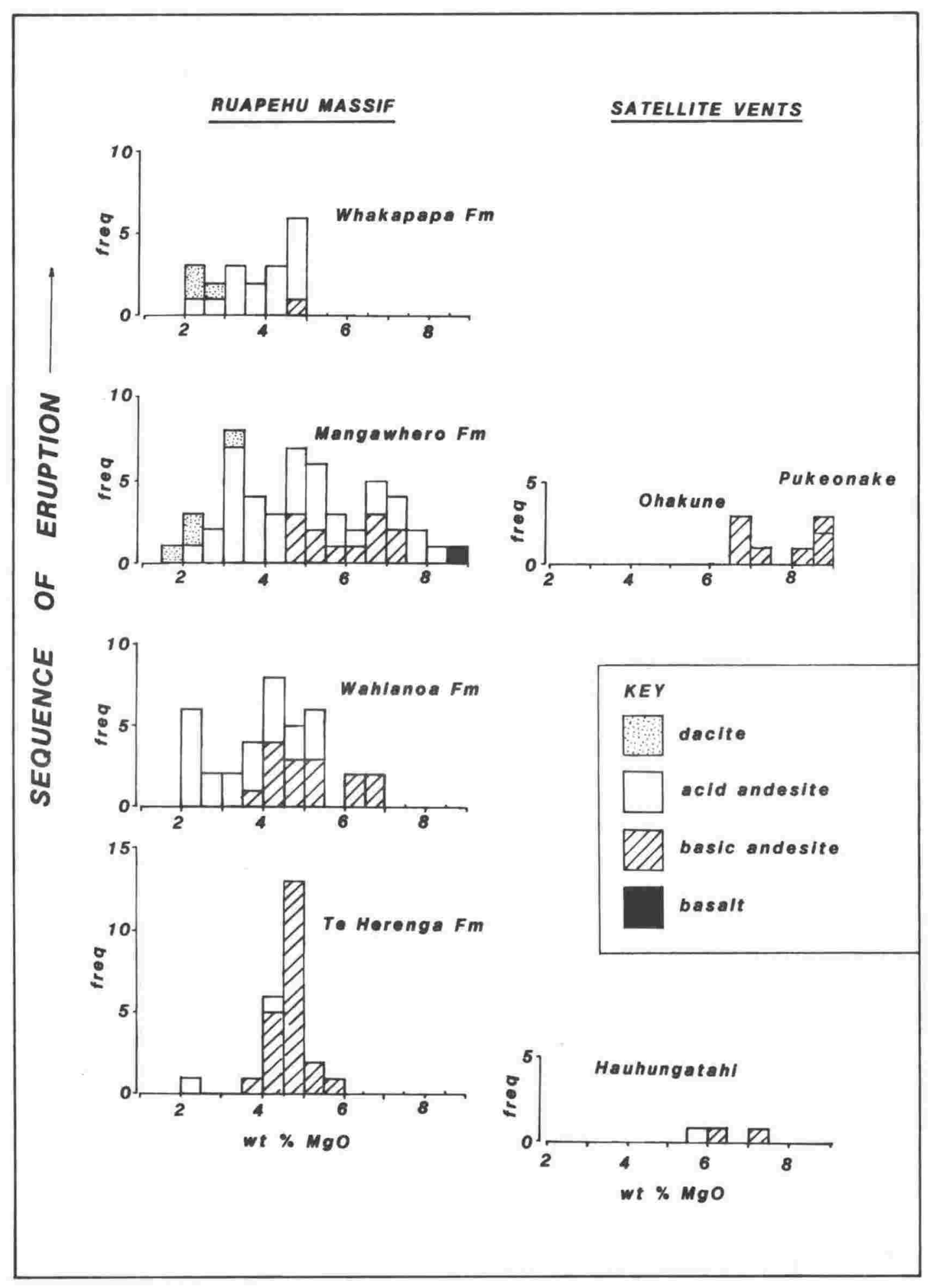

E16 125 Compositional diversity of lavas and pyroclastics from Ruapehu formations and satellite vents. "Freq" means number of analyses. Waimarino Basalt (not shown) erupted at about the same time as upper Mangawhero $\mathrm{Fm}$. 
the basis of petrography and bulk chemistry (all of these have 200-300 pprr $\mathrm{Cr}$ ). Others are accumulative in plagioclase (bulk rocks 46, 47, 52 , 54), as judged by petrography and their high $\mathrm{Sr}$ and $\mathrm{Al}_{2} \mathrm{O}_{3}$.

Lavas of the Mangawhero Fm exhibit great petrographic and compositional variation, from basalt to dacites (range: $52.2-63.6 \% \mathrm{SiO}_{2}$ ). The only known subaerial exposure of the Ruapehu basalt magma type occurs in Mangawhero Fm, and least squares mixing calculations show that this parental basalt has produced intraformational basic- and acid andesite differentiates, the liquid line being defined by bulk rocks 63,64 , and 88. Atternpts to model dacite by perfect fractional crystallization of acid andesite have failed because these calculations do not account for the effects of selective assimilation (see: section 111-6.4.2). Some lavas are accumulative in pyroxenes \pm olivine (bulk rocks 72, 76, 92, 101), plagioclase and pyroxenes (bulk rocks $75,80,99$ ) or plagioclase alone (bulk rock 100). Petrographic and geochemical studies have also led to the recognition of several basic- and acid andesite hybrid magmas (bulk rocks $69,81,82,87,93$ ) in the upper part of the formation. One of these (69) involves Ruapehu basalt as an end member, but the others may be mixtures of dacite and Waimarino Basait magma type (see: Table 10).

Pukeonake, a parasitic vent to the north of Ruapehu, erupted ca. $25 \mathrm{ka}$, about the same time as upper Mangawhero Fm. The lavas and pyroclastics of Pukeonake show unequivocal petrographic and geochemical evidence for magma mixing between Waimarino Basalt magma type and dacite (Table 10; Figs 118, 119). The Ohakune vents also erupted about $25 \mathrm{Ka}$, and these plagioclase- free basic andesites are believed to be differentiates of a magma type that is similar, but not identical to Waimarino Basalt.

Waimarino Basalt erupted about $15 \mathrm{Ka}$, from an isolated vent to the southeast of Lake Taupo. In spite of its geographic separation from Ruapehu, the petrography, mineralogy, bulk rock chemistry and field 
relations of Waimarino Basalt have received detailed attention because of its primary status and its potential parental role for andesitic lavas of the calc alkaline suite. Eruptions at Onakune, Pukeonake and summit eruptions of upper Mangawhero Frm on Ruapehu all occurred about 25-15 Ka, and all involved magmas of the Waimarino Basalt type. These observations suggest that batches of Waimarino Basalt magma type were emplaced throughout the southern TVZ between 25-15 Ka. When Waimarino Basalt was emplaced beneath Ruapehu, it either mingled with evolved melts to produce mixed magmas (hybrids of Pukeonake and upper Mangawhero Fm), or underwent fractionation (Onakune basic andesite); only at a locality far removed from the Tongariro Volcanoes was it able to arrive at the surface in primitive condition.

Lavas of the Whakapapa Fm include olivine-free acid andesites, one basic andesite and two dacites that erupted from summit and flank vents during Holocene time (range: $56.6-65.6 \% \mathrm{SiO}_{2}$ ). Most lavas are acid andesites, and overall the lavas are more evolved than in the underlying Mangawhero $\mathrm{Fm}$. No quantitative modelling has been done on any lavas from Whakapapa Fm, but most are petrographically and geochemically similar to acid andesites of Mangawhero Fm, suggesting derivation from Ruapehu basalt magma type. Several lavas appear to be mildiy accumulative in pyroxenes and plagioclase $(111-115)$, and two are plagioclase-accumulative $(118,120)$. 


\section{EPILOGUE}

In the final chapter of Orogenic Andesites and Plate Tectonics, Gill (1981) discusses "some outstanding problems requiring clarification", and poses questions that provide directions for continued research in orogenic andesites. Ruapehu is a large, composite andesite volcano associated with a convergent plate boundary, and is in many ways typical of Quaternary, subduction- related, calc alkaline volcanism at continental margins worldwide. Thus, conclusions regarding petrogenesis of Ruapehu andesites provide answers to some general questions about the origin of andesites.

A major goal of the present field and laboratory studies has been to give evidence for the primary role of basalt fractionation in petrogenesis of Ruapehu andesites. The mineralogy and bulk rock chemistry of basic andesites converge on basalt, and the parental role of basalt is strongly suggested by successful calculations to derive calc alkaline andesites from it. But in all scientific inquiry, new answers typically raise new questions. Thus, the first question:

\section{Why do orogenic andesites predominate at convergent plate boundaries if they are simply the products of basalt differentiation which occurs anywhere?}

Several replies are relevant. First, the parental basalts identified in the present study are quartz- normative, and have ca. 52 wt \% silica. One of them, Waimarino Basalt, has primitive characteristics which suggest that it originated by hydrous partial melting of the mantle wedge, with volatiles probably supplied by slab dehydration ("IRS fluid" of Gill, 1.981). Thus, parental basalts at Ruapehu are more silicic than basalts in other tectonic settings (e.g., MORB), and comparatively small degrees of 
fractional crystallization are necessary to produce andesites: Mixing calculations of the present study suggest that fractionation of 16-30 wt $\%$ crystals will yield basic andesite derivatives from silica- oversaturated basaltic parents. Second, when basaltic magmas rise through previously occupied and heated conduits beneath composite volcanoes, they are subjected to the modifying effects of magma mixing and crustal contamination. Third, the crust of the overriding plate probably acts as a filter which inhibits the passage of dense basalts, increases the tendency of basalts to crystallize in crustal reservoirs, and favours the rise and eventual eruption of less dense andesitic derivatives. In spite of concerted efforts by the present writer to collect and analyze mafic lavas, and thereby to "establish the basalt connection", only a single basalt lava flow has been found on Ruapehu massif, demonstrating the rarity of basaltic lavas. A second question is related to the first:

\section{Where are the necessary crystal cumulates?}

Mixing calculations based on phenocryst minerals in lavas indicate that most of the cumulates will be gabbroic in composition; i.e., of 'POAM' mineralogy, and this is consistent with the most common kind of igneous inclusion found in Ruapehu andesites. The cumulates are minor in volume, are part of a gabbroic lower crust, and their presence within the crust may or may not be geophysically detectable. Consider a cylindrical parcel of crust beneath Ruapehu, with the following dimensions: $10 \mathrm{~km}$ radius from Ruapehu summit, and $15 \mathrm{~km}$ deep, yielding a volume of $4,650 \mathrm{~km}^{3}$. The total volume of Ruapehu lavas, allowing for erosion, is about $150 \mathrm{~km}^{3}$. Mixing calculations suggest that ca. 50-60 wt $\%$ fractionation of 'POAM' minerals from parental basalts is necessary to produce average Ruapehu andesite with 58 wt $\%$ silica. Thus, ca. $75-90 \mathrm{~km}^{3}$ of gabbroic cumulates should be present beneath Ruapehu, comprising only $2 \%$ of the assumed 
$4,650 \mathrm{~km}^{3}$ of crust in which they reside.

Can basalt fractionation account for all of the petrographic and geochemical features of the rock suite?

No, it cannot. There is convincing petrographic and geochemical evidence for three second- order processes: accumulation of igneous crystals from earlier episodes of magma consolidation, magma mixing in common conduits, and crustal contamination. These are termed 'secondorder processes because they operate concurrently with fractional crystallization, and they affect lavas whose bulk compositions were largely pre-determined by basalt differentiation.

Lavas containing exotic igneous crystals of plagioclase, pyroxenes and olivine are common: about 10\% of rocks in the sample population $(n=144)$ are unequivocally accumulative in one or more of these phases. If lavas containing only a few hypidiomorphic-granular rock fragments or unequilibrated phenocrysts are considered, then the majority of lavas are accumulative to some degree and few lavas represent liquid compositions.

Magma mixing is less common than entrainment of igneous rock fragments: Only about $4 \%$ of the lavas have petrographic and geochemical evidence for hybrid origin, and these are restricted to parasite cones and the upper cone complex of Ruapehu. Documented examples of hybrid lavas involve mixing of distinguishable end members such as basalt and dacite, but magma mixing may be more common than is recognized because backmixing of similar end members will yield more subtle petrographic and geochemical effects.

All lavas may have undergone crustal contamination to varying degrees, since metamorphic rock fragments are ubiquitous and are often 
affected by anatexis. Crustal assimilation is apparently a selective process that largely affects $5 r$ isotopic ratios and incompatible element abundances of lavas. The positive correlation between differentiation indices (wt \& $\mathrm{SiO}_{2}$, ppm Rb, etc.) and ${ }^{87} \mathrm{Sr} /{ }^{86} \mathrm{Sr}$ ratios of lavas, together with the inability of simple 'POAM' fractional crystallization to explain dacite petrogenesis, suggest that crustal contamination has operated concurrently with fractional crystallization. One mechanism of contamination may be the breakdown of biotite in metamorphic xenoliths, involving the liberation of LIL- and ${ }^{87}$ Sr- rich fluid into host lavas. $A$ final question concerns possible alternatives to crustal contamination:

Can processes other than selective crustal interaction account for isotopic compositions within otherwise consanguineous-seeming suites of orogenic andesites which are more heterogeneous and radiogenic than those of intra-oceanic basalts? For example, is mantle heterogeneity a viable alternative?

The physical and geochemical evidence for crustal contamination of andesites and dacites is convincing, but basalts of the TVZ are also heterogeneous in LIL element concentrations and $\mathrm{Sr}$ isotopic ratios. The two parental basalts reported here are not related by fractional crystallization, are sufficiently different to be considered as separate magma types, and may have originated in geochemically or mineralogically

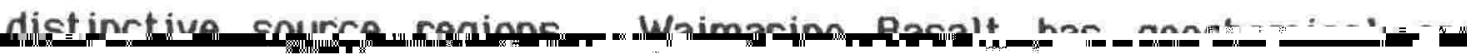


Thus, I end this discussion on a note of uncertainty: The relative roles of mantle heterogeneity and crustal contamination in basalt petrogenesis are currently unknown, and will require further collection and detailed geochemical analysis of TVZ basalts, as well as further inquiry into the geochemical budget of the crustal contamination process. Continued TVZ basalt studies may also lead to recognition of other andesite liquid lines, in addition to those reported here. However, these are matters for other dissertations by other people. 


\section{REFEREMCES CUIED}

A0I Dictionary , 1962. Dolphin Books, New York. 545 pp.

Adams, R.D., and Ware, D.E., 1977. Subcrustal earthquakes beneath New Zealand; locations determ ined with a laterally inhomogeneous velocity model. N.Z. Jour. Geol. Geophys., 20, 59-83.

Anderson, A.T., 1976. Magma mixing petrological process and volcanological tool. Jour. Yolc. Geoth. Res., 1, 3-33.

Anderson, R.N. , Uyeda, S., and Miyeshiro, A., 1976. Geophysical and geochemical constraints at converging plate boundaries. Part I. Dehydration in the downgoing slab. Geophys. Jour. Roy. Astron. Soc., 44, 333-357.

Aramaki, S., 1963. Geology of Asama Volcano. Jour. Fac. Sci. Tokyo Univ., II, 14, 233-433.

Arculus, R.J., Johnson, R.W., Chappell, B.W., McKee, C.0., and Sakai, H., 1983. Ophiolitecontaminated andesites, trachybasalts, and cognate inclusions of Mount Lamington, Papua New Guinea: Antydrite- amphibole-bearing loves and the 1951 cumulodome. Jour. Volc. Geoth. Res., 18, 215-247.

and Wills, K.J.A., 1980. The petrology of plutonic blocks and inclusions from the Lesser Antilles island arc. Jour. Petrology, 21, 743-799.

Basaltic Volcanism Study Project, 1981. Basaltic Volcanism on the Terrestrial Planets. Pergamon Press, New York. 1286 pp.

Bossard, L., 1928. Origin of the conical hills in the neighbourhood of Mt Egmont. N.Z. Jour. Sci. Tech., 10, 119-125.

Bowen, N.L., 1928. The Evolution of the Igneous Rocks. Princeton Univ. Press, Princeton, New Jersey. $322 \mathrm{pp}$.

Browne, P.R.L., 1978. Hydrothermal alteration in active geothermal fields. Ann. Rev. Earth Planet. Sci., 6, 229-250.

Buddington, A.F., and Lindsley, D.H., 1964. Iron- titanium oxide minerals and synthetic equivalents. Jour. Petrology, 5, 310-357.

Cameron, W.E., McCulloch, M.T., and Wolker, D.A., 1983. Boninite petrogenesis: Chemical and Nd-Sm isotopic constraints. Earth Planet. Sci. Lett., 65, 75-89.

Nisbet, E.G., and Dietrich, Y.J., 1979. Boninites, komotiites and ophiolitic basalts. Nature, London, $280,550$.

Carter, R.M., 1975. A discussion and classification of subaqueous mass transport with particular application to grain-flow, slurry-flow and fluxoturbidites. Earth Sci. Rev., 11, 145-177.

Clark, R.H., 1960. Petrology of the volcanic rocks of Tongar iro Subdivision. Appendix II. In: D.R. Gregg, ed., The Geology of Tongariro Subdivision . N.Z. Geol. Survey Bull. 40, 107-123. 
Clarke, D.B., and O'Hara, M.J., 1979. Nickel, and the existence of high-MgO liquids in nature. Earth Planet. Sci. Lett., 44, 153-158.

Cole, J.W., 1973. High-alumina basalts of Taupo Volcanic Zone, New Zealand. Lithos, 6, $53-64$.

1978. Andesites of the Tongariro Volcanic Centre, North Island, New Zealend. Jour. Volc. Geoth. Res., 3, 121-153.

19798. Structure, petrology and genesis of Cenozoic volcanism, Taupo Volcanic Zone, New Zealand- a review. N.Z. Jour. Geol. Gecphys., 22, 631-657.

1979b. Chemical analyses of lavas and innimbrites of the Taupo Volcanic Zone. Pub. 13 of Geology Dept., Victoria Univ. Wellington. 31 pp.

1981. Genesis of lavas of the Taupo Yolcanic Zone, North Island, New Zealand. Jour. Volc. Geoth. Res., 10, 317-337.

1982. Tonga- Kermadec- New Zealand. In: R.S. Thorpe, ed., Andesites: Orogenic Andesites and Related Rocks. Wiley \& Sons, Ltd., London, 245-258.

1984. Taupo- Rotorua Depression: An ensialic marginal basin of North Island, New Zealand. In: B.P. Kokelaar, and Howells, M.F., eds., Marginal Basin Geology: Volcanic and Associated Sedimentary and Tectonic Processes in Modern and Ancient Sedimentary Basins. Geol. Soc. Lond. Spec. Pub. 16, 109-120.

Cashman, K.Y., and Rankin, P.C., 1983. Rare earth element geochemistry and the origin of andesites and basalts of the Taupo Volcanic Zone, New Zealand. Chem. Geol., 38 , 255-274.

and Lewis, K.B., 1981. Evolution of the Taupo- Hikurangi subduction system. Tectonophysics, $72,1-21$.

and Nairn, IA. 1975. Catalogue of the Active Volcanoes of the World Including Solfatara Fields, 22. New Zealand. Internat. Assoc. Volc. Chem. Earth. Interior, Rome, Italy.

and Teoh, L.H., 1975. Petrography, mineralogy and chemistry of Pureora andesite volcano, North Island, New Zealand. N.Z. Jour. Geol. Geophys., 18, 259-272.

Crawford, A.J., 1980. A clinoenstatite- bearing cumulate olivine pyraxenite from Howqua, Victoria. Contrib. Mineral. Petrol., 75, 353-367.

Currie, K.L., 1971. [coexisting cordierite and garnet] Contrib. Mineral. Petrol., 33, 215-226.

Curry, R.R., 1966. Observations of alpine mudflows in the Ten-Mile Range, central Colorado. Geol. Soc. Amer. Bull., 77, 771-776.

Delaney, J.M., and Helgeson, H.C., 1978. Calculation of the thermodynamic consequences of dehydration in subducting oceanic crust to $100 \mathrm{~Kb}$ and $>800 \mathrm{C}$. Amer. Jour. Sci., 278 , 638-686.

Duncan, A.R., 1970. Eastern Bay of Plenty Volcanoes. Unpub. Ph.D. thesis, ladged in the Library, Yictoria Univ. Wellington. 
Eggler, D.H., 1972. Water-saturated and undersaturated melting relations in a Paricutin andesite and an estimate of water content in the natural magma. Contrib. Mineral. Petrol., $34,261-271$.

Eiby, G.A., 1955. New Zealand crustal structure. Nature, London, 176, 32.

Eichelberger, J.C., 1975. Origin of andesite and dacite: Evidence of mixing at Glass Mountain in California and at other circum-Pacific volcanoes. Geol. Soc. Amer. Bull., 86, 1381-1391.

Ewart, A., 1979. A review of the mineralogy and chemistry of Tertiary-Recent dacitic, latitic, rhyolitic, and related salic volcanic rocks. In: F. Barker, ed., Trondhjemites, Dacites, and Related Rocks. Developments in Petrology, 6, Elsevier, New York. p. 13-112.

1982. In: R.S. Thorpe, ed., Andesites: Orogenic Andesites and Related Rocks. Wiley \& Sons, Ltd.

Brothers, R.N., and Mateen, A., 1977. Mineralogical and chemical evolution of the Tonge-Kermadec- New Zeeland island arc. Jour. Yolc. Geoth. Res. , 2, 205-250.

, and Bryan, W.B., 1973. The petrology and geochemistry of the Tongan Islands. In: P.J. Coleman, ed., The Western Pacific: Island Arcs, Marginal Sees, Geochemistry. Univ. Western Australia Press, Perth, W.A., p. 503-522.

and Stipp, J.J., 1968. Petrogenesis of the volcanic rocks of the central North Island, New Zealand, as indicated by a study of $87 \mathrm{Sr} / 86 \mathrm{Sr}$ ratios and $\mathrm{Sr}, \mathrm{Rb}, \mathrm{K}, \mathrm{U}$, and Th abundances. Beochim. Cosmochim. Acta, 32, 699-735.

Fisher, R.V., 1961. Proposed classification of volcaniclastic sediments and rocks. Geol. Soc. Amer. Bull., 72, 1409-1414.

1966. Rocks composed of volcanic fragments. Earth Sci. Rev., 1, 287-298.

Fiske, R.S., Hopson, C.A., and Waters, A.C., 1963. Geology of Mount Rainier National Park, Washington. U.S. Geol. Survey Prof. Paper 444, 93 pp.

Fleming, C.A., 1953. The Geology of Wanganui Subdivision. N.Z. Geol. Survey Bulletin 52. 5-8.

and Steiner, A., 1951. Sediments beneeth Ruapehu Volcano. N.Z. Jour. Sci. Tech., B32,

Fudali, R.F., 1965. Oxygen fugacities of basaltic and andesitic magmas. Geochim. Cosmochim. Acts, 29, 1063-1075.

Gerrels, R.M., and Mackenzie, F.T., 1971. Evolution of Sedimentary Rocks. Norton \& Co., New York. 397 pp.

Gerrick, R.A., 1968. A reinterpretation of the Wellington Crustal Refraction Profile. N.Z. Jour. Geol. Geophys., 11 , 1280-1294.

Gerlach, D.C., and Grove, T.L., 1982. Petrology of Medicine Lake Highland volcanics: Characterization of endmembers of magma mixing. Contrib. Mineral. Petrol., 80 , 147-159. 
Gill, J.B., 1981. Orogenic Andesites and Plate Tectonics. Springer-Verleg, Now York. $390 \mathrm{pp}$.

Goldman, D.S., and Albee, A.L., 1977. Correlation of $\mathrm{Mg} / \mathrm{Fe}$ partitioning between garnet and biotite with $180 / 160$ partitioning between quartz and magnetite. Amer. Jour. Sci., 277 , $750-767$.

Grange, L.I., 1931. Conical hills on Egmont and Ruapehu Volcanoes. N.Z. Jour. Sci. Tech., 12. 376-384.

and Hurst, J.A., 1929. Tongariro Subdivision. N.Z. Geol. Survey 23rd Ann. Report, n.s., $5-8$.

and Williamson, J.H., 1930. Tongariro Subdivision. N.Z. Geol. Survey 24th Ann. Report, n.s., 10-13.

and Williamson, J.H., 1933. Tongariro District. N.Z. Geol. Survey 27th Ann. Report, n.s., 18-21.

Green, D.H., 1973. Experimental melting studies on a model upper mantle composition at high pressure under water-saturated and water-undersaturated conditions. Earth Planet. Sci. Lett. , 19, 37-53.

and Hibberson, W.0., 1970. Experimental duplication of conditions of precipitation of high pressure phenocrysts in a basaltic magma. Phys. Earth Planet. Interiors, 3 , 247-254.

and Ringwrood, A.E., 1967. An experimental investigation of the gebbro to eclogite transformation and its petrological applications. Geochím. Cosmochim. Acta, 31, 767-833.

and Ringwood, A.E., 1970. Mineralogy of peridotitic compositions under upper mantle conditions. Piys. Earth Planet. Interiors, 3, 359-371.

Green, T.H., 1972. Crystallization of calcalkaline andesite under controlled high-pressure mydrous conditions. Contrib. Mineral. Petrol., 34, 150- 166.

1980. Island arc and continent-building magmatism- A review of petrogenic models based on experimental petrology and geochem istry. Tectonophysics, 63, 367-385.

and Ringwood, A.E., 1968. Crystallization of basalt and andesite under high-pressure hydrous conditions. Earth Planet. Sci. Lett., 3, 481-489.

and Watson, E.B., 1982. Crystallization of apatite in natural magmas under high pressure, hydrous conditions, with perticular reference to 'orogenic' rock series. Contrib. Mineral. Petrol., 79, 96-105.

Gregg, D.R., 1960. The Geology of Tongariro Subdivision. N.Z. Geol. Survey Bull. 40. 1961. The tectonic setting of the Tongariro Volcanoes, New Zealend. Proc. 9th Pacific Sci. Congress, 1957, 12, 218-224.

Griggs, D.T., 1972. The sinking lithosphere and the focal mechenism of deep earthquakes. In: E.C. Robertson, ed., The Nature of the Solid Earth. McOraw-Hill, New York, p. $361-384$. 
Orindley, G.W., 1960. Sheet 8 Taupo. Geological Map of New Zealand, 1:250,000. N.Z. Dept. Sci. Ind. Res., Wellington.

1965. Tongariro National Park stratigraphy and structure. In: B.N. Thompson, Kermode, L.0., and Ewart, A., eds., New Zealend Volcanology, Central Volcanic Region. N.Z. Dept. Sci. Ind. Res. Information Series 50, p. 79-86.

and Mathews, W.H., 1965. Geological map (p. 80A). In: B.N. Thompson, Kermode, L.0., and Ewart, A., eds., New Zealand Volcanology, Central Volcanic Region. N.Z. Dept. Sci. Ind. Res. Information Series $\mathbf{5 0 .}$

Grove, T.L., Gerlach, D.C., and Sando, T., 1982. Origin of calc-8lkaline series lavas at Medicine Lake Volcano by fractionation, assimilation and mixing. Contrib. Mineral. Petrol., 80 , $160-182$.

Haggerty, S.E., 1976. Opaque mineral axides in terrestrial igneous rocks. In: D. Rumble III, ad. Oxide Minerals- Short Course Notes, vol. 3. Min. Soc. Amer., Washington, D.C., p. $101-301$.

1976. Oxidation of mineral axides in basalts. In: D. Rumble III, ed., Oxide Minerals- Short Course Notes, vol. 3. p. $\mathrm{Hg}-\mathrm{I}$ to $\mathrm{Hg}-100$.

Haines, A.J., 1979. Seismic wave velocities in the uppermost mantle beneath New Zealand. N.Z. Jour. Geol. Geophys., 22 , 245-257.

Halema, B.6., 1981. Stratigraphic Study of Mount Ruapehu Lava Flows- Te Herenga Series. Unpub. B.Sc. Hons. Project, Geophysics Dept., Victor is Univ. of Wellington.

Hamilton, R.M., and Gale, A.W., 1968. Seismicity and structure of North Island, New Zealand. Jour. Geophys. Res., 73, 3859-3876.

Hanson, G.N. , and Langmuir, C.H., 1978. Modelling of major elements in mantle- melt systems using trace element approeches. Geochim. Cosmochim. Acto, 42, 725-741.

Hay, R.F., 1967. Sheet 7 Taranaki. Geological Map of New Zealand, 1:250,000. N.Z. Dept. Sci. Ind. Res., Wellington.

Hezlett, R.W., 1977. Geology and Hezards of the San Cristobal Volcanic Complex, Nicaragua. Unpub. M.Sc. thesis, housed in the Library, Geology Dept., Dartmouth College, Hanover, New Hempshire. 211 pp.

Healy, J., 1962. Structure and volcanism in the Taupo Volcanic Zone, New Zealand. In: Crust of the Pacific Basin, Geophysical Monogroph 6, 151-157.

1964. Volcanic mechanisms in the Taupo Volcanic Zone, New Zealand. N.Z. Jour. Geol. Geoplys., 7, 6-23.

1965. Geological notes on the volcanoes: Lahar Mounds, Bruce Road, Ruapehu. In: B.N. Thompson, Kermode, L.0., and Ewart, A., eds., New Zealand Volcanology. Central Volcanic Region. N.Z. Dept. Sci. Ind. Res. Information Series 50, p. 100-102.

Schofield, J.C., and Thompson, B.N., 1964. Sheet 5 Rotorue. Beological Map of New Zealand, 1:250,000. N.Z. Dept. Sci. Ind. Res., Wellington.

Hill, H., 1891. Ruapehu and Ngauruhoe. Trans. N.Z. Inst., 24, 603-625. 
Hoblitt, R.P., and Kellogg, K.S., 1979. Emplacement temperatures of unsorted and unstratified deposits of volcanic rock debr is as determined by paleomegnetic techniques. Geol. Soc. Amer. Bull., 90, 633-642.

Hochstein, M.P., 1976. Estimation of geothermal resource. In: S. Nathan, ed., Yolcanic and Oeothermal Geology of the Central North Island, New Zealand. Excursion Guide No. 55A and 56C, 25th Int. Ceol. Congress, p. 44-48.

Hooke, R., 1967. Processes in arid-region alluvial fans. Jour. Geol., 75, 438-460.

Hyndman, D.W., 1981. Controls on source and depth of emplacement of granitic magma. Ceology, 9, 244-249.

Irvine, T.N., 1967. Chromian spinel as a petrogenetic indicator. Part II. Petrologic applications. Can. Jour. Earth Sci., 4, 71-103.

and Baragar, W.R.A., 1971. A guide to the chemical classification of the common volcanic rocks. Can Jour, Earth Sci., 8, 523-548.

Irving, A.J., 1978. A review of experimental studies of crystal/liquid trace element partitioning. Geochim. Cosmochim. Act8, 42, 743-770.

Jaques, A.L., and Green, D.H., 1980. Anhydrous melting of peridotite at $0-15 \mathrm{~Kb}$ pressure and the genesis of tholeiitic basalts. Contrib. Mineral. Petrol. , 73, 287-310.

Johnson, A.M., 1970. Physical Processes in Oeology. Freeman \& Co., San Francisco.

Kay, R.W., and Kay, S.M., 1981. The nature of the lower continental crust: Inferences from geophysics, surfece geology, and crustal xenoliths. Rev. Geophys. Space Phys., 19, 271-297.

Korsch, R.J., and Wellman, H.W., 1985 in press. The geological evolution of New Zealand and the New Zeeland region. In: A.E.M. Nairn, Stehli, F., and Uyede, S., eds., The Oceen Basins and Margins. Yolume 7A: The Pacific Ocaen. Plenum Press, New York.

Kuno, H., 1968. Origin of andesite and its bearing on the island arc structure. Bull. Volcanologique, 32, 141-176.

Kushiro, I., 1969. The system forsterite- diopside- silica with and without water at high pressure. Amer. Jour. Sci., 267A, 269-294.

1972. Effect of water on the compositions of megmas formed at high pressures. Jour. Petrology, 13, 311-334.

1974. Melting of myurous upper mantle and possible generation of andesitic magma. An approach from synthetic systems. Earth Planet. Sci. Lett., 22, 294-299.

Leake, B.E., 1978. Nomenclature of amphiboles. Can. Mineral., 16, 501-520.

Macdonald, 6A., 1950. Pahoehoe, 68, and block lave. Amer. Jour. Sci., 251, 169-191. 1972. Volcanoes. Prentice-Hall, Inc. Englewood Cliffs, New Jersey. 510 pp.

Mathews, W.H., 1967. A contribution to the geology of the Mount Tongariro massif, North Island, New Zealand. N.Z. Jour. Geol. Geophys, 10, 1027-1038. 
McBirney, A.R., 1979. Effects of Assimilation. In: H.S. Yoder, ed., The Evolution of the Igneous Rocks: Fiftieth Anniversary Perspectives. Princeton Univ. Press, Princeton, New Jersey. $588 \mathrm{pp}$.

1980. Mixing and unmixing of magmas. Jour. Volc. Geoth. Res., 7, 357-371.

Medar is, L.G., 1969. Partitioning of $\mathrm{Fe}++$ and $\mathrm{Mg}++$ between coexisting synthetic olivine and orthopyroxene. Amer. Jour. Sci., 267, 945-968.

Meijer, A., 1980. Primitive arc volcanism and a boninite series: Examples from western Pacific island arcs. In: D.E. Hoyes, ed, The Tectonic and Geolugic Evolution of Southeest Asian Seas and Islands. Amer. Geophys. Union Monograph 23, p. 271-282.

Mertzman, S.A., 1977. The petrology and geochem istry of the Medicine Lake Volcano, California. Contrib. Mineral. Petrol., 62, 221-247.

Middleton, B.V., and Hempton, M.A., 1976. Subaqueous sediment transportation and deposition by sediment gravity flows. In: D.J. Stanley and Swift, D.J.P., eds., Marine Sediment Iransport and Environmental Management . Wiley \& Sons, New York. p. 197-219.

Miyashiro, A. 1974. Volcanic rock series in islend arcs and active continental margins. Amer Jour. Sci., 274, 321-355.

1974. Metamorphism and Metamorphic Belts. Allen \& Unwin, London.

Modriniak, H., and Studt, F.E., 1959. Geological structure and volcanism of the TaupoTarawer District. N.Z. Jour. Geol. Geophys., 2, 654-684.

Mooney, H.M., 1970. Upper mantle inhomogeneity beneath New Zealand: Seismic evidence. Jour. Geophys. Res., 75, 285-309.

Nairn, IA, and Self, S., 1978. Explosive er uptions and pyroclastic ayalanches from Ngauruhoe in February, 1975. Jour. Yolc. Geoth. Res. , 3, 39-60.

Neall, Y.E., 1976. Lahars- global occurrence and annotated bibliography. Publication 5 of Geology Dept., Victoria Univ. of Wellington.

Nedelec, A, and Poquet, J., 1981. Biotite melting in high-grode metamorphic gneisses from the Heut Allier (French Massif Central). Contrib. Mineral. Petrol., 77, 1-10.

Nicholls, I.A., 1974. Liquids in equilibrium with per idotitic mineral assemblages at high water pressures. Contrib. Mineral. Petral., 45, 289-316.

and Ringwood, A.E., 1973. Effect of water on olivine stability in tholeites and the production of silica-saturated magmas in the island arc environment. Jour. Geology, 81, 285-300.

O'Shea, B.E., 1957. Contributions to the geology of Mt Ruapehu, New Zesland. Unpub. M.Sc. thesis, housed in the Library, Geology Dept., Victoria Uniy. of Wellington. 72 pp.

Park, J., 1886. Narrative of an ascent of Ruapehu. Irans. N.Z. Inst., 19, 327-331.

1887. On the geology of the western part of Wellington Provincial District, and pert of Taranaki. N.Z. Geol. Survey Rep. Geol. Explor., 18, 24-73. 
1926. Trans. N.Z. Inst., 56, 382-383.

Parsons, W.H., 1967. Ruapehu Volcano, New Zealand. Trans. Amer. Geophys. Union, 48, 229 (Abstract).

1969. Criteria for the recognition of volcanic breccies: Review. In: L. Larsen, ed. Igneous and Metamorphic Geology. Geol. Soc. Amer. Memoir 115, p. 263-304.

Peecock, M.A., 1931. Classification of igneous rock ser ies. Jour. Geology, 39, 54-67.

Pearce, J.A., 1984. Role of the sub-continental lithosphere in magma genesis at active continental margins. In: C.J. Hawkesworth and Norry, M.J., eds., Continental Basalts and Mantle Xenoliths. Pub. Shiva Geol. Series, p. 230-249.

Pushkar, P., and Stoeser, D.B., 1975. 87Sr/86Sr ratios in some volcanic rocks and some semifused inclusions of the San Francisco Volcanic Field. Geology, 3, 669-671.

Reid, F.W., 1983. The origin of the rhyolitic rocks of the Taupo Volcanic Zone, New Zealand. Jour. Yolc. Gooth. Res., 15, 315-338.

, and Cole, J.W., 1983. Origin of dacites of Taupo Yolcanic Zone, New Zealand. Jour. Volc. Oeoth. Res., 18, 191-214.

Reyners, M., 1980. A microear thquake study of the plate boundary, North Island, New Zealend. Jour. Roy. Astron. Soc. , 63, 1-22.

Ringwood, A.E., 1974. The petrological evolution of island arc systems. Jour. Geol. Soc. London, $130,183-204$.

1975. Composition and Petrology of the Earth's Mantle. Mocraw-Hill, New York, $618 \mathrm{pp}$.

Roeder, P.L., and Emslie, R.F., 1970. Olivine-liquid equilibrium. Contrib. Mineral. Petrol., $29,275-289$.

Campbell, I.H., and Jamieson, H.E., 1979. A re-evaluation of the olivine- spinel geothermometer. Contrib. Mineral. Petrol., 68, 325-334.

Sakuyam8, M., 1981. Petrological study of the Myoko and Kurohime Volcanoes, Japan: Crystallization sequence and evidence for magma mixing. Jour. Petrology, 22, 553-583.

Sato, H., 1977. Nickel content of basaltic magmas: Identification of primary magmas and a measure of the degree of olivine fractionation. Lithos, 10, 113-120.

Shaw, D.M., 1968. A review of $K-R b$ fractionation trends by covariance analysis. Geochim. Cosmochim. Acta. , 32, 573-601.

Sissons, B.A. 1979. The horizontal kinematics of the North Island of New Zealand. Unpub. Ph.D. thesis, housed in the Library, Victoria Univ. of Wellington.

Sparks, R.S.J., Sigurdsson, H., and Wilson, L., 1977. Megme mixing: A mechanism for triggering acid explosive er uptions. Nature, London, 267, 315-318.

Sparks, R.S.J., and Wright, J.Y., 1979. Welded air-fall tuffs. Geol. Soc. Amer. Spec. Peper 180 , p. $155-166$. 
Speight, R., 1908. In: L. Cackayne, Botanical Survey of the Tongariro National Park. App. Jour. House Rep. N.Z., CII , p. 7-13.

Steiner, A. 1958. Petrogenetic implications of the 1954 Ngauruhoe lava and its xenoliths. N.Z. vour. Geol. Geophys., 1, 325-363.

Stipp, J.J., 1968. The geochronology and petrogenesis of the Cenozoic volcanics of the North Island, New Zealand. Unpub. Ph.D. thesis, Australian National Univ., lodged in A.C.T. Library, Canberra.

Stormer, J.C., 1973. Calcium zoning in olivine and its relation to silica activity and pressure. Geochim. Cosmochim. Acta, 37, 1815-1821.

Studt, F.E., and Thompson, G.E.K., 1969. Geothermal heat flow in the North Island of New Zeeland. N.Z. Jour. Geol. Geophys., 12,673-683.

Sun, S.S., and Nesbit, R.W., 1978. Petrogenesis of Archeeen ultrabasic and basic volcanics: Evidence from rare earth elements. Contrib. Mineral. Petrol., 65, 301-325.

Toksoz, M., Minear, J., and Julian, B., 1971. Temperature field and geophysical effects of a downgoing slab. Jour. Gecphys. Res., 76, 1113-1138.

Topping, W.W., 1973. Tephrostratigraphy and chronlolgy of Late Quaternary eruptions from the Tongar iro Volcenic Centre, New Zeeland. N.2. Jour. Geol. Geophys., 16, 397-423.

1974. Some aspects of Quaternary history of Tongariro Volcanic Centre. Unpub. Ph.D. thesis, housed in the Library, Victoria Univ. of Wellington.

and Kohn, B.P., 1973. Rmyolitic tephra marker beds in the Tongariro area, North Island, New Zealand. N.Z. Jour. Geol. Geophys., 16, 375-395.

Turner, F.J., 1968. Metamorphic Petrology: Mineralogical and Field Aspects. McOraw-Hill, Now York. 403 pp.

Watson, E.B., 1979. Calcium content of forsterite coexisting with silicate liquid in the systern $\mathrm{Ne} 20-\mathrm{Cr} 0-\mathrm{MgO}-\mathrm{Al} 203-\mathrm{Si02}$. Amer. Mineral. , 64, 824-829.

1982. Basalt contamination by continental crust: Some experiments and models. Contrib. Mineral. Petrol., 80, 73-87.

Wentworth, C.K., and Williams, H., 1932. The classification and terminology of the pyroclastic rocks. National Res. Council Bull., 89, 19-53.

Williams, H., 1941. Calderas and their origin. Univ. Calif. Pub. Geol. Sci., 25, 239-346. $391 \mathrm{pp}$.

and McBirney, A.R., 1979. Yolcanology. Freenan, Cooper \& Co., San Francisco.

Wilson, L., 1976. Explosive volcanic eruptions- III. Plinian eruption columns. Geophys. Jour. Roy. Astron. Soc. , 45, 543-556.

Winkler, H.B., 1979. Petrogenesis of Metamorphic Rocks. Springer-Verlag, Now York. $348 \mathrm{pp}$. 
Wood, B.J., and Banno, S., 1973. Garnet-orthopyraxene and or thopyraxene-clinopyroxene relationships in simple and complex systerns. Contrib. Mineral. Petrol. , 42, 109-124.

Wright, J.V., 1980. Stratigraphy and geology of the welded airfall tuffs of Pentelleris, Italy. Geol. Rundsch., 69, 263-291.

Smith, A.L., and Self, S., 1980. A working terminology of pyroclastic deposits. Jour. Volc. Geoth. Res. , 8, 315-336.

Wright, T.L., and Doherty, P.C., 1970. A linear program and least-squares computer method for solving petrologic mixing problems. Geol. Soc. Amer. Bull., 81, 1995-2008. 
APPENDICES $L=V I$ 


\section{INTRODUCTION}

Written stratigraphic descriptions are given for 15 measured sections. constituting about $1.5 \mathrm{~km}$ of Ruapehu stratigraphy. Localities for measurement were selected on the basis of degree of exposure, and relevance to formation definition.

The most common method of measurement. given the remoteness and relief of the terrain, was the "eye height" method, in which the observer sights horizontally and counts the number of eye heights as he moves through the section. In addition, a metre stick was used for measurement of clast sizes and other stratigraphic parameters. Dr. BF. Houghton accompanied the writer into the field many times, and on these occasions we measured with steel tapes. During field measurement, the deposits were sketched at appropriate scales onto graph paper. Thus, the text figures are accurate visual representations of lithology. The reported thicknesses have been corrected for dip angle, so they represent true stratigraphic thicknesses. The steep slopes and terrace-like topography of valley walls often required that the measured sections be moved laterally: this re-locating is noted in the descriptions.

Ruapehu Section 3 is given particularly thorough description because the deposits are lithologically and genetically diverse: other sections are described more briefly because they are lithologically simple or because the deposits have already been discussed adequately in the text.

\section{DESCRIPTIONS}

RUAPEHU SECTION 1. $145 \mathrm{~m}$ of Te Herenga Formation exposed in Whatapapanui Gorge, northwest Ruapehu. Grid references for base of section: T20/313154: N112/059708. Refer to Fig 14. p. 42, for draving. This section represents the lower portion of the proximal facies of Te Herenga Formation.

Basal $3 \mathrm{~m}$ covered; then $2.5 \mathrm{~m}$ lava flow $\mathrm{w}$ rubbly base and top. platy and blocky interior: then $13 \mathrm{~m}$ heterolithologic tuff breccis, buff-grey colour, poorly sorted from sandy matrir to $0.7 \mathrm{~m}$ subrdd porphyritic clasts $\mathrm{w}$ similar petrography to lava flows but having variable degrees of oxidation and hydroth alteration, local 1-3m thick lenses of coarser tuff breccia are nearly monolithologic and appear sim to autobreccia but are not jurtaposed against lava flows; then $1.7 \mathrm{~m}$ lava flow; then $0.3 \mathrm{~m}$ monolithologic tuff breccia w reddened, angular clasts to $0.3 \mathrm{~m}$ and clearly derived by autobrecciation of lava flow above it. Remainder of section contains similar lithologies, but note sandy horizon (SG) at $99.5 \mathrm{~m} .100 .2 \mathrm{~m}$, and $103.5 \mathrm{~m}$ intervals. interpreted as fluvial deposits; and $0.5 \mathrm{~m}$ porphyritic andesite dyke at $101 \mathrm{~m}$ interval.

RUAPEHU SECTION 2. $80 \mathrm{~m}$ of Te Herenga Formation exposed at Te Herenga Ridge, northwest Ruapehu. Grid references for base of section: T20/307156; N112/054713. Refer to Fig 15. p. 43. for drawing. This section represents the upper portion of the proximal facies of Te Herenga Formation; i.e. is stratigraphically above RS-1. Stipp (1968) collected lava from Te Herenga Ridge, which gave a K-Ar age of $0.23 \mathrm{Ma}$.

The entire section comprises lava flows and monolithologic tuff breccias that originated by autobrecciation of the lava flows. The tuff breccias are red, poorly sorted coarse rubble, comprising angular oxidised clasts derived from the over- and underlying lava flows; ash-grade material is rare and most clasts are of $\mathrm{cm}-\mathrm{dm}$ size. 
RUAPEHU SECTION $3.223 .5 \mathrm{~m}$ of Wahiano Formation exposed in Whangaehu Gorge, southeast Ruapehu. Grid references for base of section: T20/347094: N112/098646. Refer to Fig 27, p. 63. for draving. This section is representative of the proximal facies of Wahianoa Formation.

3m oxidised, monolithologic tuff breccia; then $4 \mathrm{~m}$ lava flow; then $2 \mathrm{~m}$ oxidised monolithologic tuff breccia; then $8 \mathrm{~m}$ dart grey finely porphyritic lava flow w rubbly base and top; then $2.5 \mathrm{~m}$ turr breccis w subang black andesite clasts supported by pale yellow-brown ash-lapilli matrix; then $0.2 \mathrm{~m}$ dk grey \& red lapilli in pale yell-brn $\mathrm{mlx}$. draped over lava blocks of underlying tuff breccia, trough cross bedding in thicker portions; then $0.1 \mathrm{~m}$ shower bdd ash \& lapilli; then $0.25 \mathrm{~m}$ dk grey pumice lapilli in weathered yell-brn crs to med ash $\mathrm{mtx}$; then $2.5 \mathrm{~m}$ block $\&$ ash unit. non-stratified, w large $5-90 \mathrm{~cm}$ ang clasts of dense black andesite and lesser red oxidised andesite, in a poorly indurated sandy red-brn mix. largest clasts at top of unit: then $1.9 \mathrm{~m}$ reversely graded tuff breccia $w$ sharp planar cntcts at base and top. upper $50 \mathrm{~cm}$ is planar bdd, as def by laminations in mux, aligned clasts in upper $1 \mathrm{~m}$ define crude bedding: then $2 \mathrm{~m}$ mtx-supp tuff brecc, rev graded, basal $1 \mathrm{~m}$ weakly stratified as def by aligned clasts. $1 \mathrm{~g}$ clasts are black breadcrusted blocks, red oridised subang blocks and weathered yellow pumice, some andesite blocks have yellow weath rinds, brown sandy $\mathrm{mtx}$; then $1.5 \mathrm{~m}$ bomb- and lapilli-bearing ash, deep brown. mtx-rich, ashy deposit, bombs to $40 \mathrm{~cm}$ are mod vesic, breadcrusted and slaggy. contains thin chocolate brn secondary clay veins; then $2 \mathrm{~m}$ agglomerate $w$ rdd black mod vesic clasts to $1.2 \mathrm{~m}$ in a black-dk grey ash/lapilli $\mathrm{mtx}$, unwelded, discrete pods of banded white \& yell-brn clay occupy some interstices of mtx, these clays are not baked nor is the dep oxidised, lower $1 \mathrm{~m}$ is coarser than upper; then $6 \mathrm{~m}$ lava flow $\mathrm{w}$ slaggy base; then $4 \mathrm{~m}$ covered: then $1 \mathrm{~m}$ unwdd monolithologic tuff breccia (autobreccia): then $8.3 \mathrm{~m}$ lava flow; then $8 \mathrm{~m}$ welded monolithologic tuff breccis $w$ subvertical slabs of slaggy material, clasts have slaggy margins, top is grey, becoming incr red toward base. clasts are petrogr sim to underlying lava flow; then $7.2 \mathrm{~m}$ heterolithologic turf breccia, clasts up to $1.5 \mathrm{~m}$ are internally shattered and breadcrusted, $w$ mod vesic cores and $2 \mathrm{~cm}$ dense glassy rinds, other clasts are dense subrdd/subang blocks, contains veathered andes pum lapilli to $2 \mathrm{~cm}$. $m$ tx in upr $4 \mathrm{~m}$ is pale yel-brn ash w subordinate lapilli, $\mathrm{mtx}$ in $1 \mathrm{wr} 1.7 \mathrm{~m}$ is $\mathrm{dk}$ red-brn $w$ continuous laminated bands nr top; then $0.5 \mathrm{~m}$ finely porphyritic, thin, highly vesic, discontin lava flow. grading laterally into blocks and manuing the underlying tuff breccia: then $3.5 \mathrm{~m}$ unwelded monolithologic turf brecc $v 80 \%$ dense to mod vesic subang/subrdd clasts to $0.5 \mathrm{~m}$ but avg $20 \mathrm{~cm}$. set in a brick-red mtr of med ash and lapilli; then $1.5 \mathrm{~m}$ lava flow w irreg rubbly cntcts; then $1 \mathrm{~m}$ weakly to nonwelded monolithol tuff brecc w oxidised ang clasts to $35 \mathrm{~cm}$ but avg $10 \mathrm{~cm}$. set in red $\mathrm{mtx}$ of ash/lapilli; then section moves $100 \mathrm{~m}$ laterally to vest; then $4 \mathrm{~m}$ microvesic, porphyritic dk grey lava flow; then $7 \mathrm{~m}$ oxidised monolithologic tuff brecc. grading downward from mod wdd to unwdd at base; then $69 \mathrm{~m}$ intercalated slaggy lava flows and wdd to unwdd monolithologic tuff breccs, local m-thick lenses of agglutinate w subrdd bombs to $30 \mathrm{~cm}$ may be airfall material; then $14 \mathrm{~m}$ covered interval, section moves $20 \mathrm{~m}$ east: then $15.6 \mathrm{~m}$ heterolithologic, mtx-supp tuff brecc (Type C TBh) w several internal cntcts separating depositional units, breadcrusted internally shattered bombs/blocks of black mod vesic lava range $3 \mathrm{~m}$ to $20 \mathrm{~cm}$, second clast type is dense grey andesite as subrdd blocks to dm-size, less common weathered andes pum lapilli, mtr is pale yel-brn lithic-crystal tuff: then $2.6 \mathrm{~m}$ med grey porphyritic lava flow: then $10.5 \mathrm{~m}$ crs monolithologic turf brecc comprising red slaggy semi-plastic lava blocks to several $m$, in fmwl support, $w$ little mix of red lithic lapilli tuff; then $3.8 \mathrm{~m} \mathrm{mtx}$-supp heterolithologic turf brecc, sim to other Type C TBh described above: then $13.6 \mathrm{~m}$ of intercalated lava flows and densely to weakly wdd monolithologic turf breccias (of autoclastic origin). 
RUAPEHU SECTION $4.13 .5 \mathrm{~m}$ of Wahianoa Formation exposed in the Whangaehu Gorge, southeast Ruapehu. Grid references for base of section: T20/353092; N122/105643. See Fig 28, p. 63. for drawing. The main purpose of this section is to show lithology of heterolithologic turf breccias that form the planeze surface between the Wahianos and $\mathbf{V}$ hangaehu valleys.

Basal $0.5 \mathrm{~m}$ is monolithologic tuff brecc assoc w overlying lava flow; then then $4.5 \mathrm{~m}$ massive lava flow w arcuate vertical jnt planes \& subhoriz anastomosing platey jnts. $30 \mathrm{~m}$ to east scoriaceous material bends up around lava flow, isolating it as a discrete pod; then $0.5 \mathrm{~m}$ agglutinated turf brecc that grades downward into massive lava flow and has sharp upper cntct: then $2.5 \mathrm{~m}$ poorly exposed tuff brecc w blocks to $2 \mathrm{~m}$; then $3 \mathrm{~m}$ mtx-supp heterolithologic turf brecc $w$ subang dense to pum blocks to $60 \mathrm{~cm}$ and few subrdd bombs, crude subhoriz stratification shown by blocky horizons, mu is pale brn predom crs ash to lapilli $\mathbf{w} \mathbf{d k}$ grey-brn pumiceous andesite lapilli: then sharp cntct to $90 \mathrm{~cm} \mathrm{mtr}$-rich, rev-graded nearly monolithologic tuff brecc, basal $10 \mathrm{~cm}$ is $\mathrm{mtx}$-poor lapillistone, grading upward to fmwt-supp heterolith turf brecc $w$ clasts to $10 \mathrm{~cm}$; then $10 \mathrm{~cm}$ dk brn-grey sand $w 5 \mathrm{~mm}$ thick mud band at top; then $20 \mathrm{~cm}$ well sorted lapilli tuff $w$ weath brn \& grey andes pum up to $4 \mathrm{~mm}$, weak shower bedding: then $20 \mathrm{~cm}$ band of heterolith tuff brecc: then $5 \mathrm{~mm}$ laminated band of poorly sorted ash-lapilli; then $1.2 \mathrm{~m}$ massive heterolith tuff brecc w subrdd/subang clasts of dk grey mod to weakly vesic andesite up to $75 \mathrm{~cm}$, some clasts w breadcrust texture, mtx is pale brn, poorly sorted crs ash/lapilli, v weak rev grading.

RUAPEHU SECTION 5. $64.4 \mathrm{~m}$ of Wahianos Formation exposed in Whangaehu Gorge. eastern Ruapehu. Grid references for base of section: T20/365093: N122/128640. See Fig 29. p. 65. for drawing. This section illustrates the close association between lava flows and welded to unwelded autoclastic breccias.

The entire section comprises porphyritic andesite lavs flows and associated monolithologic tuff breccias. The tuff breccias range from unwelded to densely welded, and intercalated lenses of turf breccia within the flows demonstrate that the tuff breccias are of autoclastic origin. However, some of the tuff breccias have the appearance of coarse. stratified, agglutinated airfall and may represent plastic bomb beds that were rafted on top of flowing lava.

RUAPEHU SECTION 6. $192 \mathrm{~m}$ of Wahianoa Formation exposed in Wahianoa Valley. southeast Ruapehu. Grid references for base of section: T20/339073: N122/090621. See Fig 32, p. 68, for draving of section. This section contains similar lithologies to RS-3, and is therefore not described in detail. Like RS-3. it represents deposits of the proximal facies of Wahianoa Fm, but RS-6 is about 1-2 $\mathrm{km}$ farther from the inferred Wahianos $\mathrm{Fm}$ vent area. The main lithologic differences, relative to RS-3, are a slightly higher proportion of sand \& gravel (SG) deposits, and absence of "Type C' heterolithologic tuff breccias in RS-6.

RUAPEHU SECTION 7. $26 \mathrm{~m}$ of Wahianoa Formation exposed at Girdlestone Peak. Grid references for base of section: T20/311086; N122/060636. See Fig 31, p. 67, for drawing. The entire section comprises thin lava flows and associated monolithologic tuff breccias (autobreccias), and exemplifies near-vent proximal facies deposits of the Wahianoa Formation.

RUAPEHU SECTION $8.37 .5 \mathrm{~m}$ of Wahianoa Formation exposed in an unnamed stream valley of north Ruapehu. Grid references for base of section: T20/342155: $\mathrm{N} 112 / 090712$. This section is about $5-6 \mathrm{~km}$ from the inferred Wahianos Fm vent region, and comprises largely 'laharic' deposits of the distant proximal facies.

Base of section begins at stream course; basal $2.7 \mathrm{~m}$ comprises rev-graded heterolith 
tuff brecc, $2-20 \mathrm{~cm}$ andesite clasts are subrdd/subang and have var deg of orid \& vesicularity, clasts are supported in indurated, red-brn poorly sorted sandy mtx. grades upward into overlying clast-supp unit: then $0.6 \mathrm{~m}$ clast-supp heterolith tuff brecc $w$ mod to highly vesic ang blocks of $\mathrm{dk}$ grey andesite to $20 \mathrm{~cm}$ size: then $0.3 \mathrm{~m}$ of fining-upward ash \& lapilli crystal-vitric tuff; then $13 \mathrm{~m}$ heterolithologic tuff brecc wiverse clasts ranging $20 \mathrm{~cm}$ to $1 \mathrm{~cm}$ floating in red-brn indurated $\mathrm{mtx}$ of crs to med ash, lenticular horizons of coarse (blocks to $80 \mathrm{~cm}$ ) clast-supp tuff brecc are present, partings suggest numerous $2-5 \mathrm{~m}$ thict depositional units; then sharp undulating cntct to $0.4 \mathrm{~m}$ thick sand \& gravel deposit $\mathrm{w}$ low-angle cross bedding and pinches out over $30 \mathrm{~m}$ lateral distance; then sharp cntct to $7 \mathrm{~m}$ thick, unstrat, poorly sorted heterolithol tuff brecc $w$ abrupt planar top and sim appear to lower tuff breccs; then $3.4 \mathrm{~m}$ thick heterolithol turf brecc $\mathrm{w}$ Ig ang clasts to $1 \mathrm{~m}$. locally. Iargest clasts are nearly self-supporting and overall the deposit is nearly clast-supp, red-brn sand-gravel mix has local horizons of low angle cross bedding that pinch out over lateral dist of $1-2 \mathrm{~m}$; then sharp cntct to $0.2 \mathrm{~m}$ unit of planar bdd med sand that pinches out laterally; then $1.7 \mathrm{~m}$ of heterolithol tuff brecc sim to basal unit: then undulating cntct to red poorly sorted (mm-3cm size clasts) lapilli tuff w "wavy" internal stratification; then $7.5 \mathrm{~m}$ heterolithol nearly clast-supp tuff brecc, $1 \mathrm{~g}$ ang clasts (to $1.5 \mathrm{~m})$ are predom dense lave but some $(1060 \mathrm{~cm}$ size) are internally shattered and breadcrusted.

RUAPEHU SECTION 9. $76 \mathrm{~m}$ of Mangawhero Formation exposed at Girdlestone Peak. southeastern summit region of Ruapehu. Grid references for base of section: T20/313087; N122/062636. See Fig 50, p. 85, for drawing. The entire section comprises lava flows and intercalated coarse, monolithologic. clast-supported tuff breccias (autoclastic breccias), and needs little additional description. In the 26-41 $\mathrm{m}$ interval. some tuff breccias are weatly heterolithologic, suggesting minor reworking and mixing during slope failure.

RUAPEHU SECTION 10. $42.5 \mathrm{~m}$ of Mangawhero Formation exposed beneath Tahurangi, southern summit region of Ruapehu. Grid references for base of section: T20/309098: N122/057647. See Fig 51, p. 86, for drawing.

Base of section determined by limit of deep snow and crevasses; basal $5 \mathrm{~m}$ is porphyritic andesite lava flow w feldspathic hornfels zenos to $1 \mathrm{~cm}$ : then $1.5 \mathrm{~m}$ rubbly. fmwr-supp monolithol tuff brecc $w$ ang clasts $t 08 \mathrm{~cm}$ and set in a sparse mix of red crs ash \& ang lapilli rock frags: then $8 \mathrm{~m}$ podiform (valley-confined) porphyritic lava flow w irreg top sfc; then $0.5 \mathrm{~m}$ sand \& gravel $w$ prominent cross bedding fills valleys in lava flow top; then $1.5 \mathrm{~m}$ lapilli tuff w well sorted shower \& mantle bedded ash/fine lapilli layers, reworked top w channel fillings of sand \& gravel; then $9 \mathrm{~m}$ crs, red, fmwk-supp monolithol turf brecc. ang clasts to $1.7 \mathrm{~m}$ comprise oxidised microvesicular porphyritic andesite; then $15 \mathrm{~m}$ porphyritic andesite lava flow w platey jnting and tension gashes $\mathrm{nr}$ base and sharp upr cntct; then $1.5 \mathrm{~m}$ welded, fmwk-supp monolithol tuff brecc; then $0.2 \mathrm{~m}$ alternating planar bdd layers of crs grit \& fine mud $w$ bomb sags $n r$ base (airfall from hydroth explosion?): then $40 \mathrm{~cm}$ mod/well sorted lapilli turfs/turfs, interbedded $v$ lensoid cross bedded fine tuffs and varve-like mud laminae: then $0.5 \mathrm{~m}$ bedded lapilli tuff, clasts to $3 \mathrm{~cm}$ define crude bedding, crs, ang clasts at bottom of unit.

RUAPEHU SECTION 11. $117 \mathrm{~m}$ of Mangawhero Formation exposed in Mangaturuturu River Valley of southwest Ruapehu. Grid references for base of section: S20/279103: N122/024652. See Fig 52, p. 87. for drawing. Nearly all of the section consists of leva flows and associated monolithologic turf breccias (autobreccias), and this lithologic association is typical of the western slopes of Ruapehu. which are largely covered by lava flows of Mangawhero $\mathrm{Fm}$. The chaotic association of thin andesite lava flows and atoclastic breccias is particularly well displayed in the basal $13 \mathrm{~m}$ of the section. Local pods of heterolithologic turf breccia and sand \& gravel are probahly valley- 
confined mudflow and fluvial deposits.

RUAPEHU SECTION 12. $73 \mathrm{~m}$ of Te Herenga and Mangawhero Formations exposed in Whakapapaiti Valley, west Ruapehu. Grid references for base of section: S20/283151: N112/026700. See Fig 16, p. 44, for drawing.

The basal $23 \mathrm{~m}$ comprises numerous deposits of heterolithologic turf breccia, with each unit unsorted and unstratified, and separated by parting planes from lithologically similar surrounding units. The subrounded clasts are nearly monolithologic, comprising dense porphyritic andesite which is petrographically identical to Te Herenga Fm lava flows. Then at the $23 \mathrm{~m}$ interval, heterolithologic tuff breccia grades upward into oxidised, framework-supported monolithologic tuff breccia (autoclastic breccia) that is clearly associated with the overlying porphyritic lava flow. The top of the Te Herenga Fm lava flow (at $38 \mathrm{~m}$ interval) has a glaciallyeroded, planar top, and this marks the unconformity between Te Herenga Fm and the overlying deposits of Mangawhero Fm. The 38-43 $\mathrm{m}$ interval comprises matrixsupported heterolithologic tuff breccia whose clasts are petrographically different and more diverse than clasts of heterolithologic tuff breccias at the base of the section. The remaining $30 \mathrm{~m}$ of section comprise black and dark grey, internally shattered porphyritic andesite lava flows of Mangawhero Fm. with distinctive petrography from older lavas of the Te Herenga $\mathrm{Fm}$.

RUAPEHU SECTION 13. $117 \mathrm{~m}$ of Mangawhero Formation exposed in an unnamed stream valley of northeast Ruapehu. Grid references for base of section: T20/351135: N122/101690. See Fig 53. p. 88, for drawing. The entire section comprises lava flows and associated monolithologic turf breccias, and needs no additional description.

RUAPEHU SECTION 14. $12.5 \mathrm{~m}$ of Rangataua Momber (Whakapapa Formation) exposed in a stream valley to the east of the vent region, south Ruapehu. Grid references for base of section: T20/306065: N122/055612. See Fig 63, p. 100, for photograph and drawing.

The basal $3 \mathrm{~m}$ comprise welded, poorly sorted, unstratified, monolithologic tuff breccia $w$ ang blocks and mod vesic bombs up to $15 \mathrm{~cm}$, supp in an oxidised microvesicular mtx; then 1.5m of shower-bedded lapilli tuffs w scoriaceous bombs up to $10 \mathrm{~cm}$; then densely to mod wdd agglutinate w bombs up to $20 \mathrm{~cm}$ and well devel internal strat and good sorting: then $1 \mathrm{~m}$ red monolithologic turf brecc w angular clasts identical to overlying lava flow: then $3.8 \mathrm{~m}$ porphyritic andesite lava flow $w$ basal platy jnts, fractured interior and rubbly but locally eroded top.

RUAPEHU SECTIONS 15a,b.c. Welded airfall tuff of Pinnacle Ridge Member (Whatapapa Formation) exposed at Pinnacle Ridge, northwest Ruapehu. See Figs 68-73. p. 105-107, and accompanying text discussion, for lithologic description. 


\section{APPENDIX II: BULK ROCK CHEMICAL ANALYSES}

\section{INTRODUCTION}

Chemical analyses of major and trace elements for 184 bulk rocks are given. Strontium isotopic ratios are also given for selected samples. Three categories of rocks have been analyzed: (1) unaltered lava flows and fragmental deposits, (2) hydrothermally altered and/or weathered rocks, and (3) igneous and metamorphic rock inclusions. Unaltered lava flows and fragmental deposits are further subdivided according to formations, using stratigraphic terminology defined in Part I. Within each category or formation, analyses are listed in order of increasing silica content.

Bulk rock analyses are designated as follows:

ANALYSIS \#

SAMPLE

LOI

TOTAL

$\mathrm{FeO}(\mathrm{t})$

$"{ }^{\prime}$

"n.d.

VUW number
These numbers are referred to in the text, when presenting point counts, photomicrographs, chemical data, etc., for bulk rocks.

Refers to field number written on the sample when it was collected.

Total volatiles expressed as loss on ignition, after firing at $1,000^{\circ} \mathrm{C}$ for $1-2$ hours.

Sum of major oxides and loss on ignition.

Total $\mathrm{FeO}+\mathrm{Fe} 203$ expressed as $\mathrm{FeO}$.

Not analyzed.

Analyzed, but not detected.

These numbers are reported with the grid references and descriptive notes of section 4 , this Appendix. They are for mal sample numbers of the Petrology Collection, housed in the Geology Department, Victoria University of Wellington. 


\section{SAMPLE COLLECT'ION AND PREPARA'TION}

Specimens averaging 1 kilogram were collected in the field, and care was taken to obtain fresh, unoxidized material, except when hydrothermally altered rocks were specifically sought. Approximately one half of each specimen (400-500 g) was then broken into $1 \mathrm{~cm}$ cubes, using a hydraulic splitter. The cube surfaces were then examined for metamorphic or igneous rock inclusions in an effort to minimize the effect of foreign materials on bulk rock chemistry. Xenoliths (generally $0.5-3 \mathrm{~cm}$ size, but occasionally reaching decimetres) were separated from host rocks, using a cold chisel or diamond saw. Host rock adhering to xenoliths was removed by grinding on a cast iron lap, prior to analysis of the renoliths. The rock cubes or yenoliths were then placed in a TEMA swing mill with tungsten carbide grinding discs, and ground to 200 mesh powder. Care was taken to avoid excessive heating (and oxidation) of the samples during grinding. Bulk rock powders (ca. $300 \mathrm{~g}$ ) were then stored in polythene bags.

\section{ANALYTICAL METHODS}

\subsection{X-ray Fluorescence Analysis of Bulk Rocks.}

XRF analyses were made during 1979-1982, using a Siemens SRS-1 spectrometer housed in the Analytical Facility, Victoria University. Major element analysis was performed on glass fusion discs, by the method of Norrish and Hutton (1969). Addition of ammonium nitrate to the fusion mixture, rather than sodium nitrate, allowed $\mathrm{Na}_{2} \mathrm{O}$ determination. Correction for background was made by analysis of a series of oxide $+\mathrm{SiO}_{2}$ fusion discs. Trace element analyses were made on $4 \mathrm{~cm}$ diameter, boric 
acid- backed, pressed powder pellets containing $3.5 \mathrm{~g}$ of sample. All samples were analyzed in duplicate. Seven unknowns were analyzed at one time, together with an appropriate international rock standard and an $\mathrm{SiO}_{2}$ background disc. Details of analytical methods, and discussion of accuracy and precision are found in Roser (1983). Kennedy, et al. (1981) give results for eight U.S.G.S. rock standards that were analyzed at the same time and under the same instrumental conditions as this writer's samples.

\subsection{Determination of Ferrous Iron and Loss on Ignition}

$\mathrm{FeO}$ in bulk rocks was determined using the titrimetric dichromate method of Sarver (1927), as described in Shapiro and Brannock (1962). Loss on ignition (LOI) was determined by firing $1-2$ g of sample for 1-2 hours at $1,000^{\circ} \mathrm{C}$ and determining weight loss. Weight losses were corrected for $\mathrm{Fe} 0$ oxidation during firing.

\subsection{Strontium Isotopic Ratios}

Ratios of strontium 87 to strontium 86 for selected bulk rocks and xenoliths were obtained by Mr. Ian Graham at the Institute of Nuclear Sciences, Lower Hutt. Bulk rock powders were dissolved using a mixture of hydrofluoric, nitric, and perchloric acids, leaving chloride residues which were centrifuged to remove insoluble material and flushed through calibrated ion exchange resin columns with $2.5 \mathrm{~N} \mathrm{HCl}$ to separate elemental strontium from other cations, particularly rubidium. This yielded a pure fraction of $\mathrm{SrCl} 2$ for isotopic analysis, using the single-filament method of ionization. 


\section{PETROGRAPHIC AND LOCALITY DESCRIPTIONS}

Descriptive information for all analyzed bulk rocks is given below. Grid references are based on the New Zealand national thousand-yard grid of the 1:63,360 scale NZMS 1 topographic map series. Metric grids are also given from the 1:25,000 scale NZMS 270 topographic map series. Sheets T20 and S20 of NZMS 270 were used as a topographic base for the 1:25,000 geologic map that is inside the back cover of this dissertation.

\section{REFERENCES}

Kennedy, P.C., Palmer,K. and Roser,B.P. 1981. Chemical analyses of the eight U.S.G.S. rock standards: BHV0-1, MAG-1, QLO-1, RGM-1, SCo-1, SDC-1, SGR-1, STM-1. Publication of the Geology Department, Victoria University of Wellington, $16 \mathrm{pp}$.

Norrish,K. and Hutton,J.T. 1969. An accurate $X$-ray spectrographic method for the analysis of a wide range of geological samples. Geochimica et Cosmochimica Acta, 33, 431.

Roser, B.P. 1983. Comparative Studies of Copper and Manganese Mineralisation in the Torlesse, Waipapa and Haast Schist Terranes, New Zealand. Unpuplished Ph.D. dissertation, housed in library of Victoria University, Wellington, New Zealand, $491 \mathrm{pp}$.

Sarver, L.A. 1927. The determination of ferrous iron in silicates. American Chemical Society Journal, $\underline{49}$, 1472-1477.

Shapiro, L. and Brannock, W.W. 1962. Rapid analysis of silicate, carbonate and phosphate rocks. United States Geological Survey Bulletin 1144-A, 56 pp. 


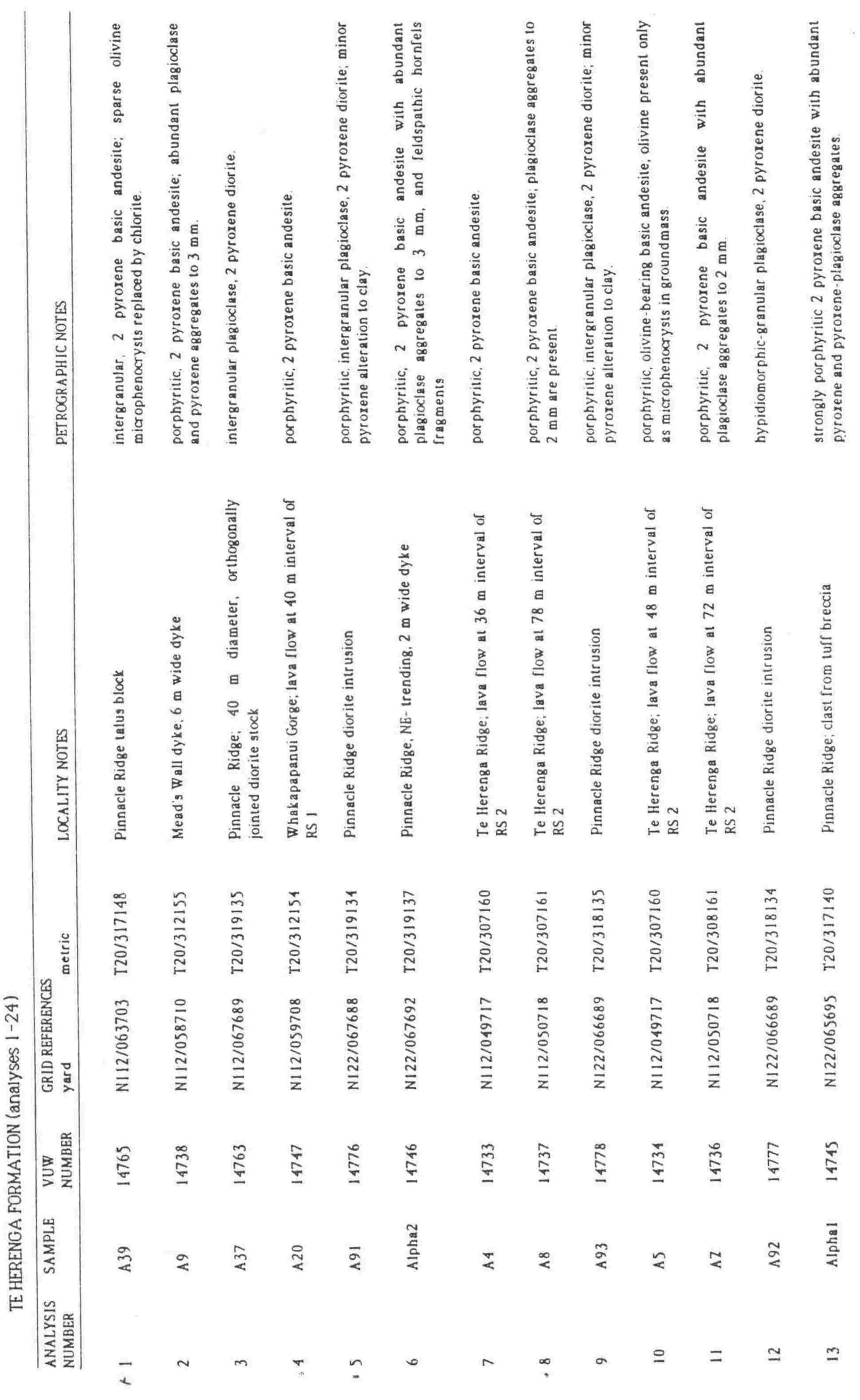




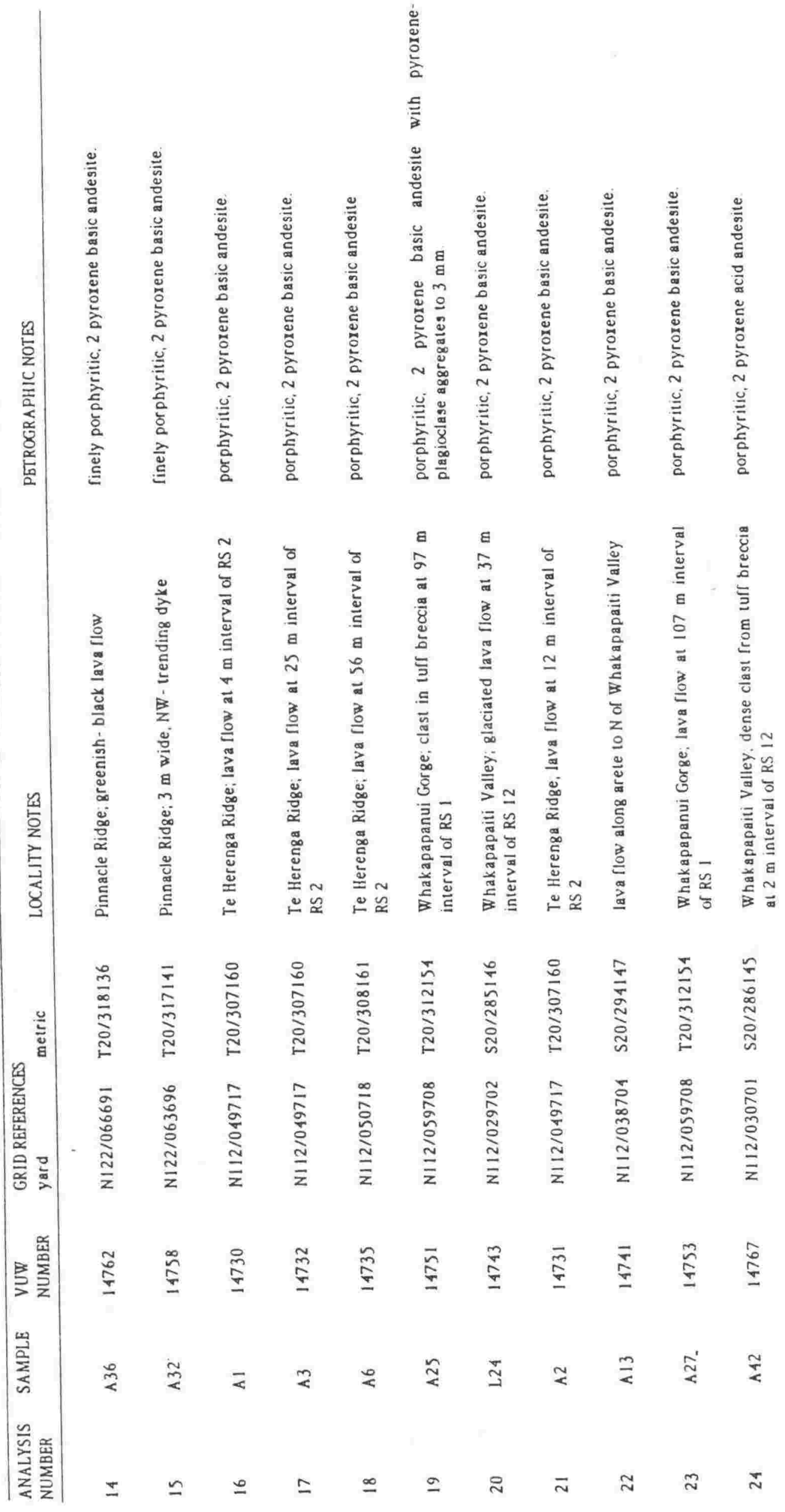




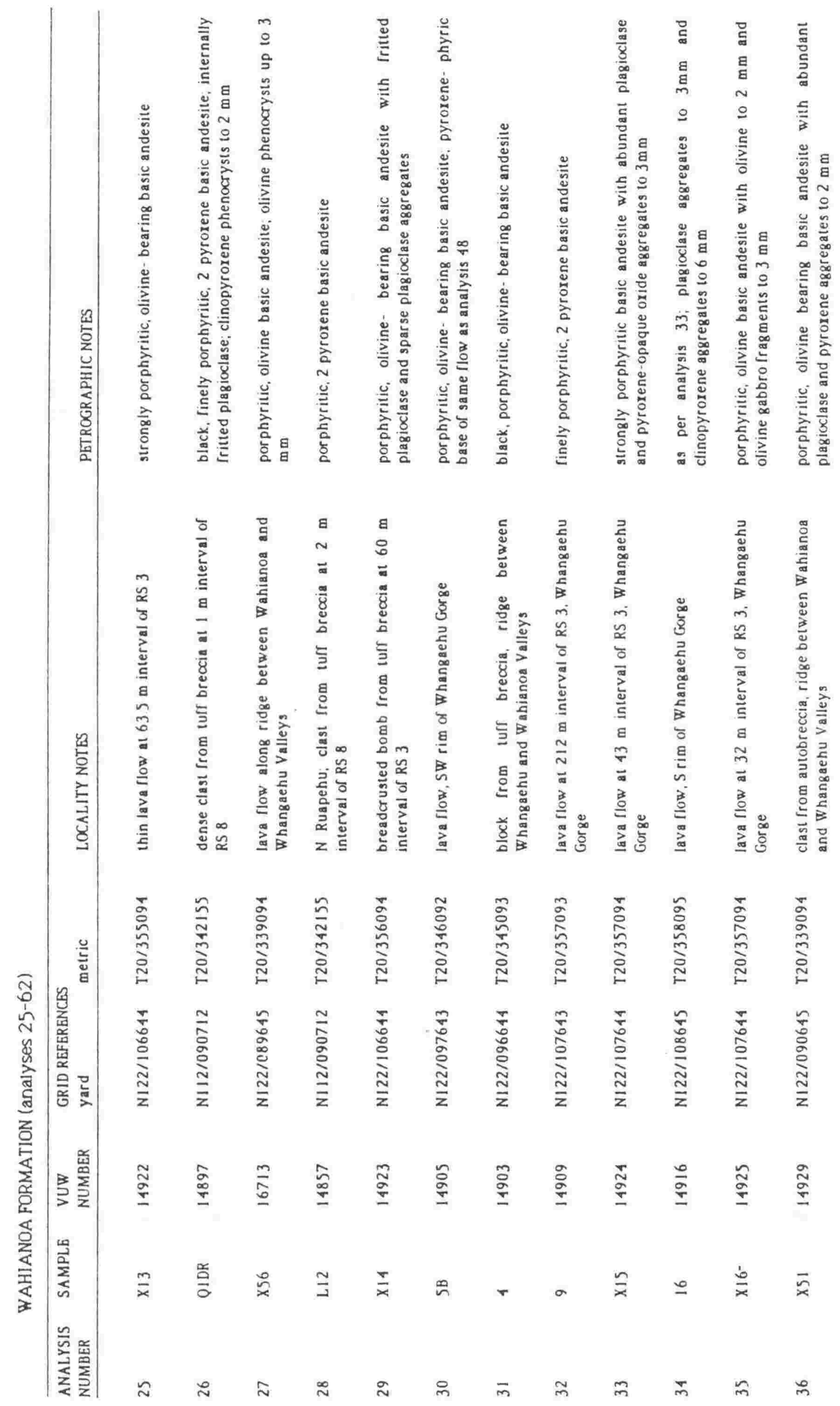




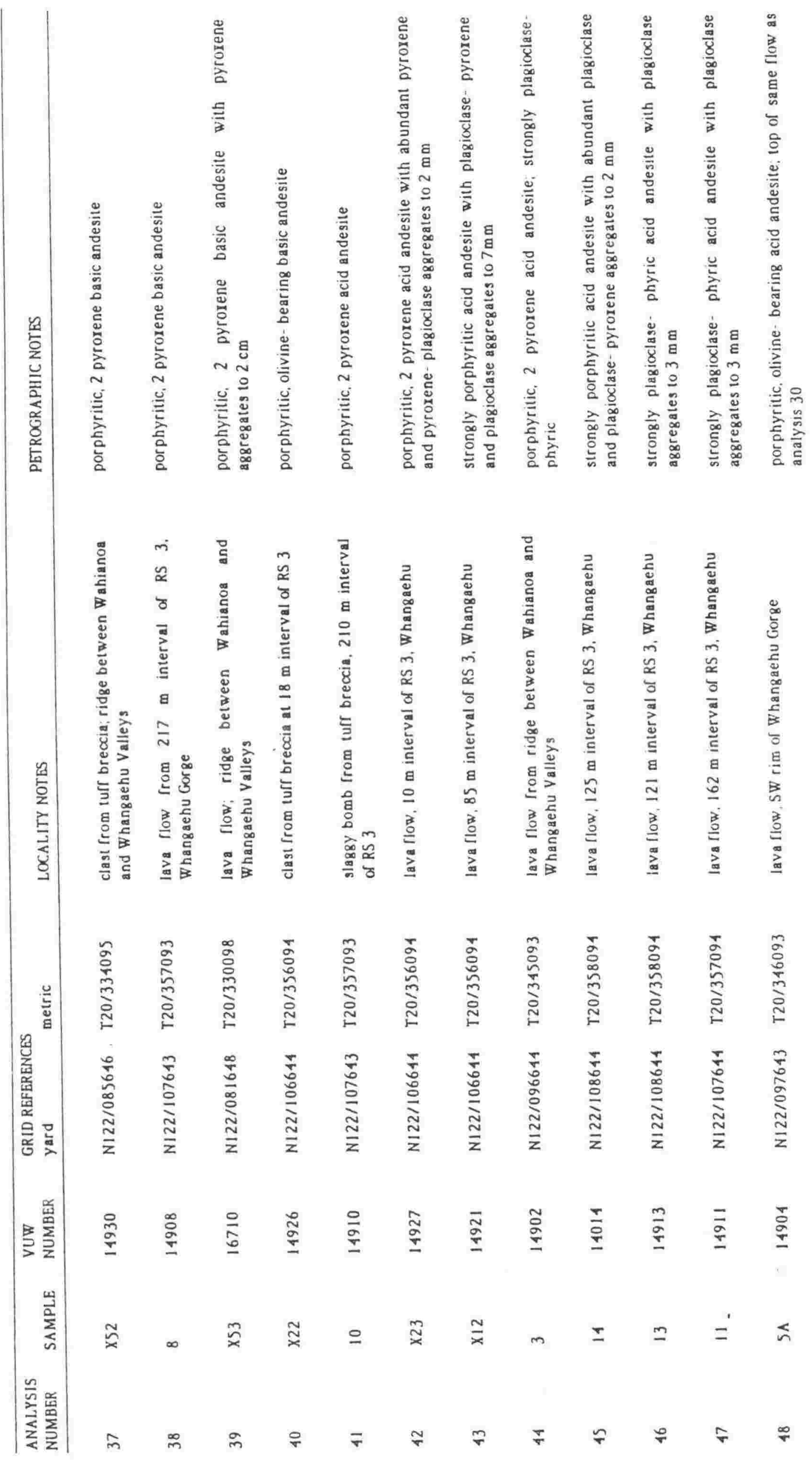




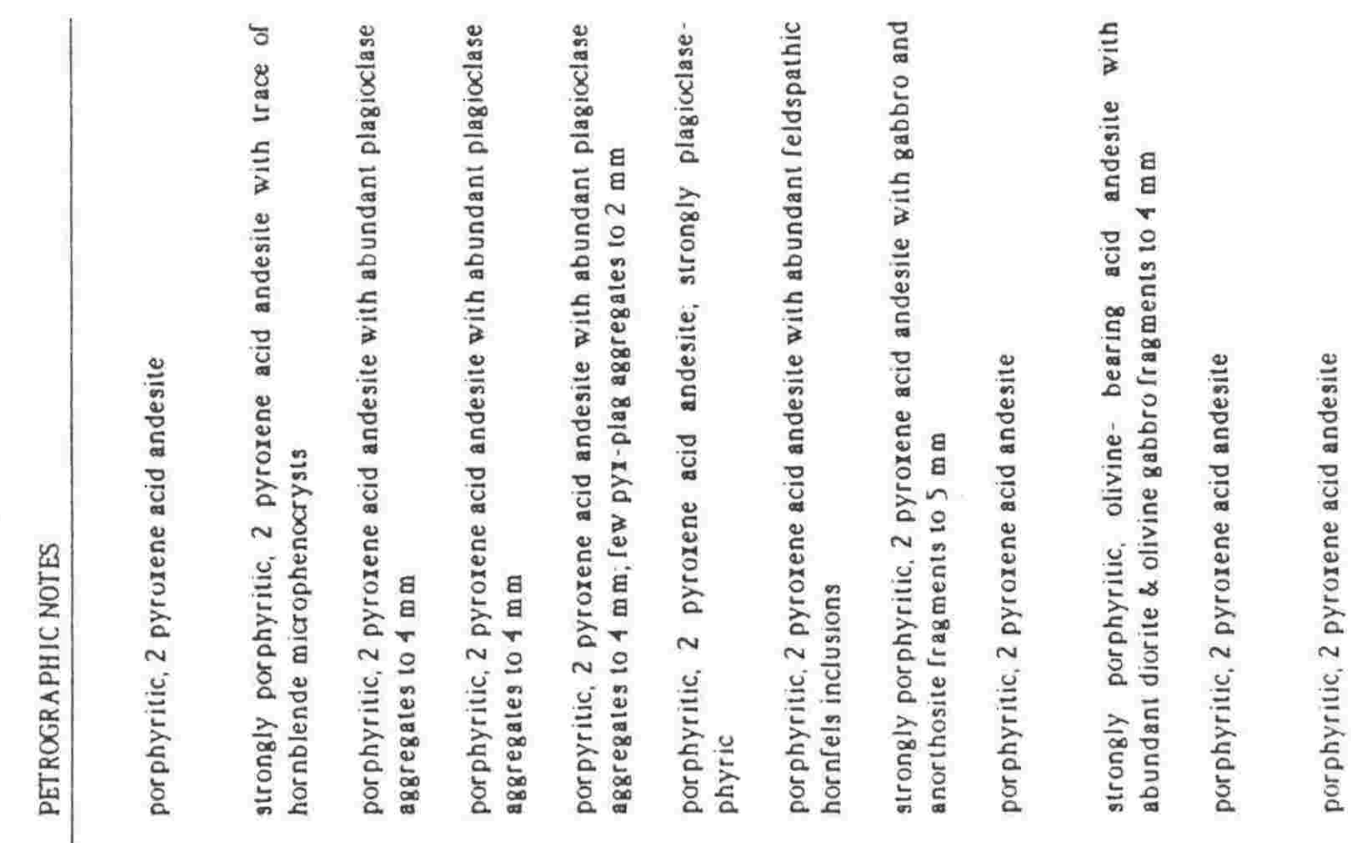

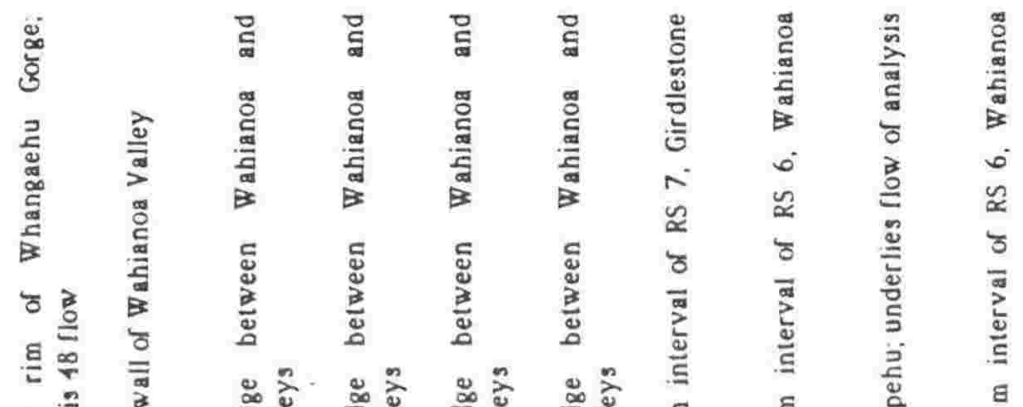

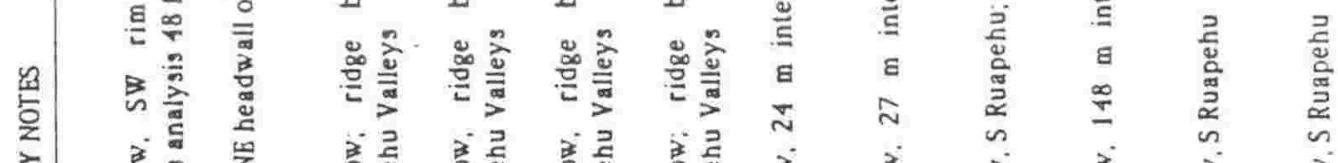

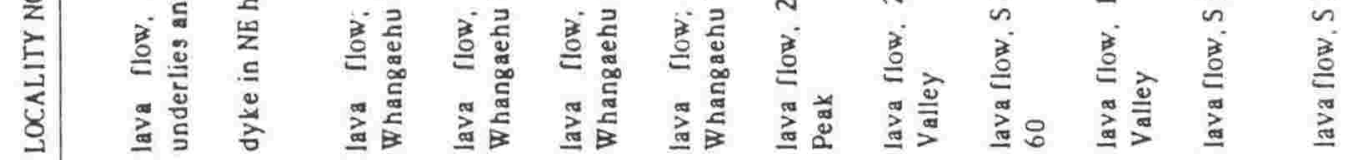

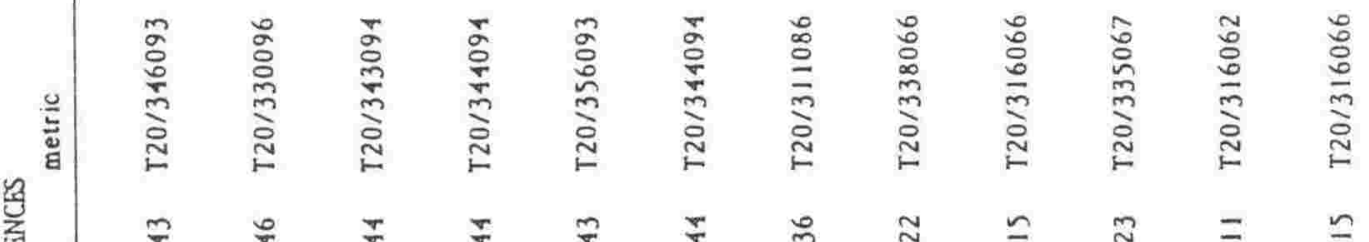

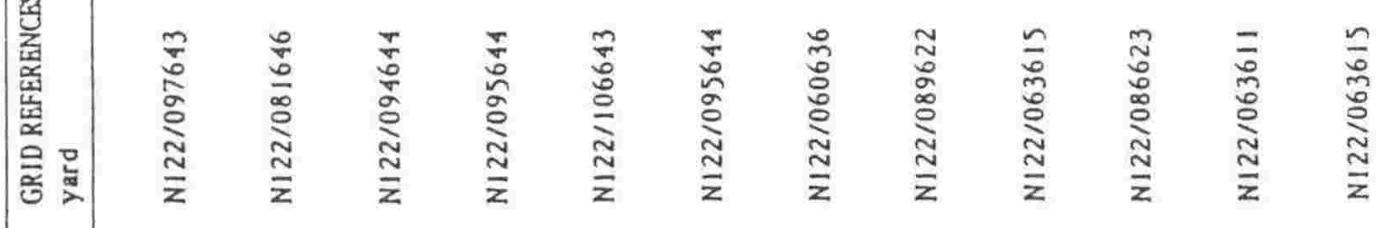

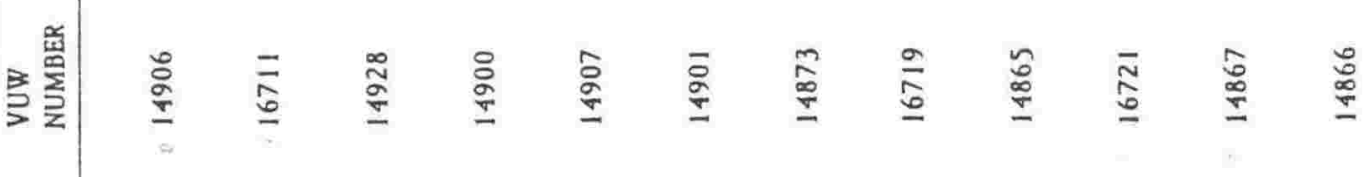

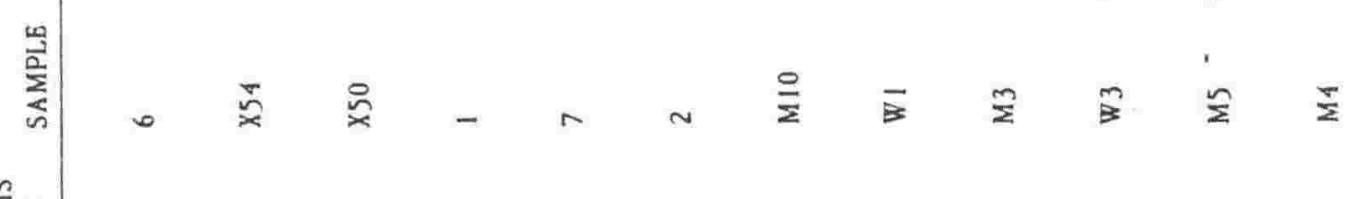

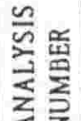




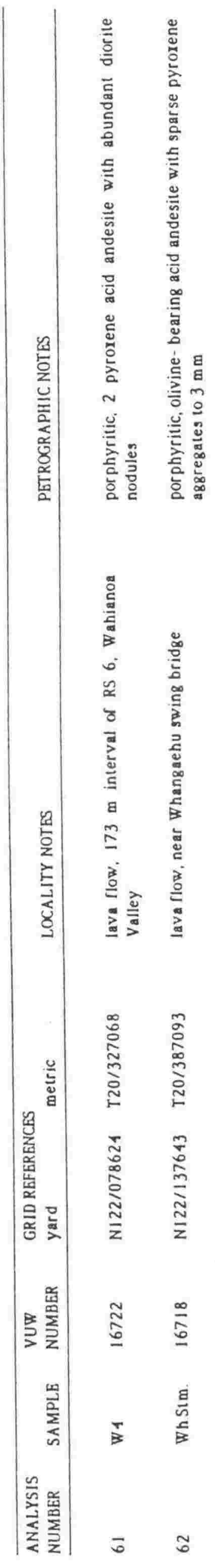




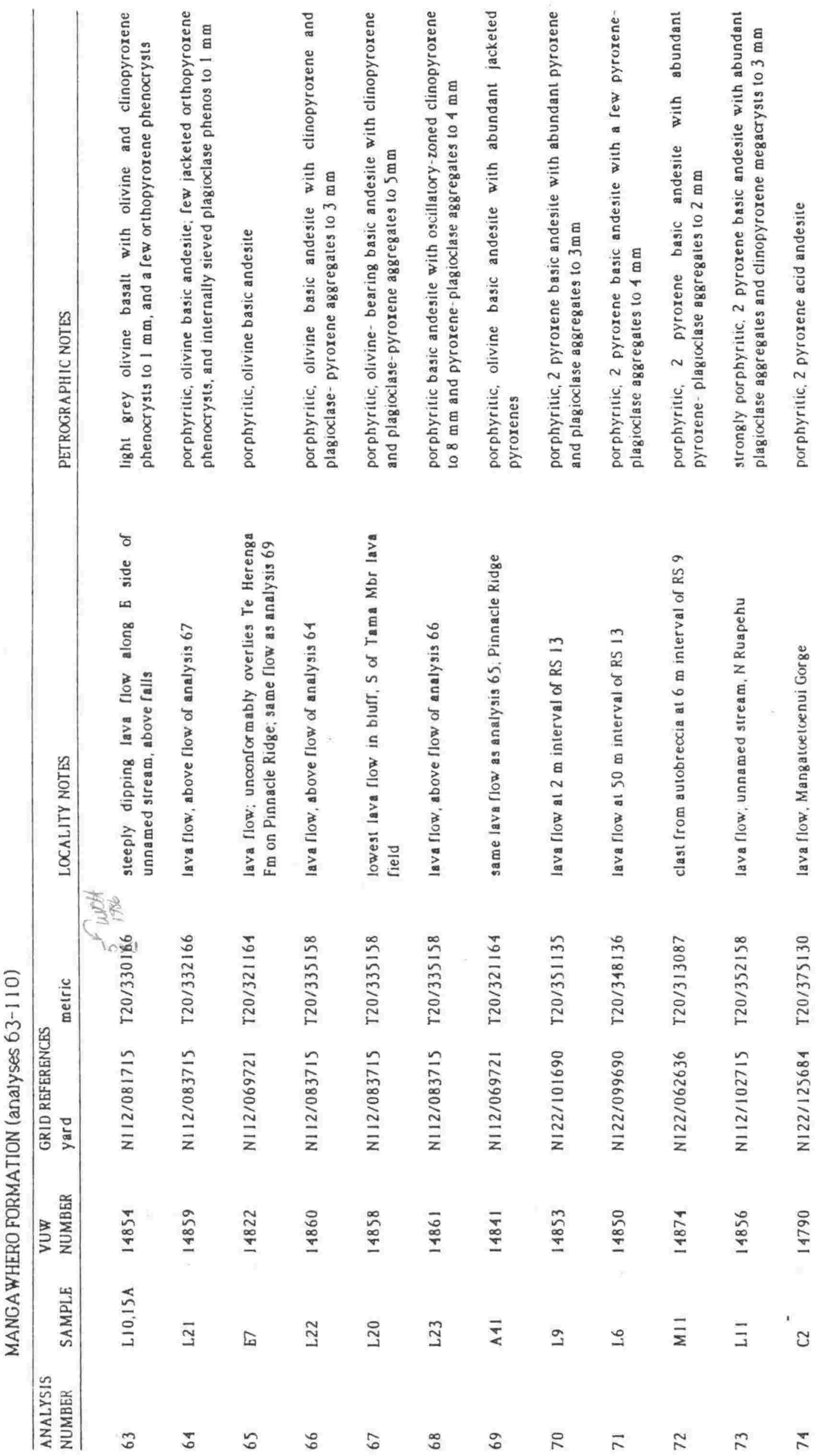




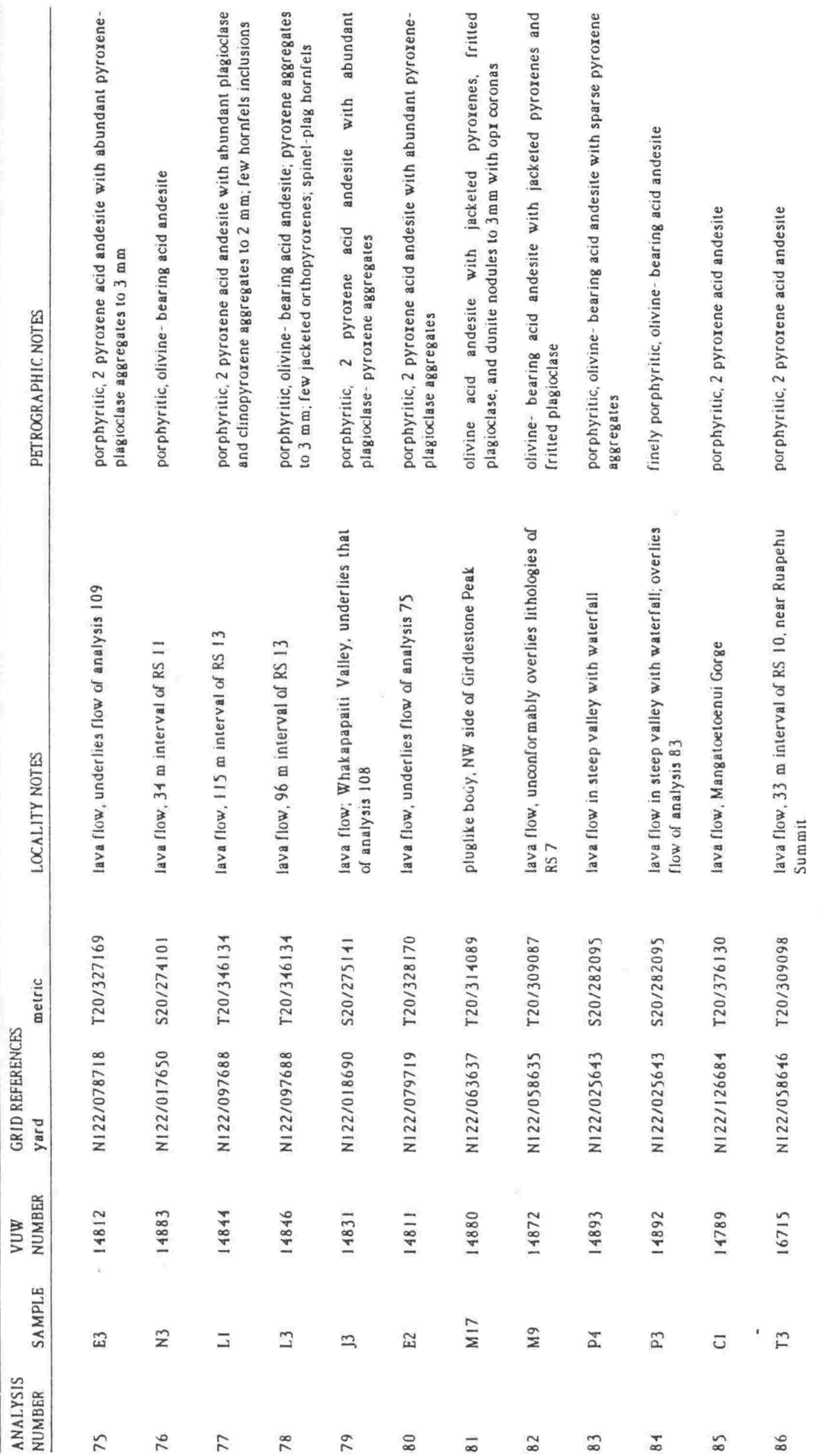




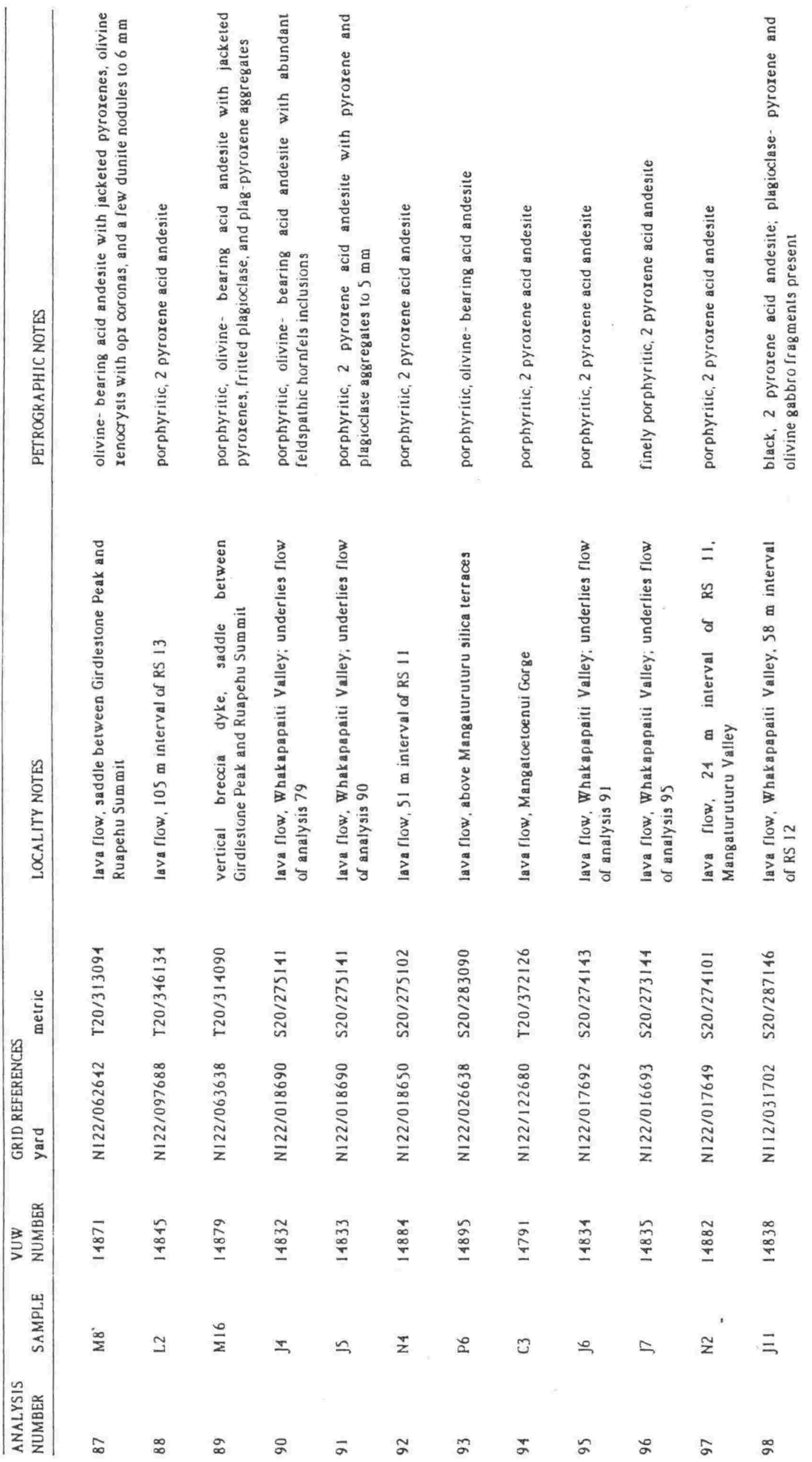




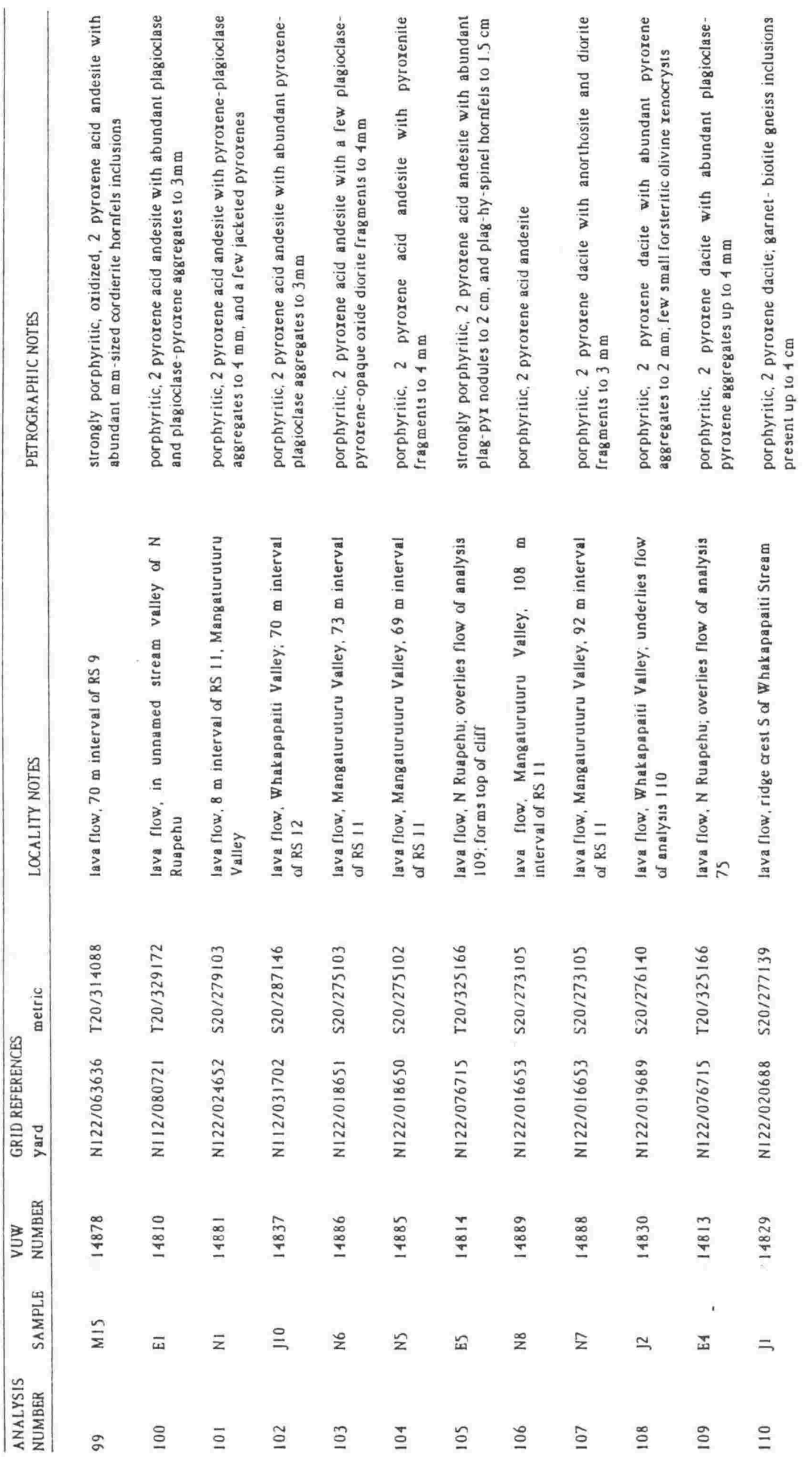




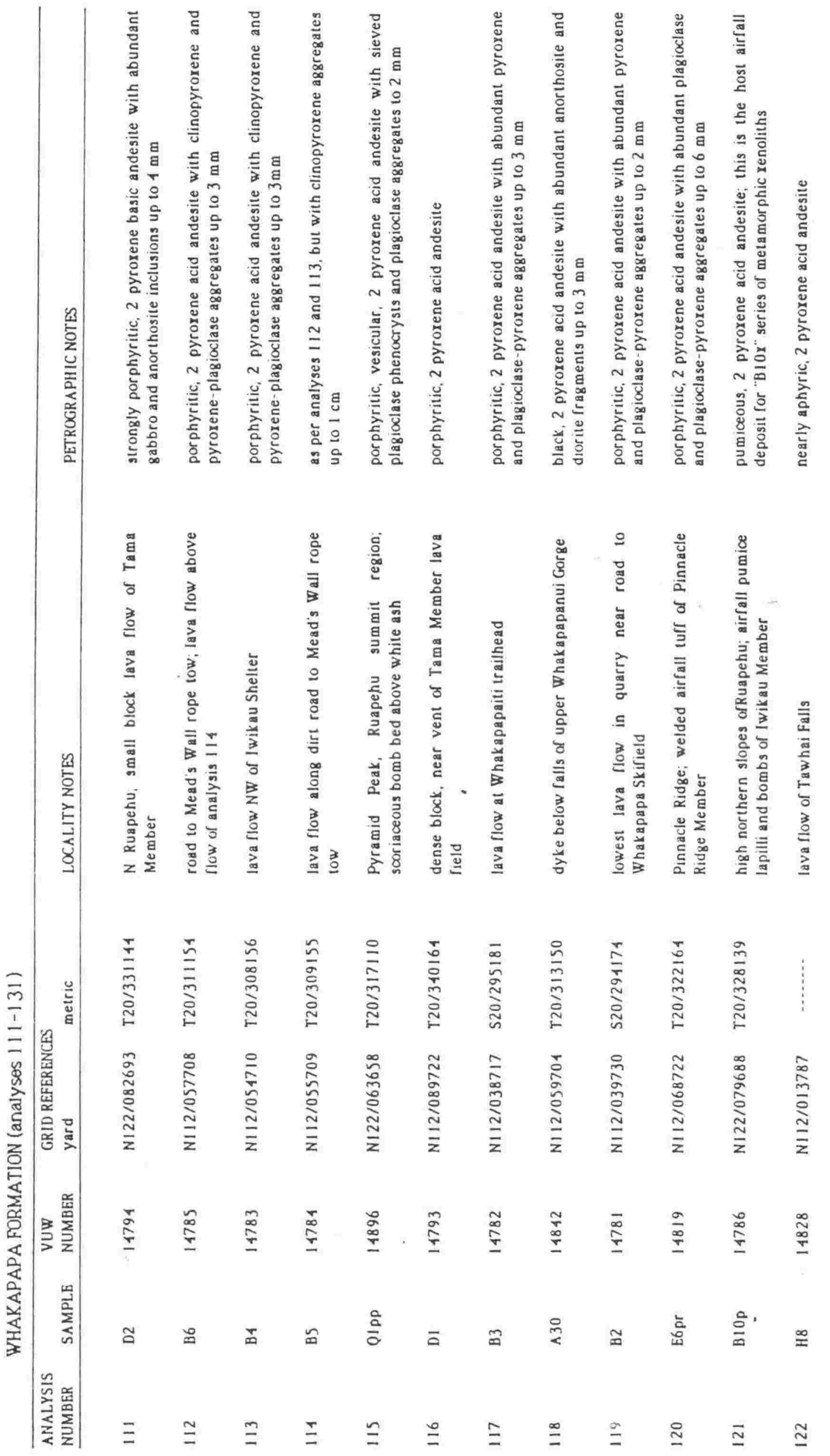




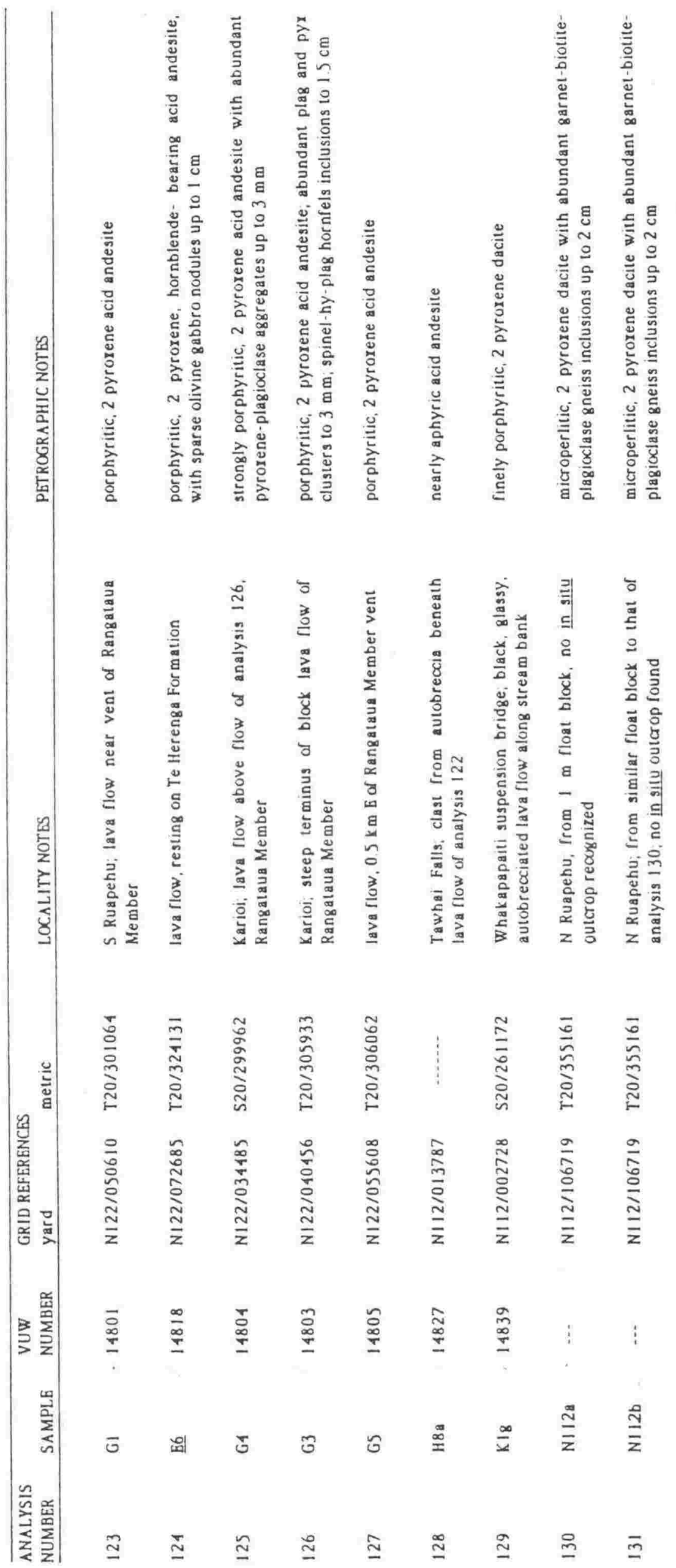




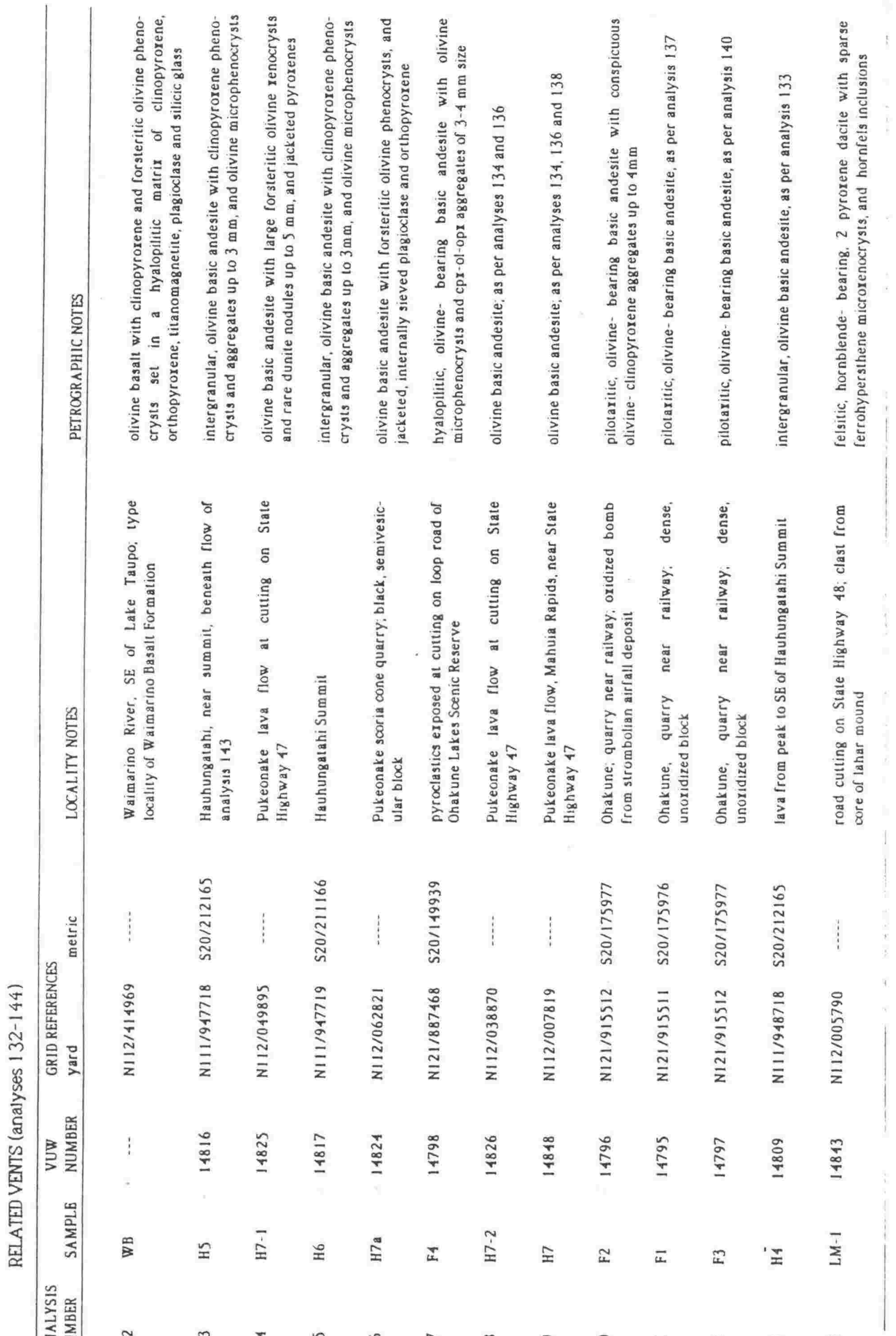

$\begin{array}{llllllll} & & & & & & & \\ 0\end{array}$

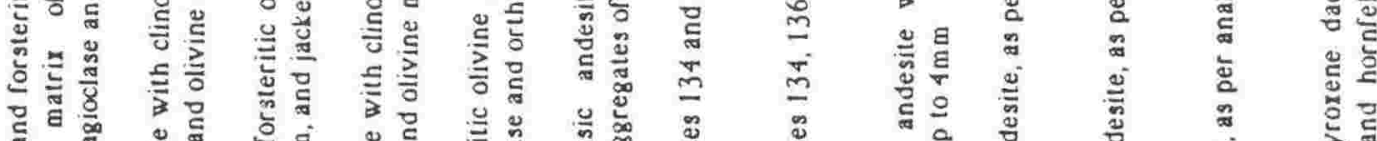

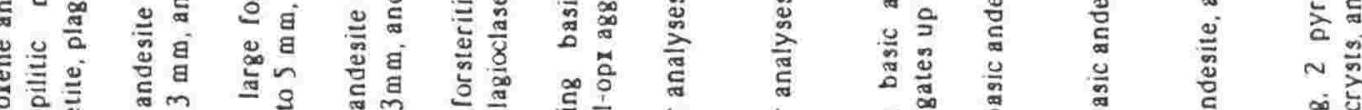

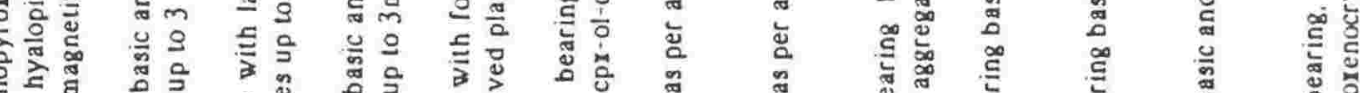

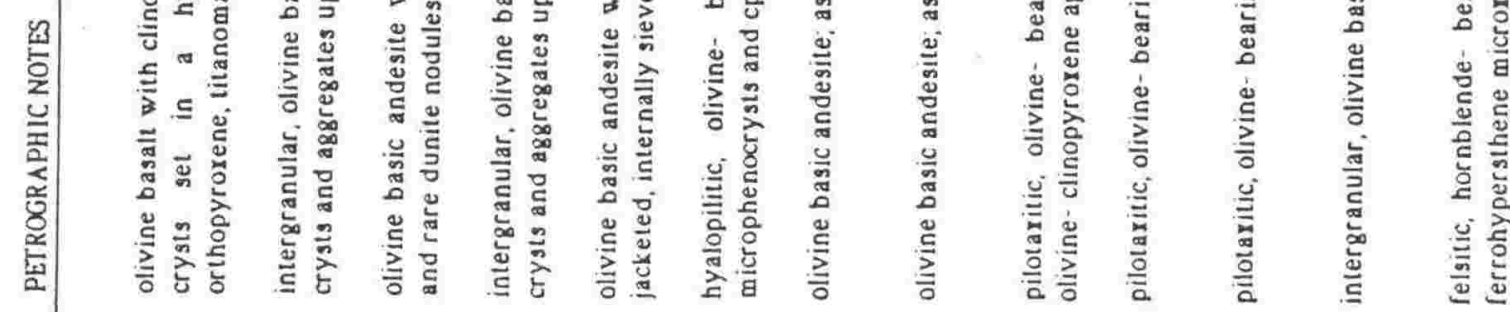

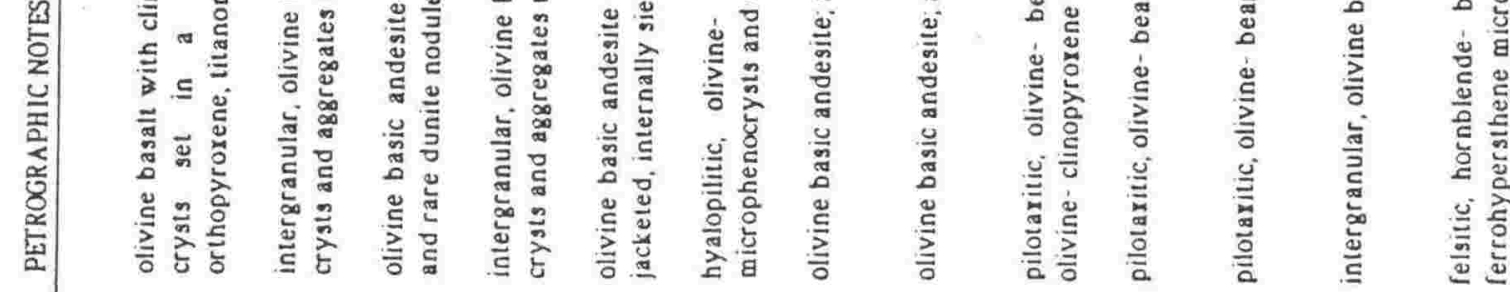

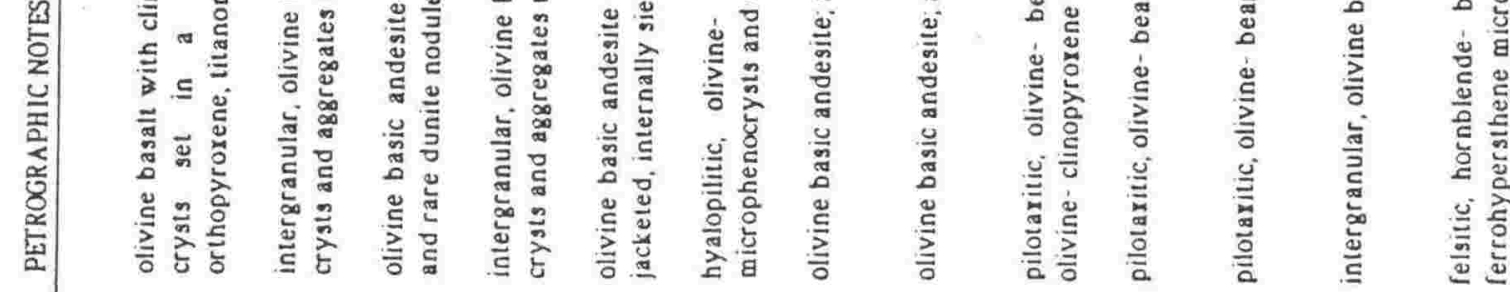

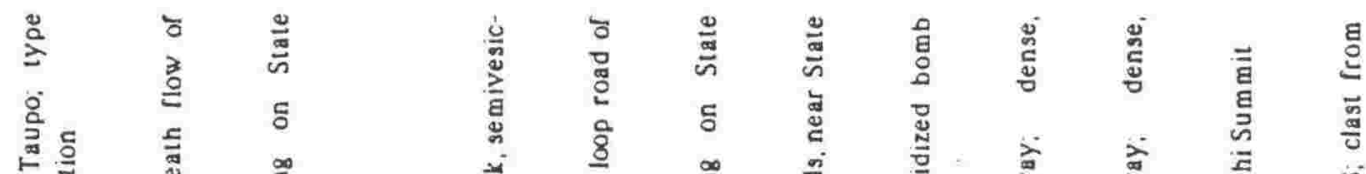

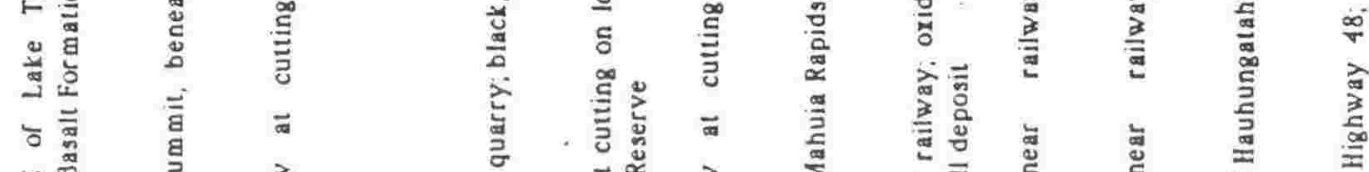

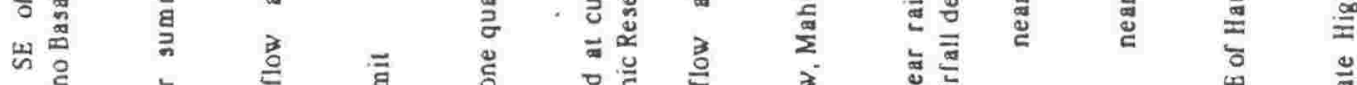

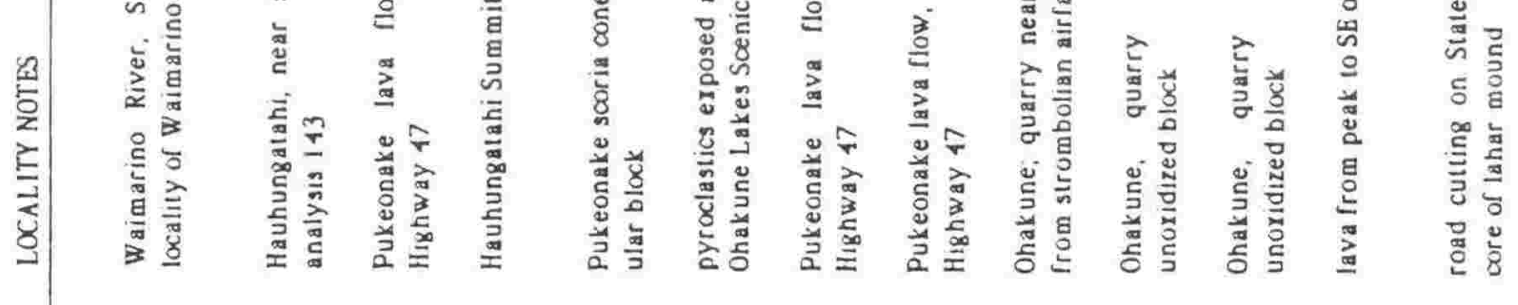




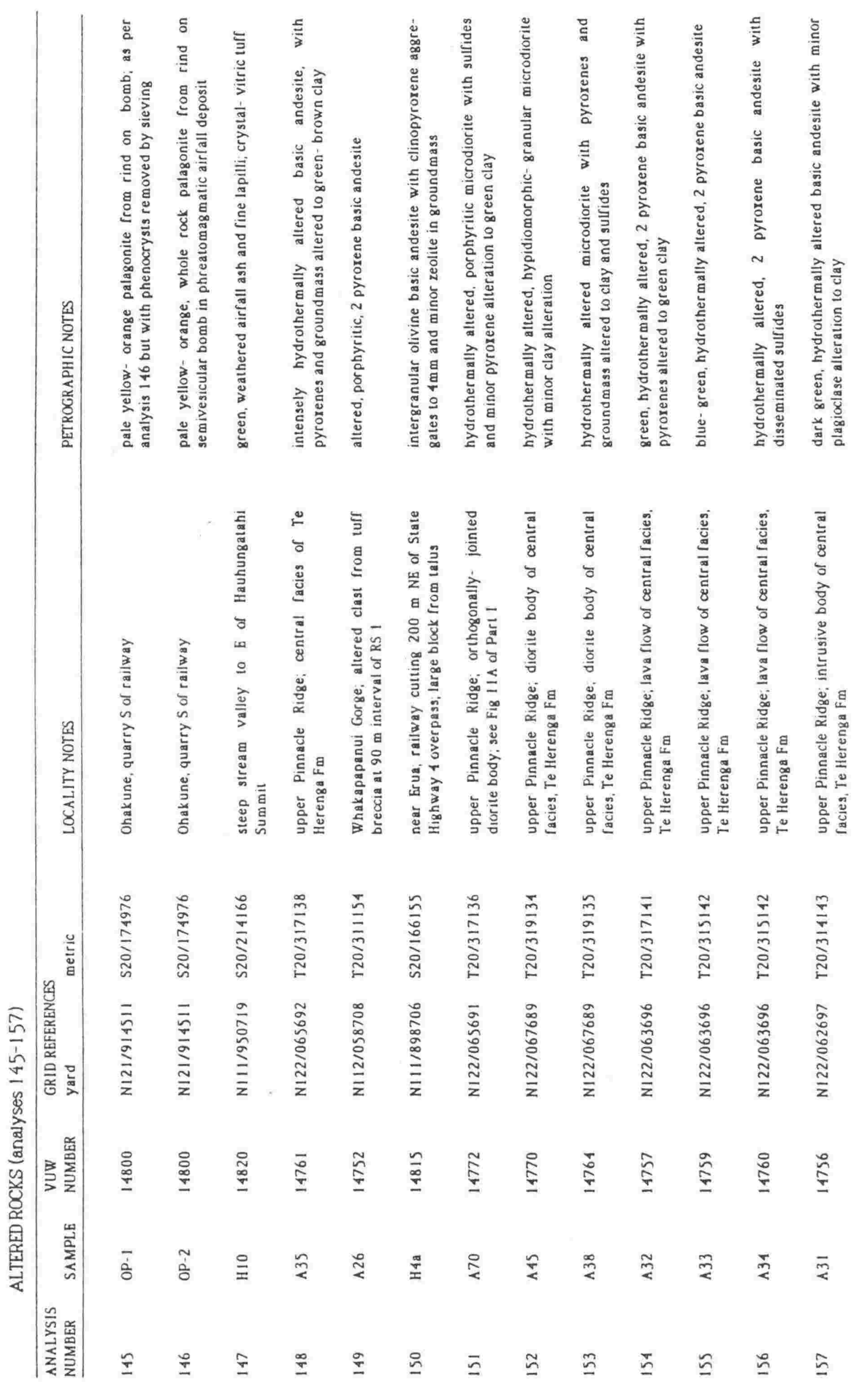




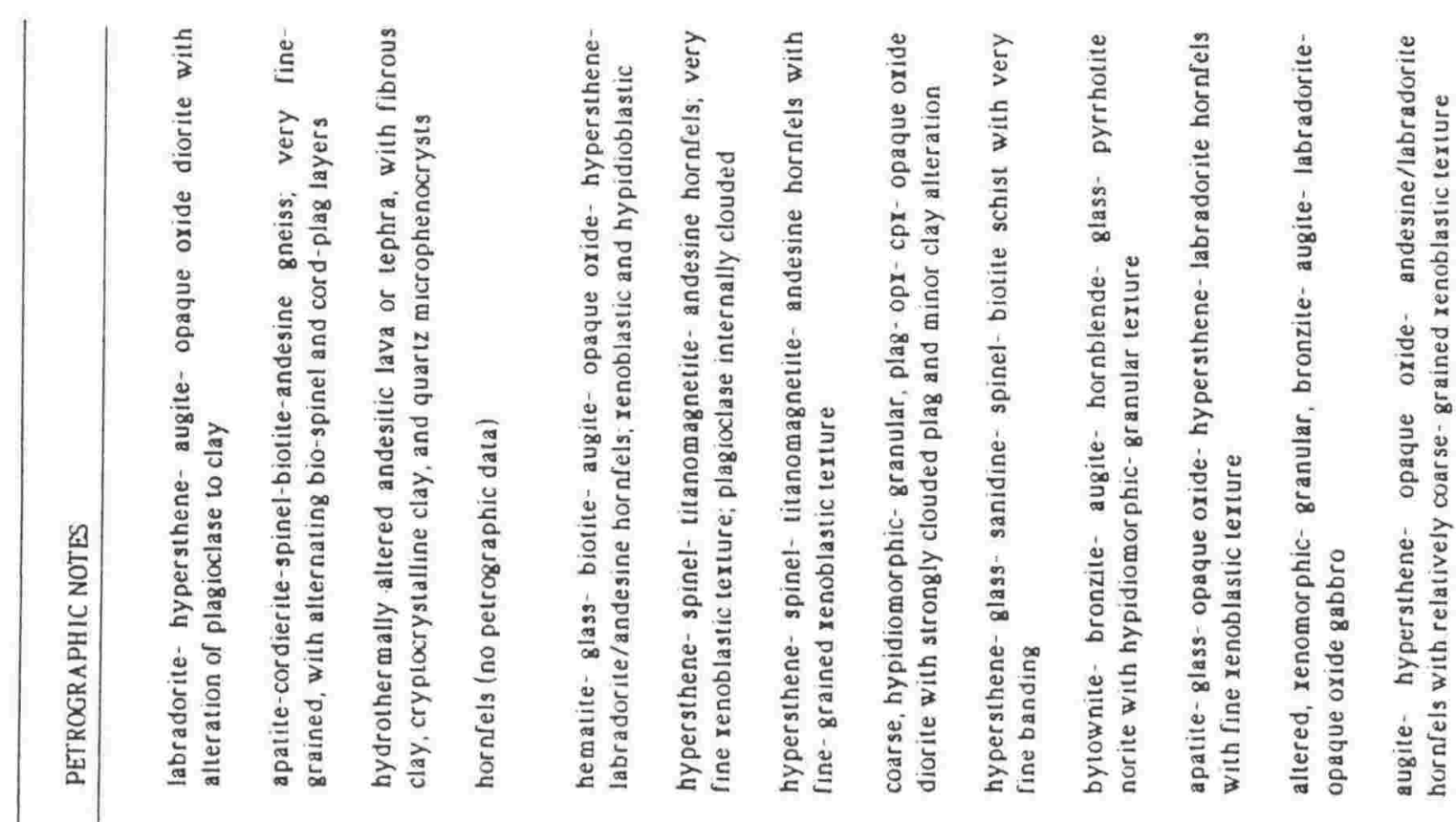

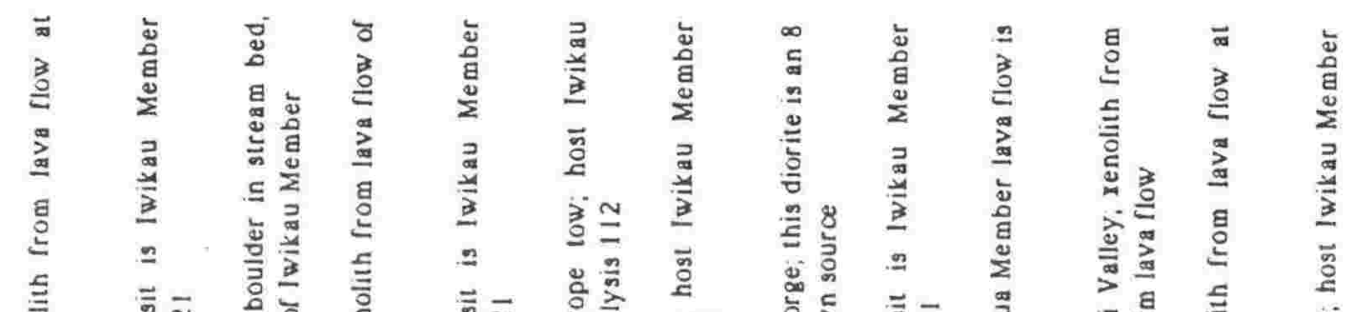

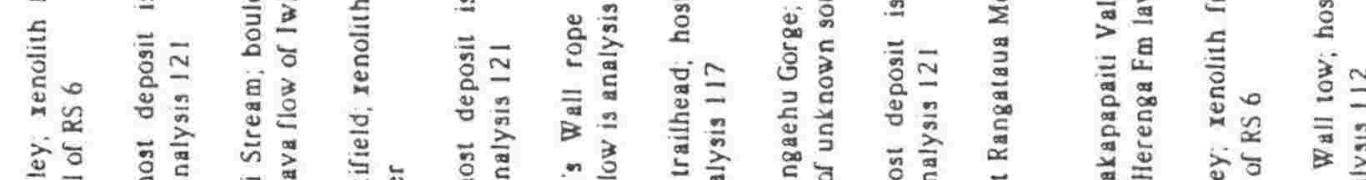

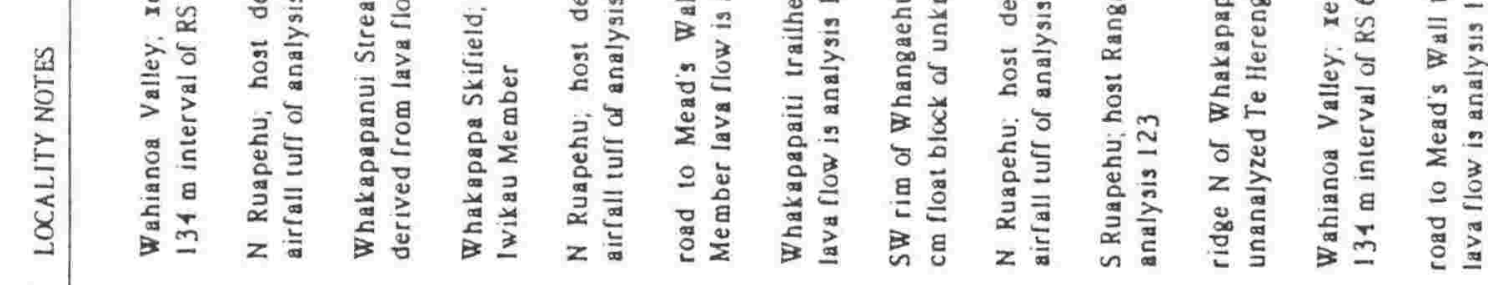

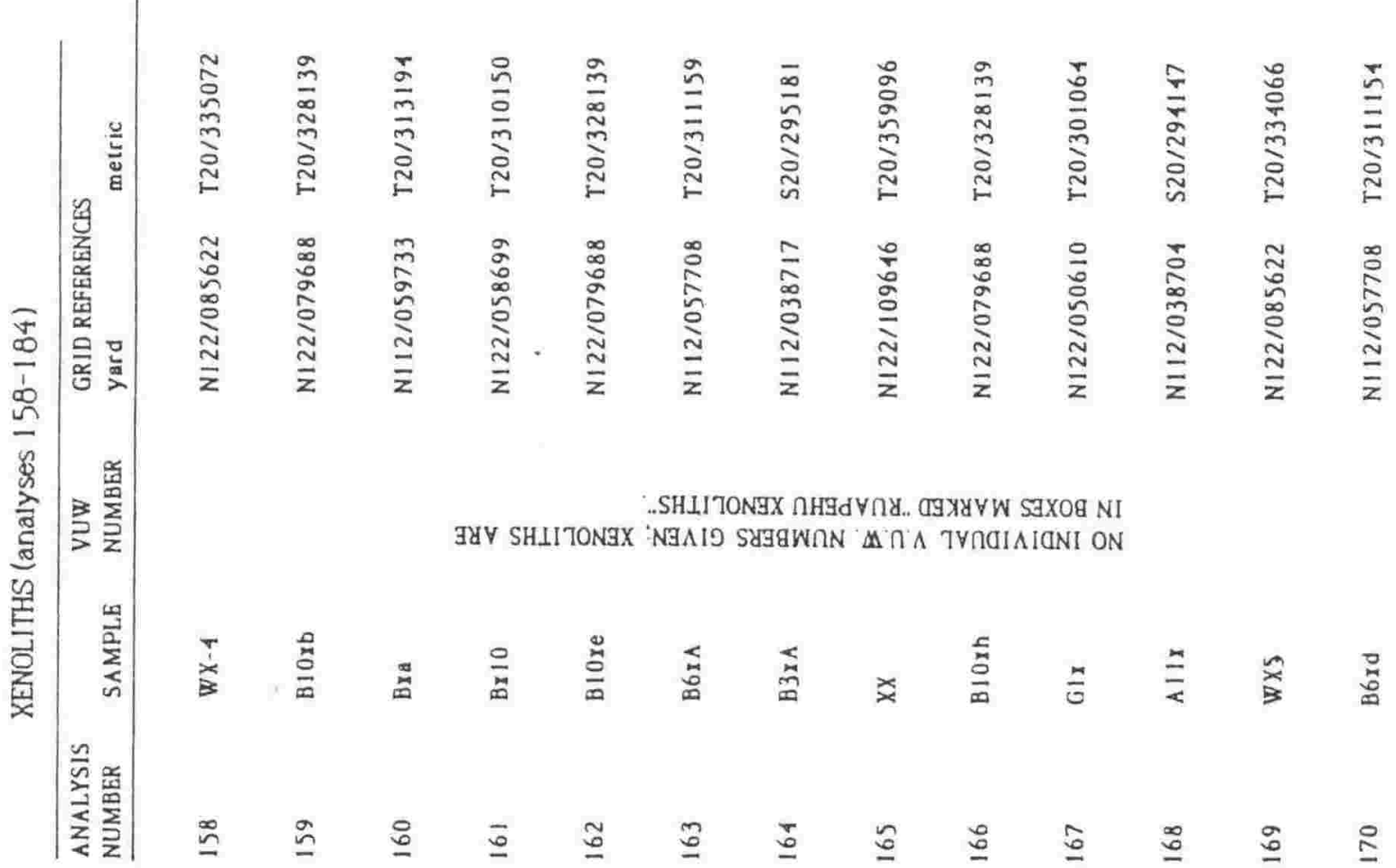




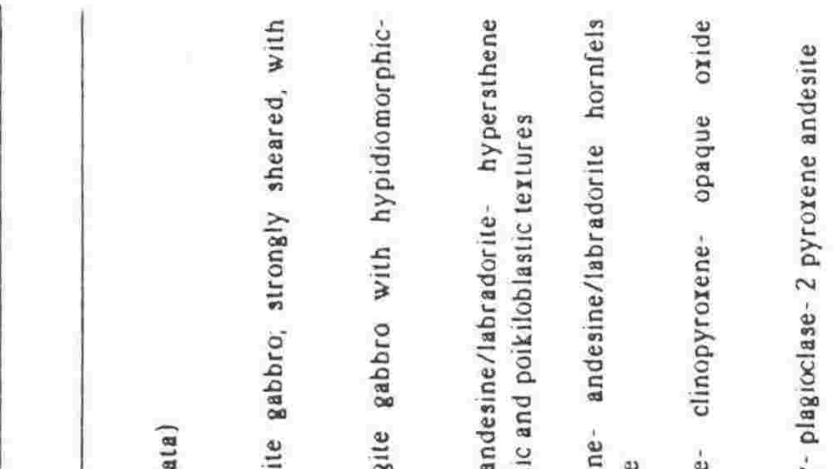

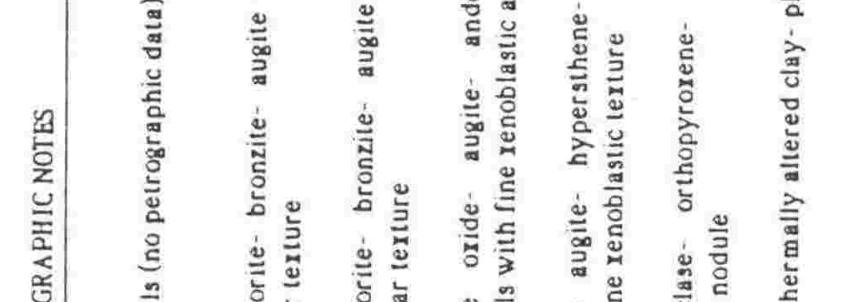

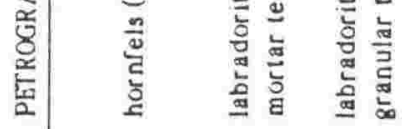

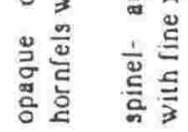

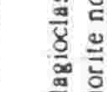

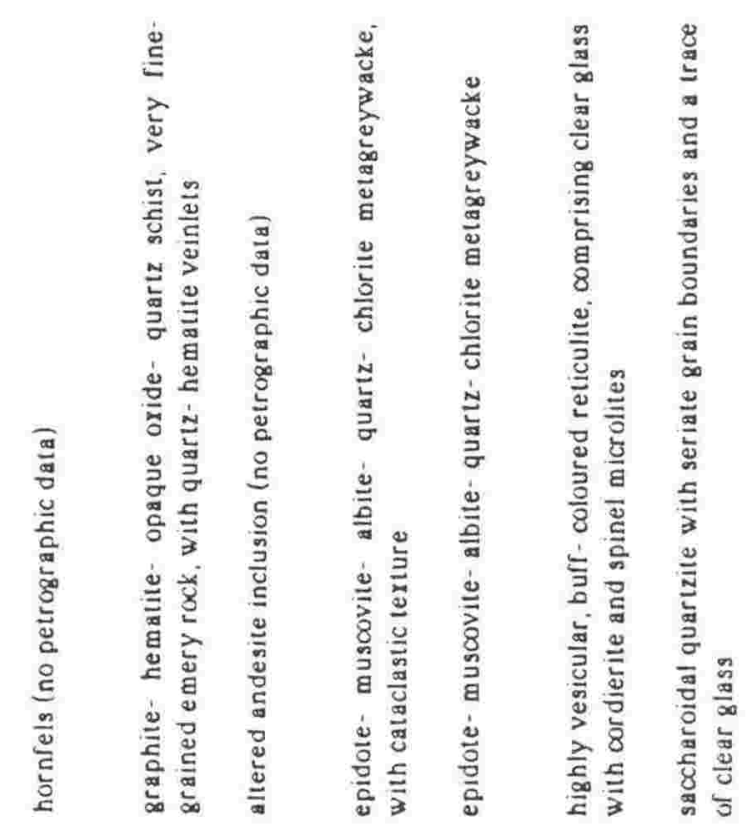

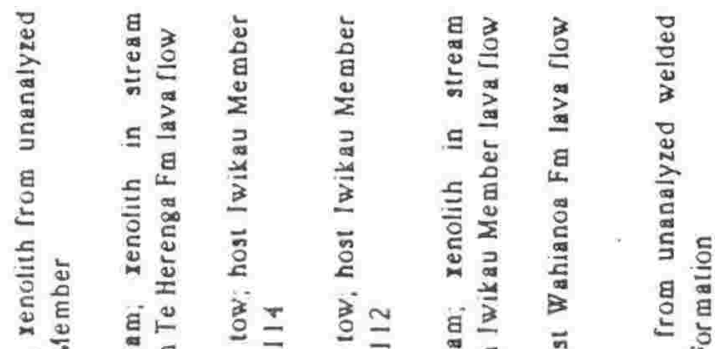

芩

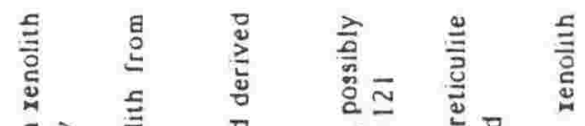

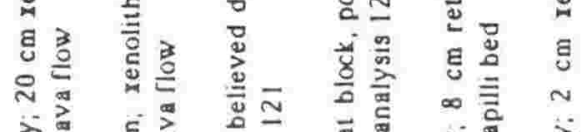

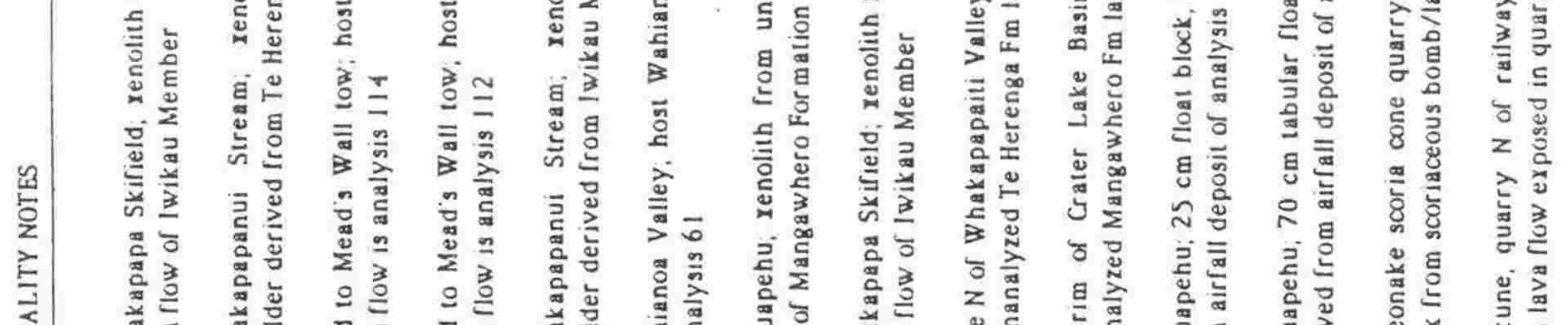

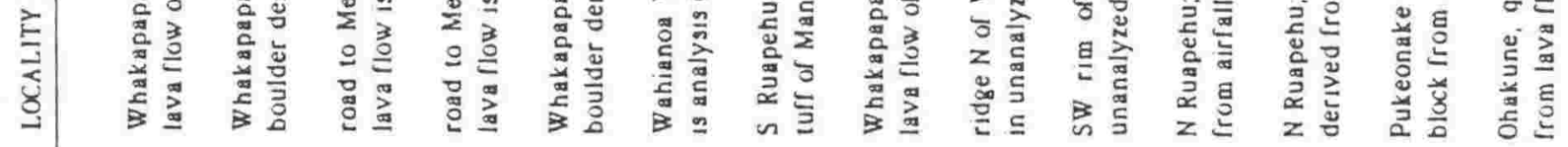

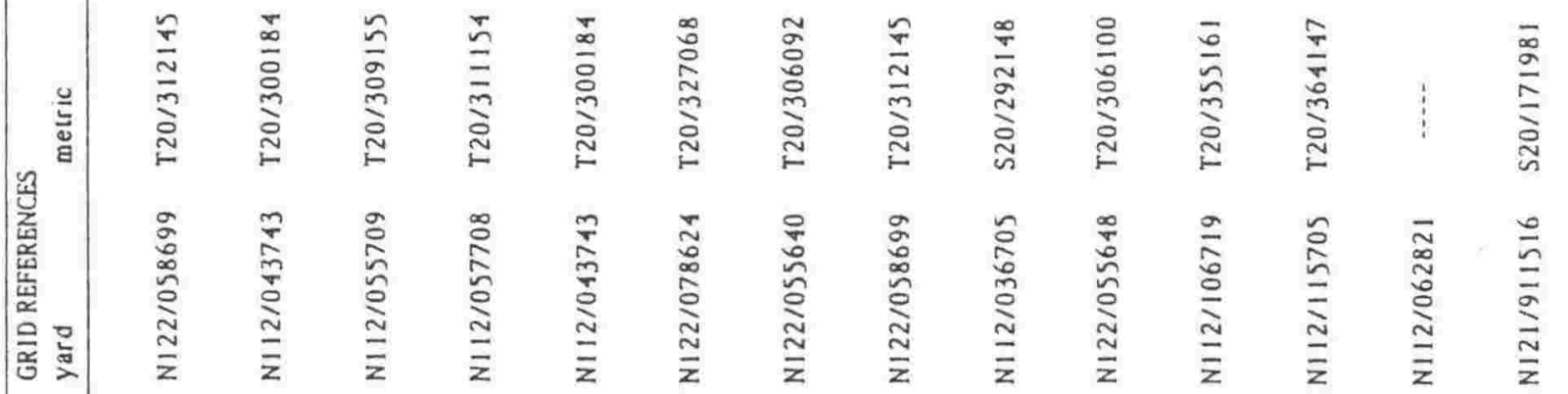

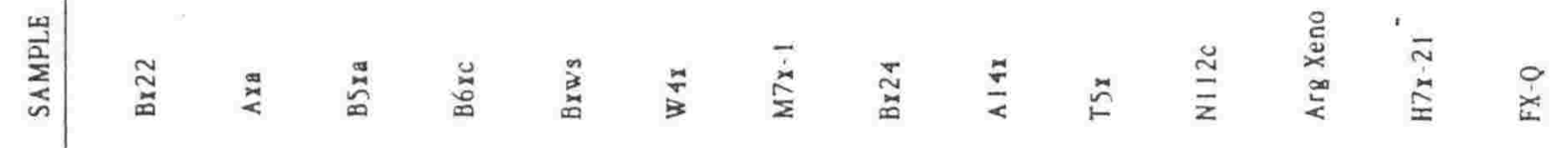


BULK ROCK CHEMICAL DATA FROM TE HERENGA FORMATION

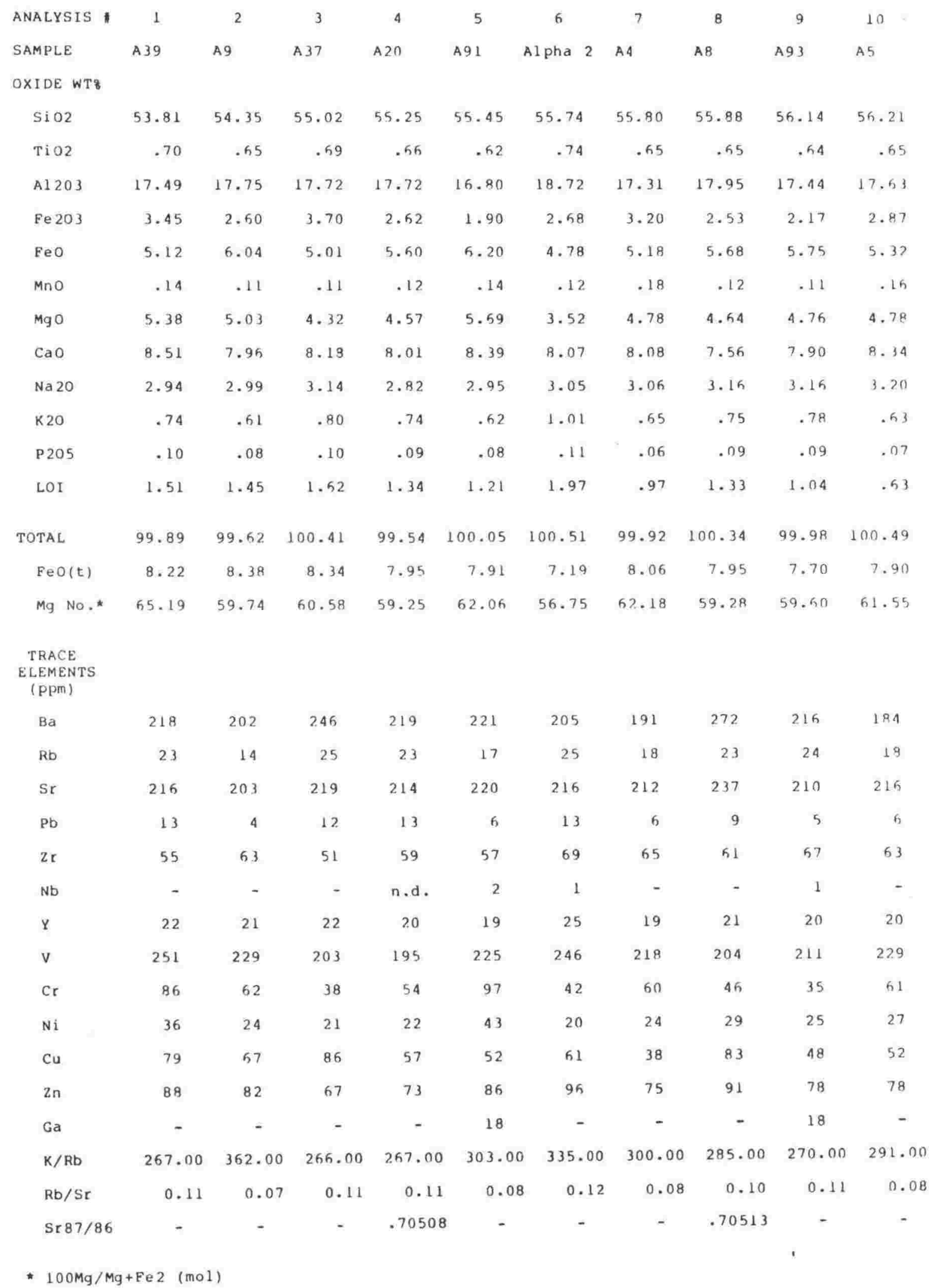


BULK ROCK CHEMICAL DATA FROM TE HERENGA FORMATION

\begin{tabular}{|c|c|c|c|c|c|c|c|c|c|c|}
\hline ANALYSIS & 11 & 12 & 13 & 14 & 15 & 16 & 17 & 18 & 19 & 20 \\
\hline SAMPLE & A7 & A92 & Alpha 1 & A 36 & A $32^{\prime}$ & Al & A 3 & A 6 & A 25 & L2. 4 \\
\hline \multicolumn{11}{|l|}{ OXIDE WTZ } \\
\hline Si 02 & 56.21 & 56.30 & 56.32 & 56.38 & 56.44 & 56.55 & 56.55 & 55.55 & 56.55 & 56.67 \\
\hline $\mathrm{TiO} 2$ & .67 & .64 & .70 & .65 & .56 & .58 & .65 & .67 & .59 & .51 \\
\hline Al 203 & 17.50 & 17.05 & 17.37 & 17.37 & 17.77 & 17.26 & 17.42 & 17.48 & 17.59 & 17.50 \\
\hline $\mathrm{Ee} 203$ & 2.58 & 3.01 & 2.81 & 4.14 & 2.29 & 2.85 & 2.56 & 2.87 & 2.84 & 1.92 \\
\hline $\mathrm{FeO}$ & 5.82 & 4.70 & 5.40 & 4.00 & 5.72 & 5.48 & 5.75 & 5.43 & 5.49 & 5.40 \\
\hline $\mathrm{MnO}$ & .17 & .11 & .12 & .11 & .11 & .19 & .17 & .18 & .13 & .11 \\
\hline $\mathrm{MgO}$ & 4.68 & $4 \cdot 56$ & 4.48 & 4.54 & 4.56 & 4.21 & 4.53 & 4.53 & 4.54 & 1.74 \\
\hline $\mathrm{CaO}$ & 8.06 & 7.63 & 7.92 & 7.55 & 8.35 & 7.90 & 7.94 & 8.08 & 7.89 & 7.82 \\
\hline $\mathrm{Na} 20$ & 3.24 & 3.15 & 3.15 & 3.02 & 3.11 & 3.33 & 3.21 & 3.12 & 3.12 & 3.13 \\
\hline $\mathrm{K} 2 \mathrm{O}$ & .79 & .76 & .74 & .85 & .70 & .56 & .68 & .78 & .74 & .84 \\
\hline P205 & .08 & .08 & .09 & .11 & .10 & .08 & .07 & .10 & .08 & .09 \\
\hline LOI & .49 & 1.39 & 1.43 & 1.51 & .87 & .85 & 1.01 & .50 & 1.19 & .56 \\
\hline TOTAL & 100.29 & 99.38 & 100.53 & 100.33 & 100.58 & 99.95 & 100.65 & 100.49 & 100.85 & 99.34 \\
\hline $\mathrm{FeO}(\mathrm{t})$ & 8.00 & 7.40 & 7.93 & 7.73 & 7.78 & 8.05 & 8.05 & 8.01 & 8.04 & 7.1 \\
\hline Mg No.* & 58.90 & 63.36 & 59.55 & 67.40 & 58.69 & 57.79 & 58.89 & 60.31 & - & 51.00 \\
\hline
\end{tabular}

\section{TRACE \\ ELEMENTS \\ (ppm)}

$\begin{array}{lrrrrrrrrrr}\mathrm{Ba} & 251 & 223 & 232 & 259 & 222 & 164 & 202 & 238 & 298 & 253 \\ \mathrm{Rb} & 21 & 24 & 24 & 25 & 2.2 & 15 & 18 & 21 & 20 & 30 \\ \mathrm{Sr} & 238 & 197 & 250 & 264 & 197 & 215 & 218 & 239 & 256 & 224 \\ \mathrm{~Pb} & 6 & 6 & 15 & 17 & 15 & 6 & 8 & 7 & 13 & 7 \\ \mathrm{Zr} & 53 & 62 & 51 & 65 & 56 & 59 & 61 & 62 & 55 & 72 \\ \mathrm{Nb} & - & 3 & \mathrm{n} . \mathrm{d} & - & - & 2 & - & - & - & 4 \\ \mathrm{Y} & 20 & 20 & 21 & 23 & 23 & 22 & 18 & 20 & 22 & 23 \\ \mathrm{~V} & 228 & 187 & 251 & 180 & 240 & 241 & 216 & 215 & 228 & 188 \\ \mathrm{Cr} & 48 & 42 & 56 & 52 & 67 & 38 & 42 & 45 & 55 & 70 \\ \mathrm{Ni} & 35 & 21 & 30 & 33 & 30 & 22 & 21 & 28 & 23 & 35 \\ \mathrm{Cu} & 54 & 54 & 54 & 55 & 53 & 38 & 67 & 48 & 53 & 52 \\ \mathrm{Zn} & 78 & 67 & 80 & 64 & 82 & 82 & 77 & 75 & 76 & 73 \\ \mathrm{Ga} & - & 17 & - & - & - & 17 & - & - & - & 19 \\ \mathrm{~K} / \mathrm{Rb} & 312.00 & 263.00 & 256.00 & 282.00 & 264.00 & 322.00 & 314.00 & 308.00 & 307.00 & 232.00 \\ \mathrm{Rb} / \mathrm{Sr} & 0.09 & 0.12 & 0.10 & 0.09 & 0.11 & 0.80 & 0.08 & 0.09 & 0.08 & 0.13 \\ \mathrm{Sr} 87 / 86 & - & - & - & - & - & - & - & - & - & -\end{array}$


BULK ROCK CHEMICAL DATA FROM TE HERENGA FORMATION

\begin{tabular}{|c|c|c|c|c|}
\hline ANALYSIS & 21 & 22 & 2.3 & 24 \\
\hline SAMPLE & A 2 & $A \perp 3$ & A 27 & A 42 \\
\hline \multicolumn{5}{|l|}{ OXIDE WT8 } \\
\hline Si 02 & 56.77 & 56.91 & 57.01 & 58.78 \\
\hline TiO2 & .65 & .65 & .71 & .54 \\
\hline Al 203 & 17.37 & 17.25 & 16.90 & 18.98 \\
\hline $\mathrm{Fe} 203$ & 3.11 & 2.90 & 3.53 & 2.45 \\
\hline FeO & 5.10 & 5.26 & 5.20 & 3.70 \\
\hline Mno & .17 & .13 & .14 & .09 \\
\hline MgO & 4.56 & $4 \cdot 34$ & 4.40 & 2.42 \\
\hline $\mathrm{CaO}$ & 8.08 & 7.37 & 7.12 & 6.94 \\
\hline Na 20 & 3.14 & 3.16 & 3.20 & 3.67 \\
\hline $\mathrm{K} 20$ & .74 & .66 & .77 & 1.04 \\
\hline P205 & .07 & .09 & .09 & .11 \\
\hline LOI & .56 & .83 & 1.25 & 1.17 \\
\hline TOTAL & 100.42 & 99.55 & 100.32 & 99.99 \\
\hline FeO $(t)$ & 7.90 & 7.85 & 8.38 & 5.90 \\
\hline Mg No." & 61.44 & 59.52 & 60.13 & 53.82 \\
\hline \multicolumn{5}{|l|}{$\begin{array}{l}\text { TRACE } \\
\text { ELEMENTS } \\
\text { (pPm) }\end{array}$} \\
\hline $\mathrm{Ba}$ & 205 & 205 & 220 & 279 \\
\hline $\mathrm{Rb}$ & 20 & 17 & 23 & 34 \\
\hline Sr & 217 & 220 & 218 & 258 \\
\hline $\mathrm{Pb}$ & 8 & 6 & 17 & 28 \\
\hline $2 \mathrm{r}$ & 61 & 60 & 58 & 76 \\
\hline $\mathrm{Nb}$ & - & 3 & - & - \\
\hline Y & 21 & 20 & 21 & 23 \\
\hline v & 212 & 215 & 203 & 130 \\
\hline $\mathrm{Cr}$ & 40 & 41 & 40 & 25 \\
\hline $\mathrm{Ni}$ & 21 & 27 & 27 & 9 \\
\hline $\mathrm{Cu}$ & 39 & 41 & 52 & 50 \\
\hline $\mathrm{zn}$ & 73 & 77 & 74 & 70 \\
\hline $\mathrm{Ga}$ & - & 18 & - & - \\
\hline $\mathrm{K} / \mathrm{Rb}$ & 307.00 & 322.00 & 278.00 & 254.00 \\
\hline $\mathrm{Rb} / \mathrm{Sr}$ & 0.09 & 0.08 & 0.11 & 0.13 \\
\hline $\mathrm{Sr} 87 / 86$ & - & - & - & - \\
\hline $100 \mathrm{Mg} / \mathrm{Mg}+$ & $\mathrm{el} 2(\mathrm{~mol}$ & & & \\
\hline
\end{tabular}


BULK ROCK CHEMICAL DATA FROM WAHIANOA FORMATION

\begin{tabular}{|c|c|c|c|c|c|c|c|c|c|c|}
\hline ANALYSIS & 25 & 26 & 27 & 28 & 2.9 & 30 & 31 & 32 & 33 & 34 \\
\hline SAMPLE & $\times 13$ & Q1DR & $\times 56$ & $\mathrm{~L} 12$ & $x 14$ & $5 B$ & 4 & 9 & $\times 15$ & 16 \\
\hline \multicolumn{11}{|l|}{ OXIDE WT8 } \\
\hline $\mathrm{SiO} 2$ & 54.30 & 54.48 & 54.87 & 55.20 & 55.23 & 55.73 & 55.95 & 56.03 & 56.08 & 56.29 \\
\hline $\mathrm{TiO}$ & .76 & .57 & .55 & .72 & .75 & .59 & .58 & .65 & .73 & .67 \\
\hline Al 203 & 17.45 & 16.26 & 16.18 & 17.56 & 17.20 & 15.52 & 14.98 & 17.30 & 17.47 & 17.23 \\
\hline $\mathrm{Fe} 203$ & 3.18 & 2.19 & 1.99 & 2.52 & 1.98 & 2.36 & 2.03 & 2.36 & 2.20 & 2.52 \\
\hline $\mathrm{FeO}$ & 4.64 & 6.34 & 5.86 & 6.12 & 6.37 & 5.45 & 5.56 & 4.92 & 5.54 & 5.52 \\
\hline $\mathrm{MnO}$ & .13 & .13 & .13 & .12 & .14 & .11 & .12 & .11 & .12 & .12 \\
\hline $\mathrm{MgO}$ & 5.02 & 6.07 & 6.62 & 4.55 & 4.93 & 6.49 & 6.85 & 4.97 & 4.46 & 4.56 \\
\hline $\mathrm{CaO}$ & 8.46 & 8.69 & 8.00 & 8.43 & 8.54 & 8.93 & 8.49 & 8.07 & 7.96 & 8.04 \\
\hline Na 20 & 2.50 & 2.91 & 2.84 & 2.88 & 2.59 & 2.55 & 2.48 & 3.03 & 2.85 & 2.85 \\
\hline K 20 & .88 & .73 & .83 & .74 & .93 & .90 & .96 & .79 & 1.08 & 1.00 \\
\hline P205 & .10 & .09 & .10 & .09 & .10 & .08 & .09 & .09 & .10 & .10 \\
\hline LOI & 1.51 & .75 & .93 & .70 & .89 & .99 & 1.45 & 1.14 & .53 & .68 \\
\hline TOTAL & 99.33 & 99.31 & 99.00 & 99.63 & 99.75 & 100.01 & 99.74 & 99.47 & 99.32 & 99.58 \\
\hline$F e O(t)$ & 7.77 & 8.31 & 7.65 & 8.39 & 8.15 & 7.58 & 7.49 & 7.05 & 7.52 & 7.79 \\
\hline Mg No." & 65.85 & 63.05 & 66.87 & 55.99 & 57.97 & 67.93 & 68.32 & 64.29 & 58.49 & - \\
\hline \multicolumn{11}{|l|}{$\begin{array}{l}\text { TRACE } \\
\text { ELEMENTS } \\
\text { (PPM) }\end{array}$} \\
\hline $\mathrm{Ba}$ & 245 & 198 & 229 & 210 & 238 & 261 & 256 & 280 & 293 & 287 \\
\hline $\mathrm{Hb}$ & 28 & 20 & 27 & 23 & 30 & 29 & 42 & 22 & 35 & 34 \\
\hline sr & 221 & 226 & 214 & 207 & 22.9 & 2.13 & 204 & 284 & 2.29 & 229 \\
\hline $\mathrm{Pb}$ & 12 & 4 & 4 & 11 & 13 & 11 & 16 & 14 & 11 & 13 \\
\hline $2 r$ & 69 & 67 & 75 & 61 & 69 & 75 & 77 & 68 & 75 & 72 \\
\hline $\mathrm{Nb}$ & 1 & 3 & 3 & 3 & n.d. & 2 & - & n.d. & $n \cdot d$. & 1 \\
\hline$Y$ & 21 & 21 & 19 & 21 & 23 & 20 & 22 & 18 & 25 & 21 \\
\hline $\mathrm{v}$ & 240 & 234 & 22.1 & 248 & 234 & 2.23 & 220 & 216 & 224 & 205 \\
\hline $\mathrm{Cr}$ & 72 & 125 & 246 & 53 & 73 & 267 & 275 & 103 & 59 & 58 \\
\hline $\mathrm{Ni}$ & 28 & 35 & 76 & 26 & 27 & 63 & 61 & 53 & 22 & 25 \\
\hline $\mathrm{Cu}$ & 67 & 56 & 58 & 57 & 64 & 98 & 82 & 65 & 52 & 49 \\
\hline $2 n$ & 84 & 88 & 76 & 84 & 81 & 69 & 72 & 77 & 73 & 76 \\
\hline Ga & - & 19 & 18 & - & - & - & - & - & - & - \\
\hline $\mathrm{K} / \mathrm{Rb}$ & 261 & 303 & 255 & 267 & 257 & 258 & 190 & 298 & 256 & 244 \\
\hline $\mathrm{Rb} / \mathrm{Sr}$ & 0.13 & 0.09 & 0.13 & 0.11 & 0.13 & 0.14 & 0.21 & 0.08 & 0.15 & 0.15 \\
\hline $5 \times 87 / 86$ & .70521 & - & - & - & .70518 & - & - & - & - & - \\
\hline * $100 \mathrm{Mg} / \mathrm{Mg}+\mathrm{L}$ & Fe 2 (mol) & & & & & & & & ' & \\
\hline
\end{tabular}


BULK ROCK CHEMICAL DATA FROM WAHIANOA FORMATION

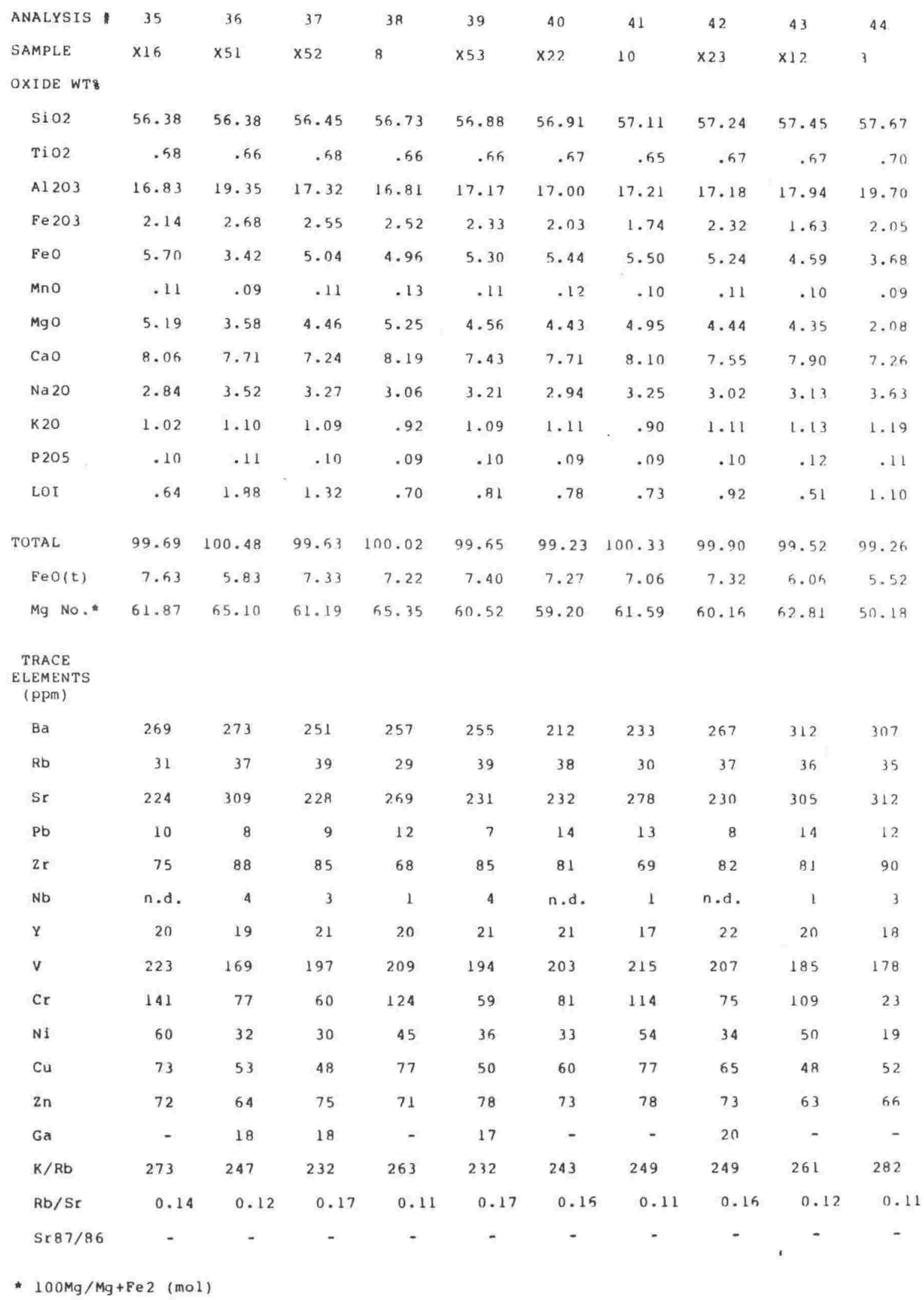


BULK ROCK CHEMICAL DATA FROM WAHIANOA FORMATION

\begin{tabular}{|c|c|c|c|c|c|c|c|c|c|c|}
\hline ANALYSIS & 45 & 46 & 47 & 48 & 49 & 50 & 51 & 52 & 53 & 54 \\
\hline SAMPLE & 14 & 13 & 11 & $5 \mathrm{~A}$ & 6 & $\times 54$ & $\times 50$ & 1 & 7 & 2 \\
\hline \multicolumn{11}{|l|}{ OXIDE WT\& } \\
\hline $\mathrm{SiO} 2$ & 57.70 & 57.72 & 57.74 & 57.98 & 58.10 & 58.18 & 58.20 & 58.23 & $5 R .29$ & 58.33 \\
\hline TiO2 & .56 & .68 & .58 & .75 & .74 & .64 & .58 & .71 & .75 & .70 \\
\hline Al 203 & 17.83 & 20.37 & $20 \cdot 34$ & 17.02 & 17.12 & 18.38 & 19.57 & 19.81 & 15.96 & 19.81 \\
\hline $\mathrm{Fe} 203$ & 2.50 & 1.58 & 2.31 & 1.70 & 1.85 & 2.39 & 2.06 & 3.54 & 1.87 & 1.82 \\
\hline $\mathrm{FeO}$ & 4.04 & 3.54 & 3.38 & 5.38 & 5.41 & 4.14 & 3.80 & 2.36 & 5.38 & 3.87 \\
\hline MnO & .09 & .06 & .08 & .10 & .11 & .10 & .08 & .08 & .10 & .07 \\
\hline MgO & 4.33 & 2.18 & 2.09 & 3.90 & 3.99 & 3.11 & 2.24 & 2.09 & 3.88 & 2.12 \\
\hline $\mathrm{CaO}$ & 7.86 & 8.08 & 7.96 & 6.94 & 7.07 & 6.48 & 7.24 & 7.44 & 6.95 & 7.55 \\
\hline $\mathrm{Na} 20$ & 3.30 & 3.57 & 3.60 & 2.94 & 2.96 & 3.27 & 3.74 & 3.98 & 3.01 & 3. 81 \\
\hline К 20 & 1.11 & 1.24 & 1.24 & 1.43 & 1.40 & 1.22 & 1.18 & 1.21 & 1.43 & 1.22 \\
\hline P205 & .12 & .13 & .11 & .12 & .12 & .10 & .12 & .13 & .11 & .12 \\
\hline LOI & .54 & .40 & .55 & 1.04 & 1.16 & 1.04 & .92 & .96 & .90 & .71 \\
\hline TOTAL & 100.18 & 99.65 & 100.08 & 99.30 & 100.03 & 99.05 & 99.83 & 100.54 & 99.63 & 100.13 \\
\hline Feo $(t)$ & 5.29 & 5.06 & 5.46 & 6.91 & 7.07 & 6.29 & 5.65 & 5.54 & 7.06 & 5.51 \\
\hline Mg No." & 65.53 & 52.32 & 52.42 & 56.37 & 56.79 & 57,24 & 51.23 & 61.21 & 56.24 & 49.40 \\
\hline \multicolumn{11}{|l|}{$\begin{array}{l}\text { TRACE } \\
\text { ELEMENTS } \\
\text { (PPM) }\end{array}$} \\
\hline Ba & 322 & 318 & 319 & 330 & 344 & 311 & 297 & 320 & 354 & 322 \\
\hline $\mathrm{Rb}$ & 37 & 40 & 40 & 50 & 49 & 45 & 37 & 35 & 51 & 38 \\
\hline $\mathrm{Sr}$ & 310 & 352 & 351 & 273 & 272 & 238 & 305 & 313 & 279 & 318 \\
\hline $\mathrm{Pb}$ & 19 & 13 & 13 & 15 & 15 & 8 & 8 & 11 & 15 & 12 \\
\hline $2 \mathrm{r}$ & 86 & 94 & 95 & 108 & 106 & 95 & 93 & 88 & 113 & 91 \\
\hline Nb & 3 & 1 & n.d. & 2 & n.d. & 4 & 4 & 2 & 1 & n.d. \\
\hline Y & 20 & 19 & 20 & 21 & 22 & 19 & 19 & 19 & 21 & 2.1 \\
\hline v & 189 & 167 & 166 & 195 & 203 & 153 & 178 & 169 & 205 & 196 \\
\hline $\mathrm{Cr}$ & 124 & 36 & 36 & 51 & 41 & 11 & 16 & 21 & 38 & 19 \\
\hline $\mathrm{Ni}$ & 55 & 24 & 25 & 19 & 17 & 10 & 15 & 19 & 23 & 19 \\
\hline $\mathrm{Cu}$ & 85 & 70 & 69 & 43 & 37 & 31 & 42 & 70 & 36 & 50 \\
\hline $2 n$ & 66 & 60 & 52 & 71 & 76 & 65 & 64 & 65 & 74 & 63 \\
\hline $\mathrm{Ga}$ & - & - & - & - & - & 18 & 20 & - & - & - \\
\hline $\mathrm{K} / \mathrm{Rb}$ & 249 & 258 & 257 & 237 & 237 & 225 & 265 & 287 & 233 & 267 \\
\hline $\mathrm{Rb} / \mathrm{Sr}$ & 0.12 & 0.11 & 0.11 & 0.18 & 0.18 & 0.19 & 0.12 & 0.11 & 0.18 & 0.12 \\
\hline $\mathrm{Sr} 87 / 86$ & - & - & - & - & - & - & - & - & ' & - \\
\hline $100 \mathrm{Mg} / \mathrm{Mg}$ & $2(\mathrm{~mol})$ & & & & & & & & & \\
\hline
\end{tabular}


BULK ROCK CHEMICAL DATA FROM WAHIANOA FORMATION

\begin{tabular}{|c|c|c|c|c|c|c|c|c|}
\hline ANALYSIS & 55 & 56 & 57 & 58 & 59 & 50 & 61 & 52 \\
\hline SAMPLE & M10 & W1 & M3 & w3 & M5 & M4 & W4 & WH.ST. \\
\hline \multicolumn{9}{|l|}{ OXIDE WT: } \\
\hline $\mathrm{SiO} 2$ & 58.52 & 58.90 & 59.74 & 59.97 & 60.40 & 60.95 & 61.03 & 61.20 \\
\hline TiO2 & .70 & .54 & .78 & .77 & .72 & .70 & .57 & .70 \\
\hline Al 203 & 16.74 & 17.69 & 15.02 & 15.08 & 17.59 & 15.10 & 15.63 & 15.75 \\
\hline Fe 203 & 1.46 & 2.13 & 1.25 & 1.14 & 1.90 & 1.15 & 1.90 & 1.42 \\
\hline FeO & 4.74 & 4.50 & 4.80 & 4.82 & 4.40 & 4.44 & 3.78 & 4.48 \\
\hline Mno & .09 & .09 & .08 & .07 & .08 & .08 & .06 & .10 \\
\hline $\mathrm{MgO}$ & 4.35 & 2.95 & 5.48 & 5.28 & 2.54 & 5.36 & 4.59 & 3.79 \\
\hline $\mathrm{CaO}$ & 6.76 & 6.60 & 6.17 & 6.09 & 5.93 & 5.87 & 6.44 & 6.02 \\
\hline $\mathrm{Na} 2 \mathrm{O}$ & 3.01 & 3.59 & 2.97 & 3.19 & 3.56 & 3.23 & 3.35 & 3.10 \\
\hline K 20 & 1.68 & 1.21 & 2.03 & 1.98 & 1.58 & 2.12 & 1.54 & 2.17 \\
\hline P205 & .12 & .10 & .15 & .16 & .13 & .15 & .13 & .14 \\
\hline LOI & 1.43 & .39 & .56 & .59 & .35 & .41 & .54 & .57 \\
\hline TOTAL & 99.60 & 98.80 & 99.13 & 99.14 & 99.18 & 99.56 & 99.76 & 99.44 \\
\hline$F e O(t)$ & 6.06 & 6.41 & 5.93 & 5.85 & 6.11 & 5.48 & 5.49 & 5.76 \\
\hline $\mathrm{Mg}$ No." & 62.05 & 53.96 & 67.05 & 66.13 & 50.71 & 68.27 & 68.86 & 60.12 \\
\hline \multicolumn{9}{|l|}{$\begin{array}{l}\text { TRACE } \\
\text { ELEMENTS } \\
(\mathrm{PPm})\end{array}$} \\
\hline $\mathrm{Ba}$ & 334 & 329 & 420 & 464 & 391 & 434 & - & 427 \\
\hline $\mathrm{Rb}$ & 69 & 42 & 88 & 86 & 57 & 93 & 59 & 99 \\
\hline Sr & 262 & 228 & 229 & 240 & 243 & 219 & 356 & 256 \\
\hline $\mathrm{Pb}$ & 10 & 6 & 13 & 13 & 10 & 10 & 10 & 12 \\
\hline $2 r$ & 128 & 96 & 160 & 163 & 119 & 159 & 117 & 160 \\
\hline $\mathrm{Nb}$ & 5 & 5 & 7 & 7 & 5 & 6 & 3 & 5 \\
\hline $\mathrm{Y}$ & 23 & 22 & 24 & 21 & 24 & 25 & 17 & 24 \\
\hline v & 172 & 149 & 167 & 163 & 172 & 139 & - & 146 \\
\hline $\mathrm{Cr}$ & 83 & 18 & 260 & 209 & 10 & 204 & - & 110 \\
\hline $\mathrm{Ni}$ & 32 & 16 & 78 & 64 & 16 & 74 & 50 & 33 \\
\hline $\mathrm{Cu}$ & 30 & 37 & 55 & 43 & 44 & 69 & 83 & 31 \\
\hline $2 n$ & 69 & 65 & 63 & 62 & 70 & 56 & 53 & 61 \\
\hline $\mathrm{Ga}$ & 18 & 20 & 16 & 15 & 19 & 18 & 17 & 17 \\
\hline $\mathrm{K} / \mathrm{Rb}$ & 202 & 239 & 192 & 191 & 230 & 189 & 231 & 182 \\
\hline $\mathrm{Rb} / \mathrm{Sr}$ & 0.26 & 0.18 & 0.38 & 0.36 & 0.23 & 0.42 & 0.17 & 0.39 \\
\hline $\operatorname{Sr} 87 / 86$ & - & - & - & - & - & - & - & - \\
\hline $100 \mathrm{Mg} / \mathrm{Mg}+\mathrm{F}$ & 2 (mol) & & & & & & & . \\
\hline
\end{tabular}


BULK ROCK CHEMICAL DATA FROM MANGAWHERO FORMATION

\begin{tabular}{|c|c|c|c|c|c|c|c|c|c|c|}
\hline ANALYSIS & 63 & 64 & 65 & 66 & 67 & 58 & 69 & 70 & 71 & 72 \\
\hline SAMPLE & L1015A & L2.1 & E7 & L.22 & L 20 & L23 & A 41 & L9 & L6 & M11 \\
\hline \multicolumn{11}{|l|}{ OXIDE WT } \\
\hline $\mathrm{SiO} 2$ & 52.23 & 53.15 & 53.37 & 53.45 & 53.83 & 54.11 & 55.42 & 55.46 & 55.56 & 56.06 \\
\hline $\mathrm{TiO} 2$ & .66 & .68 & .69 & .68 & .59 & .59 & .56 & .76 & .77 & .65 \\
\hline Al 203 & 15.57 & 17.05 & 16.97 & 16.93 & 17.08 & 17.46 & 16.56 & 17.39 & 17.40 & 14.75 \\
\hline $\mathrm{Fe} 203$ & 2.70 & 3.27 & 2.97 & 2.55 & 2.84 & 2.33 & 1.75 & 2.27 & 2.31 & 1.59 \\
\hline Feo & 6.34 & 5.60 & 5.34 & 6.00 & 5.88 & 6.12 & 5.71 & 5.58 & 5.52 & 5.14 \\
\hline Mno & .16 & .13 & .13 & .14 & .12 & .13 & .13 & .12 & .12 & .09 \\
\hline $\mathrm{MgO}$ & 8.73 & 6.56 & 7.05 & 6.92 & 6.70 & 5.95 & 6.32 & 4.71 & 5.00 & 7.49 \\
\hline $\mathrm{CaO}$ & 9.63 & 8.79 & 8.84 & 9.05 & 8.91 & 8.59 & 8.45 & 8.32 & 8.11 & 7.86 \\
\hline $\mathrm{Na} 20$ & 2.59 & 2.77 & 2.69 & 2.88 & 2.85 & 3.01 & 2.81 & 2.90 & 2.93 & 2.69 \\
\hline $\mathrm{K} 20$ & .58 & .68 & .66 & .67 & .68 & .73 & .93 & 1.04 & 1.11 & 1.15 \\
\hline P205 & .09 & .10 & .10 & .09 & .10 & .11 & .11 & .12 & .12 & .11 \\
\hline LOI & .75 & .88 & 1.72 & .44 & .79 & .57 & .78 & 1.13 & 1.09 & 1.48 \\
\hline TOTAL & 100.03 & 99.76 & 100.53 & 99.80 & 100.47 & 99.90 & 99.73 & 99.80 & 100.04 & 99.17 \\
\hline $\mathrm{FeO}(\mathrm{t})$ & 8.76 & 8.54 & 8.02 & 8.30 & 8.44 & 8.22 & 7.29 & 7.62 & 7.60 & 5.56 \\
\hline Mg No.* & 71.05 & 67.94 & 70.17 & 67.27 & 67.00 & 63.40 & 66.36 & 60.07 & 61.75 & 72.20 \\
\hline \multicolumn{11}{|l|}{$\begin{array}{l}\text { TRACE } \\
\text { ELEMENTS } \\
\text { (PPM) }\end{array}$} \\
\hline $\mathrm{Ba}$ & 193 & 232 & 386 & 221 & 246 & 255 & 287 & 273 & 314 & 283 \\
\hline $\mathrm{Rb}$ & 12 & 17 & 16 & 17 & 18 & 19 & 29 & 33 & 35 & 46 \\
\hline Sr & 200 & 222 & 226 & 215 & 213 & 223 & 232 & 234 & 253 & 233 \\
\hline $\mathrm{Pb}$ & 8 & 4 & 16 & 6 & 2 & 3 & 14 & 14 & 11 & 7 \\
\hline $2 x$ & 50 & 59 & 68 & 58 & 57 & 64 & 70 & 76 & 83 & 102 \\
\hline $\mathrm{Nb}$ & 2 & 3 & 3 & 3 & 2 & 3 & - & 1 & n.d. & 4 \\
\hline$Y$ & 17 & 21 & 21 & 23 & 19 & 21 & 22 & 21 & 20 & 21 \\
\hline v & 254 & 265 & 235 & 261 & 262 & 242 & 208 & 233 & 218 & 192 \\
\hline $\mathrm{Cr}$ & 389 & 128 & 225 & 144 & 130 & 83 & 180 & 74 & 133 & 367 \\
\hline $\mathrm{Ni}$ & 1.35 & 53 & 83 & 50 & 48 & 37 & 70 & 59 & 45 & 121 \\
\hline $\mathrm{Cu}$ & 81 & 58 & 52 & 59 & 57 & 57 & 46 & 58 & 60 & 66 \\
\hline $2 n$ & 83 & 84 & 81 & 85 & 81 & 82 & 70 & 77 & 72 & 78 \\
\hline $\mathrm{Ga}$ & 15 & 17 & - & 17 & 17 & 20 & - & - & - & 16 \\
\hline $\mathrm{K} / \mathrm{Rb}$ & 385 & 332 & 342 & 327 & 314 & 319 & 266 & 262 & 263 & 208 \\
\hline $\mathrm{Rb} / \mathrm{Sr}$ & 0.07 & 0.08 & 0.07 & 0.08 & 0.08 & 0.09 & 0.12 & 0.14 & 0.14 & 0.18 \\
\hline Sr $87 / 86$ & .70478 & .70504 & .70525 & - & - & .70518 & - & - & - & - \\
\hline $100 \mathrm{Mg} / \mathrm{Mg}+$ & $+\mathrm{Fe} 2$ (mo & & & & & & & & ' & \\
\hline
\end{tabular}


BULK ROCK CHEMICAL DATA FROM MANGAWHERO FORMATION

\begin{tabular}{|c|c|c|c|c|c|c|c|c|c|c|}
\hline ANALYSIS * & 73 & 74 & 75 & 76 & 77 & 78 & 79 & 80 & 81 & 82 \\
\hline SAMPLE & L11 & $\mathrm{C}_{2}$ & E 3 & N 3 & LI & L3 & $\mathrm{J}_{3}$ & E2 & $M 17$ & M9 \\
\hline \multicolumn{11}{|l|}{ OXIDE WT } \\
\hline $\mathrm{SiO} 2$ & 56.95 & 57.16 & 57.22 & 57.27 & 57.40 & 57.87 & 57.88 & 57.91 & 58.07 & 58.09 \\
\hline $\mathrm{TiO} 2$ & .70 & .67 & .66 & .68 & .69 & .58 & .64 & .56 & .58 & .63 \\
\hline Al 203 & 16.53 & 16.96 & 15.54 & 15.43 & 17.12 & 17.42 & 16.31 & 15.49 & 13.49 & 14.08 \\
\hline $\mathrm{Fe} 203$ & 2.14 & 2.32 & 2.70 & 1.63 & 1.81 & 1.84 & 2.01 & 2.23 & 2.91 & 2.19 \\
\hline Feo & 5.00 & 5.13 & 4.85 & 5.32 & 5.20 & 5.12 & 4.97 & 5.05 & 3.79 & 4.44 \\
\hline $\mathrm{MnO}$ & .10 & .16 & .16 & .11 & .10 & .09 & .09 & .17 & .10 & .10 \\
\hline $\mathrm{MgO}$ & 5.06 & 4.89 & 5.92 & 6.95 & 4.65 & 4.14 & 5.17 & 6.12 & 8.37 & 7.90 \\
\hline $\mathrm{CaO}$ & 7.58 & 7.83 & 8.08 & 7.50 & 7.49 & 6.95 & 7.51 & 8.22 & 7.05 & 6.71 \\
\hline $\mathrm{Na} 20$ & 3.03 & 3.33 & 2.83 & 2.71 & 3.06 & 3.17 & 2.90 & 2.90 & 2.90 & 2.68 \\
\hline $\mathrm{K} 20$ & 1.23 & 1.02 & 1.20 & 1.39 & 1.20 & 1.19. & 1.14 & 1.21 & 1.45 & 1.51 \\
\hline P205 & .11 & .10 & .10 & .11 & .10 & .09 & .08 & .10 & .11 & .12 \\
\hline LOI & .91 & 1.16 & .55 & .96 & 1.56 & 1.20 & 1.04 & .56 & .82 & 1.56 \\
\hline TOTAL & 99.34 & 100.73 & 99.91 & 100.06 & 100.38 & 99.76 & 99.74 & 100.62 & 99.64 & 100.01 \\
\hline $\mathrm{FeO}(t)$ & 6.93 & 7.22 & 7.28 & 6.78 & 6.83 & 6.78 & 6.78 & 7.05 & 6.41 & 6.41 \\
\hline Mg No." & 64.33 & 62.94 & 68.51 & 69.95 & 61.44 & 59.03 & 64.96 & 68.35 & 79.74 & 76.02 \\
\hline \multicolumn{11}{|l|}{$\begin{array}{l}\text { TRACE } \\
\text { ELEMENTS } \\
\text { (Ppm) }\end{array}$} \\
\hline Ba & 355 & 252 & 299 & 335 & 294 & 461 & 282 & 301 & 279 & 328 \\
\hline $\mathrm{Rb}$ & 40 & 35 & 43 & 55 & 38 & 39 & 40 & 43 & 51 & 55 \\
\hline Sr & 268 & 237 & 330 & 245 & 256 & 241 & 236 & 332 & 297 & 283 \\
\hline $\mathrm{Pb}$ & 17 & 9 & 12 & 5 & 15 & 13 & 14 & 8 & 9 & 10 \\
\hline $2 r$ & 90 & 85 & 88 & 112 & 95 & 91 & 88 & 89 & 108 & 124 \\
\hline $\mathrm{Nb}$ & n.d. & - & - & 4 & 1 & 2 & n.d. & - & 4 & 4 \\
\hline$x$ & 22 & 22 & 22 & 21 & 20 & 21 & 20 & 23 & 18 & 17 \\
\hline v & 198 & 201 & 201 & 191 & 194 & 193 & 195 & 205 & 170 & 163 \\
\hline $\mathrm{Cr}$ & 185 & 90 & 215 & 280 & 88 & 61 & 172 & 229 & 470 & 411 \\
\hline $\mathrm{Ni}$ & 56 & 32 & 65 & 103 & 32 & 36 & 68 & 65 & 121 & 118 \\
\hline $\mathrm{Cu}$ & 41 & 59 & 70 & 40 & 60 & 81 & 56 & 69 & 82 & 75 \\
\hline $\mathrm{zn}$ & 68 & 74 & 73 & 66 & 71 & 86 & 69 & 69 & 71 & 67 \\
\hline $\mathrm{Ga}$ & - & - & - & 16 & - & - & - & - & 15 & 16 \\
\hline $\mathrm{K} / \mathrm{Rb}$ & 255 & 242 & 232 & 210 & 262 & 253 & 237 & 234 & 236 & 228 \\
\hline $\mathrm{Rb} / \mathrm{Sr}$ & 0.15 & 0.15 & 0.13 & 0.22 & 0.15 & 0.16 & 0.17 & 0.13 & 0.17 & 0.19 \\
\hline Sr $87 / 86$ & - & - & - & - & - & - & - & - &. .70472 & - \\
\hline
\end{tabular}


BULK ROCK CHEMICAL DATA FROM MANGAWHERO FORMATION

\begin{tabular}{|c|c|c|c|c|c|c|c|c|c|c|}
\hline ANALYSIS & 83 & 84 & 85 & 86 & 87 & 88 & 89 & 90 & 91 & 92 \\
\hline SAMPLE & P4 & P3 & $\mathrm{Cl}$ & T3 & M8' & L2 & M15 & 34 & 35 & N 4 \\
\hline \multicolumn{11}{|l|}{ OXIDE WT\& } \\
\hline SiO2 & 58.22 & 58.27 & 58.27 & 58.35 & 58.48 & 58.54 & 58.67 & 58.68 & 58.83 & 58.83 \\
\hline TiO2 & .73 & .73 & .67 & .72 & .63 & .68 & .63 & .76 & .79 & .69 \\
\hline Al 203 & 16.33 & 16.29 & 17.03 & 17.44 & 14.06 & 17.41 & 14.18 & 17.36 & 16.89 & 15.14 \\
\hline Fe 203 & 1.85 & 1.83 & 2.00 & 1.76 & 1.82 & 2.25 & 1.55 & 2.10 & 2.09 & 1.90 \\
\hline FeO & 4.36 & 4.40 & 5.32 & 4.80 & 4.58 & 4.82 & 4.89 & 3.90 & 4.31 & 4.76 \\
\hline Mno & .08 & .09 & .15 & .10 & .12 & .11 & .10 & .08 & .07 & .09 \\
\hline MgO & 5.06 & 5.56 & 4.41 & 3.60 & 7.85 & 3.75 & 7.37 & 3.39 & 3.77 & 6.70 \\
\hline $\mathrm{CaO}$ & 7.04 & 7.09 & 7.37 & 6.81 & 6.88 & 7.05 & 6.78 & 6.74 & 7.00 & 7.05 \\
\hline $\mathrm{Na} 20$ & 3.27 & 3.18 & 3.38 & 3.15 & 2.74 & 3.16 & 2.79 & 3.15 & 3.05 & 2.96 \\
\hline K 20 & 1.60 & 1.53 & 1.17 & 1.54 & 1.55 & 1.20 & 1.56 & 1.79 & 1.80 & 1.60 \\
\hline P205 & .14 & .14 & .09 & .12 & .12 & .10 & .13 & .13 & .15 & .13 \\
\hline LOI & .36 & .69 & .75 & 1.44 & .72 & 1.05 & 1.05 & 1.06 & .68 & .71 \\
\hline TOTAL & 99.04 & 99.80 & 100.61 & 99.83 & 99.55 & 100.12 & 99.70 & 99.14 & 99.43 & 100.56 \\
\hline $\mathrm{FeO}(\mathrm{t})$ & 6.03 & 6.05 & 7.12 & 6.39 & 6.22 & 6.85 & 6.30 & 5.79 & 5.19 & 6.47 \\
\hline Mg No." & 67.41 & 69.25 & 59.63 & 57.20 & 75.33 & 58.10 & 72.87 & 60.77 & 60.92 & 71.50 \\
\hline \multicolumn{11}{|l|}{$\begin{array}{l}\text { TRACE } \\
\text { ELEMENTS } \\
\text { (ppm) }\end{array}$} \\
\hline $\mathrm{Ba}$ & 350 & 366 & 280 & 323 & 316 & 311 & 328 & 409 & 396 & 339 \\
\hline $\mathrm{Rb}$ & 67 & 63 & 40 & 64 & 58 & 41 & 51 & 65 & 66 & 67 \\
\hline $\mathrm{Sr}$ & 254 & 252 & 227 & 230 & 278 & 234 & 277 & 275 & 279 & 229 \\
\hline $\mathrm{Pb}$ & 9 & 9 & 8 & 11 & 11 & 18 & 12 & 14 & 15 & 8 \\
\hline $2 r$ & 130 & 126 & 91 & 120 & 122 & 86 & 125 & 134 & 137 & 127 \\
\hline Nb & 5 & 5 & - & 5 & 5 & n.d. & 6 & 3 & 2 & 6 \\
\hline$x$ & 21 & 22 & 23 & 25 & 20 & 23 & 20 & 18 & 21 & 21 \\
\hline v & 177 & 176 & 228 & 190 & 166 & 181 & 168 & 169 & 186 & 177 \\
\hline $\mathrm{Cr}$ & 170 & 194 & 73 & 47 & 409 & 43 & 380 & 57 & 94 & 291 \\
\hline $\mathrm{Ni}$ & 65 & 75 & 27 & 18 & 116 & 28 & 104 & 32 & 52 & 94 \\
\hline $\mathrm{Cu}$ & 58 & 43 & 62 & 30 & 71 & 79 & 38 & 49 & 38 & 41 \\
\hline $2 n$ & 67 & 61 & 77 & 78 & 66 & 72 & 69 & 64 & 63 & 61 \\
\hline Ga & 18 & 17 & - & 17 & 15 & - & 17 & - & - & 16 \\
\hline $\mathrm{K} / \mathrm{Rb}$ & 198 & 202 & 243 & 200 & 222 & 243 & 212 & 229 & 226 & 198 \\
\hline $\mathrm{Rb} / \mathrm{Sr}$ & 0.26 & 0.25 & 0.18 & 0.28 & 0.21 & 0.18 & 0.22 & 0.24 & 0.24 & 0.29 \\
\hline Sr $87 / 86$ & - & - & - & - & - & - & - & - & - & - \\
\hline $100 \mathrm{Mg}$ & $21 \mathrm{~mol}$ & & & & & & & & & \\
\hline
\end{tabular}


BULK ROCK CHEMICAL DATA FROM MANGAWHERO FORMATION

\begin{tabular}{|c|c|c|c|c|c|c|c|c|c|c|}
\hline ANALYSIS & 93 & 94 & 95 & 96 & 97 & 98 & 99 & 100 & 101 & 102 \\
\hline SAMPLE & P6 & $c 3$ & J 6 & J7 & N2 & $\mathrm{J} 11$ & M15 & E1 & N1 & $\mathrm{J} 10$ \\
\hline \multicolumn{11}{|l|}{ OXIDE WT: } \\
\hline Si 02 & 58.83 & 58.99 & 59.06 & 59.06 & 59.10 & 59.18 & 59.39 & 59.81 & 59.95 & 60.17 \\
\hline TiO2 & .66 & .72 & .79 & .77 & .75 & .84 & .52 & .76 & .77 & .75 \\
\hline Al 203 & 14.39 & 15.83 & 16.91 & 17.19 & 15.33 & 16.12 & 16.41 & 17.92 & 15.24 & 16.74 \\
\hline $\mathrm{Fe} 203$ & 1.49 & 1.57 & 2.21 & 1.52 & 1.40 & 1.87 & 2.25 & 2.65 & 2.01 & 1.38 \\
\hline $\mathrm{FeO}$ & 4.96 & 5.45 & 4.00 & 4.06 & 4.88 & 4.43 & 3.52 & 4.07 & $4 \cdot 36$ & 4.49 \\
\hline MnO & .09 & .15 & .08 & .08 & .07 & .13 & .09 & .14 & .08 & .13 \\
\hline $\mathrm{MgO}$ & 7.29 & 4.52 & 3.74 & 4.14 & 5.74 & 3.35 & 4.96 & 2.60 & 5.43 & 3.27 \\
\hline $\mathrm{CaO}$ & 6.81 & 7.05 & 6.63 & 7.01 & 6.54 & 6.15 & 6.32 & 6.58 & 6.38 & 6.31 \\
\hline $\mathrm{Na} 20$ & 2.92 & 3.15 & 2.91 & 3.02 & 2.85 & 4.61 & 3.10 & 3.56 & 3.27 & 3.53 \\
\hline K20 & 1.63 & 1.76 & 1.85 & 1.59 & 1.72 & 2.11. & 1.50 & 1.61 & 1.85 & 1.88 \\
\hline P205 & .13 & .10 & .13 & .13 & .14 & .17 & .14 & .11 & .14 & .14 \\
\hline LOI & .68 & .77 & 1.07 & .83 & .86 & .59 & 1.19 & .57 & .60 & .54 \\
\hline TOTAL & 99.88 & 100.16 & 99.38 & 99.50 & 99.38 & 99.55 & 99.59 & 100.48 & 100.08 & 99.33 \\
\hline Feo(t) & 6.30 & 6.87 & 5.99 & 5.43 & 6.14 & 6.11 & 5.64 & 6.45 & 6.17 & 5.73 \\
\hline Mg No." & 72.37 & 60.17 & 62.49 & 64.50 & 67.70 & 57.40 & 70.94 & 53.24 & 68.94 & 56.48 \\
\hline \multicolumn{11}{|l|}{$\begin{array}{l}\text { TRACE } \\
\text { ELEMENTS } \\
(\mathrm{ppm})\end{array}$} \\
\hline Ba & 353 & 348 & 405 & 372 & 394 & 442 & 345 & 365 & $A \perp B$ & 406 \\
\hline $\mathrm{Rb}$ & 66 & 73 & 72 & 63 & 75 & 84 & 57 & 60 & 78 & 77 \\
\hline sr & 266 & 230 & 280 & 273 & 217 & 288 & 348 & 289 & 234 & 283 \\
\hline $\mathrm{Pb}$ & 10 & 12 & 12 & 13 & 10 & 14 & 7 & 12 & 13 & 13 \\
\hline $2 r$ & 127 & 130 & 137 & 130 & 140 & 146 & 115 & 118 & 153 & 140 \\
\hline Nb & 5 & - & 4 & 3 & 5 & 4 & 5 & - & 6 & - \\
\hline$Y$ & 21 & 24 & 21 & 20 & 19 & 24 & 23 & 25 & 25 & 24 \\
\hline v & 151 & 180 & 181 & 194 & 180 & 194 & 168 & 198 & 173 & 173 \\
\hline $\mathrm{Cr}$ & 317 & 122 & 81 & 119 & 237 & 83 & 126 & 15 & 234 & 57 \\
\hline $\mathrm{Ni}$ & 89 & 35 & 48 & 76 & 76 & 32 & 53 & 11 & 77 & 31 \\
\hline $\mathrm{Cu}$ & 49 & 52 & 40 & 39 & 34 & 50 & 37 & 43 & 51 & 51 \\
\hline $\mathrm{Zn}$ & 58 & 71 & 58 & 64 & 62 & 69 & 63 & 75 & 68 & 54 \\
\hline Ga & 17 & - & - & - & 18 & 18 & 20 & - & 18 & 19 \\
\hline $\mathrm{K} / \mathrm{Rb}$ & 205 & 200 & 213 & 223 & 190 & 209 & 218 & 223 & 197 & 203 \\
\hline $\mathrm{Rb} / \mathrm{Sr}$ & 0.25 & 0.32 & 0.26 & 0.23 & 0.34 & 0.29 & 0.16 & 0.21 & 0.33 & 0.27 \\
\hline $\operatorname{Sr} 87 / 86$ & - & - & - & - & - & - & - & - & - & - \\
\hline
\end{tabular}


BULK ROCK CHEMICAL DATA FROM MANGAWHERO FORMATION

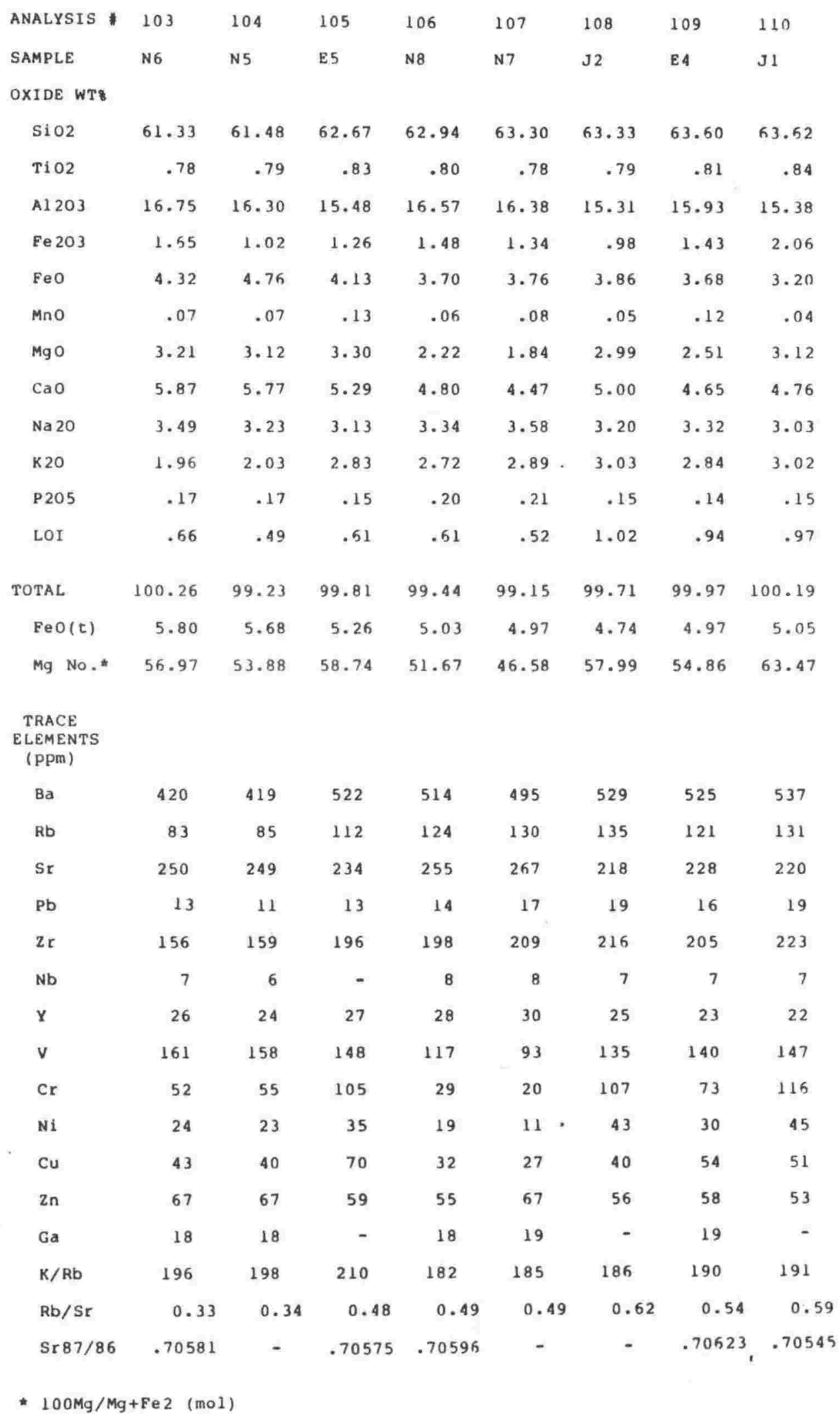


BULK ROCK CHEMICAL DATA FROM WHAKAPAPA FORMATION

\begin{tabular}{|c|c|c|c|c|c|c|c|c|c|c|}
\hline ANALYSIS & 111 & 112 & 113 & 114 & 115 & 116 & 117 & 118 & 119 & 120 \\
\hline SAMPLE & D2 & B6 & 84 & B5 & Q1PP & D1 & B3 & A 30 & 82 & EfPR \\
\hline \multicolumn{11}{|l|}{ OXIDE WT\& } \\
\hline SiO2 & 56.62 & 57.18 & 57.31 & 57.24 & 57.45 & 58.19 & 58.42 & 58.89 & 58.91 & 59.28 \\
\hline TiO2 & .70 & .67 & .68 & .68 & .65 & .71 & .67 & .77 & .67 & .78 \\
\hline Al 203 & 16.66 & 16.93 & 16.83 & 16.78 & 16.65 & 16.79 & 16.91 & 18.93 & 16.86 & 18.10 \\
\hline $\mathrm{Fe} 203$ & 1.71 & 1.69 & 2.04 & 2.12 & 1.66 & 1.76 & 1.77 & 1.62 & 1.70 & 1.51 \\
\hline FeO & 5.82 & 5.55 & 5.24 & 5.06 & 5.04 & 5.40 & 4.96 & 4.56 & 4.97 & 4.98 \\
\hline Mno & .15 & .12 & .12 & .11 & .08 & .10 & .11 & .08 & .10 & .09 \\
\hline $\mathrm{MgO}$ & 4.98 & 4.99 & 4.96 & 4.90 & 4.91 & 4.51 & 4.39 & 2.37 & 4.43 & 2.63 \\
\hline $\mathrm{CaO}$ & 7.71 & 7.75 & 7.59 & 7.58 & 7.52 & 7.24 & 6.95 & 7.15 & 6.95 & 6.62 \\
\hline $\mathrm{Na} 20$ & 3.35 & 3.33 & 3.12 & 3.15 & 3.15 & 3.18 & 3.55 & 3.62 & 3.41 & 3.51 \\
\hline K 20 & 1.33 & 1.38 & 1.36 & 1.35 & 1.32 & 1.52 & 1.60 & 1.58 & 1.57 & 1.62 \\
\hline P205 & .12 & .12 & .14 & .13 & .12 & .13 & .13 & .13 & .14 & .14 \\
\hline LOI & .96 & .77 & .64 & .62 & .55 & .61 & .58 & 1.28 & .55 & 1.00 \\
\hline
\end{tabular}

$\begin{array}{lrrrrrrrrrr}\text { TOTAL } & 100.11 & 100.48 & 100.03 & 99.82 & 99.30 & 100.14 & 100.04 & 100.98 & 100.26 & 100.36 \\ \text { FeO(t) } & 7.36 & 7.07 & 7.07 & 6.96 & 6.53 & 6.98 & 6.55 & 6.02 & 6.50 & 6.34 \\ \text { Mg No.* } & 60.39 & 61.57 & 62.78 & 63.31 & 63.45 & 59.81 & 61.20 & 48.08 & 61.37 & 48.48\end{array}$

TRACE
ELEMENTS

$\begin{array}{lrrrrrrrrrr}\mathrm{Ba} & 303 & 344 & 344 & 345 & 307 & 325 & 365 & 263 & 379 & 364 \\ \mathrm{Rb} & 52 & 53 & 51 & 52 & 50 & 63 & 62 & 53 & 62 & 56 \\ \mathrm{Sr} & 258 & 299 & 290 & 293 & 306 & 241 & 280 & 328 & 283 & 304 \\ \mathrm{~Pb} & 9 & 10 & 12 & 12 & 9 & 13 & 13 & 16 & 17 & 17 \\ \mathrm{Zr} & 94 & 111 & 108 & 100 & 102 & 115 & 123 & 113 & 130 & 114 \\ \mathrm{Nb} & - & - & - & 3 & 4 & - & - & - & - & 4 \\ \mathrm{Y} & 21 & 21 & 20 & 21 & 20 & 24 & 21 & 21 & 22 & 25 \\ \mathrm{~V} & 197 & 201 & 204 & 198 & 190 & 177 & 164 & 184 & 171 & 236 \\ \mathrm{Cr} & 95 & 76 & 75 & 78 & 99 & 76 & 73 & 18 & 74 & 20 \\ \mathrm{Ni} & 37 & 38 & 40 & 42 & 46 & 28 & 35 & 16 & 34 & 29 \\ \mathrm{Cu} & 58 & 59 & 44 & 63 & 55 & 44 & 57 & 55 & 67 & 51 \\ \mathrm{Zn} & 76 & 70 & 73 & 71 & 70 & 69 & 72 & 71 & 66 & 76 \\ \mathrm{Ga} & 18 & - & - & - & 16 & - & - & - & - & - \\ \mathrm{K} / \mathrm{Rb} & 212 & 222 & 221 & 227 & 219 & 232 & 224 & 247 & 222 & 240 \\ \mathrm{Rb} / \mathrm{Sr} & 0.20 & 0.17 & 0.18 & 0.18 & 0.16 & 0.26 & 0.22 & 0.16 & 0.22 & 0.18 \\ \mathrm{Sr} 87 / 86 & - & - & - & - & - & - & .70537 & - & - & - \\ & & & & & & & & & & 18\end{array}$

* $100 \mathrm{Mg} / \mathrm{Mg}+\mathrm{Fe} 2 \quad$ (mol) 
BULK ROCK CHEMICAL DATA FROM WHAKAPAPA FORMATION

\begin{tabular}{|c|c|c|c|c|c|c|c|c|c|}
\hline \multirow{2}{*}{121} & \multirow{2}{*}{122} & \multirow{2}{*}{123} & \multirow{2}{*}{124} & \multirow[b]{2}{*}{125} & \multirow[b]{2}{*}{126} & \multirow[b]{2}{*}{127} & \multirow[b]{2}{*}{128} & \multirow{2}{*}{129} & \multirow[b]{2}{*}{130} \\
\hline & & & & & & & & & \\
\hline B $10 P$ & н8 & G1 & $\underline{\mathrm{E} 6}$ & G4 & G 3 & G5 & H8A & $\mathrm{K} \perp \mathrm{G}$ & $\mathrm{N} \perp 12 \mathrm{~A}$ \\
\hline \multicolumn{10}{|c|}{ OXIDE WT\& } \\
\hline 59.45 & 59.67 & 59.73 & 59.92 & 59.99 & 60.00 & 60.01 & 60.19 & 63.39 & 65.42 \\
\hline .70 & .87 & .73 & .70 & .73 & .74 & .73 & .84 & .78 & .62 \\
\hline 16.61 & 17.20 & 17.15 & 17.55 & 16.67 & 15.94 & 16.49 & 16.98 & 15,13 & 15.34 \\
\hline 2.02 & 2.24 & 2.05 & 1.94 & 1.38 & 1.40 & 1.16 & 2.41 & 1.41 & .21 \\
\hline 3.99 & 4.42 & 7.79 & 4.79 & 4.95 & 5.19 & 5.00 & 4.12 & 3.52 & 3.62 \\
\hline .12 & .13 & .16 & .09 & .09 & .16 & .10 & .07 & .06 & .06 \\
\hline 3.29 & 3.07 & 3.31 & 3.21 & 3.80 & 4.12 & 3.84 & 2.89 & 2.91 & 2.19 \\
\hline 5.68 & 6.19 & 6.59 & 6.40 & 6.49 & 6.71 & 6.54 & 6.17 & 4.90 & 4.05 \\
\hline 3.40 & 3.44 & 3.25 & 3.39 & 3.27 & 3.04 & 3.13 & 3.79 & 3.23 & 3.25 \\
\hline 2.05 & 1.85 & 1.74 & 1.78 & 1.82 & 1.86. & 1.80 & 1.89 & 2.99 & 2.90 \\
\hline .14 & .13 & .11 & .14 & .17 & .12 & .13 & .16 & .16 & .12 \\
\hline 3.11 & 1.32 & .89 & .70 & .83 & 1.01 & .92 & .40 & .99 & 1.23 \\
\hline 100.56 & 100.53 & 100.50 & 100.38 & 100.19 & 100.29 & 99.85 & 99.91 & 99.57 & 99.01 \\
\hline 5.81 & 6.43 & 6.53 & 6.31 & 6.19 & 6.45 & 6.16 & 6.29 & 4.89 & 3.81 \\
\hline 59.50 & 55.31 & 55.19 & 55.64 & 57.77 & 58.59 & 57.78 & 55.56 & 58.89 & 51.88 \\
\hline \multicolumn{10}{|c|}{$\begin{array}{l}\text { TRACE } \\
\text { ELEMENTS } \\
(\text { Ppm) }\end{array}$} \\
\hline 429 & 439 & 372 & 375 & 424 & 416 & 406 & 386 & 551 & 508 \\
\hline 88 & 70 & 74 & 72 & 79 & 78 & 76 & 78 & 137 & 124 \\
\hline 221 & 262 & 244 & 250 & 290 & 288 & 287 & 257 & 221 & 211 \\
\hline 13 & 16 & 13 & 19 & 16 & 15 & 11 & 13 & 17 & 27 \\
\hline 155 & 151 & 127 & 127 & 141 & 135 & 140 & 148 & 218 & 180 \\
\hline 5 & - & - & - & - & - & 7 & 6 & 7 & 5 \\
\hline 23 & 25 & 25 & 24 & 24 & 24 & 24 & 25 & 26 & 28 \\
\hline 144 & 198 & 168 & 151 & 158 & 167 & 154 & 191 & 134 & 93 \\
\hline 65 & 21 & 32 & 47 & 63 & 60 & 49 & 19 & 109 & 57 \\
\hline 22 & 13 & 12 & 21 & 20 & 17 & 17 & 17 & 35 & 22 \\
\hline 39 & 58 & 28 & 30 & 33 & 33 & 30 & 42 & 34 & 49 \\
\hline 60 & 76 & 73 & 68 & 67 & 69 & 67 & 74 & 54 & 51 \\
\hline 17 & - & - & - & - & - & 18 & - & 17 & - \\
\hline 193 & 219 & 195 & 205 & 203 & 198 & 197 & 201 & 181 & 194 \\
\hline 0.40 & 0.27 & 0.30 & 0.29 & 0.27 & 0.27 & 0.26 & 0.30 & 0.62 & 0.59 \\
\hline - & - & - & - & .70589 & - & - & - & .70540 & .70617 \\
\hline
\end{tabular}


BULK ROCK CHEMICAL DATA FROM WHAKAPAPA FORMATION

\begin{tabular}{|c|c|}
\hline ANALYSIS * & 131 \\
\hline SAMPLE & $\mathrm{N} 112 \mathrm{~B}$ \\
\hline \multicolumn{2}{|l|}{ OXIDE WT? } \\
\hline $\mathrm{SiO} 2$ & 65.64 \\
\hline TiO2 & .62 \\
\hline A1 203 & 15.54 \\
\hline $\mathrm{Fe} 203$ & .86 \\
\hline $\mathrm{FeO}$ & 3.70 \\
\hline MnO & .06 \\
\hline MgO & 2.33 \\
\hline $\mathrm{CaO}$ & 4.16 \\
\hline $\mathrm{Na} 20$ & 3.59 \\
\hline K 20 & 2.92 \\
\hline P205 & .13 \\
\hline LOI & .92 \\
\hline TOTAL & 100.47 \\
\hline $\mathrm{FeO}(\mathrm{t})$ & 4.47 \\
\hline Mg No.* & 52.88 \\
\hline \multicolumn{2}{|l|}{$\begin{array}{l}\text { TRACE } \\
\text { ELEMENTS } \\
\text { (PPM) }\end{array}$} \\
\hline $\mathrm{Ba}$ & 527 \\
\hline $\mathrm{Rb}$ & 120 \\
\hline $\mathrm{Sr}$ & 212 \\
\hline $\mathrm{Pb}$ & 25 \\
\hline $\mathrm{zr}$ & 184 \\
\hline $\mathrm{Nb}$ & - \\
\hline $\mathrm{Y}$ & 26 \\
\hline v & 101 \\
\hline $\mathrm{Cr}$ & 63 \\
\hline $\mathrm{Ni}$ & 22 \\
\hline $\mathrm{Cu}$ & 32 \\
\hline $2 n$ & 55 \\
\hline $\mathrm{Ga}$ & - \\
\hline $\mathrm{K} / \mathrm{Rb}$ & 202 \\
\hline $\mathrm{Rb} / \mathrm{Sr}$ & 0.57 \\
\hline Sr $87 / 86$ & $\sim$ \\
\hline * $100 \mathrm{Mg} / \mathrm{Mg}$ & +Fe2 (mol) \\
\hline
\end{tabular}


BULK ROCK CHEMICAL DATA FROM RELATED VENTS

\begin{tabular}{|c|c|c|c|c|c|c|c|c|c|c|}
\hline ANALYSIS & 132 & 133 & 134 & 135 & 136 & 137 & 138 & 139 & 140 & 141 \\
\hline SAMPLE & WB & H5 & H7-1 & H6 & H7A & F 4 & H $7-2$ & H7 & F2 & P1 \\
\hline \multicolumn{11}{|l|}{ OXIDE WT\& } \\
\hline $\mathrm{SiO} 2$ & 52.18 & 55.34 & 56.31 & 56.45 & 56.53 & 56.79 & 56.82 & 57.01 & 57.05 & 57.07 \\
\hline $\mathrm{TiO} 2$ & .47 & .56 & .71 & .50 & .72 & .53 & .68 & .69 & .55 & .54 \\
\hline Al 203 & 12.68 & 15.00 & 14.71 & 15.42 & 14.52 & 14.50 & 14.36 & 14.29 & 15.09 & 14.94 \\
\hline $\mathrm{Fe} 203$ & 1.96 & 2.77 & 1.21 & 3.02 & 1.12 & 2.11 & 1.23 & 1.68 & 5.69 & 2.76 \\
\hline Feo & 6.58 & 5.06 & 5.70 & 4.95 & 5.88 & 6.07 & 5.71 & 5.54 & 2.80 & 5.24 \\
\hline MnO & .16 & .11 & .09 & .19 & .11 & .19 & .12 & .15 & .18 & .19 \\
\hline $\mathrm{MgO}$ & 13.15 & 7.13 & 8.01 & 6.24 & 8.97 & 7.07 & 8.77 & 8.64 & 6.77 & 6.53 \\
\hline $\mathrm{CaO}$ & 9.60 & 9.45 & 7.23 & 8.65 & 7.38 & 9.05 & 7.19 & 7.26 & 8.85 & 9.04 \\
\hline $\mathrm{Na} 2 \mathrm{O}$ & 1.64 & 2.21 & 2.92 & 2.25 & 2.88 & 2.32 & 2.63 & 2.75 & 2.52 & 2.49 \\
\hline K 20 & .43 & .61 & 1.36 & .69 & 1.49 & .66 & 1.38 & 1.45 & .62 & .69 \\
\hline P205 & .05 & .08 & .13 & .07 & .13 & .07 & .12 & .11 & .08 & .06 \\
\hline LOI & .70 & 1.14 & 1.32 & 2.12 & .56 & .73 & .45 & .83 & .85 & .81 \\
\hline TOTAL & 99.60 & 99.46 & 99.70 & 100.65 & 100.39 & 100.09 & 99.46 & 100.40 & 101.05 & 100.36 \\
\hline $\mathrm{FeO}(t)$ & 8.34 & 7.55 & 6.79 & 7.67 & 6.89 & 7.97 & 6.82 & 7.05 & 7.92 & 7.72 \\
\hline Mg No.* & 78.08 & 71.52 & 71.46 & 69.20 & 73.11 & 67.49 & 73.24 & 73.54 & 81.16 & 68.95 \\
\hline \multicolumn{11}{|l|}{$\begin{array}{l}\text { TRACE } \\
\text { ELEMENTS } \\
\text { (PPM) }\end{array}$} \\
\hline $\mathrm{Ba}$ & 123 & 180 & 350 & 193 & 332 & 141 & 324 & 361 & 148 & 147 \\
\hline $\mathrm{Rb}$ & 15 & 17 & 58 & 19 & 54 & 15 & 57 & 53 & 15 & 17 \\
\hline Sr & 348 & 450 & 276 & 454 & 302 & 342 & 275 & 274 & 391 & 389 \\
\hline $\mathrm{Pb}$ & 2 & 6 & 9 & 6 & 8 & 6 & 10 & 10 & 2 & 6 \\
\hline $\mathrm{zr}$ & 47 & 53 & 123 & 58 & 114 & 57 & 114 & 116 & 56 & 57 \\
\hline $\mathrm{Nb}$ & $1.5: 1$ & - & 5 & - & 3 & n.d. & 4 & 3 & - & - \\
\hline $\mathbf{Y}$ & 13 & 18 & 20 & 22 & 21 & 17 & 21 & 2 & 17 & 18 \\
\hline v & 217 & 220 & 186 & 211 & 184 & 214 & 182 & 182 & 138 & 222 \\
\hline $\mathrm{Cr}$ & 1070 & 234 & 415 & 200 & 591 & 271 & 510 & 529 & 228 & 200 \\
\hline Ni & 310 & 35 & 158 & 35 & 213 & 50 & 185 & 208 & 46 & 36 \\
\hline $\mathrm{Cu}$ & 83 & 73 & 78 & 70 & 95 & 104 & 70 & 92 & 82 & 96 \\
\hline $\mathrm{zn}$ & 77 & 71 & 69 & 70 & 67 & 74 & 67 & 68 & 67 & 74 \\
\hline $\mathrm{Ga}$ & 12 & - & 15 & - & 16 & 17 & 16 & - & 15 & - \\
\hline $\mathrm{K} / \mathrm{Rb}$ & 254 & 317 & 195 & 301 & 229 & 288 & 201 & 223 & 343 & 301 \\
\hline $\mathrm{Rb} / \mathrm{Sr}$ & 0.05 & 0.04 & 0.21 & 0.04 & 0.18 & 0.06 & 0.21 & 0.20 & 0.04 & $0.0:$ \\
\hline Sr $87 / 86$ & .70448 & .70423 & - & - & - & .70456 & - & .70476 & - & - \\
\hline
\end{tabular}


BULK ROCK CHEMICAL DATA FROM RELATED VENTS

\begin{tabular}{|c|c|c|c|}
\hline ANALYSIS & 142 & 143 & 144 \\
\hline SAMPLE & F3 & H4 & $L M-1$ \\
\hline \multicolumn{4}{|l|}{ OXIDE WTళ } \\
\hline $\mathrm{SiO} 2$ & 57.16 & 57.52 & 64.61 \\
\hline TiO2 & .55 & .61 & .51 \\
\hline A1 203 & 15.05 & 15.90 & 15.49 \\
\hline $\mathrm{Pe} 203$ & 6.35 & 1.42 & - \\
\hline $\mathrm{FeO}$ & 2.14 & 5.80 & - \\
\hline MnO & .17 & .16 & .07 \\
\hline $\mathrm{MgO}$ & 6.69 & 5.78 & 2.50 \\
\hline $\mathrm{CaO}$ & 9.00 & 9.16 & 4.09 \\
\hline $\mathrm{Na} 2 \mathrm{O}$ & 2.54 & 2.74 & 3.15 \\
\hline $\mathrm{K} 20$ & .67 & .79 & 2.95 \\
\hline P205 & .07 & .12 & .13 \\
\hline LOI & .60 & .70 & 2.07 \\
\hline TOTAL & 100.99 & 100.70 & 100.04 \\
\hline $\operatorname{FeO}(t)$ & 7.86 & 7.08 & 4.06 \\
\hline Mg No." & 84.78 & 63.97 & 56.43 \\
\hline \multicolumn{4}{|l|}{$\begin{array}{l}\text { TRACE } \\
\text { ELEMENTS } \\
(\mathrm{Ppm})\end{array}$} \\
\hline Ba & 148 & 232 & 463 \\
\hline $\mathrm{Rb}$ & 17 & 24 & 123 \\
\hline $\mathrm{Sr}$ & 376 & 482 & 218 \\
\hline $\mathrm{Pb}$ & 3 & 6 & 16 \\
\hline $2 r$ & 60 & 61 & 174 \\
\hline $\mathrm{Nb}$ & 3 & - & 6 \\
\hline $\mathrm{Y}$ & 17 & 19 & 26 \\
\hline v & 175 & 178 & 68 \\
\hline $\mathrm{Cr}$ & 210 & 152 & 82 \\
\hline Ni & 41 & 26 & 29 \\
\hline $\mathrm{Cu}$ & 105 & 75 & 25 \\
\hline $\mathrm{zn}$ & 73 & 60 & 52 \\
\hline Ga & 13 & - & 18 \\
\hline $\mathrm{K} / \mathrm{Rb}$ & 309 & 273 & 199 \\
\hline $\mathrm{Rb} / \mathrm{Sr}$ & 0.05 & 0.05 & 0.56 \\
\hline Sr $87 / 86$ & - & - & - \\
\hline * $100 \mathrm{Mg} / \mathrm{Mg}+$ & $\mathrm{Fe} 2$ (mol & & \\
\hline
\end{tabular}


BULK ROCK CHEMICAL DATA FOR ALTERED ROCKS

\begin{tabular}{|c|c|c|c|c|c|c|c|c|c|c|}
\hline ANALYSIS & 145 & 146 & 147 & 148 & 149 & 150 & 151 & 152 & 153 & 154 \\
\hline SAMPLE & $O P-1$ & $O P-2$ & H1O & A 35 & A 26 & H4A & A70 & A 45 & A 38 & A 32 \\
\hline \multicolumn{11}{|l|}{ OXIDE WT: } \\
\hline $\mathrm{SiO} 2$ & 39.83 & 40.46 & 44.64 & 52.45 & 52.82 & 54.14 & 54.16 & 55.50 & 55.68 & 57.42 \\
\hline TiO2 & .76 & .69 & .67 & .60 & .72 & .54 & .52 & .65 & .65 & .58 \\
\hline Al 203 & 21.54 & 18.87 & 18.88 & 16.33 & 18.31 & 14.69 & 16.58 & 17.57 & 17.10 & 18.70 \\
\hline $\mathrm{Fe} 203$ & - & - & 6.65 & 5.60 & 3.67 & 1.98 & 4.24 & 3.44 & 4.59 & 2.71 \\
\hline $\mathrm{FeO}$ & - & - & 2.74 & 1.74 & 5.04 & 5.56 & 3.16 & 4.14 & 3.72 & 1.98 \\
\hline MnO & .14 & .16 & .17 & .06 & .12 & .11 & .22 & .07 & .09 & .04 \\
\hline $\mathrm{MgO}$ & 4.19 & 6.23 & 5.38 & 5.36 & 4.79 & 8.78 & 4.35 & 4.33 & 4.37 & 2.35 \\
\hline $\mathrm{CaO}$ & 2.31 & 3.34 & 4.23 & 5.94 & 6.76 & 8.70 & 7.07 & 7.19 & 7.52 & 5.25 \\
\hline Na 20 & .70 & .79 & .59 & 2.00 & 2.64 & 1.99 & 2.76 & 2.95 & 2.77 & 3.04 \\
\hline K 20 & .12 & .12 & .25 & .73 & .60 & .38 & .74 & .75 & .90 & 1.02 \\
\hline P205 & .08 & .08 & .02 & .09 & .07 & .07 & .08 & .09 & .10 & .05 \\
\hline LOI & 20.65 & 19.68 & 15.36 & 8.79 & 4.94 & 2.42 & 5.50 & 2.26 & 2.67 & 6.03 \\
\hline TOTAL & 100.75 & 100.63 & 99.58 & 99.69 & 100.48 & 99.36 & 99.48 & 98.95 & 100.16 & 99.17 \\
\hline$F e O(t)$ & 9.38 & 9.19 & 8.73 & 6.78 & 8.34 & 7.34 & 6.97 & 7.23 & 7.85 & 4.42 \\
\hline Mg No.* & - & 58.75 & 77.77 & - & - & 73.78 & - & 65.08 & - & - \\
\hline \multicolumn{11}{|l|}{$\begin{array}{l}\text { TRACE } \\
\text { ELEMENTS } \\
\text { (PPm) }\end{array}$} \\
\hline $\mathrm{Ba}$ & - & 190 & - & 209 & 203 & 129 & 209 & 251 & 255 & 247 \\
\hline $\mathrm{Rb}$ & - & 10 & - & 23 & 20 & 7 & 26 & 22 & 27 & 35 \\
\hline $\mathrm{Sr}$ & - & 198 & - & 210 & 255 & 557 & 194 & 213 & 213 & 190 \\
\hline $\mathrm{Pb}$ & - & 0 & - & 13 & 14 & 2 & 4 & 4 & 14 & 11 \\
\hline $2 r$ & - & 87 & - & 60 & 61 & 50 & 62 & 62 & 62 & 67 \\
\hline $\mathrm{Nb}$ & - & 4 & - & - & - & 2 & 2 & 3 & - & - \\
\hline $\mathbf{Y}$ & - & 0 & - & 25 & 27 & 14 & 17 & 22 & 22 & 26 \\
\hline v & - & 154 & - & 255 & 225 & 185 & 168 & 247 & 206 & 272 \\
\hline $\mathrm{Cr}$ & - & 153 & - & 89 & 54 & 353 & 58 & 63 & 68 & 79 \\
\hline $\mathrm{Ni}$ & - & 51 & - & 76 & 29 & 79 & 35 & 26 & 32 & 24 \\
\hline $\mathrm{Cu}$ & - & 135 & - & 63 & 56 & 71 & 29 & 60 & 69 & 73 \\
\hline $2 n$ & - & 74 & - & 88 & 81 & 59 & 80 & 60 & 79 & 68 \\
\hline Ga & - & - & $=$ & - & - & 16 & 16 & 18 & - & - \\
\hline $\mathrm{K} / \mathrm{Rb}$ & - & 100 & - & 263 & 249 & 451 & 236 & 287 & 277 & 242 \\
\hline $\mathrm{Rb} / \mathrm{Sr}$ & - & 0.05 & - & 0.11 & 0.08 & 0.01 & 0.13 & 0.10 & 0.13 & 0.18 \\
\hline Sr $87 / 86$ & - & - & - & - & - & - & - & - & - & - \\
\hline
\end{tabular}


BULK ROCK CHEMICAL DATA FOR ALTERED ROCKS

\begin{tabular}{|c|c|c|c|}
\hline ANALYSIS & 155 & 156 & 157 \\
\hline SAMPLE & A 33 & A 34 & A 31 \\
\hline \multicolumn{4}{|l|}{ OXIDE WT\& } \\
\hline $\mathrm{SiO} 2$ & 57.54 & 58.48 & 58.96 \\
\hline TiO2 & .59 & .59 & .52 \\
\hline Al 203 & 17.87 & 18.76 & 18.55 \\
\hline $\mathrm{Fe} 203$ & 3.8177 & 4.30 & 2.76 \\
\hline Feo & 2.382 & 1.30 & 3.64 \\
\hline Mno & .05 & .01 & .10 \\
\hline $\mathrm{MgO}$ & 2.54 & 1.37 & 3.07 \\
\hline $\mathrm{CaO}$ & 2.93 & 4.55 & 7.28 \\
\hline $\mathrm{Na} 2 \mathrm{O}$ & 1.47 & 2.66 & 3.51 \\
\hline K 20 & .73 & .78 & .99 \\
\hline P205 & .05 & .04 & .09 \\
\hline LOI & 10.80 & 7.82 & 1.11 \\
\hline TOTAL & 100.76 & 100.66 & 100.58 \\
\hline $\mathrm{Feo}(t)$ & 5.81 & 5.16 & 6.13 \\
\hline $\mathrm{Mg} \mathrm{No} . *$ & - & - & - \\
\hline \multicolumn{4}{|l|}{$\begin{array}{l}\text { TRACE } \\
\text { ELEMENTS } \\
(\mathrm{pPm})\end{array}$} \\
\hline $\mathrm{Ba}$ & 265 & 227 & 250 \\
\hline $\mathrm{Rb}$ & 34 & 22 & 33 \\
\hline $\mathrm{Sr}$ & 136 & 192 & 236 \\
\hline $\mathrm{Pb}$ & 11 & 13 & 16 \\
\hline $2 \mathrm{r}$ & 71 & 66 & 63 \\
\hline $\mathrm{Nb}$ & - & - & - \\
\hline$Y$ & 17 & 15 & 19 \\
\hline v & 217 & 221 & 158 \\
\hline $\mathrm{Cr}$ & 68 & 76 & 31 \\
\hline $\mathrm{Ni}$ & 33 & 35 & 18 \\
\hline $\mathrm{Cu}$ & 106 & 50 & 23 \\
\hline $2 n$ & 88 & 32 & 73 \\
\hline Ga & - & - & - \\
\hline $\mathrm{K} / \mathrm{Rb}$ & 178 & 294 & 249 \\
\hline $\mathrm{Rb} / \mathrm{Sr}$ & 0.25 & 0.11 & 0.14 \\
\hline Sr87/86 & - & - & - \\
\hline - $100 \mathrm{Mg} / \mathrm{Mg}+$ & +Fe2 (mol) & & \\
\hline
\end{tabular}


BULK ROCK CHEMICAL DATA FOR XENOLITHS

\begin{tabular}{|c|c|c|c|c|c|c|c|c|c|c|}
\hline ANALYSIS & 158 & 159 & 160 & 161 & 162 & 163 & 164 & 165 & 166 & 167 \\
\hline SAMPLE & $W X-4$ & B10XB & BXA & $\mathrm{B} \times 10$ & B $10 \times E$ & $B 6 \times A$ & B $3 \times A$ & $x x$ & B10XH & $\mathrm{G} 1 \mathrm{X}$ \\
\hline \multicolumn{11}{|l|}{ OXIDE WT\& } \\
\hline $\mathrm{SiO} 2$ & 36.30 & 42.23 & 44.28 & 47.95 & 48.17 & 48.88 & 49.11 & 49.20 & 49.23 & 49.38 \\
\hline TiO2 & 4. 34 & 1.40 & .45 & 1.37 & 1.50 & 1.45 & 1.19 & .34 & 1.06 & .20 \\
\hline A1 203 & 20.28 & 26.11 & 21.09 & 18.03 & 16.56 & 25.42 & 24.66 & 19.19 & 25.18 & 20.01 \\
\hline $\mathrm{Fe} 203$ & 5.42 & 8.17 & 0.00 & 3.15 & 1.74 & 4.97 & 4.72 & 1.04 & 2.95 & 1.43 \\
\hline FeO & 13.78 & 3.55 & 0.00 & 5.12 & 10.96 & 2.91 & 2.91 & 6.54 & 4.26 & 5.74 \\
\hline MnO & .54 & .26 & 0.00 & .13 & .29 & .07 & .06 & .11 & .12 & .14 \\
\hline $\mathrm{MgO}$ & 8.98 & 3.91 & .09 & 6.64 & 8.55 & 2.50 & 2.56 & 7.32 & 2.96 & 8.10 \\
\hline $\mathrm{CaO}$ & 5.71 & 5.54 & .12 & 13.24 & 9.17 & 8.77 & 9.74 & 8.54 & 4.19 & 11.69 \\
\hline $\mathrm{Na} 20$ & 1.30 & 2.67 & 4.57 & 2.01 & 1.46 & 3.58 & 2.88 & 2.29 & 4.50 & 1.49 \\
\hline K 20 & .62 & 4.10 & 1.67 & .23 & .10 & .57 & .51 & .15 & 3.72 & .29 \\
\hline P205 & .30 & .09 & .09 & .18 & .05 & .20 & .21 & .01 & .26 & .03 \\
\hline LOI & 1.43 & 1.97 & 26.19 & 1.40 & 1.41 & .81 & 1.44 & 4.99 & .58 & 0.00 \\
\hline TOTAL & 100.00 & 100,00 & $100.24^{8} 1$ & 100.45 & 100.06 & 100.12 & 99.99 & 99.82 & 99.11 & 98.50 \\
\hline$F e O(t)$ & 19.56 & 10.91 & .20 & 8.95 & 12.52 & 7.38 & 7.16 & 7.48 & 6.92 & 7.03 \\
\hline $\mathrm{Mg} \mathrm{No} \cdot{ }^{*}$ & 53.73 & 66.25 & 100.00 & 65.91 & 58.16 & 60.49 & 61.05 & 66.61 & 55.32 & 71.55 \\
\hline \multicolumn{11}{|l|}{$\begin{array}{l}\text { TRACE } \\
\text { ELEMENTS } \\
\text { (ppm) }\end{array}$} \\
\hline $\mathrm{Ba}$ & 340 & 924 & 135 & 127 & 92 & 766 & 241 & 83 & 1650 & 80 \\
\hline $\mathrm{Rb}$ & 45 & 171 & 9 & 9 & 2 & 18 & 19 & 5 & 144 & 10 \\
\hline $\mathrm{Sr}$ & 356 & 272 & 146 & 374 & 207 & 899 & 552 & 236 & 713 & 287 \\
\hline $\mathrm{Pb}$ & 29 & 31 & 4 & 3 & 5 & 18 & 11 & 3 & 22 & 5 \\
\hline $\mathrm{zr}$ & 259 & 71 & 46 & 69 & 19 & 463 & 187 & 17 & 285 & 16 \\
\hline $\mathrm{Nb}$ & 23 & n.d. & - & 6 & n.d. & 11 & 6 & 1 & 13 & - \\
\hline$Y$ & 66 & 20 & 1 & 23 & 11 & 29 & 18 & 10 & 31 & 9 \\
\hline v & 517 & 397 & 107 & 264 & 363 & 220 & 227 & 220 & 164 & 119 \\
\hline $\mathrm{Cr}$ & 154 & 523 & 162 & 266 & 234 & 76 & 109 & 133 & 66 & 214 \\
\hline $\mathrm{Ni}$ & 76 & 102 & 3 & 72 & 101 & 24 & 37 & 47 & 25 & 58 \\
\hline $\mathrm{Cu}$ & 217 & 140 & 13 & 66 & 10 & 49 & 37 & 37 & 36 & 95 \\
\hline $\mathrm{zn}$ & 287 & 192 & 4 & 71 & 96 & 90 & 118 & 65 & 114 & 80 \\
\hline Ga & 30 & 27 & 4 & 22 & 19 & - & - & 19 & 38 & 15 \\
\hline $\mathrm{K} / \mathrm{Rb}$ & 114 & 199 & 1374 & 212 & 415 & 263 & 223 & 249 & 215 & 241 \\
\hline $\mathrm{Rb} / \mathrm{Sr}$ & 0.13 & 0.63 & 0.06 & 0.02 & 0.01 & 0.02 & 0.03 & 0.02 & 0.20 & 0.03 \\
\hline $5 \times 87 / 86$ & - & .71004 & ${ }^{-}$ & - & - & - & - & - &.$^{-}$ & .70593 \\
\hline
\end{tabular}

a $\mathrm{S}=2.93 \quad \mathrm{O}=\mathrm{S}=1.47$ original total $=101.71$ 
BULK ROCK CHEMICAL DATA FOR XENOLITHS

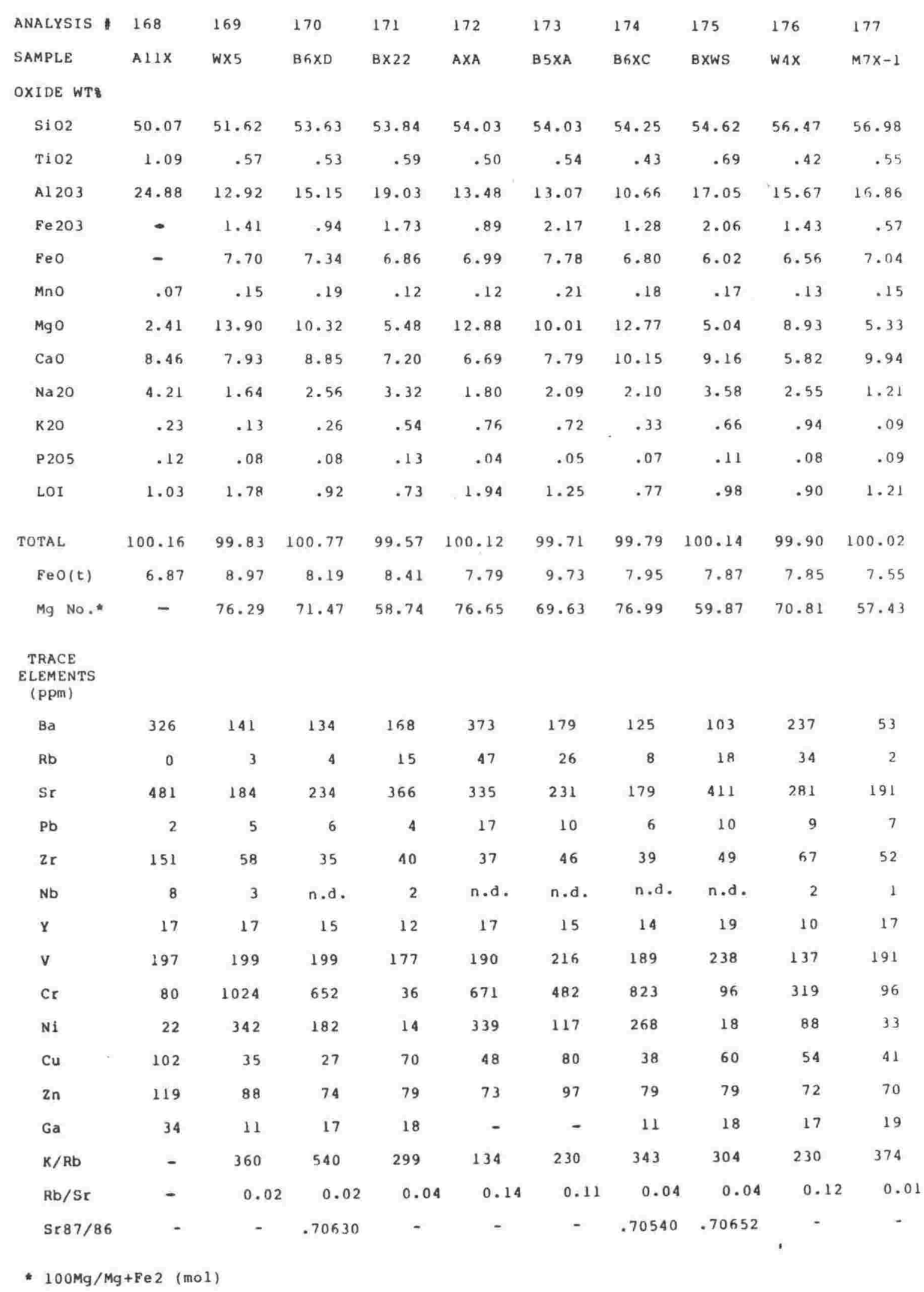


BULK ROCK CHEMICAL DATA FOR XENOLITHS

\begin{tabular}{|c|c|c|c|c|c|c|c|}
\hline ANALYSIS & 178 & 179 & 180 & 181 & 182 & 183 & 184 \\
\hline SAMPLE & $B \times 24$ & $\mathrm{~A} \perp 4 \mathrm{X}$ & T5x & $\mathrm{N} 112 \mathrm{C}$ & ARGX & H $7 X-21$ & $F x-Q$ \\
\hline \multicolumn{8}{|l|}{ OXIDE WTE } \\
\hline $\mathrm{SiO} 2$ & 57.95 & 59.34 & 62.19 & 64.58 & 67.22 & 72.09 & 96.68 \\
\hline $\mathrm{TiO} 2$ & .61 & 1.09 & .45 & .78 & .59 & .41 & 0.00 \\
\hline A1 203 & 18.74 & 18.36 & 18.64 & 16.91 & 16.82 & 12.81 & .77 \\
\hline $\mathrm{Fe} 203$ & 1.32 & 2.56 & .94 & 1.02 & .79 & .47 & - \\
\hline $\mathrm{FeO}$ & 5.70 & 123.76 & 4.40 & 4.46 & 3.26 & 2.45 & - \\
\hline Mno & .10 & .14 & .08 & .07 & .06 & .02 & .02 \\
\hline $\mathrm{MgO}=4=$ & 3.88 & 2.10 & 2.06 & 1.71 & 1.29 & .95 & .16 \\
\hline $\mathrm{CaO}$ & 7.33 & 8.19 & 6.15 & 2.18 & .95 & 1.07 & .31 \\
\hline $\mathrm{Na} 20$ & 2.21 & .47 & 3.73 & 3.11 & 4.35 & 3.09 & .19 \\
\hline K 20 & .50 & .09 & .50 & 2.69 & 3.02 & 2.12 & .07 \\
\hline P205 & .10 & .26 & .10 & .16 & .13 & .08 & .03 \\
\hline LOI & 1.83 & 4.36 & .55 & 3.14 & .44 & 3.25 & 0.00 \\
\hline TOTAL & 100.27 & 100.72 & 99.89 & 100.81 & 98.92 & 98.81 & 98.63 \\
\hline $\mathrm{FeO}(\mathrm{t})$ & 6.89 & 6.05 & 5.24 & 5.38 & 3.97 & 2.87 & .40 \\
\hline Mg No.* & 54.81 & 49.88 & 45.48 & 40.59 & 41.35 & 40.86 & - \\
\hline \multicolumn{8}{|l|}{$\begin{array}{l}\text { TRACE } \\
\text { ELEMENTS } \\
(\text { PPm })\end{array}$} \\
\hline $\mathrm{Ba}$ & 328 & 334 & 240 & 651 & 567 & 356 & - \\
\hline $\mathrm{Rb}$ & 54 & 4 & 3 & 109 & 133 & 84 & - \\
\hline $\mathrm{sr}$ & 782 & 350 & 345 & 215 & 182 & 191 & - \\
\hline $\mathrm{Pb}$ & 10 & 18 & 11 & 23 & 23 & 16 & - \\
\hline $\mathrm{zr}$ & 69 & 302 & 84 & 191 & 260 & 198 & - \\
\hline $\mathrm{Nb}$ & 3 & 8 & 3 & 10 & 10 & 7 & - \\
\hline$Y$ & 16 & 36 & 15 & 28 & 27 & 20 & - \\
\hline v & 196 & 177 & 101 & 130 & 81 & 50 & - \\
\hline $\mathrm{Cr}$ & 29 & 34 & 1 & 67 & 52 & 27 & - \\
\hline $\mathrm{Ni}$ & 8 & 18 & 8 & 19 & 20 & 10 & - \\
\hline $\mathrm{Cu}$ & 35 & 254 & 30 & 26 & 20 & 15 & - \\
\hline $2 n$ & 72 & 86 & 60 & 75 & 59 & 49 & - \\
\hline Ga & 21 & - & 18 & - & 21 & 12 & - \\
\hline $\mathrm{K} / \mathrm{Rb}$ & 77 & 187 & 1384 & 205 & 189 & 210 & - \\
\hline $\mathrm{Rb} / \mathrm{Sr}$ & 0.07 & 0.01 & 0.01 & 0.51 & 0.73 & 0.44 & - \\
\hline $\mathrm{Sr} 87 / 86$ & - & - & - & - & .71255 & .70975 & - \\
\hline
\end{tabular}

* $100 \mathrm{Mg} / \mathrm{Mg}+\mathrm{Fe} 2$ (mol) 


\section{III-1}

\section{APPENDIX 11I: MINERAL ANALYSES FROM LAVAS AND PTROCLASTICS OF RUAPEHU VOLCANO AND RELATED VENTS.}

\section{INTRODUCTION.}

Electron microprobe analyses of phenocryst and groundmass minerals are given. Analyses of mineral groups (olivine, clinopyrozene, etc.) are tabulated in the same order as bulk rock analyses of Appendix II, to allow easy retrieval of mineral data. Thus, "bulk rock 2701 " refers to analysis 27 of Appendir 11 , and the " 01 " is for computer tabulation purposes only. Locations and petrographic descriptions of bulk rocks are also found in Appendix II.

\footnotetext{
Mineral analyses are designated under 'SPEC' as follows:

CORE phenocryst core

RIM phenocryst rim

RR reaction rim on phenocryst

I inter mediate between core and rim of phenocryst

M microphenocryst; grains generally between 300 and 100 microns

$\mathrm{X}$ xenocryst; embayed grain or grain in aggregate

G;GMS groundmass; grains generally 70 to 20 microns

- a line connecting analyses indicates analyses on the same grain

OL if a mineral name is given under SPBC, the analyzed grain was an inclusion in this mineral.
} 


\section{ANALYTICAL METHODS.}

All analyses were made by the author during 1979-1982, using a JBOL 733 Superprobe housed in the Analytical Facility, Victoria University of Wellington.

Instrumental settings were:

Accelerating potential: 15 kilovolts

Specimen current $\quad: 1.2 \times 10(-08)$ amp, for minerals

: $1.5 \times 10(-09)$ amp, for glass analyses

Beam diameter $\quad: 3$ and 10 microns for minerals

: 10 to 50 microns for glass.

Analyses were corrected for absorption, fluorescence, and atomic number using the method of Bence and Albee (1968), with alpha correction factors after Kushiro and Nakamura (1970), and with additional corrections for dead time, background and probe current drift. Data were reduced using a computer program supplied with the J5OL 733 , and modified by Teruo Watanabe and Matsayuki Otsuki.

Natural and synthetic minerals and alloys were used as standards. Kakanui Augite was the internal standard most often used by the author to check analysis quality. Paul Morris compiled the following list of Kakanui Augite analyses made by JBOL 733 users between 1979 and 1981; the author contributed $16 \%$ of these analyses. 
Kakanui Augite analyses (compiled by P. Morris. Victoria University):

III-1b

\begin{tabular}{|c|c|c|c|c|c|c|c|}
\hline & n & $\overline{\mathbf{I}}$ & s.d. & $\max$. & $\min$. & range & tabular \\
\hline $\mathrm{SiO} 2$ & 87 & 50.56 & 0.441 & 51.91 & 49.85 & 2.06 & 50.73 \\
\hline Ti02 & 87 & 0.81 & 0.064 & 0.99 & 0.55 & 0.44 & 0.74 \\
\hline Al203 & 87 & 8.29 & 0.203 & 8.83 & 7.69 & 1.14 & 7.86 \\
\hline $\mathrm{FeO}$ & 87 & 6.26 & 0.180 & 6.61 & 5.64 & 0.97 & 6.77 \\
\hline MnO & 87 & 0.13 & 0.038 & 0.25 & 0.02 & 0.23 & 0.13 \\
\hline $\mathrm{MgO}$ & 87 & 16.08 & 0.257 & 16.74 & 15.30 & 1.44 & 16.65 \\
\hline $\mathrm{CaO}$ & 87 & 16.04 & 0.256 & 16.49 & 15.29 & 1.20 & 15.82 \\
\hline $\mathrm{Na} 2 \mathrm{O}$ & 87 & 1.31 & 0.082 & 1.52 & 1.04 & 0.47 & 1.27 \\
\hline K20 & 87 & 0.01 & 0.010 & 0.05 & 0.00 & 0.05 & - \\
\hline Cr203 & 80 & 0.15 & 0.031 & 0.22 & 0.08 & 0.14 & - \\
\hline $\mathrm{NiO}$ & 80 & 0.04 & 0.034 & 0.13 & 0.00 & 0.13 & - \\
\hline TOTAL & & 99.68 & & & & & 99.97 \\
\hline
\end{tabular}

Theoretical detection limits are given for oxides of interest. These are generalized values since detection limits are calculated on the basis of peak/ background ratios and peak intensity differences between unknowns and standards. Hence, detection limits will vary slightly from one analysis to another.

Theoretical detection limits (weight percent):

$\begin{array}{llllll}\mathrm{SiO} 2 & 0.10 & \mathrm{MnO} & 0.12 & \mathrm{~K} 20 & 0.05 \\ \mathrm{TiO} 2 & 0.09 & \mathrm{MgO} & 0.10 & \mathrm{NiO} & 0.12 \\ \mathrm{Al203} & 0.10 & \mathrm{C} \Omega 0 & 0.06 & \mathrm{Cr} 203 & 0.14 \\ \mathrm{FeO}(\mathrm{t}) & 0.12 & \mathrm{Na20} & 0.09 & & \end{array}$

Analyses have been reported to $\mathbf{2}$ decimal places, but are significant only in the first decimal place. 


\section{REFERENCES}

Bence, A.E., and Albee, A.L., 1968. Empirical correction factors for the electron microanalysis of silicates and oxides. Journal of Geology, 76, 382-403.

Kushiro, I., and Nakamura, Y., 1970. Petrology of some lunar crystalline rocks. Proceedings Apollo 11 Lunar Science Conference, 1. 607-626. 
II I-1

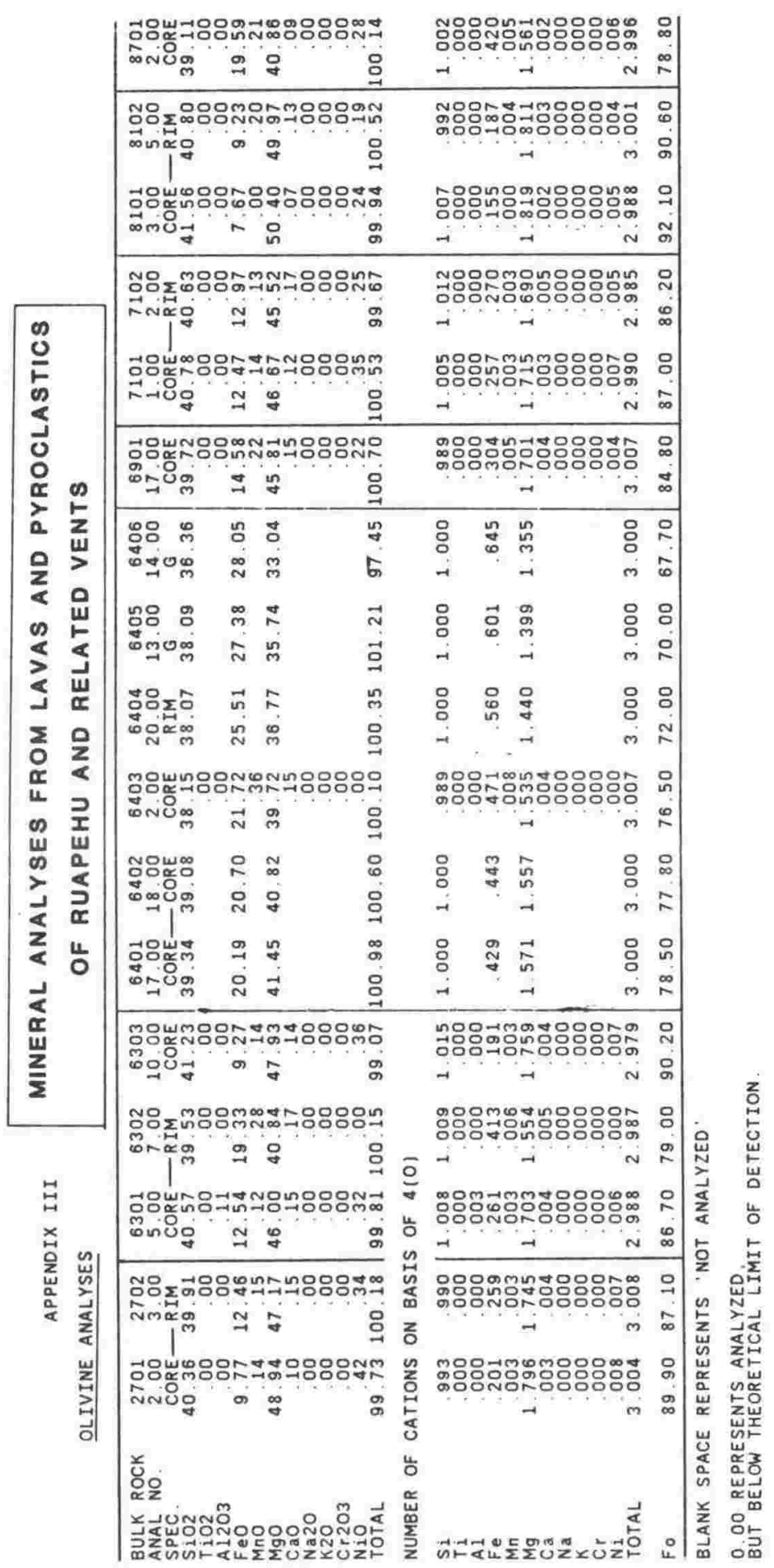




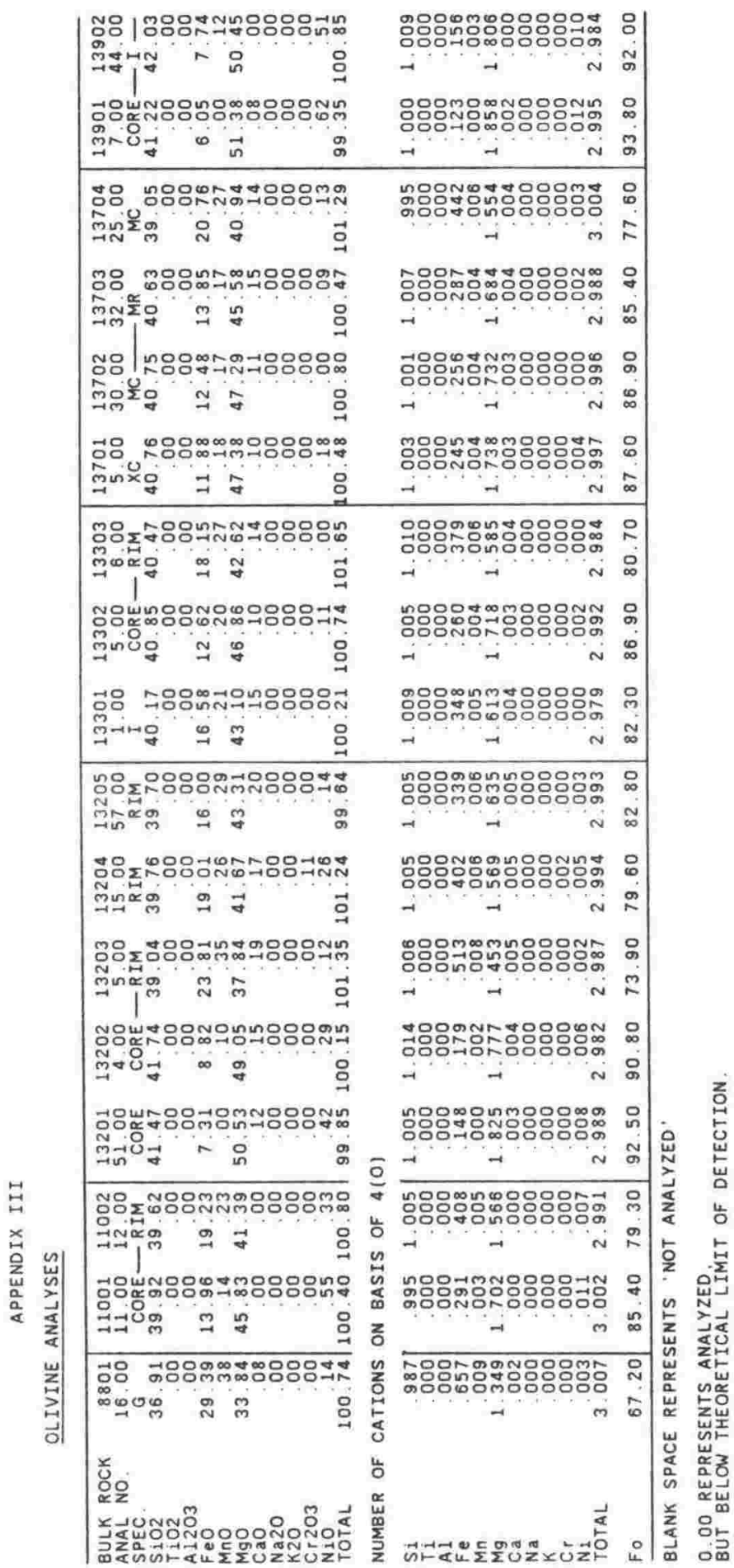


II I-3

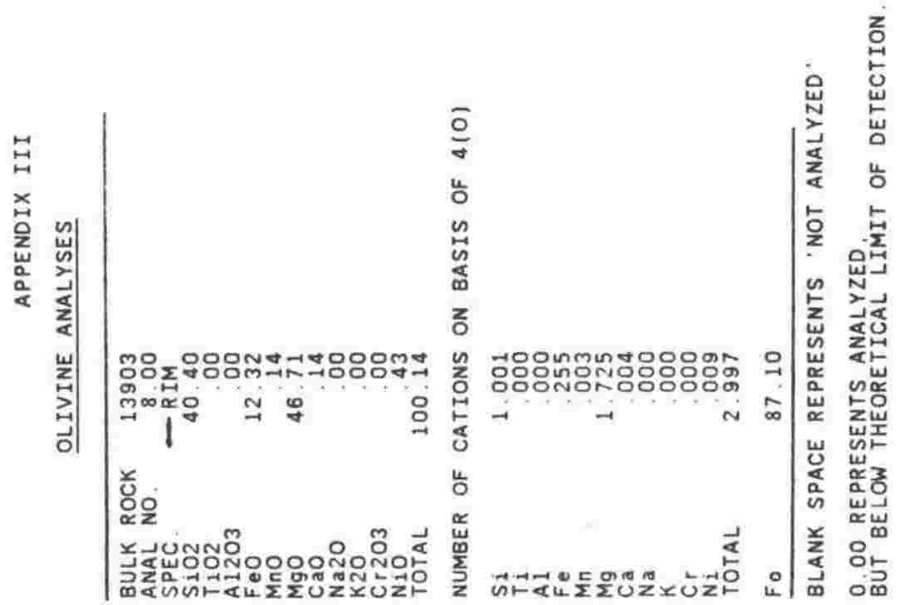




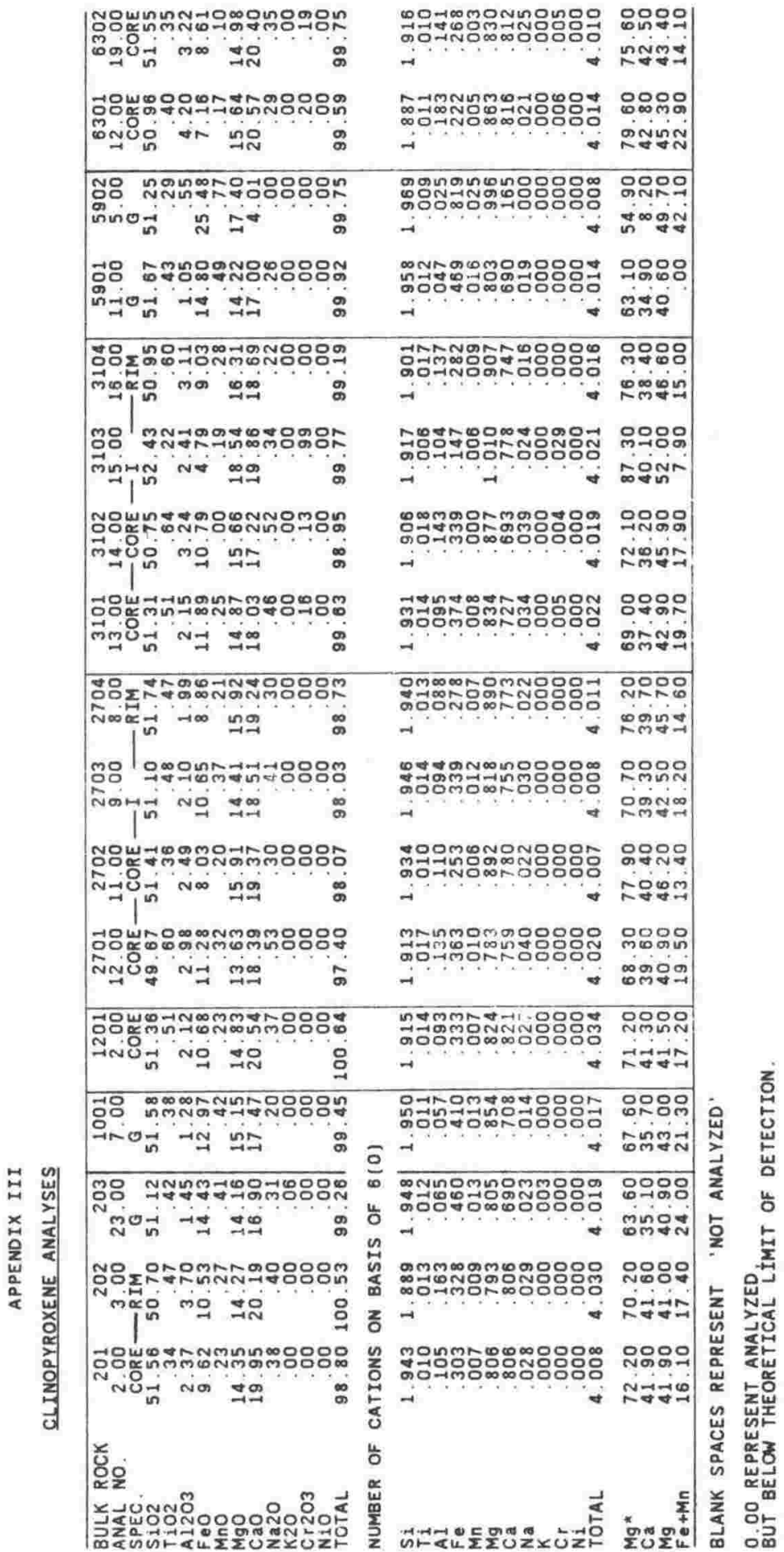




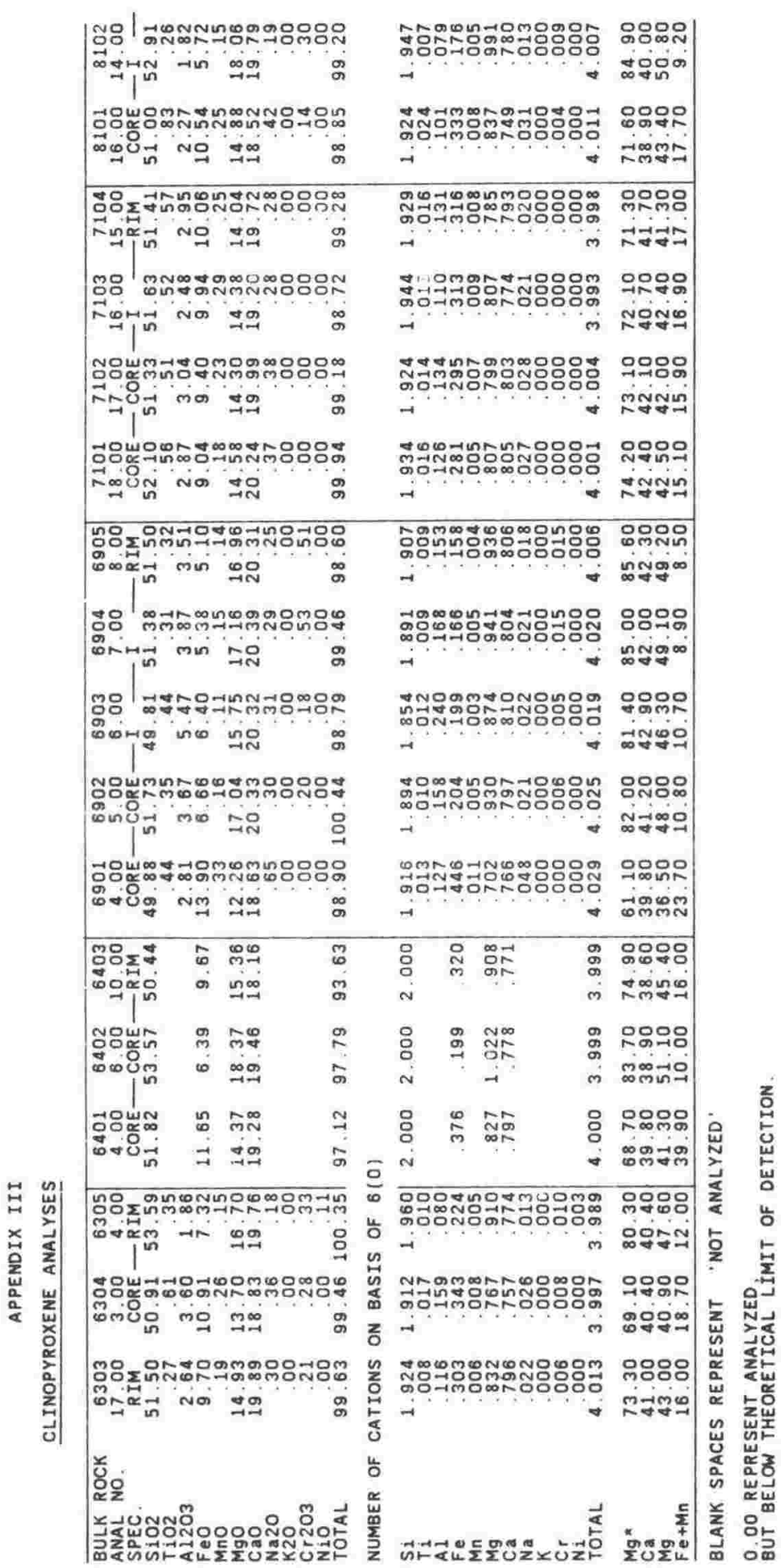




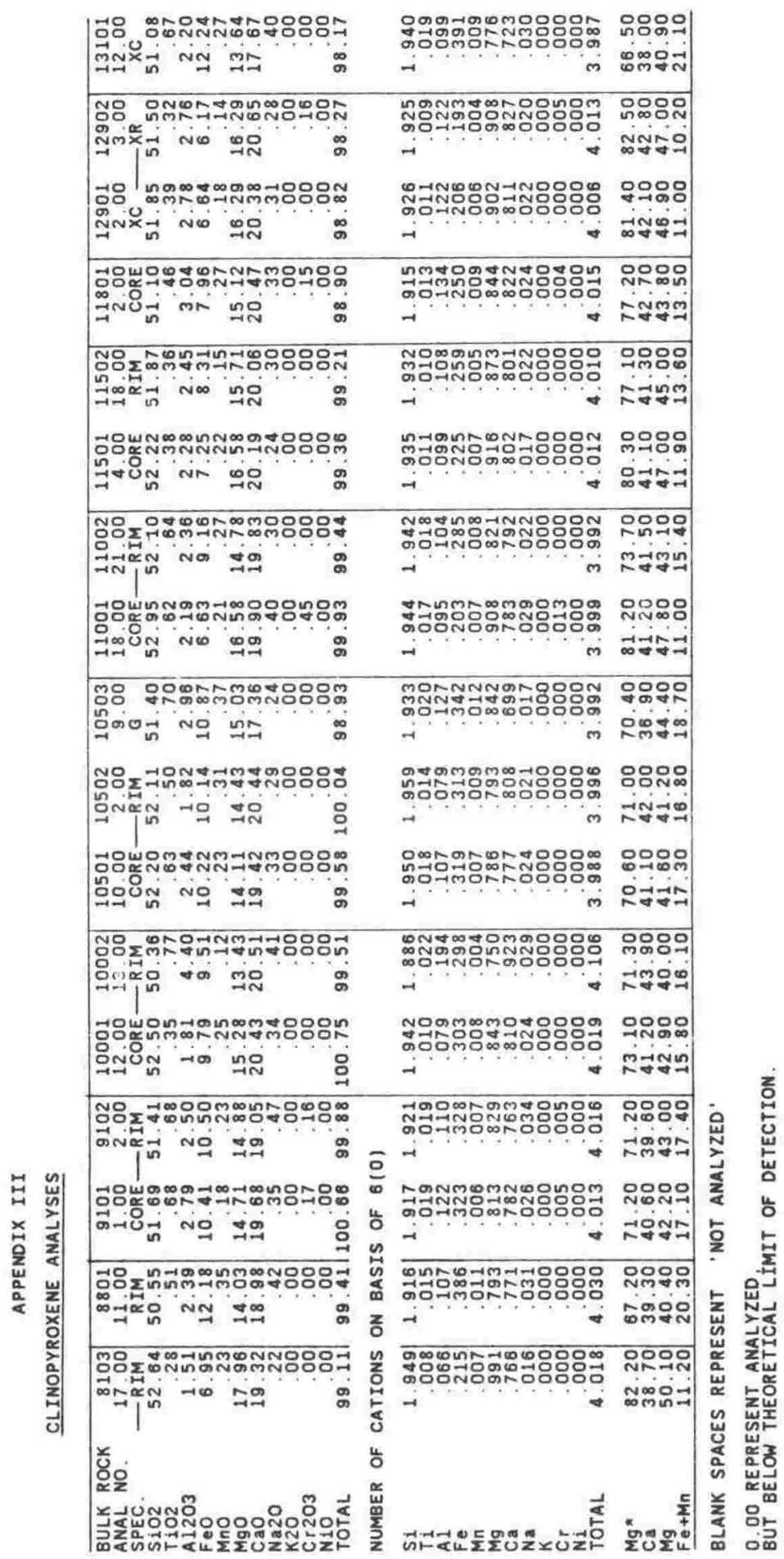




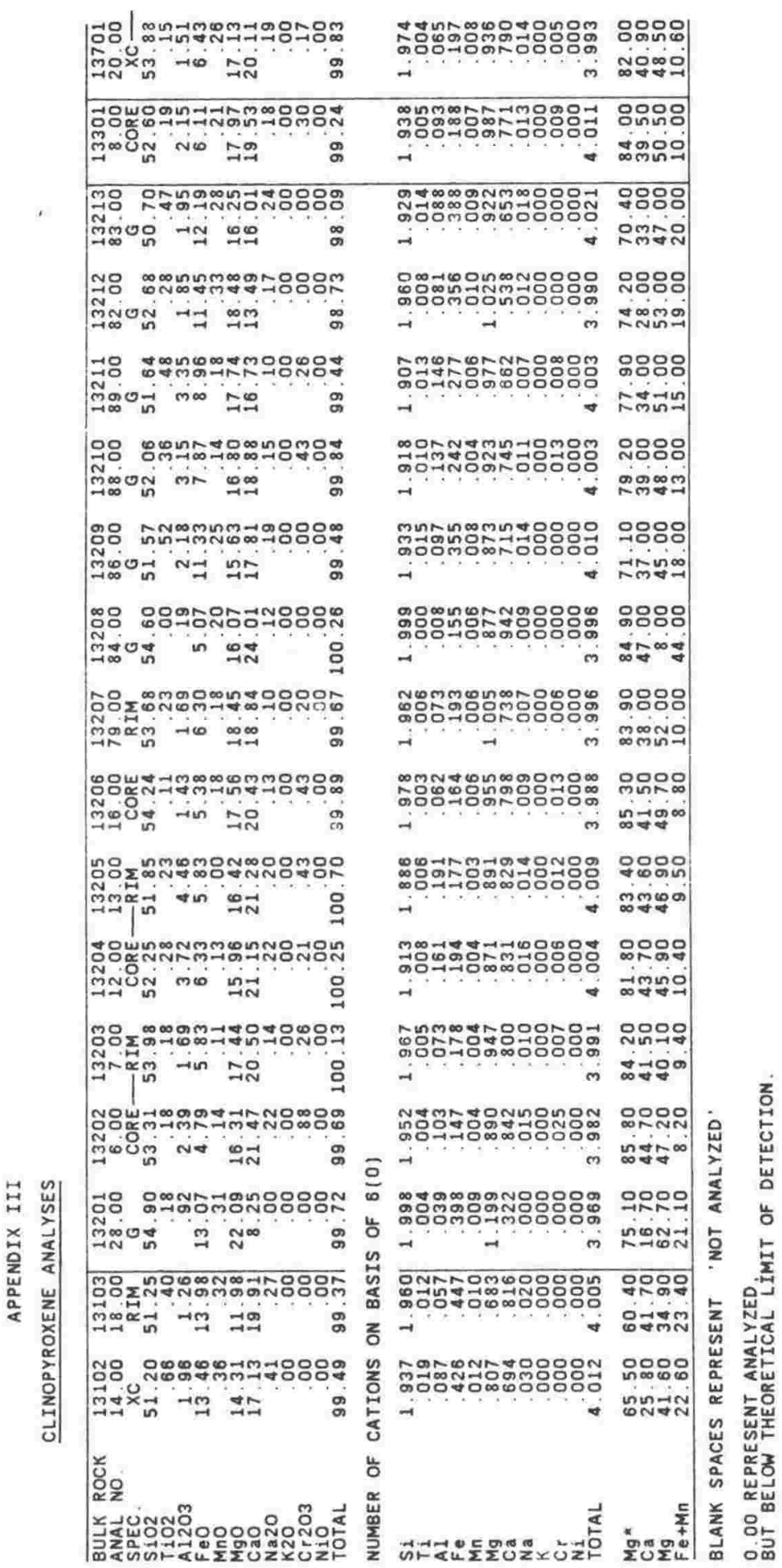




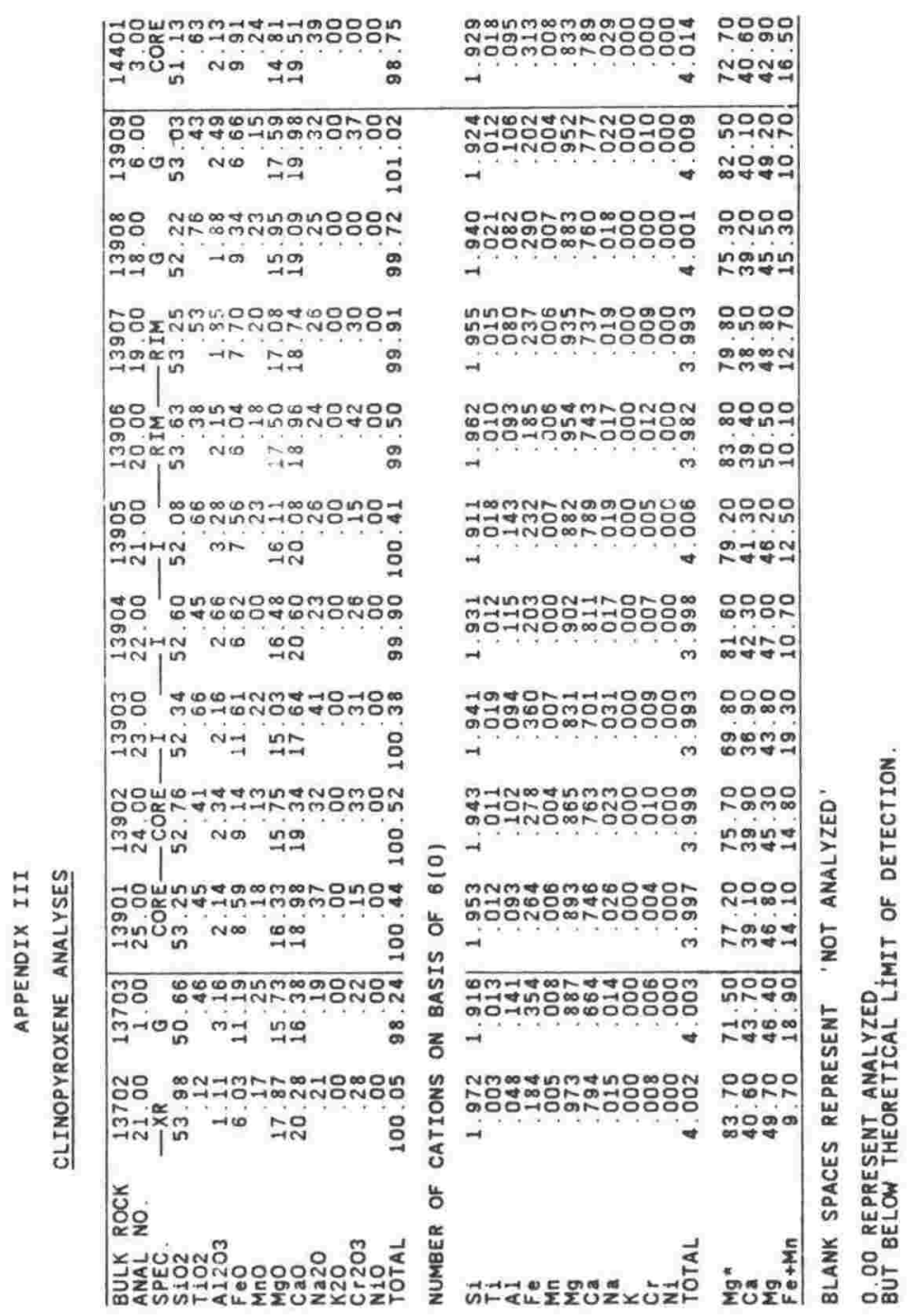


III -9

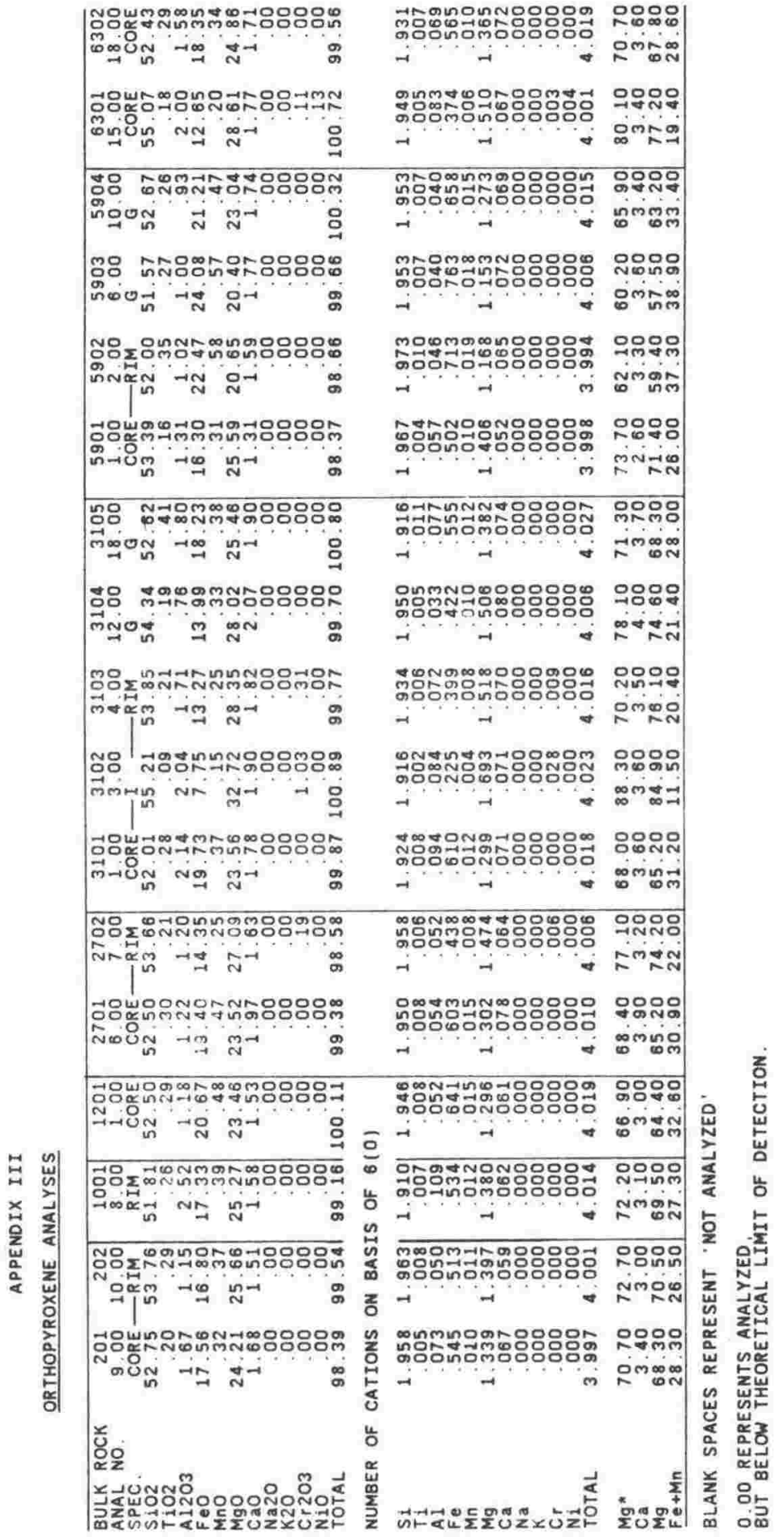


III-10

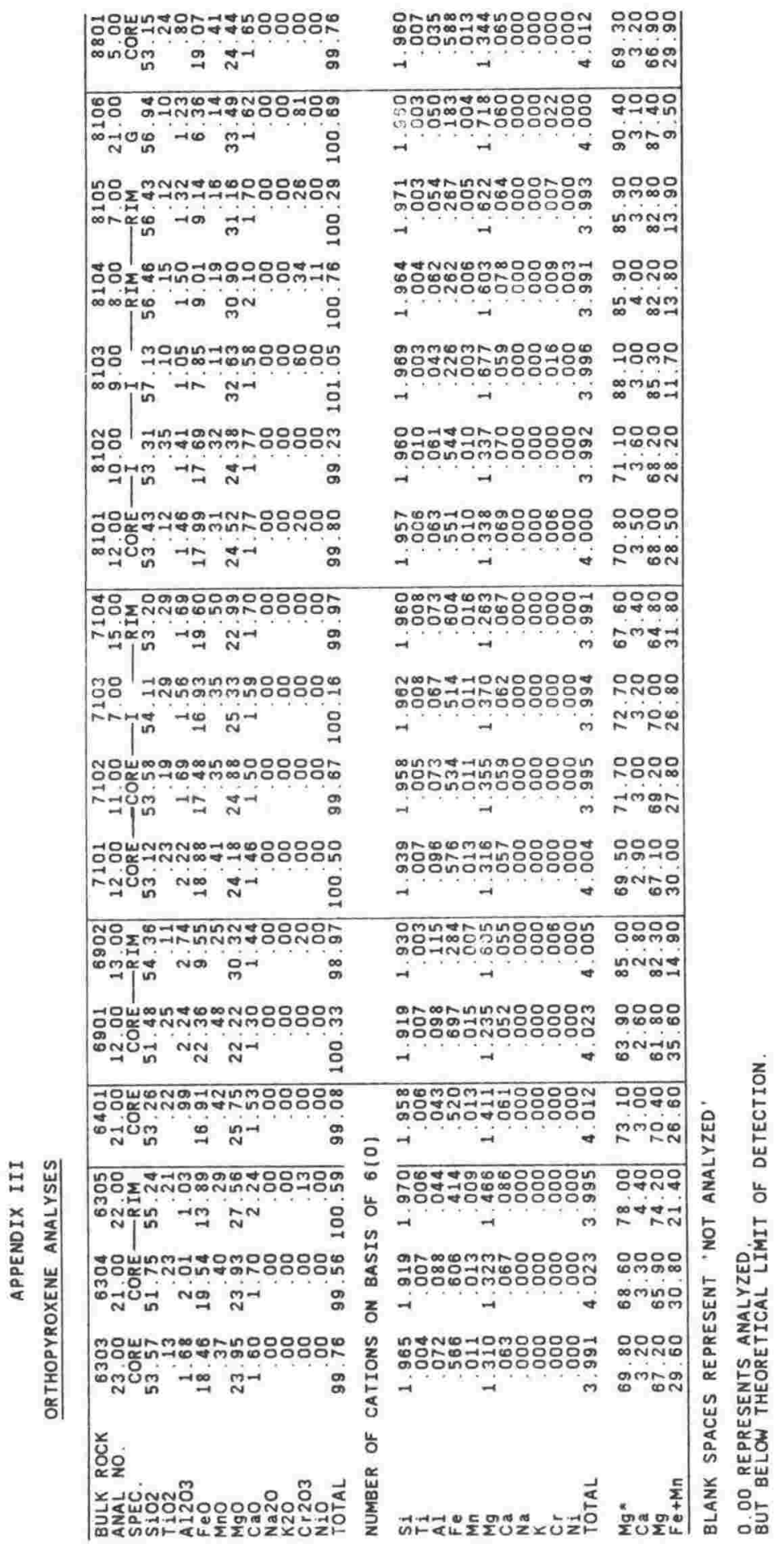


II I-11

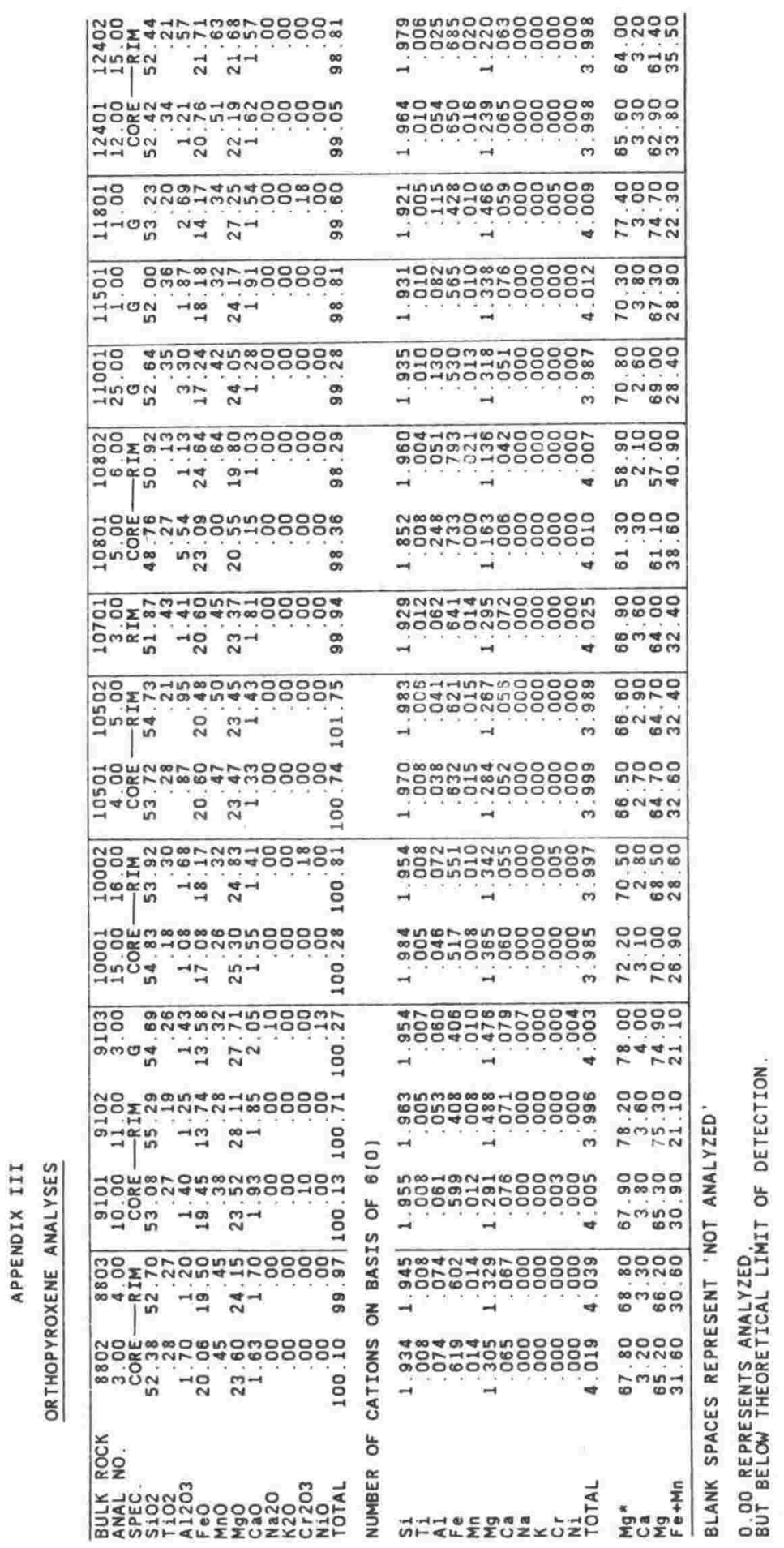


III -12

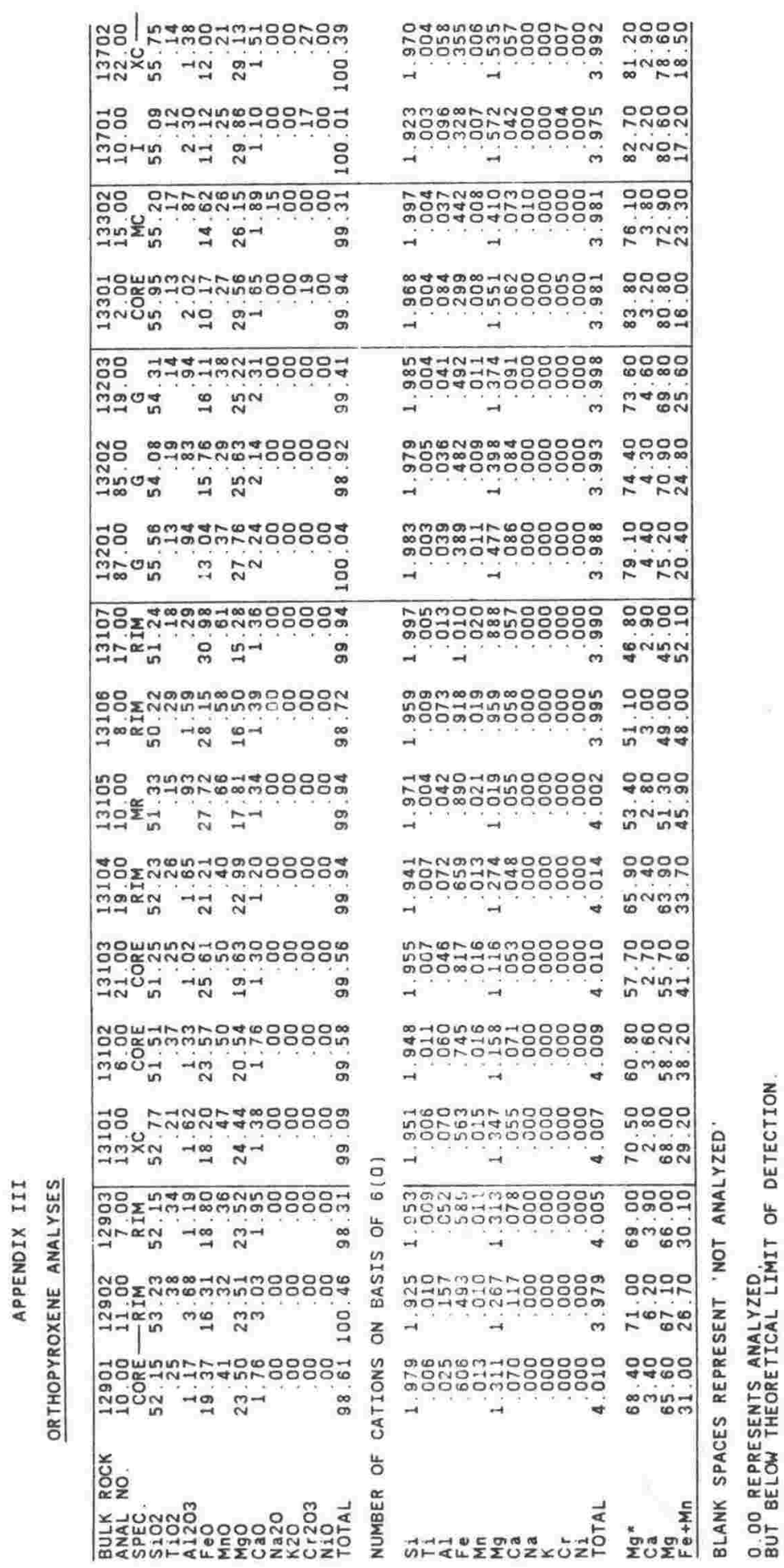




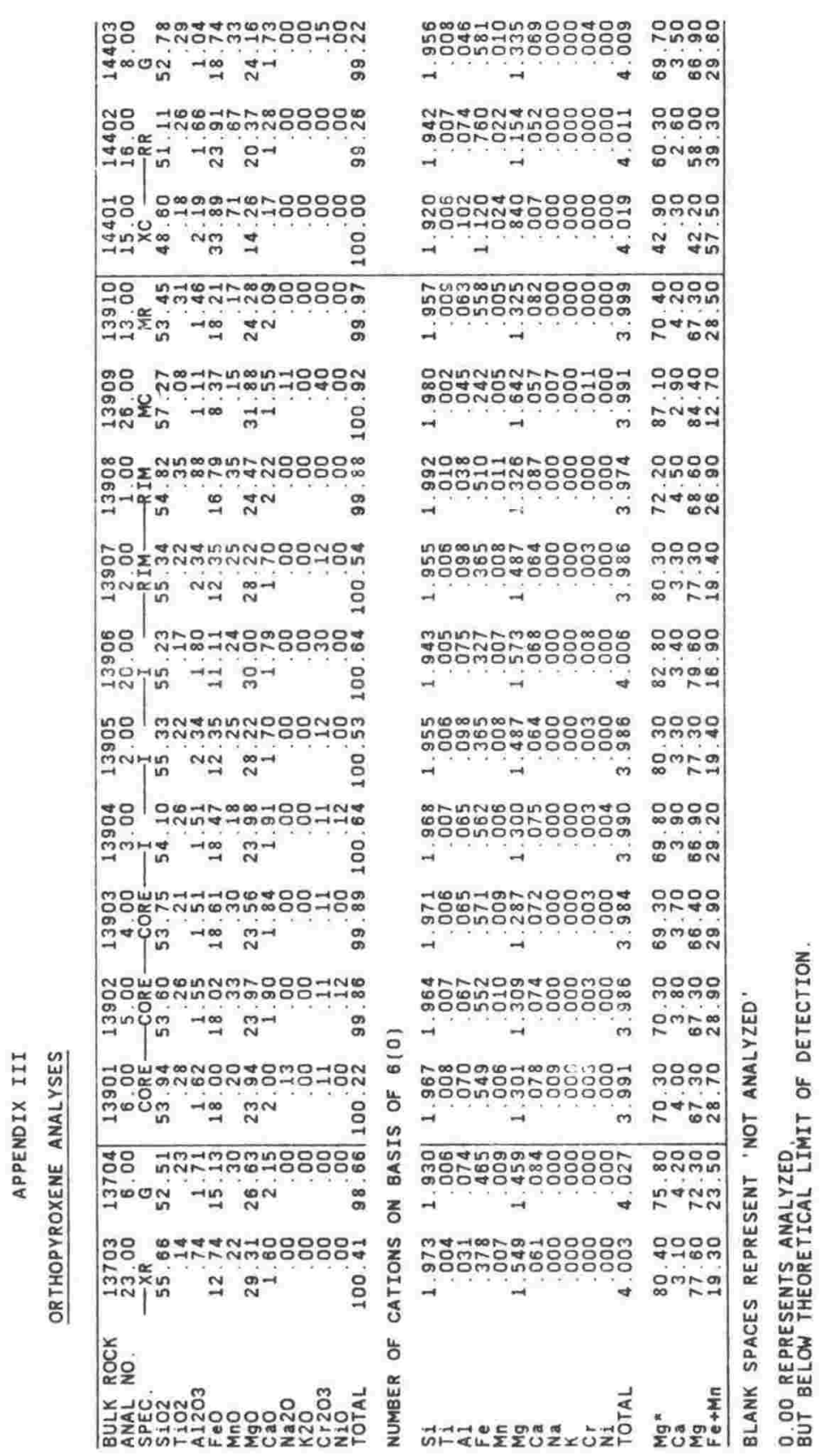




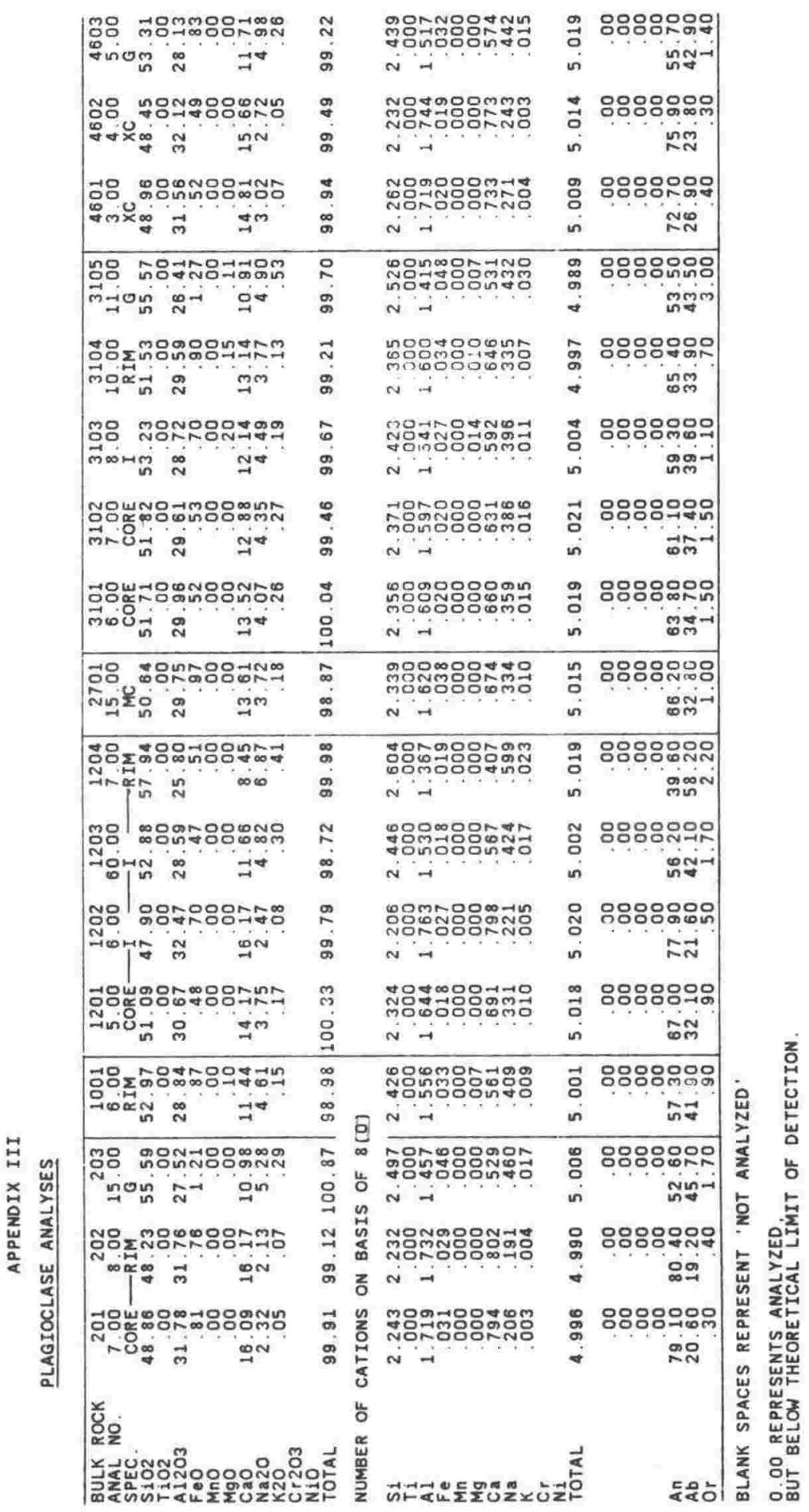


II I-15

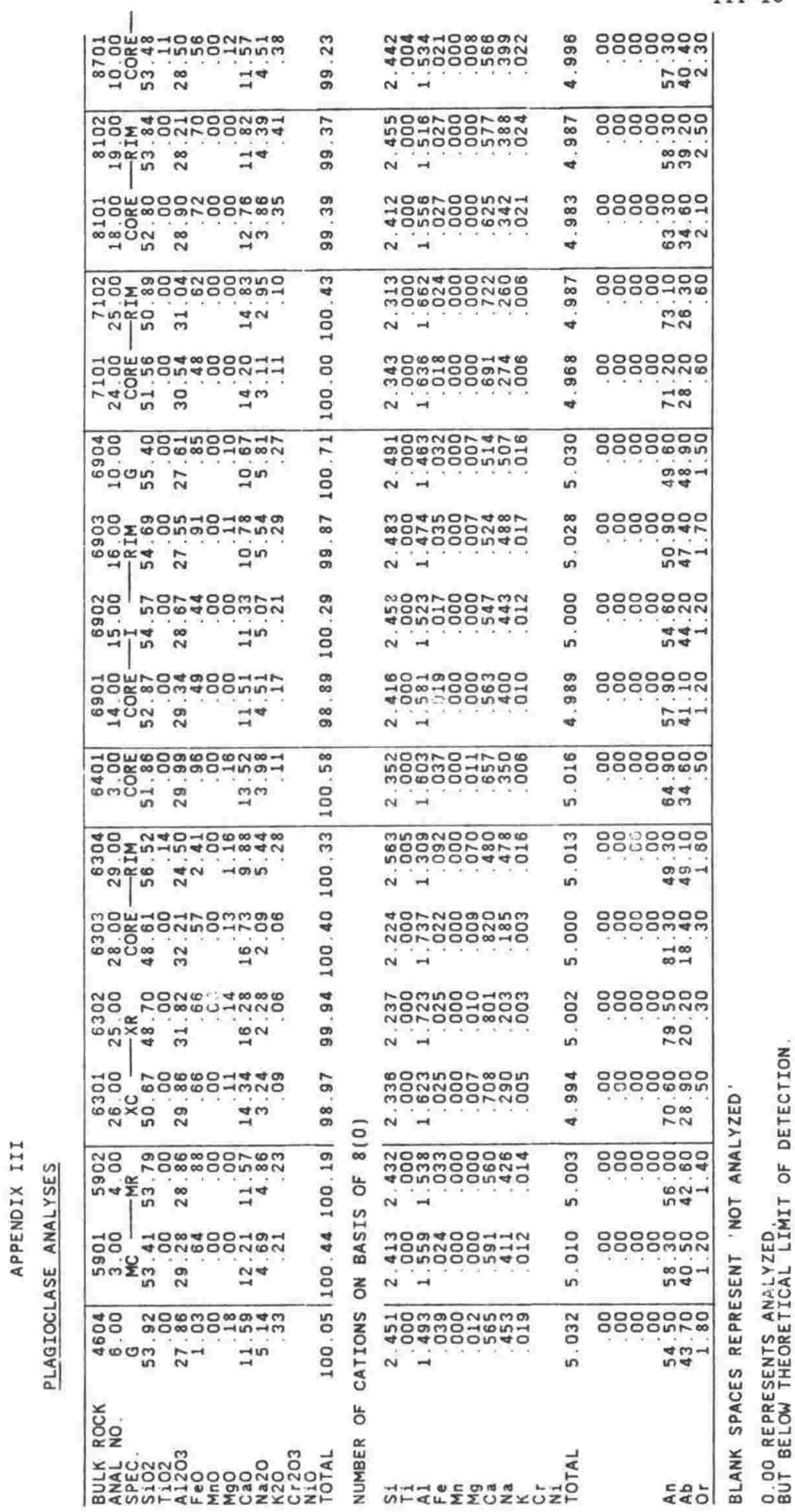


III-16

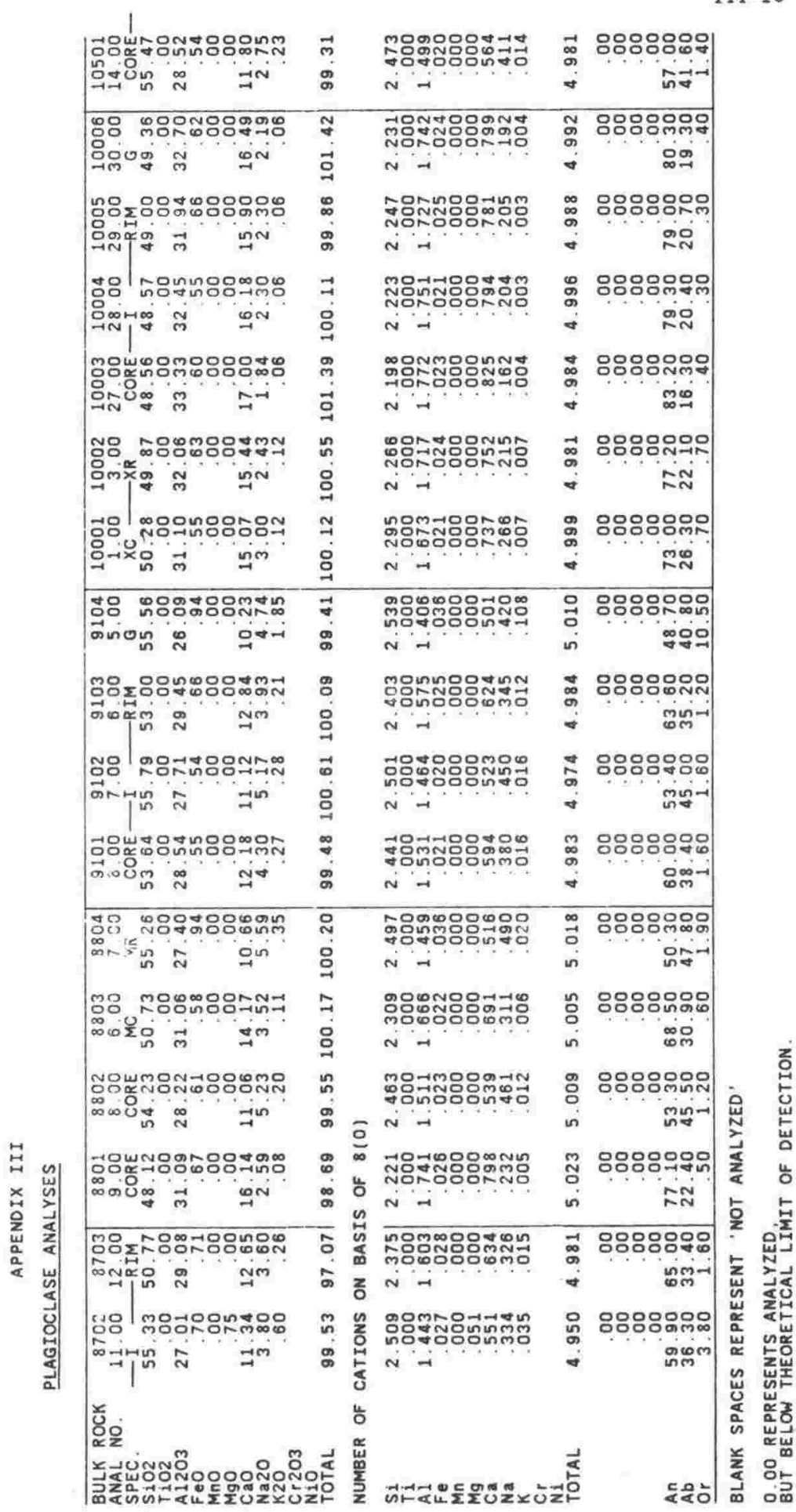




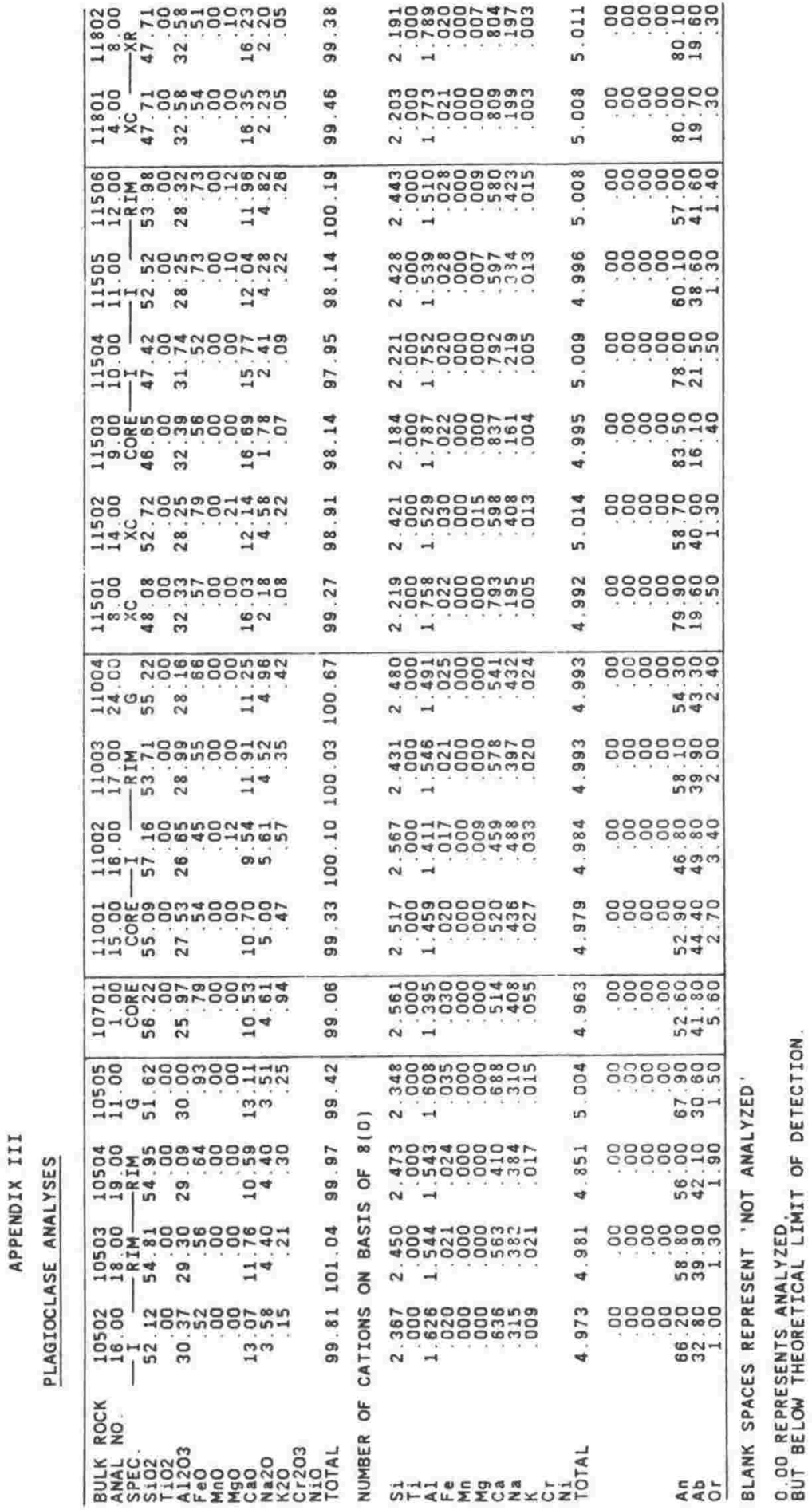




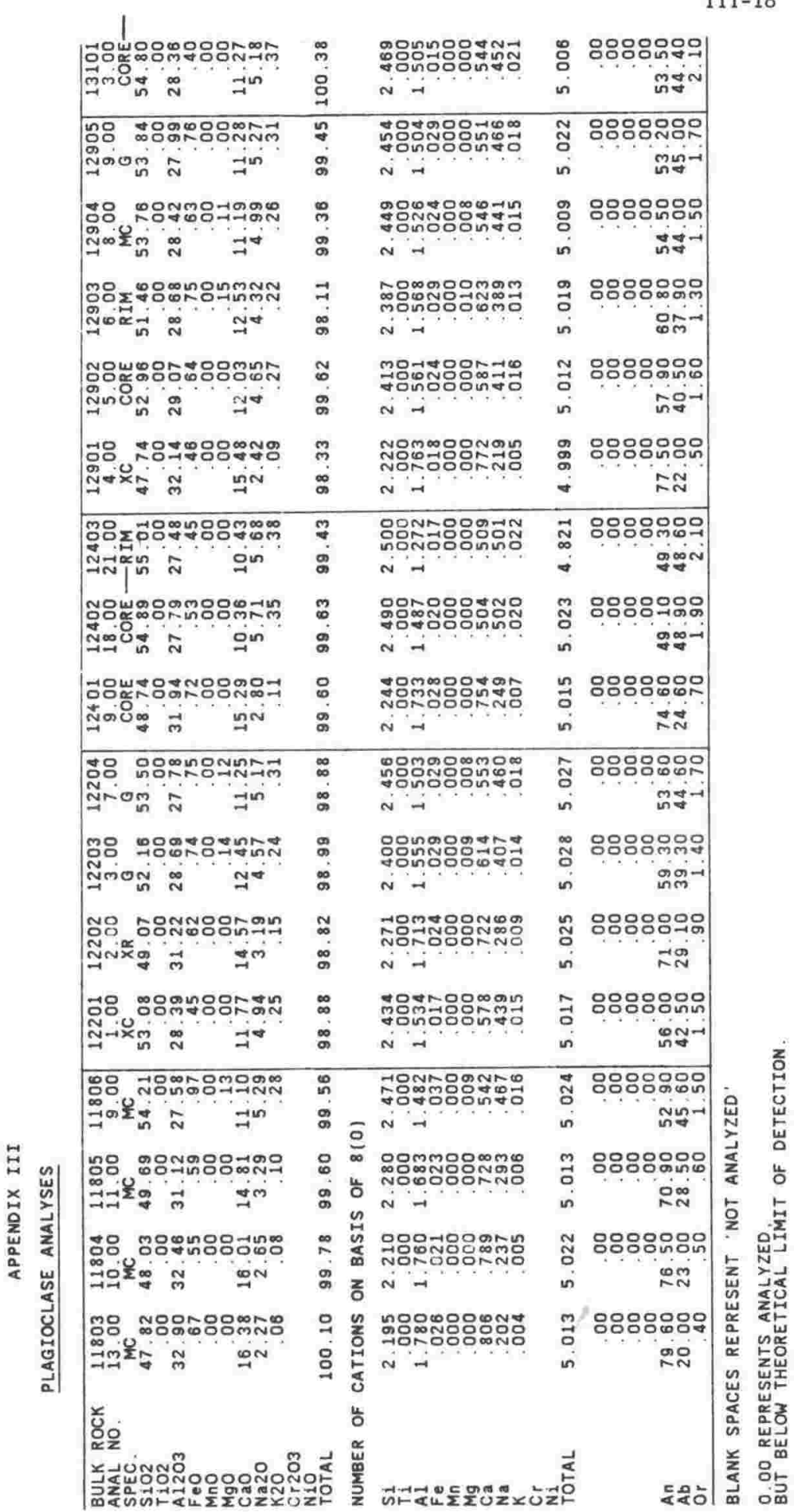




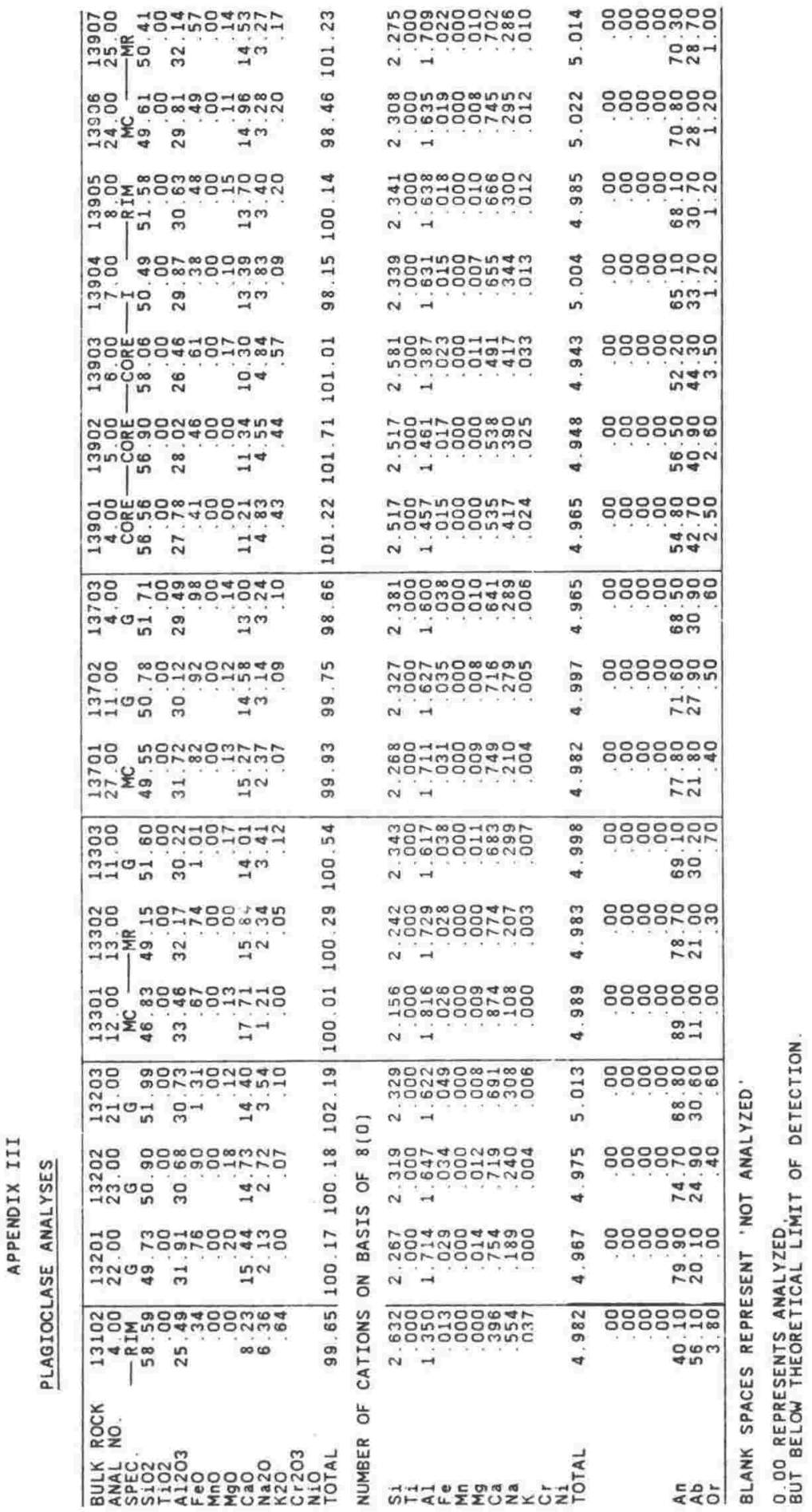


II I-20

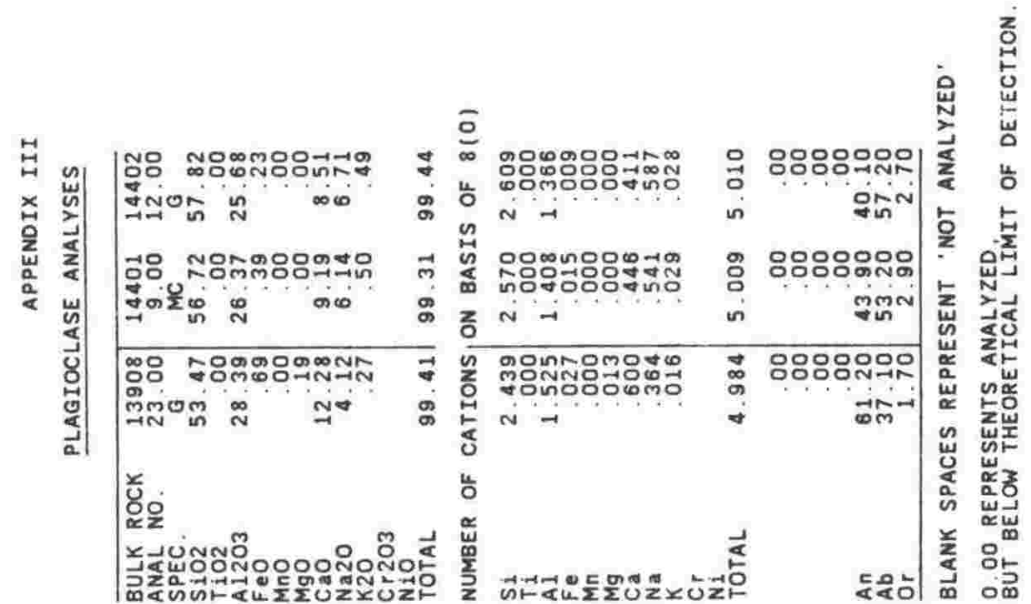




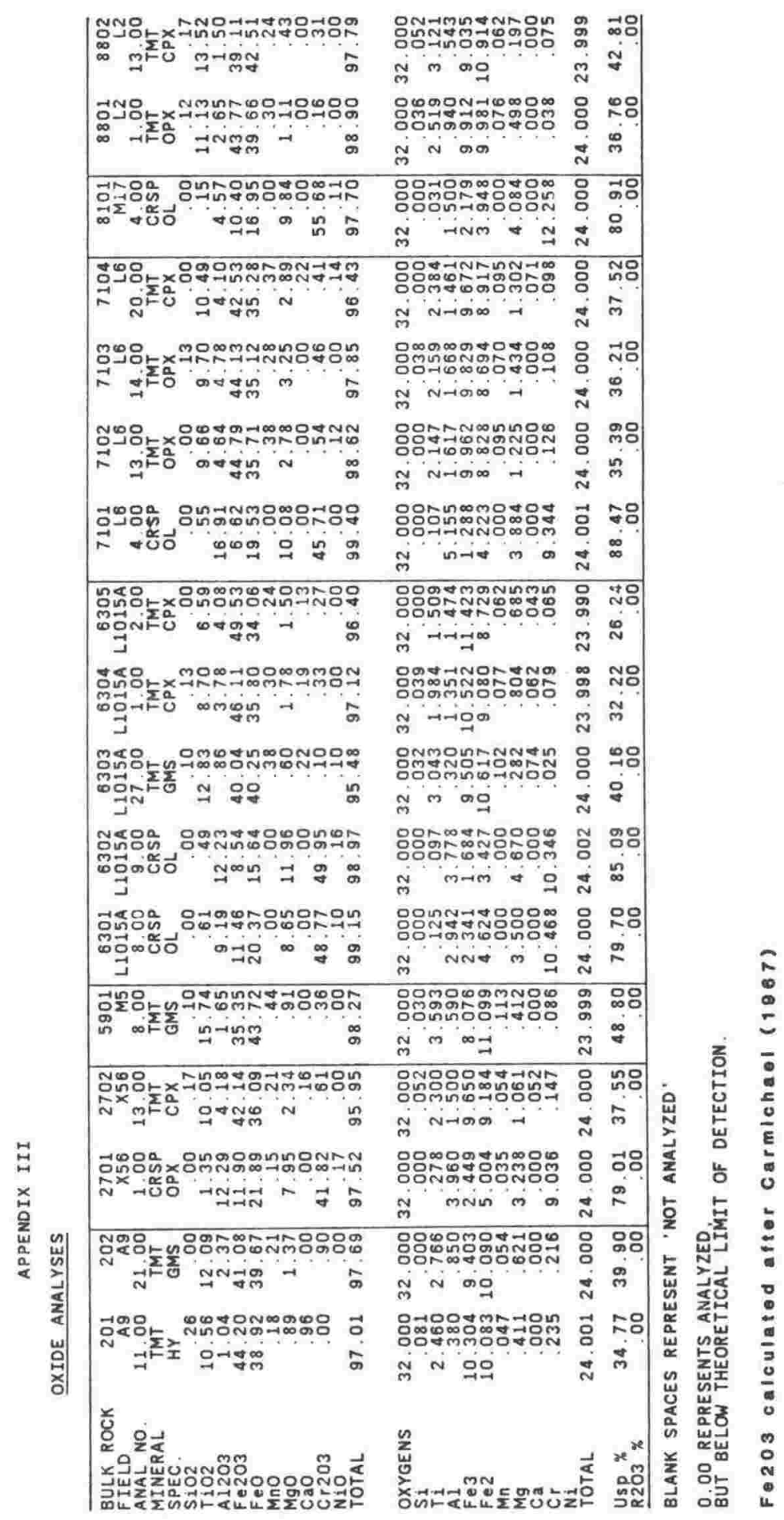




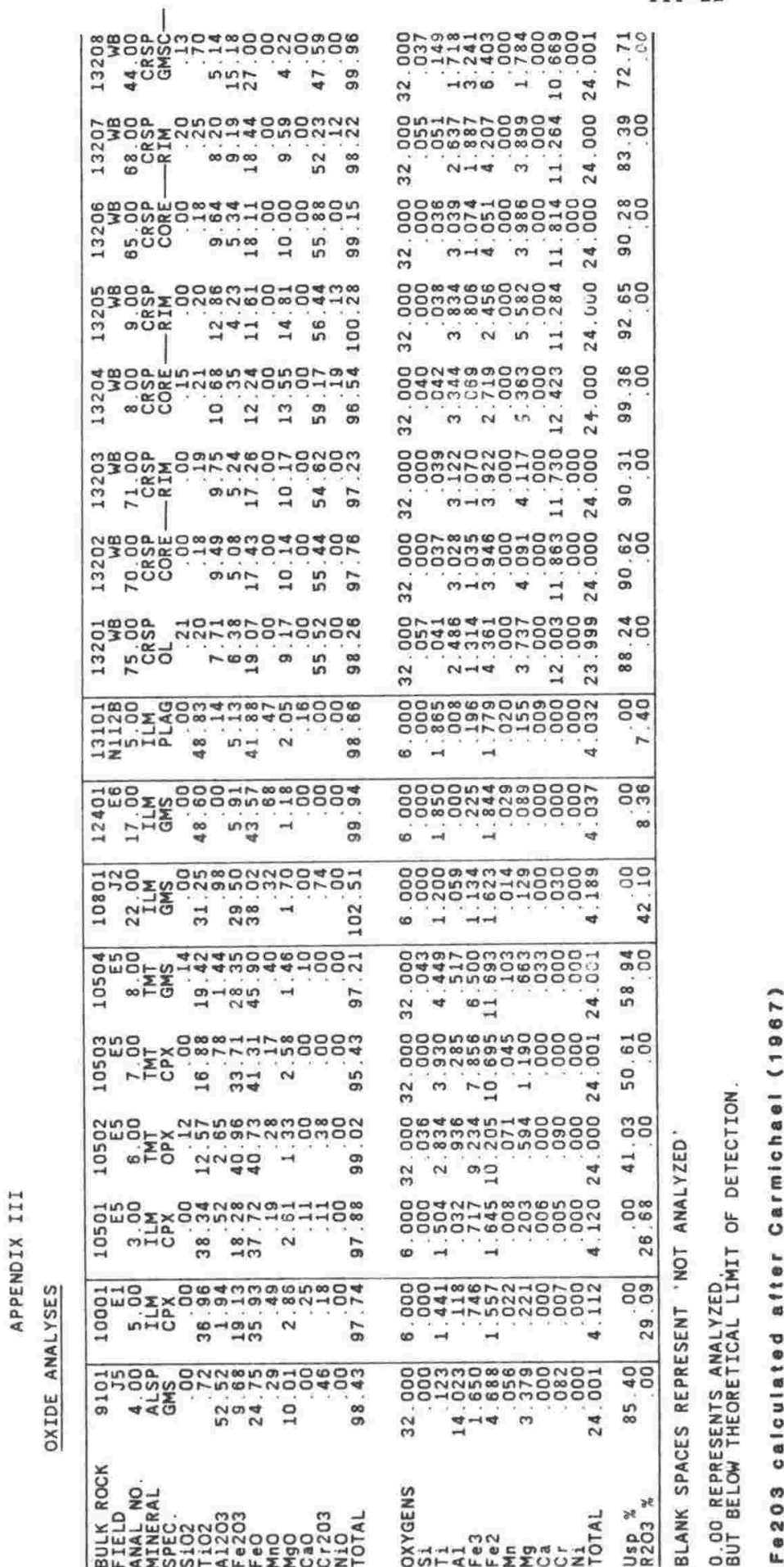




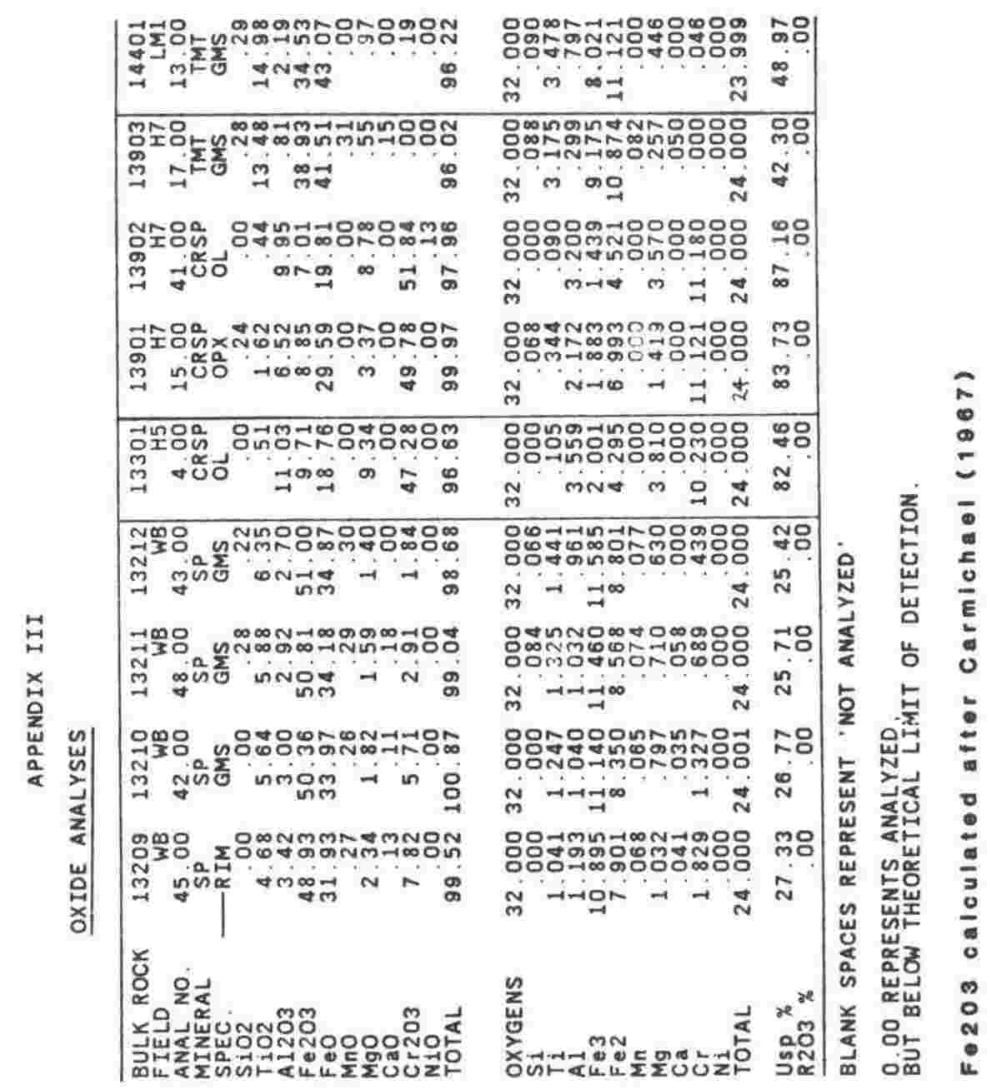


II I-24
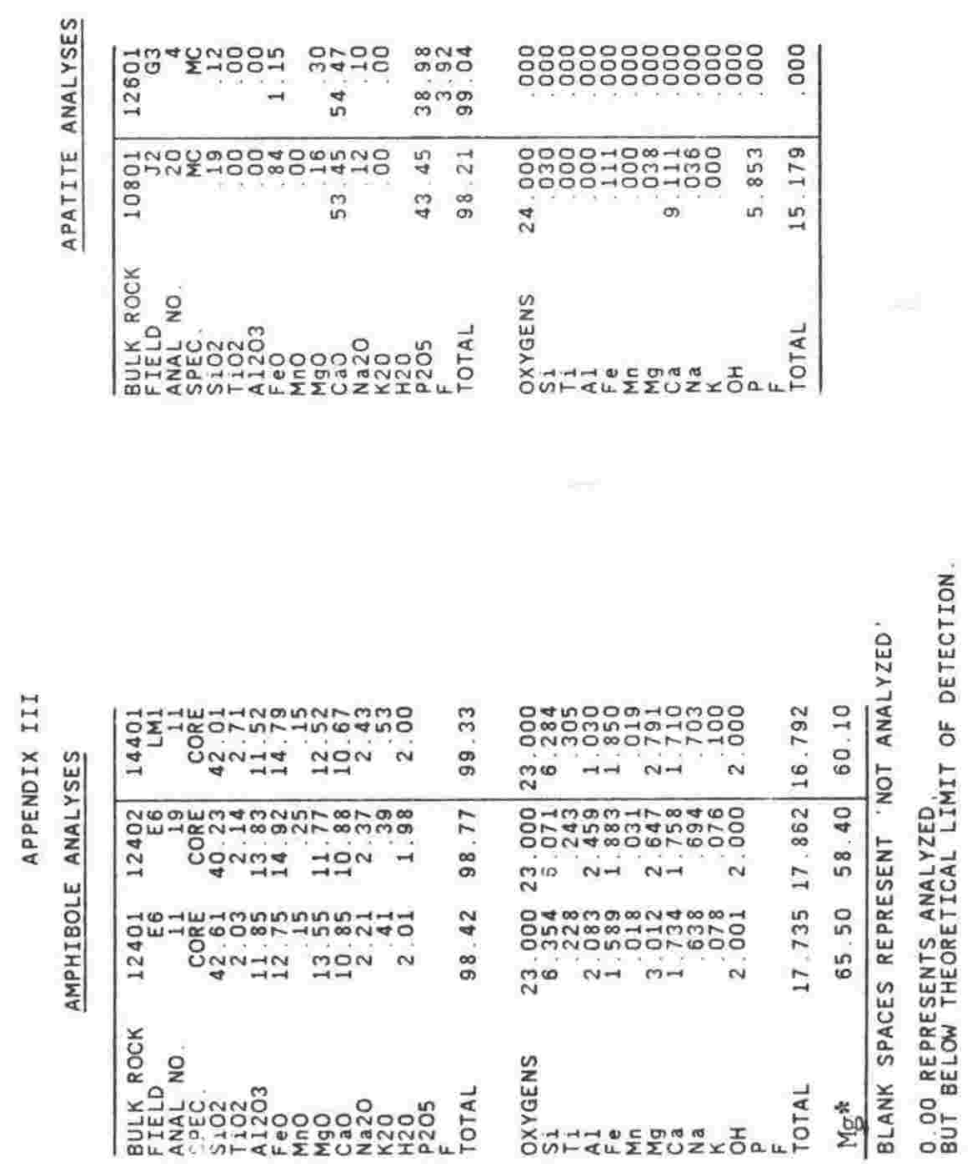


\section{APPENDIX IV: MINERAL ANALTSES FROM IGNEOUS NODULES.}

Specifications, analytical methods and detection limits are the same as given in the introduction to Appendix 111. Analyses of minerals in nodules are tabulated according to individual nodules, rather than by mineral species.

Bulk rock numbers refer to analysis numbers of Appendix II. If a nodule itself has been analyzed as a bulk rock, then this bulk rock analysis number is given. If not, then the bulk rock analysis number for the host lava is given. 


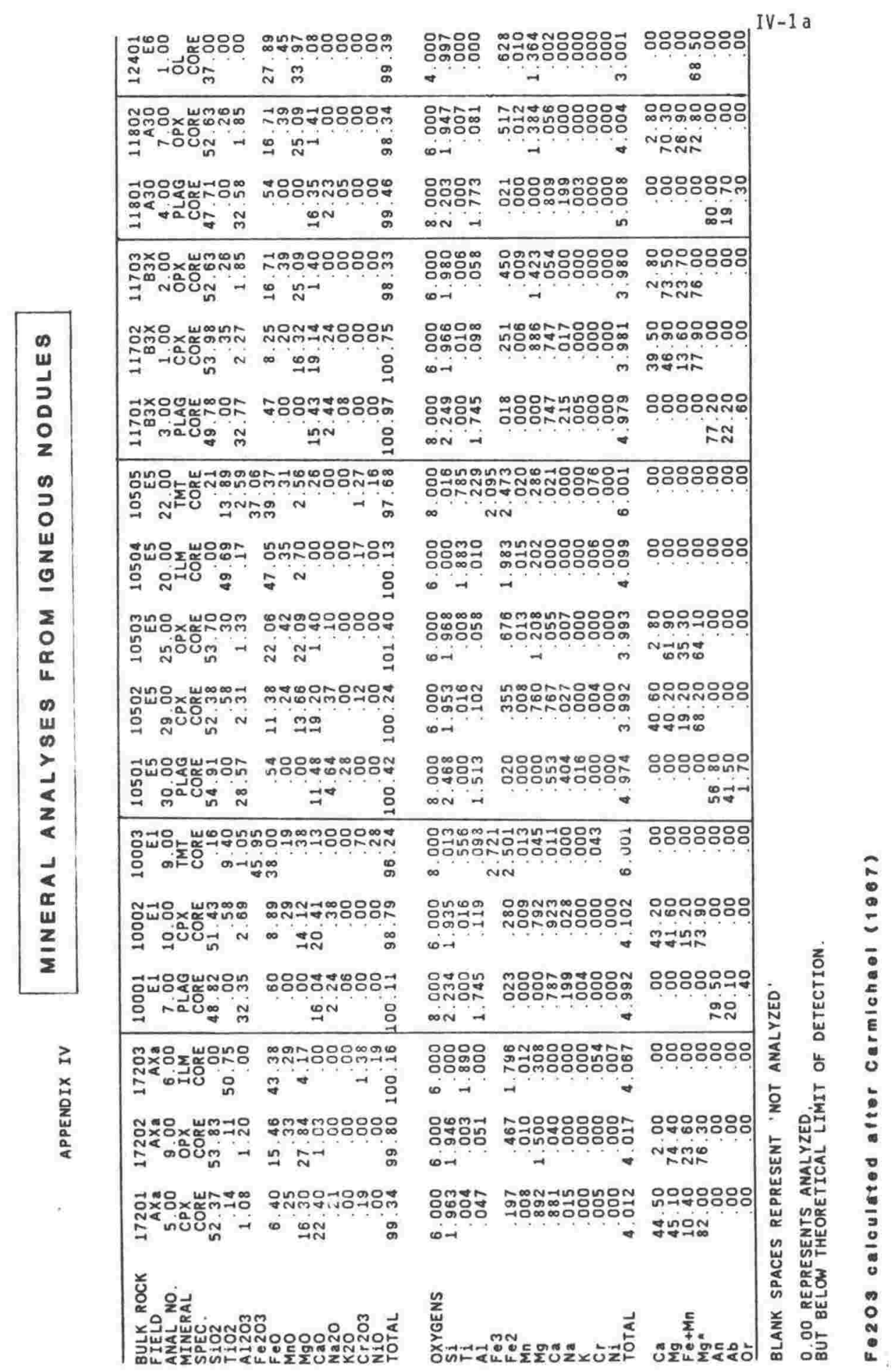




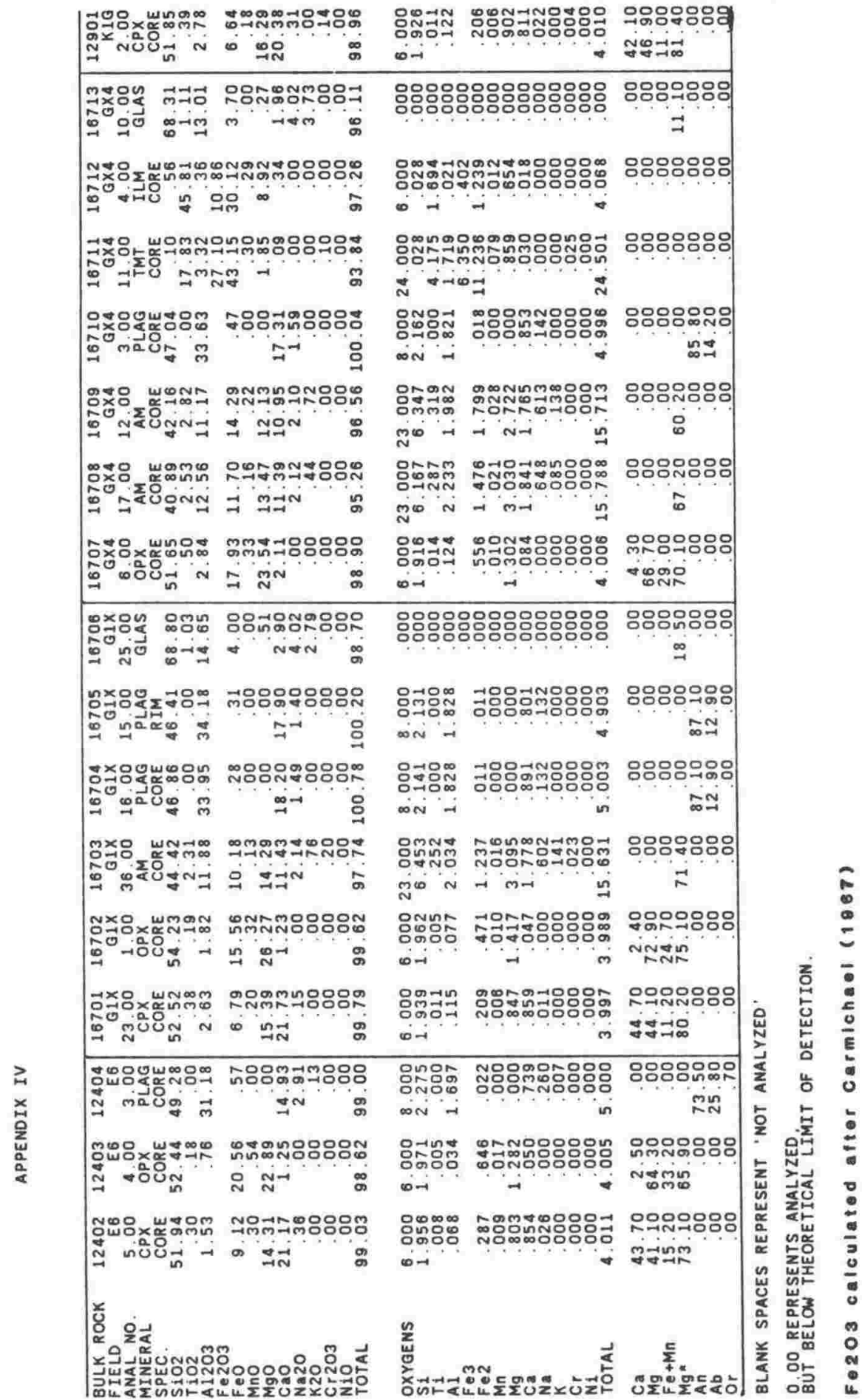




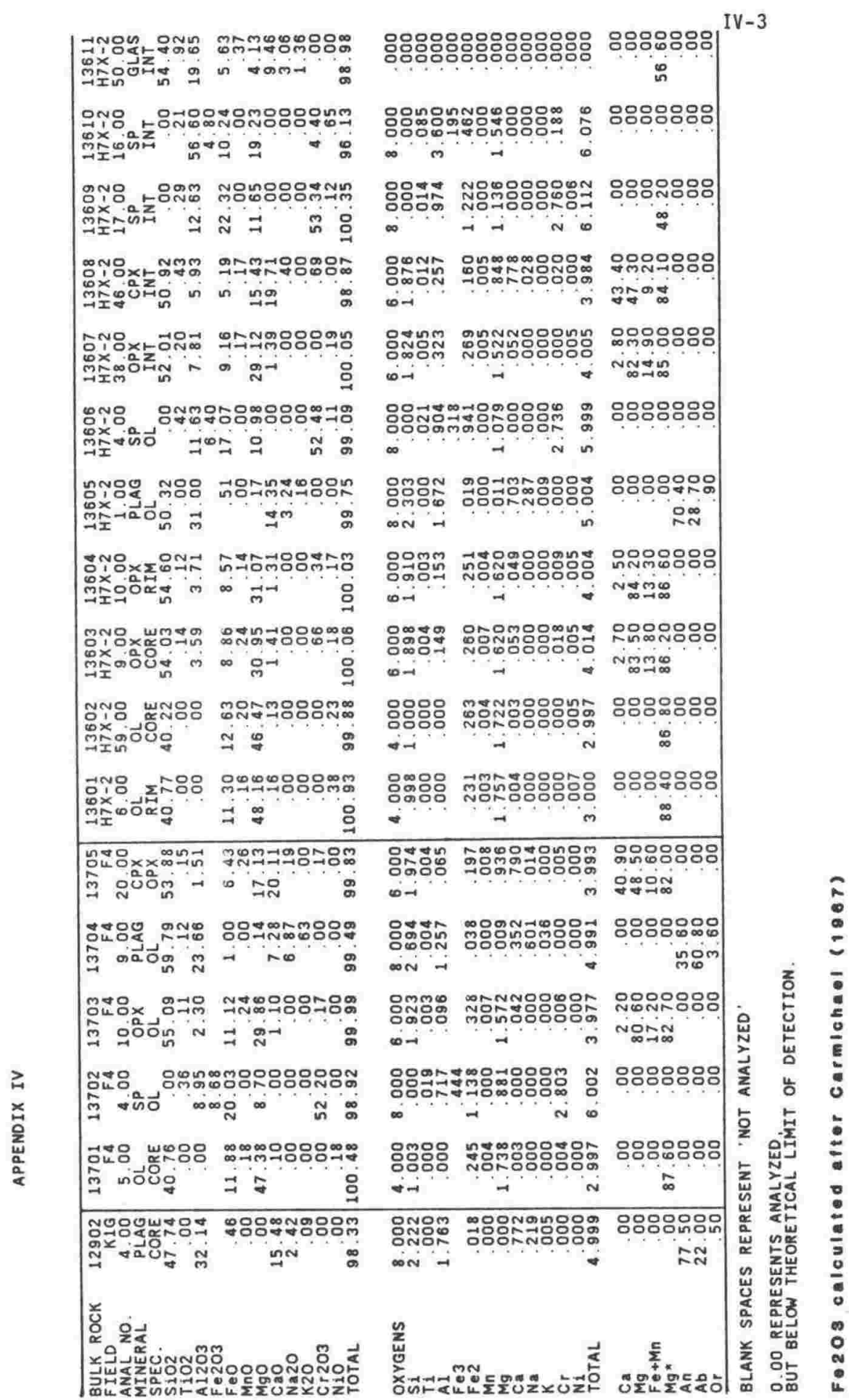




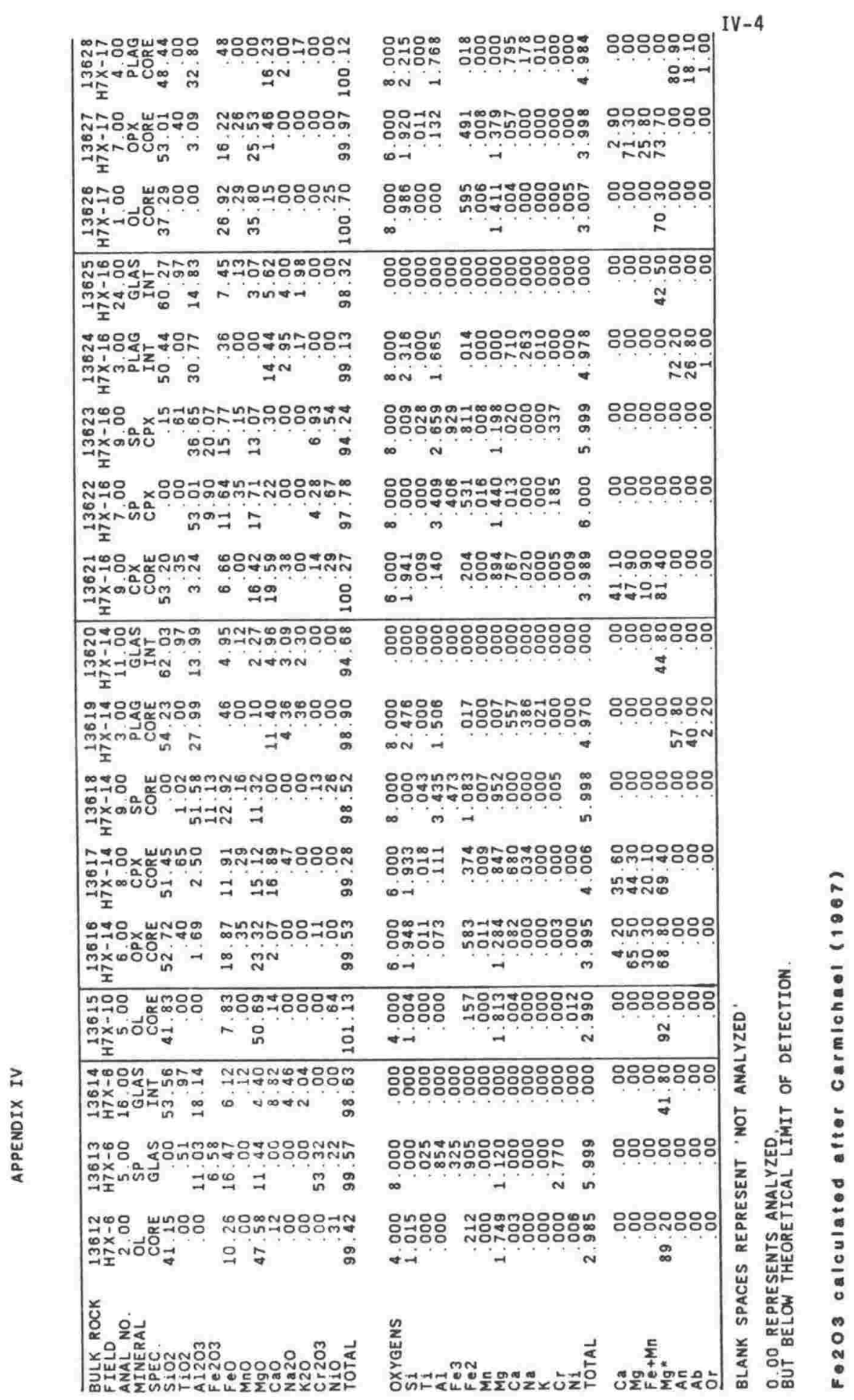


IV -5

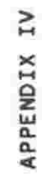

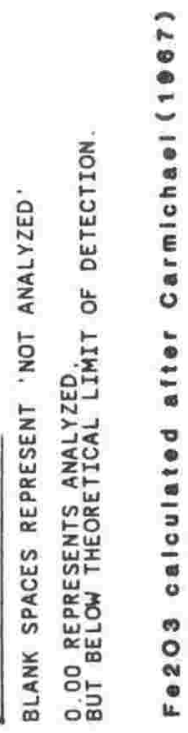


APPENDIX V: MINERAL ANALISES FROM METAMORPHIC IENOLITHS.

\section{INTRODUCTION}

Mineral analyses from metaigneous and metasedimentary renoliths are given. Specifications, analytical methods and detection limits are the same as given in the introduction to Appendix III. Mineral analyses from renoliths are tabulated according to individual renoliths, rather than by mineral species.

Bulk rock numbers refer to analysis numbers of Appendix II. If a xenolith itself has been analyzed as a bulk rock, then this bulk rock analysis number is given. If not, then the analysis number for the host lava is given. If neither the zenolith nor the host lava have been analyzed as bulk rocks, then no 'bulk rock' entry is made.

Xenolith minerals from specimens B10Xi, XC and N112C were analyzed by $M$. Otsuki. All other analyses are by the author.

\section{PETROGRAPHIC AND LOCALITY NOTES.}

Several of these renoliths have been analyzed as bulk rocks in Appendix II; locality and petrographic descriptions for these are given in Appendix II. Petrographic and locality descriptions for renoliths not analyzed as bulk rocks in Appendix Il are given below. 


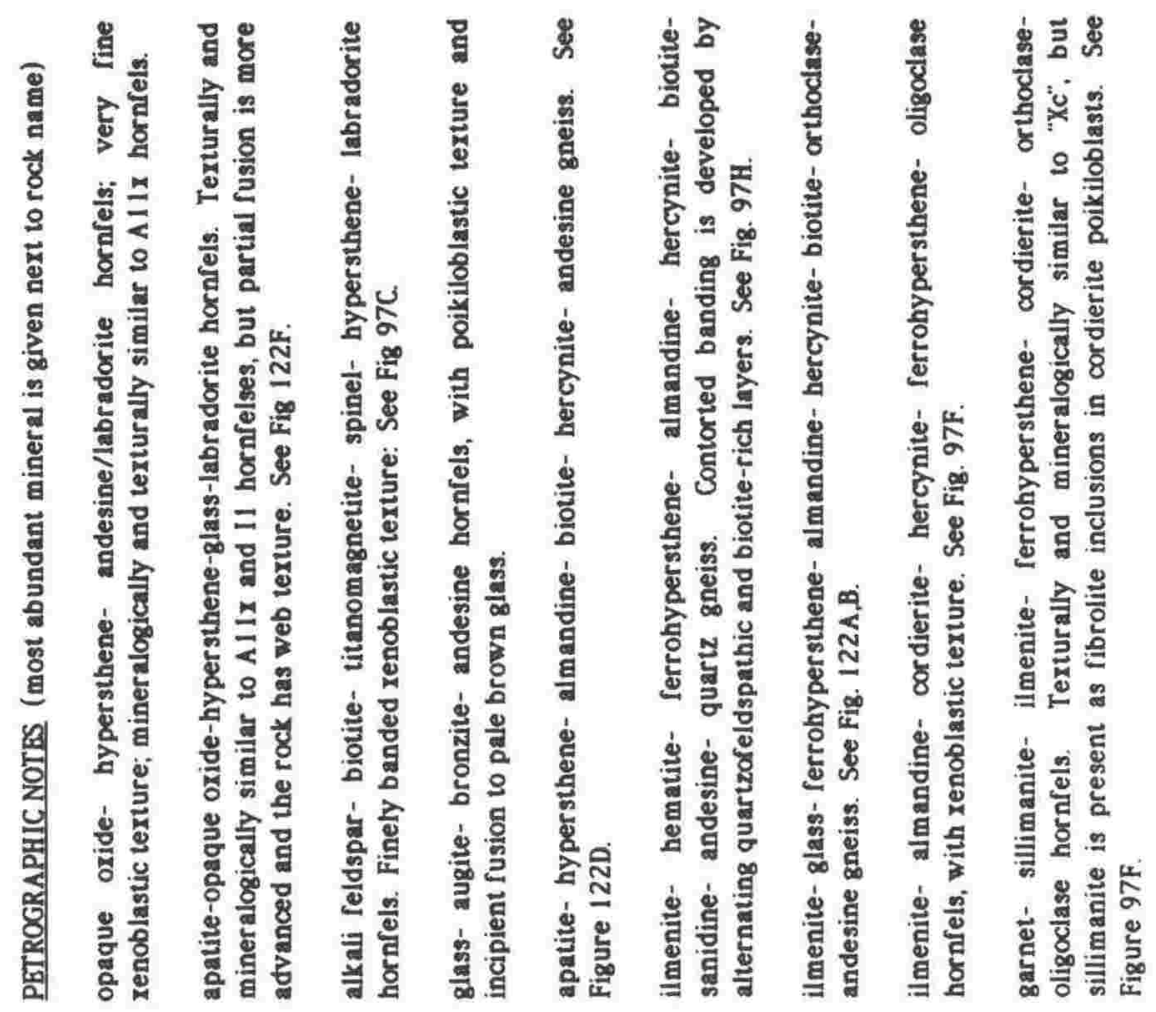

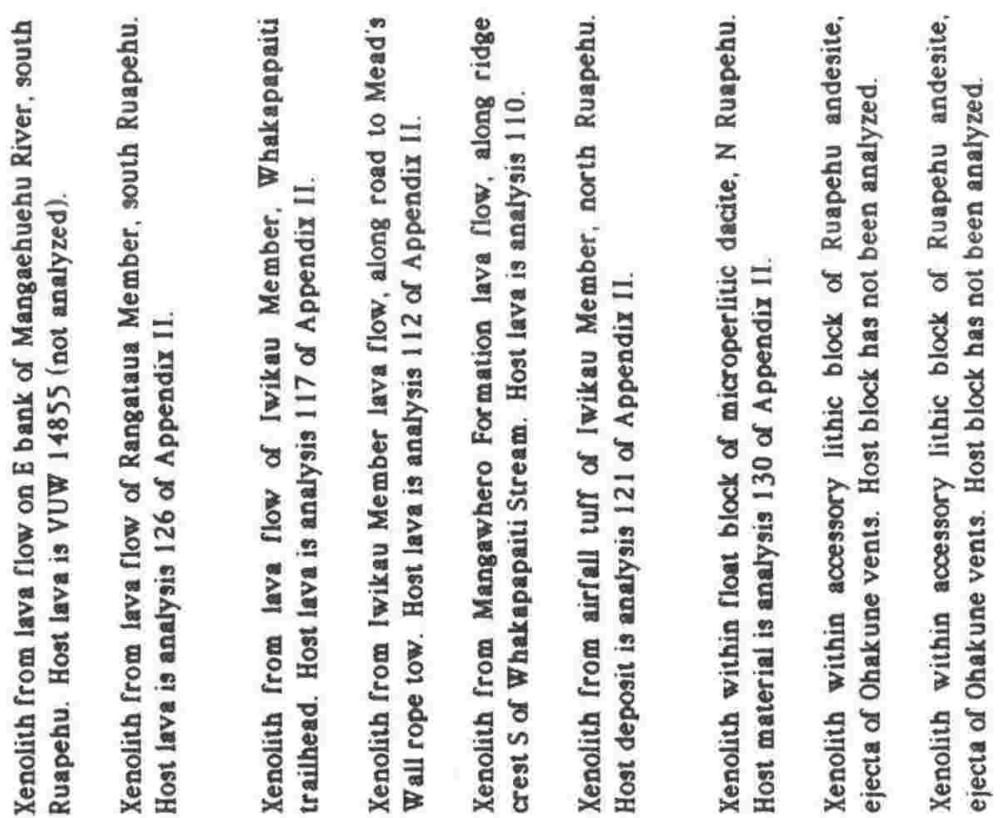

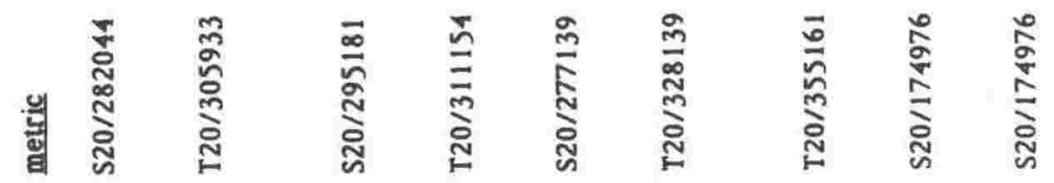

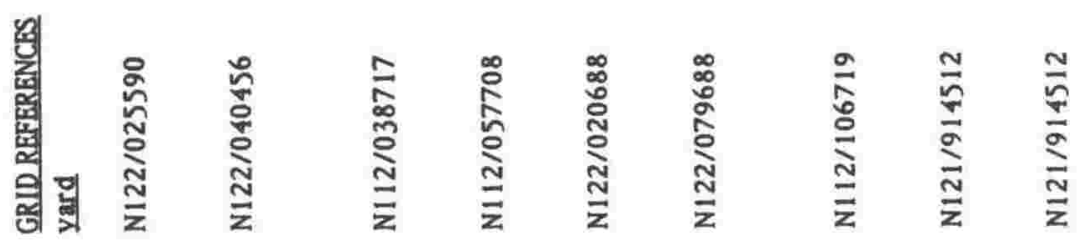

嘪 
$v-1 b$

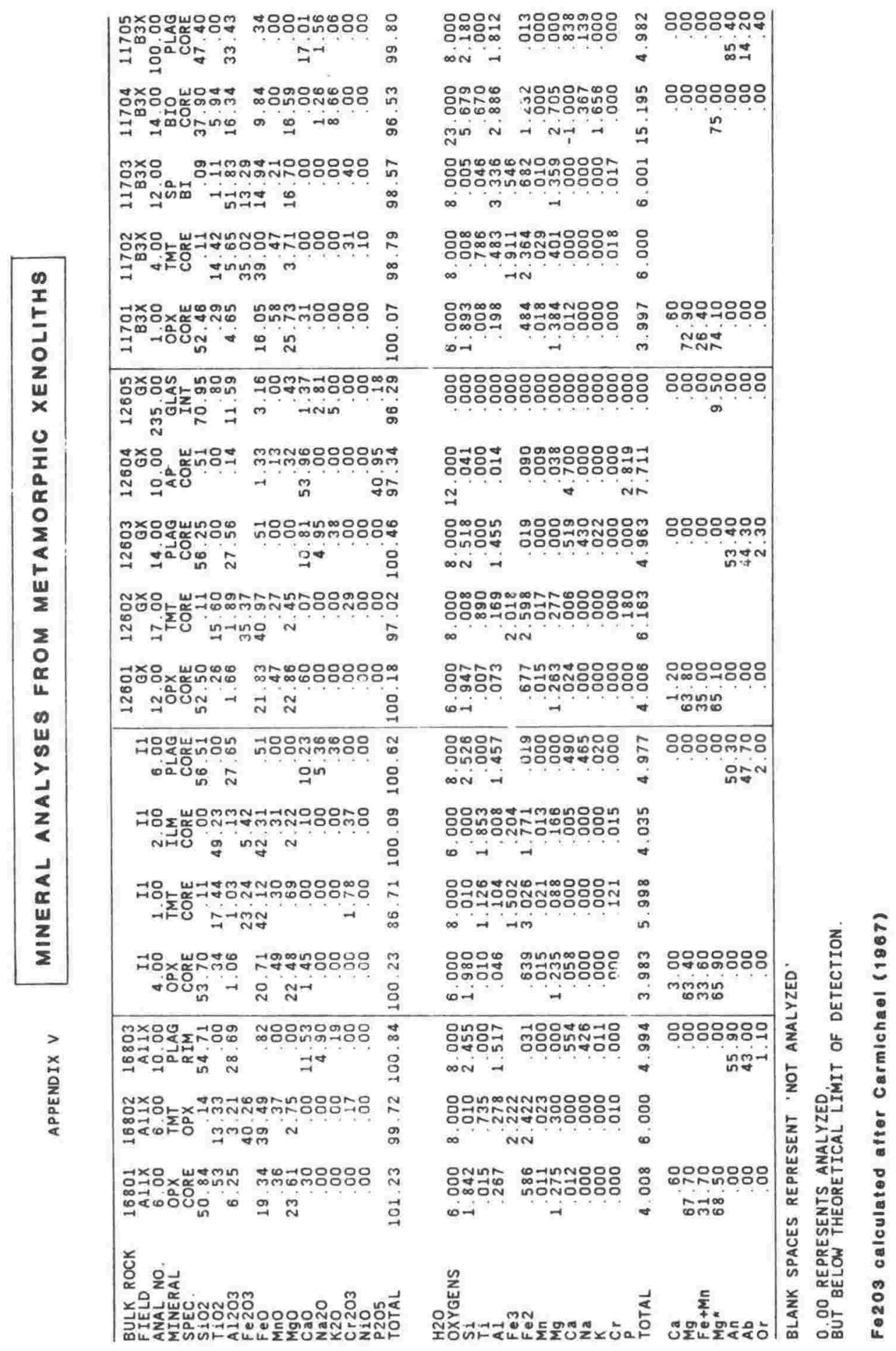




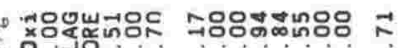

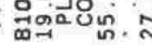

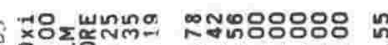

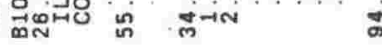

+

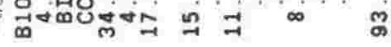

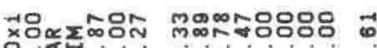

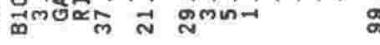

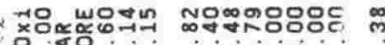

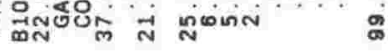

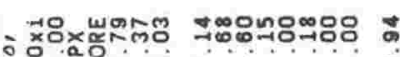
สิ \%ำำำ $\exists$ ina

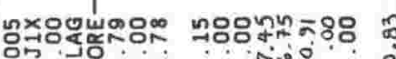

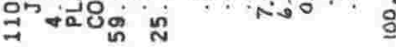

ํำ

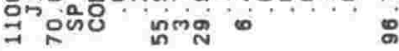

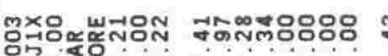

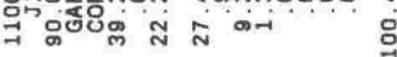

พำㅇํํํำ

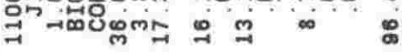

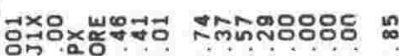

Jion in

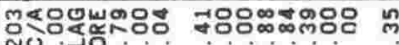

政

ㄸำ

平

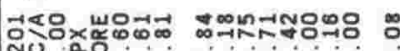

$\exists$

กำ

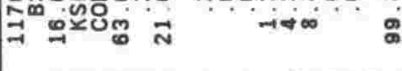

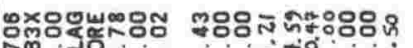

牙惯

ชั

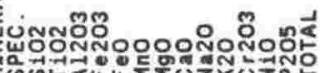

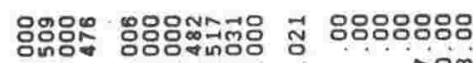
on - i in

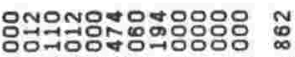
on $\mathrm{n}$ i

ㅇำ

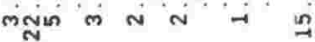

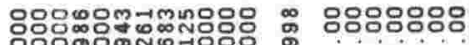
ำ - - i

: กั่ - - -

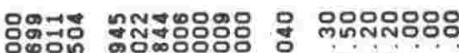
o-

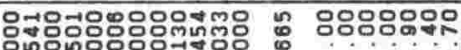

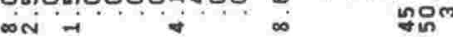

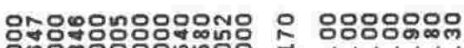
कi - in क min

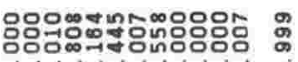
$\infty$ in - in

ํํำ ㄷำ

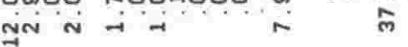

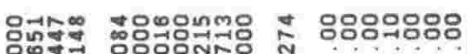

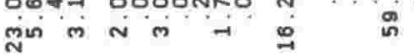

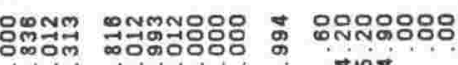

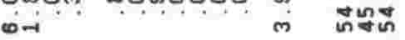

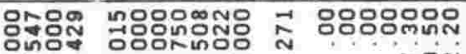
on - - a jon

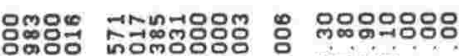
-1 - व युत

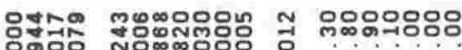

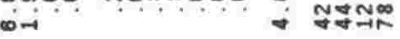

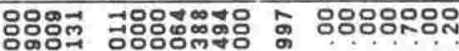
-7 ํํำ ㅁำ on in

离

运 岳. 紫 


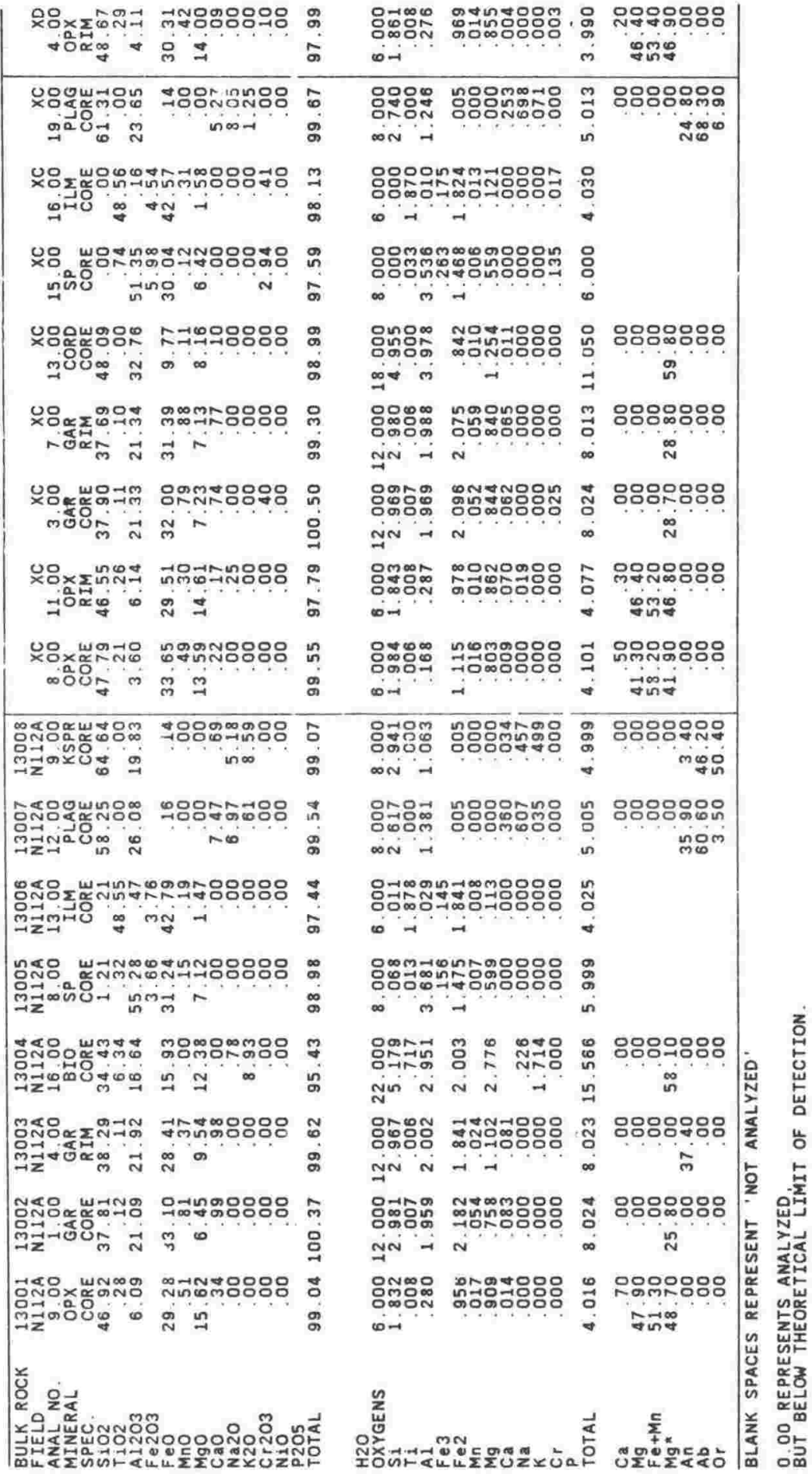




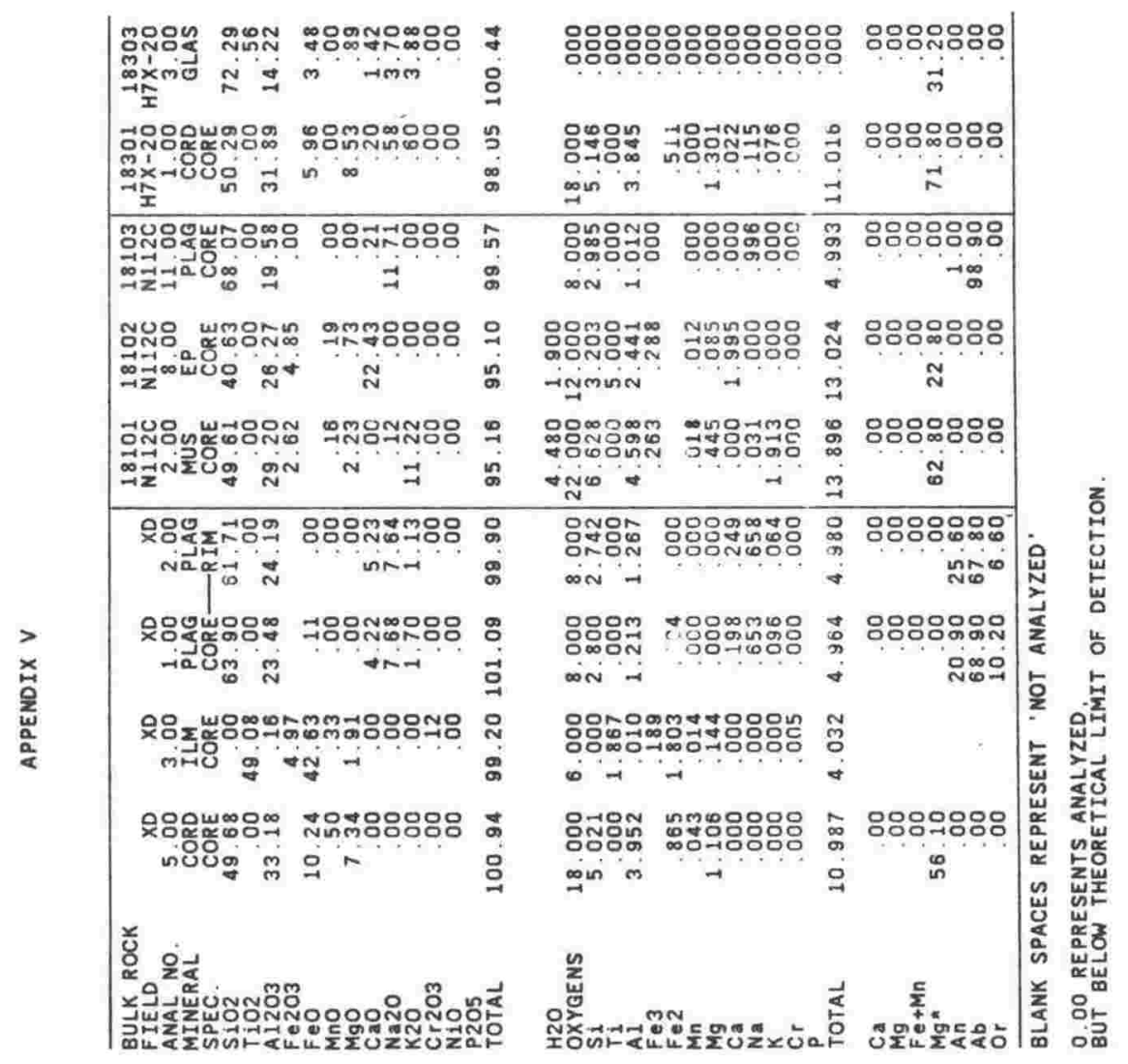




\section{APPERPI VI: LEAST SOUARES MIXIIG CALCULATIONS}

\section{INTRODUCTION.}

Ouantitative modelling of fractional crystallization, magma mixing and crystal accumulation is undertaken, using the least- squares mixing programme of $\nabla$ right and Doherty (1970), with format modifications by K. Palmer of the Analytical Facility. Victoria University of Wellington. The user must in put major element compositions for parent liquid, derivative liquid and fractionating minerals. The programme then uses the input date matrix to calculate a "match" to the observed parent magma composition, by mixing fractionaled minerals back into the derivative magma: this is algebraically equivalent to: (parent liquid) - (fractionated crystals) - (derivative magma). The programme follows an iterative procedure. whereby the best "match" is achieved when the sum of the squares of the residuals is minimized $\left(\mathbb{R}^{2}\right.$ : 'residuals' are differences between calculated and observed individual ozide concentrations).

As \#right (1974) has indicated, setting up a mixing model is usually simple. but evaluation of the result can be complex. Ideally, residuals in the solution must be below reasonable analytical error, and then the solution must be ovaluatod for consistency vith other petrologic, geologic and geophysical information. Although Vright (1974) suggests 0.1 \& as an acceptable upper limit of individual oxide residuals. acceptance or rejection of a calculation on the basis of $\mathrm{R}^{2}$ is entirely subjective. In addition to the input compositions, $\mathrm{R}^{2}$ depends on the size of the matrix; e.g., if the number of fractionating minerals plus the derivative magma composition equals the number of bulk rock oxide components, then $\mathbb{R}^{2}$ is algebraically required to equal zero, regardless of the validity of the input data.

\section{PROCEDURE.}

The following procedure has been used to derive and refine mixing calculations:

(1) Use only observed bulk rock and mineral compositions, not averaged rock analyses or idealized mineral end members.

(2) Choose parent and derivative magmas, and representative mineral analyses from the parent magma.

(3) Evaluate results of calculation and attempt to decrease $R^{2}$ by modifying mineral compositions, within limits imposed by petrography and mineral analyses. This usually involves input of pyrozenes with different $\mathrm{Mg} / \mathrm{Fe}$, plegioclese with different An content, etc. 
(4) When $\mathrm{R}^{2}$ is considered to be minimized and mineral proportions are consistent with observed modal mineralogy, trace element calculations are undertaken, using the Rayleigh fractionation equation:

$$
\begin{aligned}
& C_{i}^{\text {liquid } / C_{i}{ }^{0}-F^{(D-1)}} \\
& \mathrm{C}^{0} \text { - concentration of trace element } \mathrm{i} \text { ' in the parental } \\
& \text { c.liquid - concentration of trace element } i \text { in the residual } \\
& \mathrm{C}_{\mathrm{i}} \quad \text { liquid } \\
& \begin{array}{l}
\mathrm{F} \quad \text { - fraction of liquid remaining } \\
\mathrm{D} \quad \text { bulk distribution coefficient for trace element } i \text {. }
\end{array}
\end{aligned}
$$

For magme mixing calculations, trace elements vere calculated using linear mizture of the two end members, with proportions of ead members given by results of major element miring calculations.

(5) Evaluate results of major and trace element calculations, and comment on validity of the model.

Calculations given here are the results of extensive trial and error, and modelling has been undertaken in stepwise fashion, 10 closely monitor fractionation.

\section{RESULTS}

Fractional crystallization calculations:

VI-1: [Ruapehu basalt (bulk rock analysis II-63)] - [cpr + plag + ol + oride] = [basic andesite of Te Herenga Fm (II-1)]

VI-2: [Ruspehu basalt, Mangavhero Fm (II-63)] - [cpr + ol + plag + oxide $]$ [basic andesile of Mangavhero Fm (II-64)]

VI-3: [basic andesite of Mangawhero Fm (II-64)] - [plag + opx + cpx + oxide] [acid andesite of Man gawhero Fm (II-88)]

VI-4: [Vaimarino Basalt $(I I-132)]-[0 I+c p x+$ plag + oxide $]=[$ Hauhungatahi basic andesite (II-133)]

VI-s: [Waimarino Besalt (II-132)] - lol + cpx + plag + oxide] - Ohakune basic andesite (II-137)]

VI-6: [acid andesite of Mangavhero Fm (II-88)] - [plag + cpx + opr + oride] [dacite of Mangawhero Fm (II-106)] 
Magma mixine calculations are given in Table 10, 0. 268. and are only listed here:

VI-8: [Ruapehu basalt, Mangawhero Fm (II-63)] + [acid andesite, Man gawhero Fm (II-78)] - (hybrid basic andesite, Mangawhera Fm (II-69))

VI-9: [Taimarino Besalt (II-132)] + [dacite, Mangawhero Fm (II-106)] [hybrid basic andesite. Pukeonake (II-136)]

VI-10: [Taimarino Baselt (II-132)] + [dacite, Whekapapa Fm (II-129)] [hybrid acid andesite, Man gawhero Fm (II-87)]

VI-11: [Taimarino Basalt (II-132)] + [dacite, Thakapapa Fm (II-129)] = [hybrid acid andesite. Mangavhero Fm (II-93)]

VI-12: [Taimarino Baselt (II-132)] + [dacite, Whakapapa Fm (II-129)] [hybrid acid andesite, Mangavhero Fm (II-82)]

VI-13: [Taimarino Basatt (II-132)] + [dacite, Whakapapa Fm (II-129)] [hybrid acid andesite, Man gawhero Fm (II-81)]

Crystal accumulation calculations:

VI-14: lacid andesite. Thakapapa Fm (II-128)] + [plagioclase, $\mathrm{An}_{\mathbf{8 0}} \mathrm{I}$ [plag-accumulative acid andesite, Whatapapa Fm (11-118)]

VI-15: [acid andesite, Tahianoa Fm (11-59)] - [plagioclase, An ${ }_{76}$ ] = [plag-accumulative acid andesite, Vahianoa Fm (II-46)]

\section{REFERENCES.}

Gill. J.B., 1981 Orogenic Andesites and Plate Tectonics, Springer-Verlag. New York, 390 pp.

Wright, TL., 1974. Presentation and interpretation of chemical data for igneous rocks. Contrib. Mineral. Petrol., $\underline{48}, 233-248$.

Wright, T.L. and Doherty, P.C, 1970. A linear programming and lesst squares computer method for solving petrologic mixing problems. Geol. Soc. Am. Bull., 81, 1995-2008. 
II-1: Ruapehu basalt (II-63)-[CPX+PRAG+ OL + TMT $]=$ basic andesite $(I I-1)$ of

\begin{tabular}{|c|c|c|c|c|c|c|c|c|c|c|}
\hline & $\begin{array}{l}\text { DAU. } \\
\text { II-I }\end{array}$ & $O L$ & $C P x$ & PLAG & TMT & $\begin{array}{l}\text { PARENTT } \\
\text { II-63 }\end{array}$ & & & & \\
\hline & & & & & & & & & & \\
\hline $\mathrm{SiO}_{2}$ & 53.81 & 40.56 & 51.88 & 53.51 & 0.12 & 52.23 & & & & \\
\hline $\mathrm{TiOl}_{2}$ & 0.70 & 0.00 & 0.40 & 0.00 & 8.69 & 0.66 & & & & \\
\hline $\mathrm{Al}_{2} \mathrm{O}_{3}$ & 17.49 & 0.00 & 2.95 & 28.30 & 3.77 & 15.57 & & & & \\
\hline $\mathrm{FeO}$ & 8.22 & 12.54 & 7.37 & 0.45 & 77.27 & 8.76 & & & & \\
\hline $\mathrm{MuO}$ & 0.14 & 0.12 & 0.17 & 0.00 & 0.30 & 0.16 & & & & \\
\hline $\mathrm{MgO}$ & 5.38 & 46.00 & 16.29 & 0.00 & 1.77 & 8.73 & & & & \\
\hline $\mathrm{C}_{2} \mathrm{O}$ & 8.51 & 0.15 & 19.37 & 12.03 & 0.19 & 9.63 & & & & \\
\hline $\mathrm{Na}_{2} \mathrm{O}$ & 2.94 & 0.00 & 0.00 & 4.73 & 0.00 & 2.59 & & & & \\
\hline $\mathrm{K}_{2} \mathrm{O}$ & 0.74 & 0.00 & 0.00 & 0.18 & 0.00 & 0.58 & & & & \\
\hline$P_{2} O_{5}$ & 0.10 & 0.00 & 0.00 & 0.00 & 0.00 & 0.09 & & $O B S$ & D bulk & $C A L C$ \\
\hline & & & & & & & 82 & $193 \rightarrow 218$ & 0.00 & 275 \\
\hline & CALC & $O B S$ & RESID & & VAR. & WT. FTAC & $R b$ & $12 \rightarrow 23$ & 0.00 & 17 \\
\hline $\mathrm{SiO}_{2}$ & 52,23 & 52.23 & 0.002 & & & & Sr & $200 \rightarrow 216$ & 0.70 & 222 \\
\hline $\mathrm{T}_{\mathrm{O}} \mathrm{O}_{2}$ & 0.68 & 0.66 & 0.020 & & II-1 & 0.702 & $Z v$ & $50 \rightarrow 55$ & 0.10 & 69 \\
\hline $\mathrm{Al}_{2} \mathrm{O}_{3}$ & 15.58 & 15.57 & 0.006 & & cPX & 0.122 & V & $254 \rightarrow 251$ & 1.15 & 241 \\
\hline $\mathrm{FeO}$ & 8.76 & 8.76 & 0.002 & & PLAG & 0.098 & $C r$ & $389 \rightarrow 86$. & 5.30 & 85 \\
\hline $\mathrm{MnO}$ & 0.13 & 0.16 & 0.028 & & $O L$ & 0.063 & $\mathrm{Ni}_{i}$ & $135 \rightarrow 36$ & 4.65 & 37 \\
\hline $\mathrm{MgO}$ & 8.73 & 8.73 & 0.001 & & TMT & 0.015 & & & & \\
\hline $\mathrm{CaO}$ & 9.63 & 9,63 & 0.005 & & & & & & & \\
\hline $\mathrm{Na}_{2} \mathrm{O}$ & 2.54 & 2.59 & 0.045 & & $\% \times T 2$ & 29.8 & & & & \\
\hline $\mathrm{K}_{2} \mathrm{O}$ & 0.54 & 0.58 & 0.039 & & & & & & & \\
\hline $\mathrm{P}_{2} \mathrm{OS}_{5}$ & 0.10 & 0.09 & 0.007 & & & & & & & \\
\hline & & $\sum R^{2}$ & 0.0049 & & & . & & & & \\
\hline
\end{tabular}

II-2: Ruapehu basalt (II-63)-[CDx+oL+RAG + TMT $]=$ basic andesite $(I I-64)$,

\begin{tabular}{|c|c|c|c|c|c|c|c|c|c|c|}
\hline & $\begin{array}{l}\text { DAU. } \\
\text { II-64 }\end{array}$ & $O L$ & $C P X$ & PLAG & TMT & $\begin{array}{l}\text { PAREEN } \\
\text { II-63 }\end{array}$ & & & & \\
\hline & & & & & & & & & & \\
\hline $\mathrm{SiO}_{2}$ & 53.15 & 40.56 & 50.95 & $5 / .86$ & 0,12 & 52.23 & & & & \\
\hline $\mathrm{TiO}_{2}$ & 0.68 & 0.00 & 0.40 & 0.09 & 8.69 & 0.66 & & & & \\
\hline $\mathrm{Al}_{2} \mathrm{O}_{3}$ & 17.05 & 0.11 & 4.19 & 29.99 & 3.77 & 15.57 & & & & \\
\hline $\mathrm{FeO} \mathrm{t}^{\mathrm{s}}$ & 8.54 & 12.54 & 7,16 & 0.96 & 77.27 & 8.76 & & & & \\
\hline MnO & 0.13 & 0.12 & 0,17 & 0.00 & 0.30 & 0.16 & & & & \\
\hline $\mathrm{MgO}$ & 6.66 & 46.00 & 15.63 & 0.15 & 1.77 & 8.73 & & & & \\
\hline $\mathrm{CaO}$ & 8.79 & 0,15 & 20.57 & 13.52 & 0.19 & 263 & & & & \\
\hline $\mathrm{Na}_{2} \mathrm{O}$ & 2.77 & 0.00 & 0.29 & 3.98 & $0, \infty$ & 2.59 & & $x_{1}$ & & \\
\hline $\mathrm{K}_{2} \mathrm{O}$ & 0.68 & 0.00 & 0.00 & 0.11 & 0,00 & 0.58 & & & & \\
\hline $\mathrm{P}_{2} \mathrm{O}_{5}$ & 0.10 & 0.00 & 0.00 & 0.00 & 0.00 & 0.09 & & OBS & D bulk & CALC \\
\hline & t & & & & & & $\mathrm{Ba}$ & $193 \rightarrow 232$ & 0,00 & 230 \\
\hline & CALC & $O B S$ & RESID & & VAR. & WT FRAC & $R b$ & $12 \rightarrow 17$ & 0.00 & 15.5 \\
\hline $\mathrm{SiO}_{2}$ & 52.23 & 52,23 & 0.004 & & II -64 & 0.840 & Sr & $200 \rightarrow 202$ & 0.36 & 224 \\
\hline $\mathrm{TiO}_{2}$ & 0,66 & 0.66 & 0.000 & & $C P X$ & 0.089 & Zr & $50 \rightarrow 59$ & $0 . \infty 0$ & 59 \\
\hline $\mathrm{Al}_{2} \mathrm{O}_{3}$ & 15.58 & 15.57 & 0.012 & & OL & 0.037 & V & $254 \rightarrow 265$ & 1.42 & 236 \\
\hline $\mathrm{FeO}^{\mathrm{C}}$ & 8.76 & 8,76 & 0.000 & & PLAG & 0.028 & cr & $389 \rightarrow 128$ & 7.05 & 135 \\
\hline$M n O$ & 0,13 & 0.16 & 0.029 & & TMT & 0.006 & $\mathrm{Ni}$ & $135 \rightarrow \sqrt{3}$ & 6.02 & 56 \\
\hline $\mathrm{MgO}$ & 8.73 & 8.73 & 0.004 & & & & & & & \\
\hline $\mathrm{CaO}$ & 9.62 & 9.63 & 0.009 & & $\% \times T L$ & 16.0 & & & & \\
\hline $\mathrm{Na}_{2} \mathrm{O}$ & 2.47 & 2,59 & 0.122 & & & & & & & \\
\hline $\mathrm{K}_{2} \mathrm{O}$ & 0.58 & 0.58 & 0.005 & & & & & & - & \\
\hline $\mathrm{P}_{2} \mathrm{O}_{5}$ & 0,08 & 0.09 & 0.006 & & & & & & & \\
\hline & & $\Sigma R^{2}$ & 0.0162 & & & & & & & \\
\hline
\end{tabular}


III = 3: - Basic andesite (II- 64$)-[P A A G+O P X+C P x+7 M T]=$ acid andesite (II-88), both

\begin{tabular}{|c|c|c|c|c|c|c|c|c|c|c|}
\hline & $\begin{array}{l}\text { DAU. } \\
\text { II- } 88\end{array}$ & op $x$ & $c P x$ & PLAG & TMT & $\begin{array}{l}\text { PARÉNT } \\
\text { II-64 }\end{array}$ & & & & \\
\hline $\mathrm{SiO}_{2}$ & 58.54 & 53,26 & 51,50 & 51.82 & 0.22 & 53.15 & & & & \\
\hline TiOn & 0.68 & 0.22 & 0.27 & 0.00 & 11.45 & 0,68 & & & & \\
\hline $\mathrm{Al}_{2} \mathrm{O}_{3}$ & 17.41 & 0.98 & 2.63 & 29.61 & 2.35 & 17,05 & & & & \\
\hline $\begin{array}{c}\mathrm{FeO} \mathrm{O}^{\mathrm{T}} \\
\mathrm{MuO}\end{array}$ & 6.85 & 16.90 & 9.69 & 0.53 & 76.94 & 8.54 & & & & \\
\hline $\begin{array}{l}\mathrm{MuO} \\
\mathrm{MaO}\end{array}$ & & 0,42 & 0.19 & 0.00 & 0.24 & 0.13 & & & 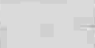 & $=$ \\
\hline $\begin{array}{l}\mathrm{MgO} \\
\mathrm{CaO}\end{array}$ & 3.75 & 25.74 & 14.93 & 0.00 & 1.06 & 6.66 & & & & \\
\hline $\begin{array}{l}\mathrm{CaO} \\
\mathrm{Na}_{2} \mathrm{O}\end{array}$ & 7,05 & 1.53 & 19.88 & 12.87 & 0.00 & 8.79 & & & $t=$ & \\
\hline $\begin{array}{l}\mathrm{Na}_{2} \mathrm{O} \\
\mathrm{K}_{2} \mathrm{O}\end{array}$ & 3.16 & 0,00 & 0.30 & $\begin{array}{l}4.34 \\
0.27\end{array}$ & 0.00 & $\begin{array}{l}2.77 \\
0.68\end{array}$ & & & & \\
\hline $\mathrm{P}_{2} \mathrm{OS}$ & $\begin{array}{l}1.20 \\
0.10\end{array}$ & $\begin{array}{l}0.00 \\
0.00\end{array}$ & $\begin{array}{l}0.00 \\
0.00\end{array}$ & $\begin{array}{l}0.27 \\
0.00\end{array}$ & $\begin{array}{l}0.00 \\
0.00\end{array}$ & $\begin{array}{l}0.68 \\
0.10\end{array}$ & & & & \\
\hline & & & & & & & $B a$ & $\begin{array}{c}O B S \\
232 \rightarrow 31\end{array} \mid$ & $\begin{array}{c}\text { D bulk } \\
0.10\end{array}$ & $\begin{array}{l}\text { CALC } \\
491\end{array}$ \\
\hline & CALC & $O B S$, & RESID & & VAR & WT FRAC & $R b$ & $17 \rightarrow 41$ & 0.04 & 38 \\
\hline $\begin{array}{l}\text { SiOn } \\
\text { TiOn }\end{array}$ & 53.16 & 53.15 & 0.006 & & & & Sr & $\begin{array}{l}222-2344 \\
(19 \rightarrow 84\end{array}$ & 0.95 & 231 \\
\hline $\begin{array}{l}\mathrm{TiO}_{2} \\
\mathrm{Al}_{2} \mathrm{O}_{3}\end{array}$ & 0.67 & 0.68 & 0.03 & & II-88 & 0.433 & $z_{r}$ & $59 \rightarrow 86$ & 0.57 & $\begin{array}{l}84 \\
175\end{array}$ \\
\hline $\begin{array}{l}\mathrm{Al}_{2} \mathrm{O}_{3} \\
\mathrm{FeO} \mathrm{t}^{\mathrm{t}}\end{array}$ & 17.05 & 17.05 & 0.000 & & PLAG & 0.311 & $v$ & $\begin{array}{l}265 \rightarrow 181 \\
28-43\end{array}$ & $\begin{array}{l}3.50 \\
3.16\end{array}$ & $\begin{array}{l}175 \\
21\end{array}$ \\
\hline & 8.54 & 8.54 & 0.002 & & $\begin{array}{l}O P x \\
C P x\end{array}$ & $\begin{array}{l}0.150 \\
0.078\end{array}$ & $\begin{array}{l}\mathrm{Cr} \\
\mathrm{Ni}\end{array}$ & $53 \rightarrow 28$ & 2,06 & 22 \\
\hline $\begin{array}{l}\mathrm{MwO} \\
\mathrm{MgO}\end{array}$ & $\begin{array}{l}0.13 \\
6.65\end{array}$ & $\begin{array}{l}0.13 \\
6.66\end{array}$ & $\begin{array}{l}0.002 \\
0.03\end{array}$ & & $T M T$ & 0.028 & & & & \\
\hline $\mathrm{CaO}$ & 8.78 & 8.79 & acos & & & & & & & \\
\hline $\begin{array}{l}\mathrm{N}_{2} \mathrm{O} \\
\mathrm{K}_{2} \mathrm{O}\end{array}$ & 2.72 & 2.77 & 0.047 & & $\% \times T L$ & 56.4 & & & 10 & \\
\hline $\begin{array}{l}\mathrm{K}_{2} \mathrm{O} \\
\mathrm{P}_{2} \mathrm{OS}\end{array}$ & $\begin{array}{l}0.60 \\
0.04\end{array}$ & $\begin{array}{l}0.68 \\
0.10\end{array}$ & $\begin{array}{l}0.080 \\
0.057\end{array}$ & & CUM \% & & & & & \\
\hline & & & & & & & & & & \\
\hline & & $\sum R^{2}$ & 0.0123 & & & & & & & \\
\hline
\end{tabular}

VI - 4. Waimaino Basalt $(I I-132)-[O L+C P X+P L A G+C P S P]=$ basic andisite

\begin{tabular}{|c|c|c|c|c|c|c|c|c|c|c|}
\hline & $\begin{array}{l}\text { DAU. } \\
\mathbb{I I}-133\end{array}$ & $O L$ & $C P X$ & PLAG & CR-SP & $\begin{array}{l}\text { AARENT } \\
\text { II-132 }\end{array}$ & & & & \\
\hline $\mathrm{SiO}_{2}$ & 55.34 & 37.64 & 51.85 & 46.83 & 0.00 & 52.18 & & & & \\
\hline $\mathrm{TiO}_{2}$ & 0.56 & 0,00 & 0.23 & 0,00 & 0.51 & 0.47 & & & $=$ & \\
\hline $\mathrm{Al}_{2} \mathrm{O}_{3}$ & 15.00 & 0.00 & 4.46 & 33.46 & 11.02 & 12.68 & & & a & \\
\hline $\mathrm{FeOt}$ & 7.55 & 14.73 & 5,83 & 0.67 & 27.50 & 8.34 & & . & s. & \\
\hline MnO & 0.11. & 0.23 & 0.10 & 0.00 & 0.00 & 0.16 & & & & $x^{2}$ \\
\hline $\mathrm{MgO}$ & 7.13 & 44.71 & 16.42 & 0.13 & 9.33 & 13.15 & & & 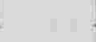 & \\
\hline $\mathrm{CaO}$ & 9.45 & 0.17 & 21,28 & 17.71 & 0.00 & 9.60 & & & & \\
\hline $\mathrm{Nb}_{2} \mathrm{O}$ & 2.21 & 0.00 & 0.19 & 1.21 & 0,00 & 1.64 & & & t & \\
\hline $\mathrm{K}_{2} \mathrm{O}$ & 0.61 & 0.00 & 0.00 & 0.02 & 0.00 & 0,43 & & & 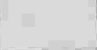 & \\
\hline $\mathrm{P}_{2} \mathrm{OS}_{5}$ & 0.08 & 0.00 & 0.00 & 0.00 & 0.00 & 0.05 & & OBS 1 & D bulk & $C A L C$ \\
\hline & & & & & & & $\begin{array}{l}B a \\
R b\end{array}$ & & $\begin{array}{l}0.00 \\
0.00\end{array}$ & $\begin{array}{c}173 \\
21\end{array}$ \\
\hline $\mathrm{SiO}_{2}$ & $\begin{array}{l}\text { CALC } \\
\text { S2.18 }\end{array}$ & $\begin{array}{l}\text { OBS } \\
52.18\end{array}$ & $\begin{array}{l}\text { RESDD } \\
0.000\end{array}$ & & $\begin{array}{l}\text { VAR } \\
\text { II-133 }\end{array}$ & $\begin{array}{c}\text { WT FRAC } \\
0.709\end{array}$ & $5 r$ & $348 \rightarrow 450$. & 0.30 & 443 \\
\hline $\mathrm{TiO}_{2}$ & 0.43 & 0.47 & 0.044 & & $O L$ & 0.142 & zr & $47 \rightarrow 53$ & 0.19 & 62 \\
\hline $\mathrm{Al}_{2} \mathrm{O}_{3}$ & 12.68 & 12.68 & 0.001 & & $c P x$ & 0.097 & $V$ & $217 \rightarrow 220$. & 1.10 & 210 \\
\hline Feot & 8.34 & 8.34 & 0.001 & & PLAG & 0.043 & cr & $1070 \cdot 234$ & 7.64 & 109 \\
\hline $\mathrm{MnO}$ & 0.12 & 0.16 & 0,039 & & CRSP & 0.009 & $\mathrm{Ni}$ & $310 \rightarrow 35$ & 7.19 & 37 \\
\hline $\mathrm{MgO}$ & 13.15 & 13.15 & 0.000 & & & & & & & 10 \\
\hline $\mathrm{CaO}$ & 9.60 & 9.60 & 0.000 & & $\% \times T L$ & 29.3 & & , & & \\
\hline $\mathrm{Na}_{2} \mathrm{O}$ & 1.65 & 1.64 & 0.007 & & & & & is & & 1010 \\
\hline $\mathrm{K}_{2} \mathrm{O}$ & 0.44 & 0.43 & 0.006 & & & & & s & & $1=$ \\
\hline$P_{2} D_{S}$ & 0,06 & 0.05 & 0.007 & & & & & & & $=n-1$ \\
\hline & & $\Sigma R^{2}$ & 0.0049 & & & & & & & \\
\hline
\end{tabular}


II-5: Waimanimo Basalt $($ II -132) $-[O L+C P X+P L A G+C R S P]=$ Ohakunc bisic andesite

\begin{tabular}{|c|c|c|c|c|c|c|c|c|c|c|}
\hline & $\begin{array}{l}\text { DAU. } \\
\text { II-137 }\end{array}$ & $O L$ & $C P X$ & PLAG & $C R \cdot S P$ & $\begin{array}{l}\text { AALENT } \\
\text { II-132 }\end{array}$ & & & & \\
\hline & & & & & & & & & & \\
\hline $\begin{array}{l}\mathrm{SiO}_{2} \\
\mathrm{TiO}\end{array}$ & 56.79 & 40.12 & 52.05 & 49.55 & 0.00 & 52,18 & & & & \\
\hline $\begin{array}{l}\mathrm{TiO}_{2} \\
\mathrm{Al}_{2} \mathrm{O}_{3}\end{array}$ & 0.53 & 0.00 & 0.36 & 0,00 & 0.36 & 0.47 & & & & \\
\hline $\begin{array}{l}\mathrm{AH}_{2} \mathrm{O}_{3} \\
\mathrm{FeO}^{t}\end{array}$ & 14.50 & 0.00 & 3.15 & 31.72 & 8.94 & 12.68 & & & & \\
\hline $\begin{array}{l}\mathrm{FeO} \\
\mathrm{MnO}\end{array}$ & 7.97 & 13.43 & 7.86 & 0.81 & 27.83 & 8.34 & & & & \\
\hline $\begin{array}{l}\mathrm{MnO} \\
\mathrm{MgO}\end{array}$ & 0.19 & $\begin{array}{l}0,20 \\
4<1\end{array}$ & 0.14 & 0.00 & 0.00 & 0,16 & & & & \\
\hline $\begin{array}{l}\mathrm{MgO} \\
\mathrm{CaO}\end{array}$ & 7.07 & $\begin{array}{r}45.44 \\
0.10\end{array}$ & $\begin{array}{l}16.80 \\
18.88\end{array}$ & 0.13 & 8.70 & 13.15 & & & & \\
\hline $\mathrm{Na}_{2} \mathrm{O}$ & $\begin{array}{l}9.05 \\
2.32\end{array}$ & $\begin{array}{l}0.10 \\
0.00\end{array}$ & $\begin{array}{r}18.88 \\
0.14\end{array}$ & $\begin{array}{r}15.27 \\
2.36\end{array}$ & $\begin{array}{l}0.00 \\
0.00\end{array}$ & $\begin{array}{l}2.60 \\
1.64\end{array}$ & & & & \\
\hline $\mathrm{K}_{2} \mathrm{O}$ & $\begin{array}{l}2.32 \\
0.66\end{array}$ & $\begin{array}{l}0,00 \\
0,00\end{array}$ & $\begin{array}{l}0.14 \\
0.00\end{array}$ & $\begin{array}{l}2.36 \\
0.07\end{array}$ & 0.00 & 0.43 & & & & \\
\hline $\mathrm{P}_{2} \mathrm{O}_{5}$ & 0.07 & 0.00 & 0.00 & 0.00 & 0.00 & 0.05 & & $O B S$ & D bulk & CALC \\
\hline & & & RESID & & VAR & wT $F R A C$ & $\begin{array}{l}B a \\
R b\end{array}$ & $\begin{array}{l}123 \rightarrow 141 \\
15 \rightarrow 15\end{array}$ & $\begin{array}{l}0.00 \\
0.00\end{array}$ & $\begin{array}{r}204 \\
23\end{array}$ \\
\hline $\mathrm{SiO}_{2}$ & $\begin{array}{l}\text { CALC } \\
52.18\end{array}$ & 52.18 & 0.000 & & II -137 & 0.603 & Sr & $348 \rightarrow 342$ & 0.84 & 378 \\
\hline $\mathrm{TiO}_{2}$ & 0.37 & 0.47 & 0.096 & & OL & 0.142 & $z_{r}$ & $47 \rightarrow 57$ & 0.00 & 78 \\
\hline $\mathrm{AhO}_{3}$ & 12.68 & 12.68 & 0.003 & & $C P X$ & 0.133 & $v$ & $217 \rightarrow 214$ & 1.17 & 200 \\
\hline $\mathrm{FeO}$ & 8.34 & 8.34 & 0.003 & & PLAG & 0.105 & cr & $1070 \rightarrow 271$ & 4.67 & 167 \\
\hline MnO & 0.16 & 0.16 & 0.002 & & CRSP & 0.017 & $\mathrm{Ni}$ & $310 \rightarrow 50$ & 6.00 & 25 \\
\hline $\mathrm{MgO}$ & 13.15 & 13.15 & 0.001 & & & & & & & \\
\hline $\mathrm{CaO}$ & 9.60 & 960 & 0.001 & & $\% \times \pi$ & 39.8 & & & & \\
\hline $\mathrm{Na}, \mathrm{D}$ & 1.67 & 1.64 & 0.029 & & & & & & & \\
\hline $\mathrm{K}_{2} \mathrm{O}$ & 0.41 & 0.43 & 0.024 & & & & & & & \\
\hline $\mathrm{P}_{2} \mathrm{O}_{5}$ & 0.04 & 0.05 & 0.008 & & & & & & & \\
\hline & & $\Sigma R^{2}$ & 0.0106 & & & & & & & \\
\hline
\end{tabular}

-6: Acid andesite (II-88) - [PLAG+CPX+OPX +TMT] $=$ dacite (II-106)

\begin{tabular}{|c|c|c|c|c|c|c|c|c|c|c|}
\hline & $\begin{array}{l}\text { DAU. } \\
\text { II-106 }\end{array}$ & $O P X$ & $C P X$ & PLAG & TMT & $\begin{array}{l}\text { PAAENT } \\
\text { II- }-88\end{array}$ & & & & \\
\hline $\mathrm{SiO}_{2}$ & 62.94 & 51.48 & 51.67 & 52.87 & 0.22 & 58.54 & & & . & \\
\hline $\mathrm{TiO}_{2}$ & 0.80 & 0.25 & 0.43 & 0.00 & 11.45 & 0,68 & & & 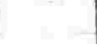 & \\
\hline $\mathrm{AH}_{2} \mathrm{O}_{3}$ & 16.57 & 2.23 & 1.05 & 29.34 & 2.35 & 17.41 & & & & \\
\hline $\mathrm{FeO}^{t}$ & 5.03 & 22.35 & 14,79 & 0.48 & 76.94 & 6.85 & & & & \\
\hline Mno & 0.06 & 0.48 & 0.48 & 0,00 & 0.24 & 0.11 & & & & \\
\hline $\mathrm{MgO}$ & 2.22 & 22.22 & 14.22 & 0.00 & 1.06 & 3.75 & & & & \\
\hline $\mathrm{CaO}$ & 4.80 & 1,30 & 17.00 & 11.50 & 0.00 & 7.05 & & & & \\
\hline $\mathrm{Na}_{2} \mathrm{O}$ & 3.34 & 0,00 & 0.25 & 4.51 & $0, \infty$ & 316 & & & & \\
\hline $\mathrm{K}_{2} \mathrm{O}$ & 2.72 & 0.00 & 0.00 & 0.17 & 0.00 & 1.20 & & & & \\
\hline$P_{2} O_{5}$ & 0.20 & 0,00 & 0.00 & 0.00 & 0.00 & 0.10 & & $O B S$ & D bulk & CALC \\
\hline & $C A L C$ & $O B S$ & RESID & & VAR & UT FRAC & $\begin{array}{l}\mathrm{Ba} \\
\mathrm{Rb}\end{array}$ & $\begin{array}{l}3 / 1 \rightarrow 514 \\
41 \rightarrow 124\end{array}$ & $\begin{array}{l}0.00 \\
0,00\end{array}$ & $\begin{array}{r}510 \\
67\end{array}$ \\
\hline $\mathrm{SiO}_{2}$ & 58.50 & 58.54 & 0.044 & & II -106 & 0,609 & $-S_{r}$ & $234 \rightarrow 255$ & 0.94 & 241 \\
\hline $\mathrm{TiO}_{2}$ & 0.71 & 0,68 & 0.026 & & PLAG & 0.238 & Zr & $86 \rightarrow 198$ & 0.00 & 141 \\
\hline $\mathrm{Al}_{2} \mathrm{O}_{3}$ & 17.47 & 17.41 & 0.057 & & $C P x$ & 0.077 & $v$ & $181 \rightarrow 117$ & 1.96 & 113 \\
\hline $\mathrm{FeO}^{t}$ & 6.84 & 6.85 & 0.007 & & $O P X$ & 0.061 & $\mathrm{Cr}$ & $43 \rightarrow 29$ & 3.91 & 10 \\
\hline $\mathrm{MnO}$ & 0.11 & 0.11 & 0,003 & & $T M T$ & 0.014 & $\mathrm{Ni}$ & $28 \rightarrow 19$ & 2.16 & 16 \\
\hline $\mathrm{MgO}$ & 3.85 & 3.75 & 0,100 & & & & & & $=$ & \\
\hline $\mathrm{CaO}$ & 710 & 7.05 & 0.052 & & $\% \times \pi$ & 39.4 & & & & \\
\hline $\mathrm{Na}_{2} \mathrm{O}$ & 3.15 & 3.16 & 0.008 & & CuM $\%$. & 77.8 & & & & \\
\hline $\mathrm{K}_{2} \mathrm{O}$ & 1.71 & 1.20 & 0,510 & & & & & & & \\
\hline $\mathrm{P}_{2} \mathrm{OS}_{5}$ & 0.12 & 0,10 & 0,023 & & & & & & & \\
\hline & & $\Sigma R^{2}$ & 0.2790 & & & & & & & \\
\hline
\end{tabular}


III-14: acid andesite (II-128) +[PLAG, Anso $]=$ plag-accum acid andesite (II-1/8)

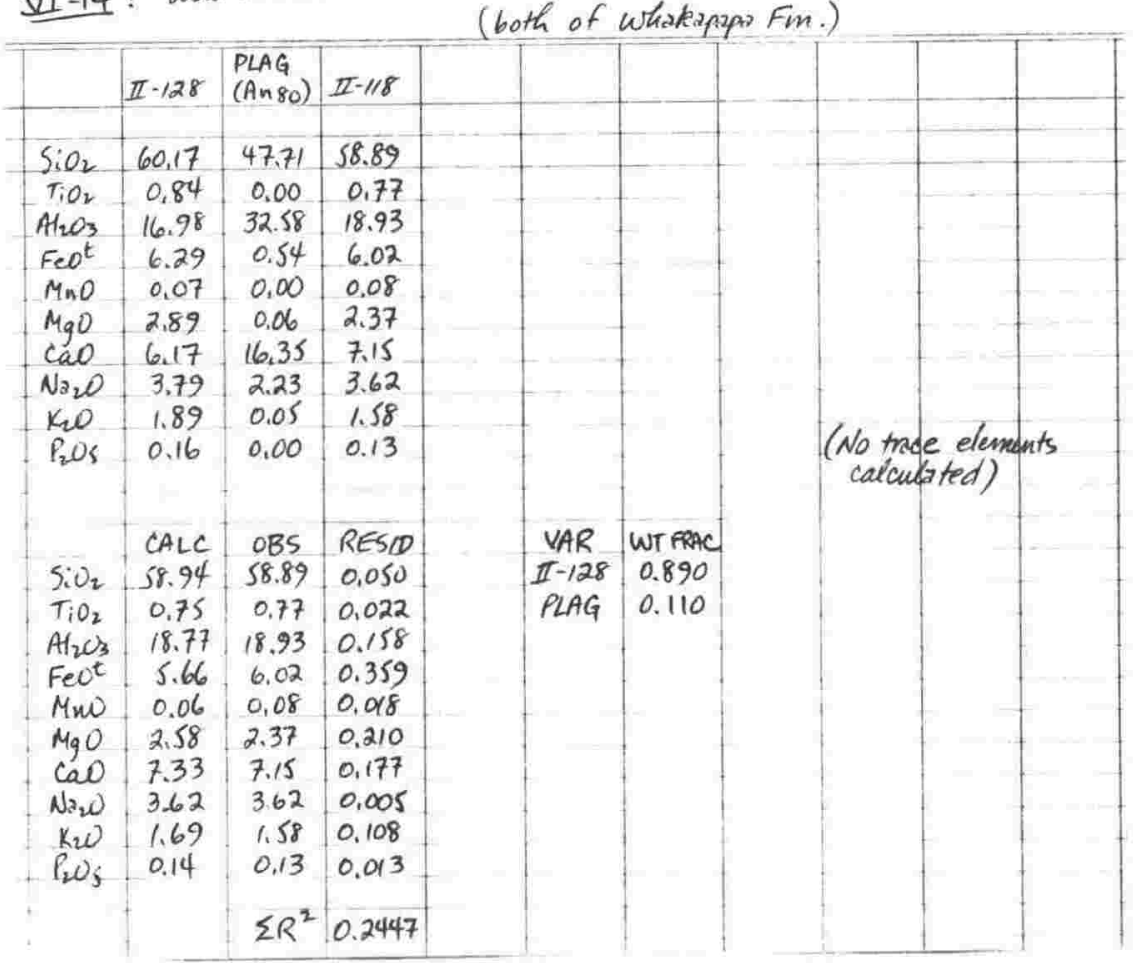

III-15: acid andesite (II.59) +[PLAG,An76] = plag-accum, acid andosite

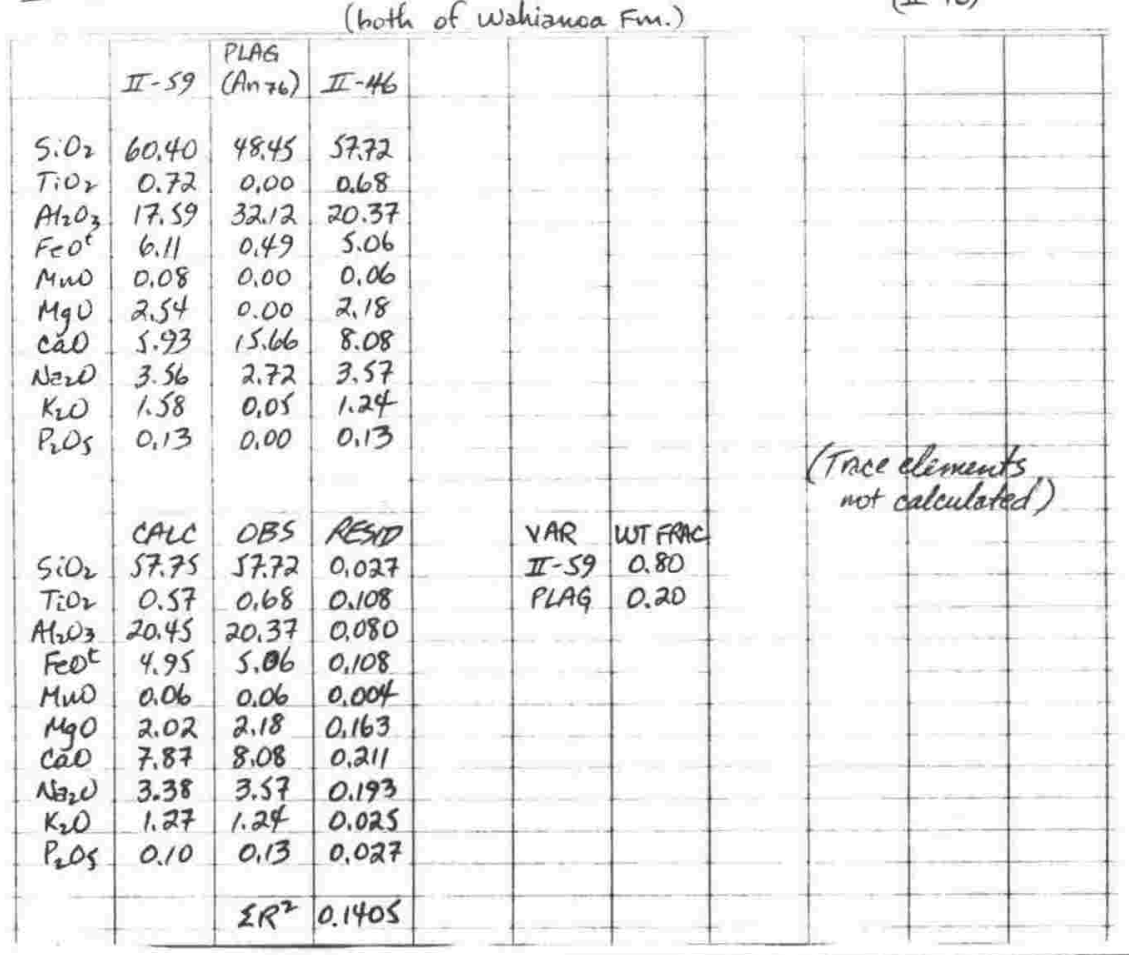




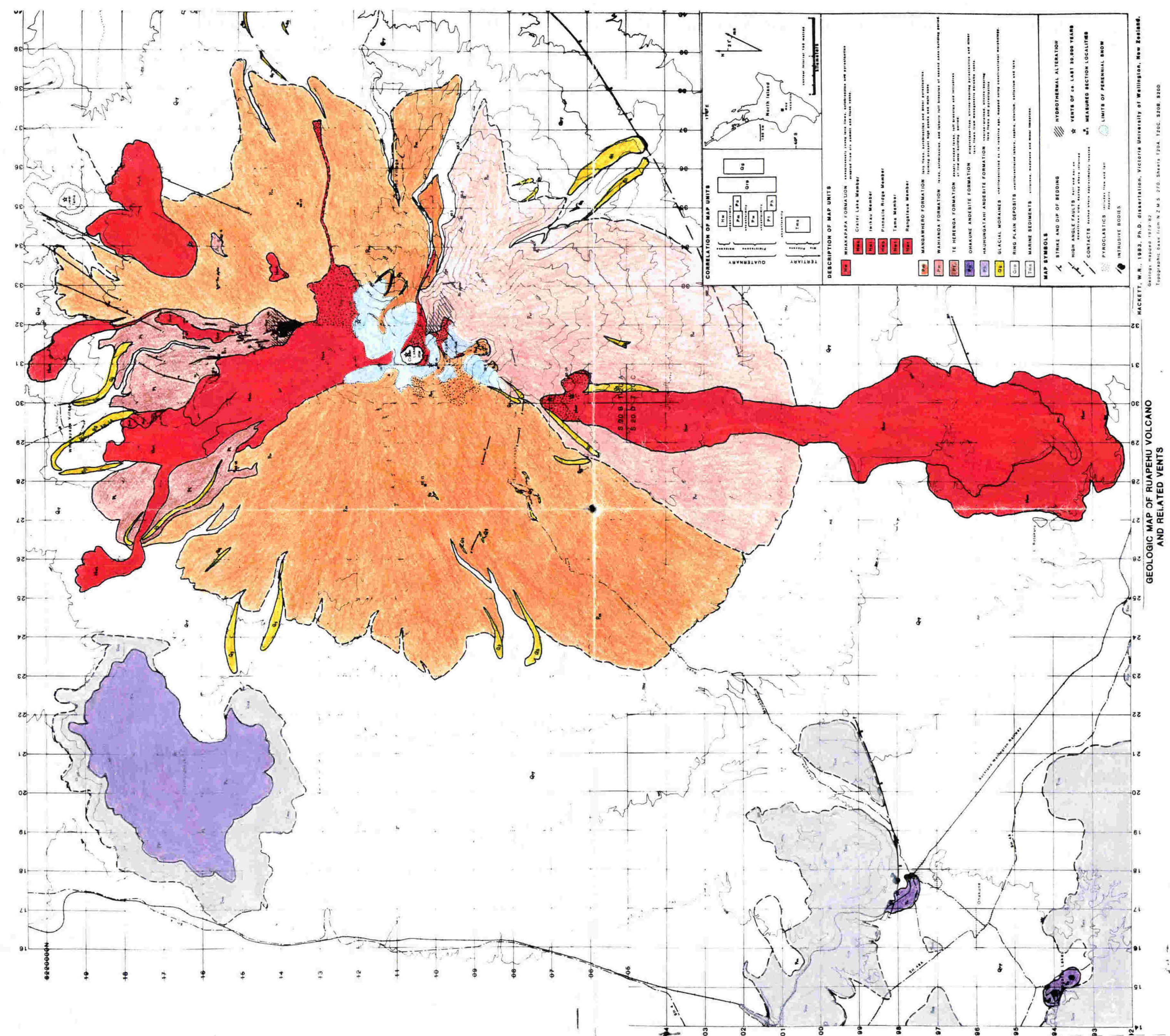

